
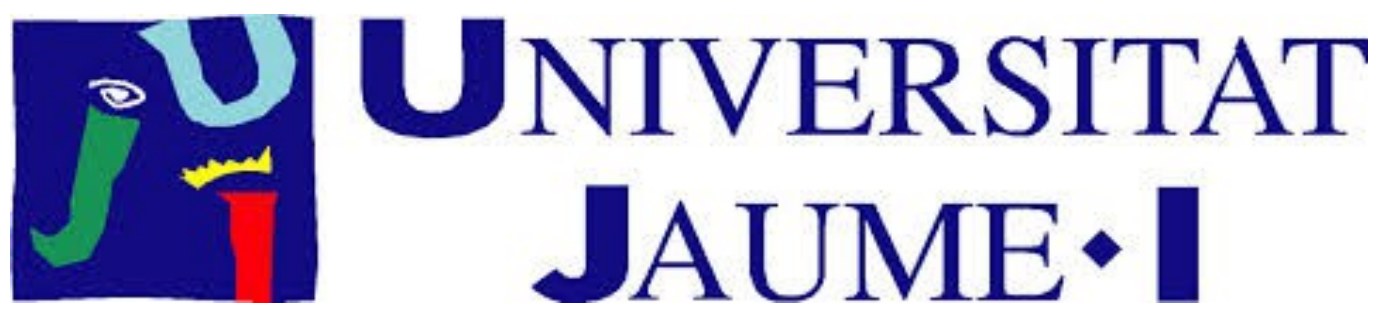

JAUME•

Tesi doctoral:

\title{
LA BARONIA DE SERRA, RIA I ARMELL, DES DE L'EXPULSIÓ MORISCA FINS A LA DISSOLUCIÓ SENYORÍVOLA
}

Policarp Garay i Martín

Dirigida per

Dr. José Antonio Piqueras Arenas

Departament de Història, Geografia i Art

Facultat de Ciències Humanes i Socials

Universitat Jaume I (Castelló de la Plana) Octubre de 2015 


\section{ÍNDEX}

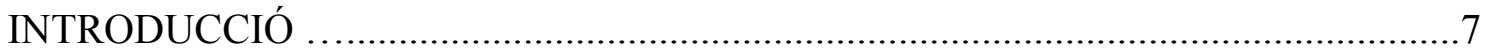

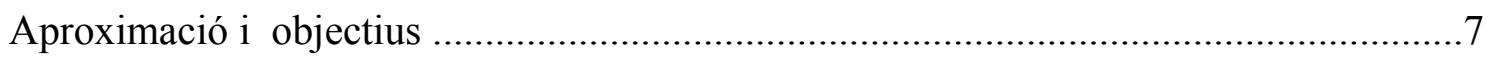

Metodologia, arxius consultats i pla de treball ..............................................................

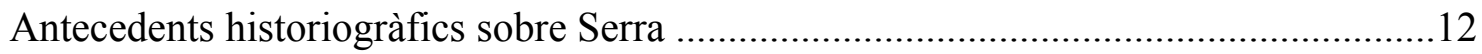

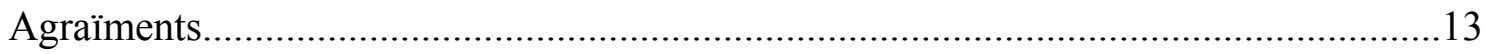

\section{CAPÍTOL 1}

TERRITORI DE LA BARONIA I DEL TERME MUNICIPAL ..............................15

1.1 Partició d'un districte castral musulmà en tres senyories cristianes ..........................15

1.2 Marc territorial a començaments del segle XVII ....................................................18

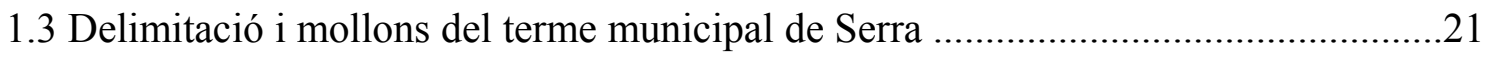

1.4 Límits històrics i conflictes territorials de la baronia de Serra ................................27

\section{CAPÍTOL 2}

CIRCUMSTÀNCIES I CONTINGUTS DE LA CARTA-POBLA DE 1609 ...........41

2.1. Nota biogràfica de Josep Folch de Cardona, senyor de la baronia de Serra ............42

2.2. Els expulsats moriscos i el despoblament de Serra i Ria ........................................47

2.3. Sobre el contingut de la carta-pobla i els diferents trasllats .................................50

2.4. Repoblar no va ser, en general, una tasca fàcil ni senzilla ...................................60

2.5. Vassallatge, establiment de cases i terres i nomenament d'oficials ........................67

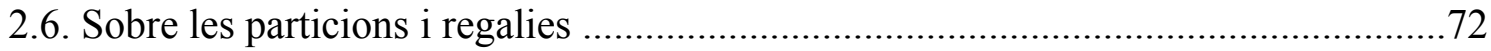

\section{CAPÍTOL 3}

POBLADORS DEL SEGLE XVII, SUBSTITUCIONS I LLINATGES .................75

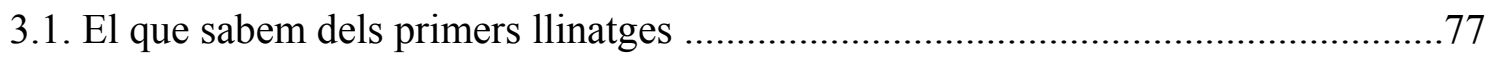

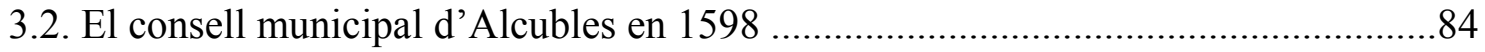

3.3. Substitució progressiva dels colons: els nous pobladors ......................................89

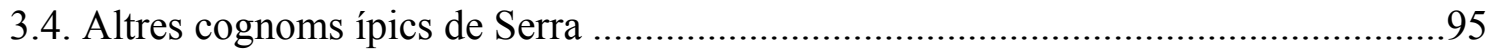

3.5. Consideracions sobre el procés de substitució dels colons ...................................101

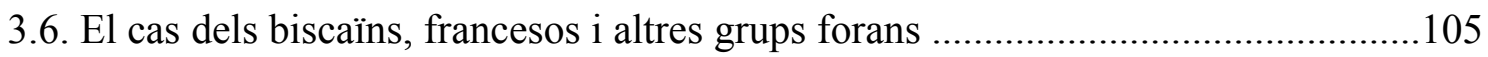


CAPÍTOL 4

DESAPARICIÓ DE RIA I EVOLUCIÓ DEMOGRÀFICA DE LA COLÒNIA ....117

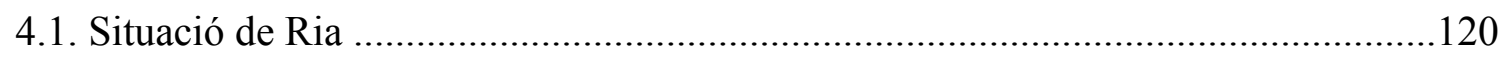

4.2. Despoblament de Ria i naixement del Bàrio .........................................................126

4.3. El cens nominal de 1646. Revisió i confrontació de dades ...................................130

4.4. El capbreu de 1779 com a font per a un cens d veïns $i$ cases ...............................137

4.5. Evolució demogràfica de la baronia entre 1609 i 1857 .......................................142

4.6. Evolució biològica de la colònia serrana a partir del Quinque Libri ......................149

\section{CAPÍTOL 5}

RECURSOS NATURALS: APROFITAMENTS I PRODUCTES AGRARIS .......155

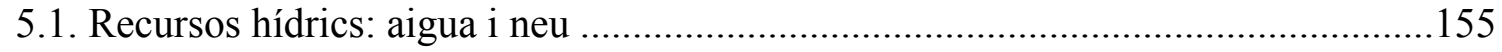

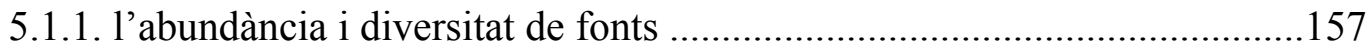

5.1.2. Quimera per l'aigua, pèrdua de cabals i conflictes hídrics .....................159

5.1.3. El negoci de la neu a Portaceli ..............................................................160

5.1.4. L'experiència de comerç de neu a Serra ................................................162

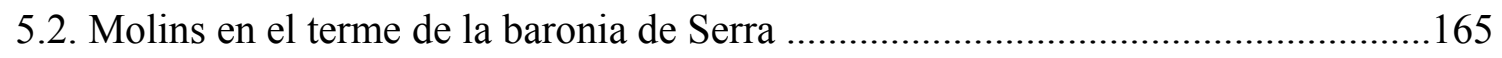

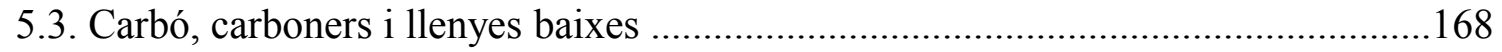

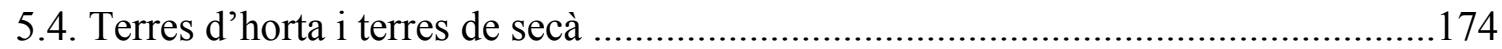

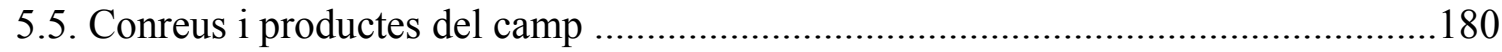

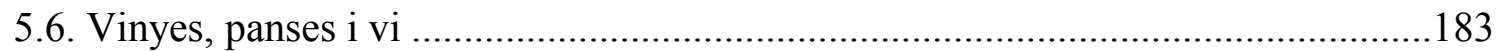

5.6.1. bons vins front a alts impostos (Serra en el segle XVII) ........................184

5.6.2. La producció de vi a finals del segle XVIII, segons Cavanilles ..............187

5.6.3. Les discòrdies i la sentència de 1808 sobre el vi de Serra .......................189

5.6.4. L’expansió final i la caiguda de la vinya (segles XIX i XX). .................190

5.6.5. Els vins de Portaceli i La Torre ...................................................................191

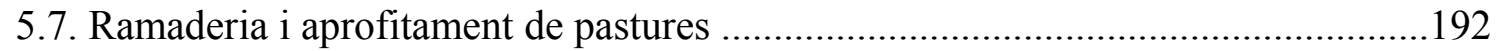

5.7.1. Els ramats de Serra segons el carnatge de Morvedre (segle XVII) .........194

5.7.2. Pastors locals $i$ vies ramaderes al segle XIX ........................................197

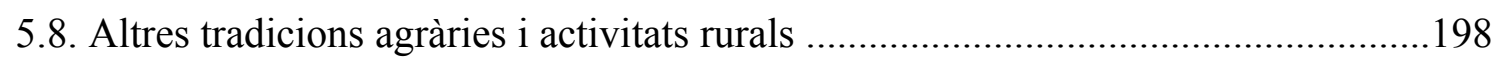




\section{CAPÍTOL 6}

PRODUCCIÓ I RENDES A PARTIR DEL REGISTRE DELS DELMES ............203

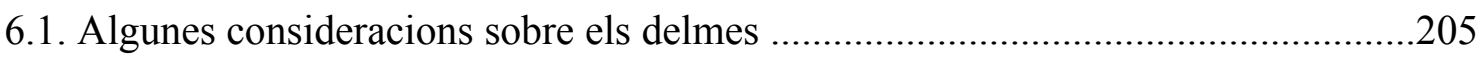

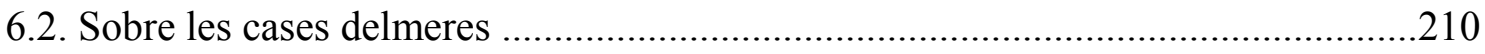

6.3. Sobre distribució i repartiment dels delmes de Serra .........................................212

6.4. Arrendadors dels delmes abans i desprès de la carta-pobla de 1609 .....................216

6.5. Evolució dels arrendaments del delme (segles XVII a XIX) ................................222

6.6. Sobre delmes i contribucions de la cartoixa de Portaceli .....................................228

6.7. Ocàs i distribució del delme i altres impostos relacionats ....................................231

6.8 Arrendaments de drets dominicals de la baronia d Serra .......................................237

\section{CAPÍTOL 7}

SENYORS DE LA BARONIA I CONFLICTES PER LA POSSESSIÓ ..................241

7.1. origen de la baronia: entre el Patrimoni reial i la donació als Bellpuig ..................242

7.2. Dels Bellpuig i els Arenós als comtes de Prades (segles XIV al XV) ....................248

7.3. Joana de Prades, senyora de la baronia de Serra entre 1414 i 1431 .......................250

7.4. Felip Boïl, senyor de la baronia desprès de sanejar-la (1431-1443) ......................253

7.5. la baronia de Serra en mans dels comtes de Cardona (segle XV) ..........................255

7.6. Dels ducs de Cardona a una branca dels Folch de Cardona (segle XVI) ................256

7.7. Josep Folch de Cardona i els conflictes amb el duc de Sogorb ..............................259

7.8. Nou plet successori contra Josep Folch de Cardona en 1641 ..................................263

7.9. Testaments de Josep Folch de Cardona i de Jerònima Lull ....................................266

7.10. Vicent d'Aragó i Cardona, senyor de Serra entre 1650 i 1676 ............................270

7.11. Els marquesos de Castellnou senyors de Serra (Teresa Milà i el seu fill) ............272

7. 12. Nou plet iniciat en 1711 pel comte de Cardona del Sacre Imperi ........................273

7.13. Els ducs de Montellano, senyors de Serra (segle XVIII) ....................................2275

7.14 Maria Vicenta Solís VI duquessa de Montellano ...................................................280

7.15 Testament $\mathrm{i}$ hereus de la duquessa de Montellano ................................................283

CAPÍTOL 8

MORIR I NÀIXER A SERRA: VIDA SOCIAL, DEVOCIONS, COSTUMS ........287

8.1. Aspectes quotidians en les primeres dècades del segle XVII ................................287

8.2. Origen de la parròquia i notícies dels primers temples (segles XVI i XVIII) ..........296 
8.3. Construcció del nou temple (finals del segle XVIII) .299

8.4. Repartiment de treball comunal i "fatigues" dels serrans .......................................302

8.5. Creació de la confraria de la Verge dels Àngels (segle XVII) ................................305

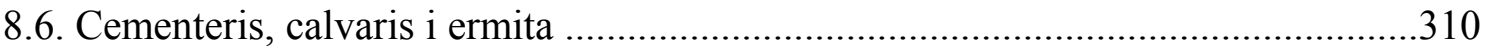

8.7. Moralitat en temps de l'arquebisbe Mayoral …....................................................314

8.8. Càrrecs públics i preus segons els protocols de Conejos (segles XVIII a XIX) .....319

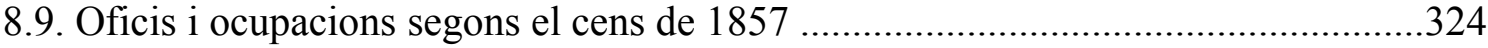

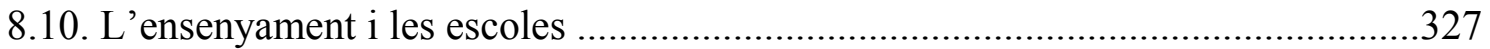

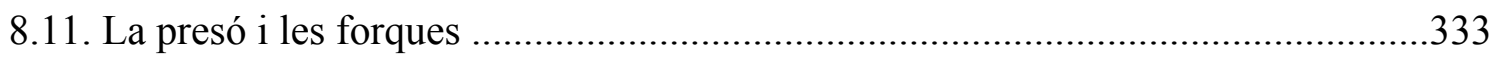

\section{CAPÍTOL 9}

EXTINCIÓ I REVERSIÓ DE LA BARONIA DE SERRA A LA CORONA I FORMACIÓ DE L’AJUNTAMENT CONSTITUCIONAL ..................................337

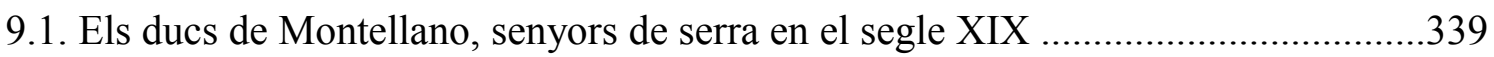

9.2. Filibert Mahy, darrer posseïdor de la baronia de Serra .........................................342

9.3. Pressió tributària al llarg del segle XVIII i principi del XIX …...............................346

9.4. Alguns casos de conflicte dominical en el segle XIX ..........................................350

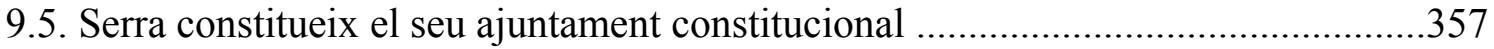

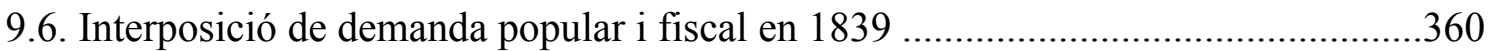

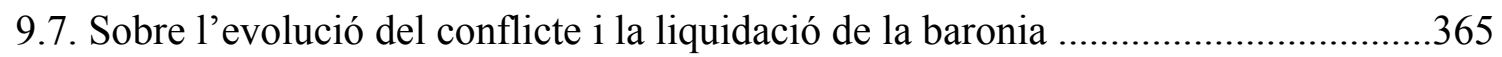

9.8. Finques particulars $\mathrm{i}$ forests públiques del terme de Serra .....................................373

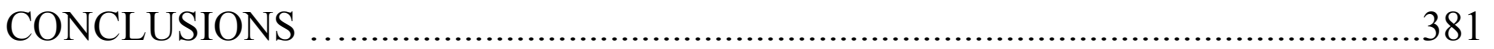

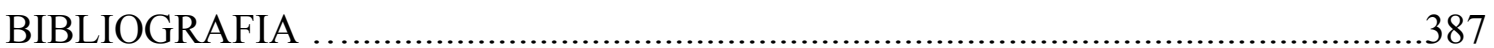

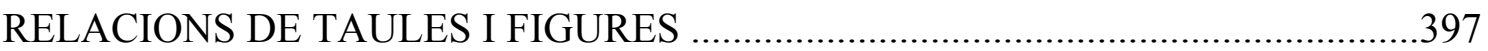

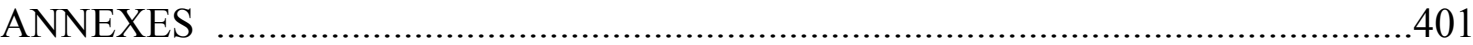

A1) Mollons que delimiten el terme municipal de Serra ................................401

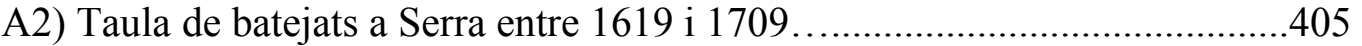

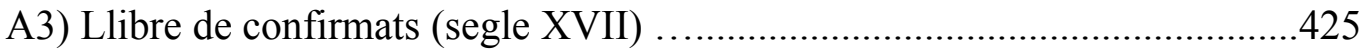

A4) Prosopografia dels cognoms que van repoblar Serra i Ria en 1609...........429

A5) Censos i dominis útils segons el capbreu del 1779 ..................................443

A6) Llibre de compte i raó del temple parroquial de Serra...............................449

A7) Índex d'instruments públics de les baronies de Serra i de Soneixa.............459

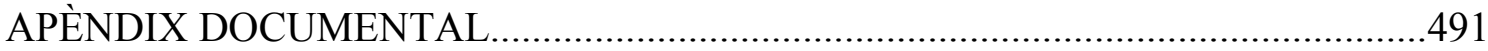




\section{INTRODUCCIÓ}

\section{APROXIMACIÓ I OBJECTIUS}

La ciutat de València i el pla al·luvial del Túria sempre han comptat amb una notable protecció muntanyenca pel nord: la que avui coneixem com a serra Calderona, una barrera natural que ha sigut element estratègic i defensiu al llarg de la història, particularment durant els diferents conflictes bèl-lics, ja des de temps medievals però, fins i tot en l'època contemporània, inclosa la darrera guerra civil ${ }^{1}$.

En mig d'aquesta barrera, la baronia de Serra, Ria i Armell ocupava la part central i meridional d'un corredor transversal o pas de muntanya, la importància del qual queda palesa, per una part, en l'abundància de restes arqueològiques trobades, especialment d'adscripció prehistòrica, ibèrica i romana, i per altra, en les restes arquitectòniques militars d'un sistema andalusí de torres i talaies depenent del castell de Serra i completat, cap al nord, pel castell de Torres Torres. Fins al segle XX va ser un camí de ferradura que en sentit nord-sud permetia atallar la ruta des d'Aragó cap al Cap i casal sense necessitat d'arribar a Sagunt. I recíprocament, permetia estalviar quasi mitja jornada de caminada per arribar des de València al camí d'Aragó, junt a Torres Torres o Arguines.

Els llocs de Serra i Ria van ser repoblats en 1609 -així ho recull la carta-poblamentre que Armell, alqueria que havia quedat despoblada un segle abans, va ser pràcticament ignorada en aquest procés, com despoblada quedaria també la població de Ria en poques dècades. En tot cas, la inclusió dels tres llocs: Serra, Ria i Armell en el títol de la Tesi queda plenament justificada perquè així es recull habitualment al llarg de la documentació històrica, especialment la de caire nobiliari i judicial.

La ubicació de Serra en aquest corredor i pas de muntanya, així com les seues estretes vinculacions amb Soneixa (baronia bessona i governada conjuntament pel mateix Senyor), Sogorb (etern litigant nobiliari per la possessió de Serra), Sagunt (partit judicial i vincle en alguns delmes) o Nàquera (parròquia compartida), entre altres llocs veïns, farà que lluny de ser una població aïllada, Serra mantinguera dins del seu creixement moderat un caràcter obert i molt relacionat amb el territori i les poblacions del seu entorn,

\footnotetext{
${ }^{1}$ Antonio M. Tenas: "La serra Calderona: de reraguarda de l'exèrcit de llevant a penúltima línia de defensa de València”. Saò, 392: 23-25. 2014.
} 
circumstància que he aprofitat en ocasions per tal d'exposar determinades dades en un marc territorial i comparatiu més ampli que el de la sola baronia.

Tanmateix cal destacar la proximitat i estreta vinculació de Serra amb la Cartoixa de Portaceli, el terme de la qual (un priorat), arran de la desamortització de Mendizábal, seria afegit novament al de Serra, tal com entenem que havien estat units, en un mateix districte castral, abans de que fora fraccionat pel rei Jaume I, segons queda palès a través del llibre del Repartiment. Aquesta circumstància justifica també l'ús freqüent que hem pogut fer de notícies procedents de fonts documentals de la Cartoixa.

Seguint les indicacions del professor Manuel Ardit Lucas, que va orientar-me en les primeres passes d'aquest recorregut històric sobre la comunitat rural i agrària objecte d'aquesta Tesi, no puc eludir referir-la a un marc que coincideix amb el títol d'una de les obres més conegudes obres: "els homes i la terra del País Valencià". Els homes en el seu significat més ampli i no sexista, com ell deixava aclarit, i la terra no només en el sentit feudal i històric de dualitat inseparable, jurisdiccional-territorial, home-terra, sinó també com a element d'estudi de camp, suport històric i vehicle de recerca per a la posta en valor del patrimoni cultural i històric. És per això que el primer capítol d'aquesta Tesi està dedicat a un coneixement més directe i històric-geogràfic sobre el territori, cenyintlo als seus límits històrics (antigues i modernes delimitacions i amollonaments), a la seua toponímia més rellevant des del punt de vista històric i als seus recursos naturals, que en definitiva han constituït el marc i la base del sosteniment de la colònia repobladora objecte de la nostra investigació.

Com tants altres llocs de la muntanya valenciana, la baronia de Serra quedaria completament despoblada degut a l'expulsió dels moriscos. Però, a diferència de la resta dels llocs despoblats, el seu repoblament fou immediat. De fet, la seua Carta Pobla, del 26 de novembre de 1609, la troben pràcticament com la primera que va ser atorgada amb èxit desprès de l'expulsió morisca del Regne de València. Aquesta carta de poblament, objecte del capítol segon, marca el començament de la colònia, però també les regles del joc, gairebé inamovibles, que havien de regir al llarg de més de dos segles, els dos segles i mig que han sigut objecte d'estudi durant la realització d'aquesta Tesi.

El títol de la Tesi és clar tant en l'objecte com del període de temps que abasta. L'objecte és la baronia, des de que naix en la nova etapa pobladora de 1609 fins que s'extingeix com a tal baronia, però el principal objectiu hem intentat que fora sempre l'evolució de la colònia repobladora, de les persones instal-lades a Serra i a Ria a 
principis del segle XVII i la seua evolució i transformació social fins arribar a la definitiva desaparició de l'Antic Règim. Però també ens ha interessat, de manera especial, intentar conèixer amb detall aquell procés final de reversió de l'antiga baronia a la Corona, el qual duria la formació d'un Ajuntament constitucional i l'alliberament per part dels serrans dels antics lligams senyorívols per a entrar en el nou marc social i legislatiu que marcaven els temps en aquells convulsos anys del segle XIX.

Les diferents fases del repoblament de la baronia, els canvis i les successions dels llinatges, la procedència i la diversitat cultural dels colons, el posterior despoblament de Ria, la vida social en aquest àmbit rural, les relacions amb els territoris veïns, els conflictes senyorívols, la distribució de la terra, les diferents tributacions i impostos, el creixement de la població i dels conreus, l'evolució de la producció i de les transformacions ocorregudes, especialment arran de l'abolició del règim senyorívol... han sigut tots ells objectius $i$ aspectes que hem intentat conèixer $i$ esbrinar per poder-los ara exposar en la present memòria de Tesi doctoral. L'objectiu últim ha sigut, per una part poder aportar un nou exemple i un referent particular com a contribució al coneixement del món rural valencià dels segles XVII i XVIII, en vespres de l'abolició de l'Antic Règim, però també, per altra part, un cas peculiar i potser atípic de com es va arribar a l'extinció efectiva del feudalisme d'una manera diferent a com es va produir en altres poblacions del mateix entorn geogràfic i altres comarques del País Valencià.

\section{METODOLOGIA, ARXIUS CONSULTATS I PLA DE TREBALL}

Desprès d'haver iniciat una aproximació prèvia (treball d'investigació dins del programa del DEA), en la qual esbossàrem el procés de repoblament i els canvis que es produïren durant les primeres dècades del segle XVII, pretenguérem aprofundir en la dinàmica d'aquest procés durant els segles posteriors. La principal hipòtesi de treball ha estat la continuïtat de les persones i els llinatges que, desprès d'aquell procés inicial habitarien ininterrompudament la baronia de Serra, adaptant-se a tots els canvis socials, polítics i tecnològics que anirien succeint-se al llarg dels següents dos segles i mig, passant pels canvis de la València foral al centralisme borbònic i, finalment, de l'Antic Règim a les transformacions liberals que havien de dur-los a la dissolució definitiva de la baronia com a tal al llarg del segle XIX. Com hem indicat adés, coneixem el punt de partida i sabem quin haurà de ser el punt d'arribada que ens espere. 
A més de la carta-pobla de 1609, el primer referent documental i fins a cert punt fil conductor de la investigació ha estat de vell antuvi el Quinque Libri de la parròquia de Serra (APS), l'estudi detingut del qual ens ha permès arribar a conèixer, amb un precís grau de detall, els protagonistes reals d'aquesta història local: els primers repobladors, aquells altres que els succeïren en el temps i llurs descendents.

La quasi absència de dades referides al període d'estudi -i encara anteriors a 1939- en l'arxiu municipal (AMS) ${ }^{2}$ s'ha presentat en tot moment com un autèntic repte, fent necessari recórrer a altres arxius on poder escorcollar fins trobar aquella informació complementària que ens ajudés a conèixer, deduir i reconstruir les condicions, els esdeveniments i els modes de vida d'aquella colònia repobladora nascuda en 1609 i alliberada dels lligams del feudalisme dos segles i mig desprès.

La metodologia de treball s'inicia amb un típic procediment d'investigació històrica que comença i passa per les consulta i recerques en diferents arxius, en molts dels quals hem trobat referències i dades d'interès sobre Serra. Concretament han estat consultats (amb resultats positius) i citats degudament al llarg de la Tesi els següents:

ABV Arxiu històric de la Biblioteca Valenciana

ACV Arxiu de la Catedral de València

ADPV Arxiu de la Diputació de València

AD-AV Arxiu Diocesà (Arquebisbat de València)

ADM Arxiu Ducal de Medinaceli (fons duplicats a la Fundació "Caja Segorbe")

AHN Archivo Històrico Nacional (Madrid)

AHN, SN Archivo Histórico Nacional, Sección Nobleza (Toledo)

AHPZ Archivo histórico de la Diputación provincial de Zaragona

AMS Arxiu Municipal de Serra

APCC Arxiu Protocols notarials del Corpus Crhisti (col·legi-seminari del Patriarca)

APS Arxiu parroquial de Serra

ARSEAPV Arxiu de la Real Sociedad Económica de Amigos del País de Valencia

ARV Arxiu del Regne de València

També incloem alguna referència concreta $\mathrm{i}$ abreujada a documents de la Biblioteca històrica de la Universitat de València (BHUV) i algunes cites puntuals a

\footnotetext{
${ }^{2}$ L'arxiu municipal de Serra va ser cremat entre els dies 15 i 16 de setembre de 1936. Així ho comunicava l'alcalde, Sixto Català, al president de la Diputació Provincial mitjançant un escrit de 20 de setembre d'aquell any: "fue asaltada la Casa Ayuntamiento de este pueblo por unos desconocidos, los cuales se llevaron toda la documentación completa que existía archivada, la cual fue quemada por los mismos en la calle de Blasco Ibáñez de este pueblo". ADPV, Diputació, E.08.02, 1936 exp. 5.
} 
determinats documents referenciats en arxius que no hem arribat a a consultar però que són suficientment coneguts, com és el cas de l'arxiu general de Simancas (AGS).

Com a principals fonts d'informació, a més de l'esmentat APS, cal destacar la part de l'arxiu del duc de Montellano relativa a les seues possessions en el Regne de València, entre les quals es troben les baronies de Serra, Soneixa i Assuévar; aquest fons, prou discontinu, forma part de l'AHN, SN (de Toledo), dins dels documents de la casa de Fernán-Núñez. Per no caure en referències massa llargues i repetitives, des d'ara farem referència a aquests fons senyorívols de Serra com AHN-FN (fons de la casa FernánNúñez de l'AHN, Secció Noblesa). També hem trobat interessants referents i fonts d'informació en els protocols notarials de Joan Font (APCC), per a les primeres dècades del segle XVII i en els de Miquel Conejos (dos notaris, pare i fill) que abasten finals del segle XVIII i les dues primeres dècades del XIX (ARV). També l'ACV ha proporcionat una llarga i interessant sèrie cronològica com és la dels delmes de la parròquia de Serra $\mathrm{i}$ Nàquera.

A banda dels arxius citats, també he tingut l'oportunitat d'accedir a certs documents privats i personals que no formen part de cap arxiu oficial, si bé hem iniciat gestions a través de l'Ajuntament de Serra per poder-les acollir, bé directament o almenys en còpia, dins un apartat "històric" de l'arxiu municipal. Es tracta de documents i materials solts, en poder de persones particulars, que bé per herència, bé per rescat en demolicions o buidats d'immobles familiars o bé per recerca i adquisició en mercats d'ocasió i rastre, llibreries de vell o per internet, han pogut ser localitzats i rescatats amb la intenció de treure'ls de l'oblit i/o la destrucció, per tal de poder-los donar el valor històric i patrimonial que realment tenen. Aquesta és una tasca de recerca que hem iniciat de manera incardinada amb el desenvolupament de la present Tesi doctoral. Per poder citar -com ho he fet ocasionalment- de manera adient algunes d'aquestes fonts disperses, he optat per referir-les amb les sigles DP (dipòsit particular o personal) seguides del nom (sigles entre parèntesi) de la persona que actualment custòdia el document, Cal advertir, per tant, que es tracta d'unes sigles provisionals i transitòries, fins que aquests fons puguen ser degudament classificades i organitzades en un únic arxiu històric, com desitgem: DP(RAN) correspon a Remigio Arnal Navarro, DP(RAT) a Rafel Arnal Torres, $\mathrm{DP}(\mathrm{ADN})$ és Àngel Domingo Navarro, DP(JCN) és José Cabo Navarro i DP(PGM) és qui açò subscriu. 
Amb tota la informació recollida, recercada i estudiada, el pla de treball ha continuat amb l'anàlisi i interpretació de les dades i amb el replantejament de possibles noves hipòtesis de treball, fins arribar finalment a les discussions i conclusions que conformen i acaben donant cos a la present Tesi doctoral.

\section{ANTECEDENTS HISTORIOGRÀFICS SOBRE SERRA}

Poder llegir el treball realitzat fa més d'un segle per Félix Iquino Parra sobre la història de Soneixa (Iquino, 1982), les notes que Ambròs Cebrián escrigué fa també un segle sobre Serra (a les que em referiré tot seguit) o el magnífic estudi de la baronia de Nàquera fet per Emili Lluch (conclòs en 1945) han sigut per al doctorant que açò escriu un estímul i una gran font d'inspiració. Per això, aquest epígraf vol ser el reconeixement al treball que feren persones que no he conegut en vida però que he admirat sempre.

El primer text historiogràfic conegut sobre el poble de Serra potser siga el que va citar Josep Sanchis Sivera (1922: 387) quan parla de Serra en el seu Nomenclàtor: "se ha escrito Monografia histórica y geográfica de Serra, por D. Ambrosio Cebrián Santos, trabajo que está inédito". Malgrat no haver pogut localitzat l'original exacte d'aquella monografia, la seua recerca em conduí a trobar un mural inèdit realitzat per Ambròs Cebrián en 1911, amb el títol Serra: notas geogràficas e históricas, del qual publicàrem el text de la part històrica (Garay i Peris, 2002).

Poc desprès de la mort d'Ambròs Cebrián, en 1933, l'Ajuntament de Serra li va rendre homenatge i li dedicà un retaule ceràmic que encara es conserva en la façana de la que fou sa casa, en el número 33 del carrer de Sant Josep. En el discurs que amb aquell motiu va pronunciar el seu amic i deixeble Emili Lluch Arnal (cronista del veí poble de Nàquera) es va comprometre públicament a recollir i enllestir les notes que sobre la història de Serra tenia escrites el seu mestre. I així, en 1935 va donar a l'ajuntament de Serra un manuscrit, que es conserva encara inèdit i que duu per títol Apuntes $i$ notas para la historia de Serra. Aquestes notes, citant-ne com a autors a Emili Lluch Arnal i a Ambròs Cebrián y Santos, van ser àmpliament utilitzades i aprofitades per Josep Senís i Domingo (1954) en la seua publicació Serra. Apuntes para su historia, obra que va ser reeditada (revisada i augmentada) en l'any 1978.

Pel que fa a la història de Portaceli hi ha tres obres fonamentals (extensibles també a molts aspectes de la història de la baronia de Serra): La Cartuja de Porta-Coeli (Tarín y Juaneda, 1897), Cartuja de Portaceli. Historia, vida, arquitectura y arte (Fuster, 
1994; reeditada i ampliada en 2003) i Los Anales de la Cartuja dePorta-Coeli (Ribes, 1998).

El conjunt de les aportacions fetes al llarg de les darreres dècades per Andrés Ferrer Taberner, formen una obra dispersa però de gran interès que precedeix cronològicament a la que nosaltres estudiem: la Serra morisca i mudèjar. Més properes a la cronologia que hem tractat hi ha tres bons treballs que hem aprofitat: l'article que Ferran Martínez Navarro va presentar en el I Congrès d'Història del País Valencià (1976): "Estudi epidemiològic de la mortalitat infantil i pre-escolar a Serra des de 1620 a 1679”, i els treballs de Miguel Àngel Rodríguez Rodríguez, un sobre "la Carta pobla de Soneixa i Assuévar. Estudi preliminar" (2009) i un altre sobre els "Plets successoris de la casa de Cardona..." (2012).

Hi ha moltes altres referències $\mathrm{i}$ contribucions que esmentarem oportunament quan pertoqui, al llarg del present text. Però, cal fer també un advertiment, en el sentit de que hi ha un gran desencert i reiterades i arrossegades confusions quan es parla de la veu Serra en enciclopèdies, diccionaris i altres obres col·lectives, en les que és freqüent atribuir la senyoria de Serra, equivocadament, a nobles com Bernat Horta, Roderic de Sant Adrià, els marquesos de Boïl o els de Cerdanyola... tots ells nobles que mai no la posseïren. Darrere d'aquestes confusions hi ha raons diverses, com la pluralitat del topònim Serra al llarg de la geografia valenciana -i també fora d'ella- i la manca de rigor en copiar referències sense contrastar-les. Sobre aquest problema vam publicar un article aclaridor (Garay, 2010).

\section{AGRAÏMENTS}

La meua aproximació al món acadèmic de la Història tingué la sort de ser nodrida per la mestria d'un extraordinari expert i una excel·lent persona, el professor Manuel Ardit Lucas, a la memòria del qual vull expressar el meu primer i sincer agraïment.

També vull estendre el meu agraïment a totes/tots els tècnics i personal de sala de tots els arxius que he consultat, doncs sempre m'han atès amb cordialitat i eficàcia.

Quede també agraït a totes les persones de Serra que d'una manera o altra m'han ajudat aportant-me informació o compartint l'entusiasme per descobrir la nostra història. No puc citar-los a tots per manca d'espai i risc d'omissió, però mantinc un record especial i emotiu per la memòria dels que se'n anaren, alguns dels quals he citat en el text. No oblide tampoc la important disposició i ajuda que he rebut de Vicent Baño, de Beatriz 
Santamarina i molts altres informadors i amics; com també de Benjamín García, anterior rector parroquial, per l'entusiasme posat per a que poguera estudiar l'APS i per al seguiment de les obres que durant la seua etapa es van fer en el temple de Serra.

Àngel Domino Navarro és una persona important, d'eixa mena de persones que bé per sana curiositat o bé per convenciment tenen la llum i l'actitud positiva de rescatar de l'oblit, de l'abandó o de l'abocador papers i documentació inservible, rebutjada, a punt de ser destruïda..., i pensen que allò és història i podria tindre un altre destí més adient en un arxiu local. Persones com ell ens ajuden a estimar i valorar la història. Gràcies Àngel.

Gràcies també als amics Cronistes Ferran Zurríaga Olocau), Juan Corbalán de Celis i Joaquín Díez (Çtorres Torres), Eduardo Tello (Gàtova), Patxi Guerrero (Sogorb), Lluís Mesa (Estivella) Benjamín Escriche (Soneixa), col·laboradors infatigables.

Dos companys esplèndids: Miquel Àngel Rodríguez, el investigador de Soneixa, i Alexandre Navarro i Tomàs, bon amic i gran estudiós de Nàquera i del llenguatge, per les seues valuoses aportacions. Moltes gràcies!, als dos.

La confiança rebuda de dos catedràtics de la Jaume I, Ignacio Morell Evangelista i Juan José Ferrer Maestro va ser decisiva per a que aquesta Tesi tirara endavant en un moment crític. Dels companys del Departament d'Història, Geografia i Art he rebut sempre suport i ajuda. A tots ells vull expressar el meu reconeixement i agraïments.

José Antonio Piqueras Arenas no és solament un magnífic director de Tesi, al que dec la major part dels encerts $\mathrm{i}$ de qui he rebut una magnífica ajuda i estímul en tot moment. A ell he d'agrair encara coses més importants, com és la confiança que ha dipositat en mi i la seu contagiosa i magnífica capacitat de treball.

Haver deixat per al final el meu agraïment a la família, la gran sacrificada en aquests casos, no ho he fet perquè no tinguen relació directa amb el contingut de la Tesi, més bé al contrari. A banda de ser la part més important dels meus agraïments, tots ells han participat activament en etapes concretes de la investigació. Robert i Andrea són sensacionals i van ser-ho especialment bussejant aquell estiu entre els protocols notarials de Miquel Conejos, buidant topònims. Guillem ha sigut el meu "assessor personal" en temes informàtics (no cal insistir dient què dur és això). Mon pare i els seus 91 anys de lluïda i precisa memòria han sigut una inexhaurible font de dades, la història viva. I Alegria, la part fonamental, la més important, perquè sense ella tot açò de la Tesi i la meua lluita personal haguera quedat en res. T'estime. Vos estime. 


\section{CAPÍTOL 1}

\section{EL TERRITORI DE LA BARONIA I DEL TERME MUNICIPAL}

\subsection{PARTICIÓ D’UN DISTRICTE CASTRAL MUSULMÀ EN TRES SENYORIES CRISTIANES}

L'actual terme municipal de Serra està format pel territori de l'antiga baronia de Serra (Serra, Ria i Armell) i l'agregació que entre 1835 i 1837 se li va fer del terme del priorat de Portaceli arran de la desamortització de Mendizábal. ${ }^{1}$ Malgrat que no coneixem documentalment $\mathrm{i}$ amb detalls els motius concretes que conduïren a aquesta decisió d'afegir a Serra l'antic priorat, sembla que no degueren ser únicament raons de proximitat geogràfica, sinó sobre tot d'antecedents històrics que es remunten fins a l'època del procés de repartiment territorial que feia el rei Jaume I segons avançava la conquesta del Regne de València. El fet d'introduir ací un assumpte tan remot com és el Repartiment del segle XIII, aparentment prescindible dins el tema concret de la present tesi, té la seua importància i, realment, com anirem veient i demostrant, la seua transcendència a l'hora de posar fi al règim senyorívol respecte a la baronia de Serra, permetent de pas posar fi a llargs conflictes nobiliaris i reivindicacions territorials que havien anat arrossegant-se durant més de 500 anys.

Per això, ve a compte fer observar, en primer lloc, que el procés de repartiment de Lullén (Portaceli), Nàquera i Serra va ser una estratègica maniobra de divisió d'una antiga demarcació o districte castral andalusí, que estaria suposadament governat des del Castell de Serra (o hisn d'Axerra), del qual eren dependents diversos llocs i alqueries ${ }^{2}$. Tot prenent com a punt de partida els assentaments del Llibre del Repartiment i altres dades concordants i posteriors, sembla clar que devien pertànyer a la demarcació del castell de Serra, al menys sis (potser set) nuclis de població: per una part, la "vila de

\footnotetext{
${ }^{1}$ Decret de dissolució de les ordes religioses (11 d'octubre de 1835), Decret de desamortització dels bens de les ordes religioses (19 de febrer de 1836) i desenvolupament d'aquest procés fins a 1837.

${ }^{2}$ Tal com observa Enric Guinot ("La creació de les senyories en una societat feudal de frontera: el Regne de València", Rev. d'Història Medieval, 8: 79-108. Dep. H. Medieval, Univ. València, 1997), Jaume I va aprofitar freqüentment, en la seua estratègia d'ordenació i delimitació territorial, l'organització del territori que hi havia abans de la conquesta, però si bé en ocasions (quan li va interessar) donà en senyoria tot el territori que havia sigut d'un mateix districte castral musulmà, altres vegades el fragmentà, fent de cadascuna de les alqueries una senyoria feudal diferent.
} 
Serra" i per altra, les alqueries de Ria, Armell, Nàquera, Lullén i una altra més, el nom de la qual desconeixem. Amb dubtes, potser que també pertanyera encara al districte del castell de Serra l'alqueria de Rocafall, de la qual parlaré desprès explicant-ne els motius. La FIGURA 1.1 mostra la distribució espacial de tots aquests nuclis de població. Són tots ells alqueries i nuclis de població que anaren despoblant-se i desapareixent progressivament, a excepció de Nàquera i de Serra, els dos nuclis més importants per haver sigut caps de sengles baronies i finalment municipis.

El llibre del Repartiment ${ }^{3}$ permet seguir el procés de fraccionament que va fer Jaume I d'aquest suposat districte castral quan, primer feu donació, al cavaller Gil d'Atrossil, de l'alqueria de Nàquera de la Serra (abril de 1237) i desprès li donà a Gil de Rada l'alqueria d'Alule (Lullén) iuxta Serram (gener de 1238); de tal manera que, quan finalment li dóna a Berenguer Burguet el castell i la vila d'Axerra (Serra) amb llurs alqueries (el 4 d'agost de 1238), ho farà ja excloent-hi tant l'alqueria de Nàquera com les de la vall de Lullén, per haver-les repartit prèviament. Dos anys desprès (1240), com que Berenguer Burguet no va vindre a prendre la possessió de Serra, el rei li revocà la donació, al temps que en feia una nova: la donació conjunta dels castells de Serra i de Torres Torres, amb llurs alqueries, a Galter de Roma, que serà el seu posseïdor discontinu (alternant amb la Corona) fins a l'any 1271, en que els dos castells (Serra i Torres Torres) i llurs dominis passaran definitivament a Bertran de Bellpuig i als seus descendents.

Un altre personatge, Ximén Pereç (reboster del Rei) que era senyor d'Andilla, es va convertir en el segon propietari de la vall de Lullén, per un pacte de canvi que va concretar amb el seu primer posseïdor. Finalment, amb consentiment i autorització expressa del rei Jaume I, la vall de Lullén seria adquirida en 1272 pel bisbe de València, Andreu Albalat, amb la finalitat de fundar en ella la cartoixa de Portaceli, com de fet es va fer aquell mateix any ${ }^{4}$.

En definitiva, l'antic districte musulmà del castell de Serra resultaria coincident, a grans trets, amb la suma dels actuals termes de Serra i de Nàquera, confrontant per l'est amb els castells de Beselga (Beselga i Estivella) i de Segart (Segart i Albalat), pel sud amb els

\footnotetext{
${ }^{3}$ He seguit l'edició de Vicent Garcia Editors (any 1979): Llibre del Repartiment de València, 2a edició, dirigida per A. Ferrando i amb transcripció de J. Camarena-Mahiques, L. Cerveró, J. Corell, A. Ferrando i J. Villalmanzo.

${ }^{4}$ Sobre la fundació i història de Portaceli resulten fonamentals els treballs historiogràfics de Francisco Tarín y Juaneda (1897) i de Francisco Fuster Serra (1993; amb una segona edició, lleugerament ampliada, de 2003), als quals em referiré en nombroses ocasions.
} 
de Montcada i Bétera (Bétera i Bofilla), per l'oest amb el d'Olocau (Olocau, Marines, Gàtova...), i pel nord amb els de Sogorb i Torres Torres (incloent aquest les alqueries d'Algímia i Alfara). Per consegüent, serà a partir de la conquesta cristiana del regne de València, que Nàquera es convertiria en una senyoria separada $\mathrm{i}$ independent de la de Serra i el seu antic districte castral, al temps que la vall de Lullén, que també havia estat separada (convertint-se en una possessió religiosa, en 1272) tornaria a ser afegida, finalment, al nou terme municipal de Serra després de la supressió de les ordes religioses i la desamortització dels seus bens a partir de 1835.

FIGURA 1.1.- Ubicació del Castell de Serra (estrella), la vila de Serra (quadrat) i les diferents alqueries (cercles), en relació amb el terme municipal de Serra (línia negra).

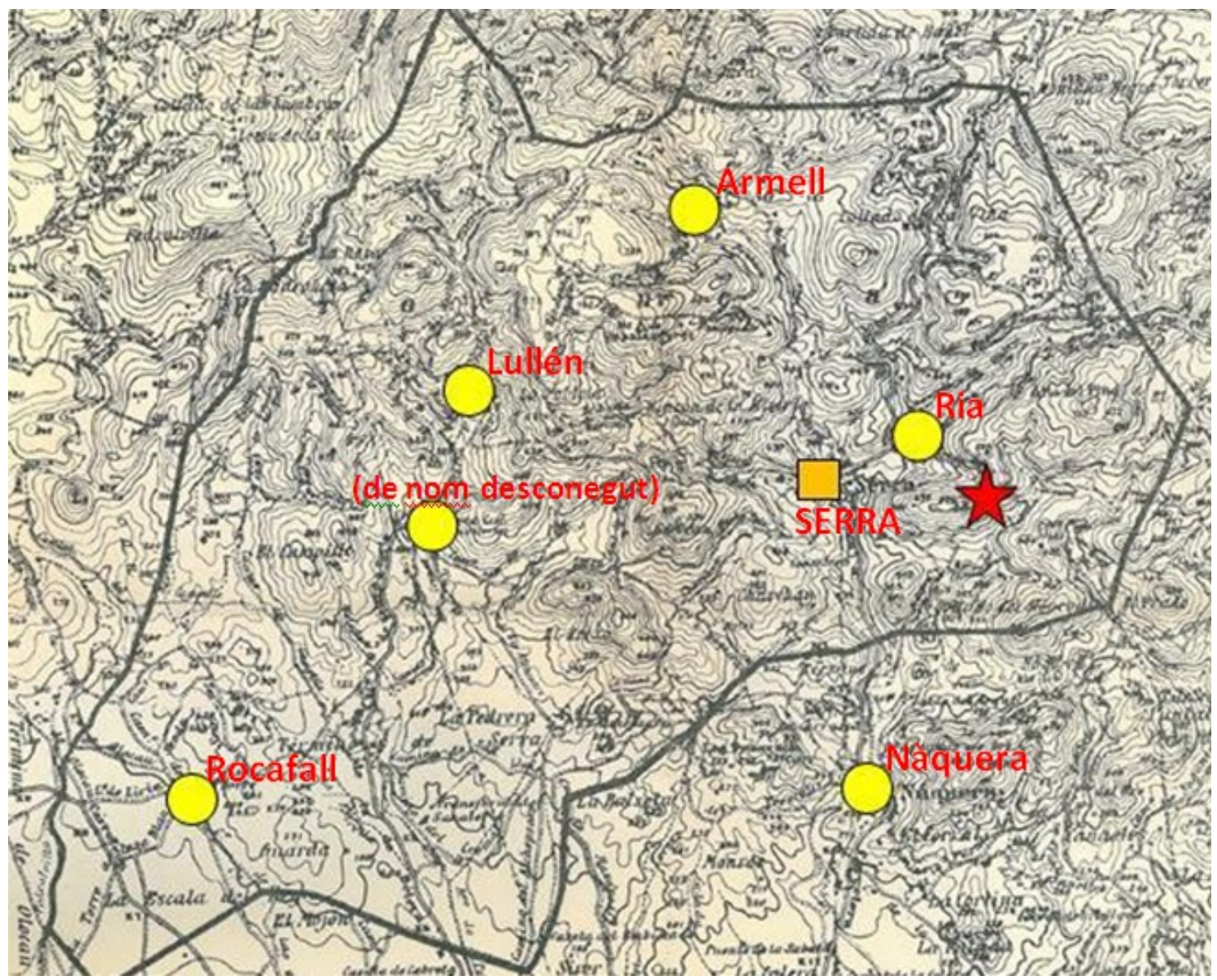

Elaboració pròpia sobre base del IGN.

En tot cas, el fet de que la senyoria de Serra passés per donació jurisdiccional a mans d'un noble o cavaller, per donació reial, i que tornara diverses vegades a la corona, fins a noves donacions, he d'insistir en que és un antecedent d'especial importància i 
consideració quan, sis segles després, es pretén la seua reversió a la Corona. Aquest és un aspecte que tornarem a tractar i analitzar més endavant.

\subsection{MARC TERRITORIAL A COMENÇAMENTS DEL SEGLE XVII}

Amb la FIGURA 1.2 hem volgut posar de relleu, per una part, les tres principals rutes reials de l'entorn de la serra Calderona (fletxes en traç blau continu), que serien el camí d'Aragó (per Terol) seguint la vall del Palància, el camí de Barcelona (i del Principat, equivalent a la tradicional Via Augusta) i el camí de Llíria (i de les terres altes del Túria). També he indicat tres rutes o passos de muntanya (blau discontinu) que des del camí d'Aragó permeten atallar cap a València sense necessitat d'arribar fins a Sagunt.

Per altra part, també indiquem tot numerant-los en la mateixa figura, els diferents termes i possessions que abastaven al conjunt de la serra Calderona a principis del segle XVII (i pràcticament fins a mitjans del XIX). Tots aquests termes vénen a ser el marc de referència més proper i històricament més vinculat a la baronia de Serra. He triat aquest moment cronològic (vespres de l'expulsió morisca i primers repoblaments posteriors) per ser, precisament, el punt de partida del present treball d'investigació.

En el centre d'aquest territori queda indicat amb el número 8 el terme de l'antiga baronia de Serra i junt a ell, marcat amb el número 9, el terme del priorat cartoixà de Portaceli. Just al nord, el número 4 correspon a la baronia de Torres Torres, de la qual depenien les alqueries (hui municipis) d'Alfara de la Baronia i Algímia de la Baronia (altrament dites Alfara d'Algímia i Algímia d'Alfara).

El número 1 indica la baronia de Soneixa (Soneja) amb Assuévar (Azuébar), molt estretament lligada a Serra per ser totes dues possessions del mateix senyor territorial, pràcticament des del segle XV. És per això que trobem nombroses referències documentals conjuntes, com també circumstàncies i situacions a sovint molt semblants. Assuévar era la població que posseïa un castell (hisn andalusí), mentre que Soneixa va ser la població principal (més poblada i millor comunicada) on residiren els senyors (de Serra i de Soneixa), almenys en bona part del segle XVII.

Les baronies de Sot de Ferrer (número 2, junt a Soneixa) i d'Algar del Palància (número 3, junt a les alqueries de Torres Torres) les hem trobades citades en alguns documents relatius a Serra, sense més relació que la mera proximitat. 
FIGURA 1.2.- Mapa dels termes, seglars i religiosos, de la serra Calderona a començaments del segle XVII, segons les dades publicades per Boronat (1901).

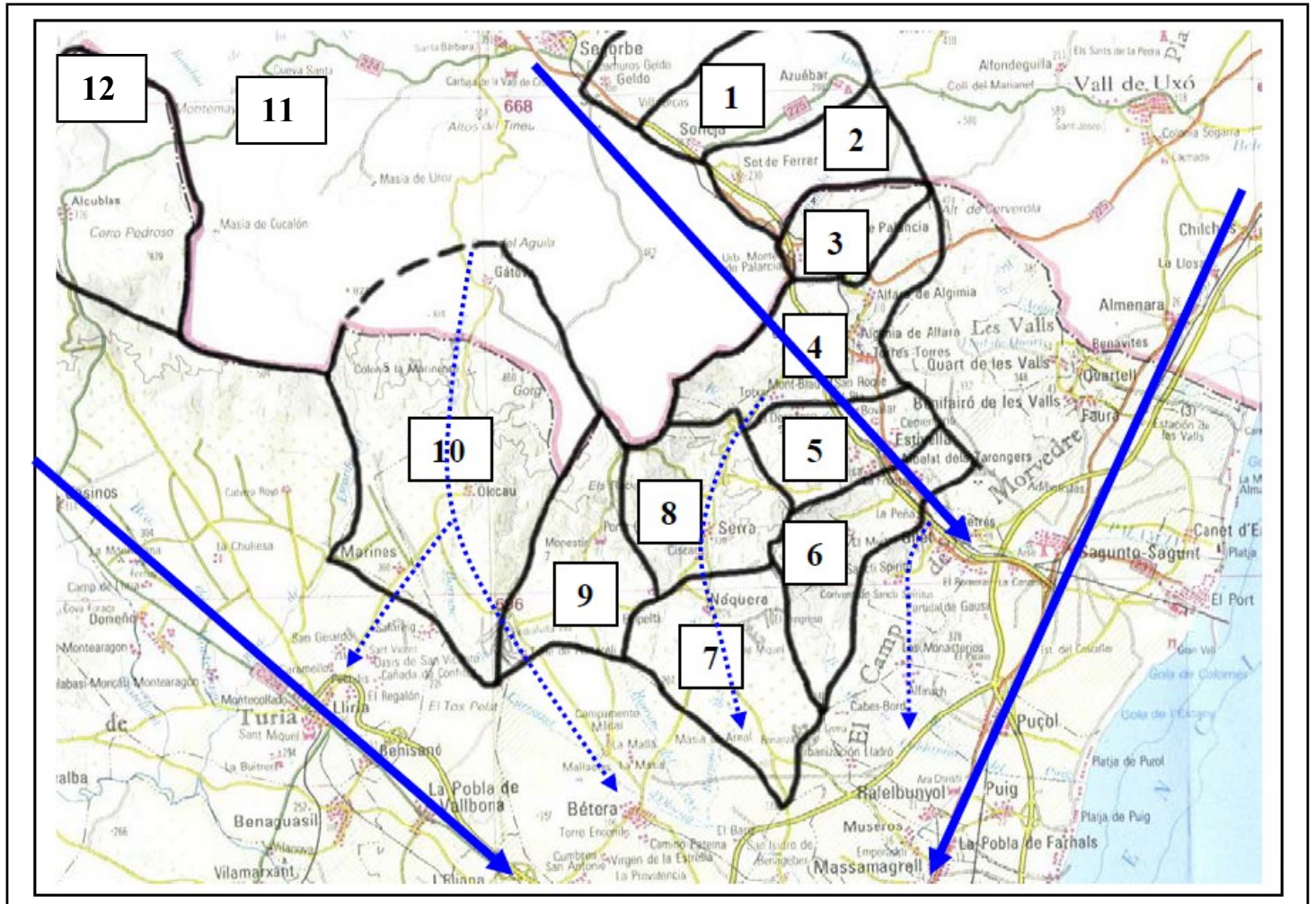

Les fletxes grans indiquen les principals rutes carreteres i les puntejades els principals passos de ferradura de la serra Calderona (per Olocau, per Serra i per Sant Esperit).

(dibuixat sobre el mapa prov. València 1:200.000 del IGN)

Més properes, però, a Serra i indicats amb els números 5 i 6, trobem encara, per l'est, els llocs de Segart amb Albalat (baronia d'Albalat dels Tarongers o de Segart; ambdues denominacions les trobem en el període estudiat) i de la baronia d'Estivella (amb Beselga). El mateix que passava en Assuévar, respecte a Soneixa, també Segart i Beselga eren llocs que posseïen sengles castells (husun), mentre que Albalat i Estivella van ser (respectivament) les poblacions que albergaven la casa senyorívola (en el cas d'Albalat una fortificació més important) i tingueren un creixement major.

Al sud de Serra, la baronia de Nàquera (número 7) destaca per la proximitat (només tres quilòmetres separen el nuclis urbans de Serra y Nàquera). Per aquesta raó $\mathrm{i}$ per damunt de la típica "rivalitat" entre pobles tan pròxims, les relacions i connexions entre els seus habitants (incloses les familiars) sempre han existit. A més a més, destaca el fet de que les dues esglésies pertanyeren a una mateixa parròquia i rectoria fins el 1897. 
A l'oest de Serra (número 10 del mapa), els pobles de la vall d'Olocau (Olocau o Pardines, Marines, Gàtova, Olla i altres llogarets menors, que quedarien despoblats) completen el conjunt de senyories i baronies de la serra Calderona que, per proximitat, més vinculació han mantingut històricament amb Serra.

El terme i ducat de Sogorb, indicat amb el número 11, no només confronta directament amb la baronia de Serra, pel nord, sinó que els seus senyors (els ducs de Cardona i de Sogorb) pledejaren llargament amb els senyors de Serra i Soneixa per la possessió d'aquestes baronies.

He indicat encara, amb el número 12, el lloc d'Alcublas (en documentació antiga més conegut com les Alcubles) que junt amb el d'Altura conformaven les principals possessions de vassallatge que tenia la cartoixa de Vall de Crist (monestir que estava ubicat dins l'actual terme municipal d'Altura). De les Alcubles hi destaca un fet rellevant, com és que la major part dels cristians vells repobladors de Serra desprès de l'expulsió morisca, procedia d'aquest lloc. A més a més, es mantingueren contactes i relacions familiars entre Serra i les Alcubles durant vàries dècades, a més d'alguna proximitat a través dels vincles entre les dues cartoixes associades: Porta Coeli i Val de Christ.

Cal no oblidar, encara, en aquest marc de referència, la proximitat i les connexions històriques de les baronies de Bétera i de la Pobla de Vallbona (tradicionalment la Pobla de Benaguasil o Benaguatzir) respecte a Serra i a Portaceli; com també, especialment des del segle XIX, la vinculació amb Sagunt (cap del partit judicial al qual pertanyia Serra).

Abans de concloure amb aquest marc geogràfic i històric de referència, cal dir que, malgrat que Serra "pertany" actualment a la comarca del Camp de Túria i al partit judicial de Llíria, i que la seua connexió ferroviària més pròxima és la de Bétera, la vinculació tradicional i històrica de Serra ha estat en genera molt més vinculada a altres territoris naturals o comarques, com són:

L'Horta: una gran part de l'economia serrana depenia de l'eixida dels productes de la terra i la destinació principal d'aquests productes era la ciutat de València $\mathrm{i}$ en menor mesura altres pobles del seu entorn. Així ho hem conegut a través dels documents històrics, de la memòria tradicional i de les històries de vida. Encara es manté bon record de les llargues caravanes que cada dia traslladaven cap al portal dels Serrans (València) els productes del camp, a més 
de molta llenya (entre altres per als forns de ceràmica de Manises o els forns de calç de Montcada i de Godella) i molta aigua de les fonts de Serra. ${ }^{5}$

El Camp de Morvedre: especialment els aspectes legals i judicials, registres, etc. (partit Judicial de Sagunt) i també de recaptació, com era el cas dels delmes del Carnatge de Morvedre, al que pertanyia Serra.

L'Alt Palància: Soneixa (i altres pobles de la comarca de Sogorb) tenien a Serra com a pas referent del camí (de ferradura) cap a València. Però també, la comarca $\mathrm{i}$ el terme de Sogorb eren els llocs d'entrada de molts ramats transhumants, procedents de les comarques aragoneses de Javalambre i Gúdar; especialment per la ruta pecuària que entra al terme de Serra entre els de Gàtova $i$ Sogorb. També, molts habitants de Serra eren posseïdors i cultivadors de terres situades fora del seu terme, particularment en el de Sogorb (partides de la Garriga, Falaguera i Penya Blanca).

\subsection{DELIMITACIÓ I MOLLONS DEL TERME MUNICIPAL DE SERRA}

La delimitació actual del terme municipal de Serra té com a referència el suport de 63 fites o mollons històrics, que són els recollits en el mapa municipal a escala 1:25.000, de 1'any 1938, del Instituto Geográfico y Catastral. Nou d'aquests mollons tenen actualment el caràcter de trifinis (triangles rojos de la FIGURA 1.3) i altres dos (triangles grocs) també ho foren en el passat, definint els límits de Serra i de Portaceli amb Sogorb, per una banda, i amb Nàquera, per altra. Per identificar i descriure els 63 mollons he optat per numerar-los tot començant pel més septentrional de tots $i$ he seguit un ordre correlatiu dextral (cap a la dreta, seguint el sentit de gir horari). D'aquesta manera, els actuals 9 mollons trifinis són: MT1, MT9, MT15, MT20, MT23, MT43, MT49, MT50 i MT59, mentre que els dos trifinis històrics són: M7 (antic MT7) i M39 (antic MT39). Aquesta enumeració de mollons, que tan senzilla i segura pareix, no estigué exempta en els segles passats de determinades complicacions i tensions entre les diferents parts, diferències que aniré comentant oportunament en les descripcions que segueixen.

Les referències del diferents actes de delimitació i amollonament, que he consultat, tant de la baronia de Serra, com del priorat de Portaceli i també, a partir de

${ }^{5}$ Beatriz Santamarina i Julio Bodí (2014) Cobijarse en la tierra y la montaña. Memoria, trabajo y paisaje en la Sierra Calderona. Univ. de València. 
1835 del terme municipal de Serra, venen indicades en el QUADRE 1.1, ordenades cronològicament.

QUADRE 1.1.- Relació d'actes de delimitació de termes que afecten a Serra i a Portaceli. ANY TERMES AFECTATS REFERÈNCIA DE LES DADES

\begin{tabular}{|l|l|l|}
\hline 1325 & Olocau-Portaceli & ARV, Reial justícia, 809/24 \\
\hline 1338 & Serra-Portaceli; sentència arbitral & AHN, Cler, 7469 \\
\hline 1451 & Serra-Portaceli & AHN, cler, 2038/12 \\
\hline 1455 & Nàquera-Portaceli & $\begin{array}{l}\text { AHN, cler, 3188/8 / també Arxiu } \\
\text { Comte de Plasència (Lluch, 2002) }\end{array}$ \\
\hline 1506 & Olocau-Portaceli & Publicats per Zurriaga (2004) \\
\hline 1662 & Olocau-Portaceli & Tarín (1897): APCC, not. Arcos \\
\hline 1737 & Sogorb-Portaceli i Sogorb-Serra & ADM, L-2/76 \\
\hline 1788 & Tota la baronia de Serra & $\begin{array}{l}\text { AHN-FN, 262/27 i altres; } \\
\text { ARV, protocols, lg. 3630 (Conejos) }\end{array}$ \\
\hline 1806 & Olocau-Portaceli & Publicats per Zurriaga (2004) \\
\hline 1826 & Nàquera-Serra & A. comte Plasència (Lluch, 2002) \\
\hline 1844 & Serra-forest de Portaceli & ADPV, C.2.1., caixa 10 \\
\hline 1847 & Torres Torres-Serra & ARV, protocols, lg. 3824 (Lorente) \\
\hline
\end{tabular}

Elaboració pròpia basada en la recerca d'arxius i fonts.

A més d'aquests actes de delimitació, també hi resulten de gran utilitat els expedients sobre conflictes dels límits de confrontació entre termes. Per una part són dignes de destacar els plets territorials haguts en el segle XIV entre la baronia de Serra i el priorat de Portaceli. Així, en 1327 es va produir el de "la Contenda", que en principi només semblava afectar als termes de Nàquera i Serra i als seus senyors, Hug de Bellpuig i Gil Martínez d'Entensa (Carreres Zacarés, 1930), però desprès acabà implicant-se Portaceli. En 1347 es va produir un altre plet pel "bovalar de Serra". ${ }^{6}$ Y en 1372 tindria lloc un tercer plet, ara pel "bovalar de La Pobleta". 7

El quadre anterior també inclou les referències al treball de Zurriaga (2004) que recull la descripció dels mollons corresponents a ls delimitacions de 1506 i de 1808, procedents de l'arxiu del comte d'Olocau (Son Berga, Mallorca).

\footnotetext{
${ }^{6} \mathrm{AMV}$, manual de consells, A-7.

${ }^{7}$ De rebus monasterii Porta-Coeli, ep. 67. Ribes, 1998.
} 
FIGURA 1.3.- Delimitació del terme municipal de Serra.

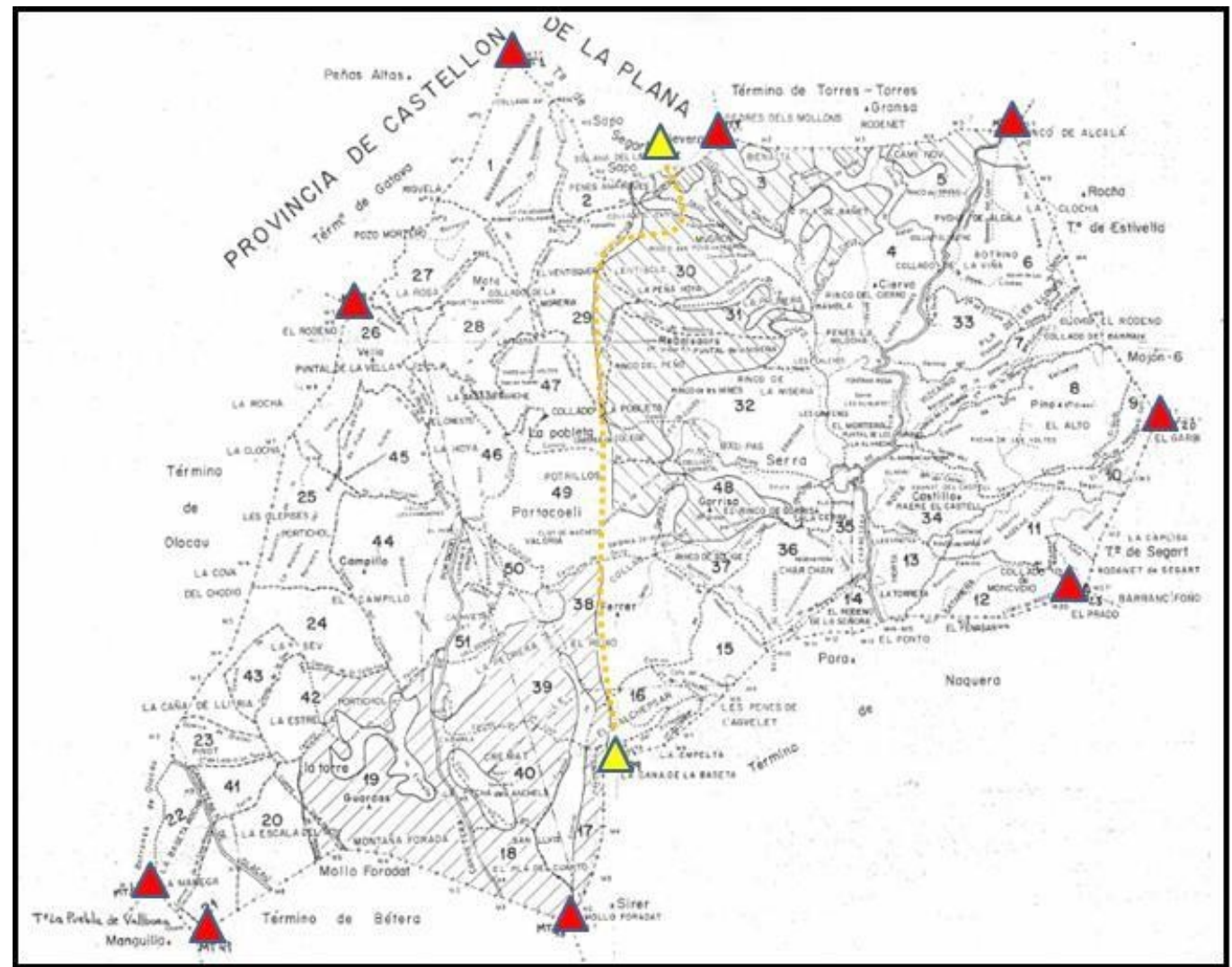

Elaboració pròpia sobre la base de la cartografia cadastral de l'any 1938, a escala 1:25000. Els números indiquen els polígons cadastrals; els triangles rojos són els mollons Trifinis i els dos triangles grocs als trifinis entre Serra i Portaceli.

Els 63 mollons vénen enumerats i descrits en l'Annex I, on han estat també indicades les correspondències entre aquests números i els de les diferents descripcions $\mathrm{i}$ referències històriques. Aquests mollons, quasi tots citats, un per un, en els documents esmentats (a manca dels mollons centrals que confronten amb Estivella i Segart), entenem que són les autèntiques i realment definitòries fites del terme municipal de Serra. Les hem seguides sobre el terreny, documentant i catalogant bona part dels mollons que encara es conserven, comprovant que originalment estaven tots fets de pedra i morter. No obstant, hem trobat que alguns d'ells havien desaparegut, potser intencionadament o per abandonament, altres (la major part) estaven mig destrossats o molt malmesos (FIGURA 1.4). Per tal de que puguen seguir fent la seua funció es fa absolutament necessari procedir a la seua restauració i recuperació quan encara es pot identificar bé l'emplaçament i les seues restes. 
FIGURA 1.4.- Restes del molló trifini (MT9), construït en 1788 per a separació dels termes de Sogorb, Torres Torres i Serra.

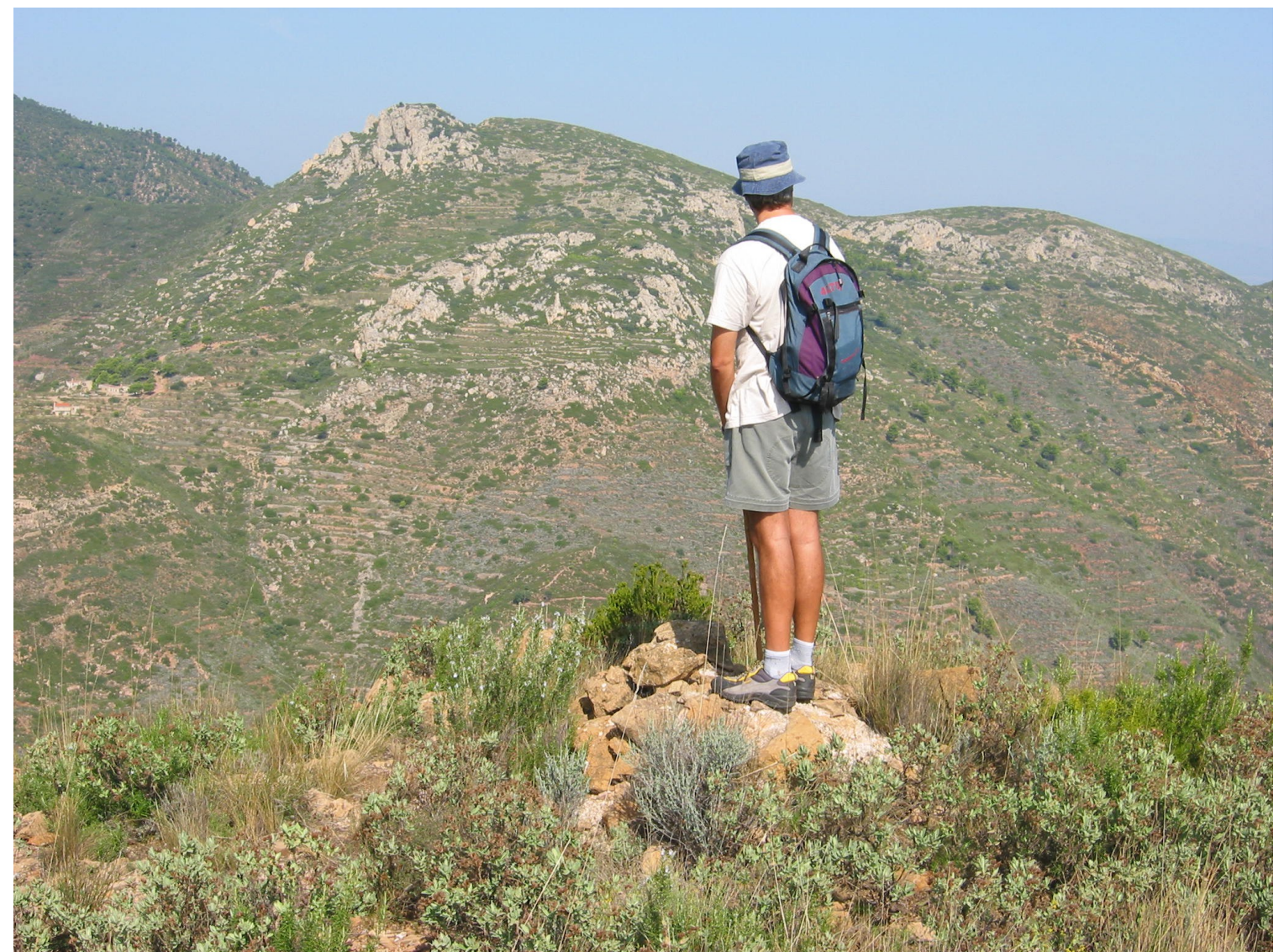

Al fons la muntanya de Penya Blanca (Sogorb).

Fotografia de l'autor.

En tot cas, volem posar de relleu una qüestió que, per raons laborals, hem tingut oportunitat de constatar en nombroses ocasions i no només a Serra, sinó en molt altres indrets del País Valencià: els límits de termes municipals que inclouen els mapes moderns del Institut Cartogràfic Valencià (escala base 1:10.000), així com els visors cartogràfics de la Generalitat Valenciana i encara altres fonts cartogràfiques, contenen a sovint notables errades i freqüents desplaçaments respecte a la realitat definida pels propis mollons històrics. La FIGURA 1.5 mostra l'exemple del MT9, posant de relleu aquest fet. 
FIGURA 1.5.- Imatge que mostra l'errada en les línies de termes del visor cartogràfic de la Generalitat Valenciana i la posició real del molló MT9 (triangle groc).

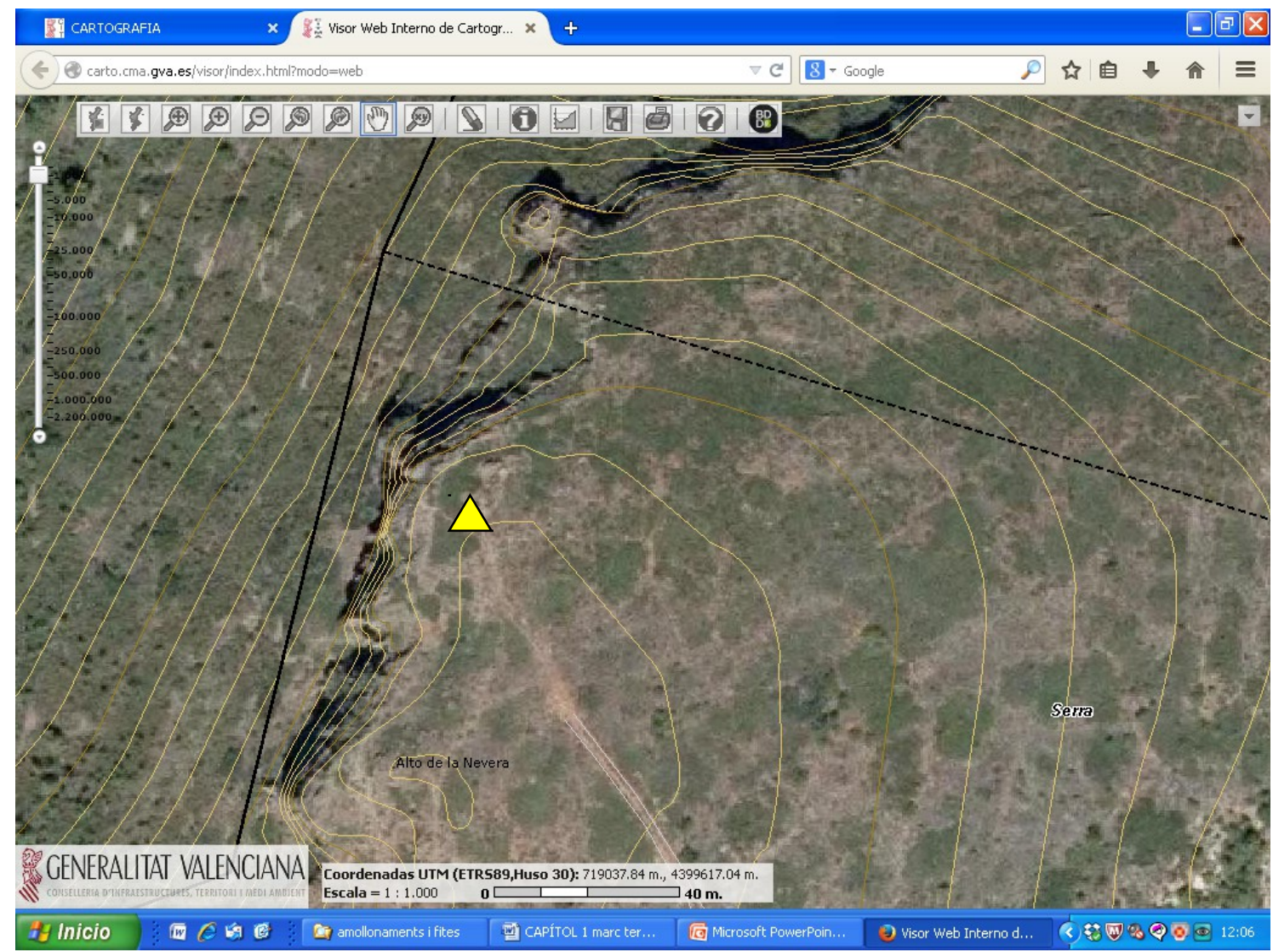

Elaboració pròpia sobe la base cartogràfica i visor de la Generalitat Valenciana.

En general són més precises les dades de les diferents edicions del Cadastre, sense dubte per estar fetes a escales més grans i de major detall. Es pot comprovar açò en el molló M39, que correspon a l'antic trifini entre els termes del priorat de Portaceli i les baronies de Nàquera i de Serra. Aquest molló té la peculiaritat de que en els seus costats té tres "senyals" indicant la direcció que prenen les corresponents línies divisòries de termes. Els "senyals" són pedres posades a mitjana altura dins del molló i que sobreïxen de la seua superfície (FIGURA 1.6).

La FIGURA 1.7 mostra la ubicació de l'esmentat molló M39 sobre el visor cartogràfic. Novament, la imatge mostra la manca de precisió tant de la línia de terme (línia negra del visor), desplaçada més de 30 metres, com de les línies parcel·làries (de color verd clar), amb un desplaçament menor però encara notable. La línia blava correspon als límits entre els polígons cadastrals i la línia morada marca també els termes municipals, ara segons la base i escala de treball del Cadastre). 
FIGURA 1.6.- Molló M39, antic molló trifini entre el termes del priorat de Portaceli i de les baronies de Serra i Nàquera.

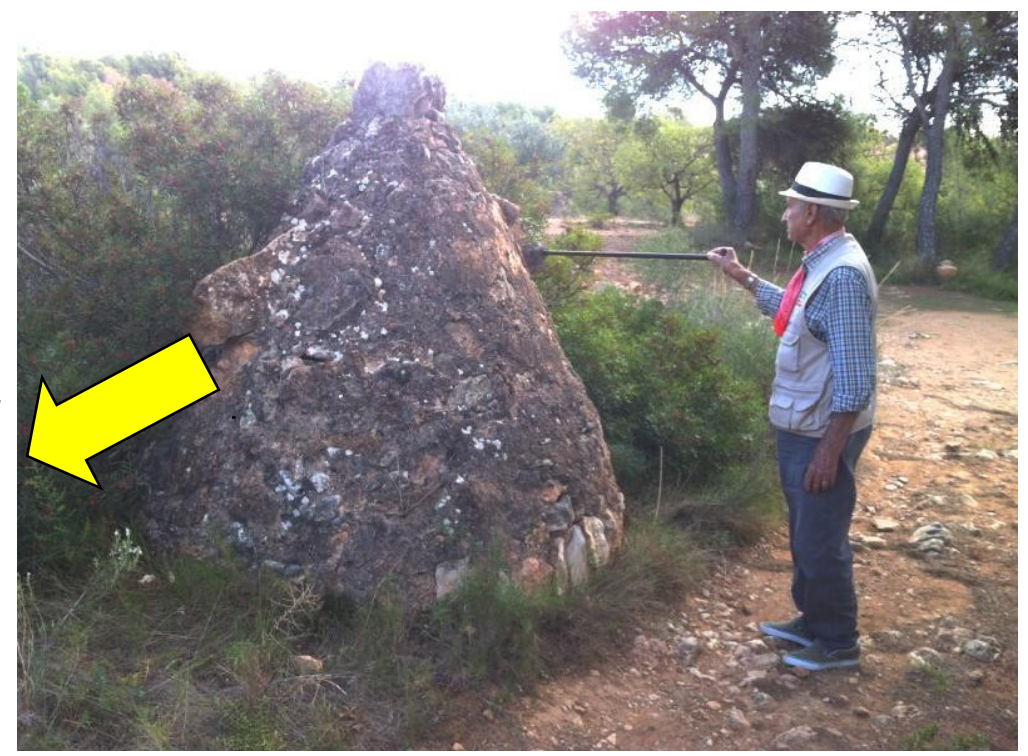

El bastó toca el "senyal" divisori de Nàquera i Portaceli. La fletxa groga prolonga el senyal de separació entre Serra i Portaceli. Darrere del molló queda el tercer senyal, de separació entre Serra i Nàquera. Fotografia de l'autor.

FIGURA 1.7.- Molló M39 (triangle groc) i desajustos cartogràfics de parcel·lació i termes.

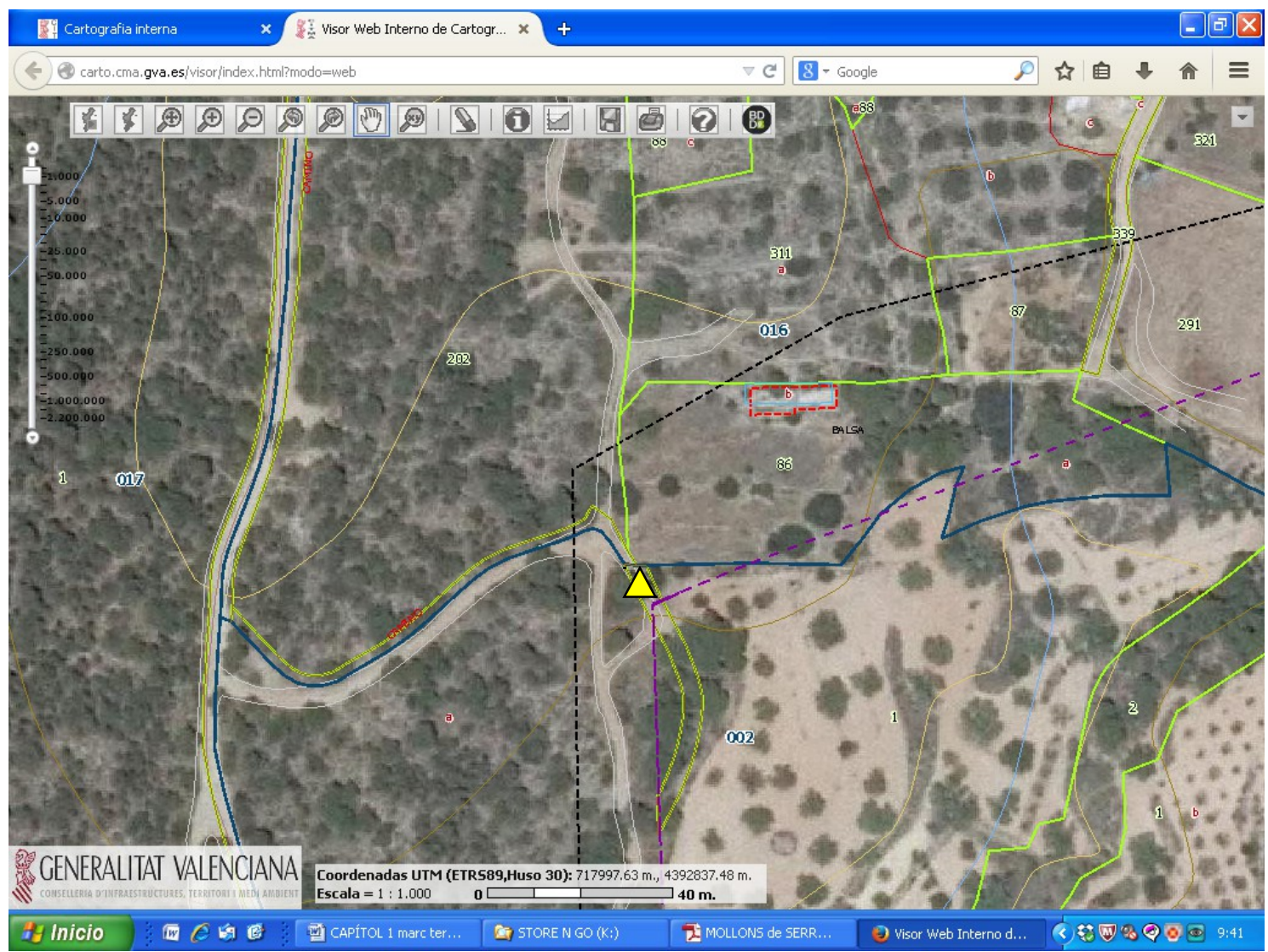

Elaboració pròpia a partir del visor cartogràfic de la Generalitat Valenciana. 
Totes aquestes errades i aparents contradiccions fan que la catalogació, restauració i recuperació dels mollons històrics es presente com a una tasca realment important i una necessitat, no solament a nivell de recuperació del patrimoni cultural valencià sinó, com he dit, per raons pràctiques i encara funcionals. Per això, en el cas de Serra he plantejat com a una proposta de treball de caràcter municipal, al marge dels objectius de la present tesi, tal i com s'ha fet en el municipi d'Alcubles. ${ }^{8}$

\subsection{LÍMITS HISTÒRICS I CONFLICTES TERRITORIALS DE LA BARONIA DE SERRA}

Entre els principals actes d'amollonament i delimitació del terme de la baronia de Serra hi destaquen els realitzats l'any 1788, per un encàrrec del Senyor de Serra, Alonso Solís Wignacourt, duc de Montellano, a l'alcalde major d'aquesta baronia, Josep Lluís Marco, qui va dirigir i executar de forma diligent aquest treball desprès d'haver acordat $\mathrm{i}$ coordinat prèviament les trobades amb les diferents comissions formades a l'efecte en cadascun dels pobles comarcans amb els que confrontava Serra, i que eren aleshores Sogorb, Torres Torres, Estivella, Albalat (avui Segart), Nàquera i la Reial Cartoixa de Portaceli. $^{9}$

D'aquesta llista de pobles crida l'atenció una significativa diferència respecte als termes amb els que limitava el del castell de Serra fins al segle XIV:

Et quia termini iam dicti castri de Serra et ad ipsum spectantes afrontant ex una parte cum termino dicti castri et ville de Torres Torres et cum termino dicte civitatis Sugurbii et cum terminis de Llullen et de Portaceli ex alia parte cum termino Castri de Betera et ex alia parte cum termino de Naquera et ex alia cum termino castri de Segart et ex alia cum termino de Beselga. ${ }^{10}$

Demostra açò la desaparició del castell de Bétera entre els termes que confrontaven amb el de Serra a mitjans del segle XIV ${ }^{11}$, car aquest text forma part de la sentència de 1349 per la qual el rei Pere IV li reconeixia al seu conseller i majordom Galceran de Bellpuig, aleshores Senyor de Serra, la jurisdicció criminal (mixt imperi), a

8 Rafael Casaña i altres (2010) "Lindes y Mojones" Alcublas Escribe, 11. Ayto. de Alcublas,

9 AHN-FN, 263/27

10 ARV, reial cancelleria, L496, f. 340-347; "llibre de jurisdiccions de certs barons", publicat per J. M. Iborra Lerma (1981): Realengo y Señorío en el Camp de Morvedre. També citat per Corbalan de Celis (2002).

${ }^{11}$ Altres dades que referiré desprès indiquen que la pèrdua del límit de Serra amb Bétera (per guany d'un tros de terme per a Portaceli, en detriment del de Serra) podria haver-se produït ja a partir de 1305 (donació de Sanxa Ferràndiz), sent ratificat en 1327 (sentència dels Jurats de València). 
més de la civil (mer imperi) que ja posseïa, per al seu estat (des d'ara ja baronia) de Serra, que Galceran havia heretat per la donació que Jaume I va fer en 1271 al seu avi, Bertran de Bellpuig, dels castells i viles de Serra i de Torres Torres, amb llurs alqueries. ${ }^{12}$

En relació amb aquesta suposada pèrdua dels límits amb Bétera bé podria estar la contesa armada que havien mantingut anys enrere (cap a 1327) Hug de Bellpuig (pare de Galceran i fill de Beltran) contra el Senyor de Nàquera (que sembla que seria Gil Martínez d'Entensa, en fonamentada opinió d'Emili Lluch, 2002, p. 87 i 88). L'origen d'aquest conflicte armat o de "bandositats" va ser recollit per Carreres Zacarés (1930) explicant com a motiu certes incursions que el senyor de Nàquera, amb homes a peu i a cavall, havia fet dins el terme del castell de Serra "cremant llenya per a fer cendra". Quan aquestes diferències entre el dos bàndols van ser elevades als Jurats de València per a la seua mediació, aquests, lluny de donar la raó a l'un o a l'altre, els hi digueren que aquelles terres en litigi no pertanyien a cap de les dues parts, sinó al terme general de la Ciutat de València, al qual pertanyia de fet el Priorat de Portaceli "com ells bé devien saber".

En la delimitació que en 1455 es va fer entre els termes de Portaceli i de Nàquera, en arribar al molló més septentrional, i trifini amb Serra, es diu que està en la partida "vulgarment apellada Bassa de la Contenda de Portaceli, de Nàquera e de Serra" (nota recollida per Lluch, 2002, p. 30).

El cas dels termes de Portaceli resulta interessant perquè, en principi (així ho expresa Fuster, 1994; p. 70) "no se sabe qué jurisicción ni qué límites tiene el valle de Lullén" "13, però, observem que poc a poc anaren resolent-se, sempre a favor del monestir de Portaceli, els diferents conflictes territorials que se li plantejaren, començant per la pròpia compra ${ }^{14}$ de la vall de Lullén que el bisbe Andreu Albalat va fer, en 1272, als testamentaris de Eximén Perez d'Arenòs, qui l'havia adquirit per una permuta feta al seu primer posseïdor, Gil de Rada, a canvi de certes possessions que aquest tenia a Catalunya

\footnotetext{
${ }^{12}$ A.C.A., cancelleria reial, reg. 16, f. 254 v (citat per Sanchis Sivera, 1922; Cebrián i Lluch, s.a; Senís, $1954 \ldots)$.

${ }^{13}$ Així ho recull clarament De Rebus (Ribes, 1998, ep. 3): "No se sabe que jurisdicción ni que confrontación teníamos en nuestro término por faltarnos los 4 autos siguientes... (que són: 1. El de la donació pel Rei Jaume I a Gil de Rada; 2. El del "trueco" que feu aquest amb Ximén Pérez d'Arenós; 3. El de la compra pel bisbe Andreu Albalat als testamentaris d'aquell, i 4. L'acte de donació que feu el bisbe Albalat al monestir) ...pues en estos autos avía de estar la calidad de la jurisdicción i afegeix: Circa iurisdictionem vide ad annum 1626, $p .185$ et seqqentes).

${ }^{14}$ Aquesta compra consta en l'acte de fundació i en l'ep. 1 de De Rebus (Ribes, 1998), però també es diu en l'ep. 18 (any 1277) que "el rey D. Pedro III nos hizo donación de este término de Lullén, por quanto los herederos de En Ximén Pérez de Arenós (o siga, na Sanxa)... le devían grandes cantidades, a cuya cuenta se le podía apropiar, y assí, por la mucha devoción que nos tenía, hizo solemne donación...
} 
(Fuster, 1994: 70). Aquesta operació, però, es va fer sense coneixement ni aprovació de Sanxa Ferrandiz, l'hereva universal d'en Ximén, qui per aquesta raó inicià el que seria un llarg plet. Però finalment, en l'any 1301 aquesta senyora faria plena concessió dels seus drets al monestir de Portaceli per no impedir una obra tan grata per a Déu i sa beneïda mare, en benefici de la seua pròpia ànima $\mathrm{i}$ amb la condició de ser reconegut el seu patronat. La donació la fa esmentant de la següent manera (i per primera vegada!) els límits de la vall de Lullén (Fuster, 1994: 76):

In perpetuum locum nostrum vocatum Lullen situm in Regno Valentiae confrontatum cum terminis de Serra, cum terminis de Olocau, cum terminis de Betera, cum terminis de Naquera et cum terminis de Segorb, et cum terminis de Benaguasil, et in dicto loco sitis et vivatis et divino cultui ministrebis...

D'aquests límits cal destacar el fet de que Portaceli ja limita amb el terme de Benaguasil (hui la Pobla de Vallbona i abans encara la Pobleta de Benaguatzir), degut a una donació tardana del seu fundador (Andreu Albalat; poc abans de morir) en 1276, qui ofereix al monestir, per a incorporar-lo al seu terme, el lloc de la Torre, amb el qual s'aconseguia que Portaceli tinguera accés directe a la seua propietat de la Casa Blanca (terme de Benaguasil) sense necessitat de passar per altres termes. Aquesta annexió de la Torre (antic despoblat de nom Rocafall) serà també font de conflictes, ara amb el senyor d'Olocau, Joan Escorna, qui finalment també acabarà renunciant a les seues aspiracions inicials en donar al monestir, en 1325, tots els dret de possessió "d'especial gràcia i per amigable composició", oferint a canvi, els monjos de Portaceli "cada any i perpètuament un aniversari per l'ànima dels pares de Joan Escorna, per ell mateix i pels seus descendents" $"$.

Els conflictes de delimitació territorial més llargs van ser els sostinguts entre la baronia de Serra i la cartoixa de Portaceli, aquella sentint-se sempre envaïda per l'intrusisme de la segona i aquesta ferma i expansiva sentint-se recolzada pels estaments superiors, ${ }^{16}$ tal i com es nota en el següent text tret dels Annals de Portaceli (Ribes, 1998; ep. 35) i que es refereix a l'any 1322:

\footnotetext{
${ }^{15}$ Aquell any es fa una delimitació (amb 7 mollons) entre els termes d'Olocau i Portaceli: ARV, reial justícia, núm. 809/24; pergamí transcrit per Fuster (1994, p. 394, document 4).

${ }^{16}$ Des de la seua constitució, Portaceli és objecte de tot un seguit de reconeixements i mantells protectors; cal recordar, com a mostra, la bula de Nicolàs IV confirmant totes gràcies apostòliques concedides pels anteriors papes (començant per Gregori X) a Portaceli, l'empara reial que li fa en 1298 Jaume II, o el reconeixement que en 1403 li fa el Consell de la Ciutat de València, no solament de la pertinència al seu terme general, sinó també per a la seua protecció, guarda i custòdia... etc. (Tarín y Juaneda, 1897; Fuster, 1994 i 2003; Ribes, 1998).
} 
Vinieron los comisarios reales y dos jurados de Valencia para renovar los términos generales de dicha ciudad, poniendo nuevos mojones para señalarlos y, los dichos términos, según declaró el rey D. Jayme en tiempo de la conquista en los fueros que hizo, comienzan en Murviedro, Puzol, Olocau, Chiva, Buñol, Turís, Monserrat, Alzira, Cullera y 100 millas dentro del mar. Y assí, viendo los Jurados que entre Puzol y Olocau está Serra, mandaron poner tres mojones en lo más alto y en las vertientes de la montaña grande, llamada la Armenia, pretendiendo que Serra, cuyo término fenece allí, confrontasse con Olocau; más entendiendo el convento, que con estos nuevos mojones le quitaban la entrada por el Collado de la Morería hasta Pedralvilla, Fuente del Lentisco y de la Falaguera y hasta el término de Segorbe, según claramente lo dice el auto de donación del presente término que nos dio Dña. Sancha Ferrandiz, y la antigua y pacifica possessión en que estava, se opuso y protestó, lo cual admitieron los comissarios y declararon que tanto cuanto entrasse nuestro término hazia Segorbe, fuese término general de Valencia. En el archivo están la protesta y la aceptación.

En 1338, 25 de setembre, van ser posats el altres 4 mollons que marcaven la divisòria entre Serra i Portaceli, segons una sentència arbitral de Domingo Aymerich ${ }^{17} \mathrm{de}$ la qual tornarem a fer esment en causes posteriors degudes al descontent que aquella primera delimitació va causar, doncs s'endinsava, sense aparent raó, en la part nord del terme de Serra fins a la font del Llentiscle. Cal indicar, abans de prosseguir, que el mapa del priorat que aproxima Fuster (1994, p. 71) no s'ajusta a aquesta delimitació en traçar una línia recta que des del molló M39 passa pel pic de la Gorrissa i el vèrtex de Rebalsadors arribant directament al molló M9, quan realment tota la línia divisòria anava més desplaçada cap a l'oest, per les vores de Rebalsadors (la sumitat de la dita cingla appellada Almenia) i girant poc a poc cap a l'est en arribar al paral·lel de la font del Llentiscle, per a girar sobre ella, novament cap al nord, fins enllaçar amb el mollló M7 (i no el M9 que suposa Fuster). ${ }^{18}$

En 1347 s'arrossegava un conflicte entre Galceran de Bellpuig, senyor de Serra, i el monestir de Portaceli per la delimitació del bovalar d'aquesta baronia, envaït pel monestir segons la versió d'aquest noble, que per això va recórrer al Consell de la Ciutat, per a que designés dues bones persones de la ciutat, prohoms de confiança que pogueren revisar la situació sobre el terreny. La petició va ser atesa i el consell designà a Berenguer

\footnotetext{
${ }^{17}$ AHN, clero, lg. 7469, papers de Portaceli (text recollit i transcrit per Fuster, 2003, p. 447, doc. 7).

${ }^{18}$ Una lectura més detinguda del text d'aquella delimitació permet comprovar açò. A més, ho ratifica també les delimitacions de la forest d'utilitat pública de Portaceli, hui propietat de la Generalitat Valenciana, que tindrem ocasió de comentar més endavant.
} 
Despuig, jurat, i a Joan Solanes, per a que anaren al lloc del dit contrast e facen prova sobre açò que els serà ben vist faedor ${ }^{19}$. Desconec com acabà en realitat aquest plet $\mathrm{o}$ contesa, però tot fa pensar el que resulta prou evident: que el bovalar era el sector del terme que queda a l'oest de la font del Llentiscle i fins al coll del mateix nom, que es suposa que devia ser en un principi el límit natural entre els dos termes, però que realment, la sentència arbitral de 1338 ja havia decantat a favor del Monestir, sense que el de Serra quedés en absolut satisfet.

Si repassem el text final de l'esmentada sentència: e de aquest molló desé, posat sobre la dita font del Llentiscle, tiren e senyalen enjús per lina dreta passant e travessant lo barranch fins al molló qui es en lo collado apelat de la font del Llentiscle, en les parts de les contendes, qui es davant la dita font, veurem la clara referència (el subratllat és nostre) a una qüestió o reivindicació que ja en 1338 venia arrossegada (des de 1305, almenys) i que, com veurem, no va quedar encara resolta.

En efecte, en 1449 la cartoixa manté un plet amb Joan Cardona, senyor de la baronia de Serra, sobre la partició i la possessió de la Font del Llentiscle. Les diferències sobre la possessió de l'esmentada font queden de nou sentenciades en 1451. La nova sentència, de 27 de juliol, marca que siguen reparats sis mollons (els que separen Serra i Portaceli segons la sentència de 1338) i que l'aigua del Llentiscle siga d'ambdós termes (el cabal de la font a mitges). ${ }^{20}$

Pocs anys desprès, en 1455, seran posats els mollons que delimitaven Portaceli amb Bétera i amb Nàquera (Lluch, 2002, p. 30); els límits entre Portaceli i Sogorb seran objecte d'un amollonament en any 1647 (Ribes, 1998, ep. 347; en ep. 4 diu, però, que va ser l'any 1649) i, encara, en 1662 seran reparats els mollons -i posat un de nou- entre Portaceli i Olocau. ${ }^{21}$ Sobre aquest $\mathrm{i}$ altres actes, anteriors (1325 i 1506) i posteriors (1806 i 1844), de delimitacions i amollonaments entre Portaceli i Olocau és recomanable i encertat el treball de Zurriaga (2004).

\footnotetext{
${ }_{19}$ AMV, manual de consells, A-7, f. $150 \mathrm{v}^{\mathrm{o}}$ (comença sessió en f. $149 \mathrm{r}^{\circ}$ ).

${ }^{20}$ AHN, clero, lg. 2038/12.

${ }^{21}$ APCC, notari José Arcos, 1662 novembre 19 (nova signatura: 591/010019). Transcrit en Tarín i Juaneda (1897, p. 233 i ss.).
} 
En resum, i segons consta en l'epígraf 4 de De Rebus (Ribes, 1998), els mollons que definien els límits de Portaceli, segons les renovacions fetes cap a 1649 (només amb el terme de Sogorb) i cap a 1722 (la resta) serien:

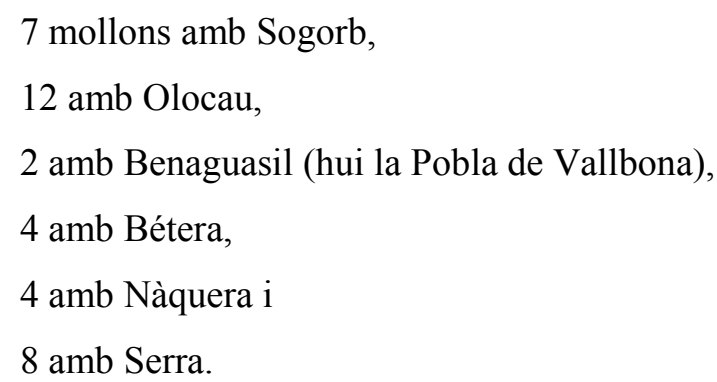

Una delimitació feta en 1730, entre el termes de Nàquera i Albalat (que incloïa aleshores a Segart) inclou com a inici el molló trifini amb Serra, MT23, que se situa junt al llit del barranc Fond, també conegut com del Meliquet. Per això estigueren presents en aquell acte, a més dels representants d'Albalat i de Nàquera, els perits de Serra Domingo Moreno i Salvador Navarro (Lluch, 2002, p. 32 i 33).

Una nova delimitació entre els termes de Bétera i Nàquera tindrà lloc en 1771 (Lluch, 2002, p. 33 i 34), la qual inclou el molló MT43, aleshores trifini amb Portaceli i avui amb Serra).

En 1737 es va fer un amollonament davant Felipe Tàrrega, escrivà de Sogorb, a instància de l'apoderat de l'excel·lentíssim senyor en Nicolàs Fernández de Córdova, duc de Sogorb, entre els termes de la Ciudad de Segorbe amb el Convento de Portaceli orden de la Cartuja i el Lugar de Sierra. Aquest acte torna a posar de relleu la disconformitat de la baronia de Serra respecte al sector nord-oest del terme (entorn de la font del Llentiscle) que després de tres segles encara continua reivindicant. Comença la delimitació en el molló trifini (MT9) que diu ser divisori dels termes de Segorve, Murviedro (sic., per Torres Torres) i Lugar de Sierra. El següent molló, número 2, situat front a la font del Llentiscle, és el de la discòrdia, on teòricament confronten Sogorb, Portaceli i Serra "según amojonamientos antiguos", però on Serra manifesta la seua discrepància: "aunque dos testigos presentados por parte del Lugar de Sierra apoyaron la pretension de este lugar, se declaró en los terminos que queda referido en la Diligencia (folios desde el 11 buelto al 20". Aquest discordant molló numero dos (trifini) serà també el primer molló dels set que descriu a continuació, en aquell acte per a la 
separació de Portaceli amb Sogorb, i que arribarà fins al trifini MT1 que separa Gàtova (aleshores pertanyent a Olocau), Sogorb i Portaceli.

Arribem així a l'any 1788, en que el senyor de la baronia de Serra, aleshores Alonso de Solís Wignacourt, duc de Montellano, va ordenar que es fera la delimitació de tot el terme de la baronia de Serra ${ }^{22}$. Als arxius he trobat, entre altres coses, còpies de les actes de delimitació de Serra amb Torres Torres i amb Nàquera, i també referències a les dels altres termes, però no la descripció detallada d'ells, malgrat que hi consta que es van fer, i de fet es va dibuixar, aquell mateix any, un mapa amb la delimitació de tot el terme $^{23}$. De fet, en la part que toca als límits de Serra amb Nàquera, que veurem tot seguit, hi consta que va ser realitzar un plànol d'aquell tram per l'arquitecte Manuel Blasco (Lluch, 2002, p. 36).

Entre Serra i Nàquera van ser definits 20 mollons. Les diligències començaren el dia 3 de juny, en haver oficiat prèviament el duc de Montellano, a través de l'alcalde major de Serra, Josep Lluí Marco, als apoderats de les altres parts: el reial monestir de Santa Maria de Portaceli (que no comparegué finalment) i el senyor de Nàquera. Començaren en el molló trifini anomenat de la Basseta (M39) i seguiren cap al Moncúdio i fins arribar, per fi, al molló trifini amb Albalat/Segart (MT23), situat junt al 1lit del barranc dit del Meliquet (Segart), del Salt (Nàquera) o Fond (Serra).

En aquella delimitació no s'esmenta cap diferència entre les parts, sembla que els principal mollons van ser trobats en el seu lloc i que tot va quedar ben entès i recollit en l'esmentat plànol. Finalment, però, no van edificar els mollons que faltaven, ni repararen els danys dels existents. Aquestes obres es farien molts anys desprès, en 1826, per un acord entre el marquès de Sardanyola i de Boïl, en Pasqual de Sant Climent, i el aleshores senyor de Serra, en Filiberto Mahy Brauli, duc de Montellano ${ }^{24}$. Així, el dia 10 de juny d'aquell any, es reuniren en la casa-palau del senyor de Nàquera, Mateo Ibáñez, alcalde ordinari,Miquel Pérez, síndic, i els perits Vicente Tomàs i Bautista Arnal, tots ells de part del senyor de Nàquera; i per la de Serra Pedro Puig, regidor degà, en defecte de l'alcalde (Josep Inglés), Francesc Pérez, síndic, i els perits Manuel Cabo i Domingo Navarro; tots ells junt amb el mestre d'obres Francesc Arnal. Es desplaçaren per realitzar

\footnotetext{
${ }^{22}$ AHN-FN, lg. 263/27 i ss.

${ }^{23}$ Per una nota afegida al final del lligall esmentat en la nota precedent, se sap que es va confeccionar aquell any 1788 un mapa general amb la divisió dels termes, mapa que existia en l'arxiu nobiliari cap a l'any 1829 i que no he pogut trobar.

${ }^{24}$ Document de l'arxiu del marqués de Boïl "hoy del Conde de Plasencia" (transcrit i publicat per Lluch, 1983: pàg. 24 i 25).
} 
l'obra projectada tot començant per la part del Salt, construint-ne un de nou en la part inferior del Moncúdio, i des d'allí seguiren cap al molló trifini de Portaceli, tot seguint l'ordre contrari al de la delimitació acordada en 1788. L'esmentat molló, últim dels previstos, el deixaren en suspens, en no haver acudit els pares de la Cartoixa.

Aquesta definitiva delimitació i amollonament es va fer "per evitar plets i debats entre els veïns terratinents i els pastor amb el trànsit dels ramats" i per això es convingué en fer mollons de maçoneria de morter (calicanto) amb una alçada adient, la qual cosa executà l'esmentat mestre d'obres a satisfacció de tots els presents. Finalment, en octubre del mateix any s'alçaria per fi el molló trifini divisori amb Portaceli, previ acord amb els monjos del monestir.

Tornant a 1788, el dia 4 de juny van ser posats els mollons entre Serra i Torres Torres, començant pel molló MT15 (trifini amb Estivella) i acabant en el MT9 (trifini amb Sogorb). La descripció d'aquest acte ha estat publicat per Corbalan de Celis (2002) i la referim també en el nostre ANNEX I.

Degut al deteriorament d'alguns mollons i a que al voltant de 1831 havien sorgit algunes diferències entre veïns de Serra i de Torres Torres ${ }^{25}$, es va fer una revisió i un nou amollonament -afegint altres dos mollons als cinc existents- en l'any $1847^{26}$. Començaren pel mateix extrem que en la vegada anterior (el molló MT15, trifini amb Estivella) i seguiren igualment cap a l'oest fins acabar en el MT9, trifini amb Sogorb.

No he trobat als arxius (ni als protocols de Miguel Conejos, ni al fons del ducat de Montellano) les diligències ni actes de delimitació amb Estivella ni amb Segart (Albalat), però, pels comentaris que li fa al duc de Montellano el seu criat, Eleuterio Alfonso, sembla clar que van ser tots ells realitzats normalment i sembla que sense cap anomalia ni diferència remarcable. El dia 10 de juny de 1788 li escriu el criat al duc, informant-lo del treball practicat pel Dr. Josep Lluís Marco, alcalde major de la baronia de Serra, sobre la renovació dels límits i mollons que la divideixen "de los pueblos comarcanos que son Segorbe, Albalat (Segart), Torres Torres, Estivella, Nàquera y Real Cartuja de Portaceli", i concreta:

“...se les escrivió las cartas a los dueños de los lugares (amb els que confronta Serra)... firmado de Don Pedro Verges como Apoderado General de V.E. y por mi como Abogado que tambien lo soi de este Colegio de Valencia. Por parte de los Pueblos confinantes han ocurrido(concurrido) los Procuradores Generales con sus Justicias

\footnotetext{
ARV, protocols lg. 3810, notari Matias Lorente.

${ }^{26}$ ARV, protocols lg. 3824, notari Matias Lorente.
} 
respectivos y peritos labradores, y por la Baronia de Torres Torres, su dueño en persona, el Conde de Castellar y de la Villa Nueva", ${ }^{27}$

Només cita com a excepció Sogorb, dient que havia respost el Regidor degà manifestant que no tenia cap dubte en els mollons divisoris, però oferint-se, no obstant, a comparèixer si fóra el cas de sorgir cap dubte. I afegeix el criat que:

“...como nuestros practicos afirmaron no tenerla, nos contentamos con poner diligencia de su reconocimiento para que en todo tiempo conste los que son en el dia. $Y$ manifiesto a S.E. lo demás practicado, porque resulta todo de los autos formados en su razón que podrá ver V.E. si gustare, cuando tenga lugar para ello; solo digo aver salido en lo general del asunto antes y mejor de lo que io pensaba, y solo resta para acabar de perfeccionarlo, el que se lebanten los mojones derruidos, que son la mayor parte, y algunos nuevos que se han acordado en los parages que demuestran las diligencias, cuio gasto ha de ser por mitad, y asi han quedado combenidos Don Pedro, y los Procuradores de los Pueblos himediatos á nombre de sus dueños para cuya ejecucion se necesita preparar primero los materiales".

Respecte a Portaceli, en aquells actes de 1788 eixiren a relluir dues qüestions de desacord. Per una part la ja secular demanda serrana sobre l'entorn de la font del Llentiscle. En aquest sentit comenta:

Con los padres cartujos de Portaceli, por las razones y motivos que se observan en la Diligencia de su reconocimiento, en autos, ni don Pedro ni io nos quisimos combenir en aquel acto á que se renovasen los mojones divisorios, y remitimos su decision a esta Ciudad, y estudio los Alfonsos donde deveria ocurrir (concurrir) su Padre Procurador con los documentos de Justificación de algunos en que hallamos reparo: esto lo executaron aier, y aviendolos reconocido, he bisto que aviendose suscitado Pleito en 1684, que terminó en 1686, entre dicha Cartuja, el Sr de Serra y Duque de Segorve, sobre la pertenecia del terreno relativo a los citados mojones y fuente de Lentisco, precedida vista ocular de un Juez de la Audiencia, se declaró por esta ser mojon trifinio la expresada fuente, con lo que otra sentencia que recaió sobre diferiencias en el mismo terreno en 1736, no alló arvitrio ni Derecho a poder reclamar lo que da á entender uno de nuestros peritos...

\footnotetext{
${ }^{27} \mathrm{AHN} F N, \lg .263 / 27 \mathrm{n}^{\circ}$ 2. (lligall també marcat-signatura antiga- com a 1169/4).
} 
Seguidament, suggereix Eleuteri Alonso al duc que, abans de renovar els mollons divisoris amb Portaceli, faça una treva d'almenys dos mesos, per tal de poder revisat si existeix en l'arxiu senyorívol algun amollonament més antic (encara que no ho veu massa provable: "io bien infiero que no le hai pero mi objeto es detener a los padres procuradores algun tiempo en espectacion, pues comprendo que se les debe tratar con cuidado en esta parte").

L'altra qüestió discordant amb Portaceli va ser perquè el molló situat en el Puntal de Ferrer (sector meridional de la línia divisòria) havia sigut objecte, per manament del conrer de Portaceli i contra tot costum i pràctica, d'un desplaçament cap l'est i dins ja de l'heretat de Cristòfol Arnal, llaurador de Serra, segons havien denunciat diversos veïns de la baronia de Serra. Per aquesta raó, el duc de Montellano va designar a Ramon Conejos $^{28}$ amanuense i veí de la baronia a instruir un expedient al respecte. ${ }^{29}$ Els fets són que en l'alt anomenat de les Corralisses, també conegut com Puntal de Ferrer, hi havia dos mollons de calicanto antics, distants un del altre unes 165 passes, poc més o menys, sense que en cap cas guardaren amb la seua posició la línia divisòria dels dos termes, la qual sempre hauria estat definida i guardada pel molló més occidental i proper al Monestir de Portaceli, estant situat l'altre molló dins el terme de la baronia de Serra. Al llarg de l'expedient es fa constar que junt a la línia divisòria de termes posseïa l'esmentat Cristòfol Arnal, quieta i pacíficament, una heretat de terra secana, amb coneixement $\mathrm{i}$ tolerància del Prior i monjos del Monestir de Portaceli, per més de 60 anys que es té memòria. Tanmateix es diu que aquesta propietat sempre ha pagat complidament els seus tributs: delmes, primícies, drets dominicals i reials en la baronia de Serra i, a més a més, les penes, danys i perjudicis que tot gènere de ramats han ocasionat en ella han sigut també jutjats, sentenciats i pagats pel tribunal de la baronia de Serra. Així ho diuen i confirmen diversos testimonis qualificats, com són Vicente Arnal, Roque Domènech i Pedro Ruiz, tots tres havent regentat, en diferents anys i ocasions, la vara d'alcalde ordinari de la dita baronia.

Segons declara el Cristòfol Arnal, el conrer de la Cartoixa de Portaceli -i sense citació a cap autoritat de Serra- el va fer comparèixer en l'esmentada partida i “despues de haverle intimidado con el falso supuesto de que si no accedia á su pretencion se le condenaría en crecidas costas" procurà que li cedira a benefici de la seua comunitat una

\footnotetext{
${ }^{28}$ Ramon Conejos era un del fills del notari de Serra Miquel Conejos, i germà de l'altre Miquel Conejos que succeiria a son pare com escrivà resident $\mathrm{a}$ Serra.

${ }^{29}$ AHN FN, 263/44.
} 
porció de la dita heretat, per apropiar-se-la com a Terme seu, " $y$ de hecho y contra todo derecho mandó á los criados que le assistian pusiesen en la línea señalada por el mismo unos montones de piedra suelta á modo de mojones y á proporcionadas distancias, de forma que por dicha linea señalada en este acto se quita á este Termino una porcion de terreno que siempre ha sido suyo".

No conec documentalment, ni jurídica, com acabà el conflicte en aquell temps, però si que hem trobat base cartogràfica i documental prou més tardana amb la qual hem pogut recolzar i constatar amb el treball de camp i que demostra clarament com la delimitació entre els antics termes de Serra i de Portaceli passava, precisament, pel molló més occidental dels existents en el Puntal de Ferrer (FIGURES 1.8 i 1.9).

La principal font cartogràfica correspon a les actes de la Delimitació i amollonament de Monte Nacional de Porta-Coeli (M.U.P. Número 13), de l'any 1875, i al projecte d'ordenació del Monte de Porta-Coeli, de l'any 1905. Ambdós documents -i la cartografia que els acompanya- recullen amb detall els mollons que delimiten la forest pública; en el primer cas, amb una acurada i descriptiva acta de delimitació i amollonament, amb 66 mollons i piquetes que fixen el perímetre extern de la forest (a més d'altres tandes de mollons que delimiten diferents enclavaments interns); i en el segon cas, amb una descripció tabulada de totes les piquetes i mollons, amb les distàncies, inclinacions i orientacions respecte a les confrontades immediates. Ambdós documents formen part del fons documental en arxiu actiu de la Direcció Territorial de València (Secció Forestal) de la Conselleria competent en matèria de Medi Ambient (avui Conselleria d'Agricultura, Medi Ambient, Canvi climàtic i Desenvolupament rural). 
FIGURA 1.8.- Ubicació dels diferents mollons i fites existents al voltant de la muntanya del Reixo, de la qual forma part el Puntal de Ferrer.

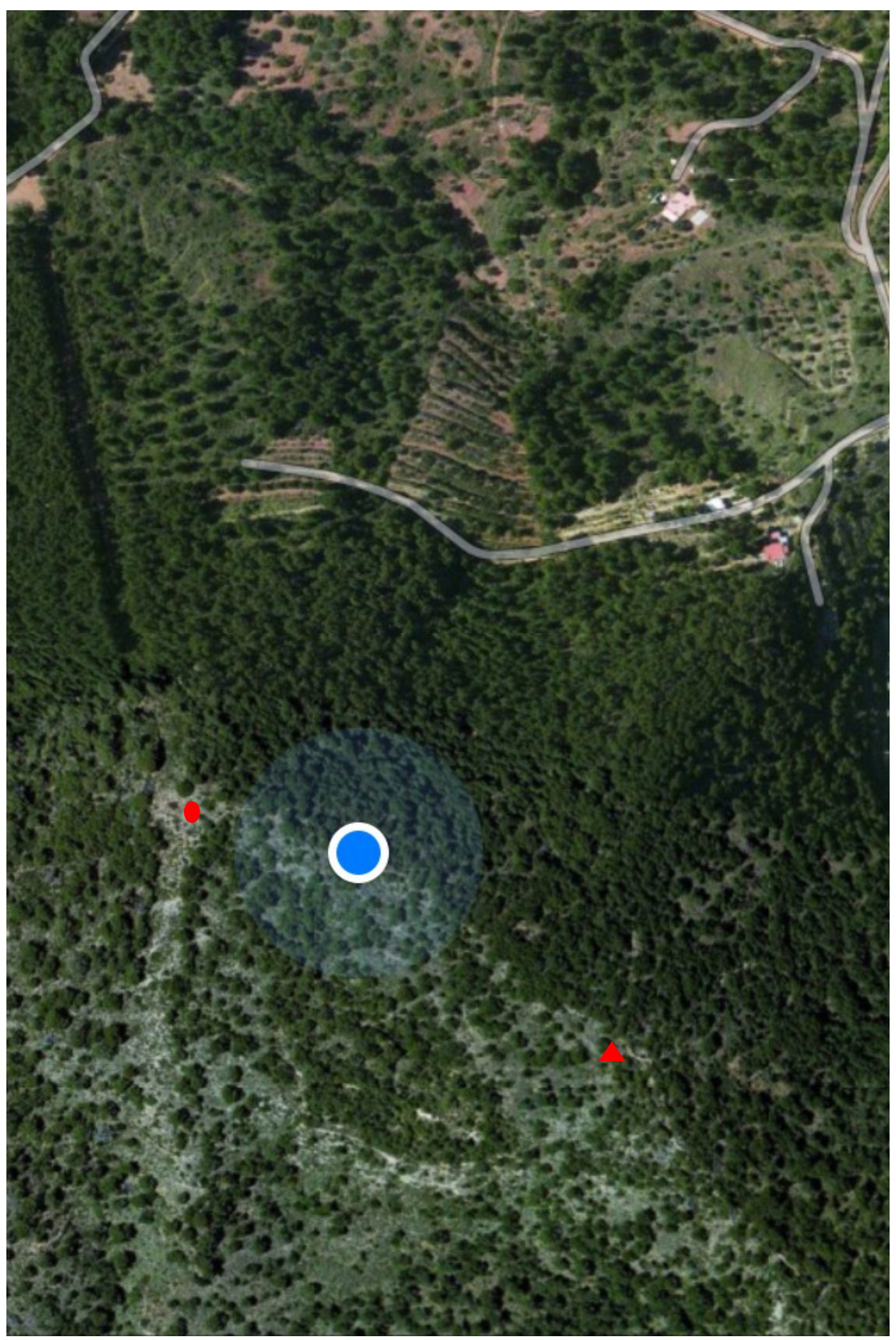

El cercle blau indica la ubicació del "molló fals" posat pel conrer de Portaceli; el cercle roig és l'antic molló de termes (figura 1.9) i el triangle roig és el molló que marca el punt més alt (vèrtex) del Puntal de Ferrer. Dibuixat sobre ortofotografia del ICV. 
FIGURA 1.9.- Antic molló divisori dels termes de Serra i Portaceli. Avui molló divisori entre les forests de Portaceli (MUP 13) i de l'Alt del Pi i agregats (MUP 105).

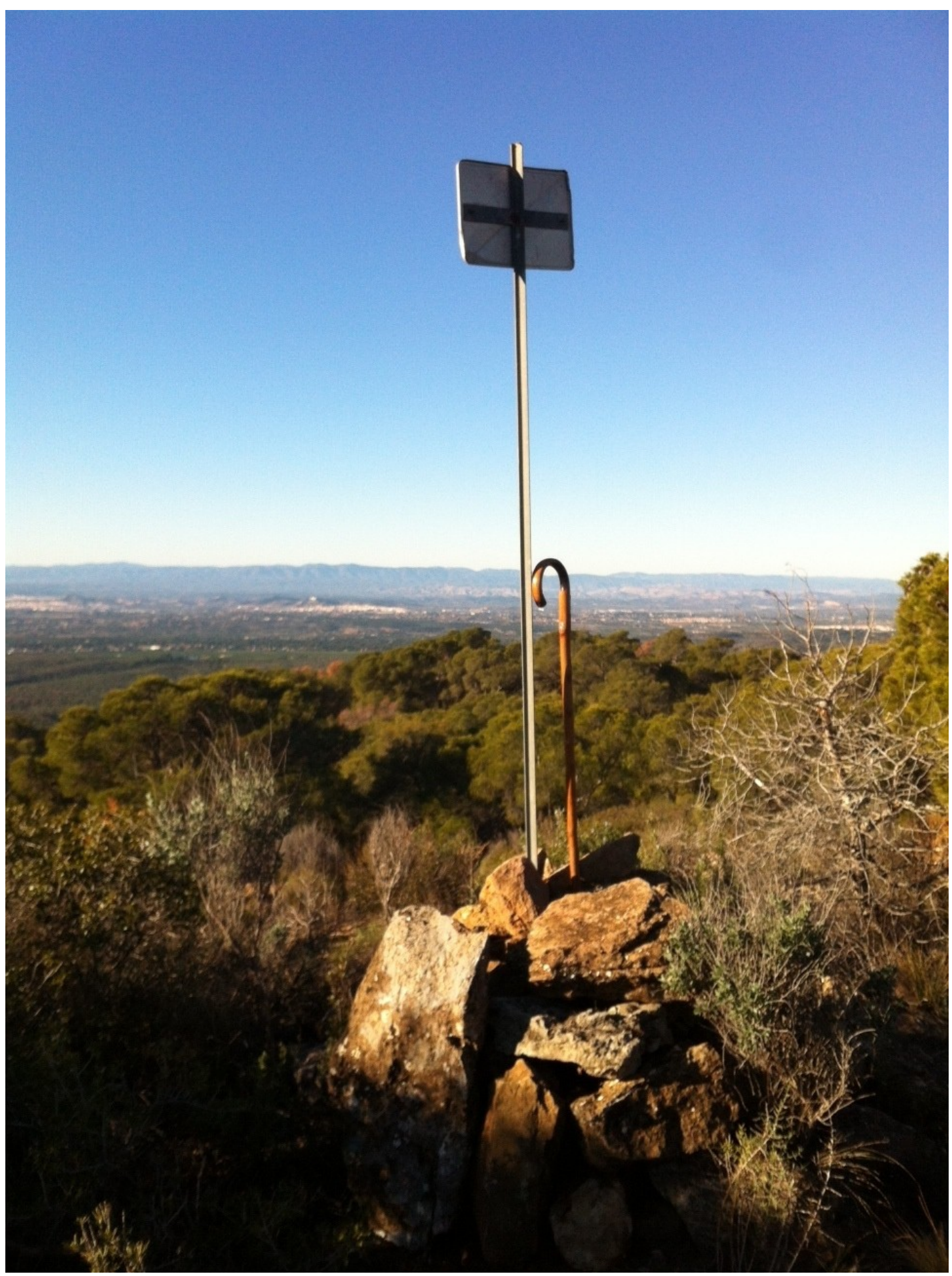

Fotografia de l'autor.

Com a font cartogràfica més moderna però encara concordant amb l'anterior podem trobar la del Mapa Topogràfic Nacional de España, (full 668-III, Serra), a escala 1:25.000, en la seua edició de l'any 2002. Concretament recull aquest mapa la situació 
dels tallafocs que, dins el projecte anomenat ZAU (Zones d'actuacions urgents, de l'administració forestal) ha anat executant la Conselleria competent en Medi Ambient al voltant de l'any 2000 i següents, seguint els límits de la forest pública de Portaceli i per tal de posar limitacions en matèria de prevenció i propagació de possibles incendis forestals. 


\section{CAPÍTOL 2}

\section{CIRCUMSTÀNCIES I ANÀLISI DE CONTINGUTS DE LA CARTA DE POBLAMENT de 26 de NOVEMBRE DE 1609}

Una vegada introduït el marc territorial d'aquesta investigació, la terra, és el moment d'ocupar-me dels protagonistes, els homes, les persones que habitaren aquest territori $\mathrm{i}$ aquells altres que simplement el posseïren com a amos $\mathrm{i}$ senyors $\mathrm{o}$ l'administraren en nom d'aquells. L'any 1609 constitueix el nostre punt de partida perquè és l'any en què comença el repoblament postmorisc, arran de l'atorgament de la Carta de Poblament -o simplement Carta Pobla- pel senyor de la baronia de Serra als nous colons i vassalls. Entorn a aquesta Carta Pobla, sobre el seu contingut, la figura de l'atorgador, els esdeveniments anteriors i les circumstàncies del moment, girarà i es centrarà aquest segon capítol.

En el cas de Serra, l'any 1609 no va ser només l'any de l'expulsió dels moriscos, sinó també l'any del repoblament de Serra i Ria, els únics dos llocs habitats de la baronia i que havien quedat totalment despoblats. Caldrà insistir en aquesta ràpida resposta: el 26 de setembre es decretà l'expulsió del moriscos, el 10 d'octubre van embarcar pel Grau de València tots els moriscos de Serra i Ria per a ser traslladats a "Berberia" i, tan prompte con el 26 de novembre d'aquell mateix any, en Josep Folch de Cardona, senyor de la baronia de Serra, atorgava carta de poblament als nous colons arribats per a repoblar-la. Aquest és un fet excepcional, si tenim en compte que la immensa majoria de les baronies valencianes que havien quedat despoblades per l'expulsió morisca no serien repoblades sinó desprès de molts mesos o encara anys. Així, de les 61 cartes de poblament recollides per Eugenio Císcar (1977) no en trobem més que quatre atorgades aquell mateix any 1609, mentre que la majoria d'elles (un 79 \%) foren atorgades entre mitjans de $1610 \mathrm{i}$ primers de 1612 (concretament s'atorgaren 9 en 1610, 35 en 1611 i 4 en 1612); les 8 restants (un $13 \%$ del total) serien atorgades posteriorment i encara al llarg de les següents dècades (entre els anys1616 i 1639).

Els altres tres casos de cartes de poblament atorgades aquell any 1609 corresponen, per una part, a la de Soneixa i Assuévar, baronia que també pertanyia al mateix en Josep Folch de Cardona, i que la va atorgar el dia següent a la de Serra, o siga, 
el 27 de novembre de 1609. La segona d'elles és la que atorgà l'Abat del monestir de la Valldigna, en 12 de desembre, per repoblar la part d'aquella vall que havia quedat despoblada arran de l'expulsió; i per últim, encara que cronològicament seria la primera, hi és l'atorgada per Baltasar Julià, Senyor de Pujol, en data 24 d'octubre de 1609, per a repoblar el seu lloc de Pujol (o Puchol). ${ }^{1}$

A banda de les recollides per Císcar (1977) i les recollides anteriorment per Torres Morera (1969) i per Gual Camarena (1989, encara que referit a un treball inèdit molt més antic), he de destacar un altre cas que ens interessa particularment. Es tracta de la Carta Pobla de Nàquera, baronia molt vinculada a la de Serra per proximitat i per història, com hem vist anteriorment, si bé, cap altra relació mantenia, almenys de caràcter nobiliari. El seu senyor, en Francesc Figuerola, va atorgar Carta de Poblament el dia 6 de desembre de $1609^{2}$.

En definitiva, deixant a banda (per ara) el cas de l'alqueria de Pujol, que ens resulta poc coneguda però no deixa de ser un interessant cas d'estudi (allunyada, no obstant, dels nostres objectius immediats), es dóna la circumstància de que la Carta de poblament de Serra va ser la primera d'una baronia en ser atorgada en el Regne de València i, per tant, a tota Espanya. D'ací la importància especial que té analitzar el seu contingut, pel fet de que no arribà a estar condicionat pels processos dilatoris que si afectarien a la resta de repoblaments del Regne de València, llargament envoltats en tota una sèrie de dificultats, reivindicacions a la Corona, intents negociadors per redimir deutes i censals, absència de nous colons disposats a acceptar certes condicions, etc. En fi, una llarga problemàtica que afectà de manera general i directa a tots els casos, però només indirecta i col·lateralment al cas de les baronies de Serra i de Soneixa (i també, òbviament supose, les de Nàquera, la Valldigna i l'esmentada de Pujol).

\footnotetext{
${ }^{1}$ Segons Torres Morera (a969, p. 63) es tractaria d'un annex de Toro, actualment despoblats dins el terme municipal d'Alzira. Entenc, però, que es tracta de l'antic poble i ajuntament d'aquest nom, Pujol, desaparegut a finals del segle XIX, en ser annexionat a Benimuslem i que encara tenia 12 veïns (56 ànimes) en 1840, segons consta en el Diccionari geogràfic-estadístic-històric de Madoz (1845-1850).

${ }^{2}$ El text de la Carta Pobla va ser publicat per Emili Lluch (1983 i 2002), citant la següent font: Archivo del Marqués de Boil. Carta Ejecutoria de Náquera.
} 


\subsection{NOTA BIOGRÀFICA DE JOSEP FOLCH DE CARDONA, SENYOR DE LA BARONIA DE SERRA}

En contra del que podríem haver suposat per la promptitud del repoblament de Serra-Ria i de Soneixa-Assuévar, el senyor d'ambdues baronies, en Josep Folch de Cardona i Cardona, no era un home llargament fet i expert administrador, sinó un jove de 25 anys d'edat sobre qui havia recaigut la responsabilitat d'administrar els seus bens per la mort de son pare feia menys d'un any. La seua joventut, però, no estigué renyida amb unes molt bones dots i capacitat d'obrar, un gran sentit de la responsabilitat i un ferm compromís militar amb la Corona. Tractaré de tractar i demostrar totes aquestes qualitats al llarg del present apartat biogràfic.

Josep Folch de Cardona i Cardona va ser l'únic fill baró de Galceran Folch de Cardona i Oms i de la seua esposa i cosina-germana Maria Anna de Cardona i Erill, que abans havien tingut una filla, de nom Violant. Josep va nàixer a Barcelona, el dia 18 de gener de 1584, i fou batejat el mateix dia amb els noms de Josep Antoni Benet Miquel i Jeroni, sent el seu padrí Benet de Toco, bisbe de Lleida, i la seua madrina Caterina d'Erill i Queralt, tia carnal seua. ${ }^{3}$ El 27 de novembre de 1601 (poc abans de complir els 18 anys) va ser investit Cavaller de l'Orde d'Alcàntera, de la mateixa manera que ho havien sigut també son pare, Galceran, en 1575, i el seu avi, Ferran, en 1548. A principis de l'any 1609 i en complir els 25 anys d'edat, Josep hagué de prendre la possessió de les baronies de Serra-Ria i Soneixa-Assuévar, per haver mort son pare a finals de l'any anterior. D'aquesta manera, pocs mesos més tard hauria d'enfrontar-se al traumàtic problema del total despoblament dels quatre llocs, ja que estaven habitats exclusivament per moriscos. Cal insistir en la seua joventut i en el fet de que els únics títols que aleshores posseïa són els que reflexa la Carta Pobla: ser Cavaller de l'Orde i Milícia d'Alcàntera, ser Senyor de les baronies de Serra i Ria i de Soneixa i Assuévar, i encara, ser "Gentil hòm de la boca de la Majestat el Rei nostre senyor", títol aquest darrer que, més que possessiu, defineix clarament el seu compromís personal amb la Corona.

El seu problema, una vegada despoblats els llocs, no es limitava a com repoblarlos per a que seguiren produint rendes (de fet eren, pràcticament, si no les úniques, si les principals rendes del jove senyor), sinó que hi havia un greu aspecte afegit, com era el d'haver de fer front al deute pels censals que suportaven aquests llocs, censals que o bé estaven carregats "sobre els moros" o almenys els suportaven ells. Evidentment, els censalistes no anaven a perdonar-ne res i això repercutia directament sobre la

${ }^{3}$ AHPZ, P/1-131-18 (referència també citada per Miguel Àngel Rodríguez, 2012). 
responsabilitat del jove senyor. Si bé aquest era un problema general en el conjunt de les baronies i senyories que havien estat ocupades per moriscos $i$ ara havien quedat totalment desertes, en Josep, potser per urgent i acuitant necessitat, havia de resoldre prompte aquella situació personal i va saber-ho afrontar i resoldre de manera diligent i efectiva. Per altra part, caldrà tenir en compte que la pretensió de molts senyors per a que els nous colons hagueren de fer front als deutes anteriors a l'expulsió, a més de la resta de càrregues habituals de vassallatge, seria un dels principals esculls pels quals molts llocs de moriscos no serien immediatament repoblats, com en el cas de Serra, sinó que romandrien deserts molt de temps, com he comentat adés.

Una de les causes del "desbloqueig” de l'esmentada situació general pot trobar-se, en part, en els processos negociadors i acords als que arriben els senyors territorials amb llurs vassalls; però, sobre tot, respon a la promulgació, per part de la Corona, de diverses pragmàtiques que rebaixant les despeses derivades de l'expulsió morisca i repartint els deutes pendents entre senyors i censalistes, aconseguirien unes condicions i un clima d'enteniment molt més efectiu, sobre el qual tornaré a referir-me desprès amb un poc més de detall. Per això, front al retard de la major part de les cartes de poblament postmorisques, crida l'atenció la promptitud amb la que Josep Folch de Cardona va saber atorgar les cartes pobles de Serra (el 26 de novembre) i de Soneixa (al dia següent), com també ho seria poc desprès la de Nàquera per part de Francesc de Figuerola. Sobre les causes d'aquesta ràpida $\mathrm{i}$ eficient resposta cal reconèixer, en primer lloc, un gran empeny i necessitat, a més de la capacitat i exercici de responsabilitat, que sens dubte demostrà tindre en Josep per a donar aquest primer pas. També analitzaré desprès açò amb més detall.

Evidentment, hi hagueren certes concessions que el senyor hauria de fer als seus vassalls, dins del conjunt de les dures mesures que, en general, contenen unes capitulacions de vassallatge, com és el cas. Sobre els detalls d'aquestes concessions també tornarem, en el moment de comentar el contingut de la Carta Pobla. També me n'ocuparé de les posteriors reivindicacions dels vassalls i les noves concessions que hi reberen en anys posteriors, en alguns aspectes i en alguns casos.

Tornant a la biografia d'en Josep Folch de Cardona, cal destacar el seu casament, en 1614, amb Jerònima Llull de Cabrera, aleshores amb el seu nom de vídua: Jerònima de Cruïlles i Santa Pau; filla de Joan Llull i d'Isabel de Cabrera. Per les seues 
capitulacions matrimonials ${ }^{4}$ sabem que va nàixer a Barcelona desprès de 1580 (aquest és l'any de la boda de son pare i sa mare). Era per tant una jove vídua, que havia estat casada amb el baró de Llagostera i I comte de Montagut, Guerau de Cruïlles de Santa Pau i de Cabrera, qui a la seua mort, ocorreguda en 1611, li havia deixat tots els seus bens $\mathrm{i}$ fins i tot el títol vitalici de comtessa de Montagut, malgrat que el comte havia tingut abans d'aquest matrimoni tres fills: Hug, Guerau i Gilabert, de la descendència dels quals i dels problemes haguts tornaré a parlar-ne en el capítol setè.

El cas és que, el títol de comtessa de Montagut el va dur Jerònima tota la seua vida, i el va compartir també amb el seu nou espòs, Josep Folch de Cardona, qui el faria servir en diverses ocasions, si bé a la mort de la comtessa, i tal como deixà escrit en el seu testament, el títol tornaria a certs descendents del seu primer marit.

A finals de setembre de 1630, en Josep, com a comte de Montagut, va ser cridat pel rei Felip IV, a través del virrei duc de Feria, per a realitzar un servei voluntari a la corona, al mateix temps que els comtes de Peralada, Santa Coloma i Vallfogona. Poc més tard van ser també cridats el comte de Jòc i el duc de Cardona (Enric Folch d'Aragó i de Cardona, cosí 3r d'en Josep), aquest últim com a noble amb el títol de més alt rang, aleshores, de Catalunya, sent també el noble català que tenia les possessions més extenses. $^{5}$

La missió d'aquell "servei voluntari” consistia en aportar reforços al malmès exèrcit amb el que el governador de Milà, Gonçalo de Córdoba, havia posat setge a la fortalesa de Casale (Casale Monferrato, al Piamonte), en una zona de conflicte bèl·lic amb els francesos (aquestes accions s'emmarquen en la "guerra de Monferrato": 16291631). També a Aragó i a València es feren lleves per contribuir amb aquestes accions. Desprès d'haver organitzat la lleva per a reclutar soldats, el 23 de novembre embarcaria

\footnotetext{
4 AHPZ P/1-131-18.

5 Joan Carrió Arumí (2008, p. 211) exposa que segons l'estimació feta per Aleix de Marimon en 1610, en la seua "Relación de la gente que su magestad puede sacar del principado de catalunia en la ocasion presente de los moriscos" (ACA, CA, 270, 120), els grans títols amb possessions a Catalunya podien mobilitzar-ne més de 3000 homes repartits de la següent manera: Duc de Cardona: 1000; Duc de Sesa: 300; Condestable de Castella: 300; Marquès d'Aitona: 300; Marqués de Camarasa: 300; Comte d'Erill: 200; Comte de Villafranca: 200; Comte de Queralt: 200, i Comte de Peralada: 200. També esmenta, sense concretar quantitats, els comtats del Rosselló i Cerdanya (i cita particularment el comte de Montagut, al comte de Canet i al vescomte de Jòc). I tanmateix diu que cada "de deu cases" tenia l'obligació d'enviar un home a les forces de la vegueria, sota comandament del veguer corresponent. Finalment afegeix que els bisbes i capítols catedralicis hi podien mobilitzar altres 2000 homes entre els vassalls de les terres sota la seua jurisdicció.
} 
en Barcelona, amb direcció a Gènova, la companyia del comte de Montagut que, "malgrat la seua pobresa", estava formada per 136 infants "muy lucidos y bien vestidos".

Aquesta no era ni molt menys l'única vegada que el comte de Montagut s'embarcava per la Mediterrània cap a terres italianes, doncs tenien, la seua esposa i ell, terres al comtat de Mòdica (sud de Sicília), que l'any 1635 li proporcionaren a la comtessa de Montagut (per herència procedent de la seua branca materna: la de Cabrera) una renda de 533 unces i 10 tarins (moneda siciliana d'argent, equivalent a un ral). ${ }^{7}$ Pels testaments d'en Josep i na Jerònima coneixem que també tenien propietats i rendes a Mallorca i a la Cerdanya (Principat). De fet, la mort d'en Josep li esdevingué en un port italià, a bord d'una galera reial espanyola, en l'any 1645.

Un lustre, però, abans de la seua mort, cap a 1640, Josep Folch de Cardona s'hagué d'exiliar fora de Barcelona per la seua pròpia seguretat, degut als conflictes de l'anomenada“guerra dels Segadors"(Vidal, 1984), doncs discrepava de la Generalitat catalana, estant més a prop de les postures i del poder del rei Felip IV. Per les circumstàncies derivades d'aquest conflicte i coincidint amb la mort de la seua fidel donzella, Àngela Barber, ${ }^{8}$ en agost de $1641,{ }^{9}$ la comtessa acabaria per traslladar-se a viure al Regne de València abans de finalitzar 1641, concretament a la seua casa palau de Soneixa (Rodríguez, 2012).

Recull Iquino (1982, pàg. 77 i ss.) que en Josep Folch de Cardona va morir a Nàpols el 26 de desembre de 1645 (tenia, per tant 61 anys d'edat), a bord de la galera Santa Àgueda ${ }^{10}$, i transcriu, traduint-lo de l'italià al castellà, el seu testament, que va trobar a l'ARV. El començament d'aquest acte, que he traduït directament de l'original en italià, resulta així:

Dia primer de maig de 1646. Nàpols. El dia 25 de desembre de 1645, compareix Cristóbal Mexia de Pedraza, Auditor de les Galeres Reials de Nàpols, en el Port de Bonifaci, en el present viatge i el meu auditor, en Varmelli Maestro, de dates d'aquells, en presència de l'il-lustríssim senyor comte de Montagut, don Josep Folch de Cardona, senyor de la baronia de Soneixa, Serra, Ria y Assuévar, en el Regne de València, estant

\footnotetext{
${ }^{6}$ Carrió (2008, pàg. 219 i 221).

7 AHPZ P/1-375-28 (també citat per Rodríguez, 2012).

8 Al seu testament, la comtessa la cita (encara que ja difunta) com Àngela Barberan.

9 AHPZP/1-24-128

10 Diu l'acta del notari de Nàpols que va ser a Port Bonifaci (Iquino, 1982, p. 77), que diu situat a Nàpols. Però Rodríguez (2012) considera més provable que el lloc de la mort fora Porto Vecchio (a Còrsega), just al nord de l'estret de Bonifaci, a la vista d'una nota biogràfica afegida en el doc. AHPZP/1-131-18 (sobre capitulacions matrimonials).
} 
malalt, en la galera Santa Àgueda, de Nàpols, però sa en enteniment, fa aquest son darrer testament que tindrà força en tot temps, el qual, en primer lloc deixa i vol que el seu cos siga traslladat per a ser enterrat a Soneixa, en l'església de Sant Miquel... ${ }^{11}$

Diu Iquino (1982) que el cos d'en Josep quedà dipositat a Nàpols, en el convent de Caputxins, fins a l'any 1649, en que el dugueren a Soneixa, desembarcant per Puçol, i rebent sepultura a l'església de Sant Miquel, a Soneixa, el dia 22 de juny d'aquell any. La comtessa moriria només quatre mesos desprès; suposa Iquino $(1983$, p. 83) que molt afectada desprès d'haver vist el cadàver del seu marit, mort quasi quatre anys enrere. El dia 17 d'octubre de 1649 seria enterrada na Jerònima Llull junt al cos del seu espòs (ella havia testat justament el dia anterior).

La sepultura estava coberta per una llosa de marbre negre que el propi Félix Iquino va conèixer i transcrigué en el seu treball sobre la història de Soneixa, en la mida en que va poder desxifrar la inscripció que duia, quasi il·legible. Segons Rodríguez (2012, en la seua nota de peu 40), aquella llosa la va manar posar Vicent d'Aragó i Cardona, hereu i successor en les baronies de Serra i de Soneixa.

\subsection{ELS EXPULSATS MORISCOS I EL DESPOBLAMENT DE SERRA I RIA}

En publicar-se el Decret d'expulsió, en 22 de setembre de 1609, els moriscos de Serra i Ria iniciaren la marxa cap al Grau de València a primers d'octubre, des d'on foren embarcats el dia 10 d'octubre de 1609 en un vaixell anomenat Santa Maria Buenaventura, sent el seu patró un tal Gaspar Borincho. Segons consta en l'estadística de moriscos embarcats ${ }^{12}$ pujaren a aquesta nau 150 moriscos, que eren 110 majors, 34 joves i 6 xiquets de pit, procedents tots ells dels llocs de Serra, Ria i Mirambell. No obstant això, considere molt poc probable que la presència de gent de Mirambell fóra rellevant en aquell grup, puix cal tenir en compte que el mateix dia també hi consta que n'embarcaven, en una altra nau, 172 persones de Mirambell (120 adults, 40 joves i 12 lactants), i tot açò crida enormement l'atenció pel fet de ser Mirambell un poblat menor que els dos de la senyoria de Serra. Efectivament, segons el cens de l'any 1602, Mirambell només tenia 23 cases, front a les 46 (justament el doble) que en tenien,

\footnotetext{
${ }^{11}$ ARV, Manaments i empares, any 1646, t. 4, m. 49, f. 33.

${ }_{12}$ AGS, estat, lligall 217; publicat per H. Lapeyre (1986): Geografia de la España Morisca.
} 
conjuntament, els llocs de Serra i Ria. ${ }^{13}$ Sembla per això, molt més probable que les 150 persones del primer vaixell foren totes de Serra i Ria i, fins i tot alguna més de les 172 de l'altre vaixell, el qual portava per nom Nuestra Señora del Rosario, sent el seu patró Especiano Samella.

Si acceptem que els 322 moriscos d'ambdues naus $(150+172)$, tots moriscos de Serra i Mirambell, corresponien a les 69 cases que sumaven els dos 1locs (46 i 23 cases, respectivament), ens trobem amb una xifra prou coherent: 4,7 de mitjana d'habitants per cada casa. ${ }^{14}$

S'ha estimat i calculat que els moriscos que hagueren d'abandonar el regne de València en aquells dies (uns 124.000, segons Lapeyre) eren més de la tercera part de la població valenciana. Aquest fet, evidentment, havia de suposar una profunda crisi en el desenvolupament social i econòmic del regne de València. Ja en els textos de l'època es manifesta diversitat d'opinions sobre la oportunitat, necessitat i conseqüències de l'expulsió, i encara avui és considerable el gran volum de literatura que es dedica a l'estudi del poblament musulmà i morisc i als efectes de la seua expulsió. Una visió interessant sobre l'evolució del pensament històric sobre els moriscos l'he trobada en el treball de Bunes (1983), tant a favor com en contra d'aquest minoria i la seua expulsió. Més recentment, coincidint amb el quart centenar de l'expulsió (1609-2009), el volum de bibliografia sobre aquest tema, en la seua vessant més humana, ha augmentat considerablement, però això escapa ja al nostre objecte.

Malgrat la possibilitat legal que deixava el decret d'expulsió, en el sentit que pogueren romandre habitades per moriscos un sis per cent de les cases de cada 1 loc, ${ }^{15}$ no hem trobat cap evidència ferma de que en la població de Serra romangués cap cristià nou desprès de l'expulsió. En Nàquera, no obstant, que formava part de la mateixa rectoria que Serra, si que en trobem al menys un cas; es tracta d'una partida de defunció que diu"16: "en 22 de mayo de 1632 murió Francisco Ays, marido de Catalina, entrambos cristianos nuevos".

En definitiva, sembla clar que la ruptura poblacional a Serra fou absoluta, i pràcticament no hi hagué solapament ni tan sols transició entre la cultura dels moriscs i la

13 ARV, Mestre racional, lligall 490, sg. 10.009; publicat per Lapeyre (1986)

14 Torres Morera (1969) aproxima a 5 el nombre de persones per cada casa de moriscos.

15 "Dimarts a 22 de setembre de 1609, a mig jorn, feren crida de com lo Senyor Rei manava que dins de tres dies s'embarquen dits moros en denis per a passar-los fora mar i que sols restessin en cada lloc, de cent cases sis cases los més vells" (dietari de Pere Joan Porcar: Coses evengudes en la ciutat i Regne de València).

16 Recollida per Emili Lluch $(1941,109)$ 
dels nous pobladors. Aquesta ruptura es manifesta fins i tot a nivell de la toponímia del terme, on són estranys i testimonials els mots que hom pot identificar amb la cultura i la parla dels musulmans i moriscos que habitaren aquestes terres durant vuit segles. Al respecte he fet una recerca toponímica, trobant com exemples que considere que poden tindre un clar origen àrab o andalusí (al menys en la seua arrel inicial) els següents:

La Rambla: partida que abasta un tram aigües avall del barranc del Llentiscle i aigües amunt de la font de Marianet. És més bé el llit torrencial aigües avall d'on es localitzava l'antic poblat mudèjar d'Armell.

La Xara (hi ha dos topònims): un ja desaparegut però que ve recollit en la Carta Pobla de 1609 com a bovalar de la baronia, junt al castell; i l'altre, un barranc situat fora ja del límit nord del terme i antiga baronia de Serra.

Moncúdio: coneguda muntanya que forma una gran penya allargada, en el sector sudoriental del terme, prop ja dels termes de Segart i de Nàquera.

Deula (Lèdua): font, barranc, basses... que semblava podia ser una variació de "teula" (font de la teula?), malgrat que alguns majors recorden antigues formes com "lleuda" $\mathrm{i}$ “nyeula". Però, en documentació del segle XVIII (notari Miquel Conejos) troben sempre escrita la forma Lèdua; per això, entenc que el topònim podria haver experimentat una evolució com aquesta: Lèdua $\rightarrow$ Leuda $\rightarrow$ Teula $\rightarrow$ Deula, a partir de la forma àrab: al$a d w a$, que ve a significar la terrassa fluvial o ribera d'un curs d'aigua.

Canaig: partida situada al sud-oest i prop de la població. Sembla referir-se a un o a diversos canats (alcavons o excavacions horitzontals per a la captació d'aigües subterrànies $o$ subàlvees) situats en dita partida i que, amb escassos recursos permetien el rec de petites hortes, com les de l'Ametllar.

El Siscar: partida situada un quilòmetre al sud de la població. Es tractaria d'un altre topònim relacionat $\mathrm{amb}$ elements hidràulics de l'agricultura. En aquest cas possiblement relacionat amb un sistar (un partidor d'aigües de rec, com el que perdura, amb el mateix nom, en la Font de Quart, a la vall de Segó). El partidor tindria el seu sentit tenint en compte que la partida es troba justament avall i contigua a "l'horta del Molí" i separant aquesta del barranc de Serra-Nàquera, on es troben les restes de l'antic Molí fariner de la baronia.

Marianet: partida, font i barranc situats dos quilòmetres al Nord de la població). En documentació del segle XVIII (protocols de Miguel Conejos, ARV) l'he trobat citat en vàries ocasions i anys com a "marignet" i encara "mariagmet" (Marià Agmet?). A més a més, un document del segle XVI, publicat per Ferrer (1988) deixa clar que "Marianet" era el nom d'un morisc de Ria. 
La resta de topònims (prou més d'un centenar) ${ }^{17}$ tenen un clar origen modern (segle XVII, valencià o castellà) generalment relacionats amb fauna, vegetació, elements del relleu o usos del territori: la Moleta, l'Alt del Pi, el Pla de les Llomes, les Penyes Altes, l'Horta Nova, les fonts de la Prunera, del Llentiscle, del Berro, el Pla dels Rebalsadors, l'Ombria, el barranc Fond, el barranc dels Llops, el Puntal del Sapo, les Aliguetes, el Puntal de les Forques, el Molí, les Penyes del Garbí, el Racó de la Misèria, el Carasol dels Ermitanys, l'Alt de la Nevera, les Vinyetes, l'Algepsar, Sant Antoni, etc.

\subsection{SOBRE EL CONTINGUT DE LA CARTA POBLA I ELS SEUS TRASLLATS}

Estrictament cal dir que una Carta Pobla i els actes formals que inicien un repoblament haurien de contindre, en essència, al menys tres parts o actes:

a) El de les capitulacions o pactes convinguts (acte de repoblament),

b) El del jurament de fidelitat o vassallatge (acte de vassallatge) $\mathrm{i}$

c) El de la designació dels primers càrrecs (acte de nomenament d'oficials).

Així ho entén Rodríguez (2009) en el seu acurat estudi sobre la carta pobla de Soneixa i Assuévar. En el cas de Serra i Ria coneixem els dos primers actes, però no hem pogut localitzar la tercera part. Nogensmenys, és evident que va ser rebuda pel mateix notari, doncs el càrrecs els coneixem parcialment, per documents posteriors $i$, a més a més, havent-se trobat les tres parts completes per a la carta pobla de Soneixa i Assuévar (del mateix notari: Gregori Tarraça; amb el mateix senyor: Josep Folch de Cardona, i signades ambdues en dos dies consecutius), res no indica que no se seguira el mateix procediment en la de Serra i Ria. ${ }^{18}$ Recordem també -ja ho havia avançat- que en cap dels dos casos (ni de Serra ni de Soneixa) hem pogut trobar els protocols notarials originals, sinó que tot el que coneixem ho és a través de diversos trasllats i còpies, com seguidament veurem.

Però, en la pràctica, moltes vegades s'assimila el sentit d'una Carta Pobla només a la primera d'aquestes parts (l'acte de poblament), que és òbviament la més transcendent amb el pas del temps; la resta, simplement s'omet, bé per no haver sigut localitzada la font original o bé per desconeixement o per manca d'interès, una vegada desapareguda la primera generació de colons. Així ho podem veure en diferents treballs de recopilació de

\footnotetext{
17 Ens basem en un estudi realitzat a partit de nombrosos registres i fonts històriques (Garay et al., 2010).

18 Així ho he vist en altres protocols notarials i, particularment, en els escassos de Gregori Tarraça que encara es conserven (APCC).
} 
cartes de poblament, com el de Torres Morera (1969), Císcar (1977) o Gual Camarena (1989).

També volem fer, encara, un parell més d'observacions al respecte. Per una part, que algunes cartes-pobles, en el seus actes de poblament ja inclouen càrrecs concrets assignats (justícia, batlle, jurats, etc.) justament darrere del nom d'alguns dels repobladors; tal és el cas, per exemple, de les cartes-pobles d'Olocau (la de 1611) ${ }^{19}$ o de Bétera (de 1910), ${ }^{20}$ amb la qual cosa no resultaria ja procedent rebre un acte posterior per als nomenaments.

El tercer dels actes citats entenc, però, que més que un sol acte hauria de considerar-se que es tractara de la rebuda de tot un conjunt d'actes, no solament el de “designació de càrrecs", sinó també una col·lecció d'actes d'assignació de béns a cadascun dels colons, un acte personalitzat per a cada repoblador, amb objecte d'assignar-li a cadascú la seua casa i terres concretes que els pertanyeren a partir del jurament de fidelitat. Així ho troben explicat ("escriptures dels establiments") per exemple, en el cas de la Carta Pobla de Sot de Ferrer, estudiada per Guerrero i Corbalán de Celis (2002). I així ho hem trobat en els escassos però gruixuts volums originals del notari Gregori Tarraça (el mateix notari que registrà els repoblaments de Serra-Ria i de Soneixa-Assuévar) que es conserven en l'APCC: carta pobla d'Alberic, Alasquer, Gavarda i altres.

Del propi contingut de la Carta Pobla de Serra i Ria també deduïm que tots aquests actes posteriors al de Repoblament $\mathrm{i}$ al de Vassallatge estaven ja prevists en els primers. Concretament:

a) Quan el capítol 17 tracta de la forma de nomenar govern (justícia, jurats, mustassaf...) preveu que del nomenament $\mathrm{i}$ jurament de càrrecs "se reben actes públics per lo escrivà de la cort de la dita baronia o per altre notari públic...”.

b) Per altra part, la carta de poblament sempre parla en futur dels establiments que s'hauran de fer de cases i terres a repartir entre els colons (capítols 4, 6, 12 i 14). Concretament, en el capítol sisè expressa que "se hagen de fer de dites cases i terres los establiments que necessari seran".

La carta pobla que en 26 de novembre de 1609 atorgava Don Josep Folch de Cardona als 30 colons que vénen a repoblar els llocs de Serra i Ria, va ser

19 Publicada per Ferran Zurriaga (1987).

20 Publicada en castellà per Domènech (1998). 
publicada, per primera vegada i incloent les capitulacions $i$ el vassallatge, en el llibre de Josep Senís Domingo (1954; amb una segona edició de 1978). Encara que el llibre no dóna informació sobre la procedència del text, hem comprovat que el va copiar directament del material inèdit que Ambròs Cebrián (mort en $1933)^{21}$ tenia recopilat per a escriure un llibre sobre la història i geografia de Serra. Tot aquest material, organitzat en part per Emili Lluch en 1935, és un opuscle que es conserva encara inèdit en l'Arxiu Municipal de Serra ${ }^{22}$. Un aspecte que crida ràpidament l'atenció en aquesta versió de la carta-pobla és una errada que trobem en la mateixa data inicial: Die XXVI mensis Novembris anno a Nativitate Dm. M.D.V.III, o siga, any 1508 (sic) en lloc de 1609. Aquesta errada la recull tant el manuscrit de Cebrian i Lluch com les dues versions de Senís (1954 i 1987). A l'escatocol final del text queda clar que es tracta d'un trasllat rebut per pel notari Joseph Insa, que diu ser regent dels protocols de Gregori Tarraça, el notari que el 1609 dugué endavant tot el procés del poblament de Serra i Ria i de Soneixa i Assuévar.

Rodríguez (2009, p. 78) posa de manifest que el notari Josep Insa hauria exercit la seua activitat pels volts del 1664-1693, període que correspon al dels seus protocols, custodiats en l'APCC. Per tant, estaríem parlant de la còpia d'un trasllat de finals dels segle XVII.

Torres Morera (1969) cita també la de Serra i Ria entre les 57 cartes pobles que va estudiar. Publica només la relació dels vassalls i refereix com a fonts documentals l'AMS (sense més), el llibre de Senís (1954) i un manuscrit existent en la biblioteca de la Universitat de València (citat com: B. U. de V., D/1730).

Una altra possible versió de la Carta Pobla de Serra es la que publicà Eugenio Císcar (1977; p. 361-367), en la que, sospitosament, també arrossega l'errada del començament: Die XXVI mensis Novembris anno a Nativitate Dm. M.D.(C, afegida a ma) VIIII (posat bé); i això fa pensar la clara possibilitat de que poguera tractar-se de la mateixa font o versió ja utilitzada per Josep Senís. La resta del text és pràcticament coincident amb el publicat per Senís i, a més a més, també al final hi consta que es tracta d'un trasllat de Josep Insa, sense posar la

\footnotetext{
${ }^{21}$ P. Garay i I. Giménez (2001): “Ambrosio Cebrián Santos (1863-1933)...”.

22 AMS, “Apuntes y Notas para la historia de Serra”; manuscrit inèdit, d'Emili Lluch Arnal i Ambròs Cebrian i Santos.
} 
data del trasllat. No obstant, com a font documental indica la següent: $A R V$, Corte Civil, Libro de Ejecutorias. Año 1774, f. 31. Curiosament, Miguel Àngel Rodríguez (2009, p. 79) comenta que va buscar aquesta versió sense èxit a l'ARV, sense poder arribar a localitzar com a tal aquell "llibre d'executòries". Per la meua part, he tornat a insistir sobre aquesta cita i, amb la inestimable ajuda de Geno Almiñana (ARV), hem arribat a la conclusió de que aquella referència correspon realment al llibre de "Reales Ejecutorias, volum 12", de la sèrie del Justícia Civil (i concretament la signatura 821 d'aquesta sèrie). Efectivament, aquest volum correspon a l'any 1774 , però, al anar a la pàgina 31 , el que trobem no és la carta-pobla de Serra, sinó la de Muro, Turballos i Gaianes (l’Alcoià), citada dins una executòria a favor del duc de Santistevan (i comte de Cocentaina) i contra la universitat d'aquests llocs, sobre el pagament de terç-delme de l'oli. La resta del volum tampoc fa cap referència a Serra.

L’obra pòstuma de Gual Camarena, sobre la seua recopilació de Cartes de Poblament (obra de 1948 publicada el 1989) cita també la carta pobla de Serra i Ria, però hi aporta dues noves referències documentals: $A R V$, Escribanias de Cámara, año 1791, exp 58, per una part, i BUV, secció manuscrits, Ms. núm. 865. De la segona font indica que és una còpia del segle XVIII. Aquesta darrera referència podem sospitar que fóra la de la BHUV, amb una referència canviada o equivalent a la del manuscrit també citat per Torres Morera (1969).

Insistint sobre aquest manuscrit (o manuscrits), sota la custòdia de la Universitat de València (dins de la BHUV), Rodríguez també el cita i el identifica com BHUV, Sección Manuscritos, ms. 803 (6). I encara l'he trobada citada en el volum primer del Catálogo de los Manuscritos existentes en la Biblioteca Universitaria de Valencia, de Marcelino Gutiérrez del Caño (1913), sota la següent referència:

No 435 Copia de la Carta Puebla de la Baronia de Serra 9 hojas a 26 líneas.- Papel 0,316 alto X 0,219 ancho: caja escritura 0,295X0,150. Letra S. XVIII. Port.-V. En bl.-Texto. Rúst'. Está escrita en valenciano y la otorgó su Señor D. José Folch de Cardona, en 26 de noviembre de 1509.

En resum, a més del número 435 de l'esmentat catàleg, el manuscrit (o manuscrits) respondrien a tres referències diferents:

$B U V, D / 1.730$. .(segons Torres Morera, 1969, p. 67)

BUV, secció manuscrits, Ms. 865......(segons Gual Camarena, 1989, p. 173)

BHUV, Secció manuscrits, Ms. 803 (6).....(segons Rodríguez, 2009, p. 79) 
Finalment, en l'arxiu de la biblioteca històrica hem trobat i comprovat que, segons les taules d'equivalències, el número 435 del Catàleg de manuscrits correspon realment al Ms. Núm. 865 de la "Secció de manuscrits", i que la referència 803 és la que té el mateix document microfilmat (i dins d'ella seria el document número 6).

En conseqüència, arribem a la conclusió que el text transcrit per Ambròs Cebrián i Emili Lluch (el que Josep Senís va publicar) està tret de la còpia (només una) existent en la BHUV. De la matixa manera, el text que publicà Eugenio Císcar correspondria també, sens dubte, al mateix text i font. ${ }^{23}$

A l'Arxiu del Regne de València, a més del document citat per Gual Camarena (1989) hem trobat un altre més, tots dos en la mateixa sèrie:

ARV, Escribanías de Cámara, año 1791, exp. 58: trasllat de 22 de desembre de 1740, fet pel notari Patricio Bernat (aquest és el citat per Gual Camarena, 1989).

ARV, Escribanías de Cámara, año 1806, exp. 15: trasllat de data 21 d'agost de 1795, fet pel notari José Velasco.

Per altra part, hem localitzat altres sis còpies o trasllats de la carta pobla en la Secció Noblesa de l'AHN, pertanyents als fons del Duc de Fernán-Núñez (dins el qual està inclòs el del Ducat de Montellano i les baronies de Serra, Soneixa, Massalavés i altres possessions del ducs en el Regne de València). Les referències són aquestes:

AHN-FN, caixa 1165, doc. 1 (1).

AHN-FN, caixa 1165, doc. 1 (2).

AHN-FN, caixa 1165, doc. 3: trasllat de data 6 de juliol de 1770, pel notari Juan Antonio Espada.

AHN-FN, caixa 1357, doc. 3 (1): còpia feta per Josep Yguals, escrivà de l'ajuntament de Serra, en data 10 de febrer de 1752, presa d'un registre conformat per Josep Insa, regent dels protocols de Gregori Terraça.

AHN-FN, caixa 1357, doc. 3 (2): còpia anònima i sense data.

AHN-FN, caixa 1357, doc. 3 (10): trasllat fet de data 28 d'octubre de 1837, fet pel notari de Madrid José Salcedo.

En el seu esmentat llibre La Carta Puebla de Soneja y Azuébar, Miguel Àngel Rodríguez (2009) fa un exhaustiu estudi sobre els diferents exemplars d'aquella carta pobla de Soneixa-Assuévar, esbrinant nombroses publicacions i registres fins a identificar no menys d'una vintena d'exemplars diferents, entre trasllats, còpies i

\footnotetext{
${ }^{23}$ De fet, a banda de citar la referència del "llibre d'executòries", Císcar indica en la pàgina 18 del seu llibre que "la referència específica" de la carta pobla de Serra-Ria seria la reproduïda en Senís (1954).
} 
traduccions. Rodríguez no va poder localitzar, no obstant, els originals de Gregori Tarraça, ni entre els escassos protocols coneguts d'aquest notari, arxivats a l'APCC, ni tampoc els primers trasllats que aquest notari hagué d'estendre a les parts afectades (Josep de Folch de Cardona i Consells de Soneixa i Assuévar) en 1609. Complementàriament a la recerca de la carta pobla de Soneixa, Rodríguez també exposa el seguiment paral·lel que ca fer sobre la Carta Pobla de Serra i Ria, tenint en compte que seria molt provable que ambdues hagueren pogut arribar a la mateixa ubicació o destí. Tampoc no va localitzar els protocols originals de Gregori Tarraça sobre la Carta Pobla de Serra i Ria. No obstant, exposa i comenta també, en el seu llibre, les diferents versions (trasllats, còpies i referències) d'aquesta, versions que són pràcticament les que he citat fins ací. Fins i tot, en un dels annexes del seu llibre inclou també, per a comparació amb la del Soneixa i Assuévar, la transcripció d'aquella versió de la Carta Pobla de Serra i Ria que ell considera que pot ser la més ajustada i fidel a l'original de Gregori Tarraça: la que correspon al trasllat fet pel notari Juan Antonio Espada el 6 de juliol de 1770: $A H N(F N)$, c. 1165 (3).

Sobre la justificació que fa Rodríguez per a concloure i defensar quines són les versions més fiables i finalment seleccionades, no puc menys que remetre'm a les seues fonamentades argumentacions i coincidir amb elles. No obstant, al marge d'això, em va cridar fortament l'atenció que l'exemplar identificat com a $A H N(F N), 1165 / 1, n^{\circ} 2$ era un element de treball i consulta dins l'arxiu del Duc de Montellano, tal com ho demostra el format, en quartilla, el fet de trobar-se prou gastada per l'ús i les anotacions marginals afegides per a l'ordenació i referència de continguts dels diferents items o capítols. He considerat, per això, que podria ser més adient, als efectes de la nostra investigació, reproduir el text (amb forma normalitzada) d'aquesta darrera versió, que incloc com ANNEX II. En tot cas, el contingut no difereix de la publicada per Rodríguez, llevat de les notes marginals.

Hem confrontat les dues darreres versions que acabe de citar, amb la publicada per Josep Senís (1954) i per Eugenio Císcar (1977), comprovant-ne la seua general i aproximada coincidència en el fons, si bé, hi ha clares diferències puntuals en quan a abreviatures, grafismes, omissions, criteri lingüístic i errades involuntàries, aspectes sobre els que no paga la pena dedicar-ne ara més atencions. Només afegirem, al respecte, que l'escriptura valenciana dels exemplars de l'AHN (SN) està més a prop de la moderna normalitzada que no la publicada per Senís (i en menor grau la de la BHUV) que sembla 
més descurada i arrossega més formes apitxades i de grafia castellana, per exemple "quansevol" per qualsevol, "reine" per regne, "huintena" per huytena (sic., AHN), etc. Hi ha, però, un aspecte que sí que considere d'especial interès revisar: la denominació dels diferents colons signants de la Carta-Pobla.

Pel que fa a la llista dels repobladors, les versions de Senís i de Císcar són quasi calcades, entre elles i també amb la còpia de la BHUV. Per això sospite que aquesta última és la font original d'ambdues publicacions citades. Totes tres coincideixen en la variada forma de repetir els noms del colons cada vegada que son citats els repobladors. Aquestes variacions, que hem revisat i confrontat són les que recollim en les diferents columnes del QUADRE 2.1.

L'acte de poblament inclou la relació de colons dues vegades: en la intitulació del protocol inicial i en la validació final, dins l'escatocol. Aquestes dues vegades són les recollides en les columnes primera i segona d'aquest quadre. Per altra part, també l'acte de vassallatge torna a citar dues vegades a tots els repobladors, primer en el seu protocol inicial i desprès en l'escatocol; i així els he citat, respectivament, en les columnes tercera i quarta. Per últim, en la columna cinquena he posat, destacat en lletra negreta i amb una grafia actualitzada (respectant els actuals acabaments amb z del castellà) el que considere que són les formes més a l'ús o, almenys, les més confiables dels noms i cognoms. És també una conclusió a la que arribe desprès de confrontar les quatre esmentades columnes amb les formes que recull, per altra banda, la versió de la carta pobla publicada per Rodríguez (2009) que, recordem, respon a la signatura $A H N(F N)$, c. 1165 (3).

A banda d'açò cal fer un aclariment i és la confusió que introdueix Torres Morera (1969) en la seua llista de repobladors, doncs en el lloc dels dos repobladors de Ria Joan Guillem i Miquel Granell, que havien sigut oblidats al inici del protocol $\left(1^{\mathrm{a}}\right.$ columna del quadre), cau en l'equivocació de posar altres dos noms que no tocava: Arnau Moles i Jaume Silvestre, dos llauradors de Soneixa que acompanyaven al Senyor) ${ }^{24}$ i que realment només actuen com a testimonis del primer acte, el de poblament, sense que res més tinguen a veure amb els vint repobladors de Serra ni amb els deu de Ria. Per això comptabilitza Torres Morera (1969, p. 67), erròniament, que dos dels repobladors de Ria eren originaris de Soneixa.

\footnotetext{
${ }^{24}$ Aquests llauradors són dos dels vassalls que signarien la carta pobla de Soneixa l'endemà.
} 
QUADRE 2.1.-Llistat dels repobladors de Serra i Ria, segons diferents versions de la carta-pobla.

SERRA

\begin{tabular}{|c|c|c|c|c|}
\hline $\begin{array}{l}\text { Bertomeu } \\
\text { Salvaterra } \\
\end{array}$ & $\begin{array}{l}\text { Bertomeu } \\
\text { Salvaterra }\end{array}$ & & $\begin{array}{l}\text { Bertomeu } \\
\text { Salvaterra }\end{array}$ & \begin{tabular}{|c} 
Bertomeu Salvaterra \\
$(1)$
\end{tabular} \\
\hline Miquel Sanchis & Miquel Sanchis & Miquel Sanchis & Miquel Sanchis & Miquel Sanchis (2) \\
\hline Joan Sanchis & Joan Sanchis & Joan Sanchis & (s'omet) & Joan Sanchis (3) \\
\hline Joan Munyoç & Joan Munyoç & Joan Munyoç & Joan Munyoç & Joan Munyoz (4) \\
\hline Antoni Salvador & Antoni Salvador & Antoni Salvador & Antoni Salvador & Antoni Salvador \\
\hline March Palacio & March Palacio & March Palacio & March Palacio & Marc Palacio \\
\hline Jaume Noguera & Jaume Noguera & Jaume Noguera & Jaume Noguera & Jaume Noguera \\
\hline Joan Teruel & Joan Teruel & Joan Teruel & Joan Teruel & Joan Teruel \\
\hline Francesch Morell & Francisco Morell & Francisco Morell & Francesc Morell & Francesc Morell (5) \\
\hline $\begin{array}{l}\text { Miquel Domingo } \\
\text { de Bartolomé }\end{array}$ & $\begin{array}{l}\text { Miquel Domingo } \\
\text { de Bertomeu }\end{array}$ & $\begin{array}{l}\text { Miquel Domin } \\
\text { de Bertomeu }\end{array}$ & $\begin{array}{l}\text { Miquel Domingo } \\
\text { de Bertomeu }\end{array}$ & $\begin{array}{l}\text { Miquel Domingo de } \\
\text { Bertomeu }\end{array}$ \\
\hline $\begin{array}{l}\text { Miquel Domingo } \\
\text { de Martí }\end{array}$ & $\begin{array}{l}\text { Miquel Domingo } \\
\text { de Martí }\end{array}$ & $\begin{array}{l}\text { Miquel Domingo } \\
\text { de Martí }\end{array}$ & $\begin{array}{l}\text { Miquel Domingo } \\
\text { de Martí }\end{array}$ & $\begin{array}{l}\text { Miquel Domingo de } \\
\text { Martí }\end{array}$ \\
\hline Sebastià Ribes & Sebastià Ribes & Sebastià Ribes & Sebastià Ribes & Sebastià Ribes \\
\hline Domingo Diago & Domingo Diago & Domingo Diago & Domingo Diago & Domingo Diago \\
\hline Antoni Esteve & Antoni Esteve & Antoni Esteve & Antoni Teruel & Antoni Esteve (6) \\
\hline Pere Joanes & Pere lbanyeç & Pere lbanyeç & Pere Joanes & Pere Ibànyez (7) \\
\hline $\begin{array}{l}\text { Dominlo Manyeç de } \\
\text { Miquel }\end{array}$ & $\begin{array}{l}\text { Domingo Manyes } \\
\text { de Miquel }\end{array}$ & $\begin{array}{ll}\text { Domingo Manyes } \\
\text { de Miquel }\end{array}$ & $\begin{array}{l}\text { Domingo Manyec } \\
\text { de Miquel }\end{array}$ & $\begin{array}{l}\text { Domingo Mànyez de } \\
\text { Miquel (8) }\end{array}$ \\
\hline Joan Palacios & Joan Palacios & Joan Palacios & Joan Palacios & Joan Palacios (9) \\
\hline Menau Lanes & Menau Llanes & Menau Llanes & Manuel Ibanyeç & Menau Llanes (10) \\
\hline Jaume Fonfria & Joan Fonfria & Jaume Fonfria & Joan Fonfria & J. (Jaume?) Fonfria \\
\hline Miquel Saeç & Miquel Saeç & Miquel Saeç & Miquel Saeç & Miquel Saez (11) \\
\hline
\end{tabular}

$\boldsymbol{R I A}$

\begin{tabular}{|c|c|c|c|c|}
\hline Miquel Ribes & Miquel Rives & Miquel Ribes & Miquel Ribes & Miquel Ribes \\
\hline $\begin{array}{l}\text { Vicent } \\
\text { Ribera }\end{array}$ & $\begin{array}{l}\text { Vicent } \\
\text { Ribera }\end{array}$ & $\begin{array}{l}\text { Vicent } \\
\text { Ribera }\end{array}$ & $\begin{array}{l}\text { Vicent } \\
\text { Ribera }\end{array}$ & Vicent Sarigó Ribera \\
\hline (s'omet) & Joan Guillem & Joan Guillem & Joan Guillem & Joan Guillem (12) \\
\hline (s'omet) & Miquel Granell & Miquel Granell & Miquel Granell & Miquel Granell (12) \\
\hline Joan Salvador & Joan Salvador & Joan Salvador & Joan Salvador & Joan Salvador \\
\hline Aich Salvador & (s'omet) & $\begin{array}{ll}\text { Antoni } & \text { Lluch } \\
\text { Salvador }\end{array}$ & Lluch Salvador & $\begin{array}{c}\text { Antoni Lluch Salvador } \\
(13)\end{array}$ \\
\hline $\begin{array}{l}\text { Domingo } \\
\text { Vilanova } \\
\end{array}$ & $\begin{array}{l}\text { Domingo } \\
\text { Vilanova }\end{array}$ & $\begin{array}{l}\text { Domingo } \\
\text { Vilanova }\end{array}$ & $\begin{array}{l}\text { Domingo } \\
\text { Vilanova }\end{array}$ & Domingo Vilanova \\
\hline Antoni Sanchis & Antoni Sanchis & Antoni Sanchis & Antoni Sanchis & Antoni Sanchis (14) \\
\hline Miquel Garves & Miquel Garves & Miquel Garves & Miquel Garves & Miquel Garrués (15) \\
\hline Joan Rubio & Joan Rubio & Joan Rubio & Joan Rubio & Joan Rubio (16) \\
\hline
\end{tabular}

Les dues primeres columnes corresponen a la versió publicada per Senís (1954; la tercera la publicada per Císcar (1977); la quarta a la copia de la BHUV, i la cinquena, destacada en lletra negreta, seria la denominació que trobem més encertada desprès de considerar les versions de l'AHN-FN i la publicació de Rodríguez (2009). 
Les notes afegides en la columna cinquena del quadre 2.1 es refereixen a la fila en que estan i responen a les explicacions següents:
1) en la $2^{\mathrm{a}}$ i $3^{\mathrm{a}}$ columna posa Salbaterra (amb b).
2) en la $4^{a}$ posa Sanchiz (amb z).
3 ) omet el nom en la $3^{a}$ però no en la $4^{\mathrm{a}}$.
8) posa sempre Manyes.
9) posa Miquel Palacio (sic.) en la $3^{\mathrm{a}}$.
4) posa sempre Muñós (amb s i accent).
5) en la $1^{a}$ posa Francisco i en la $4^{a}$ Francés.
10) en la $4^{\mathrm{a}}$ posa Manuel Lanes (sic.).
11) posa sempre saez ( $a m b z)$.
12) en la $1^{\text {a }}$ columna no estan omesos.
13) posa sempre Luch Salvador (en la $2^{\text {a }}$; omès).
14) posa Sanchiz en $2^{\mathrm{a}}$ i $3^{\mathrm{a}}$.
6) en la $3^{\mathrm{a}} \mathrm{i}$ en la $4^{\mathrm{a}}$ posa Steve (i no Teruel).
7) posa sempre Yvanyes.
15) posa sempre Miquel Garrnez.
16) posa sempre Joan Ruvio (amb v).

Observeu també que, en l'escatocol de l'acte de poblament (veure l'apèndix documental) es fa constar que dos dels repobladors de Serra, Joan Palacios i Menau Llanes, estaven absents en aquell acte del dia 26 de novembre, però el segon, Menau Llanes, també signà la carta tres dies desprès (el 29 de novembre) "en lo dit lloc de Serra", sent testimonis Nicolau Simó, escrivent habitador de València, i Francesc Palma Barrasa, criat del dit en Josep.

Igualment succeeix el dia següent, quan se signa la carta de Soneixa i Assuévar: no es troben presents en l'acte quatre dels repobladors, acte del qual foren testimonis Nicolau Simó, escrivent de València i Antoni Garcia, criat del Senyor. Dos dels absents signarien desprès, dia 29 de novembre, a Soneixa, amb presència del mateix Nicolau Simó i d'Antoni Massó, criat de dit en Josep, com a testimonis. I un altre dels repobladors absents, Arnau Moles, també s'afegí al acte de poblament de Soneixa i Assuévar però signant-lo a Serra, el mateix dia i junt a Menau Llanes i davant els testimonis dalt citats.

Per tant, dels 30 repobladors de Serra i Ria, dos no arriben a temps per a l'acte del dia 26 de novembre, i d'ells, Menau Llanes signa la carta de poblament tres dies desprès, però no hi consta, en canvi, la signatura ni jurament de Joan Palacios. Dels 45 repobladors de Soneixa i Assuévar tampoc quatre d'ells arriben a temps de signar el dia 27, però dos d'ells signaran el dia 29 a Soneixa i un tercer signarà el mateix dia a Serra junt a Menau Llanes (tampoc hi consta la possible signatura ni jurament del quart, Joan Carbó). Totes aquestes absències les trobem referides als actes de poblament (de les dues baronies) però no en canvi en els de vassallatge. 
En quan als testimonis, crida l'atenció que sempre apareix, Nicolau Simó, escrivent habitador de València (possiblement acompanyant i/o ajudant del notari Tarraça, i algun criat de Josep Folch de Cardona, que en un cas és Francesc Palma Baraça $^{25}$, en un altre Antoni Garcia i en un tercer cas Antoni Massó. Però aquest últim no és un simple criat, sinó el repoblador que apareix citat en primer lloc dins la carta pobla de Soneixa i Assuévar, qui dedicaria tota la seua vida a servir al seu Senyor, fins i tot com a batlle de la baronia de Soneixa i Assuévar. Per açò, en el seu testament, atorgat en 1649, na Jerònima Lllull, vídua d'en Josep, li deixa a Úrsula Anna Cevadero, la vídua del batlle Antoni Massó, pels molts serveis que havien prestat, la possessió franca i gaudiment de tota la seua hisenda dins els termes de la baronia, i sense que estiguen obligats en residir a Soneixa, ni ella ni els seus fills "als qual han donat l'ofici de batlle i assessor de la baronia" ${ }^{26}$.

Sobre la procedència i la descendència dels nous pobladors i la substitució de colons, o siga, "els altres" protagonistes de la carta pobla de Serra i Ria, dedicaré el següent capítol. Això no obstant, avançaré una observació, com és que en la Carta Pobla de Soneixa i Assuévar també apareixen alguns repobladors amb cognoms coincidents amb els de Serra i Ria; concretament: Martín Domingo, Pedro Domingo, Jaime Ribes, Juan Manyes, Juan Esteve, Domingo Manyes... a més dels cognoms Silvestre i Pérez, que prompte trobarem també a Serra en els anys següents. Per tot açò també resulta evident que pogueren existir, entre ambdues baronies, grans similituds en el procés de repoblament i de procedència del colons.

\subsection{REPOBLAR NO VA SER, EN GENERAL, UNA TASCA FÀCIL NI SENZILLA}

L'aparent facilitat de trobar nous pobladors, que reflecteixen les dues cartes pobles que atorgà en Josep Folch de Cardona, podem considerar que és un gran mèrit personal, si tenim en compte que són molt poques les baronies que es repoblaren en aquells primers anys 1609-1610 i no totes tingueren èxit en el seu primer intent. Així tenim un exemple molt proper, el de la veïna vall d'Olocau (Olocau, Marines, Gàtova, Torres...), el Senyor de la qual, Joan Vilaragut, va atorgar una primera carta pobla en 20 d'agost de 1610, estant en Mallorca (on residia per ser el virrei d'aquest regne), però no

\footnotetext{
${ }^{25}$ Les versions de Senís (1954) i de Císcar (1977) l'anomenen "Francisco Palma Bauraco".

${ }^{26}$ Es pot veure el testament en la Historia de Soneja de Iquino Parra (1982, p. 85).
} 
va assolir plenament els objectius perseguits; per la qual cosa, aquella carta pobla no deixa de ser un exemple de les serioses dificultats que hi hagueren per a repoblar.

Part de les dificultats són evidents en el fet de que el cristians vells no estaven disposats a acceptar fàcilment les dures condicions econòmiques i fiscal en les que es trobaven els moriscos, particularment pels censals que havien de suportar. Per una part, suposem que els nous pobladors es resistien a acceptar la càrrega d'haver de pagar els deutes d'altri, uns deutes que, a més a més, consideraven que no els corresponien a d'ells sinó als senyors de les baronies; i per altra part, hi havia una gran diferència demogràfica, de tal manera que, la quantitat recaient sobre una determinada "universitat de moros" es pretenia que ara seguira recaient sobre una "universitat de cristians vells" molt minvada, comparativament, en veïnat. I per l'altra part estaven els censalistes, que evidentment no volien ni tenien per què renunciar als seus drets i ingressos pendents.

En tal sentit és molt il·lustratiu el cas que indica Corbalán de Celis (1997, p. 27), en referir-se als llocs de la baronia de Torres Torres que havien sigut de moriscos (Algímia i Alfara), puix el 23 de desembre de 1609 havien iniciat els censalistes les execucions necessàries per al cobrament dels seus deutes. El primer en reclamar aquest pagament fou el síndic del capítol de canònics del lloc d'Alguer (regne de Sardenya). També indica com el síndic de Torres Torres respon a l'Audiència pregant que no siguen embargats per deutes comuns $\mathrm{i}$ els hi concedeixa un termini de quatre mesos en que previsiblement ja estaran ocupats de nou els llocs d'Algímia i Alfara. I abans de fer la petició, el síndic explica que en la vila de Torres Torres, que era de cristians vells abans de l'expulsió, havien quedat deshabitades més de la meitat de les 64 cases que hi tenia, degut a que molts se n'havien anat a poblar altres llocs circumdants, concretament Algar, Algímia i Alfara "i els pocs que queden estan impossibilitats de pagar els deutes i censals propis de la dita vila i universitat"; i es queixen que, allò que pagaven solidàriament les tres universitats de la baronia (300 cases de cristians nous i vells) no poden ara pagar-ho 30 o 40 cases que hi resten.

Una situació semblant es donava en la baronia de Castielmontán (Alt Palància), en que dels set llocs que havia tingut habitats, només Villanueva i Fuente La Reina eren de cristians vells (els altres cinc llocs estaven ara despoblats), i de les 20 cases que sumaven, més de la meitat havien quedat despoblades per por a que foren executats els censals. 
Per altra part, que "la repoblació tingué un caràcter regnícola" 27 és ja una frase feta i plenament acceptada pels historiadors, amb només unes concretes excepcions que, en algun cas prosperaren ( $v$. gr. els mallorquins de La Marina) i en altres casos no, com passà amb els intents de durs repobladors de les Açores, segons expliquen Boronat (1901) i Torres Morera (1969), o fins i tot l'esmentat cas dels mallorquins amb els que el virrei de Mallorca intentà repoblar la vall d'Olocau.

Per tot això, és molt provable que si Josep Folch de Cardona no haguera sigut capaç de repoblar tan ràpidament les seues baronies, no ho haguera pogut fer fins a molts mesos o encara anys desprès, tal com passaria en la majoria dels casos. No puc eludir la possibilitat de que una part de la seua decisió haguera esta motivada i animada per la seua proximitat a la corona, proximitat que ja demostrava pel fet de ser (tal com recull en la carta pobla) a més de la seua condició militar (cavaller de l'Orde i Milícia d'Alcàntera) "Gentil hòm de la boca de la Majestat el Rei nostre senyor", important títol que és reflex i defineix clarament el seu compromís personal amb la Corona ${ }^{28}$, compromís i fidelitat que mostraria tota la seua vida. No és d'estranyar, per tant, que la seua decidida actuació haguera estat fins i tot aconsellada des de la Corona.

La postura de la Corona, aquell 26 de novembre en que es signà la carta pobla de Serra i Ria, era molt clara i favorable a la repoblació com fins i tot ja ho era abans encara de l'expulsió, tal com posen de relleu alguns dels documents de principis de setembre de 1609 transcrits per Boronat (1901) o també els reportats per Torres Morera (1969, p. 77) sobre els projectes repobladors amb gent vinguda des de les illes Açores, els Pirineus, Grècia, Mallorca i altres llocs.

De fet, la Reial Pragmàtica per a la sembra de terres i la paga dels censals havia sigut ja promulgada a Madrid el dia 19 de novembre; i si no està clar que Josep de Cardona haguera pogut conèixer el text definitiu de la disposició abans de ser publicada aquesta a València (la publicació a València es demorà al dia 15 de desembre de 1609,), les coses en ella contingudes no es difícil que foren comentades i conegudes en l'àmbit de la cort reial -al que ell tenia accés directe- des de prou abans de ser sancionada.

\footnotetext{
${ }^{27}$ Conclusió principal del treball de Torres Morera (1969), reconeguda també per Halperin Donghi (1980) i Lapeyre (1986).

${ }^{28}$ En l'any 1600, també el rei tingué la merced de nomenar "Gentil hom de boca" a Joan de Vilaragut, senyor de la baronia d'Olocau, que tenia 38 anys d'edat. Aquesta designació aniria seguida d'altres importants nomenaments: Lloctinent General del Governador de la Ciutat i Regne de València, en 1604, i Virrei de Mallorca, en 1606.
} 
Del contingut d'aquesta disposició (publicada per Boronat, 1901) es pot destacar:

- Ordenamos y mandamos, primeramente, que todos los Barones, dueños de los lugares y tierras arriba dichos (els que quedaren deserts per l'expulsió morisca), dentro de diez días precisos, que secuenten del de la publicación desta nuestra Pragmática en adelante, las hayan de sembrar, o o concedellas a otros, para que las siembren, o cultiven. Y que en caso que passado el dicho térmno no lo hayan hecho, las puedan sembrar los acrehedores que las tuvieren hipotecadas, y coger libremente los frutos dellas...

- Y assi mismo, por lo que toca al beneficio de los mismos acrehedores, y para que no lo pierdan todo, exortamos a las personas que llevan décimas y primicias, a quienes debemos exortar, y a las demás mandamos, que por este primer año solamente pierdan una parte de las dichas décimas y primicias hasta la metad, y cobren solo la otra metad.

- Y que los dichos barones y dueños de los dichos lugares no lleven tampoco más de la metad de lo que les tocara por este dicho año.

- Y que los que cultivaren las dichas tierras... pagaren un rediezmo de los frutos que cogieren, demás y allende de la metad que, como dicho es, han de pagar a los a los Eclesiásticos y barones. Porque nuestra voluntad es que este rdiezmo y la otra metad que se dexará de pagar, assi de decimas y primicias como de lo tocante a los dichos Barones y dueños, se guarde y recoja por cuenta y razón en parte confidente y segura, para pagar las pensiones de los censales en la metad, o en el tercio, o por lo que rata en cantidad tocare a cada uno de los censalistas. ${ }^{29}$

Per a que tot açò fora possible sense sancions, represàlies ni abusos, la pragmàtica també manava que en dit any no es pogueren instar execucions contra els que sembraren, ni ser molestats per raó dels dits censals.

Estava clar que hi havia una profunda crisi i que els censals i deutes superaven notablement les escasses o fins i tot nul·les capacitats dels llocs per a complir les seues obligacions. Davant aquella situació, l'actuació de la Corona era ferma: per una part obligar a sembrar i cultivar, i per altra reduir clarament els impostos dels vassalls i els beneficis dels senyors, per a poder pagar, poc a poc, amb aquest estalvi, les pensions dels censals "en la meitat o en el terç...".

Està clar que quan se signà la carta de poblament de Serra i Ria (també la de Soneixa i Assuévar, evidentment), l'anterior pragmàtica, malgrat que ja existia, encara no

\footnotetext{
${ }^{29}$ Los moriscos españoles y su expulsión; t. II, Boronat, 1901: 564-568 (Doc. 20).
} 
havia sigut publicada a València (mancaven encara 18 dies), però resulta evident que diversos aspectes del contingut de la carta pobla connecten i entren directament en els plantejaments de la pragmàtica. Tal és el sentit de no molestar als vassalls amb els censals, alliberant-los de certes obligacions; així ocorre, per exemple, en el capítol 14, titolat "Càrregues de moros" diu:

Ítem, que si serà el cas que sobre alguna de les cases o terres que s'establiran per dit Senyor se trobaren carregats alguns censals per la universitat dels moros qui són estat expel-lits de la dita baronia o per alguns particulars, especialment amb llicència del Senyor, que en tal cas tinga obligació dit Senyor eximir a dita casa i terres dels dits censals.

També, en consonància amb la Pragmàtica, podem entendre el fet de que el Senyor renuncie expressament a una part dels seus drets pecuniaris directes, com és el cas del terç delme en totes les particions, tant de fruits i grans com de les produccions de les vinyes. Així queda expressat en el capítol 7 de la carta-pobla, titulat "Grans, fruits i fruites" i en el 8, titulat "Vi i pansa":

Cap.7: Ítem: que nosaltres dits nous pobladors i los nostres successors... siguem $i$ siguen tinguts $i$ obligats a pagar al dit Senyor... cascun any al temps de la collita, la sisena part de tots los grans i fruites, de qualsevol gènere i espècie que siguen, que es colliran en les terres de regadiu i la vuitena part en els de les terres del secà, sens pagar terç delme, del qual dit Senyor nos farà francs...

Cap.8:Ítem: que de lo que procedirà de les vinyes del terme de la dita Baronia $i$ llocs, ara siga vi, ara pansa, o altra qualsevol cosa, se haja de pagar al Senyor la vuitena part en allò mateix que es collirà o procedirà de les dites vinyes, sense pagar terç delme. I que en l'horta no puga haver-hi vinyes sens llicència del Senyor.

En el mateix capítol 7 continua parlant de les fuites de tots els arbres del terme, que també hauran de pagar els de l'horta la sisena part i els del secà la vuitena part, però, afegeix: "alfarrassant dites fruites $i$ fruits dels dits arbres una persona nomenada per lo Senyor i altra per nostra part i conforme al dit alfarràs s'haja de pagar lo que es deurà al dit Senyor en diners comptants, en continent que seran acabats de collir dits fruits cascun any". Seguidament exceptua d'aquest alfarrassament a les garrofes, que també pagaran la sisena o la vuitena part, segons siguen d'horta o de secà. Continua encara afegint un aspecte que ens resulta avui en dia força interessant ${ }^{30}$ : exceptuar d'aquests pagaments $\mathrm{i}$

\footnotetext{
30 Açò podria ser la raó de que la cirera va ser un dels cultius tradicionals que assoliren gran notorietat $\mathrm{i}$ fama (les famoses cireres de Serra), fins i tot produint-se una major expansió en el segle XX, desprès de la
} 
particions a les cireres, albercocs, préssecs i peres "que no hagen de pagar cosa alguna sinó que lo Senyor per a son menjar i de sa casa puga prendre la fruita que li paregués". I acaba aquest punt dient "també de la palla que es collirà en la horta i en lo secà se haja de donar al Senyor una sarrieta gran per cada casa".

Una altra cosa que crida l'atenció, quan comparem la carta pobla de Serra amb altres posteriors, és el reduït nombre de capítol o clàusules: només 20, front a les 24 que tindrà la de Soneixa i Assuévar (27/09/1609), les 32 que tindrà Nàquera (6/12/1609), les 28 que tindrà Bétera (6/08/1610), les 28 de la primera carta pobla d'Olocau (20/08/1610), les 29 que tindran Estivella i Beselga (20/12/1610), les 32 d'Alfara (18/07/1611) i d'Algímia (20/07/1611) o les 38 de Segart i Albalat (24/09/1611); per citar només una mostra de les més properes a Serra.

En cap d'aquestes altres cartes pobles, ni altres més que he observat (veure les recopilacions que ja tantes vegades he citat, de Torres Morera, Gual Camarena, Císcar...) renuncia el senyor al seu terç delme, ni tampoc allibera expressament als repobladors de les càrregues censals que suportaven els moriscos... En fi, encara el fet de tindre tants pocs capítols deixa també en l'aire altres aspectes que, en no estar regulats quedaran sense control tributari i pràcticament "lliures d'impostos", per dir-ho així. És el cas de la caça, els ruses, els algepsars, els forns de calç, etc. Lluny, però, de ser açò un oblit o una manca de meditació motivada per les preses, entenc que aquestes omissions són totalment voluntàries i conscients. La prova està en que, els quatre capítols addicionals que té la carta pobla de Soneixa i Assuévar front a la de Serra i Ria no són, precisament, per a afegir coses oblidades i una major fiscalització i control, sinó tot el contrari: en la primera d'elles (núm. XXI) diu que "per ajudar a dits vassalls i nou pobladors" els hi concedeix i dóna una casa de Soneixa -la que ell assenyalarà- per a tindre el seu Consell i reunions i per a "tot això que els hi pareixerà per a bé i utilitat de la dita baronia i els seus llocs", amb càrrec dels corresponents 30 sous de cens (com qualsevol altra de les cases donades als vassalls); en la núm. XXII dóna a la baronia i a les universitats de Soneixa i Assuévar "ajudant així a dita nova població" l'horta i rodona de Mosquera, ${ }^{31}$ com també les coves de Jàyar ${ }^{32}$ i de Xaven... i encara -per si fora poc!- la dècima part de tots els arrendaments $\mathrm{i}$ vendes que es faran dels herbatges de dita baronia a forasters, per a

crisi de la fillloxera que tan greument afectà a la vinya.

${ }^{31}$ Mosquera és una important heretat (i alqueria mudèjar i morisca) amb abundància de sureres $i$ altres recursos naturals, avui situada dins el terme d'Assuéva.

${ }^{32}$ Ferrer Taberner (1995) parla d'aquestes antigues heretats en: Repobladores moriscos en el deshabitado lugar de Ponera. Actes I Congrés d'Estudis sobre el Camp de Morvedre. Braçal, núm. 11-12. 
pasturar ramats. En els últims dos capítols limita el nombre de cases de Soneixa a 40 i les de Assuévar a 12, respectivament, dient que repartirà entre elles i per iguals parts, tota la terra de horta, excepte 6 fanecades que vol donar a l'església i vuit que es reserva per a si. Per contra, les terres de secà disposa que les repartirà com millor li pareixerà a ell.

Tenint en compte aquestes coses i circumstàncies, entenc que tant la de Serra i Ria com la de Soneixa i Assuévar són unes cartes pobles modèliques i que deixen definides les regles i coses fonamentals sense ser especialment abusives amb els vassalls; més bé pot semblar que al contrari, especialment en la segona d'elles.

Front a la benevolència del capítol 14 , que dispensa totalment als nous vassalls la càrrega dels censals heretats dels moros, altres cartes pobles, com la de la Valldigna, que duu una data d'atorgament molt propera a la de Serra (12 de desembre de 1609) és contundent en aquest aspecte quan, en el seu capítol $36^{\text {é }}$ diu:

Ha sido pactado y concordado... que por cuanto los dichos pobladores son sucesores de dichas casas y tierras del presente valle... es justo que dichos pobladores paguen y respondan de la misma manera que respondian dichos moros y cristianos... los censales.." (i continua expressant el nom de cadascun dels censalistes que tenia "censit" cada lloc de la vall). ${ }^{33}$

Una altra característica remarcable de les dues cartes pobles atorgades per Josep Folch de Cardona és (a diferència de moltes altres cartes pobles postmorisques) que dispensa els vassalls de qualsevol tipus de donacions, regals i serveis personals al Senyor, qui de fet, com ja hem vist, tenia els seus propis criats, com també la seua esposa, na Jerònima, tenia la seua fidel assistenta i/o donzella personal habitual i de confiança durant molts anys (com ho demostra a través del seu testament). Tot el contrari passa, per exemple, amb la carta pobla de Nàquera, tan propera en el temps a la de Serra $i$ Ria. En els seus capítols 21 i 22 imposa als vassalls l'obligació de donar al Senyor “cascun any i de present i donatiu graciós, una gallina lo dia de la vigília del gloriós Sant Tomàs, començant en lo present any"... i que "cada casa haja de donar al senyor graciosament i sens paga ni sustent, cascun any, dos jornals d'home i cabalcadura", jornals que seran "en lo temps i per les coses que lo dit Senyor los demanarà"; aquest servei serà dins el terme de la baronia, i no fora d'ell, etc.

També en aquest assumpte del serveis personals, la postura de Josep Folch de Cardona connecta plenament en la línia d'allò que opinava la Corona al respecte. De fet,

\footnotetext{
${ }^{33}$ Carta pobla publicada en l'annex documental de l'estudi d'Eugenio Císcar (1977).
} 
en el punt $28^{\text {é }}$ de la Pragmàtica reial de 2 d'abril de 1614 "sobre coses tocants a l'assentament general del Regne de València, pe raó de l'expulsió dels moriscos i reducció de censals" fa recordar que en anteriors instruccions ja va manar el rei als Regents Comisaris que no diessen lugar a que los pobladores nuevos, christianos viejos, se obligassen a las tandas, çofras y servicios personales que prestavan los moriscos, y que advirtiesen d'ello a los dueños de los lugares... I tot seguit afirma que, no obstant això, s'havia pogut constatar que les escriptures d'algunes noves poblacions han obligado a los nuevos pobladores a algunos d'estos cargos y servicios; y el cargar estos servicios... podría cargar muchos inconvenientes. Per això es reserva el rei (diu aquest mateix ítem de la Pragmàtica) la facultat per a poder anul-lar, reformar, commutar i moderar tots els serveis personals que hagueren estat carregats als nous pobladors. ${ }^{34}$

\subsection{VASSALLATGE; ESTABLIMENT DE CASES I TERRES, I NOMENAMENT D'OFICIALS}

Com hem vist, l'acte de poblament de Serra i Ria va seguit, en quasi tots els trasllat vistos, del consegüent acte de vassallatge, on consta que tots els repobladors esmentats en la carta de poblament tornen a ser esmentats ara dues vegades més. I mitjançant la prestació dels homenatges i juraments de fidelitat "acostumats" queden així sotmesos al fur i la jurisdicció del Senyor de la baronia.

Un dels aspectes més rellevants del poblament és que els pactes que es fan mitjançant una carta-pobla comprometen no solament als actors directes, sinó també a tots els seus descendents i successors "encara que absents", o siga, els futurs senyors que amb el temps ho seran de la baronia, com també tots els descendents del vassalls que sempre, es suposa, seguiran sent indefinidament vassalls en la dita baronia i llocs.

El lloc on es troben congregats el Senyor i els vassalls, amb el notari i testimonis presents, per tal de llegir i acceptar tant les capitulacions com el jurament de fidelitat que fan els vassalls cap al seu nou Senyor jurisdiccional és la Casa del Senyor, que va ser parcialment enderrocada en els anys setanta del segle XX per a fer nous habitatges, si bé es conserva encara la part més oriental. La casa de la senyoria abastava els dos costats (oriental i occidental) de la Torre del Senyor, seguint el desenvolupament d'un antic recinte emmurallat del que no queda avui pràcticament rastre, si bé el seu traçat és fàcil d'endevinar per la pròpia estructura urbana i topogràfica del casc antic de Serra.

\footnotetext{
34 Boronat, 1901, t. II: 629, doc. 32.
} 
El testimoni d'algunes persones majors ens permet conèixer que un dels salons de la part desapareguda de la casa del Senyor tenia, en terra, un gran retaule ceràmic que contenia diverses fruites (entre elles recorden una o vàries figues, molt característiques) $\mathrm{i}$ altres motius del camp. El veí de Serra Àngel Domingo Navarro, molt sensibilitzat pel coneixement del patrimoni històric i cultural de Serra, ens explicava que quan va saber que demolirien l'edifici (anys setanta, insistim) es va interessar pel retaule, però no li donaren opció a poder-lo rescatar. No obstant, desprès de la demolició va aconseguir, escorcollant entre els enderrocs un fragment del mateix, que correspon precisament a un escrivà o notari (FIGURA 2.1). Aquest motiu i la possible adscripció del fragment ceràmic a tècniques $\mathrm{i}$ tonalitats més pròximes al segle XVII que no les formes més policromades i vistoses del segle XVIII, fa que puguem suposar una possible relació del motiu d'aquest retaule amb el vassallatge del poble de Serra iniciat en 1609.

Amb aquest marc físic de referència pot resultar més suggestiu imaginar l'acte de jurament i fidelitat que ve descrit en l'acta notarial, on diu que tots, allí ajustats en la casa del Senyor, en lo dit lloc de Serra, de bon grat i ple coneixement, conforme als furs de València, tots allí i amb les mans dretes "corporalment tocans" juren fidelitat a Don Josep Folch i Cardona i als seus successors, davant Nostre Senyor Déu i els Sants Quatre Evangelis. I en virtut del dit jurament prometen habitar i residir en la dita Baronia i llocs de Serra i Ria, tenint allí el seu domicili major, amb llurs mullers, fills i famílies, amb el compromís de conservar i millorar les cases i conrear i curar les terres a l'ús de bons llauradors i bons vassalls, pagant anualment i puntuals tots els drets i censos de les dites cases i terres. Tanmateix, en virtut d'aquell jurament prestaren homenatge per besament de ma y de muscle al dit present Senyor en Josep "i a tots els seus successors que per temps ho seran també". A més d'això i conforme al precedent acte de poblament, renunciaren tots els nous vassalls al seu propi fur, per a sotmetre's directament al fur i jurisdicció del dit Senyor i dels dits seus successors. 
FIGURA 2.1.- Fragment del mosaic ceràmic que hi hagué en la Casa del Senyor de Serra.

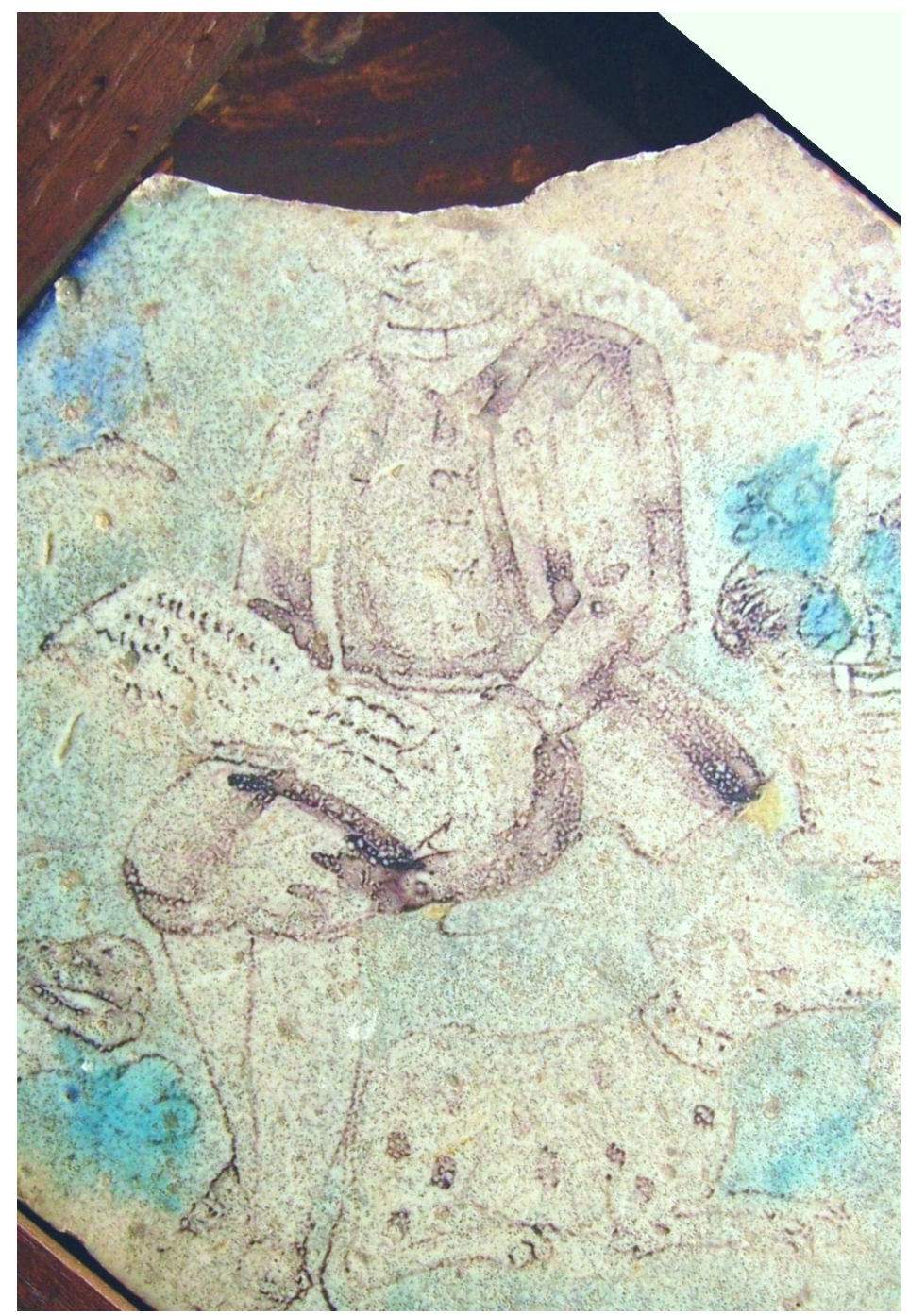

Fotografia de l'autor, per gentilesa d'Àngel Domingo Navarro.

Els nous pobladors rebran cases i terres que hauran de conservar-les i millorar-les, com hem vist, però si s'absentaren del domicili per temps de sis mesos encorrerien en pena de decomís de dites cases i heretats. Rebran aquestes cases i heretats amb caràcter de cens emfitèutic; per tant, el senyor tindrà el domini directe i el vassall el domini útil, que comportarà el pagament d'un cens o quantitat anual al seu senyor, i no podran vendre-les ni alienar-les sense l'autorització prèvia i expressa del Senyor, qui tindrà sempre prioritat per a comprar-les front a qualsevol altre comprador (dret de fadiga, amb caràcter de tanteig i retracte). Tanmateix, el venedor del domini útil (el vassall) haurà de pagar al Senyor una comissió: el dret de lluïsme; generalment el deu per cent del preu fixat en el cas de vendre la casa o l'heretat a un tercer. Les capitulacions parlen de 
"fadiga i lluïsme ab tot altre plen dret emfitèutic segons furs de València" i això fa que es també es puga incloure, a més dels esmentats, el de dret de capbrevació (reconeixement del domini directe).

De la identificació de cadascuna de les cases i terres de regadiu i de secà rebudes pels diferents vassalls cal suposar que se n'ocuparien els diferents establiments que el notari alçaria per a cadascun dels vassalls, sent una mena de títol de propietat que aquests rebien. No coneixem aquests establiments per al cas de Serra i Ria, la qual cosa impossibilita que puguem saber, directament, la identificació dels bens rebuts dins el terme de la baronia i, possiblement, altres dades d'interès sobre els vassalls, com podria ser els llocs de procedència o els oficis, que han quedat registrats en alguns casos. ${ }^{35}$

En el cas de Serra, el que si disposem és d'un capbreu de l'any 1779, el qual ens permet obtindre clara i concreta informació sobre les cases i propietats útils que, quasi 200 anys desprès del repoblament tenien els veïns de Serra. Aquest cabreu és un registre censal d'empadronament dels veïns posseïdors de terres (terratinents), on es detalla cadascuna de les seus propietats. D'aquest document tornaré a parlar en més ocasions però, de moment, el que ara avançaré és el valor dels censos que en aquell temps pagaven els vassalls per les seues cases i terres. Les cases continuen pagant 30 sous de cens, o el que és el mateix: una lliura i 10 sous (tal i com determinava el capítol cinquè de la carta de poblament; les terres d'horta venen expressades ara en fanecades, i no ja en cafisades (com indicava el capítol sisé), i les de secà s'expressen ara en jornals, i no en cafissades, si bé tenen la seua correspondència d'agrimensura pràcticament equivalent.

Segons les dades del capbreu, els valors o quotes censals, en diners comptants (lliures, sous i diners) són els següents

$$
\begin{aligned}
& \text { Per cada casa en el poble.....................1L 10s } \\
& \text { Per mitja casa.......................................... 15s } \\
& \text { Per un corral de ramat................................4s } \\
& \text { Per una fanecada d'horta..........................1s } 8 \mathrm{~d} \\
& \text { Per un quartó (1/4 de fanecada) d'horta........5d } \\
& \text { Un jornal de secà.............................................4d } \\
& \text { Un quartó (1/4 de jornal) de secà...................1d }
\end{aligned}
$$

La quota establida de 4 diners per cada cafissada de secà veiem que és la mateixa del que ara es denomina un jornal de terra de secà (un jornal = una cafissada). En canvi,

\footnotetext{
${ }^{35}$ En part ho observem en el cas de Sot de Ferrer (Guerrero i Corbalán, 2002).
} 
els 10 sous (= 120 diners) previstos per a cada cafissada d'horta, ara tenen el seu corresponent valor en els 20 diners que pagaria la fanecada d'horta, havent-hi aleshores una equivalència de 1 a 6 (una cafissada $=$ sis fanecades $=1 / 2$ hectàrea).

En canvi, crida l'atenció com en el capbreu de 1789 hi consta que es pot tributar per mitja casa (podria ser una casa compartida però amb un sol accés?) si tenim en compte que el capítol cinquè de la carta-pobla preveia que "cascuna casa que s'edificarà de nou o quan alguna de les velles es partirà donant al carrer per distint domicili i habitació" hagen de pagar igualment el mateix cens de 30 sous.

De les anteriors xifres $\mathrm{i}$ ajustos podem deduir i aproximar les següents dades $\mathrm{i}$ valors equivalents d'agrimensura:

$$
\begin{array}{ll}
1 \text { jornal } & \text { equival a } 6 \text { fanecades (uns } 5.000 \mathrm{~m}^{2} \text { ) } \\
1 \text { cafíssada } & \text { equival a un jornal ( } 6 \text { fanecades) } \\
1 \text { fanecada } & \text { equival a uns } 833 \mathrm{~m}^{2}
\end{array}
$$

Pel que fa als càrrecs públics o oficis previstos en el capítol 17 de la carta $\mathrm{d}$ poblament, ja he dit que no disposem del corresponent acte de nomenament. No obstant, està clar que immediatament desprès de fer el jurament pertinent, el Senyor designaria $\mathrm{i}$ nomenaria els ocupants dels primers càrrecs del nou Consell i Universitat de Serra i Ria, que a més prestarien 1 seu jurament previst.

El que sí que sabem, indirectament i mitjançant el quinque libri de l'APS és el nom d'algunes de les persones que ocuparen al llarg del segle XVII determinats càrrecs, $\mathrm{i}$ així ho expose seguidament.

En 1628 era batlle de Serra i Ria Bautista Donya, que és vidu i es casa aquell mateix any amb Agustina Puig, també vídua. També trobem al mateix batlle en determinats actes dels anys 1634 i 1637. Bautista Donya devia ser d'edat avançada i residia habitualment a València, encara que el seu fill Joan Baptista Donya menor (mort en Serra en 1646) residia a Serra, com també altres dos filles del batlle.

En 1641 i en 1644 trobem com a batlle a Miquel Domingo. Per altra part, l'acta local del cens de l'any $1646,{ }^{36}$ ens permet saber que aquell any era Josep Català el Lloctinent del Justícia de la Baronia, mentre que Francesc Rubio i Martí Domingo eren els Jurats aquell any. Per mig del Quinque libri hem pogut

\footnotetext{
${ }^{36}$ ARV, Generalitat, sg. 4826 , f. 227
} 
conèixer també altres càrrecs dins la segona meitat del segle XVII (QUADRE 2.2).

Baptista Domènech naix en 1646, per tant tenia 40 anys quan el trobem per primera vegada com a Batlle de Serra, i continuarà sent-ho en 1693, 1700 i encara en 1702 (amb 56 anys d'edat). En 1705 trobem com a Justícia a Batista Català.

Deixem ací, com a mostra aquestes dades sobre càrrecs trobats al llarg de les sèries i documents consultats. Es tracta d'una mostra limitada al segle XVII, en la que no he trobat altres càrrecs com el de mustaçaf o el de clavari que, no obstant, és segur que també existiren en el segle XVII, com també els trobem sovint en els segles posteriors.

QUADRE 2.2.- alguns càrrecs públics de la baronia de Serra i Ria en el darrer terç del segle XVII.

\begin{tabular}{|l|l|l|}
\multicolumn{1}{c|}{ Any } & \multicolumn{1}{l}{ Nom } & \multicolumn{1}{l|}{ Càrrecs } \\
\hline 1671 & Pedro Alvarez & Batlle de Serra; habit. en València \\
\hline 1672 & Jusepe Duran & Batlle \\
\hline 1673 & Pedro Alvarez & Batlle i Arrendador (drets dominicals) \\
\hline 1686 & Baptista Doménech & Batlle \\
\hline 1691 & Baptista Doménech & Batlle \\
\hline 1693 & Baptista Doménech & Batlle \\
\hline 1693 & Esteban Rubio & Jurat menor \\
\hline 1697 & Josep Cabo & Jurat menor \\
\hline 1700 & Baptista Doménech & Batlle \\
\hline
\end{tabular}

Dades obtingudes del Quinque Libri de Serra.

\subsection{SOBRE LES PARTICIONS I LES REGALIES}

Tots els anys, cada poblador haurà de pagar també, per cada cafissada de terra d'horta i regadiu, 10 sous de cens, amb els drets de fadiga i lluïsme. I tanmateix, altres 4 diners per cada cafissada de les heretats de secà. Aquestes quantitats per les heretats hauran de ser pagades el dia de la festa de Tots Sants anys, en una paga.

A més d'aquest cens, i sense perjudici del delme i primícia, els pobladors també havien de pagar-li al Senyor la sisena part de tots els grans $i$ fruites de qualsevol gènere $i$ espècie que es colliren en les terres de regadiu, i la vuitena part dels que es collirien en les terres de secà, però sense haver de pagar-li el terç delme, del qual dit Senyor els feia francs (els eximia). 
Per a ajustar el pagament d'aquests impostos, els fruits i fruites serien alfarrassats per una persona nomenada pel Senyor i un altra designada pels vassalls. I conforme a l'alfarrassament, de seguida que foren acabats de collir, es fixaria el valor de la collita en diners, rebent el Senyor la seua part en diners comptants. En altre punt estableix que les "ferratxes $i$ dacses $i$ altres arbres que es faran per a les cavalcadures", pagaran, en diners, la sisena part, segons l'alfarrassament que es farà. S'exceptua els alfalsos, que pagaran 12 sous per fanecada cada any.

En el cas dels garrofers no caldria alfarrassar-les; simplement pagarien la sisena o la vuitena part de les collides, segons fossen de l'horta o del secà. I quedaria exceptuat el cas de les cireres, albercocs, préssecs i peres, que no haurien de pagar cap quantitat, però a canvi, el Senyor podria prendre la fruita que li paregués per a son menjar i el de sa casa.

En el cas de la palla, tant la collida en l'horta com en el secà, no s'hauria de pagar al Senyor en funció de la quantitat, sinó simplement donar-li a aquest una sarrieta gran cada any i per cada casa.

Pel que fa a les vinyes, s'havia de pagar al Senyor la vuitena part del producte obtingut (ja fora vi, pansa o altra qualsevol cosa). No es pagarà terç delme, ni podrà haver-hi vinyes en l'horta de no ser amb llicència del Senyor.

Pel que fa al ramat, tant llanar com de cabres, s'hauria de pagar al Senyor la cria, a raó d'una per cada vuit. No parla d'altres tipus de ramats ni de bestiar, encara que si ho fa del que sembla devia ser l'antic Bovalar: "que ningun particular puga entrar en la partida dita La Xara, que està junt lo castell, a tal·lar arbres ni fer llenya, ni arrancar rabaces, so pena de seixanta sous, com la dita partida haja de restar o reste reservada al dit Senyor, açò declarat, que los ganaos així de la carnisseria com dels particulars de dita Baronia hi puguen entrar sense correr en pena alguna".

El vassalls podien fer en el terme de dita Baronia carbó, tant de llentiscle com de rabasses i "altres mates", però no d'arbres alguns. En un altre apartat establia que cap veí devia tallar arbres (pins, garrofers, oliveres, ni altres arbres), en horta ni en secà, sense llicència del Senyor, sots pena de 60 sous per cada arbre, que damunt seria confiscat. Cal suposar que a llenya no estava subjecta a cap tassa ni limitació, però en canvi, pel carbó calia pagar: 1 sou per cada càrrega gran i 6 diners (mig sou) per cada càrrega petita (d'asnet o de jumentisc).

Finalment, es reserva el Senyor els seus drets de regalies: ningú puga fer hostal, parar taverna, ni piló de tallar carn, fer forn, ni molí ni almàssera... En la dita Baronia i 
llocs, ni en son terme. I a més, tots els vassalls estaran obligats a coure en el forn, comprar en la tenda, fleca i taverna, i carnisseria del dit lloc... Sots pena de 60 sous per cascuna vegada que açò es contrafera... i amb la mateixa pena "hajam de moldre en lo molí de la Senyoria, donant a dit molí bon recapte"... I també s'havia de fer l'oli en l'almàssera del Senyor... I a més vindria també a càrrec dels veïns la neteja de la sèquia del molí, i el manteniment del seu assut, encara que el Senyor hauria d'aportar per a tal menester un mestre i la calç necessària, posant els vassalls "tot lo demés".

La carta pobla també preveu els càrrecs que cada any haurà de nomenar el Senyor: un Justícia, dos Jurats (un per a cada lloc) un Mostassaf i un Clavari. Per a la proposta de nomenament, s'haurà de ajuntar el Consell dels esmentats llocs dos dies abans del dia de Reis, i preparar una llista o nòmina de 8 veïns, que faran arribar al Senyor o bé al Batlle, que hi assistirà. Dels vuit, el Batlle o el propi Senyor podran suprimir fins a quatre noms (els que els hi pareixerà), i en tal cas afegir-ne altres tants. De la llista resultant, el Senyor, o bé el Batlle (queda clar que és una persona de confiança del Senyor) nomenarà els cinc càrrecs esmentats. Al temps, el nou Justícia procedirà a designar un Lloctinent de Justícia per al lloc de Ria.

D'aquest acte de nomenaments renovats anualment alçarà acta 1'Escrivà de la Cort de la dita Baronia. Com que els càrrecs de Batlle, Justícia i Escrivà de la Cort són regalies del Senyor, aquest es reserva la facultat de nomenar aquests càrrecs tantes quantes vegades li pareixerà, mudant-los sempre i quan voldrà, i "sens que en açò es puguen entrometre en manera alguna los vehins i habitadors de la dita Baronia”.

Com a Escrivà de Serra, almenys des de 1614 a 1645, trobem el notari de València Joan Font, veí de la ciutat però amb diverses propietats a Serra. ${ }^{37}$

\footnotetext{
${ }^{37}$ Per una inscripció de l'APN (bateig de Martí Cervera, en 18/11/1640) sabem que Joan Font vivia en el carrer de Morvedre, amb llur esposa, Tomasa Miralles.
} 


\section{CAPÍTOL 3}

\section{POBLADORS DE SERRA EN EL SEGLE XVII. PROCEDÈNCIA, SUBSTITUCIONS, MINORIA BASCA I EXPANSIÓ DE LLINATGES.}

La principal i més valuosa font d'informació sobre el creixement i l'evolució de la nova colònia instal·lada a Serra desprès de l'expulsió dels moriscos ha estat el Quinque libri que, per sort es conserva en l'església parroquial. Per tal d'esbrinar dades concretes sobre els repoblador i la procedència li he dedicat una especial atenció al primer volum d'aqueste sèrie parroquial, volum que comença en 1619 i arriba fins a 1709. D'aquesta manera, trobem concentrat en un sol volum tota la informació relativa a l'evolució de la colònia a tot el llarg del seu primer segle d'existència, o siga, al llarg de tot el segle XVII. Els registres del Quinque libri es van iniciar per manament del senyor Arquebisbe de València, el Dr. Fra Isidoro Aliaga, durant la visita que "hiso en la Parrochial de Sierra y Naquera" el dia 14 de novembre de 1619.

Un dels aspectes més cridaners que d'immediat es posa de relleu és la majoritària substitució de cognoms que es produeix ja des de les primeres dècades, de manera que la major part dels repobladors inicials (el signants de la carta pobla) i el seus cognoms pràcticament desapareixen en poc de temps (a excepció dels cognoms Domingo i Rubio), sent substituïts per altres persones i llinatges amb cognoms diferents, que aniran implantant-se i creixent fins convertir-se en els més freqüents i característics de la població actual de Serra. És el cas indiscutible dels Navarro, Cabo, Català, Arnal, Garay, Ros i pocs més, que junt als ja esmentats de Domingo y Rubio omplen els padrons municipals.

Aquest primer volum del quinque libri comença amb un índex dels batejats al llarg d'aquests primers noranta anys de registre, i aquest índex és ja bon reflex de l'expansió dels nous cognoms. Així, entre els 514 xiquets i xiquetes batejats, ja hi trobem que el cognom més abundant és Navarro (56 vegades), tal i com passa avui en el cens veïnal. Cal significar que els batejats són inscrits sempre amb un sol cognom, que correspon al del pare (estem parlant només del segl XVII i d'aquest primer volum del registre parroquial). El QUADRE 3.1 resumeix la freqüència dels cognoms més 
abundants al llarg del segle XVII, observant-se ja el predomini dels cognoms actuals, abans esmentats.

En aquest quadre es pot també comprovar que hi ha certa dualitat valencià/castellà d'alguns cognoms, a la qual tornaré a referir-me més endavant. És el cas concret de Català-Catalan, Ros-Rubio, Esteve-Esteban i Doménech-Domingo.

De la resta de cognoms del quinque libri (els que no arriben a 8 batejats) en trobem encara tres que corresponen als dels signants de la carta de poblament de 1609: Saeç (o Sáez), amb sis batejats, Diago, amb dos batejats, i Ribes (o Ribas) amb altres dos batejats.

QUADRE 3.1.- Freqüència dels principals cognoms de batejats de Serra entre els anys 1619 i 1709.

\begin{tabular}{|c|c|c|c|}
\hline Cognom & nombre de batejats & Cognom & nombre de batejats \\
\hline Navarro & 56 & Romero & 13 \\
\hline Domingo & 43 & Èpila & 12 \\
\hline Rubio (i Ruvio) & 43 & Esteve & 11 \\
\hline Cabo & 32 & Garay (i Gray) & 11 \\
\hline Arnal & 31 & Gasch & 11 \\
\hline Pérez & 30 & Catalán & 10 \\
\hline Verge & 26 & Dols (Dolz) & 10 \\
\hline Català & 24 & Ros & 10 \\
\hline Moreno & 21 & Estevan & 9 \\
\hline Domènech & 15 & Ivanyes (Ibáñez) & 9 \\
\hline Escrig & 14 & Salvador & 8 \\
\hline
\end{tabular}

En negreta hem destacat els cinc cognoms de repobladors de l'any 1609. Elaborat a partir del Quinque libri de Serra (volum primer).

Amb més d'un batejat trobem encara els següents cognoms: Aral (6) ${ }^{1}$, Balada (6), Bort (2), Chillida (2), Fos (4), Gutierres (2), Herrero (2), Làsaro (3) i Libros (6). Finalment, amb un sol batejat hi troben els cognoms Alcayde, Ascensa, Bartholomé, Bigo, Blasco, Campos, Casanya, Correja, Cavaller, Calatayud, Del Hoyo, Mallaes i Mallach (sembla tractar-se del mateix cognom), Micó, Rodrigues, Esevique, Gil, Joset, Javas, Loyola, Salinas, Sastre, Soler, San Juan, Sebastià, Tortaxada, Thomàs i Torres. Tots aquests són cognoms ja extingits a Serra.

\footnotetext{
${ }^{1}$ Realment correspon a Arnal, que és un dels cognoms que ja figuren en el quadre 3.
} 
Quan comença el registre parroquial, malgrat que han passat només deu anys des de que es va signar la carta de poblament, es nota que comencen a ser molt escassos els rastres que resten de la major part dels colons inicials, predominant, en canvi, nous $\mathrm{i}$ definitius cognoms que, com he dit, seran els que aniran imposant-se en les darreres $\mathrm{i}$ successives generacions, fins arribar als nostres dies.

La qüestió que immediatament surt és la del per què i com són substituïts els primers repobladors. Però aquest és un aspecte que cal deixar per a més endavant. Doncs, serà necessari saber de vell antuvi què passà amb els primers repobladors, quins van ser els seus destins i, finalment, com s'inicià el procés de substitució d'uns cognoms per els altres. La recerca sobre aquestes dades l'hem feta tot esbrinant en detall les referències del quinque libri i, a més a més, també he esbrinat en aquesta valuosa font documental tot el referent als padrins de batejats, als testimonis dels casaments, o a les defuncions $\mathrm{i}$ els marmessors dels difunts. He pogut obtindre així altres dades interessants i complementàries a les purament genealògiques, com són: oficis, ocupacions, càrrecs públics o "afinitats" familiars, que exposaré oportunament.

\subsection{EL QUE SABEM DELS PRIMERS LLINATGES}

Per no fer en aquest punt de la tesi una exposició massa llarga i potser desproporcionada, hem optat per extraure en un ANNEX IV el resultat del seguiment exhaustiu que hem fet de tots els cognoms dels repobladors de Serra i Ria a partir del primer volum del Quinque Libri i ocasionalment altres fonts i dades puntuals. Com a principal base de dades d'aquesta recerca prosopogràfica dels cognoms de Serra hem confeccionat també els quadres de batejats (agrupats per famílies i indicant també els padrins) que presentem com a ANNEX II i encara les llistes dels confirmats (ANNEX III) que ens ha permès completar les dades. Per això, ara es limitarem a fer una mena de resum que ens permeta sense estendre'ns massa arribar a la informació bàsica que necessitem per a poder analitzar i conèixer com va ser el procés repoblador.

Volem insistir en la qüestió dels padrins i les padrines perquè d'ells hem trobat informació rellevant que d'altra manera no tindríem, perquè no és habitual que en les partides de naixement es parle de la procedència del pares però si que es sol indicar habitualment la dels padrins, que de vegades son oncles dels nascut $i$ en tal sentit ens donen pistes valuoses sobre la possible procedència dels pares dels nadons i dels 
llinatges, en definitiva. La primera sorpresa la tinguérem quan, en les primeres dècades del XVII hi trobàvem moltes persones de les Alcubles, i això ens donà una gran pista que seguirem amb bons resultats. Tanmateix, cal tindre en compte que Alcubles mantingué certa relació de proximitat amb Sogorb, en ser una de les possessions, junt a Altura, que tenia la cartoixa de Val de Crist, propera a Sogorb; per això podria ser el fet de que trobem amb freqüència $-\mathrm{i}$ salvat el temps- coincidències amb els cognoms del cens prosopogràfic dels segles XV i principis del XVI que va elaborar Aparici (2001) per a la comarca de Sogorb.

D'aquestes recerques trobem molts detalls familiars i personals, com que Domingo Diago estava casat amb Isabel Morell, d'on es desprèn la possibilitat de que Diago i el repoblador Francesc Morell foren cunyats. Aquest Domingo Diago és també un dels pocs repobladors dels que trobem la seua defunció a Serra, concretament en 1651.

El primer fill de Miquel Domingo, de nom Bartomeu com el seu avi, es va casar a Serra en 1626, però posa en l'acta matrimonial que és natural y habitador de Las Alcublas. Això vol dir que son pare vingué a repoblar Serra sent ell un xiquet però no es quedà sempre a Serra, ja que ara es "habitador" a les Alcubles. Per cert, ve a casar-se amb Maria Català, una filla del repoblador de Nàquera Baptista Català, el qual en el certificat matrimonial ja consta com a veí de Serra. El segon fill, Miquel, també hi consta que és natural de Les Alcubles. Es casa en 1630 amb Clara Cavaller, la vídua de Juan Ribes, mort en 1628 i probablement fill d'un dels dos repobladors amb aquest cognom (Sebastià, de Serra o Miquel, de Ria). Tanmateix, el tercer fill, Martí, també consta com a "llaurador natural de Alcublas". Es casa també a Serra, amb Àngela Ribes, en 1640. El QUADRE 3.2 mostra l'expansió d'aquest llinatge Domingo en la Serra del segle XVII.

En 1641 trobem a Miguel Domingo com a batlle de Serra. El cognom Domingo també el trobem ja present en l'economia tèxtil de l'Alt Palància de finals del segle XV i començaments del XVI (Aparici, 2001); concretament hi ha un tal Bartolomé Domingo, pelaire, veí de Viver o Xèrica, com també els germans Joan i Domingo, pelaires en Sogorb, i Joan Domingo, cordeller. També la Carta Pobla de Soneixa i Assuévar recull dos repobladors de cognom Domingo: Martín i Pedro.

Domingo i Domènech, però, (un cognom que arribaria a Serra poc desprès) van ser dos cognoms i dos llinatges diferents i separats, el mateix que Rubio i Ros (aquest també més tardà). En canvi, com hem dit abans, també hi ha altres dualitats, com és el 
cas de Català/Catalan, Esteve/Esteban i Ribas/Ribes i encara Rives; aquestes sí que són variacions gramaticals dins d'un mateix llinatge, variacions degudes únicament a la manera particular d'escriure'ls i d'inscriure'ls. Així, hem vist com dels Català surt un "Catalan" que conserva el nou cognom fins als néts, però desprès d'aquests torna a ser de nou i per sempre Català.

QUADRE 3.2.- Expansió del llinatge dels Domingo en la Serra del segle XVII.

\begin{tabular}{|c|c|c|}
\hline \multirow[t]{2}{*}{$\begin{array}{c}\text { REPOBLADORS } \\
\text { Bartolomé Domingo/ Maria Catala }\end{array}$} & $\begin{array}{l}\text { FILLS/FILLES } \\
\text { 1628: Joan Agustín } \\
\text { 1633: Jusepha Luysa }\end{array}$ & NÉTS/NÉTES \\
\hline & $\begin{array}{l}\text { 1631: Miguel/ Josepa Arnal/ Maria } \\
\text { Blasco }\end{array}$ & $\begin{array}{l}\text { 1675: Josepa Maria Clara } \\
\text { 1680: Juan Miguel P. } \\
\text { 1683: Maria Blaya Franc. }\end{array}$ \\
\hline \multirow[t]{2}{*}{ Miguel Domingo/ Clara Cavaller } & & $\begin{array}{l}\text { 1685: Agustín Juan Bart. } \\
\text { 1689: Simon Andrés } \\
\text { 1693: Gerónimo C. Dom. }\end{array}$ \\
\hline & $\begin{array}{l}\text { 1633: Francisco/ Catalina Arnal } \\
\text { 1635: Agueda Dominga } \\
\text { 1637: Agustin Vicente } \\
\text { 1639: Andres Mauro } \\
\text { 1642: Pedro Joan Alejo }\end{array}$ & 1670: Clara Francisca G. \\
\hline \multirow[t]{2}{*}{ Martín Domingo/ Angela Ribas } & $\begin{array}{l}\text { 1642: Jusepa Glaudiana } \\
\text { 1644: Ana Maria Llorença } \\
\text { 1646: J. Tomàs/ Eusebia Pérez } \\
\text { 1648: Nadala Tomasa } \\
\text { 1650: Jusepe Joan Martín }\end{array}$ & $\begin{array}{l}\text { 1680: Thomàs Andreu J. } \\
\text { 1685: Visente Melchor A. } \\
\text { 1687: Antonio Pedro T. } \\
\text { 1689: Ma Francisca P. M. }\end{array}$ \\
\hline & $\begin{array}{l}\text { 1652: Joan/ Gertrudis Gil } \\
\text { 1654: Martín Mauro Andres } \\
\text { 1656: Engrasia Maria Sesilia }\end{array}$ & $\begin{array}{l}\text { 1677: Chuan Francisco B. } \\
\text { 1683: Jusepa Arcángela Mª } \\
\text { 1687: Jaume Juan Batiste }\end{array}$ \\
\hline \multirow[t]{2}{*}{ Josep Domingo/ Teodosia Moreno } & $\begin{array}{l}\text { 1659: Catalina Clara Maria } \\
\text { 1660: Clara Maurisia } \\
\text { 1663: Francisco Gaspar T. } \\
\text { 1664: Juan Bautista Domingo } \\
\text { 1668: Jusepe/ Jasinta Català }\end{array}$ & $\begin{array}{l}\text { 1689: Tomàs Domingo J. } \\
\text { 1691: Visenta Francisca } \\
\text { 1693: Maria Esperança } \\
\text { 1695: Jusepa Visenta E. } \\
\text { 1697: Rosa Maria F. } \\
\text { 1700: Cathalina Vta. D. } \\
\text { 1702: Jusepe Visente } \\
\text { 1704: Joseph Franc. J. }\end{array}$ \\
\hline & $\begin{array}{l}\text { 1671: Pablo/ Ana Maria Català } \\
\text { 1673: Maria Ursola P. } \\
\text { 1676: Carlos Joan B. }\end{array}$ & $\begin{array}{l}\text { 1706: Rosa Maria Juana } \\
\text { 1707: Juan Francisco J. } \\
\text { 1709: Theodosia Vta. J. }\end{array}$ \\
\hline
\end{tabular}

Elaborat a partir del Quinque libri de Serra. 
Un altre hàbit en les inscripcions parroquials és el de feminitzar de vegades els cognoms: Antoni Esteve estava casat amb Joana Romero, però a sovint la trobem escrita com "Romera". Abans de 1619, aquest matrimoni tenia almenys quatre fills: Martín, Joana Anna, Magdalena i Mateu², i desprès en tingueren dos fills més: Vicenta Agustina (“Austina"), en 1621, i Vicente Antonio, en 1623. La filla major, Joana Anna, es casarà en 1626 amb Joan Batista Català, i en la inscripció es fa constar que ella és natural de Las Alcublas. Sembla evident, per tant, que el cognom Esteve o Esteban (al llarg del registre el trobem escrit d'ambdues formes, indistintament per a les mateixes persones) ${ }^{3}$ procedeix també d'Alcubles. Dades indirectes com aquestes, en que almenys dos dels fills del matrimoni resulta clar que nasqueren a Alcubles ens permet afirmar que Esteve era un altre dels cognoms i repobladors que vingueren d'aquella població.

Aquest alcublà, Antoni o Anton Esteve el trobem també, entre altres actes, com a testimoni de l'enllaç matrimonial de Francesc Rubio "llaurador de Les Alcubles" i Vicenta Cavaller, en 1625. Aquesta mena de dades és la que ens ha permès anar ampliant "el rogle" dels alcublans arribats a Serra. Anton va morir a Serra en 1647 i la seua dona “Joana Romera" en 1656. Són totes aquestes dades que també ens van informant sobre l'edat que podrien tindre alguns repobladors en 1609: alguns dels d'Alcubles al voltant dels 35 anys o menys.

El cognom Esteve és un altre dels que arribaran a penetrar en el segle XVIII, i ho farà mitjançant Vicent (n. 1643), un nét d'Anton i fill de Mateu. Aquest Entenem que aquest Esteve podria estar lligar amb la forma castellana/aragonesa Esteban que trobem en l'ambit de l'economia tèxtil del segle XV a la comarca de Sogorb; cas de Bernat Esteban, sastre i habitador en Viver, i Joan Esteban, pelaire, veí de El Toro. ${ }^{4}$

D'altres repobladors, en canvi, o hen obtingut cap informació en el Quinque libri de Serra, com és el cas del repoblador de Serra Jaume Fonfria i dels de Ria Miquel Garrués i Miquel Granell. No obstant, el primer i el tercer són cognoms que actualment trobem presents i són habituals en diverses poblacions de l'Horta Nord, mentre que el segon d'ells no descartem que poguera ser d'origen navarrès o biscaí, per les raons que més endavant observarem. Per altra part, als llibres parroquials de Nàquera hem trobat

\footnotetext{
${ }^{2}$ No sabem quin era l'ordre d'edat, però hi consta que Martín tenia 12 anys quan va ser confirmat en 1619 (per tant nasqué cap a 1607).

${ }^{3}$ El fill menor d'Anton Esteve va contraure núpcies amb Vicenta Ramon, constant ell com a "Vicente Esteban”. Tingueren tres fills: Pasqual (n. 1656), Joan Batista (n. 1659) i Isabel (n. 1662), que quedaren orfes en 1663 en morir son pare "de un escopetaso".

4 J. Aparici (2001).
} 
que en 1632 es cassà en aquell lloc Magdalena Fonfria, natural i habitadora en Alcàsser, filla de Miguel Fonfria i Vicenta Guardiola. Podria ser una pista que ens duu a la comarca de l'Horta, però també hem trobat persones amb aquest cognom en l'entorn de Sogorb i durant el segle XV; cas de Joan Fonfria, veí de Mançanera, ramader que ven llana a un veí de Xèrica (Aparici, 2001).

De Joan Guillem, repoblador de Ria sabem que estigué casat amb Bàrbara Serret i que és el primer difunt enregistrat en el Quinque libri de Serra: morí el 21 de febrer de 1620 "molt pobre" i el van soterrar en el cementeri de Nàquera per no estar beneït encara el de Serra. Dues de les seues filles es van casar a Serra, en 1623 i en 1630, i una tercera a Nàquera, en 1634. En la inscripció d'aquest darrer matrimoni posa: Vicenta Guillem "natural de Serra i habitadora en Olocau", filla de Juan Guillem i Bàrbera Serret, i es va casar amb el francès Domingo Naturille. Per altra part, en 1618 trobem a Soneixa un veí de nom Joan Guillem, ${ }^{5}$ que no seria estrany fóra fill o tinguera algun grau de parentiu proper al repoblador de Serra, si tenim en consideració la pertinença de Soneixa al mateix Senyor i que Serra era lloc habitual de pas dels veïns de Soneixa cap a València. També en el segle XV hi ha presència del cognom Guillem a la comarca de Sogorb (Aparici, 2001).

Pere Ibáñez és un altre dels repobladors de Serra que tenim clar que procedia d'Alcubles, però cal dir que en un del enllaços matrimonials del que va ser testimoni a Serra posa d'ell: "Pero Yvanyeç, natural de Saragossa". Pere estava casat amb Caterina Muñoz, i eren pares de Joan Ibáñez, nascut a Alcubles, sent aquest origen de tots els Ibáñez de Serra i de Nàquera. Joan Ibáñez va morir en 1661 però l'hem trobat en moltes ocasions com a testimoni de cassaments i de batejats. Sembla que va ser un personatge molt popular i estimat, el qual també hem trobat duent els arrendaments del carnatge de Morvedre (ho veurem amb més cura en el capítol sisè).

De Menau Llanes sabem ben poc però podria ser la mateixa persona que trobem anomenada Perau Llanes en dues ocasions dins dels protocols del notari Joan Font, en la segona d'elles diu que Perau Llanes va ser propietari d'un bancal que en 1620 pertanyia a Jaume Peres i encara abans havia sigut del morisc Corcuix. ${ }^{6}$ També hem trobat un tal Anton Llanes (parent de Menau/Perau?) de València, com a testimoni de l'enllaç matrimonial entre Domingo Moreno menor i Rafela Donya, en 1624.

\footnotetext{
${ }^{5}$ És un dels signants del nou pacte i concòrdia, de l'any 1618, entre vassalls de Soneja i el Senyor, per tal de reduir les càrregues sobre les vinyes (veure $\mathrm{F}$. Iquino, 1982).

${ }^{6}$ APCC, lg. 21045; notari Font, 21/11/1620. i també APCC, lg. 21047; Font, 20 de febrer de 1623.
} 
No repetirem ací les escasses dades de que disposem d'altres repobladors, les quals queden recollides en l'esmentat ANNEX IV. En aquest cas estan Domingo Manyes, Francesc Morell, Joan Muñoz, Jaume Noguera, Marc Palacio, Joan Palacios, Sebastià Ribes, Miquel Ribes, Miquel Saez, Antoni, Lluch i Joan Salvador, Bartomeu Salvaterra, Miquel, Joan i Antoni Sanchis, Vicent Sarigó Ribera, Joan Teruel i Domingo Vilanova.

En canvi, de Joan Rubio hem de destacar la seua expansió i el fet de que siga un dels cognoms antics de Serra que ha perdurat fins el present, sent la seua expansió durant el segle XVII a Serra la que mostra el QUADRE 3.3.

QUADRE 3.3.- Llinatge i expansió del cognom Rubio a Serra, en el segle XVII.

\begin{tabular}{|c|c|c|c|}
\hline \multirow[b]{2}{*}{ Juan Rubio/ Maria Siprer } & & & 1675 Vicenta Felicia B. \\
\hline & $\begin{array}{l}\text { 161?: Vicente/ Vicenta } \\
\text { Navarro } \\
\text { 16?? Joan } \\
\text { 1621: Felicia Bárbera } \\
\text { 1624: Vicenta Emerenciana } \\
\text { 1627: Juana Anna }\end{array}$ & $\begin{array}{l}\text { 1646: Vte. Estevan/ E. } \\
\text { Català/ Ma Arnal } \\
\text { 1652: Tomàs Pere Juan } \\
\text { 1655: Pedro Juan Matías } \\
\text { 1656: Pedro Juan Pasqual }\end{array}$ & $\begin{array}{l}\text { 1679: Visenta Maria F. } \\
\text { 1685: Pasqual Jayme } \\
\text { 1689: Catalina Visenta } \\
\text { 1692: Luis Francés } \\
\text { 1696: Luis Estevan } \\
\text { 1702: Estevan Franc. }\end{array}$ \\
\hline Francisco Rubio/ Vicenta Cavaller & $\begin{array}{l}\text { 1627: Jusepha Marianna/ } \\
\text { 1628: Joan Bautista } \\
\text { 1630: Margalida Francisca } \\
\text { 1632: Felicia Francisca } \\
\text { 1634: Esperança Francisca } \\
\text { 1635: Francisco Joan Pedro } \\
\text { 1637: Cathalina Leocadia } \\
\text { 1639 Buenaventura } \\
\text { 1641: Pedro Joset Patricio }\end{array}$ & $\begin{array}{l}\text { 1657: Jusepe Basilio/ } \\
\text { Francisca Arnal } \\
\text { 1648: Marco Esteve } \\
\text { 1650: Joan B. Cristoval/ } \\
\text { Maria Garay }\end{array}$ & $\begin{array}{l}\text { 1686: Jusepa Tomasa } \\
\text { 1690: Jusepa Maria } \\
\text { 1693: Maria Gesualda } \\
\text { 1696: Jusepe Francisco } \\
\text { 1700: Francisco Juan } \\
\\
\text { 1680: Visenta Maria } \\
\text { 1682: Pedro Juan C. } \\
\text { 1685: Jusepa Madalena } \\
\text { 1688: Teresa Angela F. } \\
\text { 1691: Francisca Isabel } \\
\text { 1694: Rosana Florentina } \\
\text { 1696: Thomasa Cathalina } \\
\text { 1700: Francisco Xavier } \\
\text { 1703: Juan Manuel }\end{array}$ \\
\hline
\end{tabular}

Elaborat a partir del Quinque libri de Serra.

Rubio és un altre dels cognoms procedents d'Alcubles i que en els llibres parroquials trobem escrit de diferent manera sense respondre a cap criteri formal: La 
forma Ruvio és la dominant, però moltes vegades trobem escrit Rubio, encara tractant-se d'una mateixa persona, alternant les dues formes indistintament.

Una altra informació del Quinque libri que hem trobat força interessant i profitosa, pel seu caràcter complementari, ha sigut la relació dels xiquets que van ser confirmats a Serra en 1619. La llista està formada pels set xiquets i les tres xiquetes següents:

Juan Bautista Domènech (10 anys), hijo de Josephe Domènech y de Agustina Puche.

Juan Ruvio (3 anys), hijo de Juan Ruvio y Anna Ruvia.

Domingo Ciago (4 anys), hijo de Domingo Ciago y de Isabel Morell.

Bautisto Chathala (12 anys), hijo de Bautisto Chathalà y de Barbera Matheu.

Martín Esteve (12 anys), hijo de Antoni Esteve y de Juana Romera.

Juan Sáes (9 anys), hijo de Miquel Sáez y de Isabel Sayal.

Agustín Salvador (4 anys), hijo de Antonio Salvador y de Eufonia Teruel.

Angela Domènech (4 anys), hija de Jusephe Domènech y de Agustina Puche.

Francisca Saes (6 anys), hija de Miguel Sáez y de Isabel Sayas.

Maria Chathalan (11 anys), hija de Bautista Chathalà y de Barbera Matheu.

Noteu que dels set matrimonis dalt representats, un era repoblador de Nàquera (Batista Català) i un altre, Josep Domènec, potser fill o germà d'un altre repoblador de Nàquera (Joan Domènec). Ambdós sembla que ja són clarament veïns de Serra; almenys els seus llinatges continuaran a partir d'ara a Serra però també ells, doncs Josep Domènec morirà en 1622, i la seua vídua, Agustina Puig li sobreviurà fins a l'any 1651. Per altra part, a Baptista Català major el trobem encara en el cens de 1646, com a vidu de Bàrbera Mateu; també el seu fill Baptista Català -el confirmat en 1619- el trobem com a veí de Serra en el cens de 1646, casat amb Joana Esteve, pares de quatre fills.

Del conjunt de repobladors de Serra i Ria en 1609 seran cinc els matrimonis que tenen algun fill en edat de rebre el sagrament de la Confirmació deu anys desprès. Però, si repassem les referències posteriors, se n'adonarem que es tracta de matrimonis de certa edat, dos dels quals no tenen ja més fills. Anton Salvador i la seua muller van morir en 1631, i Domingo Diago major morí en 1651 (pel que sabem podria ser el el més durador dels signants de la Carta Pobla). Per altra part, Miquel Sàez, morí en 1623 suposem que jove (en 1621 la seua dona havia tingut una filla), com també Joan Rubio major, que morí en 1626 tenint al menys tres fills joves (nascuts en 1621, en $1624 \mathrm{i}$ un de pòstum, en 1627). Recordem que Antoni Esteve i Joana Romero tingueren encara dos fills a Serra, en 1621 i 1623, i que ell morí en 1647 i ella en 1657. 
Per aquestes escasses dades, podem suposar fàcilment que l'edat d'aquestes persones, que amb penes sí visqueren més enllà del $1650 \mathrm{i}$, en els millors casos deixaren de tindre fills en la primera meitat de la dècada dels anys 20, podia ser de l'ordre de 30 a 40 anys, com a mínim, el 1609.

Aquestes dades, unides al fet que molts dels repobladors no els hi trobem a penes referits en els registres parroquials, fan pensar la possibilitat que molts d'ells hagueren ja mort abans del 1619 o simplement, el que sembla més raonable, que hagueren mudat de lloc. Aquestes són les opcions sobre les que tornarem a insistir més endavant.

En conclusió, podem dir que al cap d'unes dècades, els repobladors originals es poden separar en tres grups:

- Aquells que perduren més temps a Serra (segons demostren les inscripcions parroquials): Diago, Esteve, Rubio, Sáez i Salvador. També els fills de Domingo i d'Ibáñez, inclosos en l'apartat següent

- Els que són prompte substituïts pels seus fills (suposats fills, o nebots, de vegades), encara que la major part d'aquests cognoms acaben extingint-se prompte: Guillem, Máñez, Morell, Muñoz, Noguera, Ribes, Sanchis o Teruel. L'excepció serien els Domingo i Ibáñez, que continuen presents a Serra.

- Els que amb penes sí deixen rastre: Fonfria, Garrués, Granell, Llanes, Palacio, Palacios, Salvaterra, Sarigó Ribera i Vilanova.

\subsection{EL CONSELL MUNICIPAL D’ALCUBLES EN 1598}

Vist que alguns repobladors (concretament sis, amb els cognoms: Domingo, Esteve, Ibáñez, Ribes, Rubio i Sáez) procedien, o semblava que podien procedir, de les Alcubles, vaig cercar dades sobre aquesta població en època prèvia però propera a l'any de l'expulsió. El resultat fou efectiu, perquè, en el "Libro de acuerdos del ayuntamiento de Alcublas (1598-1640)" que es custòdia en l'Arxiu del Regne de València ${ }^{7}$, es troben citades diferents persones que coincideixen pràcticament amb noms i cognoms dels repobladors de Serra i Ria. Fins i tot, sembla que en algun cas es tracta de les mateixes persones (QUADRE 3.4).

Una de les primeres notícies que hi consten en aquest llibre és la decisió que pren el consell general d'Alcubles de si paguen o no les despeses de l'escrivà que el

\footnotetext{
${ }^{7}$ ARV, diversos. Alcubles, llibre 9, f. 27 i ss.
} 
procurador del monestir de Valdecrist va dur per tal d'ordenar "las determinaciones del Concejo" i potser també per aclarir els comptes del lloc d'Alcubles i concretar els tributs que els hi corresponia pagar. El resultat de la votació és de 21 vots a favor i altres 26 en contra de pagar les despeses. Però el més interessant és que es tracta d'una votació nominal, per la qual cosa coneguem el nom de les 47 persones que formaven aquest consell municipal. Aquests veïns, agrupats per cognoms (veure apèndix documental), tenen clares similituds amb els de Serra i Ria, com veurem tot seguit.

Del cognom Domingo veiem que hi ha a Alcubles tres branques, els de Domingo, els de l'Adriana i els del Povil. Sembla que els dos repobladors de Serra podrien ser clarament descendents dels de la Adriana (Miquel i Bartomeu). Aquesta suggeridora sospita ens duu a suposar que els signants de la Carta Pobla, Miquel i Bartomeu Domingo foren germans (fills de la Adriana) i d'edat més bé madura o avançada. Per altra part, l'alcublà Jusepe Domingo, fill de Joan, que es casa a Serra l'any 1657, bé podria ser fill del veí d'Alcubles "Joan el del Povil".

Domingo Manyes de Miquel podria ser la mateixa persona en els dos llocs (Alcubles en 1598 i Serra en 1609). Aleshores, com que no consta que morira a Serra, i en canvi les referències del quinque libri són de la seua suposada filla Isabel i altres descendents, tot açò fa sospitar novament que el signant de la carta de poblament fora igualment una persona d'edat avançada.

La mateixa sospita envolta el cas de Joan Teruel, que en Alcubles encara és "menor" perquè tindria el mateix nom que son pare, possiblement de molt avançada edat, sinó difunt. I en canvi, a Serra ni tan sols consta la seua defunció. Potser només tinguera una filla: "Eufemia Teruel", la qual morí en 1631; sense que hi hagen més referències al cognom.

Havíem trobat que Pere Ibáñez -el repoblador- era natural de Saragossa, però en canvi, el seu fill Joan hi constava clarament que era natural d'Alcubles, i és aquest qui en la pràctica dóna origen al llinatge dels Ibáñez de Serra, lloc on es casa per tres vegades i, a més a més, es relaciona activament amb altres famílies serranes, bé apadrinant diversos xiquets, bé fent de testimoni en diversos actes socials. El que sorprèn un poc és que Pere no aparega en el consell d'Alcublas; i potser l'explicació estiga en la possibilitat de que fora el seu fill Joan el que trobem aveïnat en 1598. Açò és probable si tenim en compte que Joan va morir en 1661 a Serra, que es casà per primera vegada en 1627 (fent les amonestacions prematrimonials en Alcubles), i que va ser pare per última vegada en 
1654. Per tant, encara que molt jove, podria ser ell l'aveïnat de 1598 , o bé estar substituint directament a son pare, que potser fóra aleshores un home prou major.

QUADRE 3.4.- Comparació entre veïns d'Alcubles (1598) i de Serra (1609).

\begin{tabular}{|l|l|} 
Veïns d'Alcubles (1598) & Repobladors de Serra i Ria (1609) \\
\hline Joan Domingo menor, de Domingo & Miquel Domingo de Miguel \\
Miguel Domingo de la Adriana & Miquel Domingo de Bartolomé \\
Bartolomé Domingo de la Adriana & \\
Martín Domingo del Povil & \\
Joan Domingo, hijo del Povil & \\
\hline $\begin{array}{l}\text { Francisco Manyes de Joan } \\
\text { Domingo Manyes de Joan } \\
\text { Joan Manyes de Gavarda } \\
\text { Bartolomé Manyez de Gavarda } \\
\text { Domingo Manyes de Miguel }\end{array}$ & \\
Domingo Manyes del corral & Domingo Manyes de Miquel \\
\hline Joan Teruel menor & \\
\hline $\begin{array}{l}\text { Damian Yvanyes } \\
\text { Joan Yvanyes, peraire } \\
\text { Martín Yvanyes }\end{array}$ & Joan Teruel \\
\hline & Pere Yvanyes \\
\hline Miguel Ribas de Miguel & Sebastià Ribes \\
\hline Miguel Sanchiz & Miquel Ribes \\
\hline
\end{tabular}

Format amb dades de llibre d'acords de l'ajuntament d'Alcubles (ARV, “diversos") i la Carta Pobla de Serra i Ria.

Observem que la mare de Joan Ibáñéz i dona de Pere Ibáñez, era Catalina Muñoz, qui tenia un cognom coincident amb el del repoblador de Serra Joan Muñoz, la qual cosa apunta la probabilitat alta de que aquest colon procedira també d'Alcubles. I de fet, 
encara que no trobem cap "Muñoz" en les llistes de votació del consell municipal d'Alcubles, de 1598, si que en trobem, un tal "Anton Munyoz", en un acte d'insaculació per a nomenar càrrecs públics, que es celebra en el mateix lloc i any. Tanmateix, la primera dona de Joan Ibáñez, Catalina Garcia, tenia un cognom ja present en Alcubles a finals del XVI: per un tal "Joan Garcia” que també forma part del consell de 1598.

El cognom Ribas/Ribes ja vam veure, per inscripcions parroquials, que tenia clares connexions amb gent d'Alcubles (almenys en tres casos evidents). Dels repobladors Sebastià i Miquel Ribes amb penes sí sabem res més, però si d'un suposat fill d'un dels dos, Pere Joan Ribes, que morí en 1628 i la seua vídua es tornà a casar amb un alcublà. Aquestes dades novament són prou suggeridores de que els signants de la carta de poblament eren persones relativament majors, i que eren els seus fills els qui estaven en condicions i edat de procrear i continuar els llinatges d'aquells primers colons. I evidentment, el "Miguel Ribas de Miguel" que trobem en Alcubles és molt probable que siga la mateixa persona que, com a Miquel Ribes trobem onze anys després, en el paper de ser un dels repobladors de Ria.

També la dualitat del cognom Sanchiz/Sanchis sembla coincident en la mateixa persona; per una part el Miguel Sanchiz d'Alcubles i per altra amb la denominació valenciana de Miquel Sanchis, repoblador de Serra. Tampoc d'aquest repoblador de Serra, ni d'Antoni Sanchis, el de Ria, hi ha amb penes sí informació en el quinque libri. També açò aboga en la possibilitat que aquests repobladors foren també persones relativament majors.

De la resta de cognoms dels repobladors, també havíem vist que tant Antoni Esteve, com Joan Rubio i fins i tot Miquel Saeç tenien, si no el seu origen en Alcubles, sí almenys bons indicis de relació familiar i/o amistosa molt estreta amb aquest lloc, encara que, no obstant açò, es tracta de cognoms que no els hi he trobat en la documentació municipal adés esmentada. I per altra part, també semblava clar que els repobladors de cognom Salvador procedien de la ciutat de València, com també Morell i, probablement, Menau Llanes.

En conclusió, amb tota aquesta informació, es pot afirmant que la principal procedència dels repobladors de Serra i de Ria era el lloc de les Alcubles, que pertanyia a l'administració senyorial del convent cartoixà de Valdecrist. Concretament, hem d'admetre que almenys el 47 per cent dels colons (14 de 30) tenien aquesta procedència; un altre 17 per cent ( 5 de 30 ) procedien de la ciutat de València, i del $37 \%$ restant (11 
colons) no tenim suficientment clar el seu origen, encara que la major part dels seus cognoms hem vist que ja estaven presents, un segle abans, en la comarca de l'Alt Palància ${ }^{8}$. No obstant, cap també la possibilitat, com he comentat abans, que Bartomeu Salvaterra (cognom toponímic) poguera estar emparentat amb "Pere Joan Salvaterra", un 1lister (llisterio), habitador de la ciutat de València, però de clar origen basc-navarrès, qui trobem mantenint relació comercial amb gent de Serra ${ }^{9}$. El mateix podrien suposar de Menau Llanes, possiblement habitador a València, però del que no estranyaria un probable origen cantàbric.

Arribem així al QUADRE 3.5, en el qual resumim la procedència dels diferents signant de la carta-pobla de Serra ui Ria, segons les recerques i conclusions fins ací exposades.

QUADRE 3.5.- Resum dels llocs de procedència coneguts per als cognoms dels primers repobladors de Serra i Ria

\begin{tabular}{|l|l|}
\hline Procedents d'Alcubles: & $\begin{array}{l}\text { Domingo, Esteve/Esteban, Ibáñez, Máñez, } \\
\text { Muñoz, Ribas/Ribes, Rubio, Sàez, } \\
\text { Sanchiz/Sanchis, Teruel... }\end{array}$ \\
\hline $\begin{array}{l}\text { Procedents de la ciutat } \\
\text { de València: }\end{array}$ & $\begin{array}{l}\text { Salvador, Morell... } \\
\text { Llanes, Salvaterra (potser aveïnats a } \\
\text { València, però d'origen forà) }\end{array}$ \\
\hline & \multicolumn{1}{|c|}{...la resta. } \\
\hline
\end{tabular}

Elaboració pròpia.

Per altra part, abundant en l'esmentada idea de que bona part dels repobladors foren gent d'edat madura, caldria insistir en el fet que són escassíssims els casos de fills de repobladors batejats a Serra desprès de 1619; i tots els casos registrats ocorren dins la primera meitat de la dècada dels vint. En canvi, molts fills de repobladors estan en edat de procrear durant les dècades dels anys 20 i 30, i encara abans, i mostra d'això és

${ }^{8}$ J. Aparici, 2001, en el seu cens prosopogràfic parla de Bartolomé i Joan Domingo, Bernat, Joan Miquel i Pere Esteban, Antoni i Violant Guillem,Joan Ivanyes, Martí Munyoç, Bertomeu i Joab Morell, Francesc iJaume Noguera, Domingo Ruvio, Bertomeu i Marco Palacio, i altres...

${ }_{9}$ APCC, sg. 20584, Notari Font, 10/02/1631. 
l'elevat nombre de batejats que són néts dels primers repobladors. I com és natural, el que si hi ha en aquest període són defuncions d'alguns dels repobladors. ${ }^{10}$

Per totes aquestes dades, m'incline a pensar que l'edat mitjana dels homes que subscriuen la carta pobla de Serra i Ria no fóra mai inferior als 30 o 40 anys, i que la major part d'ells foren ja pares de fills adolescents o casaders.

\subsection{SUBSTITUCIÓ PROGRESSIVA DELS COLONS: ELS NOUS POBLADORS}

Per fer-se'n una idea de com evoluciona la primera colònia de repobladors de Serra i Ria, en el procés de donar pas a les següents generacions i a nous colons, en el QUADRE 3.6 he marcat en negreta els cognoms de serrans que hauran de perdurar, almenys fins al cens de 1646. En ell també he afegit, per raons que de seguida entendrem, la relació dels 16 colons que signaren la carta pobla de Nàquera, el dia sis de desembre del mateix any 1609, davant el Senyor de Nàquera, en Francesc Figuerola. El text d'aquesta carta pobla el trobem recollit per Emili Lluch (2002).

En la tercera columna també he resaltat en negreta els cognoms que van a estar presents en el cens de Serra de l'any 1646, la qual cosa evidencia que hi hagué relació i trasllats entre els individus de les dues colonies. De fet, a qualsevol veí actual de Serra li sorprendria el fet que la major part dels cognoms dels repobladors de Serra i Ria li són hui desconeguts (amb l'excepció de Domingo, Rubio; i casualment també Sanchis), mentre que entre els colons naquerans n'apareixen alguns molt característics i extesos a Serra, com són els de Navarro i Català.

En definitiva, de les tres columnes, han quedat resaltats en negreta els únics cognoms que trobem encara a Serra quan es realitza el cens de l'any 1646. La resta dels cognoms havien gairebé desaparegut, o estaven ja en procés prou avançat de fer-ho.

El resultat és que, dels 24 cognoms dels 30 repobladors de Serra i Ria (diversos repobladors tenen cognoms iguals), únicament 6 (el $25 \%$ ) es mantenen en 1646. La resta són cognoms que desapareixen per a sempre. En canvi, és de notar que 4 dels 16 cognoms de repobladors de Nàquera (el ressaltats en negreta) els hi trobarem també incorporats al cens de Serra de 1646.

\footnotetext{
10 Concretament hem vist que són sis els casos coneguts de defuncions de repobladors: Joan Guillem (1620), Miquel Sáez (1623), Joan Rubio (1626), Anton Salvador i sa muller Eufemia Teruel (1631 ambdós), Antoni Esteve (1647, i sa muller, Joana Romero, en 1657) i Domingo Diago major (1951).
} 
QUADRE 3.6.- Relació dels nous pobladors dels llocs de Serra i Ria (novembre de 1609) i de Nàquera (desembre de 1609).

\begin{tabular}{|c|c|c|}
\hline SERRA & RIA & NÀQUERA \\
\hline Bertomeu Salvaterra & Miquel Ribes & Joan Domenech \\
\hline Miquel Sanchis & Vicent Sarigó Ribera & Vicent Èpila major \\
\hline Joan Sanchis & Joan Salvador & Vicent Èpila menor \\
\hline Joan Munyoç & Antoni Lluch Salvador & Lluch Joan Domingo \\
\hline Antoni Salvador & Domingo Vilanova & Baltasar Navarro \\
\hline Marc Palacio & Antoni Sanchis & Durà Perera \\
\hline Jaume Noguera & Miquel Garrués & Joan Roger \\
\hline Joan Teruel & Joan Rubio & Joan Garcia \\
\hline Francesc Morell & Joan Guillem & Agustí Mompó \\
\hline Miquel Domingo de Martí & Miquel Granell & Pere Lavan \\
\hline Miquel Domingo de Bartomeu & & Baptiste Català \\
\hline Sebastià Ribes & & Domingo Hernàndez Carrasco \\
\hline Domingo Diago & & Marco Vallés \\
\hline Antoni Esteve & & Vicent Valero \\
\hline Pere Ibanyeç & & Joan Tortajada \\
\hline Domingo Manyeç de Miquel & & Miquel Cervera \\
\hline \multicolumn{3}{|l|}{ Joan Palacios } \\
\hline \multicolumn{3}{|l|}{ Menau Lanes } \\
\hline \multicolumn{3}{|l|}{ Jaume Fonfria } \\
\hline Miquel Saeç & & \\
\hline
\end{tabular}

Els destacats en lletra negreta són particularment explicats en el text. Segons les cartes pobles de Nàquera ( Lluch, 2002) i de Serra i Ria.

Per tal de poder anar seguint el procés de l'evolució de la població i de la substitució dels cognoms, també he avançat (QUADRE 3.7) la relació de veïns del cens nominal de 1646 del lloc de "Serra y Ria"." La comparació d'aquests dos quadres, $3.6 \mathrm{i}$ 3.7 , resultarà força interessant, doncs en el segon quadre es comprova que només 10 dels 25 veïns de 1646 (o siga el 40 \%) tenen cognoms dels repobladors de Serra i Ria en 1609 (els destacats en negreta); altres 7 (un $28 \%$ ) tenen cognoms que coincideixen amb els dels primers repobladors de Nàquera (concretament Navarro, Català, Èpila i Doménech). La resta (32\%) inclou el rector (veí i amb casa pròpia) i a més, entre altres, a dos dels cognoms nous que major expansió assolirien en els segles següents: Arnal i Cabo.

Comprovem una cosa que en part havíem avançat: aquell any 1646 encara es troben amb vida dos dels signants de la carta de poblament de 1609. Es tracta de Antoni Esteve, que morirà en 1647, i de Domingo Diago major, aparentment el més ancià del poble, que viurà encara fins a 1651 .

${ }^{11}$ ARV, Generalitat, sg. 4826, f. 227. 
QUADRE 3.7.- "Caps de Casa" del cens de 1646 corresponent a "Serrayria" (sic.).

\begin{tabular}{|l|l|}
\hline Jussephe Giberto (rector) & Jussephe Suastre tierrateniente \\
\hline Francisco Ruvio & Matias Cabo \\
\hline Agustín Salvador & La viuda Epila, i \\
\hline Bautista Català menor & Antonio Arnal (la mateixa casa) \\
\hline Jossephe Català & Vicente Arnal \\
\hline Martin Domingo & Joan Yvanyes \\
\hline Antonio Esteve & Jayme Perez \\
\hline Domingo Moreno & Bautista Domenech \\
\hline Miguel Domingo & Vicente Ruvio \\
\hline Matheu Esteve & La viuda Navarro \\
\hline Domingo Diago mayor, i & Domingo Navarro \\
\hline $\begin{array}{c}\text { Domingo Diago } \text { menor... } \\
\text { (tots dos en la mateixa casa) }\end{array}$ & Bautista Catalan mayor \\
\hline Jossephe Domenech & \\
\hline
\end{tabular}

Hem destacat en negreta els cognoms coincidents amb repobladors de Serra i Ria de l'any 1609.

Font: ARV, Generalitat, sg. 4826, f. 227.

A penes sis anys desprès d'haver-se establit la nova colònia de cristians vells, podem entendre que els repobladors inicials estan ja en minoria, i així queda palès a la vista d'un acte notarial de data 8 de gener de $1617,{ }^{12}$ pel qual una assemblea municipal, formada per tretze veïns de Serra, decideix autoritzar al notari Joan Font, per a que "puga pendre del cofre diners de forment" i puga anar a Sogorb o on convinga, per tal d'aconseguir blat per a sembrar. Son testimonis d'aquest acte Joan Abellan "cuidador", de València, i Domingo Diago, llaurador de Serra.

Sembla clar que aquest document es refereix a fer ús del Pòsit ${ }^{13}$ per tal d'evitar la manca de conreu de les terres destinades al cereal. Per això es planteja en començar l'any i fer-se preocupant la manca de "siment" (llavor) de blat per a la sembra. Aquesta era precisament, en origen, la finalitat de constituir un pòsit en tots el municipis, tal com disposava una Pragmàtica del 1584, de Felip II.

12 APCC, sg. 21045, f. 1

${ }^{13}$ veure epígraf 8 (aspectes de la vida quotidiana...) 
Sis dels tretze signants són encara els primers repobladors: Pere Ivanyes, Joan Ruvio, Miquel Sáez, Anton Esteban, Miquel Ribes i Joan Guillem; tres d'ells (Ribes, Guillem i Rubio) eren repobladors de Ria, i els altres tres de Serra.

Els altres set signataris són Jusep Domènech, Anton Èpila, Baptiste Català, Andrés Tomàs, Anton Peres, Benet Martínez i Francisco Ivanyes. De seguida comentarem el que sabem de cadascun d'ells.

Jusep Domènech

Tot fa sospitar que fora fill del repoblador de Nàquera Joan Domènech. Estava casat amb Agustina Puig (Puxe) i va morir, sembla que prou jove, el 23 de desembre de 1622. Pocs mesos desprès nasqué un fill pòstum, Pere Vicent. Eren també pares d'altres quatre fills, almenys, que es van casar a Serra entre 1641 i 1645: Baptista Domènech "natural de Carpesa" ho fa en 1641 amb Mariana Ribas (filla de Pere Joan Ribas); Paula es casa en 1642 amb el vidu Joan Ibáñez; Josepa ho fa en 1644 amb Vicent Arnal, i Josep amb Felicia Burgos, en 1645.

La vídua Agustina Puig es torna a casar en 1628 amb el batlle de Serra Baptista Donya, també vidu, de Rafela Albalat.

En 1627 trobem un altre Josep Domènech -potser fóra un altre fill del matrimoni anterior- entre els testimonis de l'enllaç matrimonial entre Joan Ibáñez i Catalina Garcia. Aquest Joan enviduaria Joan, i tornaria a casar-se -com hem vist- amb Paula Doménech, en 1642 .

El quart fill de Baptista Domènech i Mariana Ribas, nascut en 1646 i batejat també com a Baptista, el trobarem més tard com a batlle de Serra en 1693 i fins a 1702 almenys. Va tindre 8 fills, amb Maria Lorente, i per aquesta descendència prossegueix el cognom, expandint-se en el segle XVIII.

El fet que Baptista Domènech el major, fora natural de Carpesa, fa pensar la possibilitat que aquesta família procedira de la comarca de l'Horta. En la boda de Rosa Domènech, la filla del batlle, i Jusepe Navarro, en l'any 1700, actuen com a testimonis un rector i un notari que són de Montcada.

\section{Anton Èpila}

Sens dubte està directament emparentat aquest Anton Èpila amb els dos Vicent Èpila, repobladors de Nàquera. Potser els dos Vicent foren pare i germa d'Anton i també 
d'Isabel Èpila, una veina de Nàquera casada amb Baltasar Guasch, que tingueren sis fills entre 1620 i 1632, sense que hi consten més referències del llinatge dels Èpila a Nàquera.

En 1627 va morir a Serra Vicent Èpila el major, qui deixà per marmessors al seu fill Juan, que devia ser el més major, junt a Vicent Èpila menor (l'altre repoblador de Nàquera) i Isabel i Anton.

Resulta clar que Joan era un germà d'Anton, ja que el trobem com a padrí i oncle del xiquet Antonio Diego fill d'Anton Èpila i d'Isabel Manyes, essent la primera inscripció de batejats en el quinque libri, en 1619. Aquest matrimoni del veí de Serra Anton Èpila i Isabel Mañez (que supose filla del repoblador Domingo Manyes de Miquel) tingué onze fills, fins al començament de 1640, any en que va morir ell (el 30 de març), i uns dies desprès (el 12 d'abril) ho feia també el seu fill menut, de dos mesos d'edat.

Només tres filles i un fill d'Anton Èpila i Isabel Mañez arriben a casar-se i tindre descendència a Serra. La major d'ells era Isabel, nascuda abans de 1619, que es va casar en 1637 amb el vidu francés Antoni Correja, de qui arribà a tindre un fill, però va perdre els dos. L'any següent Isabel es tornà a casar, amb el biscaí Joannes de Loiola, amb qui tingué una filla, Vicenta. Novament enviduà en 1658, tornant-se a casar el mateix any amb el navarrés d'Otxagavia Martí Martínez.

Úrsula Ėpila es va casar en 1644 amb Antoni Arnal; la seua germana Magdalena ho va fer en 1658 amb el navarrés Pere Garay, i el germà d'ambdues, Vicent, es casà en 1665 amb Petronila Gonzàlez. Encara que Vicent morí molt jove (en 1671, amb 33 anys), el matrimoni tingué tres fills, els tres varons, però el cognom es va perdre definitivament, tant en Serra com en Nàquera.

Potser la procedència del cognom fora d'algun poble de l'Horta Nord i de la ciutat de València. Així ho suggereix l'acta d'un matrimoni inscrit a Nàquera l'any 1634: Francesc Lasierra, vidu, es casa amb Margarita Èpila, donzella natural d'Almàssera i habitadora en el carrer de Morvedre, junt a Sant Antoni, parròquia de Sant Salvador (ciutat de València).

El Baptista Català que trobavem com a veí de Serra en 1617 no sabem cert si es tracta del mateix repoblador de Nàquera (pense que això és el més provable) o fins i tot del seu fill, llaurador i natural d'Almàssera, que es casarà a Serra el 1626, amb Juanna Anna Estevan. Baptista Català major sembla que estava casat amb Bàrbera Mateu, i a més de l'esmentat fill, també tenien a Maria, que es va casar també en 1626, amb 
Bartolomé Domingo (d'Alcubles). Del contingut d'aquesta inscripció matrimonial cal destacar que els pares de la núvia són "veïns de Serra", i a més, com a testimoni hi consta un tal Cosme Català, que és veí de València. També eren fills de Baptista Català major i Bàrbera Mateu un xiquet nascut a Serra en 1622, Joan Vicent, i encara un altre fill més major, Josepe Catalan, que es va casar amb Catalina Peres en 1645. En els registres tan prompte trobem inscrita la forma Català com Catalan, que varia indistintament, amb caràcter aleatori. Aquesta situació es dona encara en èpoques posteriors, com en un capbreu de 1779 (ANNEX V), on apareixen deu veïns de cognom Català i altres dos de cognom Catalan. Un fill i nét dels anteriors, també Baptista Català, el trobem en 1705 com a Justícia de Serra (testimoni en l'enllaç Navarro-Arnal).

Respecte a Andrés Tomàs, Benet Martínez i Francisco Ivanyes, entenem que no devien de ser ser veïns de Serra en 1617. I poc és el que podem aportar. Per exemple, l'observació de que un dels repobladors de Soneixa era Jayme Tomás. Per altra part, un tal Andreu Tomàs, agricultor i habitador en Serra, apareix com a testimoni de la venda d'una mula que li compra en 1617 Pere Yvanyes a Vicent Castel, un agricultor d'Alcubles, per preu de 16 lliures. ${ }^{14}$ També trobem la referència en el Quinque libri al “guardan Jusepe Tomàs” de Gàtova, que es casà en 1668 amb Felícia Cabo, però morí abans de nàixer el seu primer fill, en 1671.

De Benet Martínez tampoc no hi ha més constància, encara que en 1628, un "veí de Serra" anomenat Francisco Martínez consta com a testimoni de l'enllaç entre el Batlle de Serra, Baptista Donya, i la vídua Agustina Puig. També sabem que Catalina Martínez i Miquel Cabo eren pares d'un jove Vicent Cabo, llaurador natural de Serra i habitador en Sot (de Ferrer), que es va casar en 1640 amb Margarita López, natural de Sot.

Francisco Ibáñez podria estar directament emparentat amb Pere i amb Joan Ibáñez, però cap constància ferma en tenim. El que si sabem és que en 1617 consta com a agricultor del lloc de Serra que junt amb Anton Esteve compren una mula a un tal August Crespo, de València, per 25 lliures ${ }^{15}$. Alguns anys desprès (en 1631) el trobem també com a carboner de Serra, i ara junt amb Patrici de Vigara venen 335 càrregues de carbó a Joan Donya i Pere Joan Salvaterra, de València. ${ }^{16}$

${ }^{14}$ APCC, 21045, f. 2

${ }_{15}$ APCC, 21045, f. 3

${ }^{16}$ APCC, 20584, Font, 10/02/1631 
Anton Pérez era el pare de Jaume Pérez, qui a finals de 1619 estava ja casat amb Catalina Garcia, i van ser pares de Jaume Antoni (n. En 1620), Domingo Agustí (1623) i Catalina (1626). Sembla que també devia ser fill de Anton i germà de Jaume, Bartolomé Pérez, casat amb Juana Ana Garcia, que consten com a pares de Bartolomé (1623) i d'un altre nadó que mor en 1625. Jaume Pérez mor a finals de 1626, i nomena per marmessor son pare, que no sabem quant de temps el va sobreviure (no hi consta en el registre parroquial de Serra). La seua vídua, Catalina, es casa en 1627 amb Joan Ibáñez i mor en 1642. Els germans Jaume menor i Catalina, fills de Jaume i Catalina, es casen en 1644 i 1645, amb Ursola Moreno i Jusepe Catalan, respectivament. Jaume serà pare de 10 fills. El sisé d'aquests fills també dit Jaume, es casa amb Anna Arnal, i tenen sis fills abans d'acabar el segle. També el seu germà Domingo, casat amb Maria Dolz, són pares de 8 fills entre 1692 i 1709. En el XVIII continua aixi l'expansió d'aquest cognom a Serra. En el capbreu de 1779 hi trobem 8 veïns amb aquest cognom.

\subsection{ALTRES COGNOMS TÍPICS DE SERRA}

Per tot el que hem vist fins ara, sembla prou evident que els primers repobladors eren gent relativament major $\mathrm{i}$, als efectes del nostre seguiment, un tant efímera, com també pràcticament ho són els nous "veïns" que hem trobat en 1617 (tres dels set nous veïns també podem dir que desapareixen sense a penes deixar rastre). En canvi, el que veiem en els llibres parroquials és que en al voltant de la dècada dels vint es registren una sèrie de matrimonis que són els que més van a "marcar" el desenvolupament i creixement de la colònia. Aquests matrimonis són principalment els dels fills i filles d'alguns pocs repobladors de 1609 i també alguns dels nous veïns de la llista de 1617. Ja en aquesta dècada dels vint, però també en les següents immediates, anem a trobar una progressiva introducció de nous cognoms (nous veïns) que completaran de forma decisiva el conjunt dels llinatges originals de la major part de la població serrana dels segles posteriors i de l'actual. Serà en aquesta època quan pràcticament s'aposta per aveïnar-se a Serra -que segurament reunia millors condicions- en detriment de Ria, que quedaria així pràcticament despoblada al cap de pocs anys.

De la mateixa manera que hem fet abans, repassarem tot seguit el que sabem de cadascun dels nous veïns que s'estableixen encara, però aquesta vegada no serà una relació exhaustiva de tots els casos existents, sinó una selecció dels més rellevants, 
atenent bé als que tingueren cert èxit procreador (continuïtat dels cognoms), o bé influïren sensiblement en la vida social de la Serra del XVII.

Un d'aquests nous cognoms és Arnal. Els primers Arnal els trobem en el anys 30, tractant-se de dos germans, Vicent i Joan, que s'havien casat poc abans a Nàquera. Els dos eren fills de Juan Arnal i de Merina Èpila. Concretament, Vicent Arnal era natural de Benifaraig i es va casar en Nàquera 8 de novembre de 1626, amb Violant Rubio, natural d'Alcubles. El seu germà Joan, que era de Montcada, es casarà justament un any desprès, també a Nàquera, amb Dorotea Valero, que era vídua de Joan Fos ${ }^{17}$. Per tant, sembla que el primer Arnal podria ser resident en un poble de l'Horta Nord, on habitaria encara desprès de casar-se amb la suposada filla d'un repoblador de Nàquera, tenint els dos fills esmentats, els quals, per la relació amb la família materna acabarien casant-se a Nàquera i, poc desprès passarien a residir definitivament a Serra, on potser trobarien unes condicions laborals i d'establir-se més adients que les de Nàquera.

Vicent Arnal i Violant Rubio encara tenen cinc fills a Serra, entre 1632 i 1641, però desprès mor la dona i ell es torna a casar, en 1644 amb Jusepa Domènech, amb qui tindrà altres cinc fills fins a 1655. Un dels fills d'aquest darrer matrimoni, Vicent Arnal menor (n. 1649) es casarà amb Josepa Gonçales (natural de Castielfabib) i seran pares de 9 fills abans d'acabar el segle.

També l'estirp dels Arnal continuarà pel segon dels germans, ja que el seu fill Joan (nascut a Nàquera en 1630) també es casà (en 1655) i visqué a Serra, amb Francesca Cabo, on tingueren altres 9 fills i 4 néts abans de fi de segle.

Altres dos fills de Joan major també es casaren a Serra: Antonio (nascut a Nàquera però habitador en Serra), que es va casar en 1644 amb Ursula Èpila (novament emparentat els Cabo i els Èpila), i tenint dos fills batejats a Serra, i Francesc (nascut a Serra en 1637) que es va casar amb Águeda Domingo el 1657. D'aquestes dues branques no he trobat cap altra referència a Serra, com tampoc d'un altre Vicent Arnal, de Nàquera, casat amb Maria San Juan, que bategen a Serra 4 xiquets entre 1689 i 1694. Potser totes aquestes branques i alguna més que no arriba a Serra, corresponga als Arnal de Nàquera, on també és Arnal un cognom molt abundant. ${ }^{18}$

\footnotetext{
${ }^{17}$ En el quinque libri de Nàquera trobem encara un altre Juan Arnal, marit de Maria Navarra (potser "filla de Navarro") que són pares del xiquet Miguel Juan, batejat en 1625.

${ }^{18}$ També està registrat en Nàquera, en 1638, el que serà fecund matrimoni de Pere Arnal (fill de Joan Arnal i Maria Navarro) i Maria Cavero. Veure nota 60.
} 
El cognom Cabo el trobem a Serra, per primera vegada, en el casament que té lloc en 1623, entre Miquel Cavo, llaurador i habitador de Nàquera, i Bàrbara Llorença Guillem, habitadora en Serra (filla del repoblador de Serra Joan Guillem, que havia mort tres anys abans d'aquest data). Com a testimonis d'aquest casament figuren Joan Salvador, mercader, i Jaume Peres, llaurador, de Serra. Daquest matrimoni no queda més rastre posterior. Potser aquest Miquel Cavo fora germà de Vicente Cavo, llaurador de Serra i habitador en Sot (de Ferrer) que es casa en 1640 amb Margarita López, de Sot; i també de Mathias Cavo que és realment el progenitor clar de la nissaga dels Cabo de Serra. Tots aquests (al menys els dos darrers de segur) serien fills de Miquel Cavo i de Catalina Martínez (possiblement filla, o germana, de Benet Martínez, un dels signants en 1617 de l'acord del préstec del pòsit).

Maties Cabo major es va casar a Nàquera l'any 1631, amb Bàrbera Estevan (filla d'Anton Esteve i Joana Romera; de Serra), i foren pares de deu fills batejats en Nàquera, entre 1633 i 1655. Dos dels seus fills es casaren desprès a Serra: Felícia Cabo ho va fer en 1653, amb Domingo Verge, i Maties Cabo menor es casà en 1665 amb Catalina Pérez. Sobre el lloc de procedència, en trobem pistes que ens duen a la ciutat de València, ja que trobem en diverses ocasions testimonis de València i, entre ells Simón Cavo "mosso vesino de Valencia", de professió tintorer (padrí d'una filla de Maties Cabo i Bàrbara Esteve, en 1633).

Per altra part, en 1666 es casa a Serra Cristoval Cavo, natural de Cantòria, diòcesi d'Almeria, fill de Cristóval Cavo i Isabel Alba, i ho fa amb Inés Sangez, natural de Carcaixent.

Hem vist en les línies precedents que les primeres grafies d'aquest abundant cognom actual venen sempre amb v (Cavo). La primera vegada que observe Cabo amb b és en 1664 (en el bateig d'una filla de Domingo Verge i de Felícia Cabo), però és una simple excepció, perquè encara desprès d'eixa data continua dominant la grafia de la $\mathrm{V}$ sobre la b.

Un altre cognom que s'estendrà i perdurarà a Serra és el de Dolz. Juan Dolz, natural de Xelva, es casa en 1666 amb Celidònia Navarro. En 1707 hauran tingut set fills i dos néts. Encara que minoritari a Serra, el cognom s'ha mantigut fins els nostres dies.

El cognom Donya desaparegué, però arribà a ser important a Serra perquè era el d'una família ben posicionada $\mathrm{i}$ influent. Hem referit en vàries ocasions que Baptista Donya va ser batlle de Serra i Ria i que es casà amb 1628 amb Agustina Puig, sent els 
dos vidus. Encara en 1637 el trobem com a batlle de Serra. Ell tenia la seua residència habitual a València, al carrer de Morvedre, encara que era veí de Serra el seu fill Joan Baptista Donya menor (que va morir en 1646). També residien a Serra dues filles del batlle i de la seua primera muller, Rafela Albalat. Les filles eren Vicenta i Rafela Donya, casades, respectivament amb Pere Navarro (en 1620) i Domingo Moreno (1624). Aquest cognom ja no tindrà continuitat a Serra.

També trobem en aquesta època el cognom Escrig, amb les grafies Eslich, Escrich, Escrix... Miguel Escrig va ser un llaurador de Llíria que en 1670 es casà en Serra amb Francesca Ibáñez. En acabar el segle tenien deu fills, i cinc néts abans de 1708 .

Garay és un altre dels cognoms d'aquesta època que han perdurat. Pedro Garay, natural de "Carri" (Etxarri?), diòcesi de Pamplona, i fill de Bernat Garay i de Catalina Garay, tots dos biscaïns, es casà en 1658 amb Magdalena Èpila. Encara que en el capbreu de 1779, abans citat, només hi ha un veí amb aquest cognom (Llorenç Garay, besnét del primer), a partir d'ell és quan comença certa expansió del cognom, que ràpidament s'estén per Serra i potser per altres llocs.

Una de les filles de Domingo Verge, Àngela Verge (n. el 1664) es casarà l'any $1681 \mathrm{amb}$ Blai Gasch, natural de Beselga (terme municipal d'Estivella). Tingueren onze fills entre 1682 i 1706, però el cognom acabà desapareguent de Serra. En canvi, el cognom Iranzo tindria més continuïtat a Serra, malgrat ser minoritari en els nostres dies. Començà en el registre parroquial amb Jusepe Iranço, natural de Moscardon (Terol), possiblement un pastor transhumant, que es casà en 1665 amb Àngela Rubio. Però envidua i, quan es torna a casar, també a Serra, fa constar que ve de Paterna i és vidu d’Àngela Rubio. La segona muller serà Francesca Rodríguez, de Gàtova.

Joan Maurici Mallach, llaurador de Serra, es casa en 1624 amb Isabel Jana Domingo, sent testimonis Pere Ibáñez i Pere Joan Ribes. Encara que no consta la procedència del nuvi, tant la núvia com els testimonis ja hem vist que procedeixen d'Alcubles. Aquest matrimoni tindrà dos fills, Martín (nascut en 1624) i Vicenta (en 1628), però la mare mor en 1630 i Joan Maurici es torna a casar el mateix any; ara amb Maria Ángela Guillem, una altra filla de primer repoblador. En 1631 són pares d'una xiqueta. També desapareixerà aquest cognom de Serra.

En 1624 es casen a Serra Domingo Moreno menor i Rafela Donya, constant com a testimonis Pere Ibáñez, natural de Saragossa, i Anton Llanes, de València. Abans 
d'acabar el segle hauran tingut dotze fills i nou néts. En 1630 trobem junts al mateix Domingo Moreno i a son pare (Domingo Moreno major i Domingo Moreno menor) com a testimonis de l'enllaç entre Joan Mallach i Ángela Guillem. En 1626 es va casar en Nàquera un suposat germà de l'anterior, doncs consta que era fill de Domingo Moreno i de Beatriu Munyoç. Es tracta de Francesc Moreno, natural de Benifaraig, que es casa amb Francesca Laura Herrero. Per aquesta informació podem suposar que aquests Moreno pogueren procedir de l'Horta Nord.

En 1639 i 1641 són batejats a Serra sengles fills d'Esteban Moreno i Dorotea Cesarii. No sé el parentiu entre aquest Moreno i els abans citats, encara que Estevan i Domingo Moreno apareixen junts, també amb Vicente Cavaller, com a testimonis de l'enllaç entre Joannes de Loiola i Isabel Èpila (en 1638).

Segons l'ordre alfabètic que venim seguint en aquesta exposició dels "nous cognoms" arribem al que acabarà convertint-se en el més estès els Navarro. És el cognom més abundant de Serra, però també un cognom abundant per tota la geografia peninsular. El trobem també ben representat en el món del comerç textil del segle XV a la vall del Palància, però també es troba present a València des del Repartiment posterior a la conquesta del segle XIII. La primera referència d'aquest cognom en la zona és la de Baltasar Navarro, el repoblador de Nàquera. A penes sabem quelcom d'ell, i en el registre parroquial de Nàquera no hi ha rastre fins a la segona meitat del segle, i potser per persones que eren foranes.

En el cas de Serra, la primera inscripció d'aquest cognom Navarro és una xiqueta batejada en 1620, Joana Vicenta, filla de Pere Navarro i de Vicenta Donya. Fins a 1633, aquest matrimoni tindrà altres set fills batejats a Serra. Encara que en cap lloc parla de la procedència del Pare, sabem que la mare procedia de València, concretament del carrer de Morvedre i parròquia del Salvador. Per això és prou provable que Pere Navarro també procedira de València abans d'establir-se a Serra per mediació del seu sogre, que era el Batlle i provablement administrador o fins i tot "arrendador" de Serra. D'un fill d'aquest matrimoni (Esteve, nascut en 1621) i dels fills d'aquest, sobre tot Pere-Joan (n. 1649) i Llorenç (n. 1651) esclata part de l'expansió que experimentarà aquest cognom a Serra. Abans de concloure el segle, seran ja diset els néts de Pere Navarro i Vicenta Donya.

Però d'aquesta eclosió dels Navarro hi ha un altre responsable, Domingo Navarro, un pastor de Camarena que, en 1633 es casa a Serra amb Magdalena Esteve, i tenen nou fills, dels quals arrivaran a tindre onze néts fins a 1708. 
El cognom Romero comença a Serra amb el matrimoni de Martín Romero i Mariana Rubio, en 1658. Ell és fill de Domingo Romero i de Hierónima Lozano, però no consta el seu origen. Quatre fills tinguts entre 1661 i 1671 i vuit néts abans d'acabar el segle donen continuïtat al cognom. El cognom Romero està prou arraigat en Gàtova, terme amb el que Serra ha mantingut sempre una estreta relació. De fet, la segona vegada que trobem un altre matrimoni de Romero a Serra es tracta de Sebastià Romero, vidu natural de Gàtova, que es casa en 1672 amb Francisca Pérez (ella també vídua, de Domingo Navarro), que tindran un fill en 1675. Però Romero sembla que és un cognom relativament abundant $\mathrm{i}$ de distribució prou àmplia. En 1648 es casa en Nàquera Pablo Romero, vidu del lloc de Santa Coloma, de la vall de Segó, amb Serafina Perera, també vídua. També trobem que el cognom Romero està citat a finals del segle XVI en Massamagrell, on el primer batejat del seu quinque libri (any 1581) és un tal Francesc Sebastià Romero, fill de Sebastià Romero i la seua muller Ursola. ${ }^{19}$

Un altre dels cognoms típics de Serra, aleshores i actualment, és Ros. Tota l'estirp del cognom Ros de Serra procedeix del matrimoni entre Miquel Ros i Càrpia Català, celebrat en 1657, que abans d'acabar el segle XVII tenien tres fills varons i sis néts. Malgrat que no consta la procedència de Miquel Ros (cognom assentat en la ciutat de València des de l'edat mitjana), sabem que era fill de Joan Ros i de Francesca Mateu, i arribà a Serra perquè sa mare, ja vídua, es va tornar a casar en 1647 amb el també vidu per dues vegades- Joan Ibáñez, veí de Serra.

Acabem aquesta relació amb el cognom Verge, que arribà a ser nombrós a Serra però que, desprès de certa eclosió inicial acaba desapareixent en relativament poc de temps. Començà amb els germans Francesc Verge i Domingo Verge, naturals de la vila de la Jana, que es casen, respectivament, amb Teresa Rodríguez (en 1648) i Felícia Cabo (en 1653). Del primer matrimoni naixeran cinc fills i del segon nou; essent 12 d'ells anteriors a l'any 1708 (final del primer volum del Llibre de Batejats).

\subsection{CONSIDERACIONS SOBRE EL PROCÉS DE SUBSTITUCIÓ DELS COLONS}

Sembla que l'inici del procés de substitució dels primers repobladors és immediat al propi acte d'acceptació i jurament de la Carta Pobla, encara que durarà uns quants anys i passarà per diverses fases. Alguns repobladors seguiran fidels a la seua nova residència,

\footnotetext{
${ }^{19}$ Moreno i León: Historia de Massamagrell, publicació de 1977.
} 
però en canvi seran molts - una evident majoria- els que seran substituïts per altres nous. Potser una bona part d'aquests vengueren prompte les seues cases i terres a preus profitosos per a ells, doncs, la demanda sembla que devia ser notable, primerament pels del propi Regne (sobre tot del Cap-i-casal i el seu entorn, i desprès pels que arribaren de més lluny en la primera dècada (anys deu) $\mathrm{i}$ en les següents.

Resulta significatiu el cas del repoblador de Serra Francesc Morell, que en primer de gener de 1615 (o siga, justament quatre anys desprès de signar-se la carta de poblament) ja resideix normalment a València, on es dedica al comerç tèxtil. En aquell any li havia venut a un nou llaurador i habitador de Ria una mula en bon estat, per preu de 16 lliures. La conclusió és que va aprofitar les oportunitats que donava el primer repoblament per a rebre cases i heretats de manera fàcil, i desprès només calia esperar a trobar el comprador o compradors que haurien de substituir el seu vassallatge $\mathrm{i}$ obligacions. Mentrestant, aquesta persona podia seguir ocupant-se de la bona marxa d'altres negocis -els que ja tenia abans a València- ja fora artesà, obrador o venedor. Si la persona era ja madura i disposava de l'ajuda dels seus fills, la cosa podia ser molt més fàcil i profitosa.

En tot cas, hem vist també com en 1617 ja ha canviat sensiblement el veïnatge de la nova colònia, amb la incorporació dels Català, Èpila, Domènech i Navarro, que eren inicialment repobladors de Nàquera però que, per les causes que foren acabaren traslladant-se cap a Serra, i quan no els repobladors directament, almenys els seus fills. La proximitat, per tant, sembla ser un dels factors que concorren en els canvis poblacionals dels primers moments o els primers anys. El fet d'haver establert llaços de parentiu amb les filles dels primers repobladors seria un altre factor decisiu (és el cas paradigmàtic que representen Anton Èpila i Isabel Manyes).

Evidentment, la incorporació dels nous colons comporta per a ells una sèrie de càrregues de treball i esforços econòmics necessaris per a poder atendre el pagament de totes les obligacions que pertanyen al propi vassallatge, segons queda recollit a la cartapobla. A més a més, però, aquests nous colons hauran d'atendre també les càrregues derivades dels acords $\mathrm{i}$ ajustos sinalagmàtics que competeixen únicament a comprador $\mathrm{i}$ venedor, i que potser es farien a voltes mitjançant censals. Aleshores, el vassall-venedor podria arribar a trobar-se amb dificultats per a rebre les quantitats o els bens acordats, $\mathrm{i}$ en tal cas, la presència del poder senyorívol no seria cap garantia, sinó més bé al contrari. 
Potser per això, una opció molt diferent i força interessant, podia ser la de contractar personal o criats que es dedicaren a les tasques més dures, per tal de mantindre en producció les heretats rebudes, i així poder obtindre els beneficis necessaris per a afrontar les diferents obligacions. La major efectivitat d'aquesta estratègia es donarà quan hi haja ma d'obra barata o fàcilment assequible, i tal com podrem comprovar més endavant, això és exactament el que succeïa amb la presència de francesos, biscaïns $\mathrm{i}$ potser altres col·lectius forans.

Cal pensar que aquesta estratègia d'incorporar o contractar gent podia ser bona tant per al nou repoblador, que rebia les possessions mitjançant un altre vassall prèviament establert, com per al primer repoblador, que podia d'aquest amanera anar aguantant fins que se li presentara el moment d'aprofitar una bona oferta que més prompte o més tard havia d'arribar.

Hem vist també que molts dels repobladors inicials només tenen filles, i com que sol ser gent relativament madura, serà a través dels gendres com canviaran de nom (i de cognom i propietari) les heretats. Açò passarà en poques dècades, d'una generació i la següent immediata. Aquest mecanisme es materialitza i reconeix prou bé analitzant nombrosos casos concrets, un per un, però també observant l'evolució del nombre de casaments, segons mostra la gràfica següent.

Ja sabem que pràcticament no hi ha dades de la primera dècada, doncs el Quinque libri comença en 1619, però sabem que en aquesta dècada -sobre tot prop del seu termini- ja es van produir uns quants casaments. Per altra part, si tenim en compte que ens trobem davant una nova colònia, establerta en un nou lloc despoblat, resulta prou lògic observar com des de la primera dècada es produeix un màxim de matrimonis cada 25 o 30 anys, que és la xifra que correspon pràcticament a l'edat més freqüent de casar-se en l'època i lloc estudiat. Podríem dir que pràcticament, cada màxim correspon a una nova generació (FIGURA 3.1).

El primer màxim, de la dècada dels 20 correspon als casaments de la primera generació de fills de repobladors que nasqueren abans d'arribar a poblar els llocs de Serra i Ria. Serien la xicalla dels més joves de les famílies, en general xiquets i xiquetes que en general no passarien del quinze anys quan arribaren ací. En aquesta dècada arriba a Serra el cognom Cabo (Maties Cabo, casat en 1623 i Bàrbera Esteve), de gent que es casava amb les donzelles d'aquests llocs, potser perquè ja es coneixien d'abans (generalment gent d'Alcubles, de Nàquera i de València i d'altres pobles de l'Horta Nord). Arnal és 
també un d'aquests cognoms que s'incorpora per casament amb donzelles filles de repobladors (Vicent Arnal, casat amb Violant Rubio).

FIGURA 3.1.- Evolució del nombre de casaments registrats a Serra en el segle XVII, agrupats per dècades.

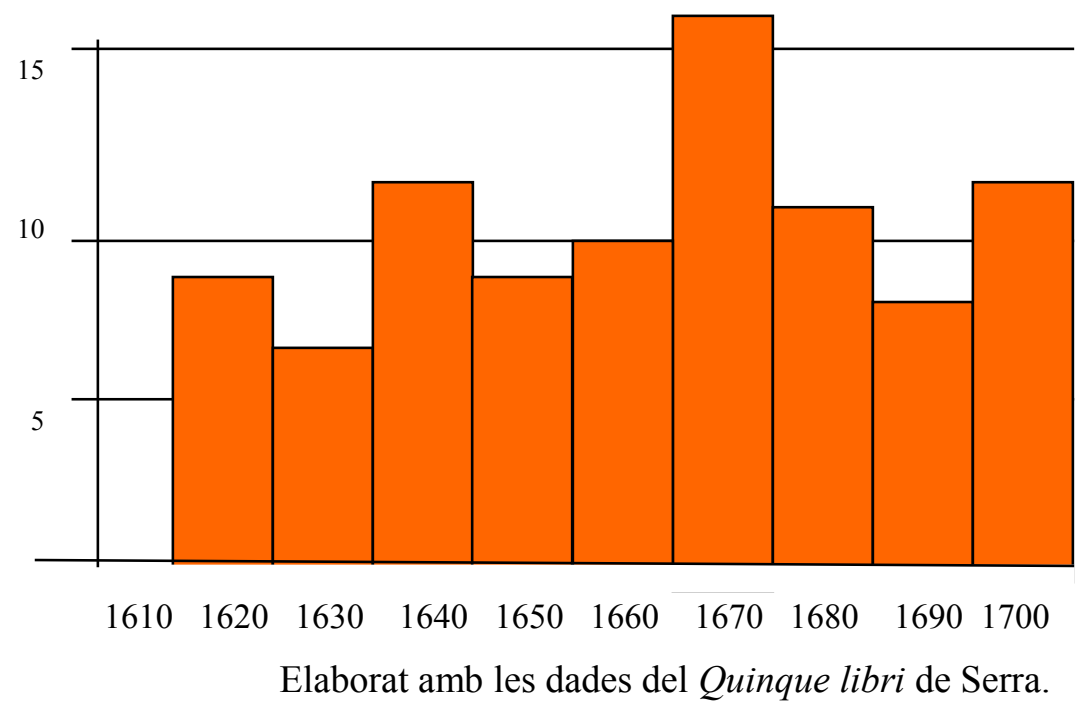

En canvi, la major part dels que es casen en la dècada dels 40 són generalment la primera generació dels fills haguts en els anteriors casaments. $\mathrm{O}$ siga, xics i xiques que van nàixer a Serra o Ria desprès de 1615 i durant la dècada dels anys 20. És la generació dels primers casaments de serrans i serranes de naixement. Aquesta serà la dinàmica dominant a partir d'ara, però també observarem més tard altres casos i circumstàncies ben diferents, com és l'arribada, sobre tot al voltant de la dècada dels anys 50 , de gent forana que, podríem dir que són els darrers nous cognoms que s'estableixen encara a la colònia serrana del segle XVII. És el cas dels cognoms Ros (Miquel Ros i Càrpia Català, en 1657), Romero (Martí Romero i Mariana Rubio, en 1658) o Garay (Pere Garay i Magdalena Èpila, en 1658), entre altres.

Aquest model i procés de renovació de la colònia no sembla que responga a un mecanisme exclusiu de Serra, sinó que més bé pareix la conseqüència d'unes circumstàncies generals que caldria estudiar si realment afectaren a tot el país i es van donar en altres indrets del Regne de València. 
En aquests aspectes, hi ha coincidència amb el que va observar J. Casey (1981) en estudiar en detall el cas de Pedralba. Va trobar que es donava aquest procés de substitució progressiva però molt ràpida al principi dels colons originals i dels seus cognoms. En aquest procés va diferenciar tres etapes:

a) Una d'afluència en massa de colons (1610-1611)

b) Una renovació forta, que aniria fins a 1630

c) Una tercera etapa, fins a 1640 , en la que es nota certa estabilitat en el creixement intern de les famílies assentades, amb un retrocés de l'arribada de forans.

Manuel Ardit (1993) observa aquestes tres etapes exposades per Casey, però afegeix que potser no es comporten de la mateixa manera en totes les localitats exmorisques valencianes. Sí que li resulta evident, no obstant açò, que els primers decennis posteriors al repoblament es caracteritzen per una forta inestabilitat i per continus trasbalsaments. Concretament, al marquesat de Llombai observa que hi ha moltes persones de famílies que apareixen i desapareixen dels registres parroquials entre $1620 \mathrm{i}$ 1640, deixant com a rastre, únicament, alguns batejats i alguns difunts. L'explicació ací podria ser que hi ha un nucli de repobladors beneficiats amb millors establiments, bé pel desigual repartiment o bé per haver incrementat el seu patrimoni mitjançant aliances familiars. Front a aquests pobladors que romangueren en les seues terres, hi hauria també uns altres repobladors "de la segona hora" que es traslladen d'un lloc a un altre fins que troben un assentament definitiu.

En un o altre cas, el que he observat a Serra és que hi ha un evident procés de canvi i substitució d'una bona part dels repobladors inicials. En síntesi de totes les observacions que venim fent en el present capítol de la tesi, podem també establir, per al cas de Serra i Ria, un procés que amb certs matisos també es pot resumir-se en tres etapes:

I. Arribada dels 30 colons que subscriuen la carta-pobla; sembla que hi ha gent casada i amb fills de mitjana edat (els d'Alcubles) i potser altres més majors i en certa manera oportunistes, que coneixen Serra però alguns conserven negoci artesà a València. Aquests acaben sent substituïts ràpidament per altres. 
II. Renovació forta (majoritària) que es produeix ja en el primer decenni i arriba fins els primers anys vint. És una generació formada per pocs signants de la carta-pobla, per fills dels primers repobladors de Serra, Ria i també Nàquera, i per altres nous colons que s'establiran definitivament ací.

III. Arribada lenta però contínua, de nous treballadors i potser colons que es casen amb les filles i les vídues dels colons ja assentats (dècades dels anys 30 als 50).

\subsection{EL CAS DELS BISCAÏNS, FRANCESOS I ALTRES GRUPS FORANS}

És ben conegut que al llarg del segle XVI es produeix una important immigració de francesos que tenen com a destinació València. Aquest corrent migratori he pogut constatar que perdura en les primeres dècades del segle XVII i que pràcticament, el dels francesos és un col·lectiu "diferent". Així ho reconeix Bartholomé Joly, ${ }^{20}$ en el viatge que féu a València el 1604, quan afirma: "los valencianos, como si el ser extranjero fuera un vicio, tratan a los franceses poco menos injuriosamente que los de Cataluña, aunque haya en esta ciudad más de quince mil franceses". També Sala Giner (1999: 116) aporta dades concretes sobre el volum de la població francesa que resideix a València en aquesta època: "Eran muchos los extranjeros residentes en la ciudad de Valencia. Se cifra en torno a los 14.000 ó 15.000 los franceses establecidos aquí a principios del siglo XVII'.

Sobre l'ambient que es creava entorn als col·lectius forans, tot sembla indicar que la situació variava prou segons els casos i els entorns. Així, contràriament al que sembla passar a València, a Serra ens pareix relativament bona i tranquil·la aquesta relació amb els forans en tractar-se de gent que, malgrat que parla altres llengües (bé francès, bé euskera...) eren cristians vells que només pretenen treballar (mà d'obra) sense entrar en competència amb els colons "terratinents" serrans. De fet trobarem molts estrangers com a padrins de xiquets i xiquetes serranes, si bé també hi trobem algun francès víctima de mort violenta. No obstant, Pel que hem vist en la documentació examinada sobre Serra, tot fa indicar que en aquest entorn rural les coses són prou més relaxades que no en

${ }^{20}$ Cita recollida per la Comtesa d'Aulnoy en el viatge que va fer en 1679 (la primera versió en espanyol és de 1892). També recull la cita Daniel Sala Giner en 1 seua obra Viajeros franceses por la Valencia del siglo XVII, publicada en 1999 (veure pàg. 117 i final de la seua nota 161). 
l'enrenou del cap-i-casal: "Es Valencia pueblo frecuentado de diversas naçiones, lleno de mucha gente, y aun ocasionado para los que en ella dan la rienda a los vicios; por cuya causa los estranjeros que a ella ocurren (acudeixen) procuran bestirse de prudente proceder, porque si esta virtud les falta, en dos palabras le diran "girau, conpare", que cuando buelban a escucharlo se hallaran con un triunfo por la cara". ${ }^{21}$

En altres passatges del seu viatge, Bartolomé Joly (citat per la comtessa d'Aulnoy, 1892) dóna una explicació sobre la causa de l'abundància de francesos en Espanya:

La ocasión principal, en mi opinión, por la que hay tantos franceses en España, es porque no pudiendo esta multitud de hombres, como enjambres de abejas, poder contenerse todos en su lugar natural, y menos ser en él empleados útilmente, es inmediato el cambio que hacen de su fortuna, porque de pobres y mal ordenados como llegaron, de pronto se ven puestos en valor y se establecen con comodidad, hallando fácilmente maestros con los que ganan mucho y son bien pagados, porque en España las manufacturas son caras. Los que no saben oficio, de la noche a la mañana se ven tomados por pajes y vestidos con libreas: esos señores se alegran mucho de tal vanidad; los que son de oficio de los campos, todavía son mejor recibidos, a causa de la pereza de los naturales, y se casan si pueden con las viudas de sus amos y se quedan allí porque no se pagan contribuciones como en Francia, donde el campesino se ve rudamente tratado." 22

El subratllat que hem fet en la frase anterior concorda prou bé amb els casos que hem comentat anteriorment: els matrimonis dels francesos Correja i Soler, a més del biscaí Loiola i sense descartar al malparat francès "Joan de Sundaña", amb el seu possible fill, que hauria viscut part de la seua vida a Benissanó (poble de la comarca del Camp de Túria, a la que també pertany actualment Serra).

En la tasca de recercar el possible origen d'algunes persones i cognoms, he rastrejat en el "Llibre d'Avehinaments" de l'Arxiu Municipal de València, i la sorpresa ha sigut trobar encara un percentatge significatiu de francesos que continuen instal·lantse en la ciutat València entre els anys 1604 i 1611, sent aquest darrer l'any en que acaba la sèrie documental. Dins aquest període es troben les següents freqüències i orígens (QUADRE 3.8.):

${ }^{21}$ (Floresta, pàg. 511), tret de Viajeros franceses por la Valencia del siglo XVII.

22 J. García Mercadal: Viajes de estranjeros por España y Portugal.., t. II, de 1952: 83-84. 
QUADRE 3.8.- Nombre de persones aveïnades en la ciutat de València entre 1604 i 1611 , distribuïdes segons la nacionalitat de procedència.

\begin{tabular}{|c|c|c|c|c|c|c|c|c|}
\hline Lloc de procedència & 1604 & 1605 & 1606 & 1607 & 1608 & 1609 & 1610 & 1611 \\
\hline Catalunya & 5 & 1 & 1 & 2 & 2 & 2 & 1 & - \\
\hline Aragó & 3 & 5 & 1 & 5 & 1 & 4 & 3 & 3 \\
\hline Castella & 2 & - & 2 & 1 & - & 1 & 2 & 1 \\
\hline València, regne & 14 & 12 & 5 & 6 & 4 & 4 & 15 & 7 \\
\hline França & 5 & 10 & 7 & 2 & 9 & 8 & 11 & 13 \\
\hline Navarra & 1 & - & - & 1 & - & - & 1 & - \\
\hline Biscàia & - & - & 1 & - & - & - & - & - \\
\hline Mallorca & - & & - & 1 & - & 2 & - & - \\
\hline Portugal & - & - & 2 & - & - & - & - & - \\
\hline
\end{tabular}

Font utilitzada: Llibre d'Avehinaments de l'Arxiu Municipal de València.

En quan a la procedència, es noten dos màxims relatius, que són el de la gent dels pobles valencians i l'encara continu degoteig de francesos, la major part dels quals, al menys en aquests anys, procedeix del principat de Béarn (país basc francès). Per altra part, hom comprova que els biscaïns i els navarresos no tenen pràcticament rellevància entre els forans que arriben a la capital valenciana. Lamentablement, la interrupció del registre no permet conèixer si aquesta minoria pogué arribar a ser significant en les dècades posteriors.

L’únic biscaí, en 1606, és un tal Pere Trevinyo, mercader natural de "San Vicente de Aranya (provincie Alaba; regni Viscaya)". Per altra part, els navarresos són: Joan de Monreal, llencer de la vila de Sangüesa, en 1604; Pere Navarro, esquimador d'Isaba, en 1607), i Martí de Huarte, en 1610 i que "fa mes de vuit anys que habita en la present ciutat" sent natural de Tudela. De tots aquests, ens resulta molt interessant el cas de Pere Navarro, que duu una carta notarial de desaveïnament del seu lloc de naixement, Isaba (la vall del Roncal, Navarra), en la qual no posa cognom d'ell ni de dels seus pares, ni tampoc el cognom patronímic tan expressiu com és el Navarro. L'ofici d'aquest home és també cridaner ("esquimar" és un mot en desús que tenia per significat de "deixar sense branques un arbre"). Malgrat no haver pogut trobar cap relació directa entre aquest Pere Navarro d'Isaba i el Pere Navarro aveïnat anys més tard a Serra, no deixa de ser aquest un exemple força interessant dins el conjunt de les observacions que venim esbrinant. 
Sembla clar, no obstant, que l'arribada de nous immigrants francesos començaria a disminuir dins el primer terç del segle i coincidint amb la política d'Olivares i el boicot al comerç francès, des de 1624. La participació de França en la guerra dels Trenta Anys (fins a la Pau de Westfàlia, en 1648) i els posteriors conflictes amb la corona espanyola, amb els territoris catalans pel mig, són factors decisius per al retrocés d'aquell llarg flux migratori iniciat el segle anterior.

Tornant al cas de Serra, i sempre mitjançant el quinque libri, sabem de la presència d'algunes persones d'origen francès. Concretament hi ha constància dels sis següents (començant pels tres que ja haviem esmentat):

Antoni Correja: el francès que es va casar amb Isabel Èpila en l'any 1637, però va morir en 1638, el mateix any que naixia el seu fill Gregori.

Esteve Soler: el francès que es va casar amb Àngela Ribes, la vídua del seu suposat amo o patró, amb la que tingué una filla (Tomasa Joana) en 1660.

Joan de Sundaña: el que treballava com a criat en casa de Maties Cabo i va morir d'una punyalada el dia 5 d'abril de 1647, havent-li de pagar el seu amo el soterrar.

Pedro Macthesig: un "mosso de nación francès" que consta com a padrí d'un fill de Bautista Domènech (en 1644) i d'un altre de Martín Domingo (en 1646).

Juan Espelet: un "franchut" que va ser padrí en 1628 d'una filla de Joan Mallach i Isabel Domingo.

Carlos Arcriso: "de nación francès" és padrí en 1658 d'una filla de Joan Arnal, i en 1660 d'una altra filla d'Esteve Soler (també francès).

Menys conegut a València és el cas dels biscaïns. En el Llibre d'Avehinaments de València no apareix pràcticament cap biscaí (encara que he trobat un navarrès, del què després parlarem), però en altres fonts, i particularment mitjançant el Quinque Libri de Serra, es posa de manifest que es tracta d'un col·lectiu notable i de cert interès durant la primera meitat del segle XVII.

Els biscaïns no semblem ser repobladors directes, desprès de l'expulsió dels moriscs; no obstant això, ja hem referit (més amunt i ANNEX IV) la possibilitat que algun dels nous pobladors de Serra de 1609 poguera ser d'aquest origen (Miquel Garrués) o bé navarrès (particularment Bartomeu Salvaterra).

Pocs mesos abans de l'expulsió dels moriscs ja se sap d'algun grup de biscaïns en les muntanyes valencianes, com el que cita Halperin (1980:19) a Iàtova, en l'any 1609. Cercant aquesta font hem pogut ampliar lleugerament la informació. Es tracta de l'expedient d'un procés de la Inquisició en el qual el processat és un morisc anomenat Hieroni Cassim que es defensa dels seus acusadors tot argumentant que tots ells el volien 
mal per alguna qüestió o diferència esdevinguda en el passat. Així és com parla de l'esmentat grup de biscaïns, exposant els motius de les seues diferències:

Otrosí dize, que unos vizcaynos que no sabe sus nombres sino del uno que era el mayoral, que se dezia Pedro y otro dellos Jones de Marcheuet, los quales hazian carbon junto del lugar de Yatoba y le hurtaron a éste un cabron, y éste se fue con el justicia a la barraca o choça donde aquellos habitavan y hallaron la çecina y el pellejo, y los truxeron presos y el conde les quito el pinar, por lo qual concibieron odio y mala voluntad a este, $y$ ansi es verdad. ${ }^{23}$

Sembla clar que el comte de Bunyol, aleshores Gaspar Mercader i de Carròs, els hi hauria arrendar un pinar per tal de fer-hi carbó. Els biscaïns no ixen massa ben parats d'aquesta declaració, en acusar-los de lladres i oferir d'ells tan dolenta imatge.

També la imatge que Cervantes dóna d'un biscaí, en El Quixot, resulta la d'un personatge un tant ridícul per la seua manera de parlar diferent: “...se fue para Don Quijote y, asiéndole de la lanza, le dijo, en mala lengua castellana y peor vizcaína, desta manera:

biscaí- Anda caballero que mal andes, por el Dios que crióme, que, si no dejas coche, así te matas como estás ahí vizcaino.

Quixot- Si fueras caballero, como no lo eres, ya yo hubiera castigado tu sandez y atrevimiento, cautiva criatura.

biscaí- ¿Yo no caballero? Juro a Dios tan mientes como cristiano. Si lanzas, arrojas y espada sacas, jel agua quán presto verás que al gato llevas! Vizcaino por tierra, hidalgo por mar, hidalgo por el diablo, y mientes que mira si otra dices cosa" 24

Aquestes desordenades expressions del biscaí i altres imatges burlesques ${ }^{25}$ duen a col·lació, no obstant, un fet interessant: el caràcter nobiliari (fidalguia) que, a diferència dels francesos i la resta de nacionalitats -inclosa la castellana o la catalano-aragonesagaudien els biscaïns pel fet de ser-ho, segons establia el propi Fuero de Vizcaya, reconegut per la corona espanyola. Això fa que, malgrat l'habitual rebuig general contra els forasters que parlaven altres llengües, els biscaïns tingueren una especial consideració de puresa de sang cristiana. Per l'esmentat fur, els biscaïns tenien reconeguts en tots els

\footnotetext{
23 AHN, Inquisición, 549, caso 22, proceso Hieroni Cacim.

${ }^{24}$ Capítol VIII del Quixot.

${ }^{25}$ No millor parats ixen els biscaïns d'altres referències literàries de l'època, com és el cas del “Vizcaíno Fingido", un dels entremesos de la mateixa ploma cervantina.
} 
regnes d'Espanya els privilegis de la fidalguia sense més prova que la de ser originaris d'aquella província $\mathrm{i}$ tenir en ella solar conegut. ${ }^{26}$

S'ha posat de manifest que tant Biscaia com Guipúscoa patiren al llarg del segle XVI llargues penúries produïdes per la manca de gra i l'excés de població. ${ }^{27}$ En tal sentit resulta també cridaner que el viatjant italià Navagiero s'estranyava que no hi haguera en Guipúscoa forest ni aspra muntanya que no estigueren plens de gent $^{28}$.

Tanmateix, Andrés de Poza, a finals del segle XVI afirmava que els biscaïns es trobaven francament angostos i constrenyits en la seua terra. ${ }^{29}$ Aquesta gran dificultat d'atendre la subsistència dels habitants de les terres basques amb recursos propis, quan espesses forests cobrien la quasi totalitat del territori, començà a alleujar-se amb motiu dels corrents migratoris cap a les Índies. Però sembla, pel que veurem tot seguit, que part de l'emigració també es va dirigir, en la primera meitat del segle XVII cap al sud de la Península, potser com a conseqüència de les notícies de l'expulsió dels moriscs i del consegüent despoblament que això hauria produït, sobre tot en el regne de València.

Tal i com mostrem en el QUADRE 3.9., prou més que francesos, el que hi trobem en el Quinque libri de Serra és un bon grapat de biscaïns que hi consten com a padrins de xiquets i xiquetes batejats en la parròquia. Açò fa suggerir que, tal com passava amb els francesos de Serra, poguera ser gent que treballaria al servei de diferents famílies del poble, amb les quals convivien i mantenien una relativament bona relació, fins el punt d'obtenir la suficient confiança com per a que els triaren com a padrins dels fills de les famílies de "pobladors de dret".

En total es tracta d'almenys 17 biscaïns (admetrem que "Merloiy" i "Miglot" puguen ser dos grafies de la mateixa persona; suposarem també que Pedro Sanz fora tan biscaí com Domingo Sanz; i per últim, admetrem la sospitosa biscaïnitat de Airnodiz, encara que arribara des d'altra població valenciana).

Amb aquesta relació -i desprès seguirem comprovant-ho- destaca clarament que els noms de pila més freqüents entre els biscaïns són Joan (Joannes) i Pedro (o Pere), que predominen sobre la resta (Cristòfol, Miquel, Martín, Llorens, Simó...)

\footnotetext{
${ }^{26}$ Domínguez Ortiz (1962) “la sociedad española en el siglo XVII” en $H^{a}$ d'España de Menéndez Pidal ${ }^{27}$ Carmelo de Echegaray (1905) "El maíz. Conferencia leida el día 14 de septiembre de 1904 en el salón de actos del instituto de Guipúzcoa”. Imprenta de la Provincia. San sebastián.

28 Ibidem; citant a Navagiero:Il viaggio fatto in Spagna...

${ }^{29}$ Ibídem; citant al llicenciat Andrés de Poza (1901): De la antigua lengua, poblaciones y comarcas de las Españas...
} 
QUADRE 3.9.- Padrins biscaïns registrats en el Llibre de Batejats de Serra.

\begin{tabular}{|c|c|c|c|}
\hline Any & batejat & nom del padrí & origen del padrí \\
\hline 1621 & Fill de Juan Rubio i Maria Siprer & Vicente Airnodiz & (de Moncada!) \\
\hline 1624 & Fill de Joan Rubio i Maria Siprer & Domingo Sanz & Vizcaino \\
\hline $\begin{array}{l}1624 \\
1625 \\
\end{array}$ & $\begin{array}{l}\text { Fill de Pedro Navarro i Vicenta Donya } \\
\text { Fill de Pedro Navarro i Vicenta Donya }\end{array}$ & Martín Herrando & Vizcaino \\
\hline $\begin{array}{l}1622 \\
1626 \\
\end{array}$ & $\begin{array}{l}\text { Sengles fills de Domingo Diago } \\
\text { i Isabel Morell }\end{array}$ & Cristoval Graciategi & Vizcaino \\
\hline 1628 & $\begin{array}{l}\text { Fill de Bartolomé Domingo } \\
\text { i Maria Català }\end{array}$ & Juan de Guale & Vizcaino \\
\hline 1628 & $\begin{array}{l}\text { Fill de Bautista Catalan } \\
\text { i Bàrbera Mateu }\end{array}$ & Francisco Sanz & --- \\
\hline 1629 & $\begin{array}{l}\text { Fill d'Anton Èpila } \\
\text { i Isabel Manyeç }\end{array}$ & Pedro de Lera & $\begin{array}{c}\text { Vizcaino y } \\
\text { vecino de Serra }\end{array}$ \\
\hline 1629 & Fill de Pedro Navarro i Vicenta Donya & Miguel de Merloiy & ---- \\
\hline 1633 & $\begin{array}{l}\text { Fill de Bartolomé Domingo } \\
\text { i Maria Català }\end{array}$ & Miguel Miglotc & Vizcaino \\
\hline $\begin{array}{l}1629 \\
1633 \\
1636 \\
\end{array}$ & $\begin{array}{l}\text { Tres fills de Domingo Moreno } \\
\text { i Rafaela Donya }\end{array}$ & Juan de Loiola & Vizcaino \\
\hline 1630 & $\begin{array}{l}\text { Fill de Joan Ibañez } \\
\text { i Catalina Garcia }\end{array}$ & Pedro de Casanova & Vizcaino \\
\hline 1639 & $\begin{array}{l}\text { Fill de Joan de Loiola (biscaí) } \\
\text { i Isabel Èpila }\end{array}$ & $\begin{array}{l}\text { Domingo Larial } \\
\text { (o Sarial?) }\end{array}$ & Vizcaino \\
\hline 1640 & $\begin{array}{l}\text { Fill de Domingo Moreno } \\
\text { i Rafaela Donya }\end{array}$ & Joanes de Balatsiar & Vizcaino \\
\hline 1640 & $\begin{array}{l}\text { Fill de Joan Saez } \\
\text { i Mariana Tortaxada }\end{array}$ & Lorenço de Nasallur & Vizcaino \\
\hline 1658 & $\begin{array}{l}\text { Filla de Domingo Herrero i Vicenta } \\
\text { Loiola (de } 19 \text { anys, filla del biscaí) }\end{array}$ & $\begin{array}{r}\text { Juan Martínez } \\
\text { Eroype }\end{array}$ & Vizcaino \\
\hline 1659 & $\begin{array}{l}\text { Filla de Pedro Garay (navarrés) } \\
\text { Magdalena Ėpila }\end{array}$ & Bernat Garay & Vizcaino \\
\hline 1666 & $\begin{array}{l}\text { Fill de Pedro Garay (navarrés) } \\
\text { Magdalena Èpila }\end{array}$ & Hernando Garneche & $\begin{array}{l}\text { Vizcaino, } \\
\text { natural de Aroa }\end{array}$ \\
\hline 1671 & Fill de Josep Navarro & Vicente Pérez & \begin{tabular}{|c|} 
"de iglesia \\
vizcaíno" i \\
natural de la \\
villa de Noxa /
\end{tabular} \\
\hline
\end{tabular}

Elaborat a partir del Quinque libri de Serra.

Algunes de les persones citades en aquest quadre les trobem també en el Llibre de Casaments. És el que passa amb l'esmentat Joannes de Loiola, que es va casar en 1638 amb Isabel Èpila, la vídua del francès Antoni Correja, o el de Pedro Garay, que es va casar en 1658 amb Magdalena Èpila. En realitat, Pere Garay (així, amb el nom valencianitzat el trobem en altres inscripcions posteriors) era nascut a "Carri, de la diócesis de Pamplona" (sembla que pot referir-se a Etxarri; actualment de Navarra), però 
hi consta que era fill de pares biscaïns: Bernardo Garay i Catalina Garay. Notem que com a padrí de boda hi consta un tal Bernat Garay, que bé podria ser el pare o un germà del nuvi.

Isabel Èpila, la vídua del francès Correja i del biscaí Loiola acabarà casant-se encara amb un navarrès: Martín Martínez, del lloc d'Ochogavia, diòcesi de Pamplona, fill de Pere Martínes i de Maria Martín.

En el Llibre de Difunts trobem assentaments referits a quatre biscaïns. El primer (en realitat probable biscaí, perquè no es fa constar) és Joannes de Berinduaga, marit de Beatriz Bardena, que morí en 26 d'octubre de 1635. En 1650 van soterrar a un "besquayno" (no posa cap nom) que va morir en casa de Vicent Rubio i no se li va administrar cap sacrament perquè ja era difunt quan arribà el rector. Un altre és Martín de Scinta?, "bescayno" que trobaren mort en la partida de Barraix, per causa d'una escopetada, l'any 1655 . El quart difunt és Juan Gambo "de nación vescayno", a qui administraren tots els sagraments i el soterraren en el cementeri malgrat que "no se dexo nada para su alma, por ser pobre y no tener nada; solamente me dieron la limosna del entierro". Aquest "Juan Gambo" sembla que seria un mot, i podria tractar-se, amb tota probabilitat, de Joannes de Loiola, ja que la seua filla Vicenta apareix de vegades com a "Loiola" i altra com a "Vicenta Gamba". A "Juan Gambo" també el trobem com a padrí d'un fill de Pedro Garay, en 1669.

Malgrat el cas del biscaí apunyalat en casa del seu amo, i el del que trobaren mort per una escopetada, tot apunta que devia haver-hi unes relacions "acceptables" entre els biscaïns i el serrans “de dret”. Només així s'entén la freqüència de padrins en el Quinque libri. El per què d'aquesta aparentment bona convivència podria estar en el fet que, des del principi, entre els nous pobladors de Serra (principalment llauradors) hi hagué un contacte directe $\mathrm{i}$ freqüent amb els treballadors forestals biscaïns, sense que pràcticament hi haguera competència d'interessos entre ells.

En el cas en que els batejats siguen fills de pares biscaïns o de francesos, és habitual trobar com a padrins a persones de la mateixa nacionalitat. Per exemple, en el cas de Domingo Herrero i Vicenta Loiola, els padrins de les seues dos filles són un biscaí: Juan Martínez, i un navarrès: Martín Martínes, respectivament. L’única filla del francès Esteve Soler i la vídua Àngela Ribes té un padrí francès (Carlos Arcriso). Però no sempre passa això, doncs, en el cas del navarrès-biscaí Pere Garay i Magdalena Èpila, dels seus set fills, tres tenen padrins biscaïns (Bernat Garay, Hernando Garneche i Juan 
Gambo) però els altres quatre tenen cognoms corrents del poble (Duran, Cabo, Domènech i Arnal). En tots els casos, les padrines són dones de Serra, i generalment es tracta de la dóna o d'una filla del "cap de casa" on es troba vivint, o per a qui treballa el foraster.

Un altre aspecte cridaner d'aquesta mostra dels biscaïns de Serra és que la major quantitat de casos (QUADRE 3.10) es dóna i per ordre decreixent, entre els anys $20 \mathrm{i}$ els anys 50 del segle XVII, amb algun cas posterior però que ja correspon a pares d'origen biscaí (o navarrès) assentats a Serra.

QUADRE 3.10.- Distribució per dècades dels biscaïns citats com a padrins en el Llibre de batejats de la parròquia de Serra (segle XVII).

\begin{tabular}{|c|c|c|c|c|c|}
\hline Anys 20 & Anys 30 & Anys 40 & anys 50 & Anys 60 & Anys 70 \\
\hline 11 & 5 & 2 & 2 & - & 1 \\
\hline
\end{tabular}

Elaborat amb dades del Quinque libri de Serra.

Sembla clar que és en els anys 20 i 30 quan s'hauria produït la màxima afluència de biscaïns a Serra. No hom pot oblidar que no disposem de dades anteriors, però bé podria ser que l'expulsió morisca haguera contribuït a augmentar la migració més forta de biscaïns (i bascs en general) cap al sud. En tot cas, la causa d'aquest corrent migratori encara no la coneixem en profunditat, però el que si sabem és que la majoria d'aquestes persones es dediquen a treballar en tasques forestals. Potser que alguns es dedicaren a la tradicional tala d'arbres (els famosos aizkolaris bascs), ${ }^{30}$ però el que si que ens consta es que molts d'ells eren carboners, com veurem amb més detall en el capítol cinquè de la tesis.

En el veí terme del priorat de Portaceli, actualment terme de Serra, trobem citat un grup de biscaïns que allà pel 1630 es trobaven fent calç front al monestir i "toscos y poco entendidos, sin saber lo que hacían ni haver quien se lo advirtiese" destrossaren, sense saber-ho, la paret de pedra que havia construït la Venerable Agnès de Montcada (Molins, 1978: 32) en l'entrada d'una coveta en la que es va refugiar per iniciar la seua vida anacoreta (açò seria cap a l'any 1418).

\footnotetext{
${ }^{30}$ Recordem també el cas de Pere Navarro, esquimador natural d'Isaba que s'aveïnà a València en 1607.
} 
També en el veí terme de Portaceli hi trobem constància del contracte que se li va fer en novembre de 1642 a Guillermo Acharte "biscaí de nació", per preu de 420 lliures, per a fer carbó de part del pinar "des del barranquet de l'algepsar fins a una senda que va al camí de València". Entre les obligacions de Guillermo Acharte estava la de "haver de deixar llansa i dardo, i si no que haja de pagar lo dany que per no deixar-lo es seguirà”, i també deuria respondre pels danys en cas d'incendi, havent de retenir dins del bosc fins a deixar complit el seu compromís, carbó en quantitat suficient per a respondre a cinccentes lliures. ${ }^{31}$ El dia 8 d'agost de 1643, el germà Domingo Conchel feia pagament al dit Acharte de les 420 lliures convingudes. ${ }^{32}$

En setembre de 1620, Joannes Graciatey, un carboner biscaí resident a Serra (sens dubte emparentat amb Cristòfol, del mateix cognom, que coneixem com a padrí en 1622 i 1626) li ven a Joan Baptiste Donya, agricultor i habitador en Serra, tot el carbó que farà de la llenya que té feta en el present lloc de Serra i en el terme de Portaceli, per preu de 57 sous la càrrega ${ }^{33}$. D'aquesta $\mathrm{i}$ altres transaccions sobre carbó tornarem a tractar en el capítol cinquè, però avançarem que han sigut nombrosos els casos de biscaïns que hem trobat ocupats en aquest ofici del carboneig. Entre ells sospitem que està un tal Pere Joan Salvaterra (recordem que Bartomeu Salvaterra era un dels signants de la carta-pobla), llister que viu a València i habitualment soci del batlle de Serra Joan Donya. Altres carboners biscaïns serien Joan Chavoyen, que fa carbó en el terme de Torís, ${ }^{34}$ Pere de Lisaralde i Joan de Tulaius ${ }^{35}$.

Aquesta freqüència de biscaïns en les muntanyes de Serra i Portaceli tingué una evident projecció en la toponímia. Així, al terme de l'antiga baronia de Serra hi ha la partida, fonteta, barranc i , cara-sol del Biscaí, també la muntanya de la Gorrissa (podria traduïr-se per "rogenca"; derivat de gorri, roig) que és un tossal en part rogenc i molt a prop del Bàrio (barri situat en l'extrem oest del nucli urbà de Serra). ${ }^{36}$

A més dels esmentats casos de biscaïns que treballaven fent carbó no solament a les muntanyes de Serra, sinó també en les de Llíria, Torís, Iàtova, etc., he trobat altres

31 Citat per Tarín y Juaneda $(1897,132)$ : La cartuja de Porta-Coeli.

32 APCC, 9998; Arcos, 24/11/1642.

33 APCC, 21045; Font, 13/09/1620.

34 APCC, 20584; Font, 26/02/1631 i 9/03/1631.

35 APCC, 20584; Font, 12/02/1631.

36 A més del Bàrio de Serra també hi ha un bàrio a Nàquera. Segons Gil i Navarro (1997), el significat del mot té origen basc, derivat de berri, que significa "nou". Vull afegir que també hi ha en euskera el mot barruti que significa “districte”. El bàrio de Nàquera també correspon a una antiga zona de creixement del poble. I també hi ha un altre Bàrio a Estivella (comunicació personal de Lluís Mesa) i un altre a Ontinyent. 
cites puntuals sobre biscaïns que durant el segle XVII treballaren i/o s'establiren a Bunyol (Estellés Zanón, 1996), a Xelva (Mares, 1681), al Villar de l'Arquebisbe (Salvo, 2000), etc. També és freqüent el topònim biscaí en moltes muntanyes, més o menys baixes, de l'entorn de la plana de València, per exemple, trobem la "Cueva del Vizcaíno" (Bugarra), la "Casa del Vizcaíno" (Bunyol; a prop de Ventamina i del camí de Set Aigües a Iàtova), el turó "Cabeza de Vizcaíno" (Tous; vessant oriental de les llomes dels Tislars), etc. A més a més, observem en els llistats de repobladors del segle XVII (Torres Morera, 1969) diversos cognoms de possible migració basca, com per exemple Pere Aramburu (Catadau) o Martín Delorri i Miguel Gorrigui (Xelva).

A banda dels biscaïns i els francesos, el Quinque libri de Serra també permet trobar, durant aquest període, certa quantitat de "padrins" de batejats que tenen per origen poblacions d'Aragó (principalment entenem que eren pastors transhumants). ${ }^{37}$

Finalment aportem en el QUADRE 3.11 una darrera recopilació de "padrins de bateig" amb altres procedències, però caldria citar encara a Francesc Bollot, un milanés que va ser padrí en 1685 d'un fill de Cristóval Rubio. Tanmateix hi trobem un parell de difunts forans: Miguel Fortanet, natural del Portell, prop de Morella (mort en 1666) i un vell anomenat Francisco de Posada, natural de Telmorera, del bisbat de Salamanca, que era pobre i el soterraren en el cementeri "por amor de Dios".

Finalment, i encara que no és informació procedent de l'arxiu parroquial de Serra, hem trobat alguna informació sobre mallorquins que ens sembla digna de consideració tenint en compte els intents que hi hagué desprès de 1609 de repoblar amb mallorquins alguns pobles del Regne de València, sobre tot els coneguts casos de la Marina, però també la propera vall d'Olocau, segons veurem en el capítol quart. A Serra sembla clar que hi arribà algun mallorquí. Per una part tenim el cas, que referim en l'ANNEX IV, de Joan Noguera, un mallorquí que residia al Regne de València en 1610, de qui ens crida l'atenció la similitud amb el repoblador de Serra Jaume Noguera. A més, però, hi ha un altre mallorquí, Baltasar Salvà, natural de Lluchmajor, que residia a Serra en l'any 1639, segons recullen Antoni Mas i Joan-Lluís Monjo (2002). ${ }^{38}$

\footnotetext{
${ }^{37}$ També hi parlarem d'aquest tema en altres capítols posteriors.

${ }^{38}$ Contacte i referència que he d'agrair als autors del treball i també a Miquel Àngel Rodríguez.
} 
QUADRE 3.11.- Altres padrins forans del llibre de batejats de Serra

\begin{tabular}{|c|c|c|c|}
\hline Any & nom del padrí & procedència & pare del batejat \\
\hline 1634 & Joan Salvà & $\begin{array}{l}\text { de nacion Catalan, criado de } \\
\text { Portaceli }\end{array}$ & Joan Saeç \\
\hline 1638 & Miguel Navarret & Provablement de Camarena & Joan Saeç \\
\hline 1646 & Simon Aleman & Mallorquí, pero vivia a València. & Jaume Peres \\
\hline 1653 & Pedro Carvios & --- & Esteve Navarro \\
\hline 1660 & \multicolumn{2}{|c|}{ Diego Cebrián Culla } & Jaume Peres \\
\hline 1668 & Miguel Escrich & Olmiche el baxo (Formiche Bajo) & Vicente Èpila \\
\hline 1670 & Francisco Gracés & Camarena & Jusepe Rodríguez \\
\hline 1672 & Juan Sierra & Begís & Domingo Navarro \\
\hline 1673 & Pedro Sanz & Molina (d'Aragó), de Castilla & Miguel Escrich \\
\hline 1674 & Arsis Güel & Girona, lugar de Catalunya & Sebastià Bort \\
\hline 1676 & Vicente Dols (Dolz) & Chelva & Juan Dolz \\
\hline 1678 & Josep Avariat & Alcalà de Xivert & Maties Cabo menor \\
\hline 1680 & Vicente Selma & Catí & --- \\
\hline 1703 & Antonio Sellés & Cocentayna & Roque Fos \\
\hline
\end{tabular}

Elaborat amb dades del Quinque Libri de Serra. 


\section{CAPÍTOL 4 \\ DESAPARICIÓ DE RIA I EVOLUCIÓ DEMOGRÀFICA DE LA COLÒNIA}

Per tal de mostrar un referent comparatiu entre la magnitud de la població morisca expulsada de Serra i la d'altres llocs del seu entorn, així com l'evolució del repoblament posterior, hem elaborat el QUADRE 4.1 amb dades d'època morisca (dades publicades per Halperin, 1980 i per Lapeyre, 1986) i de posteriors (les dues darreres columnes) que reflecteixen la lenta recuperació poblacional en la primera meitat del segle XVII. Les xifres només expressen el nombre de cases (en alguns casos veïns) i per estimar la població és habitual suposar una mitja de l'ordre de 4 a 5 persones per casa. Concretament, per als segles XVII a XIX, Bernat i Badenes ${ }^{1}$ estimen que aquest multiplicador pot arribar a variar generalment entre un mínim de 3,5 i un màxim de 4,5 habitants per cada casa o veí censat. No obstant, segons el càlcul basat en l'embarcament dels moriscos expulsats, tal com hem exposat en el capítol segon, aquest coeficient podria estar un poc més prop del 5 (referit concretament a l'època morisca $i$ en el moment de l'expulsió).

Les dades de 1609 corresponen al conegut com recompte de Caracena, dades que no sempre les estima Halperin (1980) fiables perquè a sovint dupliquen, de manera incomprensible -com es veu en el cas de Serra o en el de la vall d'Olocau- les dades que hi havia set anys abans; per això hi ha que observar-les amb gran cautela. Hem observat que aquestes xifres són pràcticament les mateixes que va publicar Boronat (1901). No obstant això, un aspecte molt interessant d'aquest recompte és que permet comparar la proporció de cristians vells respecte a la de moriscos justament abans de l'expulsió (veure QUADRE 4.2). I si tenim en compte la qüestió que ja havíem tractat en el capítol segon sobre que el repoblament va ser principalment de caràcter regnícola (com havia avançat Torres Morera, 1969) podrem així preveure quins serien, potencialment, els principals llocs d'aportació de nous colons per a les zones expulses.

En el cas de Bétera (i referint-nos aquest quadre 4.2) cal afegir una observació, doncs només indica estar poblada per cristians nous (en nombre de 170), quan la realitat és que tenia, potser, més cristians vells que moriscos, perquè en el cens del desarmament

\footnotetext{
${ }^{1}$ J.S. Bernat i M.A. Badenes (1994; pàgina 93): Crecimiento de la población valenciana...
} 
dels moriscos (any 1563) van ser enregistrades 121 cases de moriscos, mentre que el nombre total de cases a Bétera (cristians nous i vells) l'any 1572 ascendia a 282, i en 1609 es parla encara de 299 cases, en total (Garay, 2012). Per tant, podem considerar que hi hauria no menys de 200 cases de cristians vells a Bétera, a més de les 170 de moriscos.

QUADRE 4.1.- Variació del nombre de cases en llocs moriscos de la Serra Calderona, entre els segles XVI i XVII.

\begin{tabular}{|c|c|c|c|c|c|c|}
\hline any & 1563 & 1572 & 1602 & 1609 & 1611 & 1646 \\
\hline Serra & $19^{(*)}$ & \multirow{2}{*}{40} & \multirow{2}{*}{46} & \multirow{2}{*}{80} & 20 & \multirow[t]{2}{*}{25} \\
\hline Ria & 17 & & & & 10 & \\
\hline Nàquera & 25 & 25 & 33 & 34 & 17 & 28 \\
\hline Segart & 20 & 19 & 19 & 40 & 35 & 8 \\
\hline Olocau & 20 & \multirow{3}{*}{80} & 30 & \multirow{3}{*}{215} & 26 & 23 \\
\hline Gàtova & 22 & & 25 & & 11 & 12 \\
\hline Marines & 42 & & 41 & & 2 & 5 o poc més \\
\hline Beselga & 20 & 15 & 34 & 35 & 23 & 16 \\
\hline Estivella & 49 & 40 & 58 & 70 & 34 & 39 \\
\hline
\end{tabular}

La columna de 1611 recull ja dades de cristians vells i està basada en dades de diferents cartes pobles (1609-1611).

Realitzat a partir de diverses fonts (citades en el text).

No és objecte d'aquesta tesi incidir molt més en analitzar possibles fluxos migratoris "regnícoles" que tingueren lloc en aquest entorn de la serra Calderona, però hem estimat adient mostrar l'esmentat quadre perquè ajuda molt a entendre algunes de les opcions potencial que podrien haver marcat els fluxos migratoris postmoriscos. I això ho diem sabent -com ho hem vist en el capítol segon- que la població de cristians vells de Torres Torres quedà minvada a la meitat en poc de temps; i que Alcubles va veure també reduïda la seua població per haver experimentat una gran emigració cap a les baronies de Serra, Soneixa i encara altres llocs (Alcaide, 2008). En fi, les possibilitats migratòries i repobladores, a la vista d'aquest quadre eren àmplies i permeten observar el potencial que presentaven a priori poblacions com Altura o Sogorb, que estaven més prop de Soneixa i encara de Serra que no les Alcubles. Podem suposar, per tant, que en les decisions finals degueren influir de manera decisiva les encara tenses relacions personals entre els poderosos ducs de Sogorb (amb els problemes afegits pel "segrest" fiscal sobre la ciutat de Sogorb) i el jove senyor de la baronia de Serra. 
QUADRE 4.2.- Tipologia dels pobladors i adscripció de poblacions pertanyents a

l'entorn de la Serra Calderona.

\begin{tabular}{|c|c|c|c|}
\hline Població & cristians & Senyor del lloc & cases \\
\hline El Puig y La Creu & Vells & Jurados de Valencia & 148 \\
\hline Puçol & Vells & El Arzobispo & 226 \\
\hline Murviedro & Vells & Su Magestad & 610 \\
\hline Torres Torres & Vells & Miquel Vallterra & 87 \\
\hline Alcublas & Vells & Valldecrist & 171 \\
\hline Altura & Vells & Valldecrist & 279 \\
\hline Paterna & Vells & Duc de Cardona & 85 \\
\hline Pobla de Benaguasil & Vells & Duc de Cardona & 137 \\
\hline Montcada & Vells & Maestrat de Montesa & 130 \\
\hline Sogorb & Vells & El Secresto (segrestat per impagat) & 700 \\
\hline Moreria de Sogorb & Nous & El Secresto (segrestat per impagat) & 350 \\
\hline Bétera & Nous* & Jaume Sorel & 170 \\
\hline Benaguasil & Nous & Duc de Cardona & 250 \\
\hline Gilet & Nous & Francesc Llançol & 140 \\
\hline Albalat de Vilarrasa & Nous & Joan Vilarrasa & 115 \\
\hline Segart & Nous & Joan Vilarrasa & 40 \\
\hline Estivella & Nous & Gaspar Monsoriu & 70 \\
\hline Beselga & Nous & Gaspar Monsoriu & 35 \\
\hline Alfara de Algímia & Nous & Miquel Valterra & 80 \\
\hline Algímia & Nous & Miquel Valterra & 160 \\
\hline Algar & Nous & Frayles de la Merced & 40 \\
\hline Sot del Governador & Nous & Governador D. Jaume Ferrer & 112 \\
\hline Xeldo & Nous & Duc de Cardona & 103 \\
\hline Olocau (la vall) & Nous & Virrei de Mallorca & 215 \\
\hline Serrayria & Nous & Josep de Cardona & 80 \\
\hline Nàquera & Nous & D. Francisco Figuerola & 34 \\
\hline
\end{tabular}

* Bétera era realment una població mixta (veure explicació en el text). Dades tretes de Boronat, 1901 (cens de Caracena).

No tota la repoblació va ser absolutament regnícola, però, en aquest sector de la serra Calderona. Recordem al respecte el cas de la vall d'Olocau i el primer intent de Joan de Vilaragut (virrei de Mallorca) per repoblar els seus llocs amb mallorquins, mitjançant una carta pobla de 20 d'agost de 1610; repoblació que sens dubte no va ser suficient, entre altres coses perquè es tractava només de 4 vassalls. No obstant, també he comentat la possibilitat de que el repoblador de Serra Jaume Noguera poguera tindre 
alguna relació amb un altre mallorquí, Joan Noguera, que per aquell temps es trobava vivint en el Regne de València (veure capítol 3 i en ell la nota 16 a peu de pàgina).

En la mateixa baronia d'Olocau i en haver mort el virrei de Mallorca, el seu fill Alonso de Vilaragut atorgà nova carta-pobla el 10 de juliol de l'any 1611 (Zurriaga, 1987), a 39 nous vassalls que sembla podrien ser procedents del sud d'Aragó, segons Paz Lloret, sent concretament el turolià poble d'Abejuela (dit l'Abellola a Olocau) un dels principals de procedència de gent d'Olocau (Ferran Zurriaga, comunicació personal).

\subsection{SITUACIÓ DE RIA}

Ria es avui una partida del terme de Serra situada a poc més d'un quilòmetre cap al nord-nord-est de les últimes cases del casc urbà de Serra. A principis del segle XX, l'acerb i la memòria dels serrans coincidia en que Ria era l'antiga població de Serra i la dels primers pobladors musulmans, la qual cosa concorda amb les diferents notes que escrigué Ambròs Cebrián (Cebrián i Lluch, 1935; Garay i Peris, 2001). Però especialment interessant o resulta una nota que D. José Martí, que era secretari de l'Ajuntament de Serra en 1940 (i ho havia sigut també durant la República i fins a ben entrada la guerra) va escriure i la va afegir al manuscrit de Lluch i Cebrián. En ella diu:

En el archivo del Ayuntamiento, antes de ser incendiado (en 1936) aparecían documentos que hacian referencia a la población de Ría.

Este pueblo se fundó, como todos, al regazo de un manantial magnífico de aguas riquísimas que hoy se están canalizando para Serra (la font de l'Ombria).

La posterior desaparición de Ría debió originarse, sin duda, a causa de alguna extraordinaria sequía que agotó el manantial, replegándose sus vecinos a Serra, cuyo manantial de este pueblo no se ha secado jamás.

Subsisten como restos de Ría los muros de calicanto de algún edificio y la torreta o fortaleza característica de aquellos tiempos, que resulta indestructible por lo bien fabricada, a pesar de mostrar impactos de bala o proyectil de cañón".

En tot cas, si bé la possible causa per una llarga sequera no resulta totalment descartable, encara que tampoc ni haja cap certesa, sembla lògic i totalment acceptable que els veïns de Ria acabarien traslladant-se amb el temps a Serra, com també va passar en molts altres llocs del territori valencià, per raons menys dràstiques i més socials.

Ni l'esmentat treball inèdit de Cebrián i Lluc (1935) ni el posterior llibre de Josep Senís (1954) diuen res d'açò, sinó que es limiten a reconèixer que Serra i Ria van ser dos 
poblacions que visqueren paral·lelament fins a la constitució de la Carta Pobla, àdhuc. I si bé la fundació de Serra resulta evident que és andalusina (a més de la fàbrica de la Torre del Senyor, atribuïble al segle IX, Serra apareix citada en documentació del segle XI, al menys) i mai s'han trobat dades ni restes que facen sospitar una altra cosa, no passa el mateix amb Ria, que va ser prou més que un poblat "de temps dels moros". Tant Senís (1954) com abans Cebrián, donen notícia de les restes arqueològiques trobades en aquell entorn i que són testimoni de la presència humana des d'època prehistòrica. Les restes més antigues (puntes de fletxa i fragments de sílex, a més de "ceràmica carbonosa" feta a mà) podien ser neolítiques (o eneolítiques) i procedeixen de l'estratègic Salt de Ria, un puntal escarpat i reforçat amb murs de pedra ben estructurats (FIGURA 4.1).

FIGURA 4.1.- Restes arqueològiques recollides i estudiades per Nicolau P. Gómez

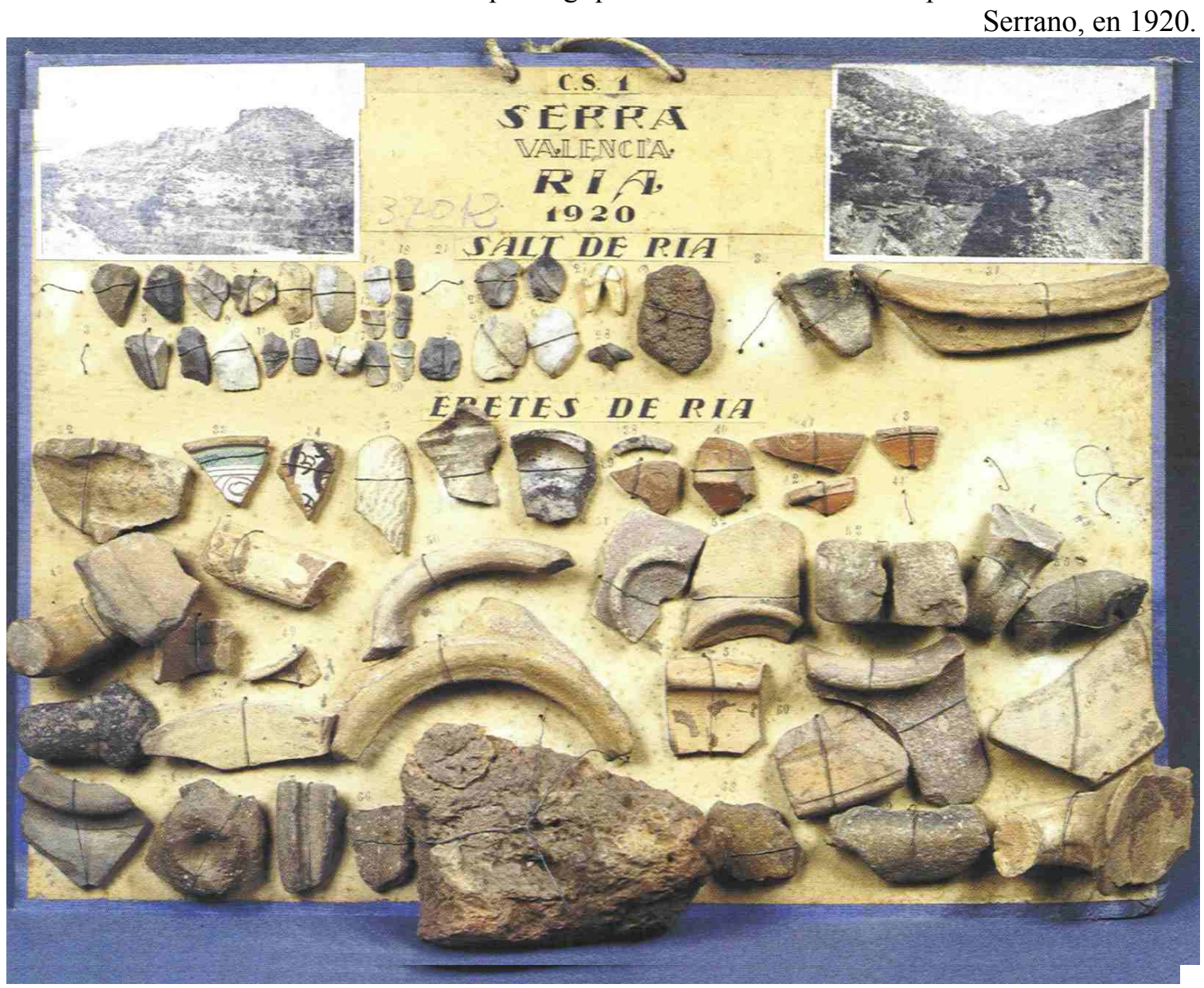

Arxiu de materials del SIP, Diputació de València. 
Els jaciments del Salt de Ria i de les Eretes de Ria van ser reconeguts per l'il·lustre valencià Nicolau Primitiu Gómez Serrano, recol·lector d'algunes de les restes que es conserven en el SIP de la Diputació de València i autor del pannell adjunt (figura 4.1). A les Eretes de Ria, una muntanyeta bessona a la que té la torre musulmana de Ria (separades ambdues pel barranc o riuet de Ria) va ser identificat per Ambròs Cebrián, i ratificat per notables arqueòlegs de època, un assentament o poblat ibèric. Se situa en un lloc prominent $\mathrm{i}$ estratègic $\mathrm{i}$ formaria part de la xarxa de poblament i domini territorial de la serra Calderona en aquesta època, junt als poblats d'Alcalà i de Portaceli (ambdós també al terme municipal de Serra), a més dels coneguts en altres municipis dels voltants, com el Puntal dels Llops, d'Olocau (Bonet i Mata, 2002).

Restes romanes també han estat localitzades en diversos indrets del terme de Serra, però particularment en aquest entorn immediat a la torre de Ria i les Eretes de Ria. La troballa de fragments de ceràmica segellada (terra sigillata) en les caigudes del puntal on s'alça la torre de Ria fa pensar que probablement foren els romans els primers que ocuparen l'espai concret on desprès s'assentà i s'estengué el poblat musulmà, morisc i cristià de Ria. Açò fa pensar també la possibilitat -ja apuntada per Josep Senís- de que el sistema de regadiu de Ria tinguera un inici romà, abans que àrab.

Sobre l'emplaçament concret que va tindre el poblat de Ria (mudèjar, morisc i post-morisc) he trobat, a més de l'existència de restes ceràmiques disperses, altres elements i arguments: per una part, la torre de Ria, de fàbrica andalusina (FIGURA 4.2) i les restes de murs amb morter que encara es reconeixen prop d'ella; per altra part, el camí empedrat d'Estivella (FIGURA 4.3) que sens dubte devia ser un carrer de Ria; tanmateix algunes restes evidents de murs de les d'antigues cases (FIGURA 4.4), i encara també, els testimonis directes de persones que havien treballat durant els anys de la segona República en la construcció de la conducció d'aigua potable per al poble de Serra (aigua captada en la font de l'Ombria) i que descobriren nombroses tombes i esquelets humans en passar la canalització a prop de Ria, sent evidències del seu cementeri musulmà, precisament ubicat cap al sud-est (l'alquibla) del poblat. 
FIGURA 4.2.- Torreta de Ria, amb evidències d'haver estat lluïda i emblanquinada.

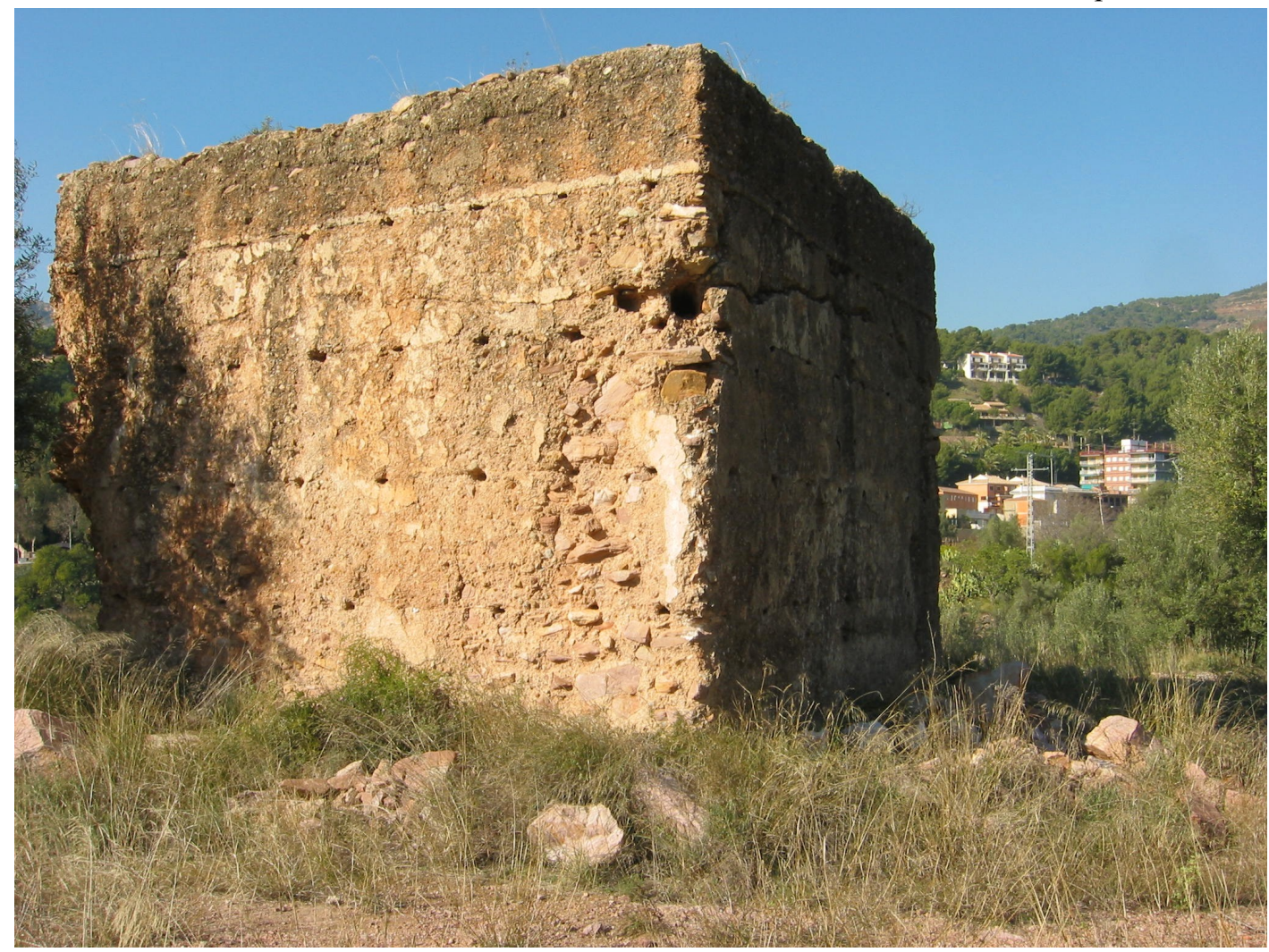

Fotografia de l'autor.

FIGURA 4.3.- Camí d'Estivella al seu pas per Ria i restes de paret d'una antiga casa.

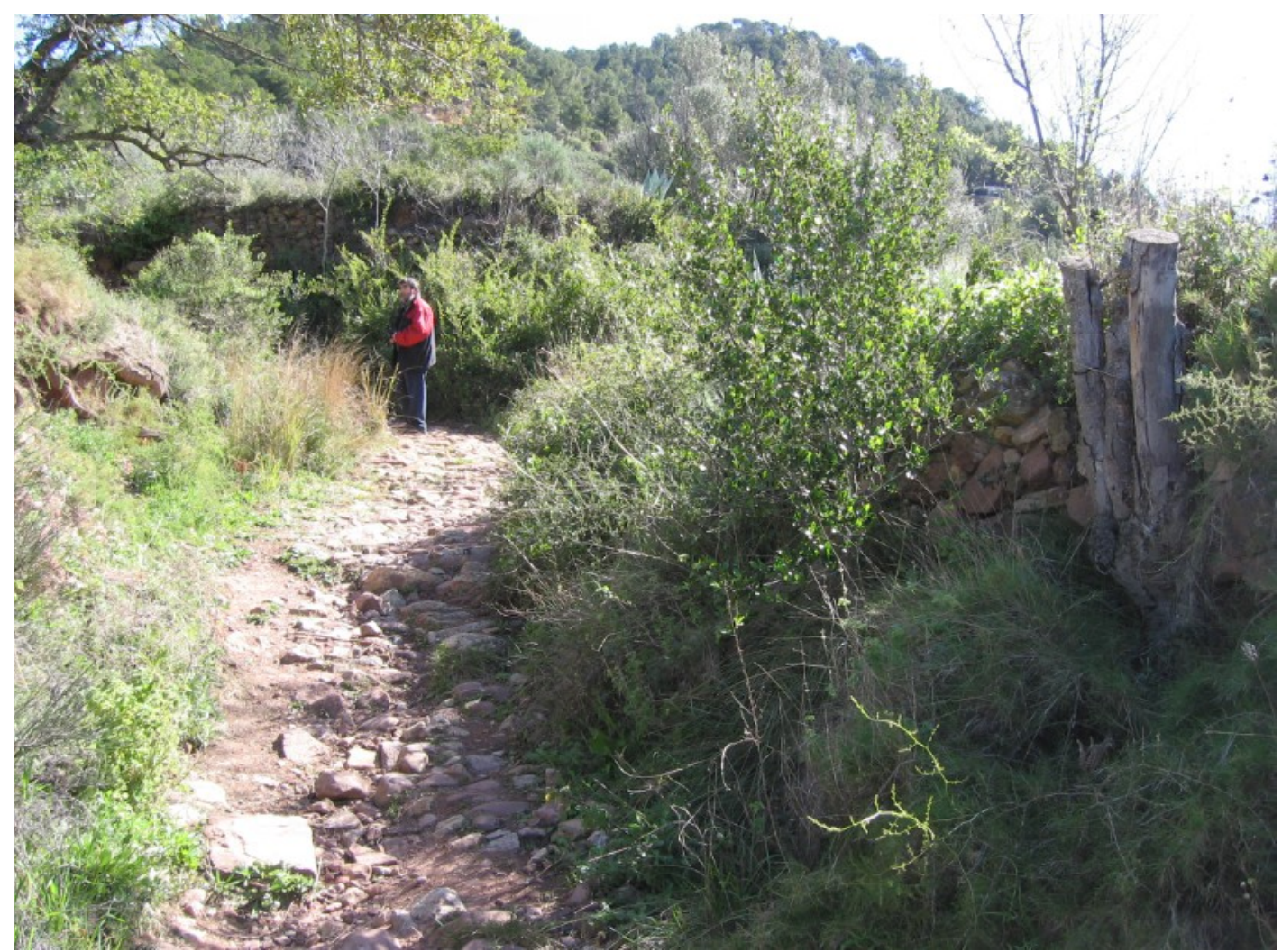

Fotografia de l'autor. 
FIGURA 4.4.- Restes de parets d'una antiga casa de Ria.

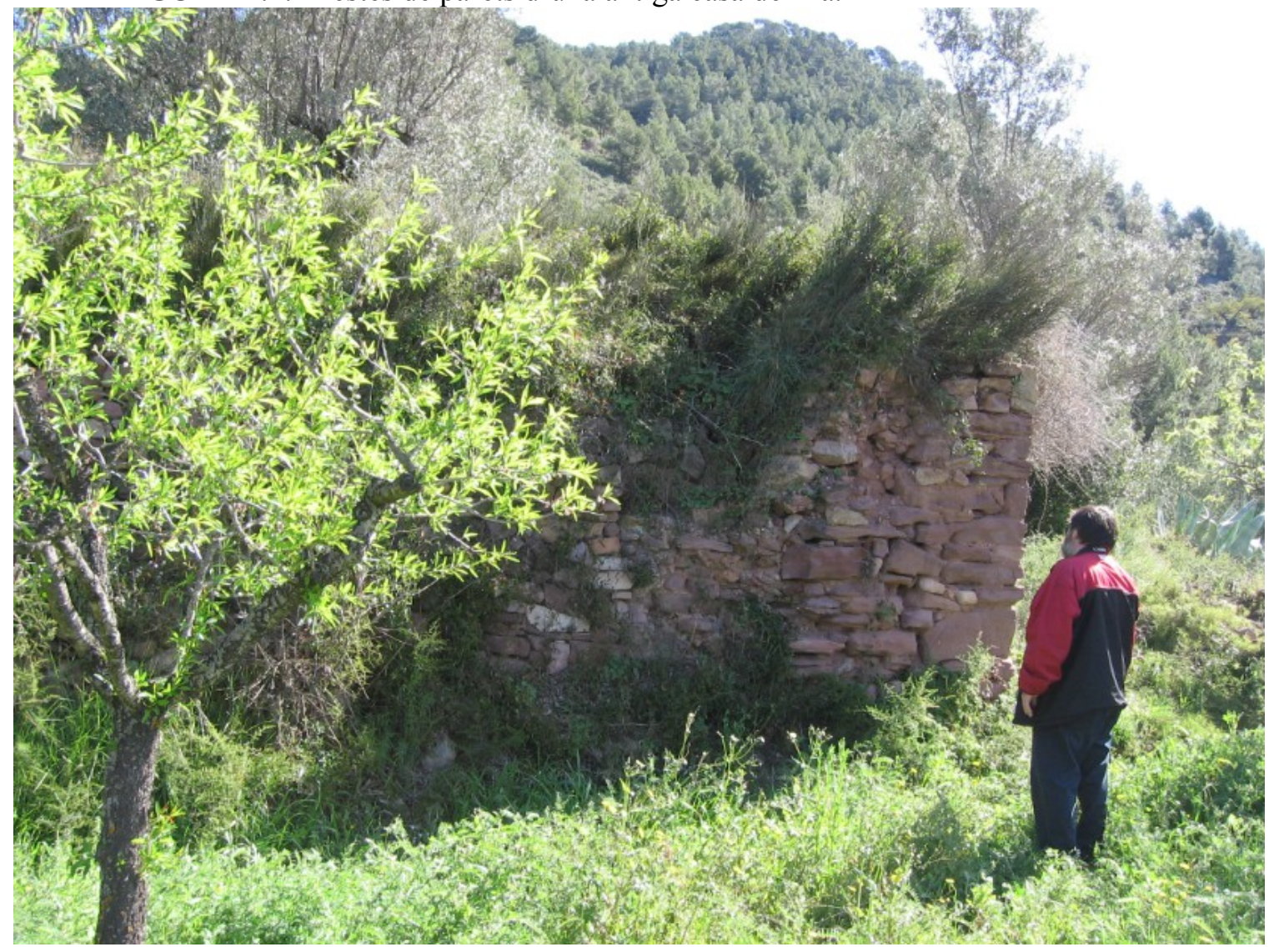

Fotografia de l'autor.

Per altra part, el plànol parcel·lari actual de la zona (FIGURA 4.5) mostra una curiosa concentració de petites parcel·les que van seguint el llarg d'ambdós costats del camí d'Estivella, i un altre sender que deriva des d'aquest cap al nord (cap a l'horta de l'Ombia). Les úniques microparcel·lacions que de vegades es poden trobar en les hortes (es veu, per exemple a l'horta de Ria, més al nord i prop del barranc del mateix nom) van seguint cotes de nivell i responen sempre a la distribució de les estructures de rec, adaptant-se de manera allargada al terreny $i$ estant sempre separades per murs o ribassos. Però no és aquest el cas que observem a Ria, doncs es tracta de parcel·letes més o menys quadrades, d'escassa superfície (entre uns 100 i poc més de $200 \mathrm{~m}^{2}$ ) i coincidents amb les escasses restes de murs d'antigues cases reconegudes. De vegades són parcel·les més allargades (i de vegades lleugerament més grans) perpendicularment a la direcció del camí o carrer i això fa pensar en que inclö̈en l'espai de corral annex a cada casa, tal com s'observava i era tradicional en moltes de les antigues cases a Serra. Entenem que aquests 
elements (una vintena aproximadament), a manca d'un estudi arqueològic adient, podrien correspondre a la situació dels antics habitatges i parcel·les urbanes de Ria.

FIGURA 4.5.- Ortofoto i parcel·lació en l'entorn de Ria. La Torre de Ria s'indica amb un punt groc, el camí d'Estivella (empedrat) i suposats carrers del poblat amb línia groga $\mathrm{i}$ les parcel·letes, que podrien respondre a antigues cases, amb punts de color roig.

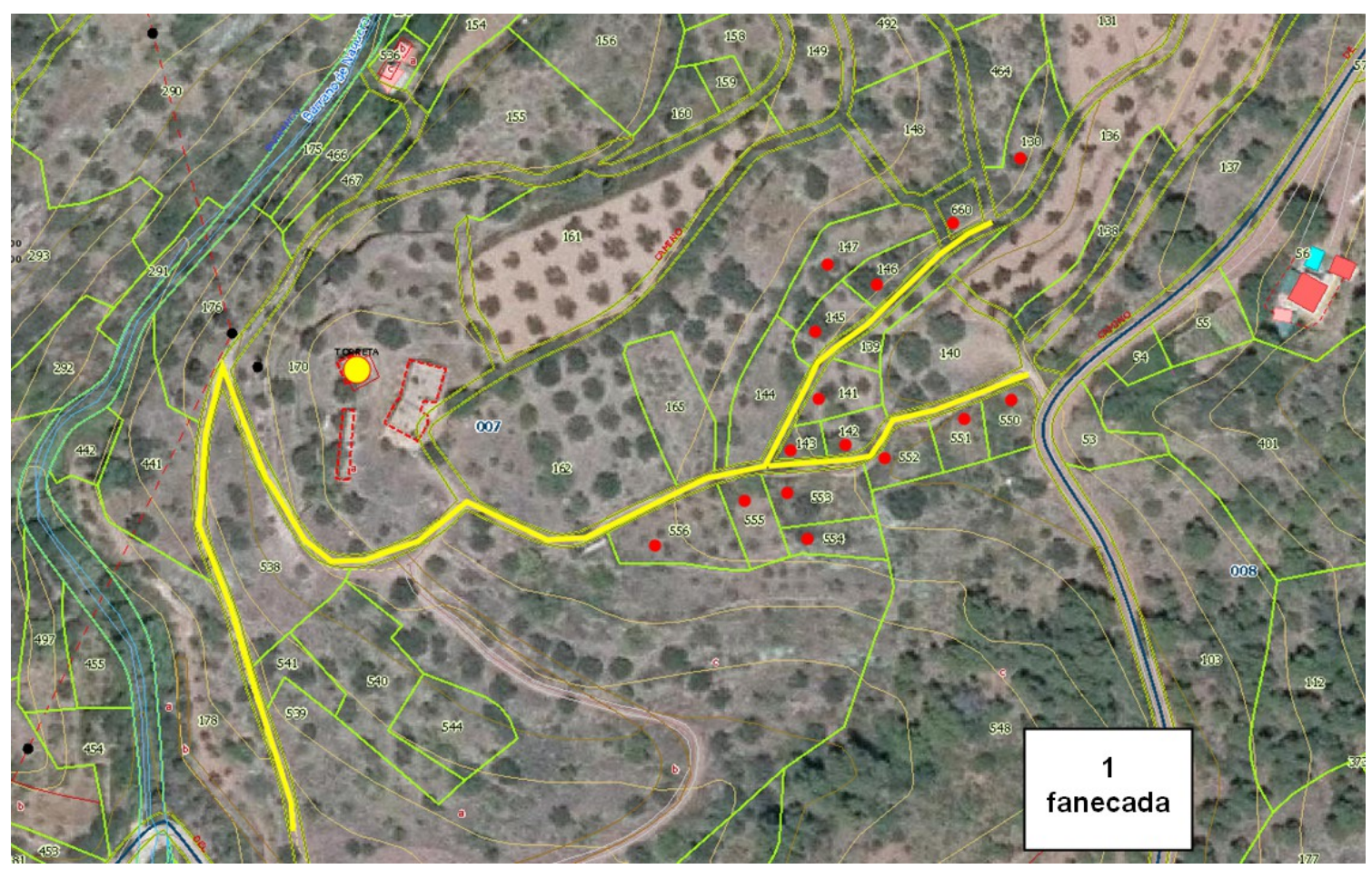

Elaborat sobre capes del visor cartogràfic de la Generalitat Valenciana.

Contràriament al que succeïa a Serra, Ria no disposava d'una font o naixement d'aigua junt a la població, però la xarxa d'aigua de rec arribava molt prop del poblat, permetent almenys certs usos en les èpoques més plujoses de l'any. Supose que l'abastiment de l'aigua de consum humà devia procedir dels aljubs de les cases i de càrregues d'aigua des de la font de l'Ombria, que era de bona qualitat i frescor. No obstant això, l'aprofitament agrícola en l'entorn de Ria era notable, i no molt lluny convergien pràcticament tres zones regades, com són l'horta de l'Ombria (avui sense a penes rec, ja que l'aigua de la font va ser captada cap a 1935 per al subministrament municipal d'aigua potable a Serra), l'horta de Ria (que aprofita les aigües de la bassa del Molí) i l'horta de Tòixima, que comença al peu de l'alteró on està la torre de Ria, amb la confluència dels barrancs de Ria i d'Ombria, i així continua fins a la part baixa del poble de Serra. 


\section{DESPOBLAMENT DE RIA I NAIXEMENT DEL BÀRIO}

Una cita documental de l'any 1713, com és l'acte de la presa de possessió de la "Baronia de Serra, Ria i Armell” per part del procurador de la nova propietària, la Senyora Josepa Folch i Cardona, resulta prou expressiva de l'estat en que es trobava Ria en aquell temps. Quan el senyor procurador pregunta als vassalls de Serra pels llocs de Ria i Armell, li responen que del lloc d'Armell no tenen absolutament cap referència i que ni els més vells del lloc han sentit mai parlar d'ell. I pel que fa a Ria, entenen que era l'antiga població de Serra, ja desapareguda fa molt de temps, que es trobava -suposenen la partida i prop de la Torre de Ria. ${ }^{2}$

En els Annals de la Cartoixa de Portaceli (Ribes, 1998) trobem una altra referència que permet acotar més la desaparició de Ria. Recordem que la versió dels Annals que coneixem correspon a la còpia realitzada al voltant de 1776 per fra José Pastor, que és alhora una nova versió de la que en 1655 va escriure el pare Juan Bautista Civera. Aquest últim recull una notícia de 1442, relativa a que en aquell temps el procurador del Duc de Cardona tractava de comprar la Baronia de Serra, Ria i Armell (que ell escriu Almuelle), que estava empenyorada per diverses càrregues censals). En relació amb aquesta notícia, el pare Civera afegeix (parlem ara de l'any 1655): Del lugarcillo de Almuelle ya no queda rastro ni memoria, y lo mismo será brevemente de Ría, pues no queda sino algunos paredones.

Per altra part, sabem pel Quinque libri de Serra que el primer de maig de 1631 encara va morir a Ria una veïna (realment l'única de la què tenim constància), Eufèmia Teruel, esposa del repoblador de Ria Anton Salvador i probablement filla o germana d'un altre repoblador de Ria, Joan Teruel. Aquestes darreres dades demostren que Ria va quedar definitivament despoblada desprès de 1631 i prou abans de 1655 . Però, malgrat que fins a 1631 encara visquera a Ria una persona, potser que el despoblament efectiu de Ria ja haguera començat a produir-se molts anys abans. Al menys això és el que indica una nota d'Ambròs Cebrián (Cebrián i Lluch, 1935) referida a una visita pastoral de 1619, en la que diu que Serra només comptava en aquell moment amb 22 cases de cristians vells, havent-ne en elles 75 persones de confessió (majors de 7 anys) i d'aquestes, 50 de comunió (majors de 10 anys), indicant que Ria estava ja "pràcticament despoblada". La xifra de 22 cases concorda amb el cens de 1646, que veurem després.

\footnotetext{
${ }^{2}$ Es tracta de la presa de possessió de les baronies de Serra i Ria (AHN-FN, c. 1.648, doc. 2).
} 
Les causes d'aquest despoblament no considere probable que responguen a cap succés catastròfic ni gran sequera -com algú havia apuntat- sinó a un procés normal de reorganització territorial i poblacional entre dos nuclis de població molt propers entre si, presentant un d'ells millors condicions d'habitabilitat: Serra era la "vila" de l'antic districte castral, amb més població (quadre 4.1), millor posició i més serveis que Ria i àdhuc que Nàquera; tenia millor accés a l'aigua corrent (diverses fonts d'aigua perenne), l'església parroquial, millor exposició i bondat climàtica, millor estructura urbana i sens dubte disponibilitat de més habitatges dels que havien sigut repoblats en 1609. Tot aquest cúmul de factors degué afavorir el trasllat progressiu dels pobladors que anirien concentrant-se cada vegada més prop de Serra. Per altra part, entenem que la denominació conjunta "Serrayria" amb la que ve recollit el lloc de Serra en el cens de 1646, del que desprès parlarem, no és casual ni capritxosa, sinó una mostra de que els dos llocs formen ja, pràcticament, un mateix nucli urbà en aquell temps (FIGURA 4.6).

Una prova en favor d'aquesta argumentació és que els pobladors de Ria que continuen vivint a la baronia els trobem molt prompte ja a Serra (quan comença el Quinque Libri, en 1619). I tanmateix, alguns repobladors de Nàquera (els Èpila, Català, Navarro, etc.) acabarien també fent el mateix.

El motiu del per què a penes queda rastre de teules, rajoles, bigues..., sinó únicament unes poques restes bassals de murs, molt testimonials, a Ria (ja des de ben prompte no quedava més que "algunos paredones", en 1655) té una explicació lògica: tot els elements de construcció tenien un valor, i de segur es degueren aprofitar tots aquells materials per a edificar o reformar les noves i velles cases de Serra. Al menys això és el que havia passat (i així estava documentat) en el despoblat d'Alèdua, pertanyent al marquesat de Llombai (comunicació personal del professor Manuel Ardit)

Per tot el que hem vist en els capítols precedents, sembla clar que els primers repobladors eren relativament majors i, fins i tot efímers -en la major part del casos- pel que fa a la seua permanència, doncs hem vist també que a la volta de deu anys quasi tots havien sigut ja substituïts per altres. A més a més, en la dècada dels vint es registren una sèrie de matrimonis que són els que més van a "marcar" el desenvolupament $\mathrm{i}$ creixement de la colònia. Aquests matrimonis són també d'alguns fills i filles dels primers repobladors, però sobre tot dels nous veïns que en 1617 havien pactat la compra de gra per a sembrar forment. ${ }^{3}$ Ja en aquesta dècada dels vint del segle XVII, però també en les

\footnotetext{
${ }^{3}$ APCC, sg. 21045, f. 1.
} 
següents immediates, hem vist que es produeix una progressiva introducció de nous cognoms (nous veïns) que completaran de forma decisiva el conjunt dels llinatges que ja dominaran la major part de la població serrana dels segles següents. Serà en aquesta època (tot el primer terç del segle XVII però sobre tot la segona dècada) quan pràcticament s'aposta per aveïnar-se en Serra en detriment de Ria, que quedaria així pràcticament despoblada en molts pocs anys.

FIGURA 4.6.- Esquema que mostra el desplaçament de Ria per a formar el Bàrio.

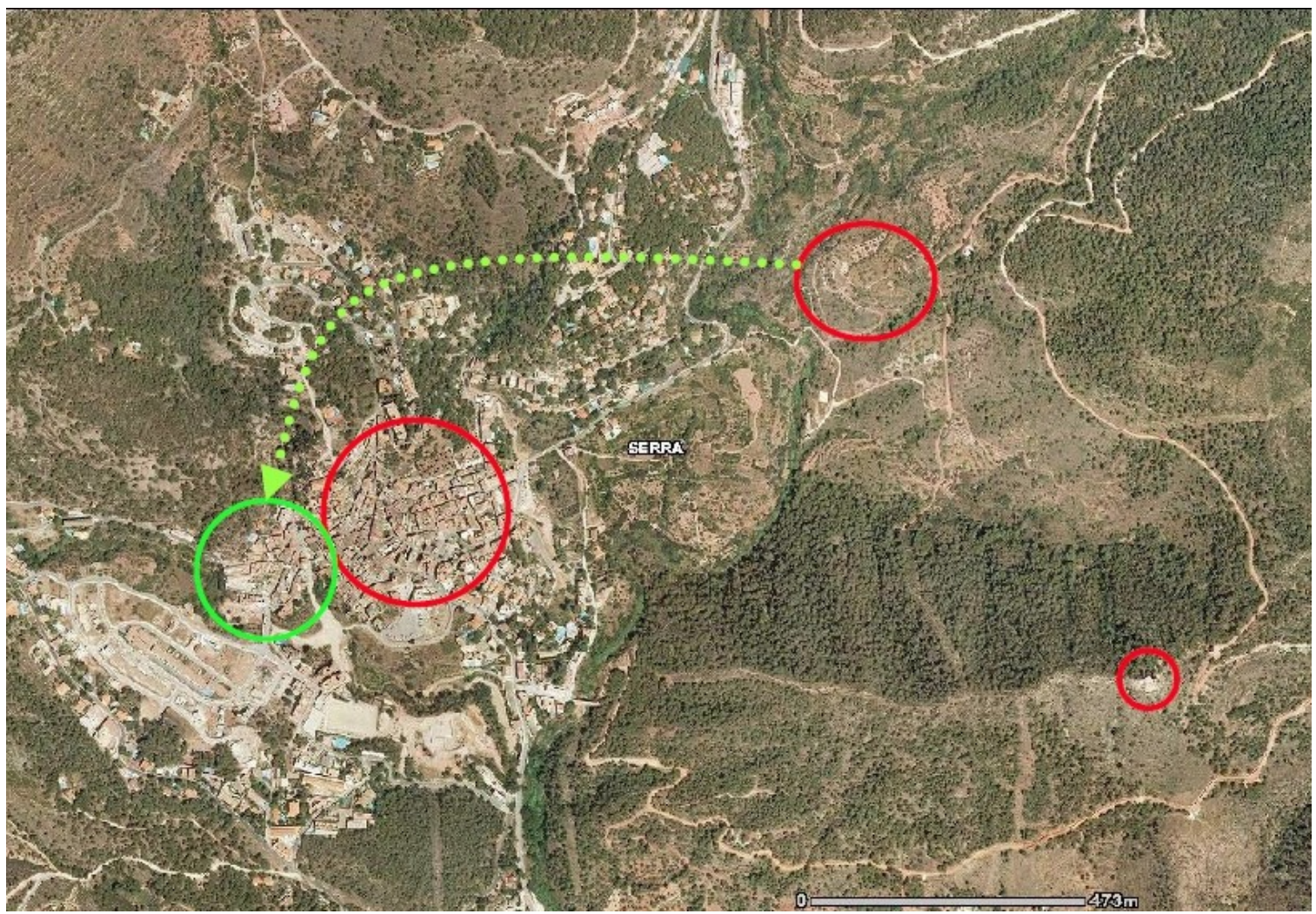

El cercle gran indica la ubicació de Serra; el Castell de Serra ve indicat pel cercle més petit, situat a l'est de l'anterior) i Ria. al nord-est de Serra està indicada per cercle roig mitjà. La línia verda indicaria el hipotètic desplaçament de Ria cap al Bàrio (cercle verd), nou raval nascut junt a Serra

Dibuix original, sobre ortofoto del Institut Cartogràfic Valencià.

Una explicació que dona major sentit al suposat trasllat de veïns cap a Serra és que en els mateixos anys $i$ els que seguiran del mateix segle, començava a formar-se junt al nucli urbà de Serra, però externament a ell, el Bàrio, el nou raval que venim citant. El barranc de la Font (més avall dit barranc de Clara) separava els dos nuclis (FIGURA 4.7), però la distància a la cabalosa Font del Poble era semblant. De fet, la font és el punt 
frontissa al voltant del qual s'articularen els dos nuclis. Cal posar de relleu que a Nàquera hi ha un altre Bàrio, i un altre més a Estivella (comunicació personal de Lluís Mesa) i si bé el nom de Bàrio ens recorda la forma "barri" (bé d'origen llatí o bé de l'àrab, doncs, ambdues opcions poden ser argumentades), el topònim tindria, en opinió de Gil i Navarro (1997) un origen basc: de berri (que significa nou), sense oblidar altres formes semblants de la llengua basca, com barruti (districte). Al respecte hem de recordar també les desenes de biscaïns que visqueren a Serra en la primera meitat del segle XVII. Per tot açò entenc que, en bona mesura, la desaparició de Ria va anar lligada a la formació del Bàrio.

FIGURA 4.7.- Pont del Bàrio, sobre el barranc de la Font del poble.

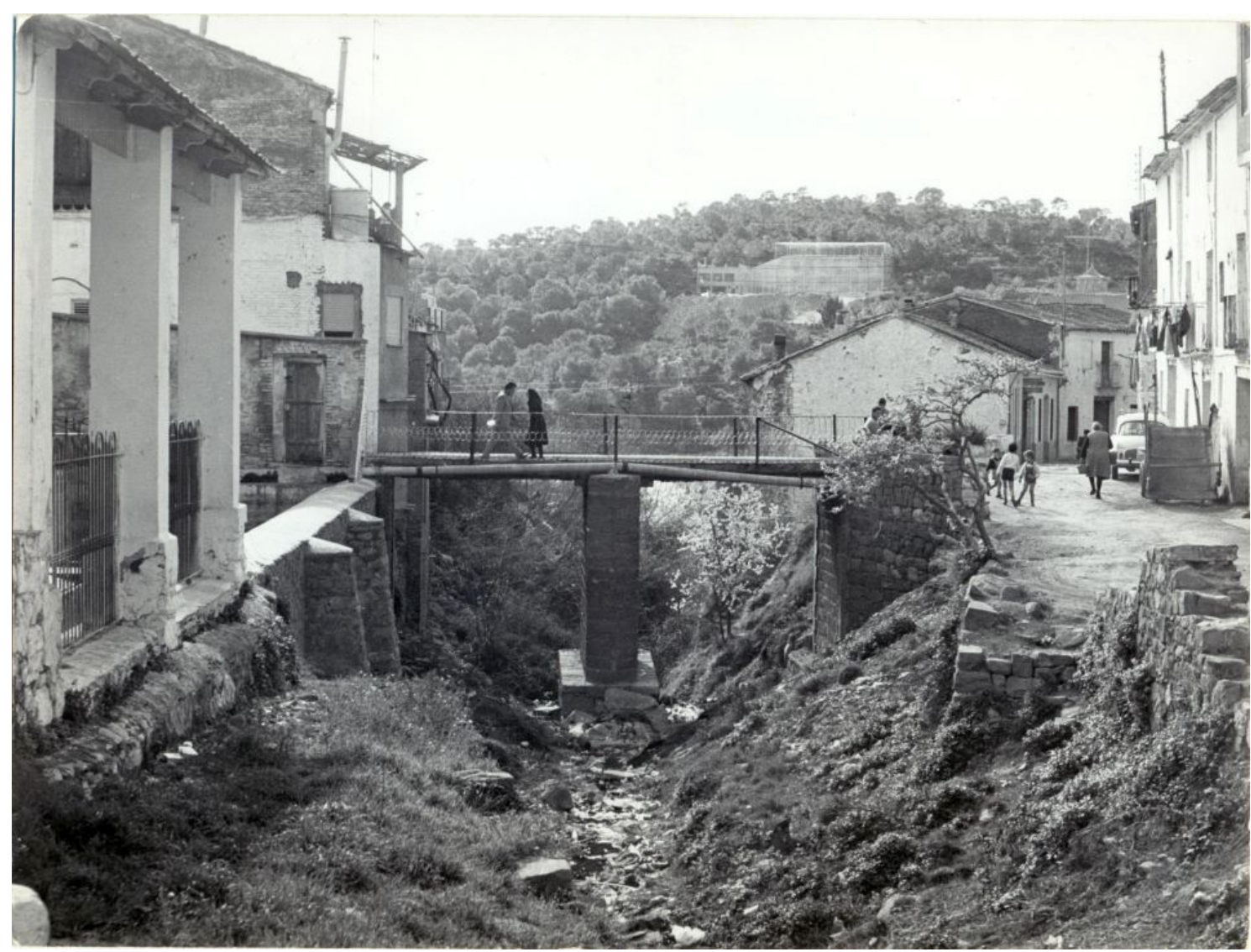

Fins als anys 80 del segle XX aquest pont servia de connexió entre Serra (a l'esquerra, amb el seu llavador) i el Bàrio (a la dreta). Fotografia feta al voltant de 1960 Arxiu fotogràfic de Juanjo Navarro. 


\subsection{EL CENS NOMINAL DE 1646. REVISIÓ I CONFRONTACIÓ DE DADES}

Segons posa de manifest Pérez Puchal $(1972)^{4}$ el cens de 1646 recull en realitat dos veïnats: un seria l'ordenat el 24 de desembre de 1645, pel virrei, el Comte d'Oropesa, als bisbes (i arquebisbe de València), els quals ho encarregaren fer als rectors i vicaris; i un altre, disposat per la diputació de la Generalitat, el dia 13 d'octubre de 1646, que va ser alçat pels jurats i justícies de cada lloc del Regne. El primer donaria xifres més baixes, i Pérez Puchal el considera afectat per certes ocultacions d'interessos; raó per la qual considera el segon prou més fiable. En el cas de Serra i Ria és aquest segon el que he consultat.

El notari i escrivà públic de València Vicent Múrria, en 15 de novembre de 1646, dóna fe de les cases i caps de cases existents en el lloc de "Serra y Ria", segons la relació jurada que li aporten Josep Català, lloctinent del Justícia, i el Jurats Francisco Rubio i Martín Domingo, tots ells càrrecs oficials de l'any en curs per a aquest lloc.

En concret, segons la versió oficial d'aquest cens ${ }^{5}$, el lloc de Serra i Ria està format per 25 caps de casa, que viuen en 23 cases. Açò es degut a que comparteixen casa "la viuda Ėpila" y Vicente Arnal, per una part, i els dos Domingo Diago, major i menor (o siga, pare i fill), per altra. Cal deixar clar que "cabeza de casa", segons el diccionari de la llengua espanyola, té el significat de la persona que per legítima descendència del fundador té la primogenitura i és hereua de tots els seus drets.

Els 25 veïns (23 cases) de "Serra y Ria" que formen el cens de 1646 posen de manifest que la població de la baronia de Serra encara estava en xifres inferiors a la de la població morisca expulsada, i fins i tot hauria disminuiit respecte als veïns repobladors de finals del 1609, ja que els repobladors de la carta pobla eren aleshores trenta (20 de Serra i 10 de Ria). El que també tenim ja clar es que Ria estava ja despoblada en 1646, com hem vist adès. Per tant, podríem entendre que el nombre de cases en Serra podria haver crescut lleugerament, al temps que Ria quedava pràcticament despoblada.

Aquestes 25 persones "vecinos cabezas de casa" son les que hi consten en la primera columna del QUADRE 4.3. En primer lloc el retor Jussephe Giberto, i tot seguit la resta de veïns, entre els quals es troben els esmentats Jurats i lloctinent del Justícia. En la segona columna he afegit el nom de la dóna de cadascú dels veïns, seguit de l'any de casament d'aquests entre parèntesi; o bé hi he fet constar l'estat civil, en el cas del rector i dels vidus. La tercera columna recull els fills comuns que hi vivien (desprès d'haver

\footnotetext{
${ }^{4}$ P. Pérez Puchal (1972): La población del Pais Valenciano hasta la época estadistica.

${ }^{5}$ ARV, Generalitat, 4826, f. 227.
} 
descomptat tots els que hi havia ja mort: prop d'una dotzena en poc més de vint anys), seguit de l'edat de cadascun d'ells i, encara en cursiva, incloc també el nom de fills corresponents a matrimonis anteriors (són diversos els casos de vidus i vídues que aporten fills al matrimoni).

QUADRE 4-3.- Relació de veïns del cens de 1646, completats amb llurs conjuges i fills.

\begin{tabular}{|c|c|c|}
\hline Caps de casa & cònjuge (any casament) & fills i edat \\
\hline Jussephe Giberto & (rector) & \\
\hline Francisco Ruvio & $\begin{array}{l}\text { Vicenta Cavaller } \\
(1625)\end{array}$ & $\begin{array}{l}\text { Jusepha Mariana } 17 \\
\text { Joan Bautista } 18 \\
\text { Margalida Francisca } 16 \\
\text { Felicia Francisca } 14 \\
\text { Esperança Francisca } 12 \\
\text { Francisco Joan Pedro } 11 \\
\text { Catalina Leocadia } 9 \\
\text { Buenaventura } 7 \\
\text { Pedro Joset Patricio } 5 \\
\text { Jusepa Agustina 1 }\end{array}$ \\
\hline Agustín Salvador & $\begin{array}{l}\text { Mariana Ruvio } \\
(1645)\end{array}$ & Joan Jusep Bertomeu $<1$ \\
\hline Bautista Catala menor & $\begin{array}{l}\text { Joana Estevan } \\
(1626)\end{array}$ & $\begin{array}{l}\text { Francisco Bruno } 18 \\
\text { MagdalenaJosepa } 14 \\
\text { Policarpa Jusepa } 10 \\
\text { Jusepe Joachim } 8\end{array}$ \\
\hline Jossephe Catala & $\begin{array}{l}\text { Catalina Peres } \\
(1645)\end{array}$ & Jusepa Agueda $<1$ \\
\hline Martin Domingo & $\begin{array}{l}\text { Angela Ribas } \\
(1640)\end{array}$ & $\begin{array}{l}\text { Jusepa Glaudiana } 4 \\
\text { Ana Maria Llorença } 2 \\
\text { Jusep Tomas } 1\end{array}$ \\
\hline Antonio Esteve & Joana Romera & Vicente Antonio 23 \\
\hline Domingo Moreno & $\begin{array}{l}\text { Rafaela Donya } \\
(1624)\end{array}$ & $\begin{array}{l}\text { Juan Bautista Domingo } 19 \\
\text { Juana Rafaela } 17 \\
\text { Domingo Aniceto, } 15 \\
\text { Violant Meljora } 13 \\
\text { Francisca Teodora } 12 \\
\text { Domingo Salvador } 10 \\
\text { Jusepe Joan Bta. } 8 \\
\text { Teodosia Paula 6 } \\
\text { Barbara Victoriana } 3 \\
\text { Pedro Pau 1 }\end{array}$ \\
\hline Miguel Domingo & $\begin{array}{l}\text { Clara Cavaller } \\
(1630)\end{array}$ & $\begin{array}{l}\text { Miguel Vicente } 15 \\
\text { Francisco Matias } 13 \\
\text { Agueda Dominga } 11 \\
\text { Agustín Vicente } 9 \\
\text { Andres Mauro7 } \\
\text { Pedro Joan Alejo } 4 \\
\end{array}$ \\
\hline Matheu Esteve & $\begin{array}{l}\text { Dionisia Sanchis } \\
\text { (1639) }\end{array}$ & $\begin{array}{l}\text { Domingo Mateo } 5 \\
\text { Vicent Andreu } 3 \\
\text { Felícia Catalina } 1 \\
\end{array}$ \\
\hline Domingo Diago mayor & $\begin{array}{l}\text { Isabel Morell } \\
\text { (abans de 1620) }\end{array}$ & Catalina Maria 20 \\
\hline
\end{tabular}




\begin{tabular}{|c|c|c|}
\hline Domingo Diago menor & $\begin{array}{l}\text { (vidu d'Isabel Gimeno, } \\
\text { des de 1642) }\end{array}$ & \\
\hline Jossephe Domenech & Agustina Puig & Pedro Vicente 23 \\
\hline Jussephe Suastre, tierrateniente & $\begin{array}{l}\text { (vidu de Maria Diago, } \\
\text { morta el mateix 1646) }\end{array}$ & Policarpa Jusepa $<1$ \\
\hline Matias Cabo & $\begin{array}{l}\text { Barbera Estevan } \\
(1623)\end{array}$ & $\begin{array}{l}\text { Maria Francisca } 13 \\
\text { Cecilia Catalina Gertrudis } 11 \\
\text { Casimiro Jusepe } 6 \\
\text { Joan Bta. Josep } 4 \\
\text { Jusepe Gil } 1 \\
\end{array}$ \\
\hline La viuda Epila y & \multirow{2}{*}{$\begin{array}{l}\text { (vidus, tornats a casar en } \\
1644 \text { ) }\end{array}$} & \multirow{2}{*}{$\begin{array}{l}\text { Juan }>30 \\
\text { Jusep Joan Anastacio }<1\end{array}$} \\
\hline Antonio Arnal, en una casa & & \\
\hline Vicente Arnal & $\begin{array}{l}\text { Jusepa oménech } \\
\text { (1644) }\end{array}$ & $\begin{array}{l}\text { Teudora Catalina } 14 \\
\text { Francisco Hysidoro } 10 \\
\text { Romualdo Vicente } 8 \\
\text { Joan Crisostomo } 7 \\
\text { Felix } 5 \\
\text { Jusepa Mauricia } 1 \\
\end{array}$ \\
\hline Joan Yvanyes & $\begin{array}{l}\text { Paula Domènech } \\
\text { (1642) }\end{array}$ & $\begin{array}{l}\text { Vicenta Clara } 16 \\
\text { Joan Romualdo } 9 \\
\text { Victoria Ninfa } 5 \\
\text { Agustina Siurana Jusepa } 3 \\
\text { Joan Mauro }<1\end{array}$ \\
\hline Jayme Perez & $\begin{array}{l}\text { Ursula Moreno } \\
\text { (1644) }\end{array}$ & $\begin{array}{l}\text { Pasquala Simona }>1 \\
\text { Rafela Andrina }<1\end{array}$ \\
\hline Bautista Domenech & $\begin{array}{l}\text { Mariana Ribas } \\
\text { (1641) }\end{array}$ & $\begin{array}{l}\text { Jusepe Hylario } 4 \\
\text { Josep Vicent } 2 \\
\text { Joan Bta. Tomás }<1\end{array}$ \\
\hline Vicente Ruvio & $\begin{array}{l}\text { Vicenta Navarro } \\
\text { (1646) }\end{array}$ & Vicente Nadal Estevan $>1$ \\
\hline La viuda Navarro & $\begin{array}{l}\text { (es refereix a Vicenta } \\
\text { Donya, vídua de Pere } \\
\text { Navarro) }\end{array}$ & $\begin{array}{l}\text { Estevan Juan } 25 \\
\text { Vicenta Francica } 17 \\
\text { Agustina Rafela } 15 \\
\text { Jusepe Joan Ambrosio } 13\end{array}$ \\
\hline Domingo Navarro & $\begin{array}{l}\text { Madalena Estevan } \\
\text { (1633) }\end{array}$ & $\begin{array}{l}\text { Ana Maria Catalina } 10 \\
\text { Pedro Joan } 9 \\
\text { Domingo Jusepe } 4 \\
\text { Joan Domingo } 2 \\
\end{array}$ \\
\hline Bautista Catalan mayor & (vidu de Bàrbera Mateu) & Juan Vicente 24 \\
\hline
\end{tabular}

Elaboració pròpia a partir dels llibres parroquials i el cens de 1646

Cal suposar, en principi, que totes aquestes persones formaven part de les aproximadament vint-i-cinc unitats familiars, i que convivien en les mateixes vint-i-tres cases, però tampoc podem descartar que hi haguera alguna excepció. Per exemple, xiques servint en altres cases, o en la ciutat, o xics treballant d'aprenents en altres llocs; encara que de cap d'aquests possibles casos en tenim constància, de moment.

Una qüestió que m'ha resultat cridanera en aquests registres de 1646, és que Nàquera presenta més veïns (28 veïns) que Serra i Ria (25 veïns), quan resulta que el 
nombre de cases de repobladors, en 1609, va ser major en Serra (30) que en Nàquera (16). Això podria significar, o bé un major èxit del procés repoblador o, per contra, la introducció d'alguna mena de defecte en l'elaboració d'algun dels dos, o ambdós censos. Cal afegir que, la situació es tornarà a invertir amb el temps (en el cens de $1692^{6}$, Nàquera té 27 cases i Serra en té ja 29). No és absolutament rebujable que en aquest fet haja pogut influir el despoblament de Ria, qüestió que desconec en detall però de la qual tornarem a ocupar-nos-en.

Segons aquestes dades nominals de 1646, el conjunt de la població de Serra arribaria a les 118 persones (o ànimes) en total, de les quals 44 en són majors de 25 anys i la resta són 74 menors que no arriben a dit límit. Així doncs, cada llar estaria formada per prop de 5 persones; concretament 4,7 per cada veí o "cap de casa" o bé 5,13 persones per cada casa. Aquests valors són sensiblement superiors al multiplicador de 4,1 deduït per Bernat i Badenes (1994: p. 93) per a la població valenciana de l'any $1842^{7}$. Però el multiplicador definitiu hauria de ser encara major, tenint en compte una sèrie de dades sobre població de fet que comentaré tot seguit.

Per exemple, en casa d'Antoni Arnal i de "la viuda Épila" (el seu nom era Ursola Épila, filla de Anton Épila i Isabel Manyes) he comptabilitzat tant el nen petit del matrimoni com a Joan, un fill del primer, que en realitat estava casat amb Dorotea Valero, i fruit d'aquest matrimoni hi havia, al menys un xiquet batejat en Serra, Francesc Joan, que en 1646 tenia 9 anys. Sembla que tots ells (i sense descartar-ne encara algun altre possible fill que haguera estat batejat fora de Serra) compartien la mateixa casa, al menys temporalment. Malgrat que tampoc no es pot descartar la possibilitat que el jove matrimoni residira realment en altra població, en tot cas, hi consta que Joan va morir a Serra, en 1678.

Per altra part, és pràcticament segur que en casa d'un dels dos germans Domènech residira la mare d'ells, Agustina Puig, vídua des de 1622 però habitadora a Serra fins a la seua mort, en l'any 1651.

També pel Llibre de Batejats se sap d'altres xiquets nascut -o almenys batejats- a Serra en les dècades precedents al cens de 1646. Alguns són fills de matrimonis oficiats a Serra, però no hi ha seguretat de que realment tingueren residència en el poble. Bé podrien viure en algunes de les cases censades del poble, però també cap l'opció

\footnotetext{
${ }^{6}$ Cens de 1692, de la Reial Pragmàtica Sanció; publicat per Bernat i Badenes (1994).

${ }^{7}$ Recordem que els mateixos autors estimen que aquest multiplicador podria variar entre 3,5 i 4,5 habitants per cada casa o veí censat, entre els segles XVII a XIX.
} 
d'habitar-ne altres no censades $o$, fins $i$ tot, tenir la residència en altres poblacions (QUADRE 4.4). En aquesta incertitud es troben, al menys, els casos següents, on he indicat la suposada edat dels fill (cap dels citats consta que haguera mort):

Per altra part, a més dels "veïns oficials" i dels familiars directes que hi vivien amb ells, també es detecta que en tota la primera meitat del segle XVII hi ha un cert trànsit de persones, generalment foranes, que treballen i habiten en el terme de Serra, bé com a criats o jornalers o bé com a arrendataris de terres o de productes forestals. Prova d'açò la trobem en el Llibre de Batejats, on sorprèn que moltes vegades el padrí és un home foraster, generalment francès o biscaí. Seria massa arriscat donar una xifra del nombre de persones que amb aquest caràcter vivien i habitaven en Serra l'any 1646, però el que resulta evident és que hi havia certa proporció de població fluctuant, d'origen estranger, que vivien en Serra i que en bona mida es relacionaven prou bé amb els veïns de dret locals, integrant-se fàcilment amb ells. Així ho demostra la freqüència amb que els hi trobem com a padrins dels xiquets batejats en Serra, i més encara, el costum de posar-los als xiquets el nom de pila dels padrins, bé com a primer, bé com a segon nom. També ocorre que, en alguns casos, aquests forasters arribaren a casar-se i establir-se definitivament en el poble.

Entre altres, trobem el cas de Joannes de Loiola, un biscaí, natural de la vila de Carubo (Biscàia) que es va casar en 1638 amb Isabel Épila, amb qui tingué una filla. Però també Isabel Épila era ja vídua del francès Antoni Correja quan es va casar amb el biscaí. Encara que Loiola morí jove, és molt probable que la seua filla Vicenta visquera en el poble en 1646 (en tindria 7 anys), i de fet, als 29 anys es va casar a Serra amb Domingo Herrero, amb qui tingué descendència.

Un altre exemple és el del francès Esteve Soler, padrí en 1656 d'una filla de Martín Domingo, que acabarà casant-se amb la vídua d'aquest, Àngela Ribes, amb la que tingué una filla, en 1660. No sabem si Esteve Soler ja residia a Serra en 1646, però és clar que aquell mateix any també hi havia un altre francès a Serra, que va ser padrí de Martín Domingo i d’Àngela Ribes. 
QUADRE 4.4.- Altres matrimonis i fills registrats en l'Arxiu Parroquial de Serra, però que no es troben censats en l'any 1646.

Matrimoni

casament fills i edat suposada

\begin{tabular}{|c|c|c|}
\hline $\begin{array}{l}\text { Joannes de Loiola (difunt des de } \\
\text { 1640) i Isabel Épila }\end{array}$ & $(1638)$ & $\begin{array}{l}\text { Gregorio } 8 \\
\text { Vicenta Isabel } 7\end{array}$ \\
\hline Joan Mallach i Angela Guillem & $(1630)$ & $\begin{array}{l}\text { Martin Juan } 22 \\
\text { Vicenta Feliciana } 18 \\
\text { Angela Clara } 15\end{array}$ \\
\hline $\begin{array}{l}\text { Joan Saez (vidu, des de 1630, d'Isabel } \\
\text { Domingo) }\end{array}$ & No consta & $\begin{array}{l}\text { Isabel Joana } 14 \\
\text { Jorge Vicente } 10 \\
\text { Angela Jusepa } 10 \\
\text { Miguel Joan } 8 \\
\text { Olalia Catarina } 6\end{array}$ \\
\hline Pedro Salinas i Joana Arnal & No consta & Paula Joana 4 \\
\hline Francisco Cavaller i Anna Dasí & No consta & Ines Geronima 7 \\
\hline $\begin{array}{l}\text { Bartolomé Domingo } \\
\text { i Maria Catalan }\end{array}$ & $(1626)$ & $\begin{array}{l}\text { Joan Agustí } 18 \\
\text { Jusepa Luysa } 13\end{array}$ \\
\hline Martín Tortaxada i Innes Donet & No consta & Laurena Salvadora 10 \\
\hline $\begin{array}{l}\text { Estevan Moreno } \\
\text { i Dorotea Cesarii }\end{array}$ & No consta & $\begin{array}{l}\text { Esteban Leandro } 7 \\
\text { Felix Simon } 5\end{array}$ \\
\hline
\end{tabular}

Elaboració pròpia, amb dades del Quinque Libri de Serra.

Un cas prou expressiu de la situació en la que estaven aquestes persones foranes que convivien en el poble, amb les famílies "de dret" el trobem en la següent inscripció de difunts de l'any 1647 :

Murió de una puñalada Juan de Sundaña, de nacion francés, en 5 de abril 1647, sin ningun testamento; enterrele en la Higlesia porque asi me lo mandó el dueño de dicho difunto, que se llama Macián Cabo (Matias Cabo) el qual ha de pagar la fabrica...

Potser que aquest francès fora pare o parent del fuster Domingo Surdaña, que trobem anys més tard com a vidu, "hijo de Benisanó" però resident en Serra -almenys entre els anys 1693 i 1701 - on consta que va ser padrí de sis xiquets, amb les dades d'inscripció que recull el QUADRE 4.5. 
QUADRE 4.5.- Relació de fillols del francès "Domingo de Surdaña".

\begin{tabular}{|c|c|c|c|}
\hline Any & batejat & pares del batejat & padrí (grafia original) \\
\hline 1593 & Maria Gesualda Vict. & Jusepe Rubio + Fran ${ }^{\text {ca }}$. Arnal & Domingo de Susdaña \\
\hline 1693 & Domingo Joan Jusepe & Juan Libros + Polinària Arnal & Domingo Duserdaña \\
\hline 1693 & Domingo Nicolàs Silv. & Andres Català + Maria Esteve & Domingo de Sordaña \\
\hline 1698 & Domingo Jusepe Jayme & Domingo Pérez + Maria Dolz & Domingo de Surdaña \\
\hline 1698 & Dionisia Margarita & Vicent Estevan + Catalina Ibañez & Domingo de Suldaña \\
\hline 1701 & Cecilia Dorotea Ursula & Andrés Català + Maria Esteve & Domingo de Surdaña \\
\hline
\end{tabular}

Elaboració pròpia.

El que també es veu en aquest quadre és el costum de posar-li al batejat el nom del padrí. Un costum que encara perdura, parcialment, en els nostres dies (el cas de qui subscriu és un exemple d'açò).

Per altra part, fent un repàs dels "padrins" d'origen francès o biscaí, dels què ja hem parlat en el capítol 3, he trobat que en almenys 11 de les 23 cases censades es dóna algun d'aquests casos -de padrins- en les dues dècades dels anys precedents al cens de 1646. Tot açò fa prou probable que en $1646 \mathrm{el} \mathrm{col} \cdot$ lectiu d'aquests forasters residents a Serra fora fàcilment d'una dotzena de persones, si més no.

En definitiva, podem concloure aquest apartat dient que, en el cas de Serra, el nombre de persones per cada casa censada és de l'ordre de 5 com a mínim. I que en el cas més extrem, el nombre total de persones residents en la població (població de fet) podria arribar a superar en gairebé un 35 per cent més la xifra de 118 persones identificades com a familiars directes (cònjuges i fills) dels censats, i encara d'un 40 per cent (si més no) en cas d'incloure al col·lectiu de persones d'origen estranger que, bé com a jornalers o criats d'algunes de les cases censades, o bé treballant en el terme, dedicats a tasques forestals, hi trobem durant la primera meitat del segle XVII.

També el professor Joan Serafí Bernat (1980) arriba a una conclusió semblant, en haver trobat que, en el municipi de la Serra d'En Galceran, mitjançant una prova de concordança amb xifres parroquials, el cens de 1646 havia de ser incrementat en un 21,7 per cent. 


\subsection{EL CAPBREU DE 1779 COM A FONT PER A UN CENS DE·VEÏNS I CASES}

L’arxiu senyorívol dels ducs de Montellano (AHN, fons Fernán-Núñez) conté un document titulat "Apeo, empadronamiento, o Cabrebe general de los vecinos terratenientes de la Baronia de Serra, que por las Casas y tierras que tenían, pagaban sus respectivos censos anuales". És un inventari de bens emfitèutics de l'any $1779 \mathrm{i}$ pertany a l'època en que era Senyor de Serra Alons de Solís Folch de Cardona. ${ }^{8}$

Mitjançant aquest capbreu, el Senyor de Serra repassava fiscalment tots els bens immobles de la baronia, un per un i identificant en cada cas a quin vassall o contribuent pertanyia. El seu contingut s'organitza identificant, en primer lloc, a cada individu pel seu nom i cognom, per a seguidament descriure tots els seus bens, començant per les cases (en el lloc de Serra), les terres d'horta, les de secà i, finalment, altres possessions, com poden ser eres de trillar, corrals, pallers o "cases de Ria" (en parlaren seguidament d'aquest concepte). De cadascun d'aquests bens emfitèutics anota el valor del cens que li correspon i finalment suma les quantitats a pagar al senyor. Entenem que els capbreus no eren a soles simples inventaris de bens, sinó també formes de controlar-los per detectar possibles canvis i evitar prescripcions, però en el cas de Serra aquest de 1779 és l'únic que he pogut trobar i del què he tingut notícia.

En total hi ha 179 "contribuents" (no exactament veïns) entre els quals es troba l'Ajuntament (que ha de tributar per una casa, només) i el "curat de Serra" que només tributa per una fanecada d'horta, si bé, a banda està el retor parroquial, com veurem tot seguit. Els 177 restants són persones físiques, identificades pel seu nom i cognom. Entre elles trobem l'administració del "difunt" rector, el Dr. Joan Baptista Costa (que havia mort feia poc) com a posseïdor d'una casa d'habitació (entenem que la casa abadia, del lloc de Serra), una era de trillar en la partida de 1'Horta del Molí, 5 fanecades de terra horta en la mateixa partida, una altra fanecada i mitja de terra horta en la partida de Baix la Torre i 6 parcel·les de terra secà, repartides de la següent manera: mig jornal Baix la Torre, 7 jornals en la partida de l'Algepsar, 3 jornals a l'Empeltada i altres 3 jornals repartits, respectivament en les partides de Xarxant, l'Arquet de Ria i Baix la Torre.

Cada casa del lloc de Serra i cada parcel·la d'horta o de secà les descriu amb detall, indicant el nom dels propietaris del bens amb els que confronta i, en el cas de les parcel·les també la partida. Per al altres bens, com les eres, corrals, pallers (casa paller) indica únicament la partida on es troben. En el cas de les "cases de Ria", però, no indica res més, quan sabem que difícilment es tracta ja de cases situades en el despoblat de Ria, ${ }^{8}$ AHN-FN, c. 2.220 , doc. 1 
que com hem explicat anteriorment, a meitat del segle XVII ja es trobava completament despoblat i les cases totalment enrunades. Per trobar una explicació adient hem d'analitzar un poc les xifres del capbreu i observar la magnitud del que estem parlant.

En aquest capbreu comptem fins a 141 "cases d'habitació" en el lloc de Serra, de les quals 134 se declaren completes (d'un únic propietari), mentre que també hi ha contribuents que declaren i paguen per mitja casa (en total 12 mitges cases, que equivaldrien a 6 cases partides) i encara un que tributa per dues terceres parts d'una casa i altres dos que ho fan per un terç (en total ixen 141 cases i 1/3). Hi ha un propietari que té 3 cases a Serra i altres 13 propietaris que en tenen dues.

El capbreu explica quins elements o quines altres cases (fins a tres) confronten amb cadascuna d'elles (tant les completes com les fraccions), emprant sempre la següent forma: "Posehe una casa de havitacion en el Poblado de la Baronia de Serra, lindante con las de...". Es tracta per tant d'una valuosa font d'informació amb la que es podria reconstruir amb certa aproximació com era la trama urbana del municipi fa 235 anys.

El cens que pagava cada casa era justament 1L10s o siga, els 30 sous que estipulava la carta pobla. No obstant això, les mitges cases pagaven només la meitat (15 sous), en aparent contradicció d'allò que es desprèn del mateix capítol cinquè de la carta pobla: "lo qual dit dret de cens de trenta sous siguem així mateix tinguts i obligats nosaltres i los nostres successors a pagar i reconèixer al dit Senyor... de cascuna casa que s'edificarà de nou o quan alguna de les velles se partirà donant porta al carrer per a distint domicili i habitació".

A banda de les cases del "poblat de Serra" hem comptabilitzat al capbreu altres 67 cases a Ria, les quals són sempre citades al final de la fitxa del contribuent de la següent forma: "Corresponde esta hacienda por el censo de Casa de Ria á la Señoria Directa de esta Baronia...” i seguit d'una quantitat de diners que, sorprenentment no és fixa, sinó fluctuant en quantitats prou baixes si les comparem amb els 30 sous estipulats. Veure al respecte el QUADRE 4.6, que recull exactament el cens que pagava cada propietari afectat. Per tant, quan es parla del "cens de casa de Ria" hem d'entendre que és un dret no sobre una casa que estiguera ubicada a Ria, sinó en un altre lloc (el Bàrio) però arrossegant una referència de Ria que la fa concordar millor amb el contingut de la carta pobla.

Resulta evident -insistim- que les 59 “cases en Ria" no estaven realment ubicades a Ria, ja que Ria era un absolut despoblat des de feia un segle i mig. El més provable és 
que les "cases en Ria" estigueren realment ubicades al Bàrio, el raval del qual venim parlant al llarg d'aquest capítol, i que s'hauria començat a edificar en el primer terç del segle XVII com a substitució del lloc de Ria i aprofitant els materials constructius d'aquell poblat que en els seus millors moments sembla que no arribaria a tindre més d'una vintena de cases (Garay, 2012: 321-333).

Per altra part, hi trobem 46 contribuents que no tenen o no tributen directament per casa alguna. Pot ser que algun d'ells no foren veïns o residents en aquesta baronia, però pels seus cognoms, la major part d'ells bé podrien ser fills de veïns que haurien rebut del seus majors determinades propietats per a treballar-les, o potser les hagueren rebudes com a dots de casament, mentre que continuarien vivint en cases per les quals tributarien encara els seus parents. Observem, al respecte, que hi ha 15 persones que tenen més d'una casa al lloc de Serra i que més de 49 dels que tenen "casa en Ria" posseeixen també una casa a Serra. Desconec fins a quin punt aquestes dobles o triples propietats d'immobles podrien ser objecte d'alguna mena de cessió o lloguer però, en tot cas es nota certa coincidència entre el nombre de persones sense casa i el nombre de cases duplicades (veïns amb més d'una casa).

Vuit contribuents del capbreu només tenen "casa de Ria", per tant sembla evident que al menys hi ha 8 cases habitades permanentment al Bàrio (en realitat seran moltes més, com veurem). Les altres 59 restants "cases de Ria" pertanyen a contribuents que també tenen casa al "poblat de Serra" i 8 d'elles pertanyen a contribuents que tenen no una sinó dues cases al lloc de Serra. Per tant, hi ha certa acumulació d'habitatges en mans de nombrosos propietaris. També hi ha contribuents que tenen dues cases a Serra i cap a Ria, i encara està Domingo Esteve, per exemple, que té tres cases a Serra però cap a Ria.

Tornant al quadre 4.6 i en relació amb l'aparent manca d'explicació a l'hora de fixar el cens poca cosa podem afegir. D'entrada resulta estrany que paguen tan poc, respecte al criteri estipulat per la carta pobla (els 30 sous per casa que si que paguen les cases del lloc de Serra). A més a més, sorprèn la gran diferència que hi ha entre el censos d'algunes cases que paguen més de mitja lliura front a altres que només paguem mig sou, una diferència que fa que no arribe ni al 5\% de cens d'unes respecte a les altres. 
QUADRE 4.6.- Diversitat de preus que es pagaven pel "cens de casa de Ria” (1779).

Nom del contribuent preu del cens Nom del contribuent

preu del cens

\begin{tabular}{|c|c|c|c|}
\hline Joaquim Domingo & $16 \mathrm{~s} 4$ & Vicent Navarro de Josep & \multirow[t]{2}{*}{$2 \mathrm{~s} 8$} \\
\hline Josep Rubio & $15 \mathrm{~s}-$ & Roc Fos & \\
\hline Joaquim Arnal major & $10 \mathrm{~s} 4$ & Josepa Català & \multirow[t]{7}{*}{$2 \mathrm{~s} 6$} \\
\hline Francesc Rubio de Josep & $10 \mathrm{~s} 2$ & Cristòfol Cabo & \\
\hline Domingo Pérez & \multirow[t]{2}{*}{$8 \mathrm{~s} 2$} & Francesc Català de Josep & \\
\hline Miquel Cabo & & Francesc Cabo & \\
\hline Ramon Montero & \multirow[t]{2}{*}{$7 \mathrm{~s} 6$} & Francesc Navarro de Batista & \\
\hline Marianna Arnal & & Marià Cabo & \\
\hline Francesca Arnal & $7 \mathrm{~s} 1$ & Tomàs Verche & \\
\hline Josepa Escrig & $6 s 10$ & Teresa Cabo de Martí & \multirow[t]{2}{*}{$2 s-$} \\
\hline Josep Escrig major & $6 s 6$ & Teresa Català & \\
\hline Blai Dasí & $6 s-$ & Vicent Inglés & \multirow[t]{7}{*}{$1 \mathrm{~s} 11$} \\
\hline Teresa Navarro & \multirow[t]{2}{*}{$5 \mathrm{~s} 9$} & Agnès López & \\
\hline Pere Puig major & & Bartolomé Ros & \\
\hline Cristòfol Arnal & \multirow[t]{3}{*}{$5 s-$} & Manuel Ros & \\
\hline Pasqual Cabo & & Pere Ros de Pere & \\
\hline Pasqual Fabregat & & Joan Ros & \\
\hline Valero Pérez & \multirow[t]{2}{*}{$4 \mathrm{~s} 5$} & Miquel Ros & \\
\hline Vicent Ros & & Francesc Escrig & $1 \mathrm{~s} 10$ \\
\hline Francesc Català & \multirow[t]{2}{*}{$4 s 4$} & Maria Arnal & $1 \mathrm{~s} 9$ \\
\hline Tomàs Cabo de Lluís & & Josep Puig & \multirow[t]{2}{*}{$1 \mathrm{~s} 8$} \\
\hline Batista Català & $4 s-$ & Francesc Dolz & \\
\hline Pere Català & $3 \mathrm{~s} 8$ & Maties Pasqual & \multirow[t]{2}{*}{$1 \mathrm{~s} 6$} \\
\hline Tomàs Cabo de Francesc & \multirow[t]{9}{*}{$3 s-$} & Vicent Navarro d'Esteve & \\
\hline Ventura Navarro & & Francesc Puig & \multirow[t]{2}{*}{$1 \mathrm{~s} 4$} \\
\hline Joan Falomir & & Vicent Arnal de Vicent & \\
\hline Josep Domènech & & Maria Puig & $1 \mathrm{~s} 3$ \\
\hline Manuel Domingo & & Vicenta Català & $1 \mathrm{~s}-$ \\
\hline Josep Català de Josep & & Eusebi Arnal & $-s 6$ \\
\hline Francesc Pérez & & Jaume Navarro & $-s 6$ \\
\hline Joan Batista Navarro & & Josep Navarro de Pasqual & $-s 6$ \\
\hline Joan Pérez & & Batista Cabo de Marià & $-s 6$ \\
\hline Cebrià Cabo & \multirow[t]{2}{*}{$3 \mathrm{~s} 9$} & Vicent Navarro de Pasqual & $-s 6$ \\
\hline Batista Cabo d Josep & & & \\
\hline
\end{tabular}

Els preus venen expressats en sous (s) i diners (darrere de $\mathrm{s}$. Elaboració pròpia a partir del capbreu del 1779 (AHN-FN, c. 2.220, doc. 1)

No sembla gens provable que el criteri puga tindre relació amb la superfície de l'habitatge (perquè estaríem parlant de diferències inversemblant), però si que podria estar en relació amb altres criteris més raonables, com podria ser la distància al nucli urbà de Serra, o a la Font del Poble, que seria un bon punt de referència per a les cases del Bàrio. En tot cas i malgrat que ho desconeixem de manera fefaent, entenem que degué 
d'existir alguna mena d'acord o concòrdia per a regular tot açò, doncs seria també molt raonable que el Senyor haguera accedit a aquestes contribucions tan barates per tal de fomentar un creixement urbanístic prop de Serra; tot això amb un resultat clar com seria l'augment de població i per consegüent de nous vassalls i majors tributs globals.

En repassar les duplicacions de "cases d'habitació" del poble de Serra hi comptem fins a 17 cases (unes poques no completes, sinó fraccions) excedents al lloc de Serra, o siga, les cases que estarien lliures d'ocupació directa pels seus propietaris útils. Podria ser que algunes d'elles estigueren ocupades per membres més joves de les mateixes famílies, aspecte que també es podria donar en algunes de les 59 cases excedents en el Bàrio. Així i tot resulta una xifra molt considerable.

Per altra part, hi trobem també 44 persones que no tenen cap casa. I això, front a la gran oferta d'habitatges suposadament "lliures" o disponibles (59 al Bàrio/"Ria" i 17 al lloc de Serra) fa pensar, inevitablement, en alguna mena de lloguer o cessions de cases a canvi de jornals, mà d'obra, prestacions o serveis domèstics o simplement diners. Recordem el cas d'alguns forans, com els biscaïns que en la primera meitat del segle XVII vivien a Serra com a treballadors, o el cas del francès Joan de Sundanya, que morí d'una punyalada en 1647 i el soterraren en l'església de Serra perquè així ho va manar l'amo de dit difunt, que era Maties Cabo.

Tenint en compte que eren molts els vassalls que posseïen vàries desenes de jornals de terra de secà i que a més hi havia un gran aprofitament forestal a la serra, com veurem amb més detall al llarg del capítol cinquè, la demanda de mà d'obra devia ser important. Alguns cognoms típics de Serra hi arriben precisament en aquest segona meitat del segle XVIII, com és el cas dels Arazo, Gimeno, Peña, Inglés, Falomir, Fabregat o Iranzo, entre algun altre, generalment procedents de llocs propers, com Bétera (els Inglés), Montcada (els Gimeno) o Sogorb (els Peña), però també de llocs més allunyats, de les serres de Terol (Arazo). Però es nota mitjançant el capbreu de 1779, que sobre tot hi havia també un gran creixement vegetatiu o autòcton, amb una gran expansió dels llinatges ja establerts des del segle XVII.

Pel que fa a la possible utilitat del capbreu com a cens de veïns, podríem dir que hi ha un veïnatge de dret d'almenys 133 persones, inclòs el rector parroquial (aquells que tenen cases en propietat, que són 125 a Serra i almenys 8 a Ria). Però també hi hauria un veïnatge de fet que arribaria fins a 177 persones (si no vassalls al menys contribuents de la Baronia), si bé la xifra podria ser inferior en la mida en que alguns d'ells bé podrien 
ser residents en altres poblacions properes, com Nàquera, i ser contribuents de la baronia de Serra però no vassalls d'ella.

El nombre de cases, com a valor censal resulta més discutible, en ser 134 cases completes a Serra (inclosa la de l'Ajuntament i la del retor), més altres 15 fraccionades (mitges o terços però habitatges, en definitiva) i les 67 del Bàrio/“Ria”, que sumen per tant fins a 216 habitatges o 208 cases originalment (abans de particions internes).

\section{EVOLUCIÓ DEMOGRÀFICA DE LA BARONIA ENTRE 1609 I 1857}

Per tal de veure el creixement poblacional de la baronia de Serra des de la instal·lació de la colònia de l'any 1609 i al llarg de l'Antic Règim, he elaborat el QUADRE 4.7, recollint en ell les dades conegudes dels diferents censos coneguts. La major part de les dades les he pres directament de la publicació de Bernat i Badenes $(1994)^{9}$ sobre el creixement de la població valenciana en el període esmentat en el títol d'aquest apartat. Concretament, i a més de les dades que he tret de les cartes pobles (1609-1611), el censos recollits en l'esmentada obra són els següents:

- El veïnatge de 1646.

- La Reial Pragmàtica Sanció de 1692, per a formar un batalló.

- El veïnatge de Campoflorido (1713).

- El padró per al pagament de l'Equivalent (1730).

- El cens d'Aranda (1768).

- El cens de Floridablanca (1786).

- El cens publicat en el Diari de València (1793).

- Les dades de Las Observaciones de Cavanilles (1793-1794).

- Les del Diccionari geogràfic-estadístic-històric de Madoz (1842).

- El cens de l'any 1857 (ADPV).

A més he afegit el cens local del capbreu de 1779 (abans comentat), com també la dada de 145 veïns aportada per a Serra per Espinalt (1784-86). Cal observar que la major part dels censos donen només dades del nombre de veïns, mentre que uns pocs (alguns entre els més recents) donen el nombre d'habitants. Només hi ha un cas (el cens publicat per Madoz: 1842) que dona les dues xifres, de tal manera que es pot obtindre així quin seria el coeficient del nombre d'habitants per cada cap de casa (veí). La xifra que

\footnotetext{
9 Joan Serafí Bernat i Miquel Àngel Badenes: Crecimiento de la población valenciana (1609-1857). Col. Arxius i Documents, 11. Ed. Alfons el Magnànim. 1994.
} 
obtenim és 4.4, lleugerament inferior al 4.7 que obtinguérem (com a mínim) per a l'any 1646, però així i tot una xifra raonable.

QUADRE 4-7.- Dades censals de la població de Serra entre 1609 i 1857.

\begin{tabular}{|c|c|c|c|c|c|c|c|c|c|c|c|}
\hline Any: & 1609 & 1646 & 1692 & \begin{tabular}{|l|}
1713 \\
\end{tabular} & 1730 & 1768 & 1786 & 1793 & \begin{tabular}{|l|l|}
1794 \\
\end{tabular} & \begin{tabular}{|l|}
1842 \\
\end{tabular} & 1857 \\
\hline Veins & 30 & 25 & 29 & 30 & 56 & & * & 168 & 160 & 212 & ** \\
\hline Hab. & & $>118$ & & & & 561 & 615 & & & 934 & 1349 \\
\hline
\end{tabular}

Amb les dades i comentaris d'aquest quadre, la FIGURA 4.8 mostra gràficament l'evolució poblacional de Serra segons el nombre de veïns. Hom veu un valor dissonant, que és el corresponent als anys 1793 o 1794, i tractant-se pràcticament del mateix any, la diferència no creguem que puga ser real sinó accidental o de criteri. Per això, a l'hora d'enllestir la figura 4-9, que mostra la funció gràfica de la mateixa sèrie de dades, hem omès una de les dues dades, deixant en principi la primera.

FIGURA 4.8.- Evolució de la població de Serra entre 1609 i 1857.

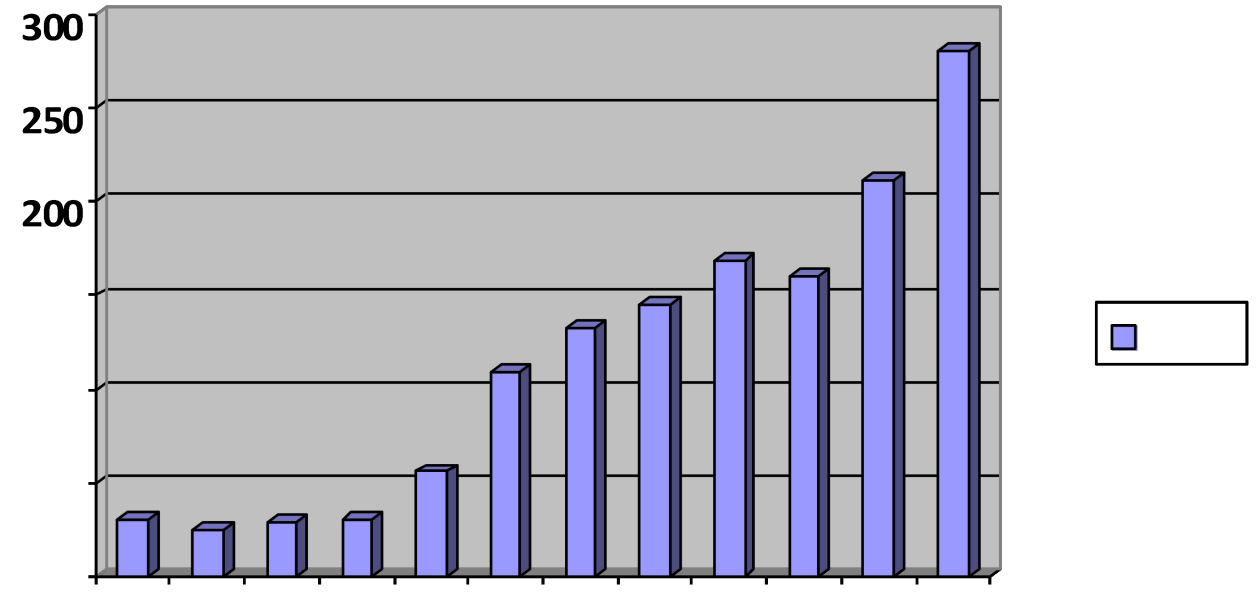

Segons les dades i notes del quadre 4.7. 
Més o menys coincident amb el cens de 1786 (651 habitants) hem posat la xifra de 145 veïns, que és la que aporta Espinalt (1784-86) per a aquells anys. També hem inclòs els 133 “veïns de dret” obtinguts del capbreu de 1779. I per al cens de l'any 1857 es pot considerar que el suposat nombre de veïns hauria sigut una xifra molt propera a la del nombre de cèdules, que en són 280. Per últim, com a nombre de veïns en 1768 (cens d'Aranda) hem posat únicament els 109 homes casats que recull aquell cens.

No hem inclòs, en canvi, en aquesta relació i gràfics, altres dades que, sense ser censos oficials introduirien algunes dissonàncies numèriques, com és el cas dels 168 veïns que tindria Serra en 1789 segons el recull de dades de justícies dels pobles publicat per Josep Royo (1998). Tampoc he inclòs però sí que volem destacar ara, pel seu possible interès, les xifres que proporcionen les visites pastorals dels anys 1782 i 1793 (Quinque Libri deSerra): 562 persones, 150 veïns i 136 cases, per al primer any, i 566 persones, 175 veïns i 148 cases onze anys desprès (dades que també han estat citades per Ferran Martínez Navarro, 2013). ${ }^{10}$

A la vista de la FIGURA 4.9 es posa de manifest que hi ha fins a quatre etapes que es poden diferenciar clarament en el creixement poblacional de Serra:

a) Al llarg del segle XVII es nota un creixement molt moderat, en general, i sense entrar de nou a analitzar el "mínim de 1646", un mínim que és realment un decreixement tant respecte al repoblament com, sobre tot si es compara amb els anteriors padrons moriscs. En tot cas, ja hem demostrat que és un cens fet "molt a la baixa" i que mostra un clar dèficit respecte a la realitat.

b) Tot el segle XVIII mostra, més que una recuperació, un fort i extraordinari creixement, un tram exponencial en el qual es produeix un creixement de l'ordre del $300 \%$ en poc més d'un segle.

c) La següent etapa mostra un clar canvi de tendència cap a un creixement molt més moderat i que basta pràcticament la primera meitat del segle XIX. No podem fer abstracció dels conflictes bèl·lics d'aquest període, sinó més bé pensar en que tant la guerra del francès com les carlistes haurien influït decisivament en aquesta tendència.

d) El darrer tram ens ve determinat únicament per l'espectacular creixement que mostra el cens de 1857. En només 15 anys augmenta la població en 415 persones, o siga, uns 68 veïns si equipàrem el concepte de cèdula amb el de veí.

\footnotetext{
${ }^{10} \mathrm{El}$ cens d'Aranda, en 1768 , ja contempla una població semblant a la indicada en la primera visita pastoral citada; per això sospitem que la xifra reflectida en les pastorals poguera ser poc més que una estimació.
} 
FIGURA 4.9.- Funcions gràfiques de l'evolució de la població de Serra entre 1609 i 1857.

Evolució de la població de Serra $(1609-1857)$

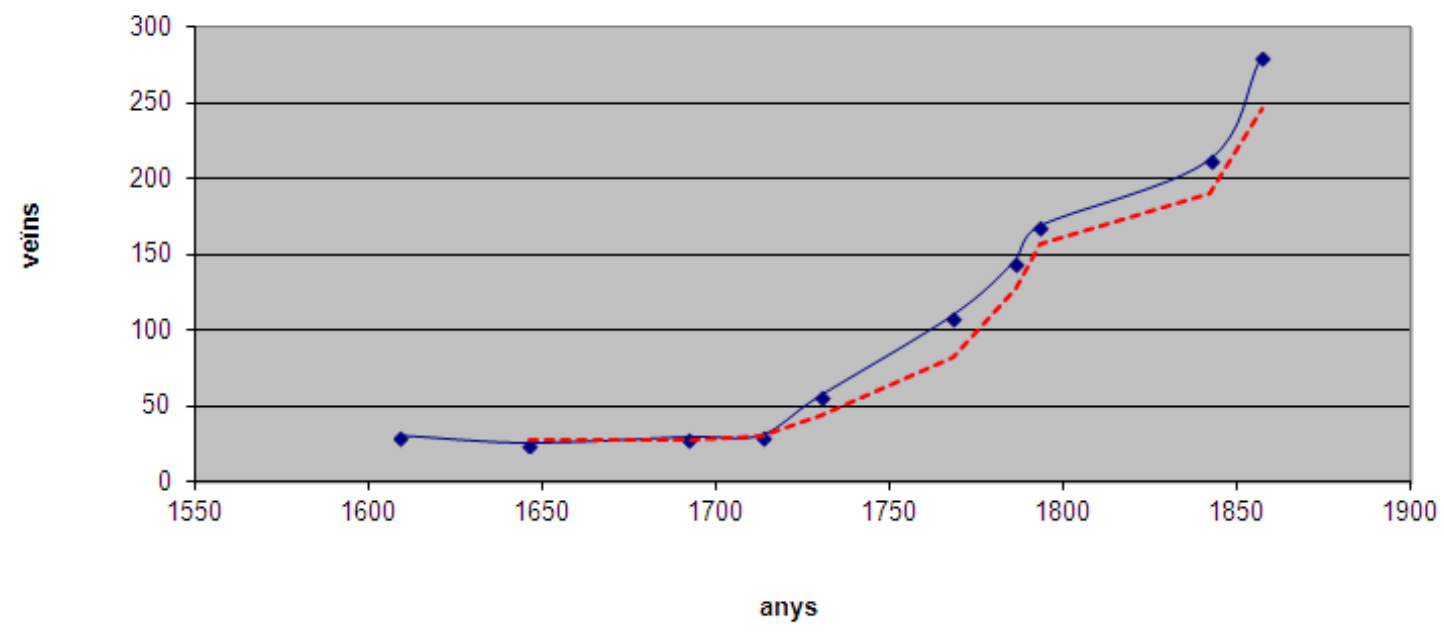

La línia discontínua és la de tendència de la mitja mòbil. Segons les dades i notes del quadre 4.7.

Evidentment, podríem pensar que una gran part d'aquest significatiu augment de població que va rebre Serra cap a la meitat del segle XIX procedira de la incorporació de Portaceli (antic priorat, ara forest pública amb enclavaments) en el mateix terme municipal de Serra. Però, mirant en detall el cens, es veu que hi ha un apartat al final dels llistats que posa "poblado de Portaceli / término municipal de Serra" i en ell trobem només que tres cèdules (les números 278, 279 i 280). O siga, que la situació amb penes canvia un poc i, per consegüent, aquesta annexió de Portaceli no n'és la causa del gran increment poblacional que registra Serra amb aquest cens. Les restants 277 cèdules, amb algunes poques excepcions, són principalment de persones amb els cognoms clàssics que ja coneixem pel capbreu de $1779 \mathrm{i}$ tants altres documents anteriors.

Ara bé, cal dir que les tres cèdules de Portaceli inclouen 98 persones. Açò no és habitual, i mentre que les cèdules de Serra registren exactament 4,52 individus per cèdula, les tres cèdules de Portaceli en registren 79, 11 i 8, respectivament. Aquestes 98 persones representen, doncs, un $7,3 \%$ de la població total del terme de Serra. Cal una observació més detinguda per a trobar interessants explicacions, com són les següents: 
- La cèdula número 278 té per cap a Francesc Navarro i Foro, Jutge de Portaceli, de 42 anys d'edat, els mateixos que la seua dona, Lulgarda Ribes. Viuen amb ells 4 fills, a més d'un prevere (Vicent Quesada i Vera), quatre matrimonis de jornalers amb fills, uns 40 homes jornalers fadrins i casats però sense parella, un fuster i 8 pastors. Sense dubte formen una mena de colònia agrària que estaria ocupant les instal·lacions de l'antiga cartoixa.

- El cap de la cèdula 279 és Hilari Urbàn Ibáñez, arrendador de terres, de 66 anys d'edat, els mateixos que la seua esposa, Tadea Romero Martínez, que viuen amb dues serventes, un jornaler, 4 llauradors i 2 pastors. Resulta fàcil suposar que són els ocupants de La Pobleta.

- La tercera cèdula (280) indica expressament que correspon a l'arrendador de La Torre, Lino Maeso Pérez, de 48 anys, que viu amb Tivencia Deporago, de 32 anys, quatre servents (un vidu de 78 anys, una vídua de 40, un fadrí de 16, i una xiqueta de 10) i dos pastors.

Es tracta, per tant, de les tres grans propietats (Cartoixa, la Pobleta i la Torre) que serien subhastades a partir de la desamortització de 1835, i que van ser adjudicades, inicialment, a Vicent Beltrán de Lis, com veurem en el capítol novè.

Tornant un poc enrere (1768) i pel seu particular interès, considerem adient recollir també, complementàriament, les dades de l'esmentat cens d'Aranda (QUADRE 4.8), tractant-se de la primera vegada que un cens aporta la distribució de la població per edats, sexe i estat civil. En el cas de Serra, dels 561 habitants un pertany al clergat (el rector parroquial), quedant la distribució dels altres 560 habitants segons s'expressa en l'esmentat quadre (aquestes dades van ser publicades abans per Ardit et al., 2001).

Per últim, i per gentilesa del historiador de Llíria Joan Adrià i Montolio (a qui faig constar ací el meu sincer agraïment) he tingut accés al contingut d'un document de 1808 que també conté dades censals dels municipis de l'antic Regne de València. Es tracta del Reglamento par la formación de compañias de vecinos honrados en el Reyno de Valencia, que defiendan sus pueblos y mantenngan la quietud, imprès en la impremta "Monfort" (1808) per ordre de la Junta Suprema. Sense entrar ara en massa detalls sobre aquest document em limite a mostrar el nombre de veïns atribuïts a Serra i, comparativament, a altres pobles dels voltants. 
QUADRE 4.8.- Distribució per edat, sexe i raó, de la població de Serra en 1768

\begin{tabular}{|c|r|r|r|r|r|r|c|}
\hline & \multicolumn{2}{|c|}{ Fadrins i vidus } & \multicolumn{2}{|c|}{ Casats } & \multicolumn{2}{|c|}{ Total } & TOTAL \\
\hline Grups d'edat & Homes & Dones & \multicolumn{1}{l|}{ Homes } & \multicolumn{1}{l|}{ Dones } & Homes & Dones & \\
\hline Menys de 7 & 76 & 57 & 0 & 0 & 76 & 57 & 133 \\
\hline De 7 a 16 & 61 & 54 & 0 & 0 & 61 & 54 & 115 \\
\hline De 16 a 25 & 29 & 20 & 2 & 6 & 31 & 26 & 57 \\
\hline De 25 a 40 & 13 & 5 & 50 & 55 & 63 & 60 & 123 \\
\hline De 40 a 50 & 0 & 6 & 29 & 27 & 29 & 33 & 62 \\
\hline Més de 50 & 11 & 10 & 28 & 21 & 39 & 31 & 70 \\
\hline Total & 190 & 152 & 109 & 109 & 299 & 261 & \\
\hline TOTAL & 342 & \multicolumn{3}{|c|}{218} & & & 560 \\
\hline
\end{tabular}

Dades del cens d'Aranda (Ardit et al., 2001)

No ha estat inclosa la població de Soneixa, en aquesta taula (QUADRE 4.9), per no haver-la trobada recollida en el cens. La tercera columna inclou el nombre d'urbans que havia d'aportar cada població amb arreglo al seu veïnatge. Per això és que hem considerat més útil ordenar els pobles en funció del seu veïnatge, de major a menor, la qual cosa permet comprovar millor com la proporció d'urbans ve a ser, poc més o menys, de l'ordre d'un per cada quinze veïns (més bé sol fluctuar entre 14 i 18).

Desconec les fonts emprades en aquest cens de 1808 però, com que la xifra de Serra (145) és sensiblement inferior als no menys de 160 veïns que citava Cavanilles (1795-97), és fàcil suposar -i també comprensible- que poguera tractar-se d'un cens de mínims, amb ocultacions o reticències per tal d'eludir la possible càrrega que comportava (en aquest cas un reclutament militar de persones honrades). Per a fer aquest cens a la baixa tampoc podem descartar que s'haguera pres com a referència alguna publicació, com la d'Espinalt (1784-86), doncs les xifres, si bé no exactament coincidents, són força semblants: Serra 145, Nàquera 80, Olocau 123, Bétera 295, Torres Torres 130, etc. 
QUADRE 4.9.- Cens de veïns de diversos pobles amb el nombre d'urbans que havien d'aportar, segons un Reglament de 1808.

\begin{tabular}{|c|c|c|c|}
\hline Població & veïns & "urbans" & percentatge \\
\hline Llíria & 1.468 & 103 & $14.2 \%$ \\
\hline Morvedre & 1.162 & 78 & $14.9 \%$ \\
\hline Sogorb & 1.011 & 66 & $15.3 \%$ \\
\hline Montcada & 429 & 28 & $15.3 \%$ \\
\hline Altura & 410 & 27 & $15.2 \%$ \\
\hline Bétera & 295 & 19 & $15.5 \%$ \\
\hline Alcublas & 280 & 18 & $15.6 \%$ \\
\hline Albalat de Tarongers & 191 & 13 & $14.7 \%$ \\
\hline Serra & 145 & 10 & $14.5 \%$ \\
\hline Estivella i Beselga & 140 & 8 & $17.5 \%$ \\
\hline Gàtova, Olocau i Marines & 123 & 8 & $15.4 \%$ \\
\hline Algímia d'Alfara & 111 & 7 & $15.9 \%$ \\
\hline Torres Torres & 110 & 7 & $15.7 \%)$ \\
\hline Alfara d'Algímia & 84 & 6 & $14.0 \%$ \\
\hline Nàquera & 79 & 5 & $15.8 \%$ \\
\hline Assuévar & 37 & 2 & $18.5 \%$ \\
\hline
\end{tabular}

Font: "Reglament per formar un Cos de Veïns Honrats i Urbans".

\subsection{EVOLUCIÓ BIOLÒGICA DE LA COLÒNIA A PARTIR DEL QUINQUE LIBRI}

Comparant les xifres anuals de batejats front a les de difunts es posa de manifest la moderada tendència creixent del segle XVII front al creixement molt més marcat i exponencial que ja hem vist que caracteritza a tot el segle XVIII. La FIGURA 4.10 permet comprovar açò en poc més del primer segle de vida de la colònia. El nombre de 
difunts permet un ajust lineal dins d'una irregular fluctuació en la que destaquen alguns pics que comentarem més avall. Per contra, els batejats mostren una tendència de creixement més pròxima a una funció exponencial, mostrant com sobre tot a partir dels anys de la guerra de Successió la taxa de natalitat es dispara.

FIGURA 4.10.- Evolució del nombre de batejats i de difunts entre 1620 i 1745

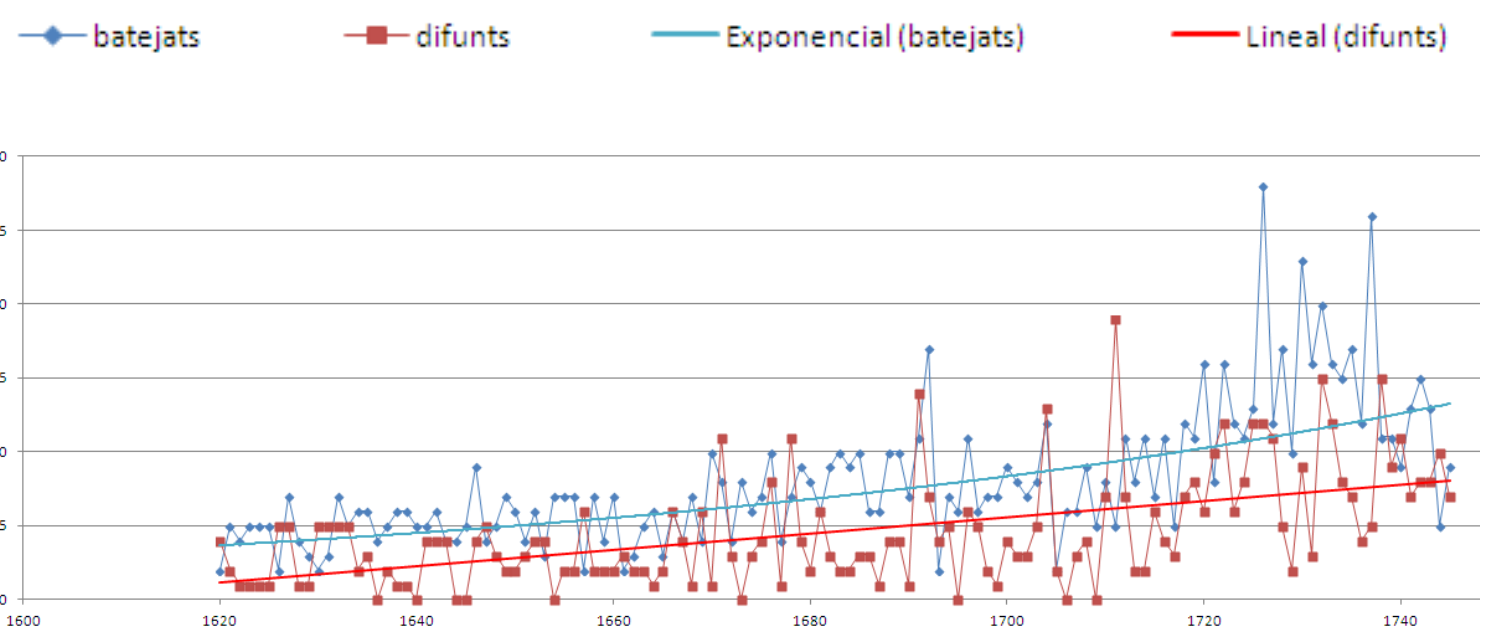

Dades procedents del Quinque Libri de Serra.

Aquesta observació, el fet ja conegut (ho hem vist al llarg del capítol 3) de que en el darrer quart del XVII i en primers anys del XVIII és prou escassa l'arribada de nous cognoms i vassalls a Serra, i en tercer lloc, la comprovació que hem fet de que els nous batejats són quasi exclusivament fills de serranes i serrans, deixa prou clar que el gran creixement poblacional del XVIII que observàvem en els censos no respon a possibles processos migratoris (almenys no únicament), sinó simplement als propis recursos genètics, per dir-ho d'alguna forma exempta de connotacions socials o religioses.

Per visualitzar millor aquest efecte, la FIGURA 4.11 mostra, davant les dades brutes de batejats i difunts (sector inferior de la gràfica), el creixement net (resultat de restar cada any a la xifra de batejats la dels difunts) acumulat, o siga, l'evolució del nombre de persones vives que habiten a Serra. El balanç, al cap d'aquest període de 120 anys és que ha hagut un creixement net de 441 persones, descomptades les que moren cada any (que fan una mitja de 3,675 difunts per any). 
FIGURA 4.11.- Augment net acumulat de població (batejats-difunts) entre 1620 i 1745.

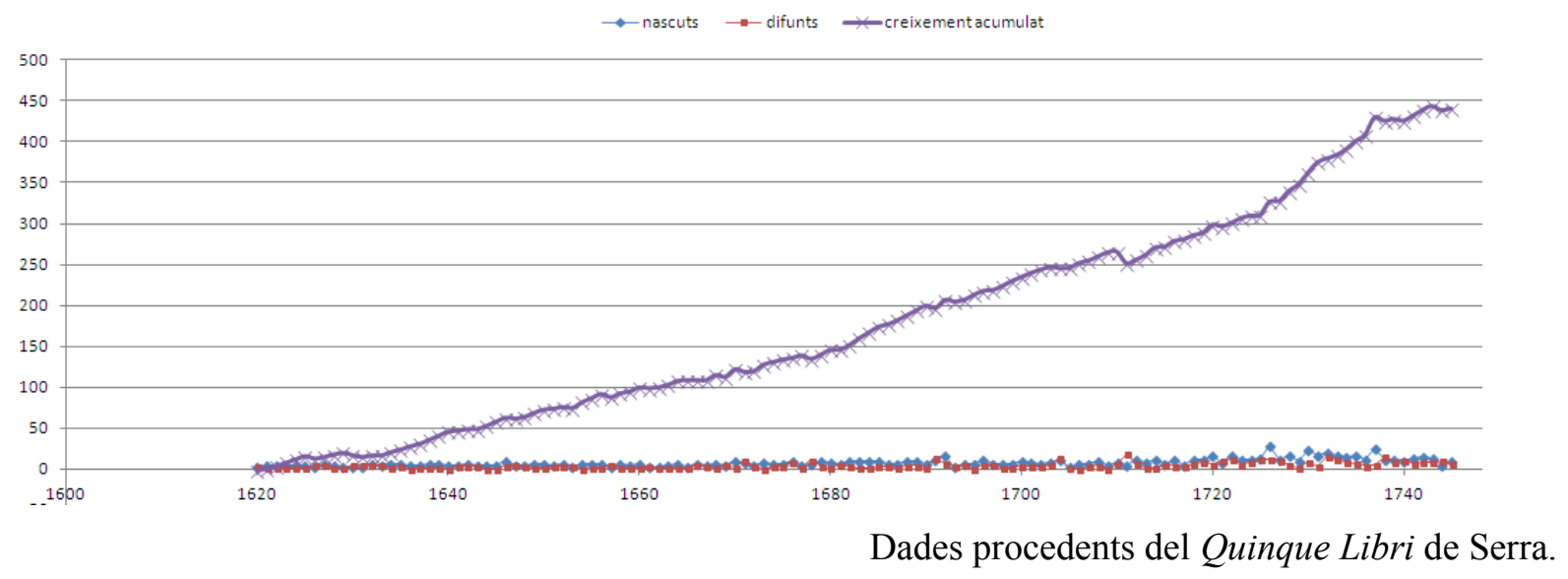

Una gran part dels difunts d'aquest període -especialment en el segle XVII- son "albats", o siga, xiquets que moren abans d'entrar en l'edat de raó; en molts casos son nadons o bé xiquets/xiquetes de pocs anys o de mesos, però hi ha alguns "albats" que són realment xiquets més majors, posant edats de fins a 7 anys i més (i ha un d'11 anys); en l'altre extrem dels albats estan alguns acabats de nàixer, con el fill de Felicia Cabo i Josep Tomàs, que mor amb sa mare en 1671, durant el part. Però, a més dels albats també hi ha molts xiquets i xiquetes que moren en aquest segle.

Vist amb més detall, dels 291 difunts registrats en el primer volum del Quinque Libri de Serra (anys 1619-1708) més de la meitat, concretament 153, o siga, un $53 \%$ són xiquets de menys de 12 anys.

La FIGURA 4.12 permet visualitzar gràficament aquesta proporció, posant de relleu que hi ha anys de mortalitat infantil especialment crítics, com els 11 xiquets que moren en 1691 o els 8 de 1704. Però també a Nàquera podem observar per a aquest període altres anys crítics, com és 1644, amb 15 xiquets que moren, o també els 9 infants morts en 1682 o els 10 de 1697 (Lluch, 22002: 201 i ss.). No són anys coincidents entre Serra i Nàquera però són dades que fan pensar en causes epidèmiques. Amb un major deteniment i una acurada anàlisi basada en l'estudi del Quinque Libri de Serra, Ferran Martínez Navarro (1976) va publicar un interessant i precursor article sobre aquest tema i per al període de 1620 a 1679. En un article més recent (Martínez Navarro, 2013) estén aquest estudi per al període de 1609 a 1759 introduint diversos aspectes de repoblament $\mathrm{i}$ migracions, a més de l'anàlisi de les dades de natalitat, nupcialitat i mortalitat. Manuel 
Ardit (1993, vol. I: 62 i ss.) apuntava que els quocients de mortalitat infantil i juvenil trobats a Serra per Martínez (136 per mil a 0 anys i 106 per mil a l'interval 1-4 anys) eren una mica més baixos que els trobats, també al segle XVII, a Pedralba (Casey, 1979), però majors que els observats a Guadalest (Pla, 1983), sent tots ells, no obstant, inferiors als calculats per ell al marquesat de Llombai, però encara molt més baixos, tots ells, que els descrits per al segle XVIII. Desprès d'exposar i comentar altres dades sobre l'esperança de vida, entén que hi ha divergències degudes a les diferents metodologies i la diversitat de les mostres, trobant, no obstant, una major coherència en els estudis més recents, com els de Bernat (1990).

FIGURA 4.12.- comparació de la mortalitat infantil a Serra, entre 1619 i 1708, front a la resta de defuncions.

adifunts adults $\quad$ difunts infants

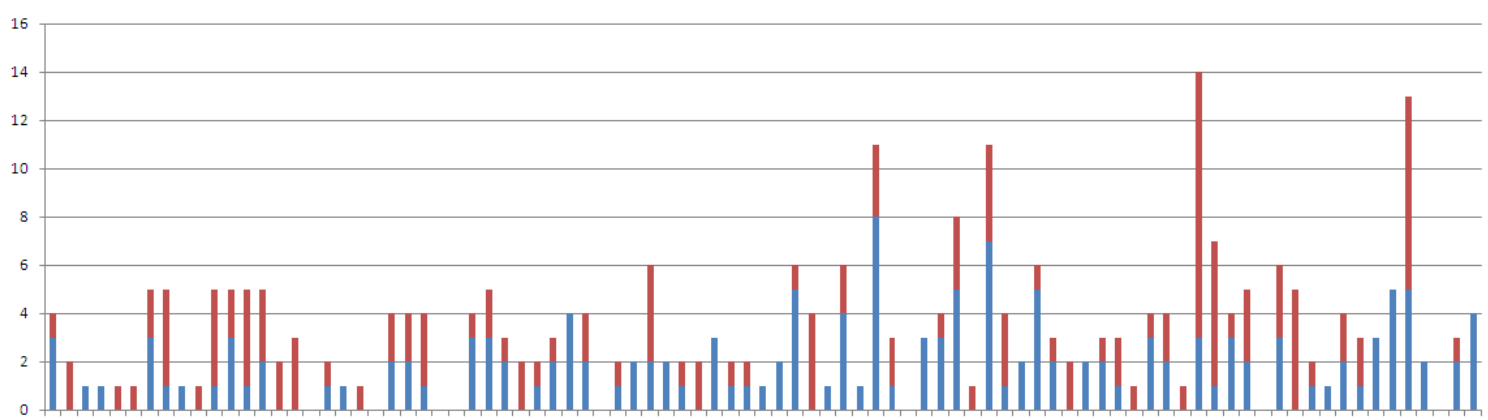

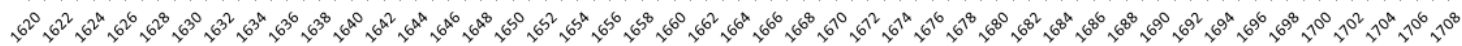

Dades tretes del primer volum del Quinque Libri de Serra.

Per tal d'aprofundir un poc més en les causes i model de creixement demogràfic obtingut per a Serra (figura 4-9) resulta oportú observar com ha sigut en el mateix període l'evolució de les taxes de natalitat (TN) i les de mortalitat (TM) per a diferents èpoques. Recordem que aquestes taxes representen el nombre de naixements $\mathrm{i}$ de defuncions, respectivament, al cap d'un any i per cada mil habitats. Cal conèixer, per tant, el balanç anual de naixements i de defuncions (generalment se solen utilitzar-se valors mitjans) tenint també en compte la població del moment. La FIGURA 4.13 mostra com han evolucionat, aproximadament, aquests índexs en comparació amb la gràfica evolutiva de la població de Serra, ara expressada en habitants (no veïns) i havent afegit, respecte a la figura 4-10, un cens més recent de la població: el de l'any 1930 (1468 
habitants), en ser un valor que ens interessa completar per a una millor perspectiva del procés demogràfic.

FIGURA 4.13.- comparació entre la corba demogràfica (en negre) i l'evolució de taxes de natalitat (TN, quadrats verds) i de mortlitat (TM, triangles rojos). L'escala esquerra indica el nombre d'habitants i la de la dreta la "taxa anual" de nascuts o morts per cada miler d'habitants.

- habitants $=\square=$ TN $= \pm-$ TM Polinómica (habitants)

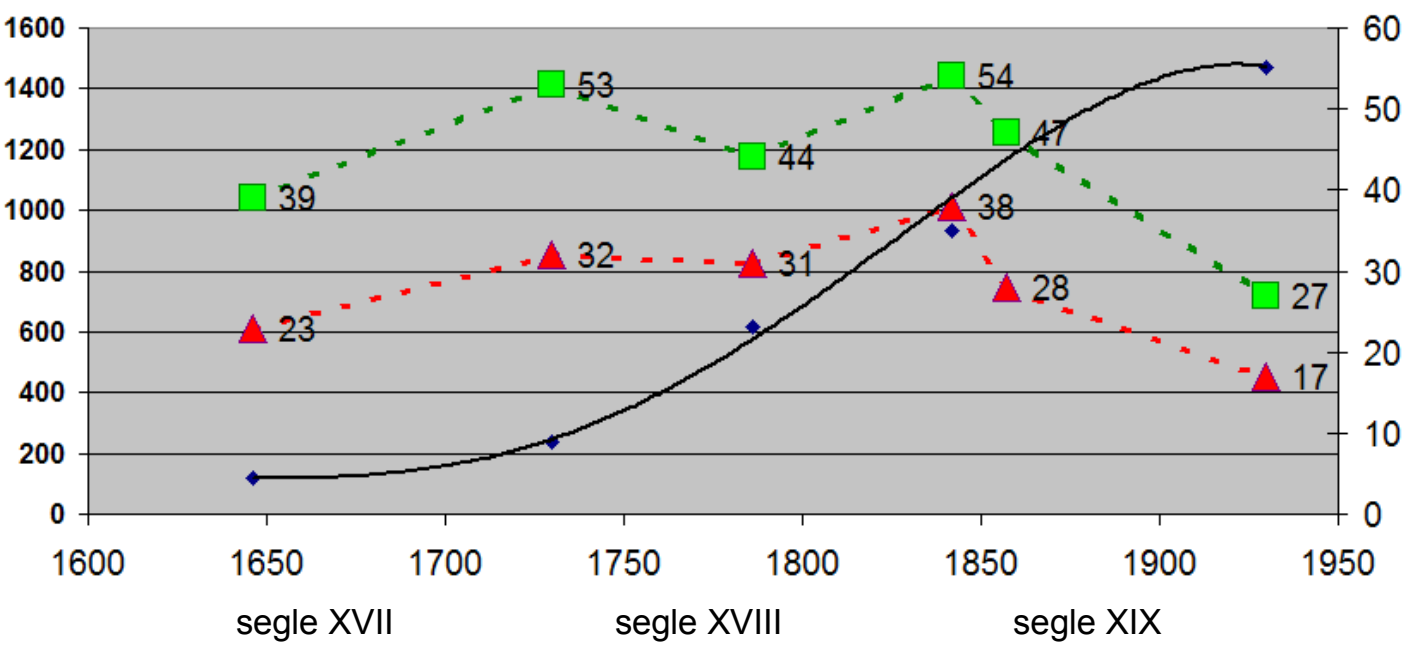

Taxes del segle XVII segons Martínez (1973); la resta d'elaboració pròpia.

La teoria de la transició demogràfica de Warren Thompson (1929) va donar explicació satisfactòria a aquesta mena de processos demogràfics en que, a major escala, es passa d'una societat preindustrial, amb un creixement demogràfic lent, a una societat postindustrial, de creixement també moderat, però tenint pel mig una llarga fase de creixement exponencial de la població. En aquesta teoria, els valors de TN i TM de la societat preindustrial són relativament alts, mentre que en la fase final acaben fent-se notablement menors (baixa considerablement tant la $\mathrm{TN}$ com la $\mathrm{TM}$ ) però, en el cas de la $\mathrm{TM}$ se passa per un ràpid i progressiu descens de pendent contrària a la del creixement demogràfic. En eixe cas, el desplegament poblacional es produeix quasi de manera proporcional a la davallada de la TM.

En el cas de Serra (figura 4-13) observem que açò no és exactament així, sinó que les taxes TN i TM semblen seguir pujant al llarg dels segles XVII i XVIII, al temps que 
està creixent exponencialment la població. I no serà fins arribar a la meitat del segle XIX quan comencen a baixar quasi en picat les dues taxes.

La conseqüència que traiem d'açò no és altra que demostrar que el increment poblacional de Serra al llarg dels segles XVIII i primera meitat del XIX no és producte d'un augment merament vegetatiu a causa de la disminució de la taxa de mortalitat, com passava en el model de Thompson, sinó que hauria d'haver altres factors o causes.

El més evident i plausible d'aquests factors és (com veurem millor en el capítol següent) que hi havia una forta demanda de mà d'obra per al conreu agrícola $\mathrm{i}$ també per a la potencialitat del forest (llenya, carbó, fusta...) i altres aprofitaments de recursos naturals, com era el cas de la distribució i venda d'aigua, ja destacada per Cavanilles (1795-97). A més a més, hi havia una bona oferta d'immobles, tal com s'ha posat de manifest més amunt, en parlar del capbreu de 1779. El resultat de tot açò va ser una migració lenta però sostinguda de persones procedents de pobles i ciutats no massa llunyans (Sogorb, “Algímia de Torres Torres”, Segart, Olocau, Montcada, Alfara del Patriarca, València...), les quals treballen i acaben quedant-se a Serra, adquirint terres, artigant i transformant el territori, treballant de jornalers i de criats també, casant-se amb serranes i establint-se finalment a la baronia. Entre aquests nous serrans arribaren, en els anys que indiquem entre parèntesi, els primers Fabregat (1713), els Iranzo i els Ximeno/Gimeno (1723), Escrig (1733), Martínez (1748), Melià (1754), molts altres que ja hem citat anteriorment i altres també que, complementàriament, hi trobem també citats per Ferran Martínez (2013). 


\section{CAPÍTOL 5}

\section{RECURSOS NATURALS: APROFITAMENTS I PRODUCCIONS AGRÀRIES}

Els recursos naturals de Serra podem dir que són comuns als de tota la serra Calderona i són majoritàriament agraris: una basta extensió muntanyenca i forestal, combinada amb nombrosos espais artigats i guanyats per a l'agricultura de secà i, en mig de tot açò, les hortes, relativament abundants però ocupant espais confinats i generalment poc extensos. I tot açò controlat per uns trets geològics molt peculiars: gran diversitat de roques, estructures geològiques complexes $\mathrm{i}$ grans contrasts entre materials de baixa $\mathrm{i}$ d'alta permeabilitat; ingredients tots ells idonis per a la proliferació de fonts. I aquesta és una clau per entendre el passat: una trentena de fonts d'aigua repartides pel terme de la baronia de Serra la feren especialment atractiva per als antics pobladors, en contrast amb altres terres, molt més planes però amb escassesa de recursos hídrics més enllà de les aigües dels aljubs.

Així ho entén també Ferran Zurriaga (2007) quan resumint el seu llibre "Olocau, cau de somnis", publicat en 2003, i referint-se a l'extensa plana del camp de Túria i els peus de munt i glacis de la serra Calderona, escriu: "Moltes vegades ens preguntem per què la nostra gent, tenint a quatre passes aquells plans ara tan vius, van quedar-se en aquest trencall de costeres i penyals. Solament una cosa ho justifica: l'aigua. S'hi van quedar perquè ací hi havia les fonts".

\subsection{RECURSOS HÍDRICS: AIGUA I NEU}

Si avui les nombroses fonts de Serra estan entre els principals atractius de l'excursionisme i del turisme de natura, en el passat eren elements fonamentals de subsistència i de riquesa per a les persones que cada dia havien de desplaçar-se per tot arreu del terme, durant hores, per arribar als seus camps i als seus punts de treball, molts dels quals eren o depenien directament dels cabals d'aigua. I és que les fonts de Serra sempre han sigut per als serrans un gran motiu d'orgull, per haver sigut històricament la base d'un important ofici tradicional: el dels aiguaders, intensament practicat al llarg dels 
segles i encara recordat vivament en moltes famílies que fins als anys setanta del segle XX el practicaven (Santamarina i Bodí, 2014). Per la seua qualitat i frescor va ser sempre molt coneguda i estimada l'aigua de la font del Llentiscle, de la que ja trobem referències de comercialització en el segle XVIII.

En paraules de Cavanilles (1795-98): "La fuente del Lentisco... se halla en un sitio hondo respecto á los altos picos que la cercan, cuyas cuestas rápidas solamente pesentan derrumbaderos y peñas desnudas. Por la raíz de un humilde cerro y entre cantos calizos sumamente áridos sale un hilito de agua, que apenas llega á quatro líneas de diámetro durante los calores: es cristalina, pura y excelente, y por tanto estimada en la capital, donde la venden los de Serra". També Castelló (en Castañeda y Alcover, 1916-24) hi parlava d'aquest ofici cap a 1783: “Metida en estos montes se halla una fuente llamada del Lentisco, de singular calidad. Conducen su agua a cargas... a Valencia".

L'èxit de les aigües de Serra es trobava en la seua salubritat -i així les recomanaven els metges- front a les aigües de pous $\mathrm{i}$ sèquies que consumien habitualment els habitants de la ciutat i pobles de l'Horta de València, que eren causa freqüent de malalties i de trastorns gastrointestinals, de vegades severs i fatals. Això explica també que diàriament portaven a València "centenares de cántaros de las ricas aguas de las fuentes de Serra" (Sarthou, 1918). En 1895, a València es pagava el cànter d'aigua de Serra a 30 cèntims, i tant les característiques organolèptiques com les anàlisis demostraven que eren aigües infinitament superiors a les de València (diari Las Provincias, de 21/10/1895).

També han sigut sempre les fonts de Serra punts estratègics d'aiguada per als desplaçaments, però especialment per als grans desplaçaments de ramats transhumants $i$ dels animals de càrrega, formant aleshores part, com a punts d'aiguada i abeuradors, de la xarxa de vies pecuàries de Serra, com són les que va classificar l'ordre publicada en el DOGV núm. 797 , de data 6/04/1988, que es basada en documentació molt més antiga. ${ }^{1}$

Però, evidentment, les fonts que presentaven cabals més abundants i constants foren les triades per als principals desenvolupaments agrícoles de regadiu, formant-se

\footnotetext{
${ }^{1}$ La documentació custodiada en la Conselleria de Medi Ambient sobre aquest expedient de classificació de vies pecuàries (iniciat a 1973) recull una transcripció de l'acta d'amollonament i delimitació d'abeuradors, assagadors i passos de ramat del terme municipal de Serra, corresponent a l'any 1850, en la qual es descriuen els mollons que, a partir de la font de la Prunera delimitaven la "brevada" reservada per als ramats del terme. En un altre expedient, de 1907 (AHN, Mesta, lg. 865/12) són ratificats els drets dels ramaders front a un ús particular que s'havia fet de la font de la Prunera.
} 
així les principals hortes i els assentaments humans. Així ho testimonien jaciments arqueològics d'època romana al voltant de les fonts de l'Horta del Molí i de la Misèria (segons Cebrián i Lluch, citats per Senís, 1954), com també a l'entorn de Ria; mentre que les principals i més extenses hortes (Ria i Tòixima, Ombria, Mugró, Misèria i Deula...) les trobem sempre lligades al voltant dels principals assentaments d'època andalusina. De la superfície regada i de la distribució i l'evolució parcel·lària en parlarem en un apartat posterior.

També en parlarem desprès de la neu i del seu aprofitament comercial, especialment en els segles XVII i XVIII, tant per part de Portaceli, on va ser una activitat econòmica important, com a Serra, on hi hagueren intents i experiències més modestes.

\subsubsection{L'abundància i diversitat de fonts}

La diversitat de litologies i la complexitat geològica del terme de Serra fa que abunden les fonts (pels freqüents contrasts entre roques permeables i impermeables) i que a més presenten certa variabilitat d'aqüífers: gresos o rodeno, dolomies triàsiques, calcàries juràssiques, guixos... Cadascun amb aigües de diferent grau de mineralització $i$ de fàcies hdroquímica (Garay, 2001). Això explica que algunes fonts foren tradicionalment diferenciades $\mathrm{i}$ assenyalades per les seues virtuts i propietats, indicades per a determinats tractaments $\mathrm{i}$ usos terapèutics. L'aigua del Llentiscle ha sigut tradicionalment recomanada per a la gana (reconstituent) i per al mal de fetge, la del Berro per al ronyó i la de l'Ombria per al sucre en sang; per només posar tres exemples coneguts d'aigües tradicionalment destinades al comerç d'aigua de beguda.

Sense pretendre haver fet un inventari exhaustiu de totes les fonts (tasca certament complexa), en una primera relació trobem no menys d'una trentena dins l'actual terme municipal de Serra; algunes perennes i cabaloses i altres més pobres i encara temporals. Una tercera part d'aquestes es troben ubicades dins del que fou terme del priorat de Portaceli; concretament serien les de l'Abella, el Berro, Dolça (a la Pobleta), la Gota, el Marge, el Molí (a la Pobleta), el Naixement (també coneguda com de l'Olla o la Mina), el Poll, el Sargatillo i Valòria.

Dins el terme de l'antiga baronia de Serra hi havia, almenys, les següents: Alcalà, Botrino, el Capellà, Deula (antigament Lèdua), l'Horteta, l'Horta del Molí, el Llentiscle, el Manyo, de Marianet (o del Molí), la Misèria (o de Santiago), del Mugró, l’Ombria, el 
Paellero, el Pardo, el Pedregal, el Poble (o de la Verge dels Àngels, a sovint referida com "fuente del Lugar" en documentació antiga), Potrillos, la Prunera, el Sabater, la Salut (o Barranquet), de Sant Antoni, de Sola, de Valero (o dels Valeros), de Xarxant...

Moltes d'aquestes fonts sofriren transformacions al llarg dels temps, bé millorant o bé empitjorant els seus cabals. Un exemple de la dificultat del inventari el trobem en la fonteta de Valòria, a l'est del monestir de Portaceli. La trobem ja documentada al segle XV quan només era un punt humit on els frares de Portaceli van excavar un pou artesà per a rec (Ribes, 1998). En els anys 30 del segle XX es va construir una galeria per conduir la seua aigua fins al Sanatori de Portaceli, però actualment només observen les restes d'una galeria subterrània seca i inactiva.

També va ser modificada la font del Capellà, al sud i a prop de Serra, avui impossible d'ubicar perquè el seu cabal va ser conduït quasi un quilòmetre fins al Llavadoret, al qual abasteix. Tanmateix es troben pràcticament desaparegudes les fontetes del Pardo (dins el barranc del Llentiscle) i de Xarxant (a la partida homònima), la primera substituïda per un pouet i la segona seca des de la construcció dels pous de Nostra Senyora dels Àngels (en els anys 60 i 80 del segle XX).

Moltes vegades hem escoltat dir, bé a gent major de Serra o als seus descendents, que les fonts de Serra eren més cabaloses fa molts anys. Considere adient aclarir que açò pot ser una mera apreciació subjectiva i parcial no exempta de certs matisos. Per una banda cal avançar que hi hagué molts casos de manipulació dels naixements d'aigua, dels què parlarem desprès, i per altra, cal dir que no és necessari al·ludir a suposades grans variacions pluviomètriques entre el passat recent i el present, sinó que es tractaria, sobre tot, d'un notable canvi de la cobertura vegetal, doncs fins al primer terç o la primera meitat del segle XX encara eren intensos els aprofitaments forestals (fusta, fornilla, carbó, margalló, espart, pastura...) i, amb bon criteri hidrogeològic, això repercutia en una major infiltració eficaç de l'aigua de pluja. Per contra, en l'estat actual predomina una densa coberta vegetal que ocasiona una major retenció (intercepció) de la pluja i les consegüents pèrdues i retorns cap a l'atmosfera (evaporació i evapotranspiració), en detriment del volum d'aigua que finalment s'infiltra per a recarregar les fonts. 


\subsubsection{Quimera per l'aigua, pèrdua de cabals i conflictes hídrics}

Per tal de possibilitar i afavorir la càrrega i aprofitament de les aigües de les fonts sempre s'han fet obres de millora i condicionament. Però, a més d'això, trobem que en totes les èpoques ha hagut preocupació i interès per augmentar els cabals naturals de moltes fonts o per captar suposats rius subterranis que, en opinió dels saurins només esperaven la construcció del pou o galeria que els fera aflorar. Concretament a Portaceli i ja des del segle XIV en trobem casos d'excavacions de pous i de galeries excavats sense èxit per indicació de saurins molt convençut però que finalment eren considerats com a farsants (Ribes, 1998; Garay, 2004). Així, l'any 1595 intentaren traure més aigua de la font del Marge "por la relación de algunos zahories", però l'única cosa que van aconseguir desprès de molts jornals va ser destrossar les calderes que els frares tenien per a escalfar l'aigua de rentar-se la roba, calderes que gastaren per a extraure "el cieno $i$ arena de la cava"; per tant, sabem que "la cava" o galeria de la font del Marge ja existia i que només intentaren aprofundir-la, sense èxit. També en la font de l'Abella van fer-se excavacions semblants en els anys 1425, 1607 i 1719. Moltes altres fonts de Serra també van ser excavades amb intenció de guanyar cabal (generalment sense massa èxit). La font de Mugró és un element històric interessant (un qanat andalusí completament inundat), com també ho és la font de l'Ombria (amb obres dels anys 30 del segle passat) o la de la Misèria, que també té una curta galeria.

Els anys 40 del segle XX també van ser protagonistes de certa ànsia per millorar els cabals de les fonts mitjançant obres d'excavació que, en contra del previst van causar minves importants i encara pèrdues inesperades. Concretament, al voltant de 1944 es van obres en la font de la Salut sense cap èxit, però no contents, una dècada desprès realitzaren una perforació per damunt de la font, amb tan mala fortuna que primer l'assecaren (potser travessaren el nivell impermeable que la mantenia) i desprès hagueren d'abandonar el sondeig per haver-se quedat bloquejada la barrena de perforació. També en els anys 40, unes obres municipals perderen bona part del cabal de la font del Poble, però amb la sort de que pogueren finalment recuperar-lo, almenys en una bona part. No va passar el mateix en la font del Llentiscle, en que les excavacions fetes a principis dels anys 50 per indicació d'un saurí (un tal "don Santiago") acabaren per reduir el cabal de la font. I així, per a desgràcia de tots, la que havia sigut en segles la font més famosa de Serra és avui una fonteta més, de pobre cabal. També es va perdre, transitòriament, el 
cabal de la font d'Alcalà, a principis dels 40, durant les obres de millora de la captació que servia (i encara serveix) per a abastir d'aigua a Torres Torres. ${ }^{2}$

En els anys centrals del segle XIX hi hagué alguns plets sobre drets d'aigua i excavacions o minats per buscar-la. Es tracta d'una època on es donen moltes iniciatives consegüents al procés d'abolició de l'antic règim. A més d'altres casos d'excavacions mineres, de les que parlarem desprès, trobem una paralització d'obres ordenada per l'Ajuntament de Serra contra els veïns José Navarro i Antonio Pérez, que en 1848 excavaven buscant aigua en terrenys de la seua propietat i partida del barranc de Deula; la paralització es va ordenar per por a que poguera afectar a "la fuente del pueblo?. Per la mateixa època i prop de l'anterior punt hi havia un altre assumpte judicial pendent, entre Vicenta Gimeno (dona de l'anterior, Antonio Pérez) i els regants de l'horta de l'Armelar, sobre una excavació o minat que aquesta havia fet buscant aigua ${ }^{4}$. També pel mateix temps, Francisco Arnal, propietari del molí de Marianet, mantenia un plet d'aigües amb els regants de l'Horteta, per l'assumpte dels torns i drets d'aprofitaments d'un naixement d'aigua que ell havia excavat en 1816, en terreny propi (sembla que en propietat de Vicente Tomás, amb consentiment), al temps que va construir també un molí fariner de dos moles, en el seu terreny i reconeixent el Domini major i pagament del cens, que li corresponia aleshores al Reial Patrimoni ${ }^{5}$.

\subsubsection{El negoci de la neu a Portaceli}

Pels annals de Portaceli $^{6}$ sabem que el monestir cartoixà va participar molt activament en el negoci de la neu i que ja en l'any 1594 es va començar a refredar aigua per a consum dels frares. La primera nevera o pou de neu que construïren sembla que va ser la de Tristany (al terme de Sogorb però molt a prop del priorat), en l'any 1624, però pocs anys desprès en construïren moltes més. La major concentració de neveres $\mathrm{i}$ ventisquers es trobava al sector de la Bellida (terme de Sacañet) on els cartoixans, tant els de Portaceli com els de Valdecrist (Altura) i encara d'Arachristi (El Puig), entre els segles XVII i XVIII arribaren a posar en marxa i regentar al voltant d'una cinquantena de neveres i ventisquers. A més de les neveres de la Bellida i la de Tristany, els monjos de

\footnotetext{
${ }^{2}$ Informacions orals de Ricardo Navarro Navarro i Ricardo Cabo de Nicasio, dos experts serrans.

${ }^{3}$ ADPV, sg. E.3.1., c-86, exp. 1615

${ }^{4}$ ADPV, sg. E.3.1., c-87, exp. 1629

${ }^{5}$ ADPV, sg. E.3.1., c-82, exp. 1491

${ }^{6} \mathrm{M}^{\mathrm{a}}$ Estrella Ribes (1998): Los Anales de la cartuja de Porta-Coeli. Inst. Alfons el Magnànim.
} 
Portaceli manaren construir el ventisquer de Rebalsadors (FIGURA 5.1) i encara un altre menor al Coll de la Moreria; tots dos en el propi terme del Priorat, si bé el primer molt a prop del que era el terme de la baronia de Serra.

FIGURA 5.1.- Ventisquer de Rebalsadors, construir junt al terme de la baronia de Serra.

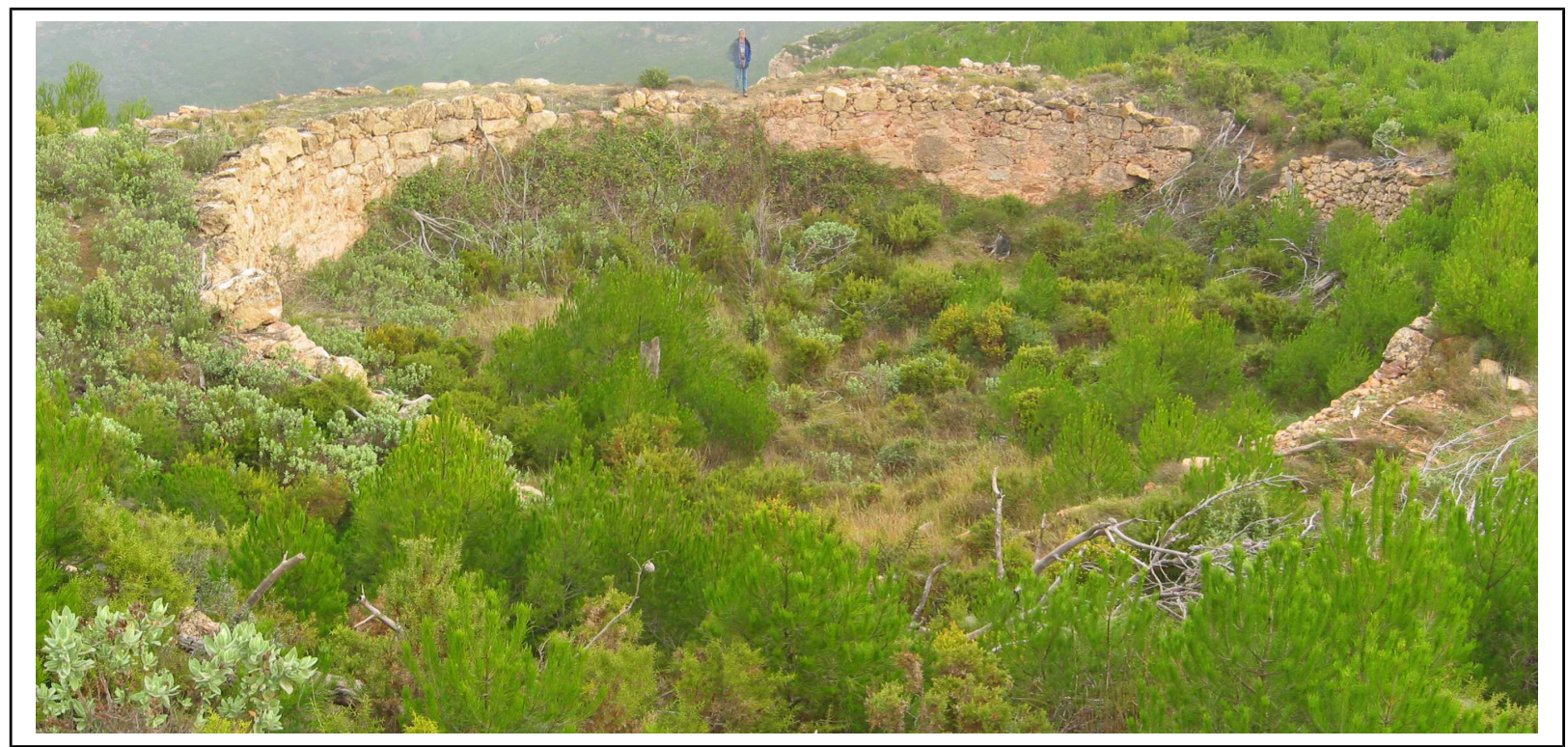

Fotografia de l'autor.

El ventisquer de Rebalsadors va ser construït l'any 1706. Era particularment important $\mathrm{i}$ estratègic per al monestir per dues raons; la primera és que quedava molt a prop d'ell i la segona era que disposar d'una extensa superfície annexa (tot el pla dels Rebalsadors, si bé bona part d'ell pertanyia a la baronia de Serra) de la qual podien recollir gran quantitat de neu en cada nevada. Va ser utilitzat, almenys, fins el primer terç del segle XIX coincidint amb l'exclaustració forçosa dels cartoixans.

Entre els segles XVI i XIX, quan nevava a la Bellida es posaven ràpidament en marxa les quadrilles d'homes que pujaven des d'Alcubles, Llíria i altres pobles amb cabassos, pales i rastells per a recollir la neu i dipositar-la en els ventisquers i els pous de neu, on anava sent compactada per altres jornalers. Durant tres o quatre dies treballaven incansablement, primer recollint $\mathrm{i}$ compactant tota la neu que es podia, i desprès cobrintla amb palla i fusta, de manera que poguera aguantar molt de temps gelada. L'altra part important d'aquesta indústria era la dels arriers que poc a poc anaven baixant la neu cap a 
València i altres poblacions, on es consumia sobre tot en estiu. El portal de Quart era la porta d'entrada $\mathrm{i}$ de tributació de les càrregues de neu que arribaven a la ciutat de València (Cruz i Segura, 1996). ${ }^{7}$

Per la particular proximitat del Ventisquer dels Rebalsadors a Serra, i per l'experiència que demostraren tindre molts serrans en aquest ofici, podem suposar que almenys una bona part dels jornalers recollidors de neu que hi treballaven ací quan era la temporada procedira de Serra, a més dels criats del monestir (sempre presents) i eventuals jornalers d'altres llocs de les rodalies. És cert, no obstant, que a sovint, els frares no gestionaven directament el negoci, sinó que encarregaven aquestes tasques als "arrendadors de la neu".

\subsubsection{L'experiència de comerç de neu a Serra}

Els frares de Portaceli arribaren a controlar la major part del negoci de la neu a València, mentre que per als serrans, que veien de prop el negoci i el potencial que tenien alguns sectors del terme de la baronia, les possibilitats de construir una nevera o participar d'alguna altra manera en el negoci de la neu depenien, o bé directament del Senyor territorial -que era qui podia tindre suficients recursos i poder per a fer-ho- o bé indirectament del mateix senyor, que com a amo jurisdiccional tenia la facultat de poder sentenciar sobre qualsevol plantejament o proposta feta pels seus vassalls, malgrat no ser ni l'aigua ni la neu productes o recursos regulats en la carta pobla. Així i tot, si finalment el Duc de Montellano (senyor de Serra) accedia a consentir que es fera, hauria de ser sota certs pactes i condicions.

Una experiència molt interessant sobre aprofitament de neu a Serra procedeix de l'any 1799. En aquella època (darreres dècades del segle XVIII) els serrans estaven intensament dedicats a la construcció de l'actual temple parroquial, i per a tal finalitat dedicaven molts esforços i recursos: per una banda el treball voluntari (mà d'obra), però també col·lectes, almoines, donació parcial de collites, criança de cucs de seda, etc. En el llibre de comptes de fàbrica, el retor Francesc Tormo exposa el balanç d'entrades i despeses relacionades amb les obres de construcció del temple, i en referir-se al citat any diu: "Son cargo setenta libras de nieve que en un domingo el Lugar recogió a favor de la fábrica (de l'esglèsia) para el Abastecedor de Valencia". Desprès, entre les despeses

\footnotetext{
${ }^{7}$ En 1658 , la càrrega de neu tributava 8 reals en dit portal.
} 
(Descargo) indica: "ocho libras con dieciseis sueldos importaron las calderas de comida que el dia que se recogió la nieve se hicieron en los Rebalsadores, para todos". ${ }^{8}$

$\mathrm{O}$ siga, que la recollida de neu aquell diumenge, que podem suposar en els primers mesos de l'any 1799, es va convertir en una concentració multitudinària de persones i en una gran festa (diverses calderes de menjar per a tots). Pràcticament aniria tot el poble (8 lliures i 16 sous pagats per a fer les calderes de menjar) i podem entendre que treballaren amb eficiència i interès, ja que el benefici econòmic obtingut d'aquella venda de neu, directament feta als abastidors de València, va ser considerable (la respectable quantitat de 70 lliures). El lloc de la concentració i de la festa va ser el Pla dels Rebalsadors, en la part oriental pertanyent a Serra, ja que la part més occidental (on es troba el Ventisquer) pertanyia a Portaceli. És obvi que era un lloc idoni per a la recollida de la neu si es té en compte la seua gran extensió en pla i el fet de ser un dels sectors més alts del terme municipal de Serra.

Per fer-se'n una idea del que representaven aquelles 70 lliures dins el volum anual dels recursos per a la construcció de l'església, podem comparar-les amb les altres entrades monetàries que es produïren aquell mateix any (QUADRE 5.1).

QUADRE 5.1.- Ingressos que tingué Serra destinats a la fäbrica de l'església, en 1799.

\begin{tabular}{|l|l|r|}
\hline Primeramente: & Por la nieve que en un domingo el lugar recogió... & $70 \mathrm{~L} 00 \mathrm{~s} 00 \mathrm{~d}$ \\
\hline Más: & Por el vino que se vendió del año pasado... & $14 \mathrm{~L} 10 \mathrm{~s} 00 \mathrm{~d}$ \\
\hline Más: & Por un legado que dejó Francisco Puig “el tio Santo”... & $5 \mathrm{~L} 00 \mathrm{~s} 00 \mathrm{~d}$ \\
\hline Más: & De los higos del año pasado 1798... & $33 \mathrm{~L} 08 \mathrm{~s} 09 \mathrm{~d}$ \\
\hline Más: & De la seda de este año... & $25 \mathrm{~L} 01 \mathrm{~s} 04 \mathrm{~d}$ \\
\hline Más: & De la limosna del trigo... & $29 \mathrm{~L} 13 \mathrm{~s} 10 \mathrm{~d}$ \\
\hline Más: & De la limosna de los higos, en dinero... & $01 \mathrm{~L} 17 \mathrm{~s} 04 \mathrm{~d}$ \\
\hline Más: & De la limosna de pan en el horno & $08 \mathrm{~L}, 01 \mathrm{~s} 02 \mathrm{~d}$ \\
\hline Más: & .. Se ha sacado, con permiso y licencia... & 231 L $00 \mathrm{~s} 00 \mathrm{~d}$ \\
\hline TOTAL & Suma el cargo en este año (1799)...: & $11 \mathrm{~s} 07 \mathrm{~d}$ \\
\hline
\end{tabular}

Quantitats expressades en lliures, sous i diners. Font: APS, Llibre de fàbrica.

El mateix rector Tormo reporta la notícia de la primera casa d'ensenyament que es va habilitar en el poble de Serra per a les xiquetes ${ }^{9}$. Degué fer-se al poc de començar el segle XIX, i per a fer-la, el retor va aconseguir restaurar una antiga casa inhabitable i mig

${ }^{8}$ A.P.S., "Llibre de comptes de la fàbrica de l'esglèsia de Serra", fetes pel rector Francisco Tormo, en 1806.

${ }^{9}$ Ibídem. 
enrunada, que havia sigut Casa de l'Ajuntament i també presó, emprant-les després com a magatzem de la fusta emprada per a la construcció de l'església. Per a rehabilitar aquesta casa i convertir-la en la primera escola de xiquetes, el rector va disposar de les 100 lliures que el Duc de Montellano (Alonso Alejo de Solís) li havia avançat per a una altra finalitat: la construcció d'un pou de neu. No sabem els detalls de com se les va enginyar el retor per a canviar el destí dels diners, ni tampoc quina seria la reacció del Senyor, però el cas és que ho va fer i va deixar constància del fet en el llibre de comptes de la fàbrica de l'església.

Entenem que les 100 lliures aportades pel duc de Montellano només començar el segle XIX i per a la construcció d'un pou de neu degué de ser conseqüència d'alguna iniciativa i petició al respecte desprès de l'experiència viscuda pels serrans en 1799. Era evident que disposar d'un pou de neu o un ventisquer dins el terme de la baronia havia de reportar grans beneficis. Podem suposar que, com era habitual en altres obres, aquelles 100 lliures podrien servir per pagar materials i un mestre d'obres per dissenyar el projecte i dirigir els treballs, mentre que la ma d'obra per a la construcció del pou de neu la posarien els veïns pel seu compte, tot $\mathrm{i}$ això sense entrar en altres condicions $\mathrm{i}$ possibles càrregues censals. Però la proposta, després d'haver rebut aquells diners, seria finalment rebutjada pel poble i pel seu alcalde. El rector Tormo ho explica així: "más sucedió que al recibir la gracia o donación de dicha montaña, se les ponía un censo ánuo de 4 libras al Lugar, cuya gracia, con este cargo o censo no quiso admitir Francisco Navarro Michavila, alcalde, ni los demás que componían el Ayuntamiento... desaire que manifestó sentir mucho el Duque".

Deduïm que el duc havia concedit el terreny (una muntanya) però a canvi d'un cens que als serrans els degué de parèixer excessiu tenint en compte que les nevades no responien a un fenomen regular i garantit ("any de neus any de bens") sinó més bé hiperanual (Cruz i Segura, 1996). Per altra part, la proposta feta al duc sembla que estaria clarament referida a un emplaçament concret i possiblement era ja per a completar una obra que ja hauria estat iniciada. No hem trobat més documentació sobre aquest projecte però si evidències de camp que indiquen que el lloc triat no estaria als Rebalsadors, sinó al pla de la Moleta, que té associat un topònim molt expressiu: l'Alt de la Nevera.

Mig ocultes per la vegetació arbustiva i quasi tancant una petita depressió o capçalera de barranc que es situa en aquest pla de la Moleta i justament al SSO del cim (l'Alt de la Nevera, $737 \mathrm{~m}$. d'altitud i junt al molló trifini) podem veure un acopi de 
pedra en forma de mitja lluna que, més que un ventisquer enderrocat sembla un intent avortat de fer-ne un seguint el model del de Rebalsadors. Junt a ell hi ha també les restes d'una caseta de pedra que per la seua ubicació, mida i característiques bé podria ser un petit refugi o una caseta d'eines possiblement lligada a dita obra.

\subsection{MOLINS EN EL TERME DE LA BARONIA DE SERRA}

Quan Jaume I fa la primera donació de Serra (castrum et villam d'Axerra cum alqueriis sibi pertinentibus...) al cavaller Berenguer Burguet, reté per a si la potestat dels drets de pau i de guerra i exclou també de la donació, expressament, els forns i molins (furnis et molendinis). Això vol dir que molt probablement hi haguera més d'un molí, malgrat que en segles posteriors trobem de vegades (per exemple quan les preses de possessió de 1650 i de 1713) referències al molí de la baronia, com si només hi haguera un. També la carta-pobla de 1609 en parla, en el seu capítol 13: "sots la mateixa pena haguem i hagen de moldre en lo molí de la Senyoria, donant al dit molí bon recapte...".

A penes un quilòmetre al sud de la població de Serra hi ha una partida de nom força expressiu: “l'Horta del Molí”, i està també la font homònima que la rega. Aquest topònim fa suposar que en algun temps pogué haver-hi allà un molí. La bassa existent $\mathrm{i}$ el fort desnivell, amb un ribàs alt i robust, fan molt factible aquesta possibilitat. No obstant, no hem trobat cap evidència documental concreta al respecte. D'haver existit un molí en aquell lloc pensem que seria anterior o coetani a la conquesta cristiana. En tot cas, aquesta horta no trobem que puga tindre cap relació funcional ni hidrològica amb el molí de la Baronia que queda ubicat en una altra vessant i a més d'un quilòmetre de distància, estant alimentat per un altre sistema hidràulic.

En canvi, a banda del molí de la Baronia, hem conegut en funcionament fins als anys quaranta del segle XX un segon molí fariner (desprès convertit en una petita fàbrica de llum) en les proximitats de la font de Marianet, al nord-nord-oest de Ria. Hem dit abans que aquest molí, que mantenia un plet amb els regants cap a 1850, hauria estat construït cap a 1816 per Francesc Arnal, , amb llicència del Domini major (aleshores del Reial patrimoni). ${ }^{10}$

Aquest molí movia amb una bassa que encara existeix, pràcticament sense ús, però que tenia dret de dues hora i mitja de reg a la setmana, procedent de la font de

${ }^{10}$ ADPV, sg. E.3.1., c-82, exp. 1491 
Marianet. Actualment ja no existeix l'edifici que albergava al molí, però era la "casa núm. 1" de la fotografia adjunta (FIGURA 5.2).

FIGURA 5.2.- Molí de Marianet (annex a l'esquerra de la Casa $\mathrm{n}^{\circ} 1$, en els anys 60, poc abans del ser enderrocats la casa i el molí; avui segueix en peu la Casa $\mathrm{n}^{\circ} 2$.

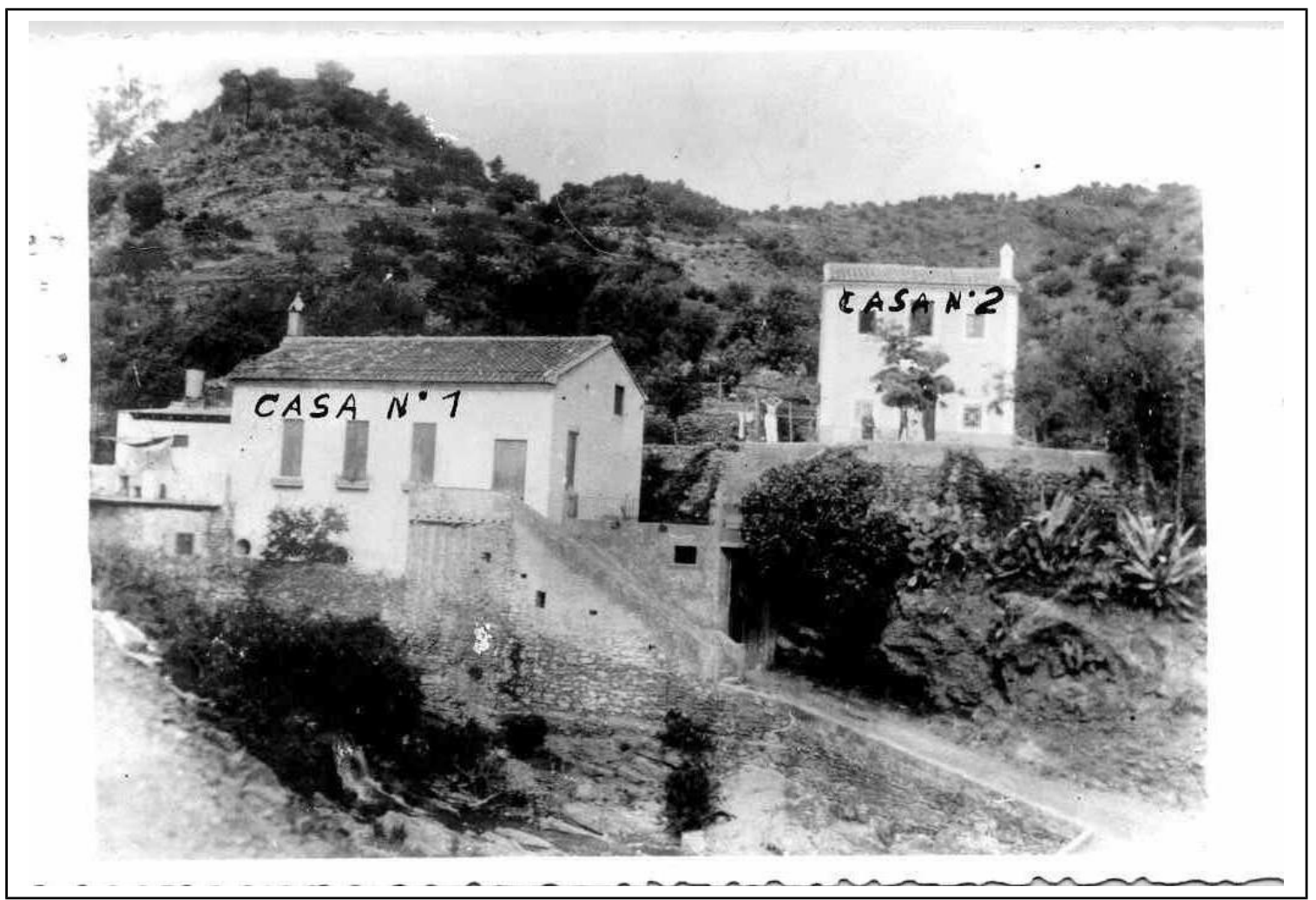

Foto cedida per Carles Tamarit, actual propietari.

El cens de molins de la província de València de l'any 1847 (Ferri, 2000) recull la notícia de que a Serra hi havia dos molins, tots dos de bassa. Curiosament, també indica que ni Nàquera, ni Olocau ni Segart tenen cap molí, però si en tenia Marines (vall d'Olocau), concretament un molí de bassa propietat del comte d'Olocau. Per altra part, si que tenien molins Estivella ( 2 o 3 molins de dues moles que treballaven de 3 a 6 mesos a l'any) i Torres Torres (dos molins senzills que abastien al poble i que només treballaven sis mesos), moguts tots ells per les aigües derivades des del riu Palància. Tampoc hi consta que hi hagués cap molí a Bétera, que pertanyia al "partit de Montcada", població que si disposava d'un gran molí mogut per la sèquia del mateix nom. 
Pel que fa al molí de la baronia, hem identificat clarament les seues restes molt prop del barranc Major i de la confluència d'aquest amb el barranc de Clara (FIGURA $5.3)$.

És obvi que entre els dos molins declarats a Serra en 1847 no estaven els molins de Portaceli, malgrat que el terme del priorat ja formava oficialment part del de Serra des de feia un decenni , almenys. Possiblement no hi hagués en aquell moment cap molí de la part de Portaceli en funcionament, però, històricament en troben sempre citats almenys un molí a la Pobleta i altres prop del monestir. Concretament coneixem la bassa dels Molinets (Garay, 2004), que queda situada prop de l'aqüeducte i és alimentada amb la mateixa font que abasteix a aquests. Del molí fariner de la Pobleta trobem encara restes de l'antic pòrtic de l'edifici, amb l'any 1790 gravat, i una mola disposada en forma de taula junt a l'antic dau (FIGURA 5.4), on una petita cascada d'aigua procedent de l'antiga bassa del molí (i de la "font del Molí") va incrustant-ho tot, formant una estructura travertínica.

FIGURA 5.3.- Restes del Molí de la baronia de Serra, ocult per la vegetació junt a l'actual col-lector d'aigües residuals. A la part superior la sala de moltura i baix la cacau, per on tornaven les aigües al sistema de reg.

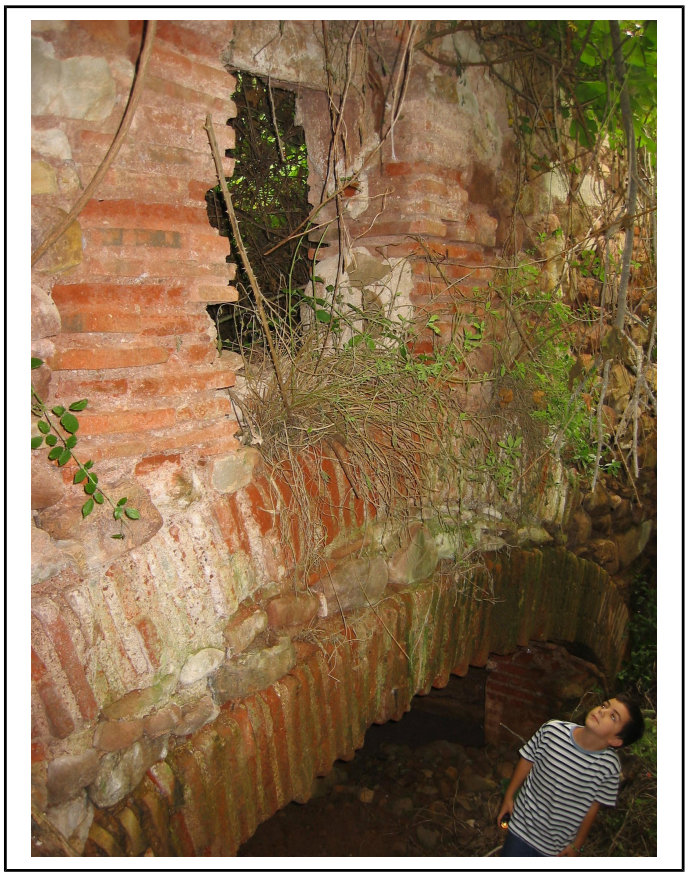

Fotografia de l'autor. 
FIGURA 5.4.- Restes del molí de la Pobleta.

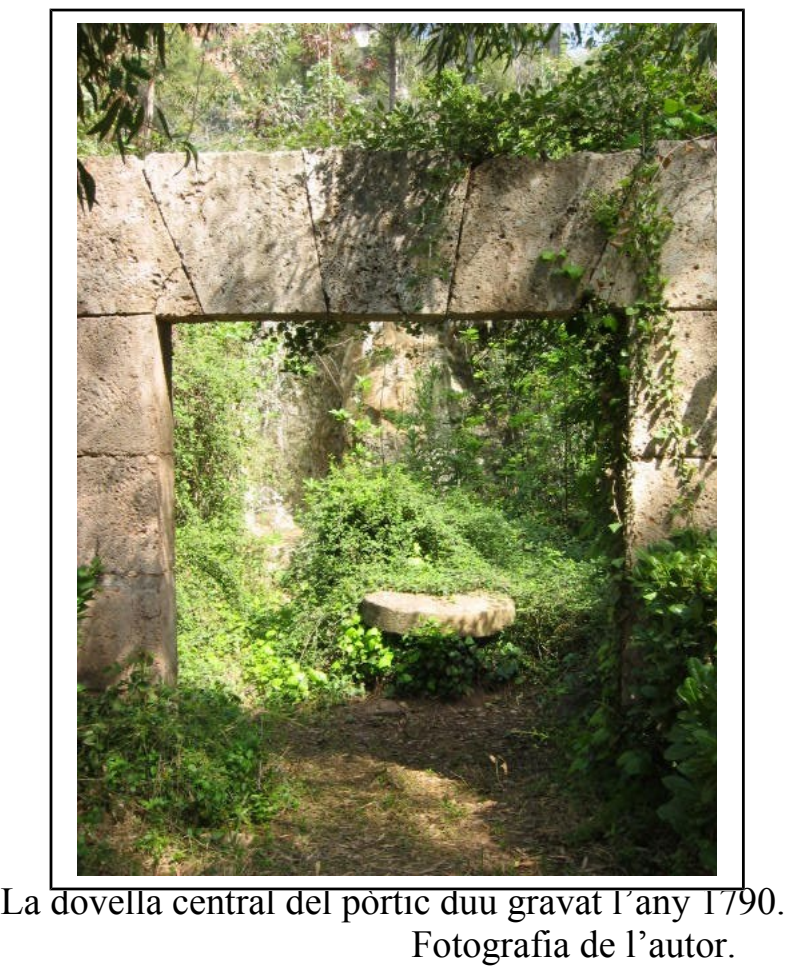

\subsection{CARBÓ, CARBONERS I LLENYES BAIXES}

La llenya i el carbó eren la principal font d'energia més enllà de la força animal i els elements hidràulics (molins, batans, serradors...) i la seua procedència era principalment les forests que envoltaven la ciutat de València i la seu Horta. Segons Halperin Donghi (1980: 19) la franja boscosa de la forest valenciana, entre les hortes i la ratlla de Castella, s'estrenyia cada vegada més per les tallades arbòries indiscriminades ja patides en el segle XVI. La causa d'aquestes tallades estava en la gran demanda de fusta i de llenya que generava una gran ciutat com València, en el consum de les indústries (entre elles les de ceràmica de Paterna o Manises) i els enginys del sucre (més centrats a la comarca de La Safor) amb els insaciables forns dels seus trapijos. El combustible era bé la llenya cremada directament (en els punts de consum) o bé transformada prèviament en carbó. Per això, diu, que recorrien els boscos valencians carboners que arrendaven als senyors el dret de posar forn (carbonera) i tallar en un determinat pinar o carrascal, citant com a exemple un grup de biscaïns que a principis de 1609 ja s'havien establert a Iàtova per a fabricar carbó.

A les muntanyes de Portaceli també hi hagueren carboners biscaïns com és el cas, que ja vaig citar en el capítol tercer, de Guillem Atxarte "biscaí de nació" a qui els frares de Portaceli vengueren per preu de 420 lliures, per a fer carbó, la part del pinar que queda 
"des del barranquet de l'Algepsar fins a una senda que va al camí de València" (Tarín i Juaneda, 1897: 131). Realment va ser el carboner qui cobrà del monestir les 420 lliures a canvi de tot el carbó que faria en aquell pinar, en el que havia de deixar "llança i dard" (entenem que no es tractava d'eliminar el pinar en si, sinó de deixar-lo net de llenya).

En el cas de la baronia de Serra és evident que el carboneig ja era una pràctica habitual en època morisca. Així s'infereix del fet de que la carta pobla de 1609, en el seu capítol desè (dret del carbó) contemplara "que dits vassalls puguen fer carbó en lo terme de dita baronia, de llentiscle, rabasses $i$ altres mates i no d'arbres alguns, pagant al dit senyor un sou per cada càrrega gran $i$ sis diners per cada càrrega xiqueta de "jumenc $o$ asnet”. Es tracta d'un preu prou més elevat que els dos diners per càrrega que pagaven al voltant de l'any 1571 els moriscos d'aquestes baronies al seu senyor en Ferran, l'avi d'en Josep Folch de Cardona, si bé altres vegades seria una partició, una càrrega de cada vuit, el que havien de pagar-li al senyor (Iquino, 1982: 42).

La referència d'aquesta taxa del carbó la coneixem perquè aquell mateix any, Ferran Folch de Cardona havia rellevat d'aquesta paga als seus vassalls durant els quatre anys de termini que duraria la venda que acabava de fer de tots els pins dels seus llocs a llurs jurats i universitats, per preu de 240 lliures cada dos anys (Iquino, op. cit.). No sabem cert el destí dels pins venuts en aquells primers anys setanta del segle XVI, però no sembla que anaren destinats a fer carbó, sinó més bé a l'aprofitament de la fusta. En tot cas, tant de les condicions que posen al biscaí Atxarte els frares de Portaceli, com de les pròpies condicions de la Carta Pobla de Serra, podem deduir que el carboneig que es practicava a la zona no era un carboneig arrabassador d'arbres, sinó que aprofitava únicament branques baixes (de pi i carrasca) i sembla que tot tipus de matollar (potser amb rabasses) i sotabosc llenyer. Així ho entén també Tarín i Juaneda (1797: 131) quan explica que els arbres per a fusta del pinar de Portaceli eren aprofitats per a la construcció, practicant-se la tallada amb prudent economia i sent destinats al carboneig el brancatge i els troncs inútils.

Desprès d'allò que hem comentat en el capítol tercer, sobre la notable presència de biscaïns a Serra durant la primera meitat (i encara més) del segle XVII, no tenim gran dubte en afirmar que aquestes persones es dedicaven principalment al carboneig, i així ho constatem en diversos protocols notarials de Joan Font (APCC), notari de Serra en la primera meitat del segle XVII. Hem trobat també en aquests protocols que Joan Baptista Donya, el Batlle de Serra, és un comerciant de València, del barri de Morvedre, dedicat 
especialment al comerç del carbó, ajudat pel seu fill, de igual nom i que viu a Serra. I encara descobrim també que el propi notari Joan Font, que és veí del mateix barri de València, també té terres a Serra, on es desplaça amb certa freqüència per a atendre assumptes de la baronia però sobre tot als seus clients serrans en les transaccions comercials que realitzen, així com en designació de procuradors o en disposicions testamentàries, entre altres actes del seu ofici.

Entre les raons del per què d'aquestes onades de biscains hi trobem especialment dues; per una banda, tant Biscaia com Guipúscoa, d'acord amb els nivells econòmics de l'època, estaven a la vora de la superpoblació i aquesta era la principal raó del corrent migratori que els dirigia cap a altres punts de la Península i també de les Índies (Domínguez Ortiz, 1962); i per altra part, en aquest procés cap obstacle jurídic s'oposava, doncs els monarques reconegueren la pretensió dels biscaïns de gaudir en tots els regnes hispànics dels privilegis de la fidalguia sense més prova que la de ser originaris d'aquella província i tindre en ella solar conegut. ${ }^{11}$

Afermar aquest "solar conegut" dels biscaïns bé podria ser un dels motius pels quals solien tornar periòdicament al seu territori d'origen, a més de dur una part dels guanys que feien fora de casa, tal com feien molts dels francesos que en aquells temps treballaven a terres andaluses i que cada quatre anys repatriaven cap a la seua terra els diners que estalviaven. Solien tornar als seus llocs d'origen agrupats en quadrilles per a millor protegir-se dels lladres i ajudar-se, en cas de necessitat. Desprès solien tornar, molts d'ells, metamorfoseats com si foren peregrins, entrant a la Península pel camí de Santiago (Eiras Roel, 1993: 214).

En setembre de 1620, el carboner biscaí Joan GraciaTey (Graciategui?), resident a Serra (i suposadament emparentat amb Cristòfol Graciategui, un altre dels biscaïns de Serra que coneixem pel capítol tercer), li ven a Joan Baptista Donya, agricultor i habitant de València, tot el carbó que farà de la llenya que té feta "en el present terme de Serra $\mathrm{i}$ en el terme de Portaceli" per preu de 57 sous la càrrega. ${ }^{12}$

Pocs mesos abans, el mateix Graciategui "biscaí resident a Serra" havia tancat una altra operació semblant amb Baptista Donya, agricultor de Serra (fill de l'anterior), per 20 lliures, corresponents al lloguer per a fer carbó, del pinar d'Antoni Massó,

\footnotetext{
${ }^{11}$ Així queda reflectit en el llibre sobre "el fur, privilegis, franqueses i llibertats dels cavallers fidalgs de la senyoria de Biscaia” (publicació de 1643). La fidalguia universal va ser més fàcil d'aconseguir per als biscains que no per als guipuscoans, malgrat que els fonaments d'ambdós eren els mateixos.

${ }^{12}$ APCC, 21045, (dia 13.09.1620).
} 
procurador general d'en Josep Folch de Cardona, pinar situat entre "la font dita de Malraig (sic., per Barraix) i la Foia de Riha”. Precisament, aquest enclavament es correspon amb un curiós topònim: la partida coneguda com Cara-sol del Biscaí (ara sabem qui era realment aquell biscaí). Per altra part, sabíem també que Antoni Massó, el procurador de Josep Folch de Cardona va ser batlle de Soneixa, però ara també sabem que posseïa almenys una propietat al terme de la baronia de Serra; un pinar, suposadament en franca propietat, doncs sabem, pel testament de Jerònima Llull que aquest home va rebre d'en Josep, en atenció als seus serveis, vàries propietats franques.

En tot cas, aquestes dues operacions mercantils de Graciategui donen idea de la bona capacitat de treball d'aquest biscaí i del considerable benefici econòmic obtingut en elles. Podem pressuposar, però, que no treballara a soles, sinó que disposara o formara part d'un equip o quadrilla.

A l'esmentat Joan Baptiste Donya (habitador a Serra) o bé son pare, Joan Donya (habitador a València), junt amb Pere Joan Salvaterra, un llister que també viu a València, els trobem individual o conjuntament en negocis de compra de carbó, no solament fet en el terme de Serra sinó també en altres llocs; nogensmenys, els fabricants de carbó amb el que tracten són sempre biscaïns. En aquest cas trobem, per exemple, a Joan Chavoyen, carboner biscaí del lloc de Turís, que fa dos lliuraments de carbó a Salvaterra, la primera per import de 110 lliures (el 26 de febrer de 1631) i la segona per altres 100 lliures (el 9 de març següent), totes dues pel “compotum de l'estall del carbó que fes en lo pinar del terme de Turís". ${ }^{13}$

Francesc Ibáñez, carboner de Serra i Patrici de Vergara, ciutadà de València, també carboner, venen 335 còvens de carbó, el dia 10 de febrer de l'any 1631, a Joan Donya, agricultor i a Pere Joan Salvaterra, llister, ambdós habitadors de València, pel preu de 100 lliures. ${ }^{14}$

Només dos dies desprès, Joan Tulaius menor, carboner biscaí, habitador de la vila de Llíria i Martí Plaça, carboner de València, aquest actuant com administrador del biscaí Pere Lisaralde (segons poder notarial aportat) li venen a Pere Joan Salvaterra i a Joan Donya, 50 còvens de carbó de "pi carrasco" a raó de 29 "dracmas besicorum" cada “còven", que serien entregats "el dia primer del juliol pròxim vinent". ${ }^{15}$

\footnotetext{
${ }^{13}$ APCC, 20584, (data: 26.02 i 9.03 de 1631).

${ }^{14}$ APCC, 20584, (data: 10.02.1631)

${ }^{15}$ APCC, 20584, (data: 12.02.1631)
} 
Aquestes operacions, en un espai tan curt de temps, venen a indicar que la capacitat del negoci del carbó que controlaven Donya i Salvaterra era certament important en volum. A més a més hi ha un detall que crida prou l'atenció, com és que el negoci es trobava situat fora de les portes de la ciutat de València, concretament junt al carrer de Sagunt, parròquia del Salvador, on sabem que Donya tenia la seua residència, segons consta en inscripcions del Quinque Libri de Serra, on la seua filla, Joana Vicenta s'havia casat amb Pere Navarro, en 1620, tenint a Serra la seua descendència.

En principi sembla que ni el carbó ni la llenya pagarien directament la cisa de pas que pagaven moltes altres mercaderies per entrar en la ciutat; potser no era un abast que entrara com a tal a la ciutat i de fet tampoc trobem ni carbó ni llenya en la tarifa dels preus de mercaderies per a la cobrança d'aquest tribu; encara que sí estaven, per exemple, les llistes de fusta: taules, taulons, jambes (xambies), etc. ${ }^{16}$

No obstant, la "Reial Crida i Edicte sobre les coses concernents al bé comú de la present Ciutat i Regne de València...” (de la que coneixem edicions dels anys 1572, $1585,1601,1628),{ }^{17}$ recull diverses disposicions sobre el comerç i venda de carbó:

a) Que los tenders que vulguen vendre carbó per menut hagen de comprar-lo obligatòriament en lo mercat de la ciutat i només una sàrria, no podent comprar una altra fins que s'acabe la primera, sots pena de perdre l'excés i multa de 60 sous.

b) El carbó no es podrà comprar pel carrer i caldrà deixar pas als traginers que el portaran fins al mercat, en lo lloc on se sol portar dins d'aquell. Que contravindrà perda el carbó i sota pena de 100 sous.

c) Les persones que porten carbó per a vendre, hagen de portar-lo sense mescla alguna, duent separats els diferents carbons, de carrasca, de llentiscle i de pi. I si són trobats mesclats seran confiscats i multat el infractor amb 20 sous.

Aquestes són disposicions que ens permeten entendre el caràcter de majoristes o emmagatzemadors de carbó que devien tindre Donya i Salvaterra, i com possiblement farien el paper d'abastadors del mercat de València.

Durant els segles següents encara continuà amb certa intensitat l'activitat carbonera que Cavanilles (1795-97: ep. 66), referint-se concretament a Serra anomena "industria de carbonear el monte", la qual produïa anualment 4.000 arroves de carbó.

\footnotetext{
16 "Tarifa dels preus i pesos de les mercaderies per a millor exacció i cobrança de la cisa de Pas que es col-lecta en les Taules de la Contribució de la present ciutat i llocs situats d'aquella" de 1671 (facsímil inclòs en Documents històrics valencians del segle XVII. Comerç, mesures i oficis. Ed. Ajuntament de València. Col·lecció 9 d'octubre, núm. 3. Any 1995).

${ }^{17}$ BHUV, Ms. 818, (Reials pragmàtiques): versió de 1601. També en facsímil. editat en 1993 per ParísValència (versió de 1572).
} 
Per altra part, ni el carbó ni la llenya hem trobat que foren productes sotmesos a contribucions eclesiàstiques (delmes i primícies...), com podrem comprovar en el capítol sisè. En canvi, en el cas de la llenya hem vist que es tracta d'un producte de primera necessitat que en alguna ocasió seria objecte d'incentius i facilitats per part de la Corona, per tal de garantir al Cap i Casal el subministrament de llenya que necessitaven els forns, tant els de pa com els de ceràmica, calcinals, algepsars, etc. que també abastien de materials de construcció a la ciutat de València. En aquest sentit es pronuncien les Reials Ordenances de Carlos III, de juny del 1760, que atorgaven els veïns i fabricants, tant de València com de la seua particular contribució, la facultat (prèvia autorització) de tallar llenya, traure pedra i fer algeps i calç. Entre 1771 i 1802 hi una gran quantitat d'expedients tramitats atenent les sol-licituds fetes al respecte, els qual són anomenats "Memoriales de Franqueza para cortar leña en los Montes Blancos", sèrie que custòdia l'AMV, leg. G (2 volums). ${ }^{18}$ Els sol-licitants solen ser de dos tipus: bé propietaris de forns, que són autoritzats per a fer llenya destinada al seu propi consum, o bé llenyaters que es dediquen a extraure la llenya de "montes blancos" i transportar-la amb els seus carros i animals de càrrega fins als llocs de demanda, on la venen directament als usuaris. La major part d'aquests darrers sol-licitants solen procedir de poblacions del cinturó de València, predominant els d'Aldàia, Alaquàs, Manises, Quart, Torrent, alguns de la ciutat de València i poc més; mentre que entre els primers, a banda dels propietaris de forns de coure pa propers a València, hi destaca certa quantitat de fabricants de calç veïns de Montcada, posant així de relleu que aquesta població (amb abundants forns de calç en el seu terme) era una mena d'abastidora principal de la calç que es consumia a València.

No hem trobat en aquesta sèrie de l'AMV serrans perquè el privilegi era per als ciutadans de València i la seua particular contribució. Però, no obstant, els subministraments de llenya per als forns de calç de Montcada el podem observar com a precursor del que encara es practicava en la primera meitat del segle XX, on l'activitat llenyera de les forests de Serra tenia com a principals consumidors i destins més recents els forns de calç de Godella (com abans són recordats també els de Montcada), a més de forns ceràmics de Manises i de Burjassot i molts altres de coure pa, tal com ha quedat àmpliament enregistrat en la memòria viva dels serrans (Santamarina i Bodí, 2014).

\footnotetext{
${ }^{18}$ AMV, leg. G (2 volums)
} 


\subsection{TERRES D'HORTA I TERRES DE SECÀ}

En referir-se a Serra, Cavanilles (1795-97) indica que naixen en el seu terme moltes fonts, totes elles pobres, però “con cuyas aguas riegan los de Serra 50 jornales de huerta". I afegeix que com tota aquesta horta està en les faldes que cauen cap als barrancs ha sigut precís posar-les en graderies assegurant els ribassos amb lledoners, tal com es practica també en la vall de Cofrents. També diu que, al mateix temps, les altes muntanyes que la defensen dels vents la converteixen en una "estufa natural" on els veïns cultiven préssecs, peres, prunes i cireres.

Si considerem que un jornal equival quasi a sis fanecades o poc menys de mitja hectàrea (segons el manual Pesas, Medidas y Monedas de la Direcció General d'Agricultura, publicat en 1930), estaríem parlant d'unes 25 hectàrees d'horta a la baronia de Serra, segons Cavanilles. No obstant, disposem per a contrastar aquesta xifra amb una altra font encara millor quantificada i detallada, com és la resultant d'una capbrevació manada fer en 1779 pel Duc de Montellano, de la qual (recollida com Annex II en aquesta memòria) tornarem a parlar-ne en posteriors ocasions. Aquest capbreu recull la relació de 177 persones que tributaven dins la baronia de Serra, a més de la casa Ajuntament, que també hi tributava amb el seu corresponent cens emfitèutic com a casa que era. D'aquestes 177 persones hi ha 44 que no tenien casa a Serra (o si la tenien no tributaven directament per ella), si bé, cal destacar que hi havia un gran excedent de cases (fins a 75) que en part podrien estar cedides o ocupades en arrendament.

La part que més ens interessa destacar ara d'aquell capbreu és que inclou el desglossament, parcel·la a parcel·la, tant de les terres d'horta com de les de secà que posseïa cada veí o contribuent. En total, la suma de parcel·les d'horta arriba fins a les 324 fanecades (la fanecada és la unitat de mesura d'horta que utilitza el capbreu) que, a un equivalent aproximat de 12 fanecades de cabuda per hectàrea fan gairebé 27 hectàrees, poc més per tant de les 25 anotades per Cavanilles.

El que pagaven els vassalls per aquestes propietats (domini útil) de regadiu eren els 10 sous, per cada cafissada d'horta de cens emfitèutic, establerts en el capítol sisè de la Carta Pobla de Serra. Si admetem que cada cafissada equival pràcticament a un jornal i que cada jornal té de cabuda unes sis fanecades, com hem dit adés, arribarem a que cada fanecada hauria de pagar 20 diners. De fet, és això el que paguen segons el capbreu: un sou i vuit diners (o siga, 20 diners). Això fa també evident la pràctica equivalència que havíem suposat entre cafissada i jornal i la seua cabuda de 6 fanecades. 
La gràfica adjunta (FIGURA 5.5) mostra la distribució de tot el conjunt de parcel·les en funció de la seua mida o cabuda i segons cadascuna de les propietats d'horta declarades al capbreu de Serra de 1779. Cal insistir en que la mesura bàsica és la fanecada, si bé s'utilitzen també la mitja fanecada i el quartó (un quart de fanecada). Tanmateix es veu que hi ha propietats que acumulen fins a 5 fanecades en una mateixa "finca". La suma total de la superfície d'horta així fiscalitzada resulta ser les 324 fanecades ja indicades (unes 26,93 hectàrees). Es comprova així la gran dispersió que es dona ja entre grans i petites propietats.

FIGURA 5.5.- Distribució per mides de les propietats d'horta en l'any 1779 (capbreu, recollit en l' Annex II), segons la seua cabuda i prenent com a unitat de mesura (abscisses) la fanecada d'horta (i el quartó, la mitja fanecada, tres quartons, etc.).

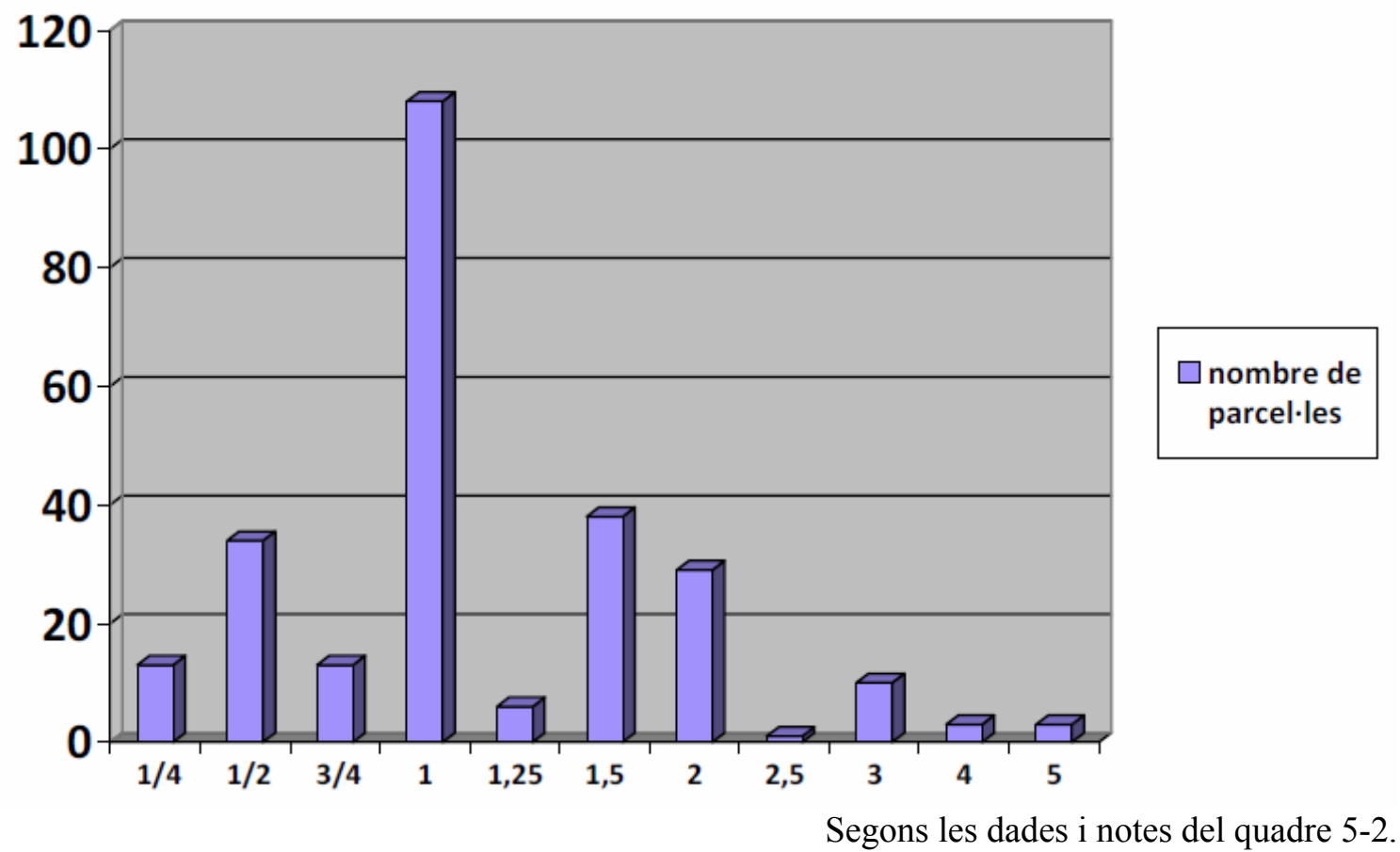

Les dades numèriques corresponents a les gràfiques adjuntes, tant l'anterior figura 5-5 com les següents (figures (figures 5-7 a 5-9) venen recollides en el quadre 5-2. Totes aquestes dades han sigut elaborades a partir de les diferents fitxes del capbreu de l'any 1779 (dades també recollides, amb més detall, en l'Annex II). En aquest capbreu es parla tant de veïns (el que tenen casa i estan reconeguts com a tals) com de terratinents, que són tots els que tenen terres a la baronia, encara que molts d'ells no són veïns. 
QUADRE 5-2.- Distribució de parcel·les d'horta i de secà segons la seua cabuda (mida) i distribució la superfície total (freqüència) que tenien els vassalls.

\begin{tabular}{|l|l|l|l|l|l|l|l|l|l|l|l|l|l|l|}
\hline MIDA: & $1 / 4$ & $1 / 2$ & $3 / 4$ & 1 & 1.25 & 1.50 & 2 & 2.50 & 3 & 4 & 5 & 6 & 7 & $>7$ \\
\hline $\begin{array}{l}\text { Horta } \\
\text { (fanecades) }\end{array}$ & 13 & 34 & 13 & 108 & 6 & 38 & 29 & 1 & 19 & 3 & 2 & - & - & - \\
\hline $\begin{array}{l}\text { Secà } \\
\text { (jornals) }\end{array}$ & 39 & 114 & - & 243 & - & 52 & 177 & 1 & 108 & 59 & 24 & 23 & 7 & 11 \\
\hline
\end{tabular}

\begin{tabular}{|l|c|c|c|c|c|c|c|}
\hline FREQÜĖNCIA: & no en tenen & $<1$ & 1 a 2 & $>2$ a 5 & $>5$ a 10 & $>10$ a 20 & més de 20 \\
\hline $\begin{array}{l}\text { Horta } \\
\text { (fanecades) }\end{array}$ & 45 & 17 & 69 & 36 & 9 & 3 & - \\
\hline $\begin{array}{l}\text { Secà } \\
\text { (jornals) }\end{array}$ & 7 & 4 & 22 & 40 & 38 & 45 & 20 \\
\hline
\end{tabular}

Dades basades en el capbreu de 1779 (Annex II).

Per veure quina repercussió té aquesta dispersió de mides de les parcel·les, grans i petites, respecte als veïns i terratinents (que hem anomenat conjuntament com vassalls), hem elaborat la següent gràfica (fFIGURA 5.6), on es veu que hi ha 45 persones que no tenen horta (una bona part d'ells tampoc tenen casa) i el que si tenen tots ells són terres de secà, en quantitats molt moderades. La major part dels veïns tenen entre una i dues fanecades d'horta, i encara fins a 5 fanecades, molts d'ells, mentre que són pocs els que s'han quedat amb una sola fanecada o en tenen més de cinc. Amb més de 5 hi ha 12 veïns, dels quals hi ha tres que tenen més de deu fanecades, concretament Domingo Esteve (en té 10 i mitja), Francesc Domènech (en té 11) i Blai Dasí (en té 11 i mitja).

Convé recordar que el punt de partida de tot açò va ser el repoblament de 1609 pels 30 repobladors que reberen -cal suposar- uns lots semblants de casa, més terres d'horta i terres de secà. Podem suposar que va ser així, doncs així queda expressat en el cas de Soneixa (capítol xxv de la carta pobla): el senyor repartiria una casa a cada vassall i les terres d'horta en proporció, a parts iguals entre ells (Rodríguez, 2009). 
FIGURA 5.6.- Distribució de les propietats d'horta en l'any 1779, segons la seua cabuda i prenent com a unitat de mesura (abscisses) la fanecada d'horta.

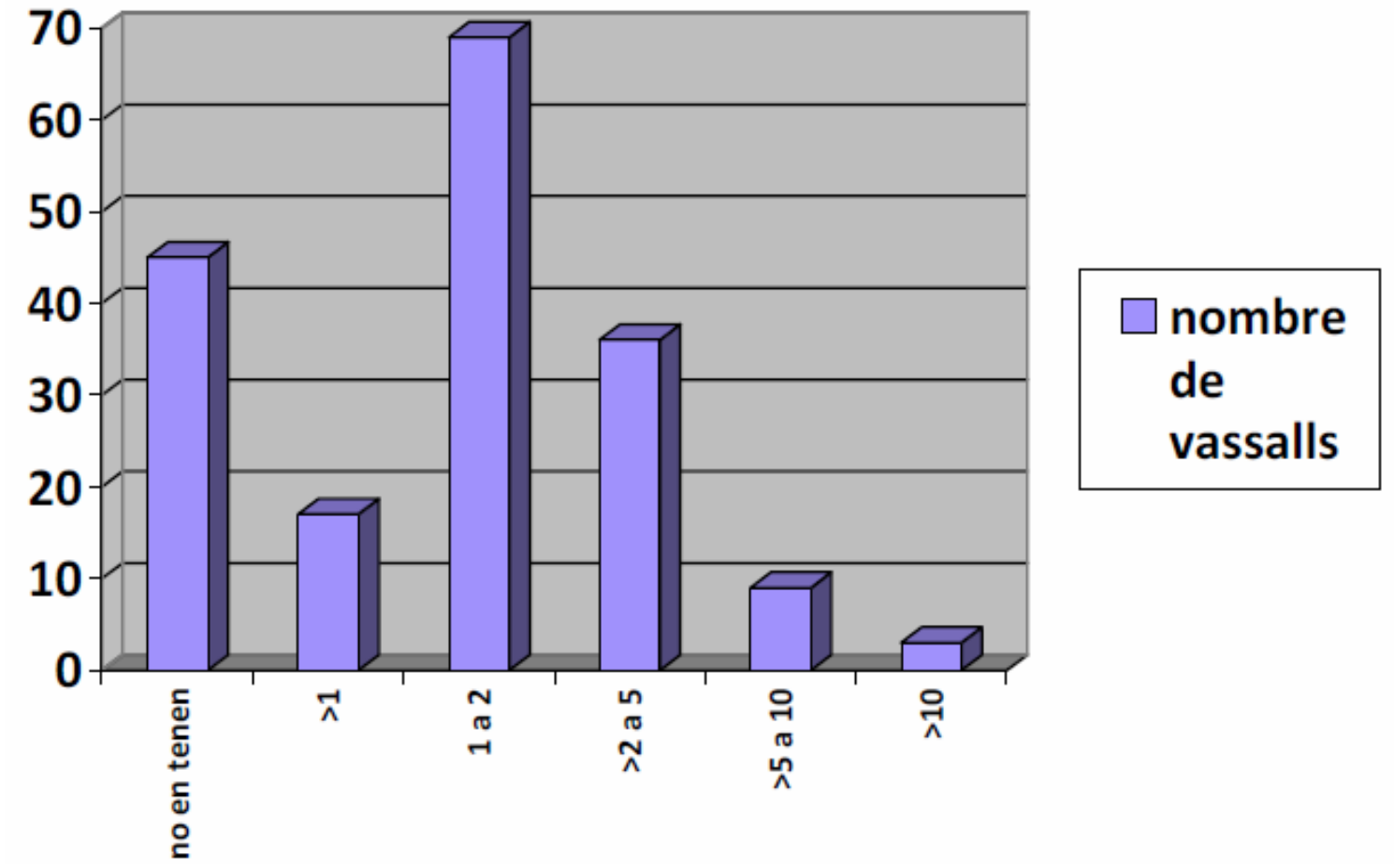

Segons les dades i notes del quadre 5.2.

Les FIGURES 5.7 i 5.8 mostren els mateix conceptes de les dues anteriors però referits ara al secà, tenint en compte ara que la unitat bàsica de mesura ja no és la fanecada sinó el jornal. Així, hom pot apreciar que també hi ha com a mesures freqüents el mig jornal i el quartó (ara quartó de jornal). Les acumulacions per a formar propietats o finques majors són més notables ara en el secà del que ho eren en les hortes. Finques de més de 5 jornals hi ha més de quaranta i, entre elles, hi ha 20 que tenen més de 20 jornals cadascuna. Amb aquestes xifres sembla evident que devia haver-hi jornalers, bé persones del poble o bé foranes (i fins i tot criats, potser) que ajudaren a llaurar, collir, segar, etc.

Els principals terratinents del secà, amb més de 30 jornals cadascú i per ordre creixent n'eren: Joaquim Arnal (30 jornals i un quartó), Vicent Arnal (31 jornals i un quartó), Roc Domènec (32 jornals), Blai Dasí (35 jornals), Francesc Navarro (38 jornals) i, amb molta més diferència, Joan Baptista Navarro ( 63 jornals). 
FIGURA 5.7.- Distribució de les propietats de secà en l'any 1779, segons la seua cabuda i prenent com a unitat de mesura (abscisses) la el jornal de secà.

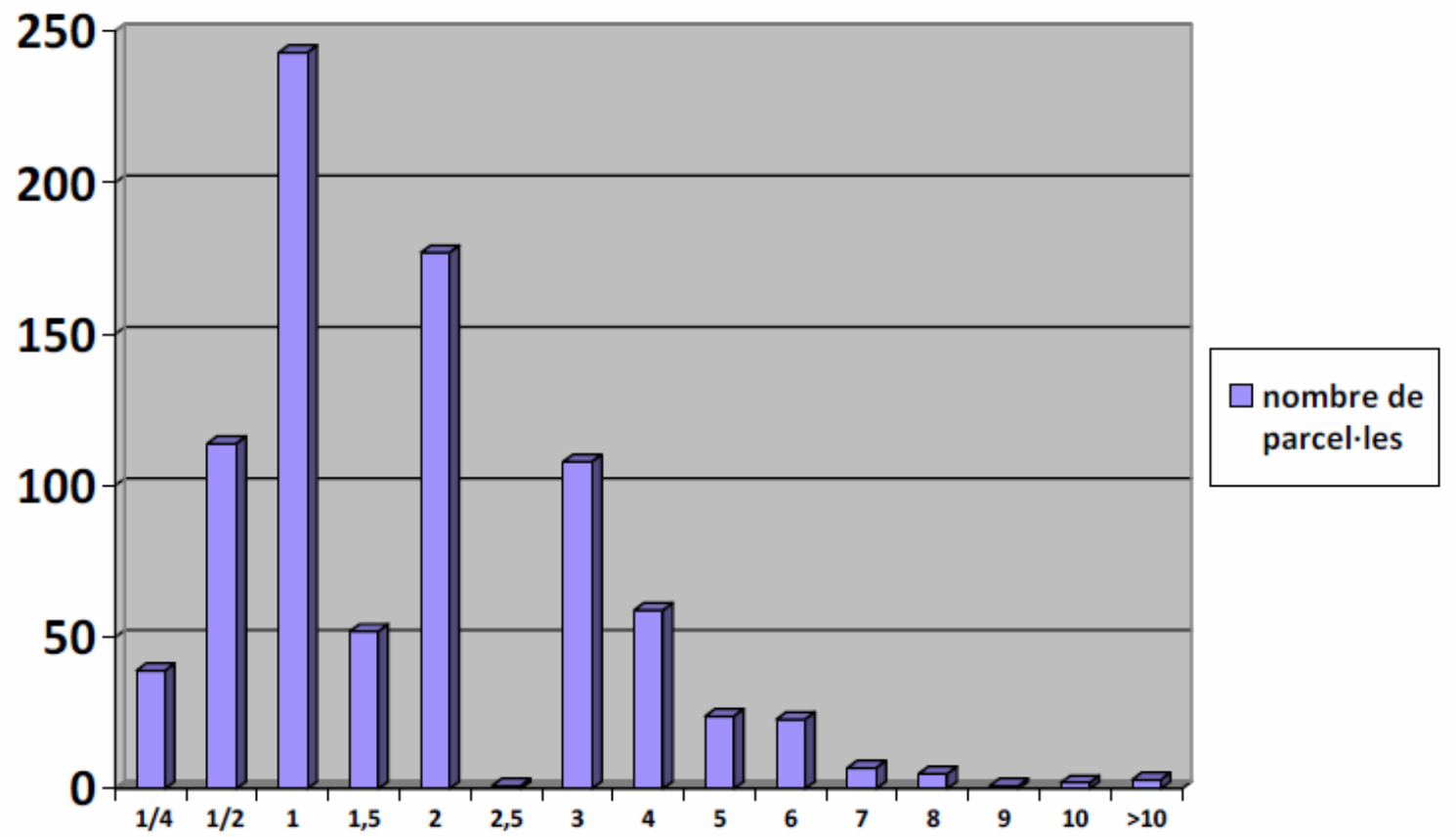

Segons les dades i notes del quadre 5.2.

FIGURA 5.8.- Distribució de tota la superfície de secà (expressada en jornals) entre les veïns o contribuents de la baronia de Serra segons el capbreu de 1779.

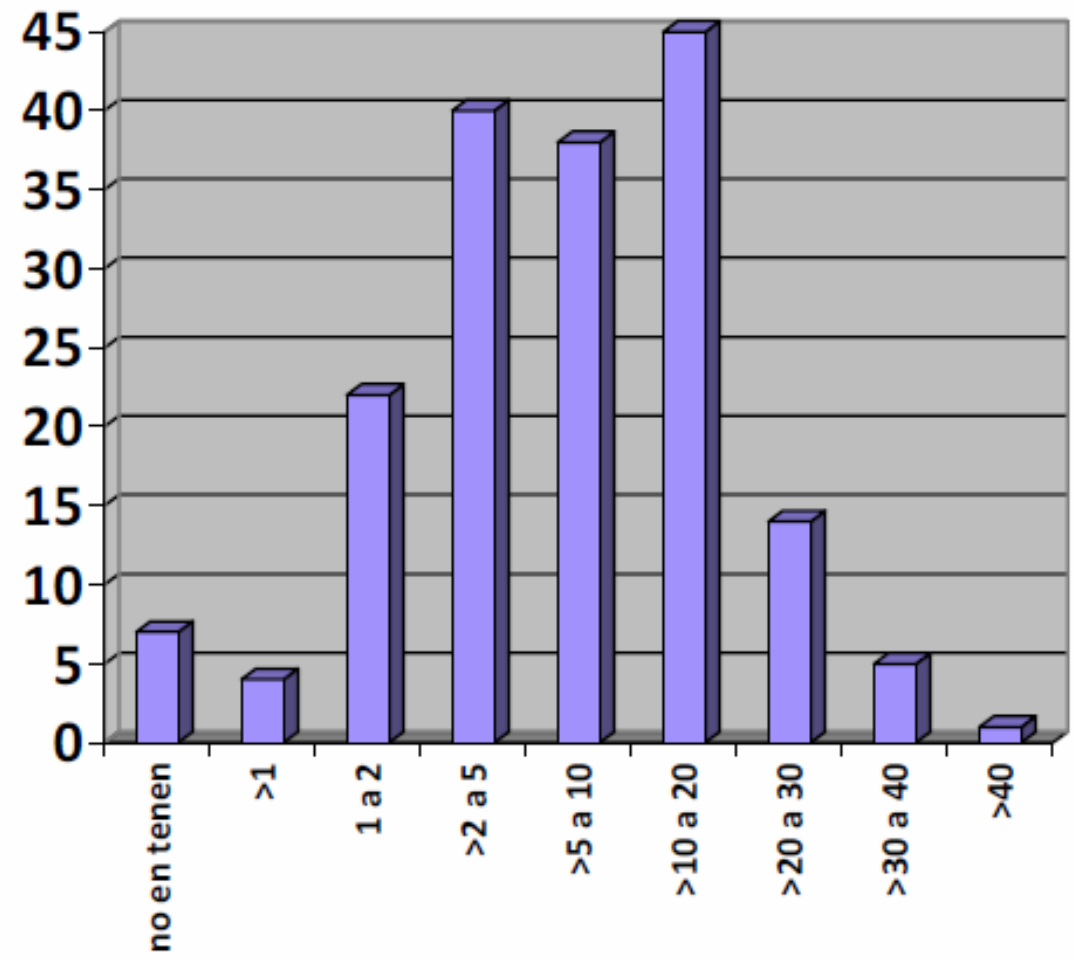

nombre de vassalls

Segons les dades del quadre 5.2. 
Aquestes quatre gràfiques de distribució demostren que es conserven bé les parcel·les petites: quartons, mitges fanecades, mitjos jornals (senyal del valor indubtable de la terra) al temps que hi ha una tendència agregatòria cap a parcel·les grans, especialment en el cas del secà, on la tendència a formar propietats majors i encara finques grans és notòria (figura 5-8).

La figura 5-6 mostra que hi ha una gran majoria de vassalls que conserven una o dues fanecades d'horta. Es pot entendre que aquesta superfície unitària és més bé la suficient per a cobrir un autoconsum familiar; aspecte que no es dona, com comentàvem adés, en el cas del secà, on la tendència és acumular superfícies cada vegades majors, fent així pensar que la raó és un objectiu econòmic i que va més enllà de l'autoconsum, tractant-se d'ampliar cultius i produccions del secà que era on estaven de fet els majors guanys i les principals rendes agrícoles, especialment des del punt de vista de la fiscalitat.

Tornant a les 27 hectàrees de regadiu que hi havia l'any 1779 trobem que de fet es conserven actualment com a regs tradicionals. Així, segons les ordenances i reglament de la Comunitat de Regants de Serra, aprovades en l'any 1960, l'objecte d'aquesta entitat és el reg de les hortes de Serra beneficiades per les següents fonts i cabudes aproximades:

Font de Marianet: 135 fanecades

Font de Deula: 45 “

Font de Mugró: 35 “

Font de la Misèria: 22 “

Font de l'Horta del Molí: 21 “

Font de la Salut: 7 “

La suma d'aquestes 274 fanecades serien pràcticament $22^{\prime} 8$ hectàrees que podem entendre-les com una declaració deficitària (potser per raons socials i polítiques del moment) davant les 27 hectàrees reals d'horta existents en els segles anteriors.

La relació dels molins de 1847 (Ferri, 2000) també cita, en el cas de Serra, l'existència de sistemes de reg dependents de les següents fonts: de Marianet, del Poble, de l'Ombria, de l'Horta del Molí, del Mugró i de la Misèria. Al respecte caldrà aclarir que el sistema de reg que anomena ací del Poble pràcticament pot ser assimilat al que abans hem citat com de Deula i encara incloent-hi el de la Salut. En realitat abastaria dos espais irrigats junt al poble: el de la Salut, més modest i situat al NE del nucli urbà, i l'altre, molt més gran, situat al SO i tenint com a punts d'inici diverses fonts, on la de Deula i la del Poble (o Mare de Déu dels Àngels) serien les principals, però també 
estarien la fonteta del Capellà i alguns minats ("canats" antics o moderns) de les hortes de l'Armelar i Baix la Torre. Tot aquest conjunt d'hortes forma un espai irrigat quasi continu (connectat).

Respecte a la font de l'Ombria, citada en 1847 però no inclosa en la Comunitat de Regants constituïda (de nou) en 1960 cal tenir en compte que l'aigua d'aquesta font va ser objecte, en els anys de la segona República, d'un expedient d'expropiació als regants, com a conseqüència del projecte de conduir-les fins a Serra per a crear la xarxa d'abastiment d'aigües potables al municipi. Fins aquell moment, la font de l'Ombria podia regar fins a unes 3 ha d'horta que pràcticament desaparegué, convertint-se en secà.

El sistema de regs que comença en la font de Marianet és també un sistema complex que té com a principal i primer element regulador l'anomenada bassa del Molí (que no és la petita bassa situada sobre l'antic molí de Marianet, sinó una molt més gran i situada aigües avall). Aquest sistema (de vegades anomenat "riu de Tòixima") inclou les hortes de Ria i de Tòixima, entre altres menors que s'articulen al llarg del barranc Major (que rep també els successius noms de Marianet, Ria, Tòixima, l'Escolaor...), passant desprès per l'Assut (prop de l'actual plaça del Castell) i seguint fins a l'anomenada Horta Nova (topònim que ja trobem citat en el segle XVIII, en protocols del notari Miquel Conejos). Tant el molí de la Baronia com el de Marianet formaven part d'aquest mateix sistema hidràulic.

Les 63 hectàrees de regadiu del terme de Serra que recull la Gran Enciclopèdia de la Región Valenciana $(1972-77)^{19}$ inclou, a més de les 27 ha de les hortes tradicionals de la baronia, altres regadius del terme, alguns clàssics, com serien les hortes de la Pobleta o de Valòria (Portaceli) i altres molt més recents (anys 70 i posteriors del segle XX) com són els dels pous de Xarxant o els nous regadius de la finca de la Torre amb aigües superficials derivades del riu Túria.

\subsection{CONREUS I PRODUCTES DEL CAMP}

Oliveres, vinyes, cereals i garrofers són els quatre pilars bàsic de l'agricultura tradicional valenciana i mediterrània que en totes les èpoques solem trobar quan es fa referència a Serra. Com a etapa més recent del període estudiat podem observar el que diu al respecte el Diccionari de Madoz (1845), com a principals produccions de Serra: vi,

\footnotetext{
${ }^{19}$ Dins l'entrada “Serra" (població), redactada per Juan Piqueras Haba (JPH).
} 
oli, forment, dacsa, seda, garrofes, mel, cera, fruites i llegums, ramat llaner i caça de conills i perdius. A més indica com a indústria: la agrícola (suposem que inclou eres, almàsseres, trulls...), dos molins fariners i una fäbrica d'aiguardent. En aquell temps, segons la mateixa font, Serra tenia 212 veïns, equivalents a 934 ànimes, i la seua capacitat productiva era de $1.206^{, 285}$ reals.

Amb poques variacions, la base agrícola i de producció que hi havia un segle $\mathrm{i}$ mig abans és, poc més o menys, la mateixa, tal com recull Cavanilles (1795-97). En aquest cas val la pena observar comparativament les produccions de Serra respectes a les de Nàquera i Torres Torres, per posar dos casos que tenen continuïtat amb Serra des d'una part a l'altra de la serra Calderona (quadre 5-3).

QUADRE 5-3.- Produccions agrícoles, segons Cavanilles, en les tres baronies del corredor Nàquera-Serra-Torres Torres.

\begin{tabular}{|l|c|c|c|}
\cline { 2 - 4 } \multicolumn{1}{l|}{} & NÀQUERA (110) & SERRA (160) & TORRES TORRES (448) \\
\hline Garrofes & 20.000 arroves & 12.000 arroves & 50.000 arroves \\
\hline Oli & 1.000 arroves & 1.000 arroves & 3.000 arroves \\
\hline Vi & 14.000 càntirs & 8.000 càntirs & 18.000 càntirs \\
\hline Grans (cereal) & 100 cafissos & 250 cafissos & $\begin{array}{c}1.000 \text { cafissos de forment } \\
\text { i } 700 \text { cafissos de dacsa }\end{array}$ \\
\hline Seda & 100 lliures & 700 lliures & 1.600 lliures \\
\hline Figues & 8.000 arroves & 6.000 arroves & 8.000 arroves \\
\hline "excel·lents fruites" & & 10.000 arroves & \\
\hline
\end{tabular}

Darrere de cada baronia (i entre parèntesi) indiquem el nombre de veïns, que en el cas de Torres Torres inclou també als d'Alfara i Algímia. També cal tenir en compte que aquesta baronia disposa de regs del Palància. Dades tretes de les Observacions de

Cavanilles (1795-97).

En el cas de Serra cal afegir a aquestes produccions "lo que rinde la industria de carbonear el monte y manufacturar el esparto, muy abundante en todo el término". De la primera -ja ho havíem avançat- solien fer cada any unes 4.000 arroves de carbó i de la manufactura de l'espart (fent peces de corda trenada que a Serra sempre s'han dit fiscar) solien treure els serrans uns 10.000 pesos cada any. Indica també Cavanilles que d'aquestes activitats es mantenien molts veïns pobres, com també de la dels aiguaders 
que transportaven fins a València (i altres pobles) l'aigua "cristal·lina, pura i excel·lent" de la font del Llentiscle, per a vendre-la.

Mentre que Serra, però, té les activitats pròpies de la forest (les esmentades i també la llenya, la fusta, la pedra i la mineria, etc.), Nàquera té un terme prou menys muntanyenc i una horta molt més reduïda, i per això "dirigen sus cuidados al secano, muy apto para árboles" i, a més a més, la natura els hi dona espart amb abundància i amb ell ocupació i riquesa; destacant, així mateix, l'aplicació d'aquells homes (els de Nàquera) que "han declarado la guerra al ocio" (Cavanilles, op. cit.).

Al capítol tercer ja vam referir com un dels primers actes notarials que hem trobat va referit a la colònia serrana de principis del segle XVII que es reunia el dia 8 de gener de 1617, davant el notari Joan Font, per a acordar prendre diners del "cofre dels diners de forment" (pòsit) per tal d'anar a Sogorb o "on convinga" per a comprar llavor de blat per a la sembra. ${ }^{20}$

Malgrat que a l'arxiu dels ducs de Montellano hi ha diverses referències dels arrendaments de les seues possessions valencianes (entre les que estaven, a més de Serra i Soneixa la baronia de Massalavés i diverses propietats del marquesat de Castellnou i altres que tenien a Sagunt, Sot de Ferrer, Sogorb i altres lloc) es refereixen més als preus dels arrendaments que no als detalls i productes obtinguts. L'excepció més completa que hem trobat amb tot el detall de les produccions és la que correspon, precisament, als últims anys de gestió efectiva i completa de l'Administració dels bens valencians del ducat: la del quinquenni dels anys 1834 a 1838. D’aquest quinquenni únicament el primer any es paga complet, i quasi complet el segon, mentre que la resta únicament registren el pagament de certs drets de regalies (ara més bé lloguers de propietats) però no de produccions agraris ni particions.

Aquell any 1834, Don Julián Álvarez, secretari i comptable de la Casa i Escrivania dels excel·lentíssims ducs de Montellano i de l'Arco, etc., presentava, referits a Serra i en producte ja de moneda de compte (lliures, sous i diners), els comptes que recollim en el següent QUADRE 5.4.

\footnotetext{
${ }^{20}$ APCC, lg. 21045, f. $1 \mathrm{r}^{\mathrm{o}} \mathrm{i} \mathrm{v}^{\mathrm{o}}$.
} 
QUADRE 5.4.- Drets dominicals de les produccions agrícoles de Serra l'any 1834 (últim any complet de tributació al senyor de la baronia).

Productes conceptes

preu: (lliures.sous.diners)

\begin{tabular}{|l|l|c|}
\hline FORMENT & $\begin{array}{l}1 / 6 \text { de les collites en terra d'horta i } \\
1 / 10 \text { de les del secà): }\end{array}$ & $5 \mathrm{~L} 7 \mathrm{~s} 4$ \\
\hline CIVADA & Id. & $2 \mathrm{~L}-\mathrm{s}--$ \\
\hline PANÍS (dacsa) & Id. & $3 \mathrm{~L} 4 \mathrm{~s}--$ \\
\hline GARROFES & $1 / 8$ & $210 \mathrm{~L}-\mathrm{s}--$ \\
\hline OLI & $1 / 8$ & $27 \mathrm{~L} 15 \mathrm{~s}--$ \\
\hline VI & $1 / 8$ part (igual que a Soneixa!) & $6 \mathrm{~L}-\mathrm{s}--$ \\
\hline FIGUES & $1 / 8$ & $47 \mathrm{~L} \mathrm{33s} \mathrm{--}$ \\
\hline $\begin{array}{l}\text { PINYOL/ BRINSA } \\
\text { (i aiguardent?) }\end{array}$ & & $1 \mathrm{~L} 6 \mathrm{~s}--$ \\
\hline PALLA & 1 "seró" de palla per cada casa & $65 \mathrm{~L}-\mathrm{s}-$ \\
\hline
\end{tabular}

Font: AHN (FN), 1.408/1 n 16.

A Serra no hi hagué en aquest decenni, o no es declaren, altres produccions que de vegades hi trobem en altres llocs de la mateixa administració, com fesols, cigrons, alls, arròs roig (a Massalavés), cànem o lli.

A més de les anteriors cal afegir 11 lliures i 6 diners (any 1834) per dret de molta en l'almàssera d'oli, i tota una sèrie d'ingressos directes en metàl·lic com són els arrendaments de la mateixa almàssera o molí d'oli (336 L), el forn de coure pa (557 L), “el Mesón" (421 L), el molí fariner (903 L), "la casa on estigué la carnisseria" (30 L) i alguns altres conceptes menors que referirem en posteriors apartats.

\subsection{VINYES PANSES I VI}

És un fet conegut que la vinya s'estenia per la major part dels pobles i les terres de secà valencianes i el terme de Serra no n'era una excepció. ${ }^{21}$ La memòria viva dels serrans incideix en el record de generacions anteriors que destacaren la gran quantitat de vinyes que hi havia repartides per tot el terme i la festa que era quan arribava la verema (Senís, 1984) fins a principis del segle XX, en que vingué la fil·loxera i acabà amb totes

\footnotetext{
${ }^{21}$ Juan Piqueras: La vid y el vino en el País Valenciano. Inst. Alfons el Magnànim. Dip. València. 1980.
} 
elles. ${ }^{22} \mathrm{Al}$ respecte, resulten força expressives les paraules d'Antònia Navarro Garay, una serrana que amb 84 anys d'edat escrivia sobre les coses que conegué de xiqueta:

...I de raïm! Quant de raïm hi havia en este poble de Serra!...

En tots els termes (partides) hi havia vinyes, de garnatxa, de verema negra i blanca, i allà al final de l'estiu quina revolució s'armava: tots trepitjant el raïm i el vi a casa es portava. I vingué l'epidèmia fil·loxera $i$ en dos o tres anys... ai Serra!... se quedà sense vinyes; que desconsolà es quedava!... ja s'acabà l'alegria!... i des d'eixa data ja no se beu tant de vi... ara reina la cervesa"... ${ }^{23}$

Un altre pràctic serrà, Ricardo Cabo “de Nicasio" ens explicava (estiu de 2002, comunicació personal): "quan el raïm va ser arrasat per la fill·loxera s'arrancaren totes les vinyes -i mira que hi havia moltíssimes!- i en el seu lloc en plantaren molts cirerers, però també unes vinyes que deien "americanes". També destacava el fet de que a més del vi es feia molta pansa a Serra i també a Nàquera, sent molt característic un dit popular que antigament s'escoltava molt (i ha perdurat, sent encara ben conegut):

\section{"Serra i Nàquera senten orgull \\ per la pansa i la figa que es cull. \\ Però si la figa i la pansa erra... \\ Nàquera i Serra estan per terra".}

El capítol vuitè de la carta-pobla de 1609 establia: "lo que procedirà de les vinyes... ara siga vi, ara pansa, o altra qualsevol cosa, se haja de pagar al Senyor la vuitena part en allò mateix que es collirà...”. Abans d'això, però, els moriscos de Serra ja cultivaven extensament la vinya, havent posat de relleu Ferrer Taberner (1988) que les vinyes, junt als garrofers i les figueres formaven els principals conreus de secà existents aleshores als voltants de Ria i de les seus hortes.

\subsubsection{Bons vins davant alts impostos (Serra en el segle XVII)}

En el primer quart del segle XVII, Serra i Nàquera es trobaven entre els pobles del Regne de València on la qualitat dels seus vins era de les més estimades. Al terme de Nàquera hi havia encara més vinyes i més producció de vi que a Serra, i això era perquè la major part d'aquell terme, en ser més pla ho permetia millor. No obstant això, a

\footnotetext{
${ }^{22}$ El diari La Vanguardia, d'11 d'octubre de 1911, recollia aquesta notícia: "En el término de Serra (Valencia), han sido invadidos los viñedos por la filoxera en términos alarmantes".

${ }^{23}$ Antònia Navarro Garay: Recordant coses antigues de Serra. Llibret "Serra en festes" de l'any 1985.
} 
Nàquera era molt més alt el tribut que havien de pagar al seu senyor, concretament la cinquena part dels productes de la vinya.

Front a la vuitena part que sempre pagaren els de Serra i la cinquena part que inicialment pagaren els de Nàquera, la càrrega dominical d'altres llocs i baronies era prou més baixa; per exemple, a la baronia de Torres Torres (desprès de les cartes-pobles d'Alfara i Algímia) pagarien només la quinzena part (1/15; Corbalán de Celis, 1997). A Nàquera acabaren també obtenint unes molt bones condicions, com també a Soneixa, que malgrat pertànyer al mateix senyor de Serra aconseguí millores fiscals que no arribarien als de Serra, sent aquest un assumpte pledejat fins al segle XIX, del qual tornarem a parlar.

Aquesta és la principal raó per la qual a Serra hi trobem certa mancança i encara ocultació de dades, especialment pel que fa a la primera meitat del segle XVII, mentre que en altres poblacions la producció de vi era coneguda i "transparent". Per a començar repasarem una sèrie d'aspectes i consideracions prèvies.

Una “Crida dels capítols conferents per a la bona administració i exacció del nou dret del general del vi introduït pera la paga del servici ofert per lo present Regne de Sa Majestat en les Corts celebrades en la vila de Monçó en lo any MDCXXVI" classificava en vàries zones el territori valencià en funció de la qualitat dels vins que produïen. En la millor d'aquestes zones es trobaven un centenar de llocs de l'antic Regne de València, i entre ells Serra, Ria i Portaceli entre altres pobles propers, com Olocau, Nàquera, Bétera o Bofilla (el desaparegut poblat prop de Bétera). En canvi, els vins d'altres pobles de l'entorn de la serra Calderona, com ara Llíria, Sogorb, Altura, Xèrica, Viver, o Soneixa, per exemple, es troben entre "els de menor qualitat" (Felipo, 1985).

A més dels elevats impostos o càrregues senyorívoles (a més del delme i primícia eclesiàstics) que ja suportaven les vinyes, en les Corts de Monçó de l'any 1626 (De Lario, 1973: 220) van acordar la imposició d'una nova cisa o càrrega sobre el vi, per tal d'aportar el valencians a la Corona una major contribució per a fer front a les elevades despeses per requeria fer valer la seua hegemonia en tot l'imperi i, particularment, per afrontar els conflictes amb els Països Baixos. El nou impost seria de 20 sous per cada bóta seixantena (la que conté 60 cànters; uns 650 litres, aproximadament) de vins de la millor zona abans esmentada (on es trobava Serra), com també 12 sous per als pobles que produïen els vins de menor qualitat, ó 16 sous per bóta si es tractés de pobles que no es trobaren en cap de les dues zones. 
Acte seguit, per a fer efectiva la mesura anterior, es van recollir poble per poble les dades sobre la quantitat de vi que es produïa en cada lloc del nostre Regne. Aquestes dades, que conformen la sèrie dels manifests del vi o "dret del vi" (ARV) han estat estudiades per Amparo Felipo (1985). Però, el que resulta molt cridaner és que en un llistat tan ampli i precís, on es recullen les produccions de tots els pobles, any per any entre 1627 i 1631, no aparega mai ni Serra ni Ria; per què?. Per fer-nos idea vegem el QUADRE 5.5, amb algunes poblacions properes a Serra (les quantitats corresponen a cànters, sent cada cànter de vora de 12 litres):

QUADRE 5.5. Cànters de vi produïts per diferents pobles de l'entorn de Serra.

\begin{tabular}{|l|l|l|l|l|l|}
\hline & Any 1627 & Any 1628 & Any 1629 & Any 1630 & Any 1631 \\
\hline Estivella & 1.707 & 1.764 & 1.238 & 1.577 & 1.372 \\
\hline Nàquera & 1.108 & 281 & 569 & 1.577 & 1.798 \\
\hline Olocau & 975 & -- & -- & -- & -- \\
\hline Serra & $?$ & $?$ & $?$ & $?$ & $?$ \\
\hline Soneja & 718 & 823 & 554 & 970 & 2.055 \\
\hline Torres Torres & 3.952 & 5.648 & 3.176 & 6.133 & 4.873 \\
\hline
\end{tabular}

Dades tretes de Felipo, 1985 (font: ARV, Generalitat: manifest del vi).

Com en casos anteriors, cal recordar que Torres Torres incloïa a Alfara i Algímia; Olocau a Gàtova, Marines i altres llocs que es troben avui despoblats, i Soneixa a Assuévar.

Portaceli no apareix individualment en aquests llistats per estar inclòs dins la contribució general de València, on pertanyia (a banda de les possessions que tenia en altres termes). En tot cas, per a l'any 1630, la producció de vi de Portaceli queda recollit que va ser almenys de 3.600 cànters (1.200 per la contribució de Llíria i els altres 2.400 per la de València).

Per poder conèixer amb més precisió i detall el problema de Serra, calia anar a les fonts documentals, i així, en la sèrie del Dret del vi (ARV) trobem el cas de Serra fent la següent declaració:

Dia 18 de gener de 1628: Domingo Moreno, jurat del lloch de Serra, comparet... etc... etc... diu i manifesta que en lo dit lloch ni en tot son territori no se ha collit vi algú en lo any proppassat 1627 . I així, no es devia fer càrrech a d'aquell de cosa alguna. ${ }^{24}$

\footnotetext{
${ }^{24}$ ARV, Generalitat, 4830, f. $81 v^{o}$.
} 
Pràcticament passarà el mateix per a tots els anys. Vegem per exemple el que declaren el 14 de juny de 1632:

Miquel Domingo i Joan Baptista Català, jurats de Serra, compareixents... etc...mediant jurament... etc... dixeren e feren relació que en dits llocs (Serra i Ria) ni terme d'aquells, no hi ha vinyes ningunes plantades, per no haver-hi aparell per a plantarles. Així mateix, lliuraren i entregaren una certificatòria feta per Joan Baptista Donya, batlle de dits llocs, per la qual consta lo mateix de que ells, dits compareixents, han fet relació. $^{25}$

Els colons de Soneixa i d'Assuévar als que Josep Folch de Cardona atorgà cartapobla un dia després que als de Serra i Ria, també tenien la mateixa clàusula de la vuitena part de tot allò procedent de les vinyes, sense pagar-ne terç-delme i que "en les hortes no hi haja vinyes i les que hi ha les puguen llevar". A diferència, però, del que passà a Serra, els veïns de Soneixa i Assuévar van aconseguir introduir modificacions a aquesta clàusula nou anys desprès, mitjançant un acord amb el Senyor: una "carta de transacció i concòrdia" de data 5 de maig de 1618. Amb aquesta concòrdia es tractà de donar un gran impuls al conreu de la vinya i per a d'això, el senyor oferí a cada vassall quatre jornals de terres de muntanya per a que en elles plantaren noves vinyes, que esperaven serien ja productives en el termini de quatre anys. De cadascun d'aquests jornals haurien de pagar un cens anual de quatre diners i, a més a més, del vi que collirien d'aquestes noves terres pagarien al Senyor un càntir de cada quinze i mig que feren. En el mateix acte es concreta com s'ha d'alfarrassar i lliurar el impost: si en diners desprès de la venda, en verema -si es ven així- o en espècie, abans de vendre el vi (Iquino, 1982).

\subsubsection{La producció de vi a finals del segle XVII, segons Cavanilles}

La gran expansió que assoliren les vinyes i la producció del vi en altres poblacions, com Soneixa, no tingueren la mateixa repercussió a Serra; molt possiblement degut a les raons dalt esmentades, de manca de revisió de la pressió físcal senyorívola. Així i tot, sembla que també hi hagué un clar creixement respecte al segle anterior, però molt més moderat que en altres baronies. Les dades de les produccions de vi que recull Cavanilles (1795-97) en les seues Observacions (QUADRE 5.6) són expressives de la nova situació a la volta d'un segle i mig.

\footnotetext{
${ }^{25} \mathrm{ARV}$, Generalitat, 4835, f. $63 v^{o}$.
} 
QUADRE 5.6. Producció de vi de diverses baronies a finals del segle XVIII.

\begin{tabular}{|l|l|l|}
\hline Baronia & Població (1794) & Producció de vi \\
\hline Torres Torres (amb Alfara i Algímia) & 438 veïns & 18.000 cànters \\
\hline Soneixa (amb Assuévar?) & 285 veïns & 40.000 cànters \\
\hline Serra & 160 veïns & 8.000 cànters \\
\hline Olocau (amb Marines, Gàtova i altres) & més de 98 veïns & 9.000 cànters \\
\hline Nàquera & 110 veïns & 14.000 cànters \\
\hline
\end{tabular}

Font: Cavanilles (1795-97).

Recordem que la capacitat d'un cànter era a les terres de València de l'ordre de 12 litres (podrien ser 11,7 litres, segons diverses fonts). Olocau tenia només 60 veïns (a causa d'unes epidèmies que va patir), i 38 Marines, però no es conegut quants n'hi havia repartits entre Gàtova, Olla i Cucaló. Tampoc queda clar del tot si la producció de Soneja incloïa també, o no, la dels 90 habitants que tenia Assuévar. En tot cas, queda palesa la gran diferència (ponderada al nombre de veïns) que hi ha entre Serra i els altres pobles de comparació. El cas de Soneixa entenem que queda explicat amb la concòrdia de 1618.

Pel que fa a Nàquera, Cavanilles diu: “sus vecinos (110) que apénas llegaban á 40 á la mitad del presente siglo (XVIII), en tan corto tiempo han triplicado el cultivo..., ... y han aumentado considerablement las viñas" (a més de figueres i garrofers). Recordem - ja ho hem destacat adés- la carta-pobla de Nàquera obligava els vassalls a pagar al seu senyor una abusiva cinquena part dels productes de la vinya, però els naquerans es negaren sistemàticament a fer-ho, argumentant que seria "la cinquena part de les vinyes existents", però no de les que plantarien desprès de 1609 (pràcticament com en el cas de Soneixa). Desprès de llarga disputa i plets, per fi l'any 1751 arribaren a una concòrdia amb el seu Senyor, qui els concedí la gràcia de retirar-los aquest impost de la cinquena part, atenent "a lo costoso i laborioso que son de criar las viñas" (Lluch, 1941). Des d'aleshores només pagarien el delme i primícia; i d'això el terç-delme que li correspondria al Senyor.

Les esmentades produccions de Nàquera (garrofes, figues i sobre tot el vi) eren majors que les de Serra. No obstant, en altres productes agrícoles eren semblants (oli: 
unes 1.000 arroves) o prou superiors a Serra (seda, cereal i diferents tipus de "excelentes frutas"), sense entrar ja en els aprofitaments forestals i minerals. En tot cas, aquestes dades ens permeten conèixer com el problema de la vinya detectat en el segle anterior a Serra encara continua i, a més a més estava frenant un ritme d'expansió que en altres localitats del seu entorn i de tot el Regne de València estava produint-se.

\subsubsection{Les discòrdies i la sentència de 1808 sobre el vi de Serra}

Al llarg del segle XVIII, el duc de Montellano i senyor de la baronia de Serra va pledejar amb els veïns de Serra per a que li lliuraren la vuitena part que li corresponia però que els veïns trobàvem excessiva i injusta. En 1735 va atorgar poders el duc al seu procurador per a que reclamés els seus interessos. En 1791 va plantejar un nou plet contra l'ajuntament de Serra sobre la manera d'alfarrassar els fruits per a les particions. Novament en 1802 interposava davant l'Escrivà reial una demanda contra els veïns recol·lectors de vi de la baronia de Serra. El motiu que al·lega és, precisament, que troba que els veïns no compleixen la seua obligació - derivada de la Carta de Poblament de 1609- d'aportar a l'amo de la baronia, el duc de Montellano, la vuitena part del vi que feien (després d'haver pagat el delme eclesiàstic). El procurador explica que, encara que els veïns criadors de vinyes reconeixen la seua obligació de pagar la vuitena part del vi "pretenden verificarla de un modo arbitrario y expuesto a los mayores fraudes y perjuicios para mi Principal...”. El cas era (segons la protesta) que quan els veïns avisaven a l'arrendador dels bens del Senyor, per a que prenguera del cup o trull la seua vuitena part, ja havien extret una bona part del vi, sense dir ni fer constar quina havia sigut realment la producció o collita. ${ }^{26}$

Aquest procés duraria alguns anys, i en diverses ocasions -i de manera reiteradasuccessives ordres judicials manaren fer bàndols públics per tot el poble, com aquest de 1807:

Que todos los cosecheros de vino no puedan extraerle del lagar o cubo, sin avisar antes al Arrendador o Colector de los derechos dominicales, medirle en su presencia y separar lo correspondiente a la partición dominical (la vuitena), bajo la pena de 25 Libras.

\footnotetext{
${ }^{26}$ ARV, Escribanías de Cámara, 1806, exp. 15
} 
Les 25 lliures suposaven una respectable multa que sens dubte superava les possibilitats de la majoria dels veïns. Finalment, aquest procés concloïa el 27 d'abril de 1808, quan es dictava sentència, favorable al Senyor, amb el següent contingut:

Se declara que los vecinos y cosecheros de la baronía de Serra deben cumplir puntualmente y a la letra el capítulo octavo de la Escritura de Encartación otorgada ante Antonio Terrasa, de 26 de noviembre de 1609 (la Carta Pobla) y se libre certificación... (notificació a les parts).

Òbviament, els anys següents a aquesta executòria van ser propicis al seu incompliment: primer la invasió francesa, desprès l'abolició de les senyories per les Corts de Cadis (1811), la restauració de l'absolutisme (1814), el trienni Lliberal (182023)... Així i tot, el 18 de setembre de 1815 es dictava una nova sentència (hi consta annexa en l'expedient ja esmentat), també favorable al Senyor, que es limita a dir "que se haga lo que consta (suposem que en la carta-pobla) y fuese de dar" (la vuitena part, cal pensar).

\subsubsection{L'expansió final i la caiguda de la vinya (segles XIX i XX)}

Quan Madoz (1845-50) parla de quines eren les produccions de Serra, indica el vi en primer lloc; i cita també, entre les indústries, una fàbrica d'aiguardent. Aquestes dues dades fan suposar, amb certa raó, que el vi poguera ser la principal producció del poble o almenys una de les produccions més notables.

En tot cas, la fàbrica d'aiguardent sembla clar que era la d'un veí de Serra anomenat Simeón Domingo, i estava situada a prop del molí de la baronia (junt a l'entrada del poble i per baix de les primeres cases que hi ha a mà dreta. Aquella antiga fàbrica o "colador d'aiguardent" és l'origen d'un topònim que encara es conserva: “l'Escolador”, “el Colaor” o el "barranc de l'Escolaor”. La importància d'aquella fàbrica és que ve a demostrar el fet de que, efectivament, a Serra es produïa molt de vi, fins el punt de que el seu rebuig o brisa ("piñol u orujo") encara donava per a fer aiguardent generant al duc de Montellano, en 1834, un guany d'una lliura i 6 sous, i tenint en compte que això era només la vuitena part, estaríem parlant d'un negoci declarat de poc més de 10 lliures a l'any. ${ }^{27}$

\footnotetext{
${ }^{27}$ AHN (FN), 1.408/1.
} 
Enllacem ací amb els comentaris inicials, quan hem destacat allò que havia suposat històricament i en la memòria viva (veure també Santamarina i Bodí, 2014) el vi per a Serra. Segons la Gran Enciclopèdia de la Regió Valenciana (1972-77) encara a principis dels anys 70 del segle XX hi havia encara 16 ha de vinya al terme de Serra.

\subsubsection{Els vins de Portaceli i La Torre}

El conreu de la vinya i la producció de vi propi degueren de practicar-se, molt probablement, des dels primers temps de la constitució del monestir de Portaceli. En 1418 ja se cita una bodega i se sap que hi havia plantacions de vinya a la partida de Valòria, però el principal lloc vitivinícola del priorat va ser sempre la masia de la Torre. Al seu voltant, en l'any 1432, foren plantats 2.400 sarments (Garay, 2004).

Cap a 1603 es va construir un nova bodega a La Torre, que seria ampliada o modificada en 1614 (FIGURA 5.9). Referint-se al segle XVIII, Castañeda i Alcover (1919) destaca les més de 4.000 fanecades de la Torre, plantades quasi totalment de vinyes.

Per altra part, indica Madoz (1845-50) el fet que l'heretat de la Torre la va manar tancar amb un alt mur Bonifaci Ferrer (que va ser Prior de Portaceli i General de la Orde dels cartoixans) per tal de poder criar arbres i vinyes sense que l'abundant caça major i menor que hi havia en la zona perjudicara els conreus. També posa de manifest la bona reputació dels deliciosos vins anomenats "de la Cartuja", "habiéndose conservado en su espaciosa bodega, hasta el año 1811, madres y vinos de cosechas que hubo en vida de Bonifacio y de su hermano San Vicente Ferrer". La masia de la Torre, avui una heretat privada, conserva encara la monumental bodega del segle XVII, si bé no es troba ja en producció perquè les vinyes van ser substituïdes per altres conreus, a partir dels anys seixanta $i$ gran part de la seua superfície passà a altres propietaris $i$ usos. 
FIGURA 5.9.- Fotografia actual de la bodega del segle XVII de la masia de La Torre.

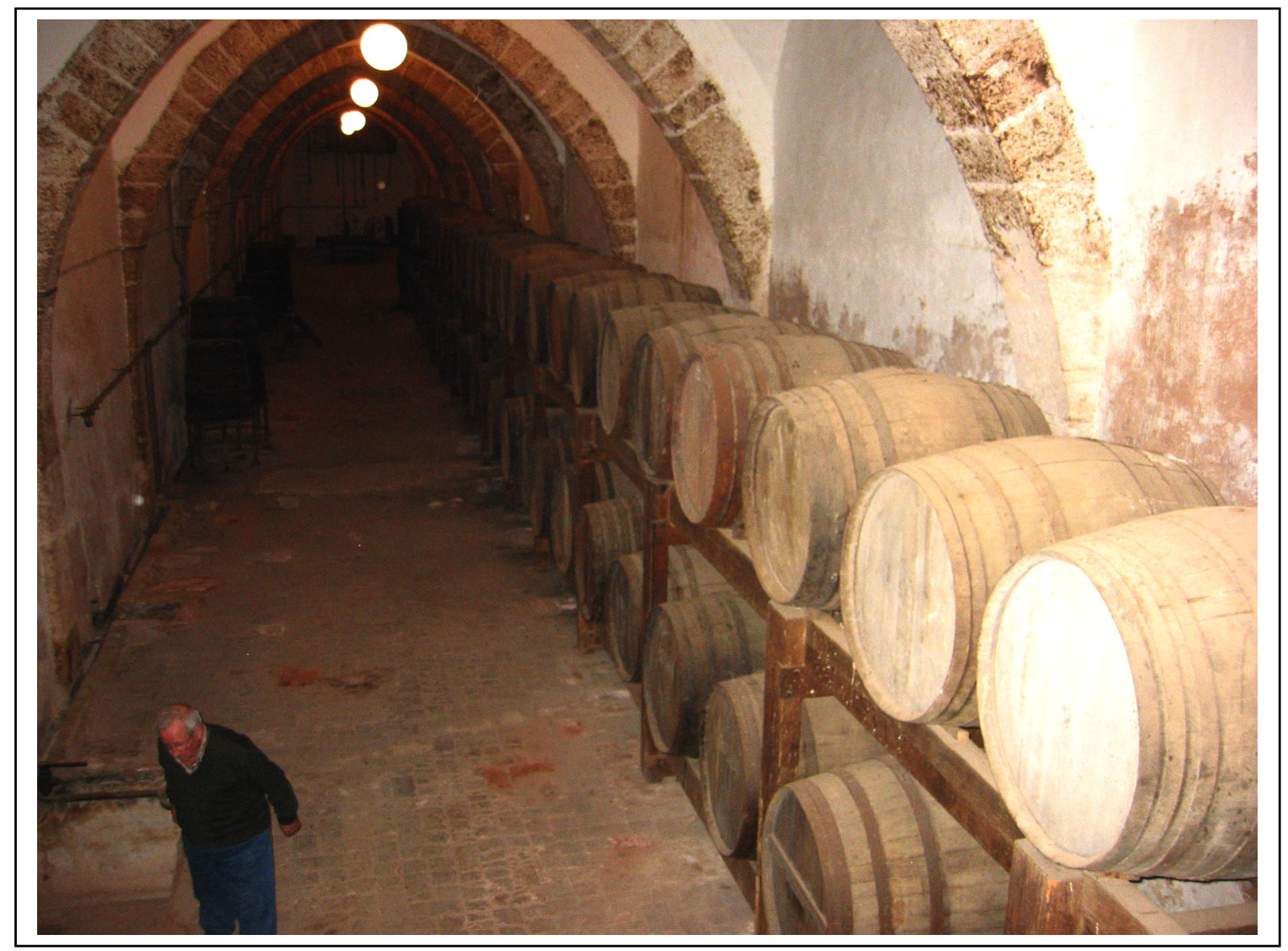

Fotografia de l'autor, amb permís de la propietat.

\subsection{RAMADERIA I APROFITAMENT DE PASTURES}

L'activitat ramadera sempre ha sigut molt important a Serra, sent habitualment un dels pilars importants de la seua economia rural. No obstant això, les primeres notícies escrites relatives a la pastura a Serra no tracten sobre els ramats propis, sinó sobre els drets d'altres per a poder entrar a pasturar lliurement. La referència més antiga que coneixem es remunta al segle XIII, quan Jaume I atorga a la ciutat de Sogorb un privilegi, en 1256, pel qual ordenava a tots els veïns i alcaids, així presents com futurs, d'Altura, Gaibiel, Almonezir, Almedixar, Castronovo, Azueba, Pellunes (alqueria de Soneixa), Xóvar, Sot, Àrguines, Gàtova, Marines i Serra, que permeteren pasturar lliurement en els seus termes a tots els ramats de Sogorb, et sine aliquo impedimento et sine aliquo erbagio, carnagio, parizone sen qualibet alia racione vel causa, ganatum totum predictorum hominum in locis superius nominatis. ${ }^{28}$

\footnotetext{
${ }^{28}$ ARV, pergamins, caixa 12, núm. 17. Document publicat per García Edo (1987): Segorbe en el siglo XIII; també citat per Cabanes (1981): Documentos i datos para un estudio toponímico de la
} 
Per altra part, Portaceli tingué sempre una gran tradició ramadera que es practicava tant dins com fora del seu terme. Com que Portaceli s'assimilava dins els termes generals de la ciutat de València, per això gaudia del privilegi de poder transitar, pasturar i abeurar lliurement els seus amats per tot el Regne sense haver de pagar portatge, pontatge ni herbatge; només indemnitzar els possibles danys que pogueren causar, però sense poder ser retinguts, ni els pastors ni els bestiars. Aquest benefici estava ratificat expressament pels privilegis atorgats per diversos monarques: Pere II, en 1340; Joan II, en 1450, i Carlos I, en 1540 (Fuster, 1994). La presència de pastors va ser sempre important dins el conjunt de criats del Convent. Fins i tot, just abans de la desamortització estaven empadronats a Portaceli, entre els criats, 17 pastors (Tarín y Juaneda, 1897).

En el cas de Portaceli cal dir que, a més de l'abundant ramat de llana i també cabrum, hi hagué una selecta cria de ramat mular que assolí gran renom i prestigi entre els segles XVI i XIX. Generalment no naixien els animals en el priorat, sinó que es dedicaven els frares a comprar les mules molt joves en les fires de Xàtiva o d'Enguera, per a desprès criar-les i enfortir-les dins el terme del priorat fins que arribaven a una edat i aspecte adients per a assolir una bona cotització (Garay, 2004). Però açò seria una excepció, doncs els d'ovelles i/o de cabres són els ramats tradicionals als que sempre ens referim, quasi exclusivament, al llarg d'aquest apartat.

Pel que fa a Serra, hi hagué sempre una important cabanya local i una més abundant cabanya estacional transhumant, formada per ramats procedents generalment de les comarques turolianes de Gúdar i de Javalambre. De fet, alguns pastors aragonesos es troben entre els avantpassats de molts serrans (pastors que freqüentaven i passaven llargues temporades d'hivern a Serra, relacionant-se amb els seus veïns i que, finalment acabaven establint-se en el poble). Tal és el cas de Domingo Navarro, un pastor de Camarena, fill de Mateo Navarro i Maria Clemente, que es va casar a Serra amb Magdalena Esteve, en 1633 i tingueren 9 fills, entre els anys 1634 i 1652.

\subsubsection{Els ramats de Serra segons el carnatge de Morvedre (segle XVII)}

Els registres dels delmes percebuts per la Catedral de València en el segle XVII ens han permès conèixer certs detalls sobre la qüestió ramadera en el sector oriental de la

región valenciana. 
serra Calderona i encara tota la comarca del camp de Morvedre, sector al que pertanyien les baronies de Serra i Nàquera conjuntament, ja que constituïen una mateixa casa delmera i parròquia. Així sabem que Serra, amb Nàquera, formaven part del Carnatge de Morvedre, un delme que era arrendat cada quatre anys i que tenia per objecte recaptar el delme ramader d'un extens territori que abastava els pobles (baronies i parròquies) de l'actual comarca del Camp de Morvedre incloent-hi Serra i Nàquera.

De la importància relativa que tenia Serra respecte a la resta de baronies i cases delmeres d'aquest àmbit territorial trobem evidències prou significatives. Per una part, l'arrendador dels delmes d'aquest gran delmari és, entre els anys 1646 i 1651, un veí de Serra, Joan Ibáñez, llaurador, junt a Simeó Falcó, un mercader de València. El preu que paguen per aquest arrendament el primer any (1646/47) és de 46L.18s.4d., mentre que els quatre anys següents hi pagaran 46L.16s.8d. Aquestes quantitats són pagades en dues meitats cada any, una per Tots Sants i l'altra per Carnestoltes. El pagament el fa sempre un col·laborador d'ells, Gaspar Miedes, que ho ingressa en metàl·lic en la mensa canonical de la Catedral. ${ }^{29}$

El següent arrendament que es fa del carnatge de Morvedre, entre els anys $1650 \mathrm{i}$ 1654, també correspon a un altre llaurador de Serra, Esteve Moreno, junt a Josep Isidoro, un escopeter de València. El preu és ara de 40L.3s.4d. ${ }^{30}$

El següent arrendament, que comença en l'any 1654/55 el fan ara tres persones: Miquel Miró, notari de Morvedre, Marià Carles, llaurador, i Diego Ros, batlle de Bétera; per preu de 50L.6s.8d., cada any. Pot resulta curiós que un dels arrendataris siga batlle d'una baronia que no pertany a l'àmbit territorial del Carnatge de Morvedre, però tampoc no és d'estranyar si tenim en compte que Bétera està en un dels punts de connexió i de pas de Serra i Nàquera cap a València, que dista uns $12 \mathrm{~km}$ de Serra i altres $12 \mathrm{~km}$ de València. ${ }^{31}$

Una nota solta cosida dins la sèrie dels delmes que custòdia l'arxiu catedralici ens aporta una valuosa informació sobre les produccions ramaderes dels diferents pobles inclosos en aquest carnatge, referint-se les dades a dos exercicis: 1679/80 i 1680/81:32

En el primer d'aquests anys (1679/1680) l'administrador dels delmes és mossèn Antoni Rubert, qui dóna la relació de càrrecs (ingressos) recollits en el QUADRE 5.7, la

\footnotetext{
${ }^{29} \mathrm{ACV}$, c. $4242-\mathrm{II}$

${ }^{30}$ ACV, c. 4243-I.

${ }^{31}$ Ibídem.

${ }^{32}$ ACV, c. 4247 II; any "1680 en 1681”, f. 68 (nota cosida).
} 
suma dels quals ascendeix a 65 lliures, 17 sous i 9 diners, si bé queda perdent de recaptar tres partides, que serien les següents: el senyor de Gilet deu 9L.11s.-d., de les seues ovelles (per l'esquim, llana i corders); manca el manifest de la llana d'Anton Navarret, carnisser d'Estivella, i manca també el manifest de la llana d'un tal Canpos, de Gilet. Encara hi ha una darrera anotació, dient que manca afegir a l'anterior manifest uns cabrits que havia venut Isidre Emperador, de Segart, per 16 sous i 8 diners.

QUADRE 5.7.- Delme obtingut del carnatge de Morvedre de l'any 1679/1680.
Subjecte
Població
concepte
valor del delme

\begin{tabular}{|c|c|c|c|}
\hline Francesc Mora & Alfara & De cabres i per cabrits que comprà & 3L.13s.-d. \\
\hline Molina i Joan Serrano & Alfara i Gilet & Els seus respectius ganaos & 2L.11s.6d. \\
\hline Gasquet & Beselga & Cabres & 1L.5s.6d. \\
\hline Vicent Campos & Santa Coloma & Esquim i cabrits; ha tocat al delme: & 6L.4s.-d. \\
\hline Anton Navarret & Estivella & D'esquim i corders & 2L.4s.4d. \\
\hline $\begin{array}{l}\text { Veïns de Serra i } \\
\text { Nàquera } \mathrm{i} \text { aragonesos } \\
\text { que han hivernat }\end{array}$ & $\begin{array}{l}\text { Serra } \\
\text { i Nàquera }\end{array}$ & & 14L.3s.3d. \\
\hline Antoni Carreres & Petrés & De l'esquim, llana i corders & 4L.14s.8d. \\
\hline Francesc Inglada & Quart & Cabres & -L.11s.-d. \\
\hline Miquel Mingarro & Quartell & Ovelles, esquim, llana i corders & 4L.5s.-d. \\
\hline Francesc Ribelles & Quartell & De l'esquim, llana i corders & 8L.3s.-d. \\
\hline Ganados aragonessos & $\begin{array}{l}\text { Morvedre i La } \\
\text { Vall }\end{array}$ & Han hivernat. & 13L.13s.-d. \\
\hline "un aragonès" & Rafelbunyol & & 1L.-S.-d. \\
\hline Andreu Faulí & Estivella & (Estivella i una "noceda" de Segart) & 3L.5s.6d. \\
\hline
\end{tabular}

Font: ACV, c. 4247-II.

Segons aquestes dades (i a manca dels deutes del senyor de Gilet $\mathrm{i}$ altres), el delme aportat pel delmari de Serra i Nàquera, amb els seus ramats aragonesos, suposa prop d'un $22 \%$ del total. La següent major aportació seria la dels ramats aragonesos que hivernaven a Sagunt i les Valls (possiblement a les marjals), que puja un altre quasi 21\%. 
Una altra dada interessant és que entre els posseïdors de ramat es troben alguns carnissers dels pobles, com és el cas d'Anton Navarret, carnisser d'Estivella i d'Antoni Carreres, carnisser de Petrés

Front a aquest càrrec, l'administrador dels delmes, Antoni Rubert, fa també el corresponent "descàrrec" o relació de despeses suportades per a fer el seu treball. Entre aquestes despeses està sis vegades el preu unitari de 10 sous corresponent al lloguer d'un home i un rossí que el va acompanyar a delmar a diferents destins i a que portaren els cabrits o corders a Morvedre; entre aquests destins estan: les cabres de Jaume Campos (de Santa Coloma), Alfara de la Baronia, Serra i Nàquera, Estivella, Quart i Quartell, i els corders dels aragonesos de la Vall i de Morvedre. A més, per un home (sense rossí) que llogà per a anar a Petrés en pagà només 4 sous. Tot açò puja a 3L.4s.-d., que deduirà del càrrec abans de fer-lo efectiu davant la mensa canonical de la Catedral.

Aquestes xifres, tal com veurem en el capítol setè, serien només la tercera part (la que es diu del Contrallibre) del total del delme. Per tant, podem estimar que el delme real de tot el carnatge serien poc més de 197 lliures (poc més de 42 en el cas de Serra i Nàquera) i que la producció total seria de l'ordre 1.970 lliures (unes 420 en el cas de Serra i Nàquera).

Per a l'any següent (1680/1681) trobem dades semblants, però amb la diferència de que els ramats aragonesos són contabilitzats en una relació a banda, que reporta 36L i 5 sous, mentre que la suma de tot allò que van produir aquell any els ramats dels veïns va ser prou més elevada: 84L.13s.7d.

De Nàquera només hi ha un ramat, de Bertomeu Novella, que aporta al delme 5L.4s.4d., mentre que els veïns de Serra (no aporta cap nom) "per tots els ramats de dit poble" contribueixen amb 30 cabrits ("xotos") que, havent sigut venuts a 13 sous cadascun munten 19 lliures i 10 sous. Aquesta de Serra és l'aportació local més nombrosa, seguida de la que fan els ramats de Morvedre (amb un únic propietari: Vicent Campos) que és de 10L.5s.4d.

Cap dels ramats que vingueren aquell any d'Aragó va herbejar a Serra. Van ser deu els ramats i tingueren per destí Canet, Puçol, Morvedre (dos casos), Albalat dels Tarongers, Estivella, Rafelbunyol, Quart, Torres Torres, i Faura.

Totes aquestes dades donen a entendre que els ramats de Serra són principalment de cabres, mentre que els que venien d'Aragó són quasi exclusivament d'ovelles. Del conjunt de poblacions que formen aquest carnatge de Morvedre i exceptuant els ramats 
transhumants, Serra torna a ser el principal contribuïdor, amb un $23 \%$ del total. Pel mateix raonament que hem fet abans, els 30 cabrits delmats serien la tercera part del delme, per la qual cosa, el delme/dècima d'aquell any serien 90 cabrits i la producció total d'uns 900. Amb aquestes dades podem suposar que que la cabanya ramadera de Serra podria estar prop del miler de caps de ramat cabrum, quantitat certament significativa tenint en compte que el nombre total de veïns podria ser de poc més de 30 , tal com hem vist en el capítol quart.

La resta de poblacions del carnatge tenen tant cabres com ovelles i mentre que les primeres tributen només per la partició de cabrits, els altres tributen també per l'esquim i la llana. El preu de venda dels cabrits de Serra hem vist que va ser de 13 sous per unitat, el mateix preu que els d'Alfara, però els de Beselga es veneren a 10 sous (al mateix amo) i uns altres d'Algímia es veneren uns a 12 i altres a 13 sous. Els corders dels aragonesos es veneren generalment entre 8 i 10 sous per unitat.

\subsubsection{Pastors locals $i$ vies ramaderes al segle XIX.}

L'abolició del règim senyorial i els processos desamortitzadors que es donen en la primera meitat del segle XIX van fer que l'Estat vera la necessitat de preservar certs valors i elements naturals i patrimonials, com són les vies ramaderes i els boscos. És dins d'aquest procés que es crea el cos d'enginyers forestals i, més tard, la Asociación General de Ganaderos del Reino (d'Espanya). He trobat vàries referències que posen de manifest que l'any 1850 es va realitzar una delimitació i classificació de les vies ramaderes del terme de Serra, del qual acte (avui desaparegut o desconegut), encara es custodiava en 1907 una còpia en l'Ajuntament de Serra. ${ }^{33}$

Com en altres poblacions de la zona, en la segona meitat del XIX tenia Serra la seua Junta Local de Ramaders, on estaven representats tots els veïns que tenien ramats. La junta tenia un president $\mathrm{i}$ un secretari que eren elegits pels propis ramaders $i$ desprès els nomenava l'autoritat competent a petició d'aquestos. A més hi havia un càrrec de "Visitador municipal de ganadería y cañada" que era una espècie de funcionari nomenat per a fer funcions de guarda i policia del ram. En 1892, fou nomenat visitador Ramon Romero Martínez, després de la proposta feta pels ramaders del poble, que eren,

\footnotetext{
${ }^{33}$ AHN, secció de la Mesta, lg. 865 / 12
} 
Constantino Aliaga, Vicente Sanchis (absent en aquell acte), Joaquin Meliá, Salustiano Domingo i el propi Ramon Romero, que va exercir el seu ofici, almenys, fins el $1907 .^{34}$

Els ramats de les serres de Terol continuaren baixant ininterrompudament cada any fins a mitjans del segle XX com s'havia fet sempre; les subhastes de pastures es feien cada quatre anys rematades per una quantitat de diners que revertien en el comú del poble, a més de les indemnitzacions econòmiques que pagaven els pastors pels danys concrets causats als cultius (Santamarina i Bodí, 2014). Però, el principal interès de molts llauradors era rebre els ramats en els seus propis corrals, que cedien gratuïtament a canvi del preat fem que produïen els ramats i que tan valuós era per als cultius. A més de cedir els corrals, els llauradors oferien als pastors vi i oli, que els ajudaria a passar l'hivern.

Una mostra de la gran activitat ramadera és el gran nombre de corrals que es poden encara identificar per tot arreu del terme de Serra (QUADRE 5.8).

\subsection{ALTRES TRADICIONS AGRÀRIES I ACTIVITATS RURALS}

L'apicultura es troba entre les activitat tradicionals que han perdurat en els darrers quatre segles. La producció de mel i de cera devia ser notable en el segle XIX, tal com la cita Madoz (1845), però les referències puntuals que hi trobem són molt més antigues. Per exemple, entre l'inventari de bens i eines que posseïa Miquel Sàez (un dels repobladors), que va morir cap a 1622, incloïa 191 "colmenes" plenes d'abelles i diverses eines d'apicultor. En algunes confraries (segle XVII) trobem també partides de cera adquirides a veïns de Serra, i fins i tot, en algun testament, com el de l'esmentat Sàez, disposa que per al seu sepeli s'empre cera de la seua casa. Portaceli també tingué una gran tradició abellera, amb més de 1.000 arnes a principis del segle XVII, que el 1611 produïren 740 arroves de mel i 60 de cera (Garay, 2004).

QUADRE 5.8.- Inventari de corrals de ramat del terme municipal de Serra.

Nom latitud N longitud W altitud
\begin{tabular}{|l|c|c|c|l|}
\hline Banyet (El Pilar) & $39^{\circ} 42^{\prime} 35^{\prime}$ & $0^{\circ} 25^{\prime} 54^{\prime}{ }^{\prime}$ & 597 & Abservacions \\
\hline Penya & $39^{\circ} 42^{\prime} 47^{\prime}$ & $0^{\circ} 25^{\prime} 22^{\prime}$, & 521 & Nord de Banyet \\
\hline Campillo & $39^{\circ} 41^{\prime} 09^{\prime}$ & $0^{\circ} 29^{\prime} 34^{\prime}$ & 305 & Corral nou (postguerra) \\
\hline La Corralissa & $39^{\circ} 41^{\prime} 54^{\prime}{ }^{\prime}$ & $0^{\circ} 26^{\prime} 08^{\prime}$, & 578 & Amb un aljub \\
\hline Les corralisses 1 & $39^{\circ} 40^{\prime} 05^{\prime}$ & $0^{\circ} 29^{\prime} 49^{\prime}$ & 302 & Anant a l'Algepsar \\
\hline
\end{tabular}

\footnotetext{
${ }^{34}$ AHN, secció de la Mesta, $\lg .903$ / 58
} 


\begin{tabular}{|c|c|c|c|c|}
\hline Les corralisses 2 & $39^{\circ} 39^{\prime} 48^{\prime \prime}$ & $0^{\circ} 26^{\prime} 52^{\prime \prime}$ & 269 & Anant a l'Algepsar \\
\hline Les corralisses 3 & $39^{\circ} 39^{\prime} 46^{\prime \prime}$ & $0^{\circ} 26^{\prime} 46^{\prime \prime}$ & 267 & Anant a l'Algepsar \\
\hline Falaguera & $39^{\circ} 42^{\prime} 44^{\prime}$ & $0^{\circ} 28^{\prime} 02^{\prime \prime}$ & 637 & Cases en antics corrals \\
\hline Filibertos & - & - & - & Barranfond cap al Garbí \\
\hline Els Frares & $39^{\circ} 40^{\prime} 48^{\prime \prime}$ & $0^{\circ} 28^{\prime} 37^{\prime \prime}$ & 305 & De grans dimensions \\
\hline L'Horteta & $39^{\circ} 41^{\prime} 50^{\prime \prime}$ & $0^{\circ} 25^{\prime} 23^{\prime \prime}$ & $420 \mathrm{~m}$ & Sembla que hi havia dos \\
\hline La Pobleta & $39^{\circ} 41^{\prime} 34^{\prime \prime}$ & $0^{\circ} 28^{\prime} 11^{\prime \prime}$ & 400 & (entorn arqueològic?) \\
\hline Dalt de La Pobleta & $39^{\circ} 41^{\prime} 42^{\prime \prime}$ & $0^{\circ} 28^{\prime} 17^{\prime \prime}$ & 485 & Antiga casa de guardes \\
\hline Manotes & $39^{\circ} 41^{\prime} 16^{\prime \prime}$ & $0^{\circ} 26^{\prime} 19^{\prime \prime}$ & 426 & Pel clot del Dolçainer \\
\hline El Marge & $39^{\circ} 41^{\prime} 35^{\prime \prime}$ & $0^{\circ} 28^{\prime} 29^{\prime \prime}$ & 411 & Convertit desprès en casa \\
\hline Montesinos & $39^{\circ} 42^{\prime} 27^{\prime \prime}$ & $0^{\circ} 27^{\prime} 29^{\prime \prime}$ & 786 & Pla dels Rebalsadors \\
\hline Mugró (conjunt) & $39^{\circ} 42^{\prime} 27^{\prime \prime}$ & $0^{\circ} 26^{\prime} 33^{\prime \prime}$ & 584 & Conjunt de 6 corrals \\
\hline L'Ombria & $39^{\circ} 41^{\prime} 17^{\prime \prime}$ & $0^{\circ} 25^{\prime} 06^{\prime \prime}$ & 361 & Restaurat-conservat \\
\hline Simionet & $39^{\circ} 42^{\prime} 17^{\prime \prime}$ & $0^{\circ} 24^{\prime} 33^{\prime \prime}$ & 548 & Al Pla de les Llomes \\
\hline Pla Llomes & $39^{\circ} 42^{\prime} 21^{\prime \prime}$ & $0^{\circ} 24^{\prime} 13^{\prime \prime}$ & 503 & Antic corral? \\
\hline EI Poll & $39^{\circ} 42^{\prime} 57^{\prime \prime}$ & $0^{\circ} 27^{\prime} 56^{\prime \prime}$ & 654 & Antic corral? Casa guardes \\
\hline La Prunera & $39^{\circ} 42^{\prime} 17^{\prime \prime}$ & $0^{\circ} 26^{\prime} 23^{\prime \prime}$ & 592 & N'eren dos (desapareguts) \\
\hline $\begin{array}{l}\text { Carrer de la } \\
\text { Pobleta }\end{array}$ & $39^{\circ} 41^{\prime} 07^{\prime \prime}$ & $0^{\circ} 25^{\prime} 57^{\prime \prime}$ & 351 & (corral?) \\
\hline La Rosa & $39^{\circ} 42^{\prime} 13^{\prime \prime}$ & $0^{\circ} 28^{\prime} 51^{\prime \prime}$ & 551 & Un dels més antics \\
\hline El Siscar & $39^{\circ} 40^{\prime} 18^{\prime \prime}$ & $0^{\circ} 25^{\prime} 60^{\prime \prime}$ & 309 & Entrada "Monteamor" \\
\hline Xarxant & $39^{\circ} 40^{\prime} 13^{\prime \prime}$ & $0^{\circ} 26^{\prime} 20^{\prime \prime}$ & 278 & Sector sud de Xarxant \\
\hline Aliguetes & $39^{\circ} 41^{\prime} 41^{\prime \prime}$ & $0^{\circ} 25^{\prime} 30^{\prime \prime}$ & 450 & Antic (dalt de Marianet \\
\hline
\end{tabular}

En lletra negreta queden destacats els situats dins de l'antic priorat de Portaceli.

Segons Garay (2009).

El cultiu de la morera a Serra, més enllà de la producció sedera i de vegades exportadora de fulla que arribà a donar-se en Portaceli (Garay, 2004), sembla que va ser dedicat generalment a l'autoconsum, perquè el que hi trobem sempre són referències a la seda obtinguda. Recordem (quadre 5-3) com la producció anual era de 700 lliures a Serra i de 100 lliures a Nàquera, en temps de Cavanilles.

Segons l'Alfarràs de la seda de 1738 (Franch, 1994), la producció sedera havia sigut de 181'5 lliures a Serra, de 211'5 lliures a Nàquera i de 172 lliures a la Cartoixa de Portaceli. Si comparem aquestes dades, i altres del mateix alfarràs, amb les aportades per Cavanilles uns 50 anys després comprovarem que en els pobles de l'horta hi ha una tendència a baixar la producció de morera, mentre que en els pobles de muntanya (com Serra) sol augmentar lleugerament. En certa manera sembla com si començara a donar-se certa crisi en el regadiu (altres conreus començarien a ser més rentables) i certa tendència a mantenir-se i encara augmentar la producció en certes terres de secà potser menys 
productives per a altres conreus. Per altra part, en aquells anys la fàbrica de Vinalesa (junt a la ruta de Serra-València per Montcada) fou un intent de millora de l'economia sedera que finalment, sembla, no va quallar com s'esperava (veure Franch, 2003).

No disposem de dades concretes sobre la producció de suro, però el seu aprofitament és un altre dels recursos tradicionals serrans, sobre tot al segle XIX, on no menys de 13 serrans eren propietaris de sureres situades en el terme de Gàtova quasi confrontant amb el de Serra. ${ }^{35}$ El suro era també un recurs clàssic de Portaceli que es feia servir per a la fabricació de taps de botes i cànters (Garay, 2004).

A les partides de Penyes Altes, Brihuela, la Falaguera i Sargatillo (forest de Portaceli) era on estaven les principals sureres del terme de Serra i el suro arrendat que s'extreia d'elles i de les esmentades propietats del terme de Gàtova era dipositat, fins a mitjans del segle XX en l'anomenat "corral del Suro" (junt a l'actual carrer del Doraor), des d'on era distribuïda i comercialitzada, conjuntament, la producció de cada any.

Un arbre molt present i remarcable en les hortes de Serra era i és el lledoner. Recordem que ja el destacava Cavanilles (1795-97) com arbre molt utilitzat a Serra per a assegurar i estabilitzar els ribassos de les hortes. A més d'això era l'arbre tradicional per a proveir mànecs d'eines i tot tipus d'estris: garrots, bastons, forques, aladres, cadires, peces de carros i de cavalcadures, etc. A més a més, cita també Cavanilles un ús tradicional lligat a la indústria del vi: "les cortan las ramitas, dejando sola la principal, que se levanta hasta adquirir el grueso y largo correspondiente a las perchas, que partidas por medio, longitudinalmente, siven para formar anchos aros de cubas". La possible indústria de fabricació de botes no l'hem trobada documentada, però si que continua donant-se als llidoners el tractament tradicional per a fer perxes (FIGURA 5.10) que encara en temps no massa llunyans eren tallades i venudes en gros.

L'obra de Bernardo Espinalt (1784) ofereix una visió més o menys paral·lela i coetània a la de Cavanilles, pel que fa a les principals ocupacions i produccions agràries de Serra i els pobles del seu entorn. En el volum 8, pàgines 257 a 259, d'aquesta publicació parla de Bétera, Nàquera i Serra, dient que en els tres termes es cullen els mateixos tipus de fruits de les moreres, nouers, ametllers, vinyes... Que produeixen forment, civada, ametlla, oli, vi llegums, seda, hortalisses i fruita, i que, a més d'això, en les muntanyes de Serra hi ha caça major i menor i bones pastures per al manteniment de la gran criança de ramat "de les seues alqueries". Açò aporta certa visió complementària

\footnotetext{
${ }^{35}$ Fons històric de la Biblioteca Valenciana: BV/NP34/F191 i F192.
} 
a la que coneixíem, per exemple, destacant la producció de l'ametlla, un notable cultiu tradicional a Serra, però que fins ara no havíem trobat citada.

FIGURA 5.10.- Llidoners de les hortes de Serra (A: horta de Ria; B: horta de l'Ombria) mostrant les seues grans soques i la tradicional i típica formació de perxes.

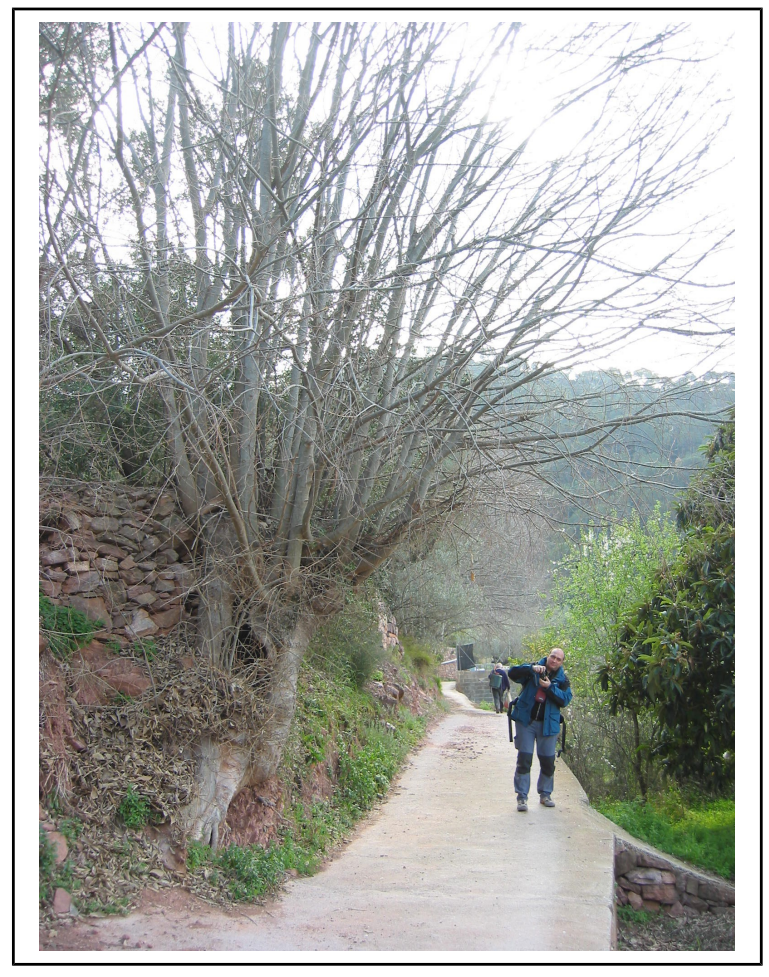

A

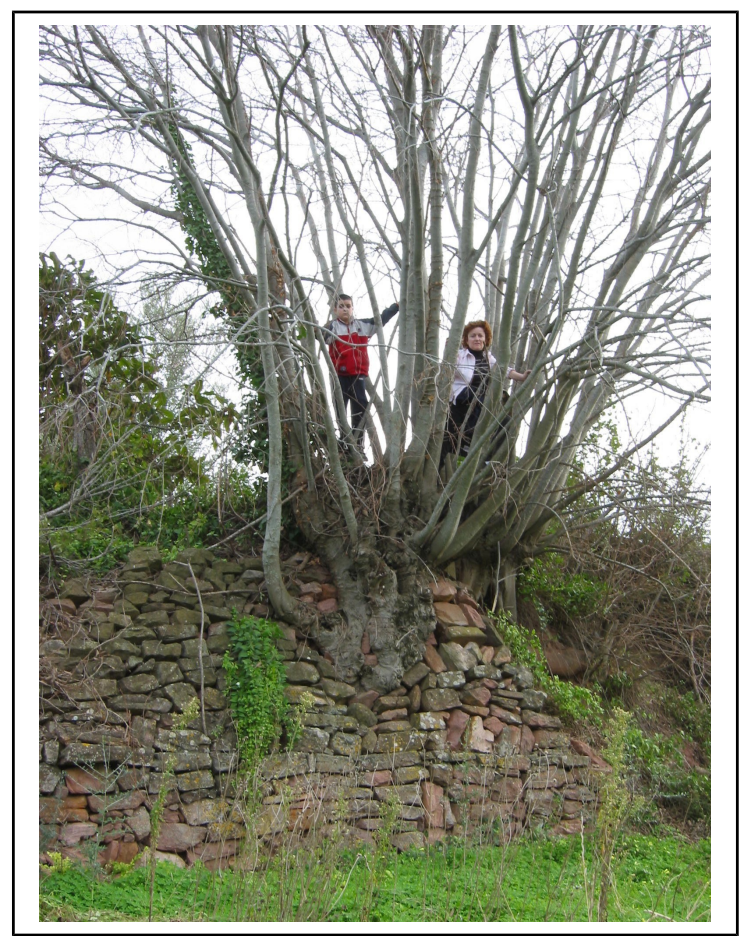

B

Fotografies de l'autor.

També ens crida l'atenció, en el cas d'Olocau, (pàgines 255 i 256 de dita obra) quan diu que és fèrtil en forment, civada, dacsa, seda, lli, cànem, etc. Afegint que a una llegua d'aquest lloc i a quatre de la Ciutat de València està situat el monestir de la Cartoixa de Portaceli dins el terme del qual es cull "el millor vi d'aquest Regne".

De Soneixa també diu que produeix molt de vi i que del sobrant que tenen fan aiguardent en quatre fàbriques que hi ha a l'efecte i que són "el principal tràfec dels seus habitants" (en les produccions de 1834 a 1838 de l'administrador del duc de Montellano, però, que abans hem citat, res d'açò posava). 
El treball de la pedra ha estat una gran ocupació dels serrans en totes les èpoques. Per una part els algepsars (pedreres d'extracció de guix, que hi havia tant a Portaceli, com a Nàquera i a Serra) i els forns de coure el guix, que solien estar junt als primers; per altra les "caleres" o forns de calç (al terme de la baronia de Serra en tenim identificades almenys quatre que han estat en ús fins el segle XX); però, sobre tot, des de mitjans del segle XIX hi hagué una gran eclosió de l'extracció i manufactura de la "pedra de rodeno"; i en molta menor mesura també l'aprofitament de pedra "clapís" (dolomia). La demanda de pedra de rastell de caràcter fort, com era la de rodeno, es va iniciar poc a poc a València i altres poblacions de l'Horta i de la Ribera, que començaren a enllambordar i fer voreres en carrers principals. Però la principal obra que faria potenciar aquest tipus de mineria a cel obert va ser el Mercat de València, el 1838. Desprès vindria un gran projecte d'adoquinar els carrers de la ciutat, sobre tot a partir de 1850 (Carsí i Gil, 2011). Desenes de pedreres repartides per tot el terme, però moltes d'elles concentrades junt al poble ("les Pedreres") en són mut testimoni d'una activitat que va ocupar gran part de la mà d'obra de Serra durant més d'un segle.

També serien executats, en diferents èpoques, nombrosos treballs de mineria metàl-lica, tant de prospecció com d'explotació minera, com és el cas de les mines de plom que cita Cavanilles (1795-97, v. I: 123) entre els termes de Serra i de Sogorb, o les explotacions de coure, beneficiades des del segle XV a Portaceli (Garay, 2004), a prop de la font del Llentiscle i del terme de la baronia de Serra. L'estudi dels aprofitaments històrics de tota aquesta mena de recursos geològics el deixem pendent per a posterior ocasió, tot i que poden formar un cos individual que potser se'n eixiria massa de l'àmbit històric i territorial d'aquesta tesi. 


\section{CAPÍTOL 6 \\ PRODUCCIÓ I RENDES A PARTIR DEL REGISTRE DELS DELMES}

Desprès d'haver conegut al llarg del capítol precedent les diferents produccions, els aprofitaments i els modes de vida de l'economia local, hem volgut conèixer l'evolució de la productivitat i la fiscalització al llarg del període estudiat. A tal efecte i a manca d'altres fonts directes i llargues que no hem pogut aconseguir, hem recorregut als registres de delmes que es custòdia en l'Arxiu de la Catedral de València. Es tracta d'una sèrie rigorosa en les dades, molt completa i llarga en el temps -abastant tot el període que ens ocupa- i relativament confiable per als nostres objectius, si bé, com ja posara de manifest James Casey (1979 i 2006: 8 6) les seues dades no reflecteixen l'estat real de les collites, sinó els preus dels arrendaments que s'havien preestablert abans de començar cada quadrienni; i per tant, ni es tracta d'una guia perfecta de la producció agrícola ni els registres serien útils per a un treball detallat al respecte. Així i tot, Casey volgué posar de relleu que, malgrat aquest obstacle, el delme continua sent un recurs indispensable per a obtenir informació sobre l'economia rural. De fet, va recollir en apèndixs del seu conegut llibre les dades globals de l'arquebisbat de València per als segles XVI i XVII, utilitzant com a base els llibres d'arrendament del Delme (ACV, caixes 4388 a 4397).

També el professor Manuel Ardit prestà bona atenció a l'estudi dels delmes, afirmant que la principal font per a l'estudi de l'evolució de la producció agrària és el delme eclesiàstic (Ardit, 1993, II: 93). En diversos treballs va publicar algunes llargues sèries de delmes que van des del segle XVI fins al XIX (Ardit, 1975, 1987 i 1989), però en la seua publicació de 1993 treballa amb un buidat més complet. Tant Ardit com Casey utilitzen les dades dels llibres d'arrendaments de delmes, citats més amunt. En el nostre cas, però, hem recorregut, sobretot als comptes del "Contrallibre", una altra sèrie documental que ens consta que no ha sigut fins ara massa consultada, com seguidament explicarem.

El buidat que va realitzar Manuel Ardit (base de l'estudi inclòs en la seua publicació de 1993) és molt ampli i extens, doncs abasta pobles de tota l'arxidiòcesi des de 1501 a 1835 , sent una gran base de dades posada a l'abast d'altres investigadors, que 
la citen. Segons exposa Ardit (op. cit.), a més de certes discontinuïtats que es donen en el segle XVI, la sèrie inclou algunes llacunes -que en el cas del "Contrallibre" no hem trobat- i també arrendaments rescindits que la mateixa Església s'encarrega de recaptar i tornar a subhastar. Bé per les llacunes o per omissions parcials, amb xifres inutilitzables, considera Ardit que no es possible una agregació simple i homogènia, i per això es decanta per utilitzar certs índexs per a cada sèrie, agregats com a mitjanes ponderades en les sèries comarcals i sectorials que finalment analitza i inclou en la publicació. Es tracta, a més a més, de sèries deflacionades en haver eliminar d'elles la influència d'un nivell general de preus que, en aquest cas l'assimila als preus del blat, segons dades provinents, per a diferents èpoques, de Hamilton (1975), Palop (1982) i Ardit (1975). Cal dir que, en el present cas, nosaltres hem utilitzat i presentarem les sèries en brut, sense introduir cap ponderació (que no ve al cas, en ser una sèrie única i completa) ni deflació. No obstant això, també farem, finalment una comparació amb els índex generals de preus, no ja per a deflacionar la sèrie, com podria ser d'esperar, sinó simplement per intentar detectar esdeveniments de possible causa-efecte.

Els delmes de Serra i Nàquera sempre els trobem junts, en tractar-se d'una única parròquia $\mathrm{i}$ per tant delmari, independentment de que hi hagueren dues baronies $\mathrm{i}$ cadascuna amb el seu propi temple parroquial. Com diem, no hem consultat només els documents citats per Casey i per Ardit (dalt referits), sinó també la llarga sèrie de l'anomenat "Contralibro de la colecta de Diezmos canonicales desde 1608 a 1836 " (ACV, 4236 a 4276; més de 40 caixes) que recullen, any per any, a més del nom dels adjudicataris i els preus dels arrendaments, els assentaments de cadascuna de les quantitats abonades i el nom de la persona que les feia cada vegada. Els anys no són naturals sinó fiscals, de manera que comencen durant la primavera i tenen com a terminis de pagament dos meitats: la primera per a Tots Sants i l'altra passat Carnestoltes. Malgrat que el títol general de la sèrie està escrit en castellà, crida l'atenció que cada volum del Contrallibre està escrit sempre en valencià, a diferència del que passa amb els Quique Libri parroquials, com els de Serra i Nàquera o el d'Estivella (Mesa, 2009), que per norma general sembla que havien d'estar escrits en castellà. ${ }^{1}$ Per cert, el Contrallibre era,

\footnotetext{
En els esmentats Quinque libri trobem com a dominant l'ús del castellà en tot el segle XVII, desprès del repoblament postmorisc, i especialment ho és a partir de mitjans del segle XVIII, en que comencen a trobar-se limitacions expresses a l'ús del valencià per part dels visitadors pastorals. Una de les prohibicions més primerenques és la de 1740, de l'arquebisbe Mayoral, citada en el $Q L$ d'Estivella per Vila (1983).
} 
a més del nom del llibre de comptes, el nom del càrrec o ofici de la persona encarregada de dur-lo i escriure en ell (valuós aclariment que agraesc al canonge arxiver, el Dr. Vicent Pons Alós). A més a més, el propi llibre, degudament enquadernat, era en la pràctica una mena d'arxivador de notes soltes $\mathrm{i}$ fulls que recollien diversos comptes $\mathrm{i}$ informes, com són les despeses per reparacions en algunes cases delmàries, reculls de collites d'alguns llocs o incidències de tota mena.

Per tal de poder analitzar millor les fluctuacions dels delmes de Serra i Nàquera al llarg dels segles XVII i XVIII i encara fins a la seua desaparició a partir de la Reial Disposició de 29 de juliol del 1837, han estat també observades, per tal de poder-les comparar, les fluctuacions que tingueren els respectius delmes a altres llocs de l'entorn de la baronia i durant el mateix període. Les dades obtingudes de l'arxiu han sigut organitzades en l'Annex III.

Pel que fa al priorat de Portaceli cal dir que gosava pràcticament d'exempció de delmes al Capítol catedralici, doncs ja el bisbe fra Andreu Albalat, el seu promotor i fundador, va concedir al monestir en 1272 els delmes de tots els seus termes, amb l'única obligació de satisfer al Bisbe i al Capítol 10 sous anuals en el dia de Sant Miquel de setembre ${ }^{2}$.

Per altra part, cal també tenir en compte, com veurem en detall més avant, que les baronies de Serra i de Nàquera, en matèria de ramats, pertanyien al delmari del Carnatge de Sagunt, del qual també formaven part Torres Torres amb Alfara i Algímia, els pobles de la vall de Segó, Petrés, Gilet i altres del baix Palància.

\subsection{ALGUNES CONSIDERACIONS SOBRE ELS DELMES}

Si bé l'origen del delme es pot remuntar a la tradició bíblica, en ser consignat al Pentateuc, en el cas del Regne de València s'inicia amb la pròpia institució dels Furs, per part de Jaume I, aspecte que en la recopilació feta per Taraçona (1580) queda recollit així (Títol XIII):

Quan lo gloriós rei Jaume primer, de feliç recordació, conquistador de la ciutat i Regne de València, determinà amb son Consell de emprendre dita conquesta, prometé que si Déu li ajudava a conquistar dita ciutat i regne, que primerament, ans de totes les coses, dotaria a l'Església Catedral i altres sufragànies, de mode que lo Bisbe i capellans hi viurien honestament.

\footnotetext{
${ }^{2}$ AHUV, lg. 145/18: sobre "Distribución de los diezmos y creación de canonicatos y dignidades".
} 
I haguda la victòria complí lo promès. Entre altres coses donà los dos terços de tots los delmes dels fruits de la terra i animals i peixos de la mar i l'albufera i dels forns i molins, fets i per fer de totes les terres dels Cristians i dels Moros...

I lo Bisbe donà en feu al Rei lo terç dels delmes, excepte los bens trets dels bens de cavallers, capellans i llocs de religiosos, i los delmes de les pròpies collites de Rei... Lo qual terç haja de posseir lo Rei a feu de l'Església, perquè li sia lleial i defensor...

El primer de juliol de 1249 i a requeriment del rei, el bisbe Ferrer de Sant Martí i el Capítol disposaren que el bisbe rebria la meitat de totes les possessions i l'altra meitat el Capítol. I que es practicara el mateix pel que fa als $2 / 3$ restants del delme, una vegada descomptat el terç-delme del Rei o del Senyor, pel que feia als termes del territori de València "çò és, des de Puçol fins a Almussafes, Espioca, Picassent, Torrent, Manises, Paterna i Montcada, i tal com s'estén la sèquia fins a Puzol i tot inclusiu fins a Cullera", i de la resta de pobles del bisbat reba el Capítol la tercera part ${ }^{3}$.

Hem vist com en la Carta Pobla de Serra i Ria, Josep Folch de Cardona deixa aclarit en diverses clàusules que els seus vassalls restaven francs de pagar-li el terç delme pels grans i fruits recollits tant en terres de regadiu com de secà, com també de les produccions de vi i panses. Respecte al bens semovents, establia que els vassalls havien de pagar al Senyor, únicament pel ramat llaner i cabrum, de cada vuit cries una "per tot delme i primícia".

Aquesta concessió en favor dels vassalls, renunciant el Senyor de la baronia de Serra al terç delme que li corresponia, no és gens habitual.

Per entendre de primera ma com funcionava açò del pagament del delme i del terç delme, la segona clàusula de la Carta Pobla de Nàquera resulta especialment aclaridora, quan expressa com s'havia de fer la repartició de fruits i grans de les hortes:

$2^{\circ}$ Primo: Que de les terres i heretats de les hortes del dit terme (Nàquera) s'haja de pagar i es pague per dret del Senyor, al dit Francisco Figuerola i a sos successors en dita Baronia, que per temps seran respectivament, la cinquena part del forment, panís i dacsa, pagant-se primer lo delme degut a l'església, i al Senyor lo terç delme que és també del Senyor, i la primícia al retor de la església de dit lloc; i tinga obligació qui culla los dits fruits, aprés de segats, portar-los a la era, i trillats i nets fer la dita partició fent valer en la forma justa i acostumada en l'horta de València, i de la palla s'hagen de fer cinc parts i la quinta part sia per al Senyor, triant i elegint la part lo Senyor o lo qui

\footnotetext{
${ }^{3}$ AHUV, lg. 145/18. Cfr. Diago (1613: 329).
} 
per ell estarà, i així los grans com la palla lo haja de portar lo amo del fruit des de la era a la casa del Senyor en lo dit lloc i no fora de aquell, i posar-los en son graner i lloc que tindrà per a recollir-los francament $\mathrm{i}$ sens paga alguna $\mathrm{i}$ amb pròpies cavalcadures del amo dels fruits.

Per al cobrament del terç-delme en les zones directament reials, Casey (2006, p. 75) ho explica així: “d'allò que el conreador lliurava, el rector de la parròquia en prenia el primer tall, les primícies, equivalent a dues novenes parts del delme sencer; aleshores, el rei prenia el seu terç i la resta anava al bisbe i al capítol de la diòcesi”.

Com que l'església de Nàquera era realment part d'una mateixa parròquia, junt amb la de Serra, amb els dos temples parroquials regits $i$ administrats per un mateix rector parroquial, totes les referències que hi trobem respecte a l'església de Nàquera (com ara la primícia al rector) venen a ser extensives a la de Serra, amb les degudes diferències derivades del fet de pertànyer realment a dues baronies diferents.

La següent clàusula de la Carta Pobla de Nàquera estableix que també en el cas de l'oliva haja de pagar al Senyor "lo mateix dret que s'ha dit del forment, collint lo Senyor útil la oliva, i lo oli forçosament l'haja de fer en la almàssera del dit Senyor i ningú més puga tenir almàssera, $\mathrm{i}$ hagen de pagar un diner de dret al Senyor per cascun cabàs de les olives de la premsa, i lo pinyol i ós molt de la oliva reste per al Senyor".

Aquestes condicions posen de relleu que el cost final que suportava el vassall anava més enllà de la estricta dècima part i posterior partició de fruits, doncs havia de posar (segons les esmentades capitulacions de la carta-pobla de Nàquera) la mà d'obra $\mathrm{i}$ el transport per a posar en casa del Senyor tant el terç delme com la partició d'un producte ja segat, trillat i net, en el cas del cereal, i molt i premsat, en el cas de l'oliva i l'oli, a més de pagar per l'ús obligat de l'almàssera de la Senyoria i deixar tot el pinyol per al Senyor.

Maria Menjón Ruiz (1992) reconeix que de manera general, en el cas del delme, el percentatge final a pagar superava en bona mida la dècima part del total, al no comptabilitzar les despeses ni les inversions realitzades, tractant-se així d'una tributació molt onerosa per al camperol, qui com a única opció de resistència al pagament li quedava o bé l'ocultació d'una part dels beneficis obtinguts o bé, quan era possible, donar com a part tributària el producte de menor qualitat ${ }^{4}$. En el cas de Serra, aquestes

\footnotetext{
${ }^{4}$ Per evitar aquesta pràctica, una pragmàtica reial de 1491, de Ferran i Isabel, a la Vega de Granada estant, determinava que el gra dels delmes i terces s'havia de pagar net, eixut i sense pallús ni pedres, terra ni cap altra cosa (Novísima Recopilación de las Leyes de España..., 1805).
} 
dues opcions serien utilitzades, no ja en el delmes (potser també) sinó en els conflictes sobre la producció de vi que mantingueren els vassalls amb el seu Senyor, segons tractarem en el capítol vuitè.

Per a ciutats reials, com Llíria, el repartiment era semblant. Casey (2006: 75) el descriu així: d'allò que el conreador lliurava, el rector de la parròquia en prenia el primer tall, les primícies, equivalent a dues novenes parts del delme sencer; a continuació, el Rei prenia el seu terç, del que era donat, i la resta anava al Bisbe i al Capítol de la diòcesi.

Però, contràriament a aquestes consideracions de les sobrecàrregues suportades pels vassalls, el que observem en nombroses notes de liquidació de delmes, de les inserides entre les pàgines del Contrallibre, sembla ser precisament el contrari: els arrendadors dels delmes presenten uns comptes de liquidació on fan constar, primer el recull de totes les produccions hagudes i a continuació els descàrrecs, on inclouen les despeses suportades, no solament per al transport dels productes del camp, sinó també per a la col·lecta dels grans i dels fruits, les reformes en les cases delmeres, la compra de contenidors o encara lloguers de magatzematge temporal. Ja hem tingut ocasió de veure alguns exemples d'açò en el capítol anterior.

Aleshores, el que no resta clar del tot és fins a quin punt totes aquestes despeses incloses en els comptes de liquidació dels arrendadors eren reals i pagades com a jornals o si pel contrari se n'aprofitaven o es beneficiaven -al menys parcialment- d'un treball que podia ser "obligatori" dels vassalls (com es desprèn, concretament, del cas de Nàquera i pel que fa al seu terç-delme).

Encara hi ha un aspecte de la Carta Pobla de Nàquera que crida l'atenció per la seua afinitat amb un conflicte que davant el tribunal de Delmes arrossegava contra el Capítol catedralici la ciutat de Sagunt. Els veïns de Morvedre tenia guanyada una sentència que eximia els seus veïns de pagar delme per les garrofes, fulla i azibar ${ }^{5}$, per possessió immemorial, sentència reconeguda en les Corts de l'any 1547. En canvi, des d'aquella data, el procurador de l'Arquebisbe, el Capítol i els arrendadors dels delmes venien exigint el delme corresponent sobre les garrofes i les fulles, emparant-se en diverses demandes i sentències posteriors que també havien guanyat. En setembre de 1722, aquest assumpte estava novament llest per a sentència davant el Jutge de Delmes, segons conté un memorial de l'època ${ }^{6}$. Al conflicte de les garrofes i la morera fa expressament menció Casey (2005, p. 2 61), tot posant de relleu que el cultiu de la

\footnotetext{
${ }^{5}$ Acíbar és la forma castellana del sèver, un dels subproductes obtinguts de l'àloe, que tenia (i té)
} aplicacions en tractaments cutanis i com a purgant, entre altres usos medicinals. 
garrofa va tindre una gran expansió durant l'època moderna, lligada a la substitució dels bous pel cavall com animal de llaurar i a l'explotació, per primera vegada, de molt terrenys àrids del territori valencià. Per altra part, l'estament eclesiàstic, durant les Corts celebrades a Monsó l'any 1626, alertava també de la desmesurada proliferació de les plantacions de moreres, garrofers, pomeres i altres arbres que excusaven el pagament de delmes per no estar clarament previst en el furs; causant així una gran disminució i perjuí sobre els delmes i "el terç delme que hi té lo Reial patrimoni”.?

Al respecte, la carta pobla de Nàquera concorda amb la pretensió o dret que defensaven els veïns de Sagunt, quan diu que "de la garrofa no és acostumat pagar delme ni primícia i únicament s'ha de pagar al Senyor lo quint de la collita per lo poblador i senyor útil, i haja aquell de portar lo dret a casa del Senyor, com los demés grans". Aquesta partició de Nàquera era més exigent que la suportada pels colons de Serra, on la garrofa "només" havia de pagar la sisena part de les collides a l'horta i la vuitena part de les del secà.

A més de la Primícia que es pagava al rector parroquial (2/9 del delme sencer) hi havia una altra part del delme que es deia excusat (o "escusado") i que era un tribut destinat directament la corona, independentment dels terç-delme reial que rebia de les zones de reialenc. L'excusat era una gracia papal (breu pontifici, de 21 de maig de 1571) per la qual, la corona tenia dret a rebre directament el delme de la casa que més contribució aportés al delmat de cada parròquia i de cadascuna de les parròquies dels regnes d'Espanya (exceptuades les Índies) i illes adjacents. En principi s'atorgà per a un quinquenni però successives disposicions anaren prorrogant i ratificant l'excusat fins ferlo permanent, mitjançant una butlla de Benedicte XIV, de 6 de setembre de 1757.

L’objecte de l'excusat va ser, inicialment (i per concessió de Pius V a Felip II), costejar la guerra contra els heretges alçats a Flandes i contra les invasions turques. Gregori XIII, en 25 de novembre de 1578, declarava que devien contribuir a la gràcia de l'escusat i les concòrdies que s'havien fet al respecte, tots els regulars, les seues ordes i monestirs, els seculars i persones de qualsevol orde militar i les seues cases, universitats, etc. Sense perjudici de les seues possibles exempcions i privilegis anteriors per a no

\footnotetext{
6 “Jesus, Maria, Joseph. Por el Muy Ilustre Cabildo de la Santa Iglesia Metropolitana de esta Ciudad. Sobre la cobranza de los diezmo de hoja y algarrobas. Contra la villa de Murviedro y demás comprehendidas en su Diezmario". Facsímil, de 33 pàgines, editat en 2010 per Antonio Navarro Llopis (D.L.: V-2662-2010). ${ }^{7}$ Cortes del Reinado de Felipe IV. Cortes valencianas de 1626 (Lario Ramírez, 1973, p. 93).
} 
pagar delmes. ${ }^{8}$ Açò fa pensar que també hi podrien haver estat afectades algunes de les possessions del monestir de Portaceli, cosa de la qual parlarem més endavant.

\subsection{SOBRE LES CASES DELMERES}

Casey (2005, p. 259) diu que en el segle XVI eren 92 els delmaris o circumscripcions en que es dividia el capítol de l'arxidiòcesi de València i que hi havia tres tipus de delmes: els principals, més coneguts com de "pa i vi", els dels ramats i els de les fruites de les grans zones de regadiu, que eren les de València, Sagunt i Xàtiva. El tradicional delme de "pa i vi" agrupava realment totes les collites subjectes a contribució, particularment els cereals i el vi, però també llegums, oli, pansa, etc. Els ramats (pràcticament ovicaprins i poc més) eren controlat amb els delmaris anomenats de "carnatge" (d'onze àrees geogràfiques en el segle XVI), mentre que les grans produccions de fruites i verdures de les grans zones de rec eren els "paners".

No obstant, en el contrallibre de l'any 1649/1650 trobem que la taula del delmari de la Seu de València està formada ja per 125 delmaris o administracions de delme, de les quals 16 son carnatges (Dènia, Xàtiva, Ontinyent i Biar, Calp i Altea, Bocairent i Banyeres, Gandia, Alcoi, Llutxent, Morvedre, València, Sueca i Cullera, Penàguila, Perputxent, Castalla, Quesa i Bicorp i Cocentaina), només dos són paners (Morvedre i València) i a més hi ha tres delmaris de peix (de la mar, de la taula i arraixos). Aquesta xifra puja fins a 199 delmaris en l'any 1800/1801, moltes de les quals sorgeixen per particions de delmaris grans, com el d'Alcoi (dividit ara en "part primera" i "part segona"), el d'Ontinyent ("solana" i “ombria”) o el de Castelló de la Vilanova ("mà dreta" i "mà esquerra"), mentre que es mantenen els 16 carnatges i encara un únic paner (el de Patraix) i apareixen de nou 7 delmaris de cànem (parròquies de Sant Salvador, Sant Bertomeu, Burjassot, Campanar, Carpesa i Borbotó, Patraix, i Sant Tomàs i Sant Esteve). En l'Annex IV hem recollit les llistes dels delmaris dels dos exercicis esmentats, amb un segle i mig de diferència entre ells.

En el cas que ens interessa, Serra i Nàquera, el trobem sempre com a delmari invariable al llarg de tot el període, i cal entendre que inclou tant el delme de "pa i vi" com el paner de grans i fruites, però no així el delme dels ramats, que queda inclòs dins el carnatge de Morvedre. L'examen detallat de tota la sèrie del Contrallibre no ens ha

\footnotetext{
${ }^{8}$ Novísima recopilación de las leyes de España... (1805): Llibre II, Títol VI, p. 307 i ss.).
} 
permès trobar cap afegit ni nota de cap any que descriguera els productes delmats en el delmari de Serra i Nàquera. No obstant això, algunes notes i relacions que citarem més avant, referides a llocs de l'entorn, proporciona valuoses dades per a entendre la mena de productes que eren objecte de control i mesura en aquest delmari, com en els altres del mateix entorn muntanyenc (vall d'Olocau, Segart, Estivella, Torres Torres...).

Per al control dels productes delmats era necessari disposar d'un espai adient, com era un local o casa delmera, com també uns contenidors (tonells, piques i cànters) adaptats a cada producte de contribució. Algunes cases delmeres entenem que eren de propietat del Capítol (destacades serien les de Llíria, Albal o Massamagrell, entre altres), doncs hi consta al llarg del període estudiat importants despeses en obres de manteniment i ampliació. Altres, en canvi, eren llogades, normalment per quadriennis coincidents amb els dels arrendaments. En aquest cas es trobaria el delmari de Serra i Nàquera, almenys així ho hem vist en alguns anys de principis del segle XVII. Concretament, en desembre de 1607 era arrendada per un dels tres administradors del delme de Serra (Francés Gorris, tintorer) i per Joaquim Pujades (mercader) la "casa delmera del escusado" de la pica de Nàquera, per als anys 1608 a 1610, per preu d'arrendament cascun any de 30 lliures pagadores a Tots Sants i Carnestoltes, "amb certs pactes i condicions". 9

Un dia abans que la de Nàquera era també llogada la casa delmera de l'excusat de la pica de Bétera a Hieroni Gonzales, donzell, amb fermança d'en Carles de Castellví, pel preu de 80 lliures cascun any. I encara al juliol del mateix any havien sigut també llogades les cases delmeres de l'excusat de les piques de Torres Torres, Algímia i Gilet a Francés Fuster i a Llorens Bendicho, mercaders, per preu d'arrendament cascun any de 50 lliures, corresponents 35 lliures a Torres Torres i Algímia i les altres 15 lliures a la de Gilet.

Per aquestes dades podem entendre que la casa delmera de Serra i Nàquera es trobaria ubicada a Nàquera, cosa lògica també per raons de distància, si tenim en compte que el destí de les produccions es trobava cap al sud, principalment en la ciutat de València.

Per altra part, recordem que l'excusat era un impost de concessió papal en favor de la Monarquia hispànica (una de les "tres gràcies", concedit en 1596), consistent en la percepció del delme d'aquell contribuent que més pagava en cada parròquia. Amb el nom

\footnotetext{
${ }^{9}$ Acte rebut pel notari Gaspar Palamicino, en 13 de desembre de 1607 (ACV, lg. ).
} 
d'excusat era també conegut el corresponent parroquià i propietari útil de la casa que habitualment era llogada per a dur i concentrar la resta de delmes de la parròquia.

\subsection{SOBRE DISTRIBUCIÓ I REPARTIMENT DELS DELMES DE SERRA}

Hi ha un expedient de la parròquia del lloc de Serra i el seu annex Nàquera on el rector, que en aquell any (1769) era Juan Bautista Costa, informa sobre els comptes de la fàbrica de l'església de Serra, fent alguns comentaris que resulten interessants pel que fa a certs aspectes sobre el delme de Serra. Diu que "los llevadores de los Diesmos perciben, por estar arrendados, en renta líquida..." per cascun any la quantitat de 360 lliues (360L-s) i afegeix que no hi ha memòria de que hagen contribuït mai en res ni a la fàbrica de l'església, ni a la reedificació, ni a la còngrua parroquial. A continuació afegeix "Certifico el abaxo firmado Rector de la Iglesia Parroquial de Serra y Náquera que los llevadores de los Diezmos de Serra y Náquera son el Cabildo y Sr. Arzobispo de Valencia, y assi mesmo, que en Serra no hay Tercio diezmo porque el Sr del Lugar lo sedió a los vezinos, y en Náquera, el tercio diezmo es del Senyor del Lugar, que lo cobra su arrendador (30 sept. 1769)". ${ }^{10}$

Per altra part, en el registre de la sèrie del Contrallibre de la col·lecta dels delmes canonicals, a la que desprès ens referirem més àmpliament, trobem que en aquell any 1769, els adjudicataris per al cobrament del delme de Serra i Nàquera eren Vicent Bellver, tractant i comerciant de València, i Manuel Pelayo, llaurador de Museros, que el tenien arrendat just per 120 lliures (la tercera part del que deia el rector Costa). Per tant, el que registraria el Contrallibre és la tercera part del delme que se'n duen "los llevadores de los Diezmos". Vist així, se'ns plantejava el dubte de si en aquell delme estava ja inclòs el terç delme senyorial-reial, mentre que els altres dos terços serien un per al Capítol (allò que registra l'esmentat Contrallibre) i l'altre per a l'arquebisbe?. O si d'altra manera, aquelles 360 lliures de "los llevadores" havien de ser ja les 2/3 parts del delme, desprès d'haver sigut separat prèviament el terç-delme senyorial, aquell que en el cas de Serra havia sigut concedit pel seu senyor als vassalls (mitjançant la carta pobla) però que en el cas de Nàquera el cobrava religiosament el seu senyor, Francesc Figuerola.

El informe del rector Costa no entra en aclarir si el terç-delme dels serrans era directament separat i exceptuat de la recaptació del delme (el més probable, cal pensar) o

\footnotetext{
${ }^{10}$ (A.C.V., lg. 4689: 35)
} 
si bé era recaptat per a desprès revertir-lo als contribuents d'alguna manera o si es destinava a alguna altra causa, com podia ser un fons comú o algun altre "benefici".

Un altre document del arxiu catedralici (ACV, lg. 4428) ens permet conèixer amb tot detall com era la distribució dels diners del delme, aplicant-lo a un cas, el de l'any 1797/1798. Aquell any, pel Contrallibre sabem que era arrendador del Delme de Serra i Nàquera Mariano Mauricio Algarra, de València, i que el valor anual era de 333 lliures, 6 sous i 8 diners, o siga, just un terç de 1.000 lliures, i aquesta és, precisament, la quantitat que corresponia aquell any a Serra. El contingut d'aquest document, per al cas concret de Serra i Nàquera és el recollit en el QUADRE 6.1.

QUADRE 6-1.- Repartiment del delme de Serra i Nàquera de l'any 1797-98, segons el "Llibre per a formar els comptes de particions dels delmes".

Serra i Nàquera: este diezmario se arrendó en 1796 por $1.000 \mathrm{~L}$

De este precio se saca 1/3 del Cabildo y se resta, quedando las otras dos partes; de esta resta se saca 1/10 para el Arcediano Mayor, y esta décima se resta de la cantidad anterior; y lo que queda es la parte que toca al Sr Arzobispo. Exemplo:

Precio $\quad 1.000 \mathrm{~L}$

el 1/3 333 L 06 s 08 al Cabildo.

resta: $\quad 666 \mathrm{~L} 13$ s 04

el 1/10 66 L 13 s 04 para el Arcediano Mayor.

resta: $\quad 600 \mathrm{~L}$ al Sr. Arzobispo.

Recopilación:

Sr. Arzobispo $600 \mathrm{~L}$

Arcediano mayor (1/10)_ $66 \mathrm{~L} 13 \mathrm{~s} 4$

Cabildo (1/3) 333 L6s8

SUMA $1.000 \mathrm{~L}$

Font: ACV, lg. 4428, f. 235.

El que resulta sorprenent és que aquest document correspon a un llibre fet per a formar els comptes de partició de delmes d'aquell any, i està fet com a una mena de manual de referència que, en el cas de Serra i Nàquera parteix justament de la quantitat 
redona que serien les 1.000 lliures per al import global del delme d'aquell any. Sorprenentment no té per a res en compte el terç-delme del Senyor ni dels vassalls de Serra. Serien les 1.000 lliures equivalents als 2/3 del delme total? Haurien descomptat abans les primícies i el terç delme del noble? En fi, no ens queda gens clar.

Desglossats amb els mateixos criteris també trobem en l'esmentat llibre el Carnatge de Morvedre, del qual formava part Serra, i la resta de llocs (cases delmeres), dels que donem la referència per a alguns dels més propers a Serra (QUADRE 6.2).

QUADRE 6.2.- Referències al documents explicatius del repartiment de delmes al voltant d 1795 .

\begin{tabular}{|c|c|c|c|}
\hline Casa delmera & any & import & doc. \\
\hline Carnatge de Morvedre & 1795 & 551 lliures & $\mathrm{ACV}, 4428$, f. 83 \\
\hline Albalat i Segart & 1795 & 620 lliures i 10 sous & $\mathrm{ACV}, 4428$, f. 38 \\
\hline Bétera & 1795 & 1.713 lliures & ACV, 4428, f. 57 \\
\hline Estivella i Beselga & 1795 & 513 lliures & $\mathrm{ACV}, 4428$, f. 134 \\
\hline Olocau & 1796 & 650 lliures i 10 sous & ACV, 4428, f. 180 \\
\hline Torres Torres & 1795 & 1.555 lliures & ACV, 4428, f. 242 \\
\hline
\end{tabular}

Font: Arxiu de la Catedral de València.

Pot ser que en el cas de Montcada, que es va arrendar en 1797 per 2.405 lliures i 10 sous (ACV, 4428, f. 169) aquest criteri de repartiment fóra adient, tot tenint en compte que el lloc pertanyia al propi Arquebisbe. Però, en la resta de casos esmentats no acaba de quedar-nos clar que el criteri fora correcte si s'aplicava a tot el delme. La possibilitat de que es tractés d'una errada en la previsió és descartada quan, en repassar registres prou més antics (fins del segle XVI) trobem casos semblants. Per exemple, el delme de Serra i Nàquera de l'any 1583 el van arrendar dos moriscos, Melchior i Alonço Miquel Carehueni ${ }^{11}$ i un cristià vell, Hieroni Rebolledo, pel preu de 129 lliures, fent constar en el mateix assentament ${ }^{12}$ el repartiment aplicable com segueix:

Arquebisbe.............................77L8s- $\quad(2 / 3-10 \%$ de $2 / 3)$
Artiacha (sic.) Major..................... 8 L12s- $(10 \%$ de $2 / 3)$

\footnotetext{
${ }^{11}$ Alonso Carahueni i Melchior Carahueni són dos veïns moriscos del poble d'Olocau, segons el desarmament de 1563 (Garay, 2012).

${ }^{12} \mathrm{ACV}, 4392$, f. $121 \mathrm{r}^{\circ}$.
} 
Amb el mateix criteri de repartiment hi trobem molts altres casos. ${ }^{13}$ Per això, entenem que els preus esmentats no són el delme complet sinó els $2 / 3$, una vegada descomptat el terç-delme reial, senyorial o eclesiàstic corresponent.

Els aclariments als possibles dubtes que fins ací han quedat plantejats o no han sigut ben resolts, els podem trobar novament de la mà de del ja esmentat expedient de l'any 1769 del "rector parroquial del lloc de Serra i el seu annex Nàquera", en Joan Baptista Costa, el qual acaba, desprès d'haver rendit comptes dels ingressos i despeses relacionats amb la fàbrica de l'església de Serra, aportant també els comptes de tot el que ell personalment rep i aporta cada any des del seu propi ministeri i pel seu càrrec. ${ }^{14}$

Abans caldrà tornar a recordar que segons el Contrallibre, en els exercicis previ $\mathrm{i}$ posterior a dit any 1769, el delme de Serra està arrendat per 120 lliures, o siga, equivalent a 360 lliures en total, segons hem vist més amunt.

El rector Costa declara que els seus ingressos anuals o "Renta del Cura" són:

- D'allò carregat a cens i peu d'altar: 150 lliures

- De la Primícia que és del rector 170 lliures

- De la mensa arxiepiscopal 50 lliures

Per altra part, les càrregues que suporta cada any són:

- Paga a sa Majestat q.D.g., del Subsidi..... 1 lliura i 13 sous

- Paga per recollir la Primícia. 8 lliures

- Gasta cada any en mantindre una aca per a anar a l'annex (Nàquera) .30 lliures

- Està obligat sense almoina a celebrar missa Pro-populo els dies de precepte, almoina que importa. 15 lliures

Anteriorment havia dit (recordem-ho) que els portadors dels delmes percebien en renda líquida, cada any 360 lliures "i no hi ha memòria de que mai hagen contribuït en cap cosa ni a la fàbrica de l'església ni a la reedificació ni a la còngrua parroquial".

En conseqüència, si la primícia (que sabem estava estipulada en 2/9 del delme complet) suposa $170 \mathrm{~L}$, el delme brut serien $765 \mathrm{~L}$ i la producció teòrica (estimada a priori) 7.650L. Tanmateix, el delme desproveït ja de primícia serien 595L, el terç-delme

\footnotetext{
${ }^{13}$ Les $60 \mathrm{~L}$ de l'any 1557 (20 per a la Pavordia de Juny, 4 per a l'Arcedià major i 36 per a l'Arquebisbe) $\mathrm{o}$ les $25 \mathrm{~L}$ de 1504 (8L6s8 per al Pavorde, 1L13s4 l'Arcedià i 15L l'Arquebisbe).

${ }^{14}$ (A.C.V., lg. $4689: 35 \mathrm{r}^{\mathrm{O}}-37 \mathrm{v}^{\mathrm{o}}$ ).
} 
seria aleshores 198L6s8 i la resta serien 396L13s4. En tal cas, la diferència amb el preu d'arrendament (360L) serien 36L13s4. Aquesta quantitat representa aproximadament un 9,3\% que, considerem, podria correspondre a l'excusat, concepte del que ja hem parlat.

\subsection{ARRENDADORS DELS DELMES ABANS I DESPRÈS DE LA CARTA-POBLA}

En un principi, els responsables del cobrament dels delmes serien els 12 pavordes (cada un amb el nom d'un mes de l'any) que formaven la Pavordia, dignitat creada pel bisbe Albalat i el Capítol en l'any 1259, amb objecte de que cada pavorde, en el seu mes, s'encarregués de col·lectar tots els bens decimals de la Mensa capitular. Aquestes dignitats s'encarregaven també de que els canònics i beneficiaris residents reberen cada dia la porció senyalada que els pertanyia. Segons indica Sanchis Sivera (1909, p. 19 i ss.) aquests càrrecs tenien caràcter de benefici perpetu i gaudien d'unes rendes que en el segle XVII eren de tres a quatre mil ducats, arribant així a excitar la cobdícia de tal manera que els sol·licitaven i obtenien les persones més il·lustres de València i no pocs cardenals. Sense conèixer massa detalls del grau de relació que hi poguera haver amb els comptes del Contrallibre, el que resulta evident és que aquest (llibre) reflecteix que normalment cada quatre anys hi ha una adjudicació a nous arrendataris de delmes, els quals s'encarreguen de retre comptes davant el Contrallibre (càrrec). Aquesta adjudicació es fa mitjançant un acte oficial davant el notari del Capítol, fent constar la identitat de les persones (normalment en són diverses) adjudicatàries, de vegades la dels seus avaladors (sovint familiars i esposes o marits), la data i el termini (normalment 4 anys), la quantitat anual (per a cadascun dels anys del termini) i les quotes (sempre dues: la de Tots Sants i la de Carnestoltes.

A través dels llibres d'adjudicacions (ACV, 4388 a 4397; citats per Casey, 1981) podem conèixer qui eren els arrendataris de cada delmari abans i després del començament del Contrallibre (que pràcticament va de 1611 a 1837) i també constatar que els preus d'aquests arrendaments reflecteixen la quantitat total del delme (tota la dècima), que sempre és, justament, el triple d'allò que queda enregistrat pel Contrallibre de la part pertanyent al Capítol.

En el cas dels delmes de "Serra i Nàquera" (que com sabem formaven un mateix delmari) resulta interessant comparar el perfil dels arrendadors d'abans i desprès de 
l'expulsió morisca. A l'efecte hem elaborat el QUADRE 6.3, on es recullen dates corresponents a les darreres dècades del segle XVI i les primeres del XVII.

QUADRE 6.3.- Arrendadors dels delmes de Serra i Nàquera en les dècades pròximes a l'expulsió morisca $(\mathrm{ACV}$,$) .$

Any Termini Preu cada any Arrendadors

\begin{tabular}{|l|l|c|l|}
\hline 1571 & 4 anys & $104 \mathrm{~L}$ & $\begin{array}{l}\text { Francesc Garcia i Lluís Honorat Forés, } \\
\text { mercader. }\end{array}$ \\
\hline 1575 & 4 anys & $100 \mathrm{~L}$ & $\begin{array}{l}\text { Joan Josep Romeu i Joan Gómez de la Torre, } \\
\text { mercaders. }\end{array}$ \\
\hline 1579 & 4 anys & $95 \mathrm{~L} \mathrm{10} \mathrm{s}$ & $\begin{array}{l}\text { Joan Ferrandiz isla, mercader, Miquel } \\
\text { Figuerola, ciutadà i Cristòfol Claramunt, } \\
\text { cavaller }\end{array}$ \\
\hline 1583 & 4 anys & $129 \mathrm{~L}$ & $\begin{array}{l}\text { Melgior Cherehueni, Alons Miquel } \\
\text { Cherehueni i Hieroni Rebolledo. }\end{array}$ \\
\hline 1587 & 4 anys & $105 \mathrm{~L}$ & $\begin{array}{l}\text { Domingo Gàrate, paraire } \\
\text { Martín Vasco, paraire. }\end{array}$ \\
\hline 1591 & 4 anys & $122 \mathrm{~L}$ & $\begin{array}{l}\text { Hieroni Alasa, Gaspar Alasa i Gaspar Melo, } \\
\text { de Bétera. }\end{array}$ \\
\hline 1595 & 4 anys & $156 \mathrm{~L} \mathrm{10} \mathrm{s}$ & $\begin{array}{l}\text { Francisco Domingo, escuder, Joan Sancho } \\
\text { López, notari i Joan P. Pareja, mercader. }\end{array}$ \\
\hline 1599 & 4 anys & $167 \mathrm{~L} \mathrm{10} \mathrm{s}$ & $\begin{array}{l}\text { Pau Sancho, Joan Molina, Miquel Barchet i } \\
\text { Joan Disolas, cristians nous de Nàquera. }\end{array}$ \\
\hline 1603 & 4 anys & $167 \mathrm{~L} \mathrm{10} \mathrm{s}$ & $\begin{array}{l}\text { Dionís Aranda, calceter i Francés Górriz, } \\
\text { tintorer de València. }\end{array}$ \\
\hline 1607 & 4 anys & $201 \mathrm{~L} \mathrm{10} \mathrm{s}$ & $\begin{array}{l}\text { Guillem Giralt, tintorer de seda, Francés } \\
\text { Górriz, tintorer i Batiste Donya, veler.. }\end{array}$ \\
\hline 1611 & 4 anys & $190 \mathrm{~L}$ & Martín Frayle i Fabià Alabarda, mercaders. \\
\hline 1615 & 4 anys & $182 \mathrm{~L}$ & Vicent Giner, flaquer i Jaume Périz, peraire. \\
\hline 1619 & 4 anys & $155 \mathrm{~L}$ & $\begin{array}{l}\text { Antoni Roca, fuster, Agustí Becer, fuster i } \\
\text { Jeroni Romeu, escrivent. }\end{array}$ \\
\hline 1623 & 4 anys & $140 \mathrm{~L}$ & (no especifica noms) \\
\hline 1627 & 4 anys & $140 \mathrm{~L}$ & $\begin{array}{l}\text { Jaume Font, ferrer del camí de Morvedre, } \\
\text { Batista Donya, batlle de Serra i Pere Navarro, } \\
\text { cabanyer de Serra. }\end{array}$ \\
\hline 1636 & 4 anys & $182 \mathrm{~L}$ & Pere Marcell i Jordi Esteve, llauradors. \\
\hline 1643 & 4 anys & $140 \mathrm{~L}$ & $\begin{array}{l}\text { Jeroni Sanz, carnisser, Lleonard Herrero i } \\
\text { Diego Torregrossa, algutzir de València. }\end{array}$ \\
\hline
\end{tabular}

Font: llibres d'arrendaments de delmes (ACV, 4388 a 4397)

Un dels aspectes a destacar és que durant el segle XVI i fins a l'expulsió morisca trobem que en els arrendaments dels delmes era relativament habitual trobar-ne tant moriscos com cristians vells. En el cas de Serra, per al període ressenyat en l'esmentat quadre hi trobem, per als anys 1583-1587 dos moriscos d'Olocau de cognom Carahueni (vegeu nota 5 a peu de pàgina, d'aquest capítol). També per als anys 1599-1603 són 
arrendataris altres dos moriscos, cristians nous de Nàquera; un d'ells (Miquel Barchet) el trobem també en la presa de possessió de la baronia de Nàquera en gener de 1609 (Lluch, 2002; p. 367). Els més destacats, però, per la seua posició potser siguen Gaspar Melo i els seus socis Jeroni i Gaspar Alasa que arrenden el delmari per als anys 1591-1595. Aquests dos llinatges, els Alasa i els Melo (també dit Melon) van ser citats pel pare Fonseca (1613) con a exemple de la bona posició i poder que tenien algunes famílies de moriscos, aspecte que també recull Eugenio Císcar (1993, p. ) en referir-se a aquest personatge, Gaspar Melo, casat amb una filla de Lluís Asquer (d'Alasquer) i reputat com a un del moriscos més cèlebres i importants del seu moment. A més de l'arrendament de Serra i Nàquera, Gaspar Melo també va arrendar, generalment associat amb el seu sogre (Lluís Asquer) i amb els Alasa de Bétera o també amb cristians vells, altres delmes en les dues darreres dècades del segle XVI, concretament els de Bétera, els d'Alberic i Alcocer, el del carnatge de València i pot ser alguns més.

Altres delmaris situats al voltant de Serra i Nàquera també eren arrendats sovint per moriscos en aquestes darreres dècades. És el cas, per exemple, de l'arrendament que feren d'Olocau, entre 1603-1607 i per valor de 340 lliures, els moriscos de Bétera Jeroni Alaf i Jeroni Melich; o el cas de l'arrendament d'Albalat i Segart que feren en 1577, per import de 140 lliures anuals, Jaume Zaet i Cristòfol Centelles.

Pel que fa als oficis i ocupacions dels arrendataris dels delmes de Serra i Nàquera en aquestos anys, s'observa que predominen artesans i comerciants (mercaders, paraires, tintorers, calceter, fuster, flaquer, fuster, carnisser...) i rarament els llauradors. Però veurem, no solament amb aquesta mostra sinó al llarg dels segles que segueixen, que també era habitual trobar notaris i escrivents, i encara algun noble i fins a un algutzir de València.

Els cognoms del ciutadà Miquel Figuerola i el del seu noble soci, el cavaller Cristòfol Claramunt, arrendadors dels delmes en 1579, no poden negar la seua vinculació familiar amb el difunt senyor de Nàquera, Melcior Figuerola Claramunt, faltat pocs anys enrere.

Més interessant ens resulta Batista Donya, coarrendador dels delmes de Serra i Nàquera, primer en $1607 \mathrm{i}$ desprès en 1627. En la primera ocasió el trobem citat simplement com a veler (fabricant de veles de navegació) i 20 anys desprès com a batlle de Serra, ara junt amb Pere Navarro, cabanyer ${ }^{15}$ de Serra, i Jaume Font, ferrer del camí de

\footnotetext{
${ }^{15}$ El significat d'aquest ofici, segons el Diccionari Català-Valencià-Balear (Moll, IEC) es: "propietari o conductor d'una cabanya o ramat de bestiar transhumant", que és exactament el que ja sabíem d'aquest
} 
Morvedre, a València. En aquest grup trobem ja un altre aspecte que veurem que es fa habitual, com és que molts d'aquests arrendataris i comerciants vinculats amb Serra habiten o procedien del mateix carrer de Morvedre (València) o del barri d'aquest carrer. És el cas ara de Jaume Font, però també del propi Batista Donya i encara del notari Joan Font, de qui hem parlat en el capítols precedents.

Pel que fa als preus dels arrendament en aquest període, la FIGURA 6.1 ajuda a comprovar que abans de l'expulsió venia produint-se una certa tendència creixent dels preus (observada també al llarg del segle XVI) ${ }^{16}$, tendència que es tallarà de sobte arran de l'expulsió caient en la gran crisi subsegüent, de la qual hem tractat en altres capítols.

FIGURA 6.1.- Evolució dels arrendaments del delme de Serra i Nàquera abans i desprès de l'expulsió morisca.

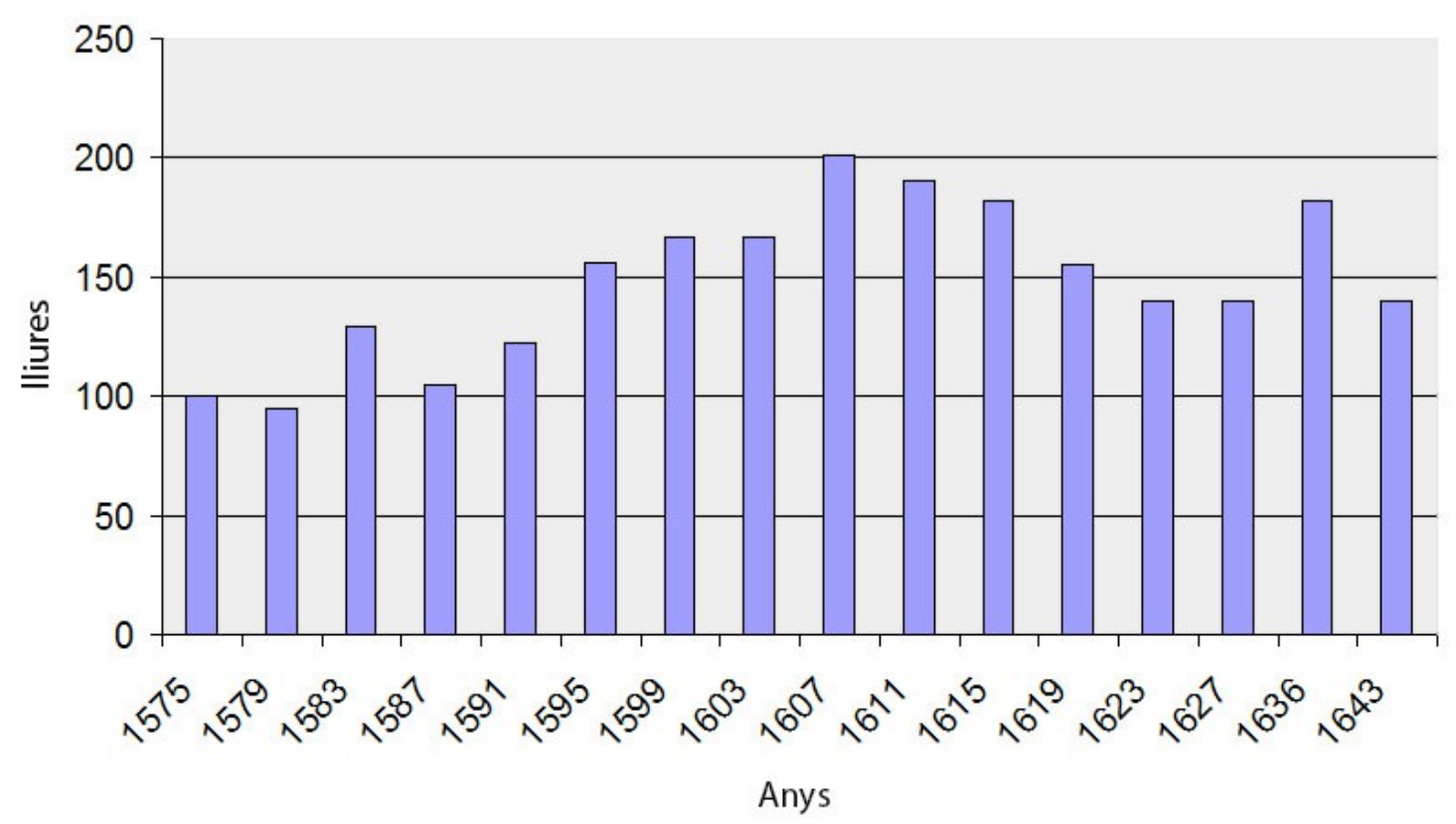

Elaborat amb les dades del quadre 6-2).

El continu increment de preus que va experimentar tot el segle XVI sembla que hauria començat arran de la desmonetització que ja a finals del segle XV iniciaren els reis Catòlics per tal de retirar i substituir la gran quantitat de moneda d'argent desgastada, retallada i reduïda de pes que estava en circulació. A més d'això i particularment a València, el gran increment del comerç havia creat una considerable mancança de

vassall de Serra, que era un pastor vingut de Camarena (Quinque Libri de Serra).

\footnotetext{
${ }^{16}$ Recordem que en un apartat anterior hem posat de relleu que el delmari de Serra i Nàquera va ser arrendat en l'any 1504 per 25 lliures, mentre que en 1557 ascendia ja a 60 lliures.
} 
moneda fraccionària pròpia (no s'havia encunyat billó al regne feia més de mig segle) que era substituïda per una gran entrada de moneda estrangera (aragonesa, catalana, florentina, sienesa i "altres prohibides", segons recollien algunes pragmàtiques de Ferran II) amb valors nominals més baixos que el de la valenciana. En fi, aquests problemes i un altre posterior derivat del gran increment de moneda falsa que s'incorpora a la circulació seran objecte d'una gran atenció per part de la Corona, tal com explica Hamilton (1975, p. 118 i ss.) amb gran detall.

Pel que fa als anys reflectits a la figura 6-1, i seguint a Hamilton (1975), cal recordar que en 1595 i desprès en 1603 el virrei de València confirmava una crida de 1578 per la qual s'establia una pena de 4 anys de galeres per possessió de "cunys o instruments de falsificació de diners" a no ser que els lliuraren immediatament a les autoritats, i també multes per possessió de moneda falsificada, en quantitat superior a 4 lliures. En 1609 (pocs mesos abans de l'expulsió) argumentant que continuava l'augment de falsificació de moneda de billó "que estava omplint el regne i la Ciutat de monedes falses”, una altra Crida elevava la pena a 6 anys de galeres i multa de 50 lliures.

Podem suposar que l'expulsió dels moriscos facilitaria l'eixida a l'exterior de cert volum de moneda fraccionària, però evidentment, la principal causa de la baixada dels preus d'arrendament dels delmes havia de ser la crisi migratòria i la gran disminució de la mà d'obra. No obstant això i de la gran crisi general, l'immediat repoblament postmorisc tant de Serra com de Nàquera, farien que aquesta caiguda i la seua durada quedaren més amortides que en altres casos que seguidament veurem (figura 6-2). Així, mentre que la pujada dels arrendaments s'havia incrementat vora un $100 \%$ en la darrera dècada, o poc més, abans de l'expulsió, la decaiguda posterior seria en el cas de Serra i Nàquera relativament lenta $\mathrm{i}$ de l'ordre d'un 50 \% al cap de 10 anys, mantenint-se en aquest llindar vàries dècades $i$ fins $i$ tot amb alguns signes de recuperació uns 25 anys desprès (figura 6.1).

Els altres llocs que mostra la FIGURA 6.2 són quatre baronies molt properes a la de Serra i pertanyents també a l'àmbit geogràfic de la serra Calderona; amb la diferència, però, de que no van ser repoblades amb la mateixa rapidesa ni eficàcia. Les conseqüències econòmiques es nota que foren més acusades i sensiblement més dolentes, sens dubte, per a totes les parts. En aquests casos veiem que la magnitud de les devaluacions sofertes pels arrendaments desprès de l'expulsió morisca tingué caigudes 
que van des del $200 \%$ d'Olocau fins al 100\% d'Estivella-Beselga i de Albalat-Segart, passant per la caiguda escalonada, però encara més forta, de Torres Torres.

FIGURA 6.2.- Diagrama de l'evolució dels arrendaments de delmes en baronies properes a la de Serra,).

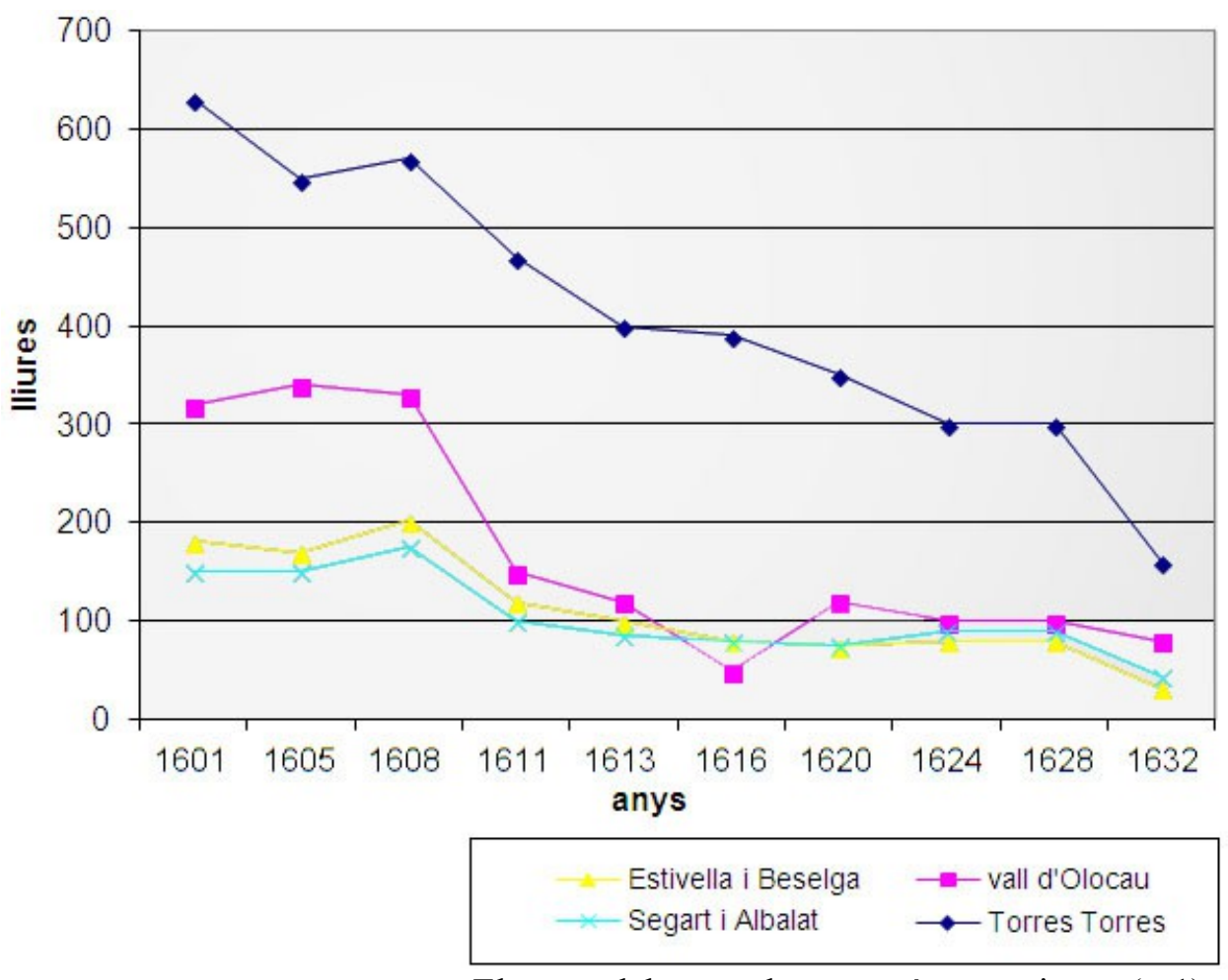

Els anys dels arrendaments són aproximats $( \pm 1)$. Font: ACV, 4388 a 4392.

La caiguda que veiem en 1611 i anys següents, respecte a 1609, es produeix malgrat els esforços monetaris de la monarquia, com és l'autorització que signà Felip III en agost de 1610 per a l'encunyació de 100.000 lliures en reals i mitjos reals d'argent ${ }^{17}$ en dos anys, complementàriament al pla d retirada de billó vell. El rei atorga a la ciutat de València el senyoratge sobre aquesta emissió, com també el d'una segona emissió, en 1612, d'altres 100.000 lliures, ara en monedes de billó, per a substituir "les monedes falses" retirades de la circulació. Segons Hamilton (1975, p. 132) les grans encunyacions que s'havien fet en 1608 i 1609 havien sigut excessives i ja hi hagué aleshores acusacions de falsificació, però aquestes, junt a les posteriors emissions de billó entre

\footnotetext{
${ }^{17}$ La llei i valor nominal de les noves monedes romania, però no així el seu pes, que baixava prop d'un $12 \%$ respecte a les monedes anteriors.
} 
1610 i 1614, suposaven el 98\% de tot el billó que s'havia encunyat en tot el segle anterior, resultant de tot açò un excés de moneda en circulació (tant d'oficial com encara de falsificada). El billó es convertia així (i en paraules de Hamilton) en un poderós mitjà d'inflació durant el segon decenni del segle XVII. Potser aquesta siga, en part, la raó del manteniment que es veu a la gràfica desprès de la gran caiguda de 1609-1611 i almenys fins al nou descens que reflexa novament l'any 1632.

\subsection{EVOLUCIÓ DELS ARRENDAMENTS DEL DELME (SEGLES XVII a XIX)}

La FIGURA 6.3 mostra la sèrie completa del delme de Serra i Nàquera per a tot el període estudiat, que és des de que comença el Contrallibre (1611) fins a que acaba, en 1837, per la supressió del delme.

Per tal de poder utilitzar una mesura numèrica única i més senzilla que la forma original en lliures, sous i diners, les dades d'aquesta gràfica venen expressades en sous, Però, de tota manera, cal recordar que aquestes quantitats que mostrem serien només la tercera part de la dècima, tal com hem vist i explicat en l'anterior epígraf quart. Per conèixer tota la part de delme eclesiàstic caldria, doncs, multiplicar aquestes xifres per tres, entenent que això seria ja el preu que s'hauria apagat com a dècima (o més bé $2 / 3$ de la dècima, segons hem vist abans) a priori i, per tant, no seria exactament un valor basat en la collita real sinó una quantitat preestablerta i aproximada. Per això, també cal notar en la gràfica que els preus venen donats en blocs de quatre en quatre anys. Tanmateix, la gràfica incorpora una línia de tendència polinòmica (d'ordre 6) que ajudarà a analitzar les variacions $i$ tendències.

FIGURA 6.3.- Delmes de Serra i Nàquera (1611-1837) de la sèrie del Contrallibre de l'Arquebisbat de València. 


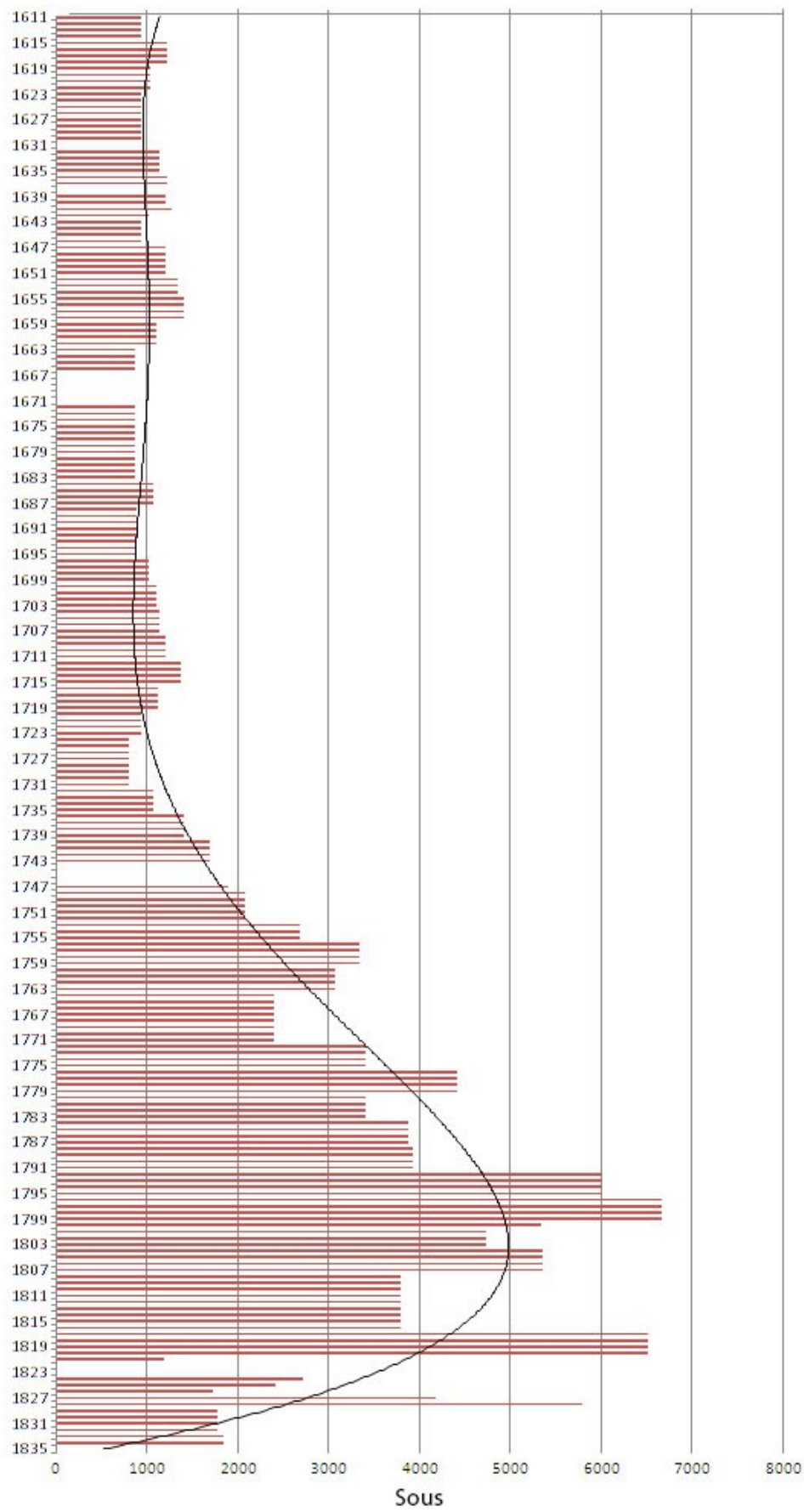

Font de les dades: ACV, caixes 4236 a 4276.

Tornant a la qüestió del billó, cal dir que també en les noves emissions de moneda de billó de l'any 1634 hi hagué acusacions de falsificació de moneda. Finalment, la seca va ser tancada a l'emissió de billó entre 1648-1650. L'encunyament de moneda d'or havia també finit en 1631 i únicament es continuà emetent argent. Concretament, s'havia encunyat entre 1627 i 1629 més marcs d'argent que en els 126 anys precedents, i 
novament, entre 1641 i 1650 s'encunyaren més encara, doblant-se així el total dels que havien estat encunyats en tot el segle XVI (Hamilton, 1975, p. 135).

En tot cas, la figura 6-3 mostra escassa fluctuació general de preus en l'arrendament dels delmes de Serra i Nàquera al llarg del segle XVII, a diferència del que hom pot veure en un període posterior. Així, tant el diagrama de barres com la seua línia de tendència polinòmica permeten interpretar que haurien hagut tres grans etapes en les fluctuacions dels arrendaments:

A) La primera abasta tot el segle XVII i encara el primer terç del XVIII, caracteritzada per unes fluctuacions relativament suaus, entorn als 1000 sous (50 lliures \pm 10 ), que comencen a remuntar imparablement a partir dels anys 30 del segle XVIII.

B) La segona respon a un creixement quasi continu que es dona al llarg del segle XVIII, passant dels poc més de 800 sous (40 lliures) a les més de 333 lliures del darrer quadrienni del segle XVIII (les 1.000 lliures de delme total referides en el quadre 61).

C) A partir de l'any 1800 comença una molt fluctuant però en general forta baixada dels preus d'arrendament fins que definitivament desapareix el tribut cap a 1835.

Per tal de poder analitzar aquesta dinàmica amb altres elements de comparació hem recorregut a les sèries dels índex de preus de les mercaderies elaborades per Hamilton (1975 i 1988), i concretament les referides a València (FIGURA 6.4). Recordem que són sèries elaborades i obtingudes a partir de la consideració i integració d'un gran nombre de registres que el seu autor considera en general molt fiables i entre els quals destaca alguns especialment valuosos, com és el cas de les sèries procedents dels arxius valencians de l'hospital dels Innocents (avui ADPV) i el Col·legi de Sant Tomàs de Vilanova (Hamilton, 1988, p. 122, 125 i 148). ${ }^{18}$

Respecte a l'índex de referència d'aquesta sèrie cal dir que el va obtindre Hamilton prenent com a referència (valor 100) els índex aritmètics no ponderats de la dècada de 1671-1680 i referits a les quatre regions estudiades per ell (València, Andalusia, Castella la Vella i Castella la Nova).

\footnotetext{
${ }^{18}$ Hamilton (1988, p. 151) destaca que front a les considerables variacions de preus que mostren altres regions, València es caracteritza per haver tingut un comportament més estable, sens dubte com a conseqüència d'haver tingut un sistema monetari independent $i$, si bé, les monedes d'or i argent de Castella eren les que circulaven realment, aquestes no estaven taxades en pesos, reals o maravedís de billó, com passava en les altres regions, sinó que ací es mantenien les unitats de compte valencianes, de lliures, sous i diners. Per això estima la gran importància d'aquestes sèries per al estudi del comportament de preus en altres regions.
} 
FIGURA 6.4.- Evolució de preus de les mercaderies (expressats en índex de referència) entre 1650 i 1800, segons Hamilton (1975 i 1988).

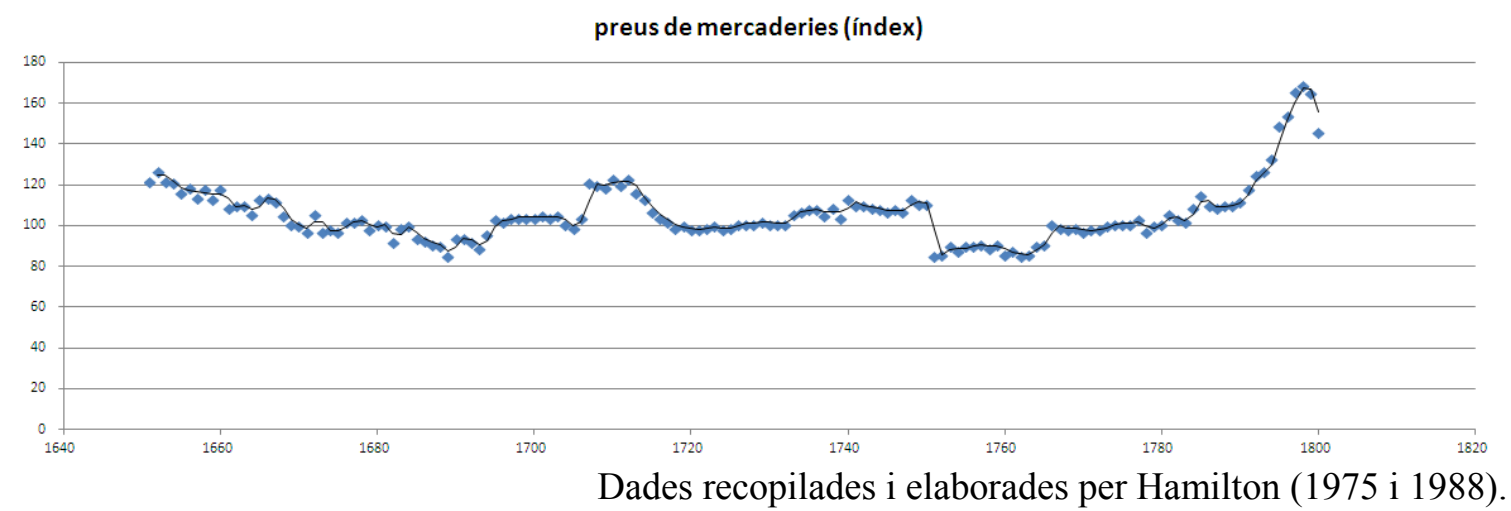

En aquest gràfic, la línia de tendència és una mitja mòbil senzilla (de període $=2)$, que ajuda a comprovar com encara durant la segona meitat del segle XVII continua una tendència general a la baixa dels preus però amb dues pujades clares, una cap al final del segle, aproximadament coincident amb el període de l'anomenada Segona Germania ${ }^{19}$, i l'altra ja començat el segle XVIII, coincident i arran de la guerra de Successió. Al llarg del segle XVIII observem que desprès d'una progressiva caiguda inicial de preus, posterior a la guerra, hi ha una progressiva recuperació i alça de preus en general, que només es veurà trencada per la sorprenent i brusca caiguda de l'any 1751. A partir d'aquest any es produeix una progressiva i forta recuperació que cap a finals del segle es converteix en un espectacular creixement exponencial. La caiguda de 1751 podria ser conseqüent amb els efectes de les regulacions monetàries promulgades l'agost del 1750 per Ferran VI, error monetari important en opinió de Hamilton (1988, p. 88).

A partir de les fites i tendències generals dels preus de mercaderies que acabem de comentar podem analitzar i intentar entendre, ara millor, la gràfica dels arrendaments dels delmes de Serra. En aquest sentit mostrem tot seguit juntes i comparades les dues sèries en un mateix gràfic (FIGURA 6.5).

\footnotetext{
${ }^{19}$ Malgrat que els principals actes d'aquesta revolta tingueren lloc en 1693, en comarques situades al sud de la ciutat de València (Momblanch 1957, Pla Alberola 1994...), cal observar que un informe del marquès de Castel Rodrigo, virrei de València, ja al·ludia a l'actuació d'un notari de camp de Morvedre, Fèlix Vilanova, que des de 1689 venia parlant de privilegis que eximien als camperols de certes contribucions als senyors (Casey, 1994.). i recordem que també entre els anys 1687 i 1690, Catalunya patia la "revolta de les barretines" (Dantí, 1994) deguda, no obstant, a causes i matisos diferents als de València.
} 
FIGURA 6.5.- Comparació entre les gràfiques de preus de Hamilton (dalt, en blau) i els arrendament dels delmes de Serra i Nàquera (gràfica inferior, en roig) durant el període 1651-1800.

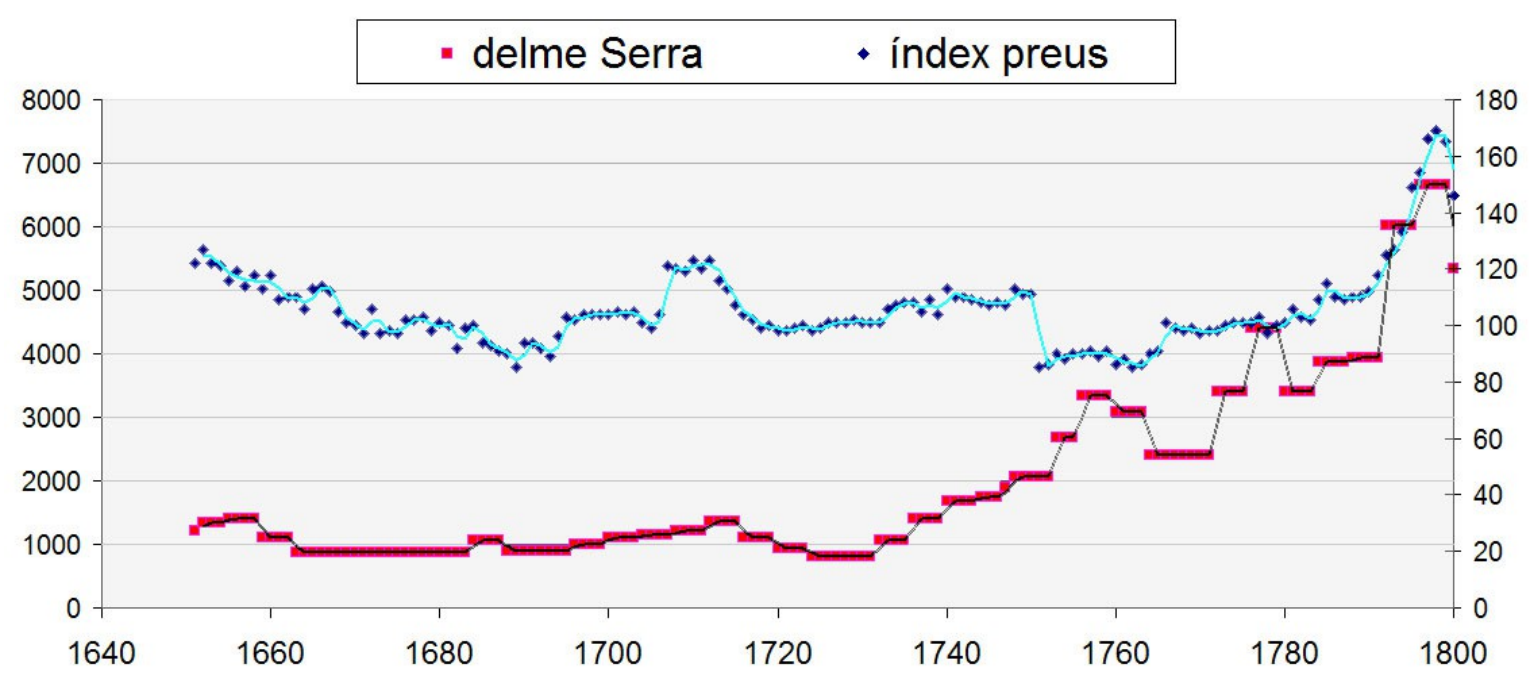

L'escala de l'esquerra expressa el valor en sous dels arrendaments, mentre que la dreta indica un índex de preus de mercaderies, entorn al valor 100 de referència.

Dades tretes de Hamilton (1988) i le l'ACV (c. 4236 a 4276).

Entre les dues sèries (anys 1651-1800) existeix un coeficient de correlació no massa significatiu $(r=0.490)$, però aquest millora, considerablement, si el calculem a trams per tal d'evitar fets concrets com son la forta baixada de preus de l'any 1750 (que no té reflex directe en els arrendaments) o fins i tot el punt d'inici de la pujada de preus que s'hauria produït durant els 20 anys anteriors (al voltant de l'any 1730 o poc desprès). ${ }^{20} \mathrm{Si}$ tallem per aquests dos punts les dues sèries aconseguim seccionar en tres trams diferents les sèries inicials, guanyant aleshores homogeneïtat el rang serial de cada tram. D'aquesta manera, observem que la correlació en cadascun dels tres trams resultants augmenta considerablement:

-El tram de 1651-1730 (80 anys) té un coeficient de correlació $r=0,679$

-El tram de 1731-1750 (20 anys) té un coeficient de correlació $r=0,739$

-El tram de 1751-1800 (50 anys) té un coeficient de correlació $\mathrm{r}=0,897$

Podem dir que, en certa mesura, les fluctuacions dels preus generals de mercaderies si que influeixen directament en les tendències (creixents i decreixents) dels preus dels arrendaments, però no podem dir que tinga una relació de proporcionalitat

\footnotetext{
${ }^{20}$ Entre les causes d'aquesta progressiva pujada podrien estar les disposicions fetes per Felip V entre $1726 \mathrm{i}$ 1730 en el sentit d'abaratir el preu de les monedes d'argent.... (Hamilton, 1988, p. 73 a 77).
} 
massa marcada. A més a més, també es pot veure que certs fets (com la forta baixada de preus de 1751) haurien passat quasi inadvertits en els arrendaments de Serra i Nàquera.

Una altra qüestió seria la magnitud dels arrendaments, particularment en la segona meitat del segle XVIII, on el fort creixement experimentat, malgrat que siga també correlacionable amb l'augment dels preus de mercaderies, entenem que respon, per una part, a l'espectacular augment demogràfic que experimenta Serra en aquests anys, tal com hem vist en el capítol IV (figures 4-9 i 4-11), però també a l'expansió dels cultius.

Per últim, i pel que fa als arrendament de Serra i Nàquera durant el segle XIX (figura 6-3), podem afegir una clara observació: que dins el decreixement general que es veu, les principals pujades responen a les instauracions absolutistes (bàsicament les de $1814 \mathrm{i}$ 1823), mentre que els trams de baixada dels arrendaments vindrien a coincidir clarament amb quatre fets de caire liberal o bé revolucionari:

a) El malestar pre-revolucionari de finals del segle XVIII i de principis del XIX; passant pels avalots i motins de 1801 (Ardit, 1977 i Mesa, 2014),

b) La guerra del Francès (1808-1814),

c) El trienni liberal (1821-1823) i

d) L'etapa liberal iniciada amb la regència de Maria Cristina de Borbón-Dos Sicilias.

Resulta clar, per tant, que els grans esdeveniments polítics i socials del segle XIX foren també causes directes que influïren en les fluctuacions dels preus dels arrendaments.

Finalment, per comprovar si l'evolució dels preus dels arrendament de Serra i Nàquera foren semblants als d'altres llocs, aportem una gràfica comparativa (FIGURA 6.6) amb els corresponents a altres delmaris dels encontorns, concretament el de Torres Torres (amb Algímia i Alfara) i el de Segart (amb Albalat dels Tarongers), en presentar aquests uns rangs de valors situats per damunt i per baix, respectivament, dels registrats a Serra, la qual cosa facilita una millor comparació visual de les gràfiques. Tots tres són llocs corresponents a un mateix domini territorial, la serra Calderona.

Observem que les similituds són grans, si bé amb lleus variacions que no entrarem a analitzar per evitar desviar-nos més encara dels nostres objectius generals. No obstant, el tema de Portaceli si que requereix una especial atenció, no solament per les seues peculiaritats intrínseques sinó, sobre tot, per la seua transcendència i repercussions 
en aspectes relacionats amb la que ja serà immediata incorporació del seu terme al de Serra.

FIGURA 6.6.- Comparació dels preus (sous) d'arrendament, entre 1700 i 1834, dels delmaris de Serra-Nàquera (negre), Segart-Albalat (verd) i baronia de Torres Torres (roig).

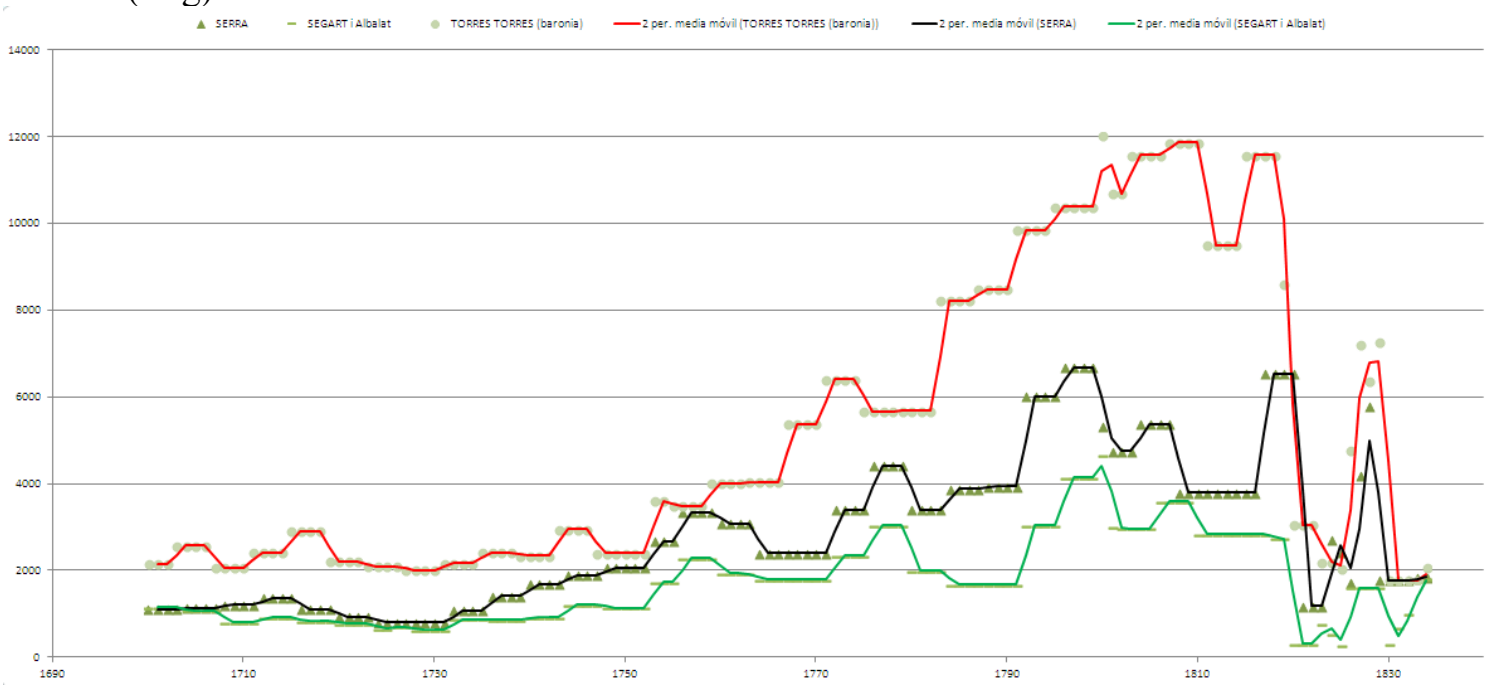

Elaboració pròpia a partir dels registres (ACV, c. 4236 a 4276)

\subsection{SOBRE DELMES I CONTRIBUCIONS DE LA CARTOIXA DE PORTACELI}

No cal tornar a insistir en la posició privilegiada que la Cartoixa de Portaceli tenia per haver sigut objecte de nombroses concessions i privilegis, tant de reis com de papes. Alguns epígrafs dels Annals de Portaceli (Ribes, 1998) recullen encapçalaments com aquests: "Porta-Coeli y sus bienes están bajo la protección de la Santa Sede" o “Confirman los Papas la incorporación de la retoría de Liria". L'anotació més concreta sobre els delmes la trobem en l'epígraf 13 d'aquest text (referint-se ara a l'any 1273, un any desprès de la fundació del monestir) que diu així:

13. Del término ni pagamos primicia, ni terciodiezmo, ni diezmo, sólo sí pagamos 5 libras al Obispo y 5 libras al cabildo. De lo dicho hasta aqui se colige que si no pagamos diezmos de nuestro término, es porque el señor obispo y canónigos nos los dieron, según dice el auto de fundación con el onus de pagar 10 libras cada año por la fiesta de San Miguel, y no pagamos terciodiezmo porque también nos lo dieron, como queda dicho. Ni primicia porque dichos señores nos unieron la retoría de Liria, en cuyo distrito se fundó este monasterio. 
Però aquesta quantitat de 10 lliures (5 al Bisbe/Arquebisbe i altres 5 al Capítol) no concorda amb la indicada al principi d'aquest capítol (veure nota 2 a peu de pàgina) on trobàvem que l'obligació era la de satisfer al Bisbe i al Capítol no 10 lliures, sinó 10 sous anuals en el dia de Sant Miquel de setembre. Per altra part, al Contrallibre de la Catedral de València no trobem reflectides com a delme ni les 5 lliures (al Capítol) ni part dels 10 sous, sinó únicament un altre concepte del delmari, anomenat "Alqueria de Portaceli", consistent en una quota fixa anual de 2 lliures i 10 sous (50 sous), invariable al llarg dels més de 200 anys del registre consultat. Aclarint el tema de si eren 10 sous o 10 lliures les que havien de pagar de delme trobem que el manifest de rendes i despeses de l'any 1776 (recollit com document número 26 per Fuster, 2003) contempla entre els descàrrecs 5 sous pel delme a la mensa "Archipiscopal” i altres 5 sous de delme a la mensa Canonical.

Pel que fa als ingressos de 2L10s anuals referits en el Contrallibre com "Alqueria de Portaceli", observem que els primers anys eren pagades en dos cops, d'una lliura cinc sous, mentre que desprès les trobem sempre pagades d'un sol cop, generalment pel procurador o el síndic de Portaceli, però de vegades també pel propi Prior. Cap la possibilitat de que puga tractar-se dels delmes corresponents a l'alqueria de l'horta de Benicalap que va donar a la cartoixa el pare D. Font el 1596, quan ingressà en la orde, amb obligació de que mai no es poguera alienar i que servira per a determinades millores i serveis, per exemple donar 15 lliures a un criat que llave la roba dels monjos tantum, que escombrés cada dissabte els claustres i ajudés en altres coses. Aquesta alqueria la tenien censida al voltant de 1640 a l'Hospital General i el rector de Sant Bartomeu, parròquia a la qual pertanyia, pretenia que li havien de pagar Primícia, mentre que la cartoixa encara debatia sobre si devia pagar o no delme (Ribes, 1994, ep. 337).

Per altra part, Portaceli tenia una delegació administrativa a la ciutat de València, l'anomenada Casa Procura de Portaceli, que estava ubicada a la Placeta de San Gil (on avui està el portal 6 de la plaça Cisneros), molt prop del portal dels Serrans, ${ }^{21}$ En ella

\footnotetext{
${ }^{21}$ Les excavacions arqueològiques realitzades en aquest lloc a finals del segle XX van permetre revisar $\mathrm{i}$ comprovar moltes de les dades documentals obtingudes per Català i Gorgues (2000). Aquest immoble havia sigut comprat al cavaller Roger de Cardona, en novembre de 1371, per preu de 120 lliures. I havia pertanyut abans al monestir de les Santes Creus. En 1427 va comprar Portaceli una segona casa annexa, per 31 lliures i 10 sous "que hace de censo muerto a San Lorenzo 3.010 libras". En 1652 es va comprar una tercera casa, per 100 lliures, que és la que estava més a prop del "cementeri de Sant Llorenç". Aquesta tercera casa és la que habitava el pare Procurador. Encara l'any 1664 comprava el monestir una gran casa que estava al costat de la Procura de València, en el carrer que va al portal de Serrans (al carrer de Nàquera), per preu de 1.670 lliures, la qual havia sigut la casa solar d'en Josep Alpont, olim de Camanyas, virrei de Cerdenya.
}

En 1757, la casa Procura (sembla que els tres primers immobles) va ser enderrocada fins els fonaments $i$ desprès tornà a ser alçada, depenent-ne més de 6.000 sous (Català i Gorgues, op.cit.). 
residia de manera permanent un pare procurador $\mathrm{i}$ alguns criats, dedicats a administrar $\mathrm{i}$ controlar els bens que la cartoixa posseïa i que produïen en 1776 unes 18.352 lliures entre censos, bens arrendats i bens directament cultivats; entre aquests estaven les terres de la Pobleta, del mas de la Torre, de la Majoralia (el propi monestir), de Casa Blanca (la Pobla de Benaguasil) i del mas del Camp (Llíria) i, entre els bens arrendats hi havia els de l'horta de València (Petra, Benicalap, Rambla, Closa, el Grau...), Borriana, Onda, primícia de Benaguasil i la Pobla, primícia del carnatge de Llíria i d'Olocau, el terçdelme d'Alfara, etc. (Fuster, 2003: doc. 26).

La casa procura era també lloc d'habitació i escala quan els cartoixans del monestir havien de desplaçar-se a València, com passà el diumenge 6 d'octubre de 1624, en que desprès de la missa a la Catedral s'acomiadaren de l'arquebisbe per tornar a Portaceli però, com amenaçava tempesta $\mathrm{i}$ tronava $\mathrm{i}$ "queien llamps damunt dels alterosos cingles de Rebalssadors", el pare Prior decidí deturar-se a la Casa Procura, tot i que ell i dos dels germans, només cantar matines, tots plegats a l'oratori, es van adreçar en la galera, amb el majoral, fins a Portaceli (Català, 2000: 43 i ss.).

Malgrat que Portaceli estava exempta de pagar delmes més enllà dels 10 sous estipulats en el segle XIII i de les 2L10s que pagava invariablement cada any a la mensa capitular per "l'alqueria de Portaceli", el cert és que també contribuïa a les aportacions de l'Església a la Corona. Així ho constatem en un escrit de 4 de gener de 1788, del prior Josep Alcover, en que comunica als canònics de la Seu que ha rebut notícia de:

...como el Exmo. Sr. Arzobispo de esa Santa Iglesia y su Muy Ilustre Cabildo han concordado con su Magestad (que Dios guarde) por otro cuarto Cuatrienio sobre la Colectación, cobranza y pago de la Casa Mayor Diezmera de este Arzobispado, con la obligación de haberle de satisfacer en cada un año 181.562 Reales y 9 maravedies vellón, que deben repartirse a proporción, con más los gastos... ${ }^{22}$

La resposta que dóna el prior és que esperant el repartiment equitatiu que farà el Capítol acudiran puntuals a satisfer la part que els pertoqui pel terç dècim d'Alfara del Patriarca. Tant la referència a "altre quadrienni" com la quantitat fixa a satisfer la casa major delmera a la Corona fan pensar que poguera tractar-se de la contribució del Subsidi, ${ }^{23}$ que junt a la de l'Excusat i la butlla de la Croada formaven "les tres gràcies"

\footnotetext{
${ }^{22}$ ACV, 4276, nota solta inserida.

${ }^{23}$ La gràcia del Subsidi va ser atorgada inicialment per Pius IV a Felip II en 1561, com a contribució de 420.000 ducats anuals durant 5 anys, sobre les rendes i fruits de l'Església, per al sosteniment de 60 galeres en la Mediterrània per defensar els fidels cristians i les seues terres de les invasions dels turcs $i$ altres
} 
de concessió pontifícia a la corona hispana per tal de defensar la religió i fer front a l'heretatge. Com les altres dues gràcies, el Subsidi també acabaria per fer-se permanent. Així, una reial ordre de 5 d'agost de 1763 regulava el mode de procedir en les causes de col·lecta i pagament del Subsidi i Excusat, conforme a les concòrdies a les que s'anava arribant.

Un altre exemple d'aportació "solidaria" que Portaceli havia de fer en favor de la Corona són les 265L18s que li correspongueren en 1688 per atendre la concessió de 800.000 ducats imposats sobre la dècima eclesiàstica que Innocenci XI havia fet al rei espanyol. ${ }^{24}$

\subsection{OCÀS I DISTRIBUCIÓ DEL DELME I ALTRES IMPOSTOS RELACIONATS}

Hem vist com la gràcia de l'Excusat repercutia directament sobre els delmes eclesiàstics detraient un part significativa d'ells com era la del principal contribuent de cada parròquia. També el Subsidi es podria entendre com una contribució que en part estaria repercutint sobre el delme, si bé no directament ni de manera exclusiva, doncs era una quantitat determinada que havia de pagar l'Església a la Corona dels seus propis recursos (no necessàriament el delme). ${ }^{25}$

La tercera de les gràcies, la butlla de croada, entenem que és l'única que no repercutia de cap manera sobre els delmes eclesiàstics, doncs procedia d'unes aportacions diferents $\mathrm{i}$ voluntàries a canvi de certes indulgències i privilegis personals. Però hi hagueren encara altres dos tributs més o menys relacionats amb els delmes: el Novè i els Novals. El Novè va ser un tribut lligat directament lligat al delme però que no requeia directament sobre els contribuents, sinó sobre l'Arquebisbat, en el cas de València. Un breu de Pius VII, de 3 d'octubre de 1800 i una reial ordre de 25 d'abril de 1801 determinaren que s'havia de pagar a Sa Majestat, per temps de 10 anys "i més si fora necessari" un novè en cada any del valor total de tots els delmes i terç-delmes de l'Arquebisbat. ${ }^{26}$

enemics de la fe catòlica. Amb el temps acabaria convertint-se en un impost de caràcter perpetu, mitjançant el breu de Benedicte XIV de data 6 de setembre de 1757.

${ }^{24}$ Fuster (2005), pàgina 285.

${ }^{25}$ Per a recaptar aquest impost sembla que devien participar també les parròquies. Ja hem vist com el rector de Serra contribuïa l'any 1769 amb una aportació anual d'una lliura i 13 sous.

${ }^{26}$ Libro para formar las cuentas de particiones de los diezmos... (ACV, lg. 4428; f. 293). 
Per altra part, la butlla de Novals ("Novales") va ser concedida a Ferran VI per "la Santitat de Benet IV" el 30 de juliol de 1749. Consistia en destinar directament a la Reial Hisenda els delmes que designaren per novals i que responien a l'augment de fruits pel benefici del reg (transformació a regadiu) i també per la rompuda de terres, artigant terrenys que abans no permetien el cultiu.

L'aplicació d'impostos lligats al concepte de Novals va causar malestar, queixes i recursos que diferents bisbes i capítols d'esglésies catedrals elevaren al Consell de sa majestat entre novembre de 1765 i juny de 1766. En resposta, Carles III hagué de dictar una llarga disposició aclarint que els Novals que havien de repercutir directament en la reial Hisenda eren, en el cas dels nous regadius, aquells deguts a aigües derivades per sèquies o conductes construïts "á nuestras Reales expensas" i, en el cas de rompudes de forest $\mathrm{i}$ altres camps posats en producció només quan tingueren lloc en territori de reial domini i propietat. Tanmateix decretava, en la mateixa disposició, el cessament del Jutge executor de la butlla de Novals i la reposició de tot allò obrar per ell. ${ }^{27}$

La butlla de Novals no era, per tant, aplicable a baronies, el que si que resulta evident és que en el segle XVII (sobre tot en la seua segona meitat) l'expansió de noves terres per a cultiu va ser notable al terme de la baronia de Serra, com hem vist amb més detall en el capítol cinquè i com hem referit també al comentar, a la vista de la figura 6-5, el gran creixement, no solament poblacional, sinó també de transformacions agrícoles que es va produir en aquell període.

En síntesi, l'esquema adjunt (FIGURA 6.7) mostra gràficament com era la distribució de la càrrega contributiva que suportaven els vassalls de Serra i com era, particularment, la distribució del seu delme.

La figura permet observar més clarament que "el terç" registrat en el Contrallibre era realment un terç de sobrants, desprès d'haver deduït $2 / 9$ de Primícia, el Terç-delme (reial o senyorial però que, en el cas de Serra pertanyia als vassalls) i l'Excusat, una quantitat aquesta que podia ser molt variable d'uns llocs a altres i en el temps. En el cas de Serra i Nàquera desconeixem a quin contribuent corresponia aquest tribut i, fins i tot, suposem que únicament hi havia un excusat (un per parròquia), sense poder descartar la possibilitat de que hi hagueren dos (un per baronia), cosa que sembla poc probable.

\footnotetext{
${ }^{27}$ Novísima Recopilación de las Leyes de España... (1805): 1libre I, títol IV, p. 59 i ss.
} 
FIGURA 6.7.- Esquema de les càrregues suportades pels vassalls de la baronia de Serra.

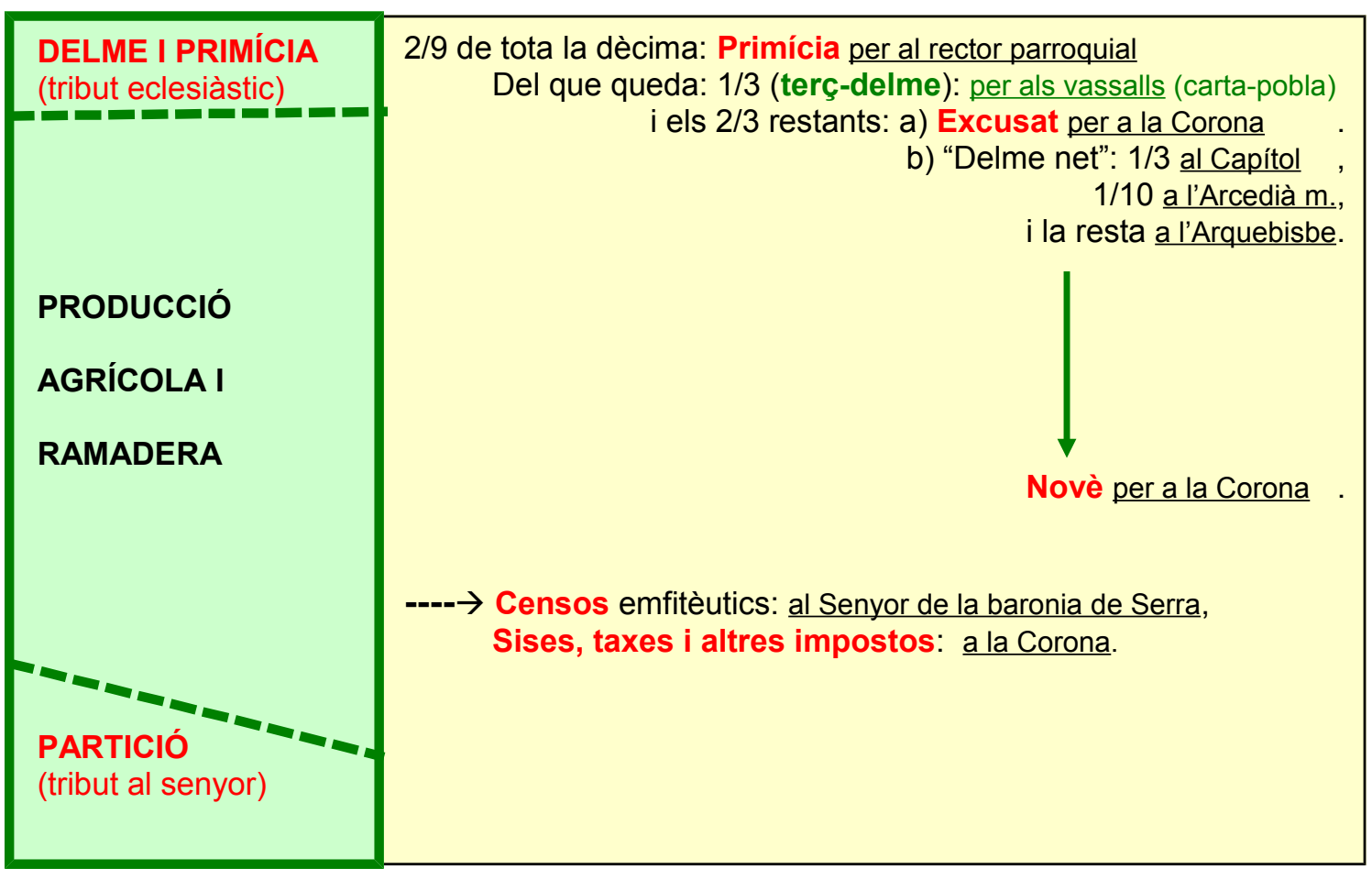

Elaboració pròpia.

Hem suposat que la magnitud de l'excusat de Serra i Nàquera podria ser el 9,3\% obtingut en l'apartat tercer d'aquest capítol però, observem també com a mer exemple i sense que siga una referència massa vàlida per a nosaltres, que també en l'edat moderna, a Castella i Lleó l'excusat venia a suposar entre un 8 i un 14\% del delme (Hernández i Pérez, 2008). Una altra dada de comparació més propera i global la podem obtindre mitjançant la súplica que en 1607 l'arquebisbe de València feia a Sa Majestat de pagar una quantitat fixa de 80.000 reials entenent que dita quantitat venia a representar la mitjana del que havia contribuït l'excusat, en conjunt, durant el quinquenni anterior. ${ }^{28}$ Aquests 80.000 reials, tenint en compte els preus del delme global de "pa i vi" per al quadrienni 1701-1704 (Casey, 1981) i que l'equivalència del real castellà a finals del segle XVI venia a ser de dos sous i escaig, suposaria un 6'9 \% del delme de pa i vi. Si incloérem també carnatge i paner la xifra baixaria fins al 6.4\%, del delme total.

Per tot el que venim comentant al llarg d'aquest capítol i per altres observacions $\mathrm{i}$ notes inserides en els llibres del Contrallibre, de les que no hem parlat massa per no afectar directament a Serra i Nàquera, sinó a altres delmaris, queda clar que el ${ }^{28} \mathrm{ACV}, 4531-\mathrm{I}, \mathrm{n}^{\circ} 2$. 
Contrallibre registrava no solament els beneficis (cada pagament que es feia sobre cadascun dels arrendament) sinó també el control de les despeses i del estat de la infraestructura delmera. En les nombroses notes inserides entre les pàgines del Contrallibre hi podem trobar: pressupostos de reparacions en cases delmeres i almàsseres, rebuts i raó de les obres realitzades en elles, inventaris d'eines, lloguers de magatzems, adquisició de botes, jornals per a fer certes recol·leccions i tractaments de les produccions destinades al delme, transports dels productes fins als mercats, etc.

En definitiva, el Contrallibre és un llibre que registra les entrades que corresponen al terç d'un delme residual (exempt de primícia, terç-delme i excusat), però que es correspon amb els preus d'arrendament de delmes subhastats cada quatre anys, si bé contempla també, implícitament, despeses dels arrendadors i accions per al estat i manteniment de les infrastructures necessàries per a la cobrança i administració de tot el delme.

Una altre aspecte a ressaltar és el progressiu creixement dels impostos i contribucions que reverteixen en la Hisenda reial: excusat, subsidi, novè, novals... Totes aquestes càrregues les suportava l'Església en detriment dels interessos econòmics, però clar, era el propi Papa qui atorgava, ratificava i ampliava aquests beneficis al rei d'Espanya, sempre amb un objectiu i una clara raó de fons: la lluita contra els heretges i la defensa de la religió i la catòlica. Protestes i mostres de malestar per part dels bisbats i arquebisbats existiren, sobre tot quan es produïen abusos o excessos, com els dels Novals que hem citat abans. També l'excusat fou objecte d'acords i compensacions, com passà amb la concòrdia a la que arriba el rei amb el bisbat de Zamora sobre l'excusat de 17981807, disposant que podia disposar d'ell per tal de resarcir-se del préstec de 800.000 reals que acaba de fer a la reial Hisenda (Álvarez, 1984). També hem vist com l'arquebisbat de València en 1607 demanava molt respectuosament a Sa Majestat que alçara i cessara l'administració de l'excusat i que tractés de fer concòrdia amb totes les esglésies del regne. La resposta del monarca va ser atorgar novament la concòrdia de 1604, obligantse l'Església a contribuir cada any amb 80.000 reals (que com hem vist adés era gairebé el mateix que venia pagant per l'arrendament de l'excusat). ${ }^{29}$

La desamortització de Mendizával faria que els cartoixans es veren obligats a abandonar Portaceli. Segons Fuster (2003) ho feren el 28 d'agost de 1835 però deixant un monjo i dos frares per a custodiar el monestir fins que l'Estat en prenguera possessió

\footnotetext{
${ }^{29}$ Ibidem.
} 
d'ell. A partir d'aleshores començarien les vendes dels fruits i ramats i les subhastes per als arrendaments de la Majoralia, la Torre i el pinar (la forest). Aquest últim serà rematat per un termini de 12 anys i un preu de 90.368 reals de billó per cada any, contemplant el plec de condicions (de 28 de novembre del mateix 1835) la possibilitat de que l'arrendatari poguera utilitzar les dependències del monestir mentre no fóra aquest venut. La Majoralia també va ser arrendada, a principis de 1836, a José Cortina, veí de Portaceli (potser un dels criats de la darrera comunitat de Portaceli) i açò crea certes dificultats amb els arrendadors del pinar, que escriuen en abril de 1837 al Comissionat principal dels arbitris d'amortització de València comunicant-li, per una part, sobre la presència d'una facció rebel (dirigida pel carlista Martínez) que ha apressat, apallissat i desarmat els guardes de la forest i, per altra, que "els arrendadors de la Majoralia són els propis cartoixans i llurs empleats, que continuen conservant el monestir", que els cartoixans que se n'anaren conserven les claus de les seues cel·les, confiant en tornar, i que a més a més, hi hauria una mena d'enteniment entre els carlistes i els cartoixans "conspirant per a que no s'extraga cap valor d'aquell pinar". ${ }^{30}$

L'any 1834-35 és l'últim en que el Contrallibre registra pagament de les 2L10s de l'alqueria de Portaceli. Altres llocs (baronies dels voltants) continuen pagant pel delme i es fan anotacions fins a l'any 1836-37, si bé, aquest darrer any les pagues no són completades, fent-se únicament la paga de Tots Sants de 1836.

Les dues dècades anteriors a aquesta data van ser, en general, prou caòtiques pel que fa a les obligacions de pagament dels arrendadors a la Seu. Per exemple, entre els anys 1816 i 1820, l'arrendament de Serra i Nàquera el duu Josep Peyró, de Catarroja, per 326L1s6 anuals que paga degudament, però els anys següents, els pagaments del nou administrador dels delmes, Domingo Cabo, de Nàquera, són escassos, incomplets i molt retardats. Per exemple, de les quotes de l'any 1820-21 hi consta un únic pagament, de 59L6s, però es fa molts anys desprès, el 18 de febrer de 1825. En el següent quadrienni (1823-24) el Dr. Soler, "tresorer", ingressa fins a 136L i 23diners en la caixa del Contrallibre, pel producte dels fruits i grans de Serra i Nàquera en tres tandes: juliol de 1824, novembre de 1824 i agost de 1825. Del delme de 1824-25 només es pagaran 120L9s1 en dues vegades; l'arrendador era Joaquim Villarroya, rector de Bétera, però els ingressos, en la "mensa canonical" sorprenentment no els fa ell, sinó de nou l'esmentat Dr. Soler, el abril de 1825 i el desembre de 1826. El següent any (1825-26) només

\footnotetext{
${ }^{30}$ Fuster (203), pàgina 422.
} 
registra el Contrallibre 86L8s9 pagades. De tot aquest període cal tenir en compte que en 1621 les Corts van reduir el delme a la meitat i que les reduccions continuaren sent reivindicades els anys següents i fins a la restauració absolutista.

A diferència de la inestabilitat, respecte als delmes, de l'anterior període, l'any 1826/27 pujaren els ingressos per caixa del Contrallibre fins a 175L8s10, procedents del delmari de Serra i Nàquera; i en l'any 1827/28 arriben a 289L16s2. El quadrienni següent (1828 a 1831/32) s'estabilitzà el preu de l'arrendament en 89L i 9 diners, i puja a 92L per al següent quadrienni (fins a l'exercici 1835/36), en que se liquidaren encara totes les pagues completes.

Finalment, mitjançant una reial ordre, de 29 de juliol de 1837, la Reina Governadora establia que serien cobrats per aquell present any decimal (que concloïa en febrer de 1838) tots els drets que composaven la contribució "coneguda fins ara amb el nom de Delmes i Primícies", declarant que tots els productes d'aquesta contribució pertanyien exclusivament a l'Estat. No obstant això, afegia que el Govern "si ho trobés convenient" podria administrar o arrendar en pública subhasta els productes de la dita contribució i, en el seu cas, dividir el seu import total aplicant-li una meitat a les obligacions del culte, clergat i partícips llecs, en proporció a llurs drets, destinant l'altra meitat a les atencions del Tresor Públic. ${ }^{31}$

Per part del delmari de Serra i Nàquera, encara consta al Contrallibre un pagament de 73L3s10 fet en 22 d'abril de 1837 per mà del seu arrendador, Vicent Domingo, de Serra, "pel delme administrat a compte del producte de 1836". Es tracta dels darrers registres de la sèrie, malgrat que sembla que en algun cas encara persistiren i per això s'arribà en 31 d'agost de 1841 a una definitiva llei que els anul·lava definitivament però instaurava una "contribució de culte i clergat".

\subsection{ARRENDAMENTS DE DRETS DOMINICALS DE LA BARONIA DE SERRA}

A partir de diferents documents de l'arxiu dels Ducs de Montellano (AHN-FN) hem pogut obtindre algunes dades sobre arrendaments de la baronia de Serra entre finals del segle XVII i mitjans del XVIII, tal com es mostra en el QUADRE 6.4.

\footnotetext{
${ }^{31}$ Colección de la Leyes, Decretos y Declaraciones... (1838).
} 
QUADRE 6.4.- Arrendaments dels drets dominicals de Serra en diferents anys (finals del segle XVII i primera meitat del XVIII).

Any doc. Quadrienni Arrendador/s Preu annual Referència

\begin{tabular}{|c|c|l|c|l|}
\hline 1685 & $1685-1788$ & Anaclet Esparza & $400 \mathrm{~L}$ & $\mathrm{AHN}(\mathrm{FN}), 263 / 29$ \\
\hline 1689 & $1689-1692$ & Joan Navarro & $320 \mathrm{~L}$ & $\mathrm{AHN}(\mathrm{FN}), 263 / 29$ \\
\hline 1719 & $1719-1722$ & $\begin{array}{l}\text { Josep Cabo major, Josep Cabo de } \\
\text { Lluís, Jeroni Fabregat i Joan Garay }\end{array}$ & (496? L)* & AHN(FN), 35/19, n4 \\
\hline 1740 & $1741-1744$ & Vicent Sales i Josep Llorens & $550 \mathrm{~L}$. & AHN(FN), 35/19, n³ \\
\hline 1745 & $1745-1748$ & Vicent Sales i Josep Sales & $625 \mathrm{~L}$. & AHN(FN), 35/19, n² \\
\hline
\end{tabular}

Font: diferents documents citats en la darrera columna.

L'arrendament de 1685 es va fer conjunt amb la baronia de Soneixa, per una quantitat total de 1.250 lliures que corresponien 400 a la baronia de Serra i les altres 850 a la de Soneixa. Amb aquesta proporció i sabent que l'arrendament de 1719 també va ser conjunt de les dues baronies i per un total de 1.550 lliures (sense indicar-se en aquest cas cap repartiment) hem estimat que la part pertanyent a Serra estaria en poc menys de 500 lliures, que és la quantitat que hem posat, com aproximació provisional, en el quadre anterior.

Aquests arrendaments, tal com passava amb els dels delmes, es feien a priori i per una quantitat prefixada molt abans de conèixer com podria ser el comportament real de les collites i produccions. Per consegüent -el mateix que amb els delmes- no podem dir que les quantitats convingudes amb els arrendaments vagen a ser exactament la dècima $o$ qualsevol altra partició de la producció real de fruits. A més a més, en el cas dels arrendaments del drets dominicals, el seu objecte no serà únicament la previsió estimada sobre una producció de les collites, sinó que inclourà també altres conceptes diferents $\mathrm{i}$ fixes, com el lloguer d'algunes regalies: forns, molins, carnisseries $\mathrm{i}$ altres tendes $\mathrm{i}$ establiments; no així els drets de la jurisdicció civil i criminal, els beneficis de la qual resten reservats al Senyor. Queda concedida als arrendadors, no obstant, la jurisdicció civil (exercida mitjançant el Justícia) exclusivament necessària per a la custòdia i cobrament dels fruïts i censos, rendes i emoluments dominicals objecte d'arrendament durant el termini de l'arrendament pactat en cada ocasió.

Entre les capitulacions incloses en aquests contractes d'arrendaments sol posar-se que cada anualitat haurà de ser pagada per meitats en dues pagues, una per Sant Joan i 
l'altra per Nadal, amb diners corrents de València que seran degudament posats en casa $\mathrm{i}$ mà del Procurador del Senyor de la baronia de Serra, o bé en la persona que aquell designe, sempre a la ciutat de València.

De les tendes i establiments que són regalies arrendades en el mateix acte, els arrendadors hauran de fer inventari i valoració de les eines i continguts que tinguen abans i desprès del termini de l'arrendament, per tal d'afavorir la seua conservació i reposició, pagant els deterioraments però no podent exigir res a canvi sobre les possibles millores que s'hagueren pogut introduir i aportar.

L'arrendament del 1719 (veure Apèndix documental) és el més complet dels esmentats i recull, a més d'aquestes capitulacions, que semblen repetir-se generalment en tots els contractes, altres pactes i condicions més abusives, com és que els arrendaments es fan "a tot risc i perill dels arrendadors", o siga, que aquests no podran reclamar rebaixes ni exempció per raó de: fams, pestes, guerra, esterilitat, avingudes d'aigua, pedregades, emboirats, neu, llagosta, despoblament, ni cap altre "accident, incidència climàtica ni malícia humana", entenent-se contingudes, en tal sentit i dins del mateix capítol, "las condiciones con que se arriendan los frutos y derechos decimales del Arzobispado".

Els arrendadors haurien de fer-se càrrec de les obres de reparació dels forns, molins i altres cases de regalies sempre que no passaren de 10 rals, i essent més havien de presentar prèviament la proposta de la despesa al Senyor. Tanmateix, els arrendadors devien pagar les despeses de l'escriptura notarial de l'arrendament i fer arribar una còpia completa i franca d'ella al Senyor o al seu Procurador.

Pel que fa al cas de Soneixa, les capitulacions d'arrendaments solen incloure referències a la casa-palau i el seu hort, de Soneixa i al garroferal del Senyor, del mateix lloc, excloent-los expressament dels arrendaments i quedant reservats al Senyor. Res es diu, en canvi, de la casa-palau de Serra, que possiblement seria emprada per a emmagatzematge i gestió dels fruits contributius de les collites, sota la supervisió sempre del Procurador del Senyor, que és qui realment solia utilitzar-la ocasionalment.

Si comparem els imports anuals dels arrendaments dalt exposats amb les quantitats corresponents als arrendaments dels delmes para els mateixos anys observarem certa proporció i correlació. Així, entenent que el valor total del delme és el triple de les dades del Contrallibre, tal com hem explicat en apartats precedents, per als esmentats anys hem trobat les següents xifres: 
Any 1685: 160 L. de delme front a $400 \mathrm{~L}$ de l'arrendament de Serra.

Any 1689: 133 L. de delme front a $320 \mathrm{~L}$ de l'arrendament de Serra.

Any 1719: 167 L. de delme front a 496? L de l'arrendament de Serra.

Any 1740: 253 L. de delme front a $550 \mathrm{~L}$ de l'arrendament de Serra.

Any 1745: 283 L. de delme front a $625 \mathrm{~L}$ de l'arrendament de Serra.

A simple vista s'observa una bona correlació entre els arrendaments dels delmes i els dels drets dominicals, amb un únic punt desviat que és concretament el que havíem estimat (podem pensar ara que per excés) per a l'any 1719. Cal aclarir, no obstant, alguns aspectes abans de fer les xifres comparables; en primer lloc, els anys de tributació dominical són naturals (amb pagues a Sant Joan i a Nadal) mentre que els del delme són compostos (pagues a Tots Sants i a Carnestoltes de l'any següent), però tenint en compte també que els terminis son per quatre anys (en uns i altres), això no suposa cap impediment ni planteja diferències significatives. Més delicat és el fet de que les xifres no són directament comparables perquè les dels delmes inclouen conjuntament a Serra $i$ Nàquera, sense que puguem establir de manera certa la proporció que correspondria a cadascun dels dos llocs; no obstant, utilitzant com a criteri orientatiu les diferents produccions aportades per Cavanilles (recollides en el quadre 5.3) i sabent -tal com hem exposat en el capítol cinquè- que els serrans potser mantenien un reduït grau de transparència en les seues declaracions, podríem entendre que la part de delme pertanyent a Serra fora pràcticament la meitat o poc més del $50 \%$ del conjunt del delme (considerant també que el nombre de veïns era major que a Nàquera).

Suposant aquest $50 \%$ aproximatiu i tot entenent, com teòricament resulta ser, que el delme havia de ser la dècima part de la producció dels fruits, arribarem a la conclusió de que el valor dels arrendaments dels drets dominicals de Serra (exceptuada l'estimació de l'any 1719 , que seria major) vindria a ser de l'ordre d'un $46 \%$ (entre $43 \%$ i $50 \%$ ) de l'esmentada producció de fruits, uns valors percentuals que vindrien a concordar o potser superar clarament el que calia esperar segons els plantejaments exposats al voltant de la figura 6-7, tenim també en compte que englobaria tant el conjunt de les particions com també tots els drets pagats per les regalies (forn, molí, almàssera, carnisseria, taverna, tendes...).

Pel que fa als arrendadors de delmes i dels drets dominicals no observem coincidències en els del segle XVII ni en l'any 1719, però sí en els posteriors, doncs el cognom Sales que trobem en els arrendaments dominicals de 1741 a 1748 és molt 
habitual entre els arrendadors dels delmes de Serra i Nàquera entre 1712 i mitjans del segle XVIII: un tal Valero Sales, junt amb Francesc Bel, tots dos llauradors del carrer de Morvedre, i Sebastià Sales, llaurador del camí del Cabanyal, són els arrendadors del delme per als anys 1713-1716; Vicent Sales i Sebastià Sales, llauradors de la partida de Cap de Calixte, l'arrendaran durant quatre quadriennis seguits (entre els anys $1716 \mathrm{i}$ 1732); a continuació ho arrendaran Vicent i Josep Sales, llauradors de l'esmentada partida, entre 1732 i 1736; finalment, al cap de dos quadriennis absents de Sales, tornaran a arrendar el delme de Serra i Nàquera Pere Sales i Vicent Sales, llauradors de la partida del Cap de Calixte, a l'horta de València i espatlles del Real. 


\section{CAPÍTOL 7}

\section{SENYORS DE LA BARONIA I CONFLICTES PER LA POSSESSIÓ}

Coneixem bé la possessió plena de la baronia de Serra en la primera meitat del segle XVII per estar en mans d'en Josep Folch de Cardona, promotor i atorgador de la carta de poblament del 26 de novembre de 1609 als 30 nous colons arribats amb les seues esposes i fills a la baronia per repoblar els llocs de Serra i Ria. En realitat, però, ni aquesta possessió estigué lliure de plets ni tampoc les que la precediren i les que la succeïren.

Dels antecedents nobiliaris d'en Josep Folch de Cardona i per quins drets i raons arribà a ser el posseïdor de la baronia ho veurem en els següents epígrafs, però el que cal destacar, abans de res -i serà també objecte d'aquest capítol- és que durant els segles que seguiren al repoblament de 1609, la baronia de Serra (generalment nomenada com Baronia de Serra, Ria i Armell), i sempre de manera conjunta amb la de Soneixa (generalment nomenada amb l'addició d'Assuévar, Pellunes i Mosquera), va ser objecte de conflictes successoris entre diferents nobles pretendents. I si els primers litigis ja estaven plantejats quan Josep Folch de Cardona va prendre'n la possessió, les causes al·ludides en tots ells (anteriors i posteriors) es remunten sobre tot als dos segles precedents, bé durant el govern dels comtes de Prades (segle XV), bé durant el del primer duc de Cardona, o bé arran unes capitulacions matrimonials atorgades per l'avi d'en Josep, en Ferran Folch de Cardona (segle XVI).

A més a més, sabedors que el caràcter bé jurisdiccional (article 1) o bé territorial (article 5) de la senyories i baronies pareixia ser la clau per la qual el decret de 6 d'agost de 1811 determinava que foren incorporació a la Corona o quedaren com a propietats privades, una vegada derogat el règim feudal, hem dedicat una especial atenció a aquest assumpte al llarg de la història de la baronia. Aquesta dualitat de senyories jurisdiccionals front a les territorials va ser durant quasi un segle (el XIX) l'argument de llargues discòrdies i plets entre vassalls/veïns i senyors. Feren falta dues lleis aclaridores d'aquell Decret per a intentar aportar llum a la qüestió. En el capítol novè ens ocuparem en profunditat d'aquest assumpte i, finalment, arribarem a exposar, com a colofó 
d'aquesta tesi, les nostres conclusions particulars al respecte. Però, mentre tant, hem hagut de dedicar una gran atenció a aquest tema perquè ens pareixia, en principi, que podia contindre peces i arguments clau per a la resolució final, en la línia que deixaven veure els treballs ja clàssics de García Ormaechea (1932) i Moxó (1959).

En el sentit expressat, repassar tots els antecedents possibles sobre el caràcter de les donacions reials del Castell i la vila de Serra, a diferents cavallers, durant el segle XIII, es convertia en un objectiu adient. Per això, l'estudi de la possessió senyorívola de Serra no l'hem cenyit exclusivament al segle XVII i posteriors.

Ha existit també una altra raó de pes que ens ha dut a estudiar i investigar sobre els segles anteriors al XVII, i és que la gran quantitat de plets que trobem en època moderna estan sobre tot basats en successos i esdeveniments del passat, qüestions que volíem i necessitàvem conèixer de bell antuvi.

Per tot açò i seguint un ordre cronològic, dedicarem els primers epígrafs d'aquest capítol als antecedents senyorívols de la baronia de Serra, Ria i Armell.

\subsection{ORIGEN DE LA BARONIA: ENTRE EL PATRIMONI REIAL I LA DONACIÓ ALS BELLPUIG (SEGLES XIII AL XIV}

Ja hem comentat en el primer capítol com el rei Jaume I havia fet donació a sengles cavallers, primer de l'alqueria de Nàquera de Serra (abril de 1237) i desprès de l'alqueria d'Alule (Lullén) iuxta Serram (en gener de 1238), de tal manera que, quan li dona a Berenguer Burguet ${ }^{1}$ el castell i la vila d'Axerra, amb llurs alqueries (el 4 d'agost de 1238), ho fa excloent-hi tant les alqueries de Nàquera i de la vall de Lullén, que ja havien estat atorgades a altri, com també els forns i molins. I reté encara, el rei per a si, els drets de pau i de guerra i la potestat, a l'ús de Barcelona².

Aquesta retenció dels "drets de pau i de guerra i la potestat" es pot dir que és habitual, puix es repeteix llargament en el Repartiment; recordem, per exemple, el cas d'Andilla: castrum et villam de Andilla, retentis pace, guerra et potestate ${ }^{3}$, feta al mateix cavaller, Ximén Pérez (reboster del rei) que poc desprès es faria amb la possessió del lloc de Lullén (la vall de Portaceli) per canvi amb el seu primer rebedor Gil de Rada.

1 Aquest cavaller era un veguer de Barcelona, segons Miret i Sans (1918: 143).

2 Assentament 2188, del llibre del Repartiment.

3 Assentament 2180, del llibre del Repartiment. 
Amb aquest tipus de concessió, el rei està reservant-se la sobirania sobre el territori; i així, el que realment concedeix ve a ser una mena de possessió senyorívola jurisdiccional que en última instància depèn de la corona, $\mathrm{i}$ en certa manera no deixa de ser també una mena de vassallatge dels senyors cap al rei. Açò, vist ara així, té una rellevant importància quan, a la vista dels jutges i els juristes del segle XIX, el que es dirimeix sempre, davant els decrets d'abolició de les senyories és si cadascuna d'aquestes responia a un clar caràcter territorial (propietat de la terra, per compra) o simplement jurisdiccional (possessió jurisdiccional, per concessió reial). Entenc que aquesta és en bona mesura el quid de la qüestió. I sobre açò mateix tornaré a referir-me en el capítol 9 d'aquesta memòria.

Recordem també que dos anys desprès, aquella primera concessió seria revocada pel Rei, perquè Berenguer Burguet no havia vingut en el seu dia a prendre'n possessió. En el mateix acte ${ }^{4}$ el rei farà ara una donació conjunta: la del Castell i la vila de Serra junt amb el castell i la cila de Torres Torres, que té com a beneficiari a un altre cavaller: Gauteri de Roma (la data és el 24 de juliol de 1240).

Cal observar que totes les anteriors donacions les havia fetes el rei abans de prendre possessió de la ciutat de València, mentre que aquesta, de 1240, la fa després d'haver pres i posseït el Cap i Casal. Sembla clar, llavors, que es tracta d'una donació més tranquil·la i meditada, doncs, pel fet de deixar en mans d'una única autoritat senyorívola el conjunt dels dos vessants (Sud i Nord) de la ruta natural de Serra-Torres Torres, sembla que el rei pretén garantir o reforçar el control sobre d'aquell estratègic pas: una tradicional ruta de comunicació ben estructurada i fortificada, encara en aquell temps, com posen de relleu les diferents estructures defensives (castells de Serra i Torres Torres, torre de vila de Serra...) i el diversos punts de vigilància (talàies) de l'època andalusina. La persona beneficiada (responsable d'aquesta suposada pretensió o encàrrec reial) seria un cavaller estranger de Roma, i més que un simple croat (com bé suposa Borja, 2000 que podria ser el cas), entenc que Gauterius Romanus (Gauteri de Roma) és fins $i$ tot un enviat, recomanat o observador pontifici, doncs el trobem com a familiar directe del Papa en el text d'un diploma recollit per Miret (1918: 143-144), diploma especialment interessant perquè posa de relleu que el rei i la reina Violant li fan aquesta donació en compensació o premi d'alguna cosa, estant a València, el dia 9 de les calendes d'agost de 1240 (el subratllat següent és nostre):

4 assentament 2255 del Llibre del Repartiment 
"ob honorem et reverenciam Romane ecclesie et quod dominus Papa et fratres sui cardinales quorum preces semper proponimus exaudire pro te dilecto nostro Galterio, familiario domini Pape nos afectuosisime rogaverint et cum dudum eorum serviciis fideliter immorando ecclesie Romane meruises graciam et favorem, nos per eis tibi gratum retribucionis premium facemus... damus, laudamus et concedimus per hereditatem sive alodium proprium... tibi Galterio et tuis in perpetuum castrum et villam quom dicitur Serra et castrum et villam quod dicitur Torres, juxta Sogorbium, ad habendum et possidentum...".

Signaren aquest diploma com a testimonis, i desprès del signe del rei, $\mathrm{P}$. Fernández, senyor d'Albarracín; P. Cornel, majordom; Ximén d’Urrea i Garcia Romeu. El text no concreta el motiu de la gratitud o gratificació que expressa el rei cap a l'església romana, però les causes podrien ser ben diverses, des de la butlla de santa croada que el rei pretén aconseguir de la cúria papal per a la conquesta del Regne de València ${ }^{5}$, fins a l'anul·lació del seu matrimoni amb Elionor de Castella, la seua primera esposa.

En qualsevol cas, sembla que les expectatives reials sobre el control efectiu d'aquest territori de Serra-Torres Torres no degueren ser plenament complides, i malgrat que Gauteri de Roma hauria sigut (potser discontínuament) el Senyor de Serra i Torres Torres entre 1240 i 1264, o siga, al llarg de 24 anys, també resulta evident que el rei, en més d'una ocasió estigué a punt d'alienar-li la possessió. Per exemple, quan en 1257 li ofereix a la ciutat de Morvedre ${ }^{6}$ l'opció de poder comprar els llocs de Serra i Torres Torres.

També recull aquesta darrera referència Diago (1613) quan parla de Sagunt, dient que en 1257 va atorgar el rei Jaume I a la vila de Sagunt el privilegi de poder comprar els llocs de Torres Torres i de Serra, els quals s'havia proposat amar i afavorir sempre, i per això, els ajudaria donant-los 10.000 sous sempre que volgueren executar la compra; però posà també una condició: que en el cas de fer-se la compra i volguera la vila de Sagunt vendre després els dits llocs, els hi haguera de vendre a ell (o llurs successors) pel mateix preu; i només en el cas de que ell no volguera comprar-ho, poguera aleshores la dita vila de Sagunt vendre'ls a qui volgués, sempre que foren persones de servei ${ }^{7}$. Però, segons

\footnotetext{
5 recordem: Robert I. Burns: El Regne croat de València (de 1993), i Fonaments del Regne croat de València (de 1994), ambdós publicades per l'editorial Tres i Quatre.

6 ACA, cancelleria reial, reg. 16, f. 254v.; citat també per Borja (2000).

7 Facultat donada a Lleida, pridie kalendas september anno 1257, en presència de Pere de Montcada, Jordà de Peralta, Guillem de Cardona, Guillem d'Anglesola i Jasbert de Castronovo (ACA, reg. 9, f. 32 $\mathrm{v}^{\circ}$ ).
} 
anoten Cebrián i Lluch ${ }^{8}$, el 7 de juliol de 1264, el rei prometé a Gauteri de Roma no posar-li dificultats en els seus castells de Torres Torres i de Serra fins que s'haguera cobrat amb els seus rèdits tot allò que el rei li devia ${ }^{9}$. Cinc anys més tard (any 1269), el dos llocs, Serra i Torres Torres, amb alguns altres, són embargat en favor de Pere Ferran, fill del rei. ${ }^{10}$

Uns anys desprès, Serra deixarà de pertànyer al patrimoni reial mitjançant una nova i sembla que ja definitiva donació, ara a favor del seu escuder Bertran de Bellpuig, home de la seua plena confiança, al qual, en juliol de 1270 el rei reconeixia deure-li 8.500 sous que corresponien als serveis prestats per son pare (Guillem de Belpuig) ${ }^{11}$.

L'acte de donació ${ }^{12}$, inclou novament i de manera conjunta els castells i llocs de Serra i de Torres Torres, amb tots els seus llocs i pertinences, però també el de Polop (encara que no guarda relació territorial amb els dos primers). Però inclou l'obligació de residir personalment en el Regne de València, i afegeix que, en cas de no tenir fills barons, haurà de custodiar els dits castells el parent baró que determine dit Bellpuig.

Cal destacar que Guillem de Bellpuig, el pare d'en Bertran, va ser conseller en la Cort de Jaume I, es va casar amb Fàtima Fernández (una de les filles de l'antic rei musulmà de València Zeit abúZeit, convertit al cristianisme amb el nom de Vicent Fernández), i va rebre com a donació la Baronia de Castellmontant (que incloïa Montán, Montanejos, Font de la Reina i Aranyuel). Per la seua part, el seu fill Bertran, sent ja senyor de Serra i de Torres Torres, va arribar a ser Lloctinent del rei en la vila reial de Montpeller, segons queda palès en la carta amb la que Jaume I (5 de juny de 1276) comunica als prohoms de Montpeller que el seu lloctinent en la dita vila, Bertran Bellpuig, havia de servir en la present guerra de València pels castells que posseïa en l'esmentat regne i que, durant la seua absència, n'ocuparia el càrrec de lloctinent A. Fernández, militem nostrum ${ }^{13}$.

D'aquesta "guerra" (les revoltes mudèjars) que cita el rei, cal destacar el fet de que en abril del mateix any, Jaume I havia perdonat (cartes de capitulació pel mig) als musulmans de d'Orxeta i de Polop desprès d'haver ofegat la seua rebel·lió, al temps que

8 Ambrosio Cebrián i Emilio Lluch: "Notas históricas de Serra", manuscrit enllestit cap a 1935. (Arxiu Municipal de Serra).

9 Segons Cebrián i Lluch (op. cit.) la font documental és: ACA, reg. 13, f. 196.

10 Font documental, segons Cebrián i Lluch (op. cit.): ACA, reg. 16, f. 166.

11 ACA, cancelleria reial, Reg. 16, f.200 (citat per Miret, 1918, p. 441).

12 ACA, cancelleria reial, Reg. 16, f.254v (citat per Sanchis Sivera, 1922; Cebrián i Lluch, s/a; Senís, 1978; Borja, 2000 i altres...

13 citat per Miret (1918; pàg. 533). 
concedia permís als seus respectius senyors, Pere Ferrando i Bertran de Bellpuig, per a que els musulmans d'aquestes poblacions no foren expulsats i s'hi mantingueren en les condicions de poblament anteriors (Guinot, 1991; carta 164) ${ }^{14}$.

Les revoltes encara continuaven actives l'any següent en altres sectors del regne i guarda relació amb elles la carta de capitulació i establiment dels musulmans rebel·lats de Serra ${ }^{15}$, amb la qual es posava fi a la seua sublevació; carta atorgada ja pel rei Pere III, a Xàtiva estant, el 15 de febrer de 1277. La rendició dels moros de Serra es produïa dues setmanes desprès que la dels moros de Torres Torres, que es resolgué amb unes capitulacions semblants atorgades pel mateix monarca el dia 24 de gener, estant aleshores a Morvedre ${ }^{16}$.

La família Bellpuig mantindrà el compromís de residència adquirit amb la concessió del rei Jaume I i arribarà a tindre plena possessió d'aquests dos llocs estratègics (el pas natural de Torres-Torres-Serra) al llarg del segle XIV, mitjançant els descendents d'en Bertran: Hug de Bellpuig, Galcerà de Bellpuig i finalment na Timbors de Bellpuig.

Coneixem que el successor d'en Bertran, el seu fill Hug de Bellpuig posseïa i administrava els dos castell i llocs (Serra i Torres Torres) en 1304, però exercia tan arbitràriament la jurisdicció que, tot desconeixent les prescripcions dels Furs de València, usava el mer imperi per a castigar delictes que incorrien en la pena de mort, sense tindre realment cap facultat per a fer-ho. ${ }^{17}$

En 1345, Pere IV li atorgava a Galcerà de Bellpuig la jurisdicció plena: mer i mixt imperi, per a les seues possessions de Serra i de Torres Torres, i ho ratificava en $1348^{18}$. D'aquesta manera i des d'aquell moment, Serra es converteix en una senyoria jurisdiccional plena i, per consegüent, en baronia.

14 Enric Guinot dóna aquesta referència: ACA, reial cancelleria, reg. 23, f. 68v.

15 ACA, reial cancelleria, reg. 39, f. 162v-163r. Text ecollit per Guinot (1991; carta 177) i abans per Soldevila (1962).

16 ACA, reial cancelleria, reg. 39, f. 151v. Recollida per Guinot (1991; carta 176) i per Soldevila (1962). 17 Castañeda (any..., t. II, p. 88). També citat i copiat per Senís (1978): “Llamado por don Jaime II a la corte para responder de tan arbitraria conducta, compareció en Calatayud, en donde el monarca perdonó sus desafueros, según privilegio dado en dicho Calatayud en 3 de las kalendas de abril de 1304, y por este mismo instrumento perdonó, asimismo, a todos los habitadores de Serra y de Torres Torres de cuantos delitos hubiesen cometido hasta la fecha, equiparando en el perdón a los vasallos con su Señor. Trasladado el monarca a Tarazona, en 12 de las kalendas de mayo del propio año de 1304, dirigió Carta Real a Hugo de Bellpuig intimándole para que en lo sucesivo no invadiera, con el ejercicio del mero imperio, lo que constituia atribución real'".

18 ARV, cancelleria reial, L. 496, f. 340-347. Text recollit en Diez (1992). 
Aquest fet entenem que torna a ser rellevant a l'hora de poder analitzar i entendre esdeveniments futurs de la baronia, quan arribem al segle XIX i es planteja repetidament l'abolició del règim senyorívol i, particularment en aquest cas, el retorn o "reversió" de Serra a la Corona.

Timbors de Bellpuig, filla de Galcerà de Bellpuig i de Ramona de Riusec ${ }^{19}$, va ser l'hereua de les baronies de Serra i Torres Torres. Es va casar amb Gonçal Ximenes d'Arenós, de qui enviduaria deixant com a hereua universal dels dos llinatges a la filla comuna: Sança Ximenez d'Arenòs ${ }^{20}$, qui casaria més tard amb el Comte de Prades, unintse així tres importants llinatges en una mateixa branca: la dels Comtes de Prades.

Fins ací, el resum dels diferents Senyors de la senyoria/baronia de Serra al llarg dels segles XIII i XIV queda reflectit en el Quadre 7.1.

QUADRE 7.1.- Senyors de la senyoria de Serra entre els segles XIII i XIV.

\begin{tabular}{|c|c|c|}
\hline Cronologia & Senyor de Serra & observacions \\
\hline $1238 \ldots$ & Berenguer Burguet & $\begin{array}{l}\text { Non venit ad diem... } \\
\text { (no prengué possessió)r }\end{array}$ \\
\hline $1240-1257$ & Gauteri de Roma & $\begin{array}{r}\text { Donació reial i possessió... } \\
\text { (potser discontínua) }\end{array}$ \\
\hline $1257-1264$ & $\begin{array}{l}\text { El Rei } \\
\text { (administrada per Gauteri de Roma?) }\end{array}$ & \begin{tabular}{|lllll} 
En 1257 el Rei ofereix la compra a \\
Morvedre
\end{tabular} \\
\hline $1264-1269$ & $\begin{array}{l}\text { Gauteri de Roma } \\
\text { (per consentiment temporal del Rei) }\end{array}$ & 1269: passa definitivament a la Corona \\
\hline $1269-1271$ & El Rei & \\
\hline $1271 \ldots$ & Beltran de Bellpuig & Donació reial \\
\hline$\ldots 1304,1327 \ldots$ & Hug de Bellpuig & Sense jurisdicció plena \\
\hline$\ldots 1345 \ldots$ & Galcerà de Bellpuig & Pere IV li atorga mer i mixt imperi en 1349 \\
\hline$\ldots 1360$ & $\begin{array}{c}\text { Timbors de Bellpuig (1317-?) } \\
\text { Casada amb } \\
\text { Gonçal Ximénez d'Arenòs (1313-1357) }\end{array}$ & $\begin{array}{l}\text { Ramona de Riusec (vídua de Galcerà) i sa } \\
\text { filla Timbors (vídua de Gonçal Ximénez } \\
\text { d'Arenòs) donen el seu llegat en la dot de la } \\
\text { seua néta i filla Sanxa Ximén d'Arenós... }\end{array}$ \\
\hline $1360 \ldots$ & $\begin{array}{c}\text { Sança Ximenez d'Arenòs (1335-?) } \\
\text { i Joan d'Aragó i Prades (1335-1414) } \\
\text { (COMTES DE PRADES })\end{array}$ & \\
\hline
\end{tabular}

Elaboració pròpia.

19 Ramona va estar casada primer amb Berenguer Boïl (en 1349, però, ja era uxor de Bellpuig, segons comunicació personal de Juan Corbalán de Celis, amb la ref.: LC-AC Valencia 1650 f. 82v).

20 ADM, Sogorb, 114/2776: testament d'en Gonçalbo Eximenes d'Arenòs (7 idus septembris 1345) a favor de la seua filla Sanxa Ximén d'Arenòs. 


\subsection{DELS BELLPUIG I ELS ARENÓS ALS COMTES DE PRADES (SEGLES XIV} AL XV)

Sança Ximenes d'Arenós fou l'hereua tant dels Bellpuig (per via materna: Serra i Torres Torres) com dels Arenós (per la paterna: Andilla, Soneixa-Assuévar, Xest...) ${ }^{21}$. Per això, el fet de casar-se amb un noble de la categoria de Joan d'Aragó i Foix, o simplement Joan de Prades (hereu del comtat de Prades), seria molt ben vist per la seua mare (Timbor) i la seua àvia (Ramona de Riusec), que en 1360 li cedien a Sança els drets de jurisdicció i mer imperi de Serra, Torres Torres i altres poblacions que foren del difunt Galceran de Bellpuig, com a dot aportada al seu matrimoni amb qui ja era III Comte de Prades. ${ }^{22}$

La carta de perdó i capitulacions que Pere IV atorga en 1365 als moros de Serra, desprès de la súplica d'aquells per haver estat recolzant el castellans durant la guerra dels Peres (Ferrer, 1999) ${ }^{23}$, deixa clar que per aquell temps, els mudèjars de Serra pagaven els seus tributs dominicals a Timbor de Bellpuig i al seu gendre, el Comte de Prades. Tanmateix, de la corresponent carta de perdó i capitulacions dels moros del Castell i la Tinença d'Assuévar, carta atorgada per Pere IV estant a Torres Torres, el 20 de març de 1365 , es desprèn que aquesta baronia ja era també propietat del Comte de Prades. ${ }^{24}$

És la primera vegada que concorren en un mateix noble les possessions de Soneixa i Assuévar, per una banda, i de Serra, per altra. A partir d'ara, però, ambdues baronies aniran sempre parelles en la seua possessió, passant sempre juntes a mans de successius senyors i barons; al mateix temps que, com veurem, canviarà de mans, poques dècades desprès, la possessió de la baronia de Torres Torres.

Aquest matrimoni dels Comtes de Prades va tindre 6 fills, el major i primogènit, portador dels títols familiars, serà Pere (Pere d'Aragó, també dit Pere de Prades, i encara Pere d'Entença). Pere de Prades i Aragó (1352-1395), citat com Pere d'Entença es va casar en $1385 \mathrm{amb}$ Joana Cabrera i van tindre quatre filles: Margarida, ${ }^{25}$ Joana, Elionor i

21 Per altra part, la seua cosina-tercera, Violant d'Arenós (1340-1411) heretaria, per altra banda, la baronia d'Arenós. Violant fou esposa d'Alfons el Vell, I Duc de Gandia, i filla de Gonçal Díez d'Arenós, un cosí prim de Gonçal Ximénes d'Arenós (pare de Sança).

22 Joan es va convertir en el III Comte en 1358, any en que son pare, el Infant Pere d'Aragó, li va cedir el títol just abans de retirar-se al convent de Sant Francesc, a Barcelona.

23 ACA, reial cancelleria, reg. 1341, f. 142v (estudiat i publicat per Andrés Ferrer Taberner, 1999).

24 veure text en Guinot (1991; carta 275): ACA, reg. 1209, f. 54v-55v.

25 Margarita de Prades (1387-1429), que junt amb les seues germanes i per mediació de sa mare (que era cortesana) havia sigut educada -desprès de la mort de son pare- en la cort de Maria de Luna, acabaria convertint-se en la segona esposa del rei Martí I el Humà (contragueren matrimoni en 1409, però el matrimoni durà molt poc, doncs el rei morí en el mes de maig de l'any següent). D'aquesta manera, l'herència dels títols nobiliaris del comtes de Prades recaigué en la seua germana Joana. 
Elisabet. Pere va morir a Torres Torres el 20 de novembre de 1395, a l'edat de 43 anys. ${ }^{26}$ L'esquema successori i genealògic és el recollit en l'esquema següent:

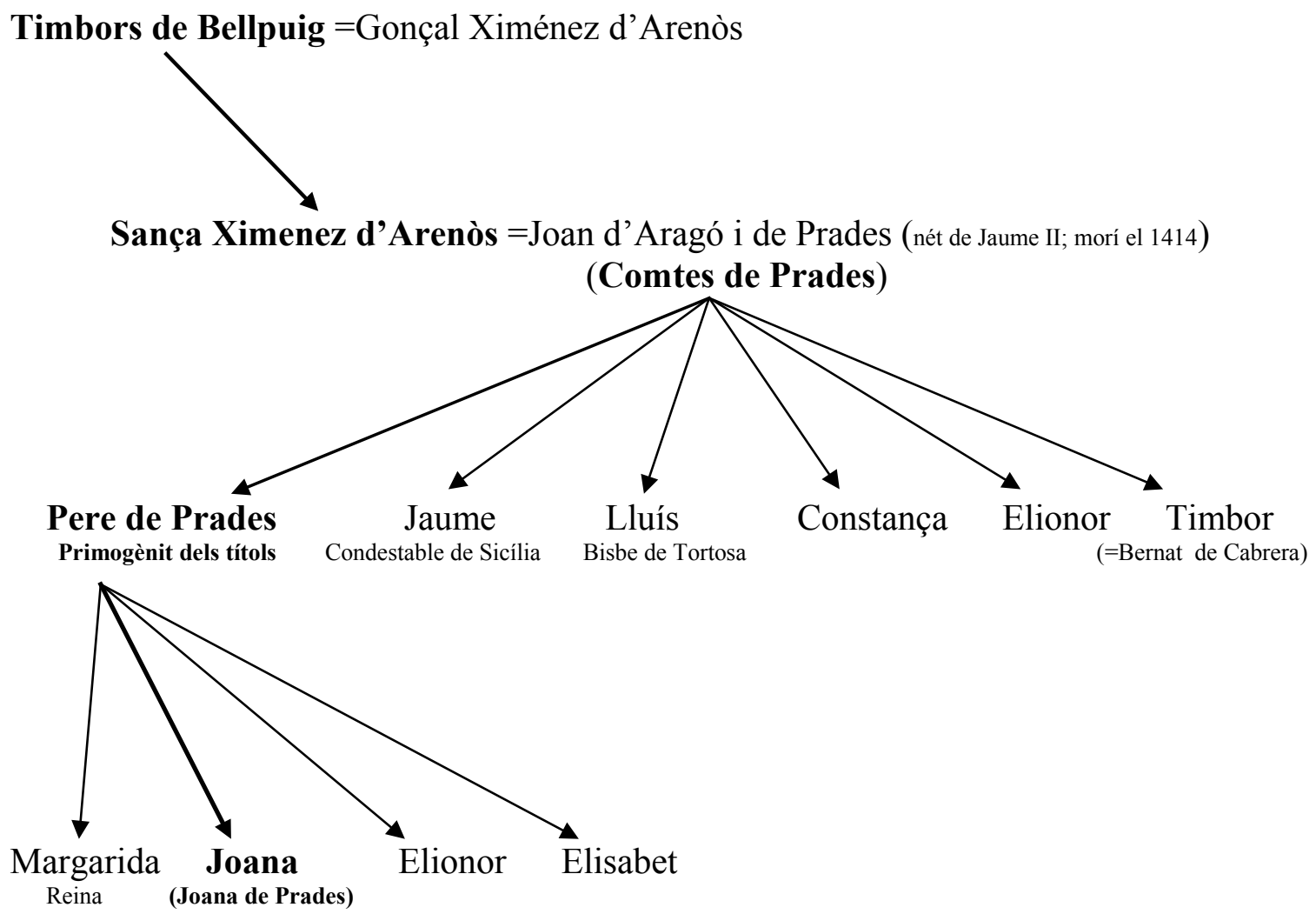

A Joana de Cabrera, l'esposa vídua de Pere, la trobem de vegades citada com a Joana de Prades, però cal no confondre-la amb la seua filla (la genuïna "Joana de Prades"). Visqué fins el 1419, però va ser la seua sogra, Sança, la persona més rellevant en la preparació dinàstica i educació de la seu filla i néta, respectivament, Joana de Prades i Cabrera (1392 -1445), fins que aquesta la va succeir el 1414 (en morir els seus avis). En 1412, els drets de successió li van ser ja atorgats deixant constància la seua àvia, en llur testament, de l'orgull que tenia de la seua néta:

Vos, Doña Gonzalba Ximenez de Arenos, nieta nuestra muy amada, hija del Egregio Don Pedro de Prades quondam hijo primogénito nuestro, que soliais ser nombrada Doña Juana de Prades, haver assi diferido, y dado lugar al honor del dicho nuestro padre, que havéis querido tomar el nombre y apellido de aquél, y llevar las armas con sus señales, assi que os haveis hecho nombrar y nombrado Gozalba Ximenez de Arenós... ${ }^{27}$.

$26 \mathrm{http}: / / \mathrm{www}$. fundacionmedinaceli.org/casaducal/fichaindividuo.aspx?id=1330.

27 referències al testament en una Adición al memorial ajustado... (AHN-SN, F.N., lg. 263/28-30). 
Efectivament, Joana d Prades, poc abans de que fera testament de la seua àvia, va decidir i va fer el canvi del seu nom, adoptant-ne el del seu besavi (pare de Sança): Gonçalva (Gondiçalva) Ximénez d'Arenós, que sempre trobarem citat seguit del olim, o bé alias, "Joana de Prades". En les raons del canvi sembla clar que pot haver-hi un intent de consolidar - $\mathrm{o}$ simplement previndre- drets i clàusules successòries dels Arenós. ${ }^{28}$

\subsection{JOANA DE PRADES, SENYORA DE LA BARONIA DE SERRA (1414-1431)}

Joana de Prades (Gonçalva Ximénez d'Arenós, des de 1412) heretarà el 1414, de la seua àvia Sança, unes possessions tan hipotecades i carregades de censals que pràcticament estaven en mans dels censalistes. Els drets successoris (drets relatius, sobre possessions empenyorades, sembla) de diverses baronies (Andilla, Xest, Gestalgar, Assuévar i, entre elles també Serra) van ser atorgats al jove Joan Ramon Folch, futur III Comte de Cardona, com a futur marit de Joana i part de la dot d'aquesta.

En el seu testament, de data 6 de febrer de 1412, Sança nomenava a Joana (per a després de la seua mort) com a hereua del vincle o fideïcomís establert per son pare (Gonçal Ximenes d'Arenós) sobre els castells, vila i llocs d'Andilla i de Cortes (d'Arenós), amb tots els seu termes i pertinences i amb tota jurisdicció, mer imperi, i tots altres drets. També refereix seguidament els drets successors respecte a les baronies de Serra i de Torres Torres, però diu al final d'açò un curiós però significatiu condicionament, quan afegeix: "si en algun moment pogueren ser descarregats els censals que pesaven sobre els castells, vila i llocs d'Andilla i Cortes, per part de qui algun dia poguera tenir o posseir els castells, tinença, llocs i alqueries de Torres Torres, de Serra, de Gestalcamp i d'Assuévar, o qualssevol d'ells". En altre moment del estament fa constar que els castells, tinença i llocs de Xest (Xestalcamp) i d'Assuévar, amb tots els seus termes, pertinences i drets eren "estats" que pertanyien al domini de Sança, en haver-li estat atorgats pel testament de son pare $\mathrm{i}$ en haver-se ratificat aquesta adjudicació, fora de tot vincle, mitjançant sentència judicial promulgada per l'honorable Misser Bartholomé del Mas, jutge delegat del Molt Alt Senyor Rei.

28 De fet, el 1345, el testament de Gonçal Diaz d'Arenós (parent de Gonçal Ximénez d'Arenòs, el pare de Sança), senyor de la baronia d'Arenós i pare de Violant (qui es casaria amb Alfons el Vell, duc de Gandia) incloïa una clàusula que determinava l'herència dels bens familiars a favor del primer fill mascle de la seua descendència (el primer nét), amb la condició de que adoptés les armes dels Arenós i el cognom de l'avi matern. (informació recollida per Jaume Castillo, 2012, p. 45). Sembla que aquesta clàusula seria argument d'un futur plet sobre la successió de la baronia d'Arenós, bastants anys desprès (ARV, G 2.229, mà 26, f.1rv). 
Per aquest testament coneixem que la família dels Comtes de Prades tenia fixada la seua residència a Morvedre, d'on Sança pràcticament no podia sortir ni desplaçar-se per malaltia, necessitat i "accidente que tiene en su persona". Per això, es desplacen a sa casa, a fi d'autoritzar el testament i decretar les donacions i contractes "fets i faedors" les següents persones: Vicent Blai de Camanyes "doctor en lleis, salut i honor", en substitució del Lloctinent General l'honorable Arnau de Vilarnau, que es trobava malalt; el virrei i governador general del Regne de València, en Arnau Guillem de Bellera; el bisbe de Mallorca i "camarlengo de Nuestro Señor el Papa", don Luis de Prades (fill de Sança); Joana de Prades, la mare (Joana Cabrera), i Joana de Prades, la filla (Gonçalva).

Desconeixem la data exacta de la mort de Sança però, per les dades que manege, no sembla provable que sobrevisqués més enllà de 1414, l'any en que va morir també el seu marit, el III Comte de Prades. Pel que sembla, l'àvia i l'avi no havien estat ben avinguts i de fet havien viscut durant més de 30 anys separats l'un de l'altre. ${ }^{29}$

Aquell mateix any 1414, Joana contragué matrimoni amb Joan Ramón (II) Folch de Cardona (1400-1471), hereu i successor del II Comte de Cardona, que també tenia per nom Joan Ramon (I) ${ }^{30}$. Potser que la mort del III Comte de Prades (com també la de na Sança) haguera generat raons de conveniència o d'oportunitat, que precipitaren la boda de la seua néta, de 20 anys d'edat, amb un nuvi que sembla només tenia 14 anys.

El 14 de maig de 1414, Joan Ramon Folch, fill del II comte de Cardona, reconeix haver rebut com a dot de la seua esposa, Joana de Prades (Gonçalva) els drets sobre les següents possessions: Cortes, Andilla, Torres Torres, Serra, Assuévar, Soneixa, Gestalgar i Gestalcamp, en virtut dels capítols matrimonials signats dos any enrere ${ }^{31}$. En canvi, el títol del comtat de Prades havia estat tot el temps en mans del marit de Sança.

En morir Joan de Prades i Aragó, en 1414, les desavinences que havia tingut durant tant anys amb la seua esposa, Sança, prengueren més forma i l'herència pel títol del Comtat de les Muntanyes de Prades entrà en un conflicte de successió, en haver mort aquest III comte de Prades sense que li sobrevisqués el seu fill Pere i sense descendència masculina d'aquest. Per això va reclamar l'herència Alfons ${ }^{32}$, duc de Gandia i nebot del

29 Segons Mireia Comas Via: Sança Eximenis d'Arenós i de Bellpuig, en "Diccionari Biogràfic de dones": http://www.dbd.cat/index.php?option=com biografies\&view=biografia\&id=461. (consulta: 2014 ).

30 Aquest Joan Ramon (I), II Comte de Cardona, era fill d'Hug de Cardona (I Comte), serà el primer de quatre comtes amb el maix nom de "Joan Ramon Folch de Cardona". L'espòs de Joana de Prades és, doncs, el segon d'aquest nom i es convertirà en el III Comte a la mort de son pare, en 1441.

31 ADM, Segorbe, lg. 115, paquet 127, núm. 28.

32 Es tracta d'Alfons "el Jove", oncle segon de Joana de Prades (cosí germà del pare de Joana). Aquest Alfons era fill d'Alfons "el Vell", duc de Gandia i germà de Joan, el III comte de Prades. Els dos 
difunt. Desprès també entraren a litigar Timbor de Prades (filla del difunt i tia de Joana) i Violant (filla de Jaume de Prades i per tant també néta del difunt i cosina germana de Joana), ambdues dones defensaven un mateix candidat: Joan Cabrera i de Prades (fill del Comte d'Osona i de l'esmentada Timor de Prades i, en 1420 marit de Violant de Prades i de Villena) $)^{33}$.

Aquest litigi no es resoldria fins a 1425, en que el rei Alfons el Magnànim va dictar sentència adjudicant-li a Joana de Prades i al seu marit el Comtat de Prades i la baronia d'Entença ${ }^{34}$. Així, quan la seua esposa "Joana de Prades" (Gonçala) es convertia en IV Comtesa de Prades, el seu marit, Joan Ramón (II) era només vescomte de Vilamur, el títol tradicional que rebien els hereus del Comtat de Cardona.

Joana de Prades/Gonçalva Ximénez d'Arenòs no deixa de ser un personatge singular en la història de les seues possessions nobiliàries, sobre les que hagué de prendre importants decisions i fer front, sent encara molt jove, a circumstàncies $i$ fets de certa responsabilitat. A més a més, cal no oblidar que era la representant i successora d'alguns dels llinatges de més soca-rel de la corona d'Aragó, no solament pels seus títols nobiliaris (baronies dels Bellpuig, dels Arenòs i d'Entença, i comtessa -disputada- de Prades) i els del seu espòs (hereu del comtat de Cardona), sinó també per la seua ascendència reial (rebesnéta del rei Jaume II: el seu avi Joan era nét d'aquest rei, i fill de l'Infant Pere d'Aragó); per no parlar-ne també de la seua condició de germana de la reina Margarida de Prades (segona esposa del rei Martí I el Humà; mort el 1410).

Potser per haver deixat de rebre les rendes de les muntanyes de Prades i de la baronia d'Entença, desprès d'haver perdut el seu avi (i sobre tot la seua àvia), o bé per haver de fer front al litigi per la successió del comtat de Prades que s'inicià a continuació, o potser encara per altres problemes amb les administracions de les altres baronies, el cas es que acabant el primer terç del segle XV, la seua situació econòmica i financera havia esdevingut molt dolenta i malmesa, fins el punt que degué plantejar-se la necessitat de vendre algunes possessions, com van ser les baronies de Serra i de Soneixa

germans, Alfons i Joan d'Aragó i Foix moriren el mateix any 1414. A més a més, Alfons el Jove era germà de Joana de Gandia, la mare de Joan Ramón (II) i sogra de Joana de Prades. I per a major cúmul de circumstàncies, resulta que la mare de Joana de Gandia i d'Alfons el Jove (l'esposa d'Alfons el Vell) era Violant d'Arenós, cosina de Sança, l'àvia de Joana de Prades.

33 Conflicte citat per Armand de Fluvià (1979) i per Gerard Marí i Brull (2009, p. 49).

34 Sentència recollida per Manuel Romero i Tersa Pallet (1991). Citada també per Iquino (1982, p. 27). 
en 1431. Sembla que també Xest (Xestalcamp) correria la mateixa sort per aquell temps, sent venuda a Joan Vallterra. ${ }^{35}$

\subsection{FELIP BOÏL, SENYOR DE LA BARONIA DE SERRA DESPRÈS DE SANEJAR-} LA (1431-1443)

En 1431, Joan Ramon Folch i la seua esposa Joana (Comtes de Prades) reconeixen que tenen carregats molts censals sobre les seues possessions, i, amb poder per a alçar-los, acorden la venda a Lluis Aguiló milite i els seus hereus, dels llocs de Castro et tinencia d'Adzueva, cum locis d'Adzueva, de Soneja, de Pellunis et Mosquera, cum iuribus eorum et pertinentiis universis, per preu de 84.000 sous, en reals de València; i al mateix temps, acorden també la venda, a Joan Alegre, ciutadà de València, del Castrum de Serra et alquareas eius scilicet Riera et Armell, per preu de 70.000 sous, en reals de València. Seguidament, en el mateix acte ${ }^{36}$ es fa constar que aquest Joan Alegre actua per encàrrec $\mathrm{i}$ amb poder d'Agnès de Vallterra i del seu espòs, el noble Felip Boïl, dels Boïl de la Scala.

La presència en aquestes transaccions d'un representant dels Boïl de la Scala no ha de resultar del tot estranya si tenim en compte que d'alguna manera estaven emparentats amb Joana de Prades, doncs, el primer marit de la seua rebesàvia (Ramona de Riusec) va ser Berenguer Boïl, abans de que envidués i contraguera nou matrimoni amb Galceran de Bellpuig. I d'aquell matrimoni havia nascut Pere Boïl (germà de Timbor de Bellpuig, per part de mare). Aquest Pere Boïl era nebot dels Senyors de Manises: Ramona Boïl i el seu marit Juan Ximénez de Urrea. Per altra part, resulta també cridaner el cognom de la dona de Felip Boïl: Agnès de Vallterra, doncs cal tenir en compte que els Vallterra van seran els futurs posseïdors de Torres Torres. A més, ja hem dit que Xestalcamp va ser venuda pels comtes de Prades a Joan Vallterra. ${ }^{37}$

En un document enregistrat pel notari de València Nicolau Esteve, amb data de 3 de gener de 1443, Joan Ramon Folch i Gonçalva Ximénez d'Arenós, comtes de Prades, reconeixen un deute a favor de Joan de Vallterra, llur procurador i receptor en el regne de

35 http://iespana.es/Arenos.htm. Veure també Navarro: Monografia historica de la villa de Cheste al Campo...

36 ARV, Reial cancelleria, 269, f. 6.

37 Vid. nota 37. 
València, per valor de 23.484 sous i 4 diners, pels censals carregats sobre Torres Torres ${ }^{38}$. Dotze anys desprès (11 de març de 1445) i poc abans de morir la comtessa de Prades, els comtes de Prades (ara també de Cardona), amb llurs fills, li venen al mateix Joan de Vallterra la vila de Torres Torres, amb les alqueries d'Alfara i Algímia, per preu de 28.500 florins, a efectes de "quitament" de censals ${ }^{39}$.

Entre la documentació del segle XIX continguda en l'arxiu senyorívol de Montellano/Fernan Núñez (AHN, secció noblesa), hi ha diverses referències i una còpia de l'escriptura de venda del Castell de Serra i els llocs o alqueries de Ria i Armell, amb tots els seus drets i pertinences ${ }^{40}$, atorgada per Joan Alegre, ciutadà de València, a favor de Felip Boïl, davant Lleonard Vilar, notari de València, el 20 de juliol de 1436, pel preu de 80.000 sous. $^{41}$

En el temps que transcorre entre la compra de la baronia de Serra per Joan Alegre (any 1431-1432) i la seua venda a Felip Boïl (1436), i segons es diu en l'esmentada escriptura, el primer es dedica a rescatar i recuperar censals, per tal que Felip Boïl puga obtenir major presència i possessió (totalment lliure de càrregues i obligacions) en la seua nova pertinença del Castrum de Serra et loca sive alcareas de Ria et Armell,et ipsorum totum terminum ac territorium in Regno Valencia constituta... ipsorum habitantibus, habitaturis, cum pratis,pastetum, montaneis, montibus, vallibus, silvis, nemoribus, garriguis, venationibus, erbagiis, ligniis, arboribus et plantus fructiferiis et infructiferiis, fontibus, aquiis, cequiis et aquarum ductibus et cum furnis etiam mancellis, tabernis, laudimis, faticus, morabatino seu monetagio, tertiodecimi, herencius, peytis, donationibus, quertis, demandis, exactionibus, penis, caloniis acque multis, etc.

Desconec quant de temps roman la baronia de Serra en mans de Felip Boïl i la seua dona Agnès de Vallterra, però sembla clar que el 1443 (desconec la data i detalls de la possible compra) novament els comtes de Prades (i ara també de Cardona) havien ja recuperat les baronies de Serra i de Soneixa. Per entendre millor les raons que permeteren fer aquesta nova compra, cal tindre en compte un fet prou rellevant: el 1441

38 ARV, Batllia, perg. Núm. 745. (conservació deficient). Veure índex 784 del CD sobre els fons de l'ARV.

39 Acte passat davant Pere Besalú, secretari reial (ADM, Segorbe, lg. 116 n $\left.^{\circ} 2814\right)$. Dades facilitades per Elios Borja.

40 AHN, nobleza, Fernan-Núñez, Montellano, papelera 22, lg. $1, n^{\circ} 1$.

41 Tornaré a fer menció d'aquest acte en el capítol 9 d'aquesta memòria de Tesi, doncs, aquesta compra de Serra feta per Joan Alegre, seguint un encàrrec de Felip Boïl, i la posterior compra de Serra per part del mateix Felip Boïl, és un referent important a l'hora de determinar si la possessió de la baronia era només jurisdiccional o també territorial. Aspecte que importa i molt en els plet del segle XIX. 
moria el pare de Joan Ramon, de manera que ell es convertia ara en el III comte de Cardona i posseïdor de tots els seus dominis. I com hem vist (notes 40 i 41 a peu de pàgina), al final d'aquestos trascolaments, Torres Torres acabaria en mas dels Vallterra.

El 29 de desembre de 1443, Joana fa donació al seu marit, Joan Ramon Folch (comte de Cardona) i al seu fill, Joan Ramon (III) Folch de Cardona (i ara nou vescomte de Vilamur) "per sempre i sens vincle" dels llocs de Serra i de Soneixa ${ }^{42}$.

\subsection{LA BARONIA DE SERRA EN MANS DELS COMTES DE CARDONA (S. XV)}

En 1444 es va casar Joan Ramon (III), el fill dels comtes de Prades i de Cardona, amb Joana d'Aragó o d'Urgell (filla de Jaume II d'Urgell "el Dissortat" i germana d'Isabel, l'esposa del rei Pere de Portugal). D'aquest matrimoni naixeria més tard el successor dels comtats.

Aquell mateix any, Joana va prendre una decisió que duria molts problemes als seus successors al llarg dels segles següents, i va ser la d'agregar al Comtat de Prades la Baronia d'Entença i les de Serra i Soneixa, creant un vincle. ${ }^{43}$

En 1445 moria Joana de Prades i sembla que per aquesta raó el seu marit, el III Comte de Cardona, va renunciar al Comtat de Prades en favor del seu fill Joan Ramón (III) Folch de Cardona, convertit així en el V Comte de Prades, i que arribaria amb el temps a ser també el IV Comte de Cardona, a la mort de son pare. No obstant això, el pare, en quedar vidu de Joana de Prades, es tornaria a casar, tenint encara altres tres fills. Morí en 1471.

El següent hereu del comtat de Prades, fill de Joan Ramon (III) també dugué el nom dels seus pare, avi i besavi; va ser Joan Ramón (IV) Folch de Cardona (1446-1513) qui es convertiria, en morir son pare en 1486, en el VI comte de Prades i el V de Cardona. Però amb aquest Joan Ramon (IV) acabarà el comtat de Cardona per a convertir-se, en mercè d'una concessió reial de l'any 1491, en ducat de Cardona.

El futur I duc de Cardona (cinquè i últim comte de Cardona) s'havia casat en $1467 \mathrm{amb}$ Aldonça Enríquez (tia del rei Ferran II el Catòlic) i van tindre 12 fills.

A mode de resum i síntesi, en el QUADRE 7.2 indiquem ordenadament els diferents posseïdors de la baronia de Serra (i a l'hora de la de Soneixa) durant el segle 
XV. No he posat, finalment, a Pere de Prades (casat amb Joana Cabrera) per no tindre total seguretat de que arribara a ser nomenat i prenguera realment possessió, com a senyor, de la baronia de Serra, doncs el seus pares encara el sobrevisqueren molts anys desprès que ell va morir, relativament jove.

QUADRE 7.2.- Senyors de la baronia de Serra al llarg del segle XV.

\begin{tabular}{|c|c|c|}
\multicolumn{1}{c|}{ Any } & Senyors de Serra & \multicolumn{1}{c|}{ observacions } \\
\hline $1360-1414$ & $\begin{array}{c}\text { Sança Ximénez d'Arenós } \\
\text { =Joan d'Aragó i Foix (III comte de Prades) }\end{array}$ & $\begin{array}{c}\text { Néta de Sança. } \\
\text { (Comtes de Prades) }\end{array}$ \\
\hline $1414-1431$ & $\begin{array}{c}\text { Joana de Prades (Gonçalva Ximénez d'Arenós) } \\
\text { =Joan Ramon (II) Folch de Cardona } \\
\text { (per mediació i per encàrrec a Joan Alegre) }\end{array}$ & $\begin{array}{c}\text { Compren la baronia de } \\
\text { Serra i la sanegen. }\end{array}$ \\
\hline $1431-1443$ & $\begin{array}{c}\text { Felip Boïl i Agnés de Vallterra } \\
\text { (coma de Prades i Joan Ramon (II) }\end{array}$ & $\begin{array}{c}\text { Compren (ara sanejada) la } \\
\text { baronia de Serra }\end{array}$ \\
\hline $1444-1445$ & $\begin{array}{c}\text { Joan Ramon (III) Folch de Cardona } \\
\text { (V comte de Prades i IV de Cardona) }\end{array}$ & $\begin{array}{c}\text { Casat amb } \\
\text { Joana d'Urgell i Aragó }\end{array}$ \\
\hline $1445-1486$ & $\begin{array}{c}\text { Joan Ramon (IV) Folch de Cardona } \\
\text { (VI comte de Prades i V de Cardona; i I duc) }\end{array}$ & $\begin{array}{c}\text { Casat amb Aldonça } \\
\text { Enríquez }\end{array}$ \\
\hline
\end{tabular}

Elaboració pròpia.

\subsection{DELS DUCS DE CARDONA A UNA BRANCA SECUNDÀRIA DELS FOLCH}

\section{DE CARDONA (ELS SENYORS DE SERRA EN EL SEGLE XVI)}

El I duc de Cardona, Joan Ramon (IV) Folch de Cardona, va ser també I Marqués de Pallars Sobirà, VI comte de Prades, vescomte de Vilamur, i Senyor de les baronies d'Entença, Soneixa-Assuévar i Serra (entre altres, potser).

El seu fill Ferran (1469-1543) es convertirà, a la mort de son pare, en el II duc de Cardona i molts altres títols nobiliaris, exceptuats els de les baronies de Serra i de Soneixa, que recaigueren en el seu germà Pere. Va ser també nomenar Cavaller (núm. 160) de l'Orde del Toisó d'Or. Es va casar amb Francisca Manrique de Lara, amb la que tingué quatre filles però cap fill. També estigué casat després amb Isabel Agustí, de la que tingué dues filles més.

A la mort de Ferran de Cardona, el títol de Duc de Cardona i dels seus estat recaigué en la seua filla Joana, mentre que les baronies de Serra i de Soneixa havien passat un any abans (1542) a mans de Ferran, el cosí germà de Joana i fill del seu oncle 
Pere, a qui a partir d'ara trobarem habitualment citat com Ferran Folch de Cardona, estenent així la preferència de la forma "Folch de Cardona" sobre la forma "Cardona" als seus descendents, si bé totes dues branques familiars arriben a fer un ús indistint d'ambdues formes.

Joana de Cardona (Joana Folch de Cardona i Manríquez), la III duquessa de Cardona, es va casar amb Alonso d'Aragón, el II duc de Sogorb, de manera que, a partir d'aquest matrimoni, el títols dels dos ducats (Cardona i Sogorb) quedaran units i units passaran a llurs descendents. El comtat de Prades i la baronia d'Entença també passen en la línia successòria units per sempre als ducs de Sogorb i Cardona. En canvi, Serra i Soneixa seguiran un camí diferent i no exempt de conflictes successoris, perquè, durant segles, els descendents del ducat de Sogorb-Cardona pledejaran amb els titulars de les baronies de Serra i Soneixa-Assuévar, intentant recuperar-les per entendre que eren indivises del comtat de Cardona i la baronia d'Entença, segons l'agregació feta en 1444 per Joana de Prades.

D'aquesta manera, els senyors de les baronies de Serra i de Soneixa-Assuévar, es convertirien en una mena de branca de parents deslligats de l'alt eix nobiliari dels ducs de Cardona-Sogorb, però no per això oblidats i tranquils, sinó al contrari, ja que mantindran durant algunes generacions una curiosa pugna successòria. Per una part, els senyors de Serra reclamaran el títol del ducat de Cardona esgrimint que ells són la línia agnatícia del ducat, que mai devia haver recaigut en Joana de Cardona desprès de la mort del segon duc sense descendència masculina. Per altra part, com he comentat, els ducs de Cardona reclamaran les baronies de Serra i de Soneixa esgrimint el vincle de primogenitura creat per Joana de Prades, entenent que la separació que d'aquestes dues baronies va fer el primer duc no seria correcta ni acceptable.

Pere de Cardona i Enríquez, el nou senyor de Serra, es va casar amb Joana Requesens i Baucio, i arribà a ser Lloctinent General de Catalunya, entre 1524 i 1546. Cap a 1542 li cediria al seu fill primogènit, Ferran, el títol i possessió de les baronia de Serra i de Soneixa, mentre que un altre fill de Lloctinent, Pere de Cardona i Requesens, seguiria les passes de son pare, ocupant el mateix càrrec públic (des de la seua mort, en 1546 i fins a 1552); també un nét de Pere, Enric de Carmona i Erill, arribarà a ser Governador de Catalunya ${ }^{44}$. Un altre fill del matrimoni, Galceran de Cardona Requesens,

44 Salazar i Castro (1685, p. 46). 
va ser coper de Carles V i destacà com a militar i com a humanista, sent conegut com "la llum del duc de Cardona".

Ferran Folch de Cardona i Requesens, amb la seua muller, Anna Oms, seguiran vivint a Barcelona, ciutat on havien nascut $\mathrm{i}$ on tenien una bona posició pel càrrec patern, a més d'una bona reputació i reconeixement social, en ser Ferran nét del primer duc de Cardona i nebot i fillol de Ferran, el II duc. No obstant, cal suposar que passarien llargues temporades a Soneixa (més que a Serra) ja que era al Regne de València on tenien les seues propietats i dominis. En 1563 els trobarem citats en les actes del desarmament dels moriscos de Serra, Ria, Soneixa i Assuévar.

Ferran i Anna Oms tingueren al menys dos fills, Galceran, que seria l'hereu, i Joana, que es casaria amb Alfons de Milà. Els va succeir en la possessió de la baronia de Serra el seu fill, Galceran Folch de Cardona, que es casaria amb Mariana Cardona i Cardona, cosina germana seua, filla del seu oncle Pere, el governador. D'aquest matrimoni naixeria, per fi, en Josep Folch de Cardona i Cardona, el protagonista del ràpid repoblament de les baronies de Serra i de Soneixa en 1609.

El QUADRE 7.3 resumeix i sintetitza la successió dels senyor de la baronia de Serra al llarg del segle XVI i primera meitat del XVII, de la que he anomenat "una branca secundària" dels Cardona.

QUADRE 7.3.- Els Folch de Cardona, senyors de la baronia de Serra en el segle XVI.

\begin{tabular}{|c|c|c|}
\multicolumn{1}{c|}{ Any } & Senyors de Serra & observacions \\
\hline $1486-1513$ & $\begin{array}{c}\text { Joan Ramon (IV) Folch de Cardona } \\
\text { (I duc de Cardona, des de 1491) }\end{array}$ & $\begin{array}{c}\text { Casat amb } \\
\text { Aldonça Enríquez }\end{array}$ \\
\hline $1513-1546$ & $\begin{array}{c}\text { Pere Folch de Cardona (fill del duc) } \\
\text { (governador de Catalunya) }\end{array}$ & $\begin{array}{c}\text { Casat amb } \\
\text { Joana Requesens i Baucio }\end{array}$ \\
\hline $1642-1579$ & $\begin{array}{c}\text { Ferran Folch de Cardona (nebot del duc) } \\
\text { (cavaller de l'Orde d'Alcàntera: any 1548) }\end{array}$ & $\begin{array}{c}\text { Casat amb } \\
\text { Anna Oms }\end{array}$ \\
\hline $1579-1608$ & $\begin{array}{c}\text { Galceran Folch de Cardona } \\
\text { (cavaller de l'Orde d'Alcàntera: any 1575) }\end{array}$ & $\begin{array}{c}\text { Casat amb } \\
\text { Mariana Cardona }\end{array}$ \\
\hline $1609-1645$ & $\begin{array}{c}\text { Josep Folch de Cardona } \\
\text { (cavaller de l'Orde d'Alcàntera: any 1601) }\end{array}$ & Jerònima Lull i Cabrera \\
\hline & $\begin{array}{c}\text { Jerònima Lull (vídua d'en Josep) } \\
\text { (comtessa de Montagut) }\end{array}$ & \\
\hline
\end{tabular}

Elaboració pròpia.

En resum, la possessió de la baronia de Serra al llarg del segle XVI i primera meitat del XVII ha estat en mans d'una de les diverses branques familiars dels Cardona, 
que continuen dient-se habitualment Folch de Cardona. La dels senyors de les baronies de Serra i de Soneixa és una branca secundària i prou més modesta que altres més notables de la mateixa família i cognom. Al seu costat va allunant-se el parentiu respecte a la dels ducs de Cardona (a partir de la III duquessa lligats al ducat de Sogorb), o la dels governadors de Catalunya (amb Enric de Cardona i Erill, cosí germà de Galceran), o la dels barons (i des de 1542 marquesos) de Guadalest (amb Sancho de Cardona i Ruiz de Liori), o una branca propera a l'anterior, la dels barons (i des de 1639 també marquesos) de Castellnou, representada per Alonso de Cardona Borja i Milà d'Aragó. Un fill d'aquest últim va ser Josep Folch de Cardona i Erill (1651-1729), personatge austriacista a qui Carmen Pérez Aparicio (2002) va dedicar un interessant estudi. ${ }^{45}$ En el QUADRE 7.4 hem representat els principals personatges i línies genealògiques d'aquests llinatges.

\subsection{JOSEP FOLCH DE CARDONA I ELS CONFLICTES AMB EL DUC DE SOGORB}

Quan Josep Folch de Cardona pren possessió de la baronia de Serra, ja mort son pare uns mesos abans, "heretarà" també un parell de plets que aquest venia arrossegant des de feia vàries dècades. El primer plet l'havia iniciat ja l'avi d'en Josep, Ferran, desprès de la mort sense descendents barons del seu oncle Ferran, el segon duc de Cardona, succeïda en 1543 (moria el duc amb 74 anys d'edat). La demanda l'havia interposat contra la tercera duquessa i cosina germana seua, Joana de Cardona (15041564) i la filla d'aquesta, Joana d'Aragó i Cardona (1542-1608), que amb el temps es convertiria en la $\mathrm{V}$ duquessa de Cardona. Amb aquesta demanda reclamava, per al seu fill Galceran, el ducat de Cardona, sobre la base de la clàusula de fideïcomís perpetu i agnatici instaurada per Joana de Prades $^{46}$.

L'altre plet va ser una causa paral·lela iniciada per Joana d'Aragó i Cardona (V duquessa de Cardona i IV de Sogorb) en 1576. Era un plet de demanda per la possessió de les baronies de Serra i de Soneixa interposada contra el seu cosí segon, Galceran, el pare d'en Josep (aquest encara no havia nascut).

QUADRE 7.4.- Diferents branques dels Cardona que pledejaren per la possessió de Serra.

45 És la segona vegada que el cognom Erill s'introdueix en una branca dels Cardona; també havia sigut Erill, de segon cognom, Enric, el governador de Catalunya i cosí germà de Galceran.

46 ARV, Manaments i empares, 1702, L. 1, mà 4, f. 39r a 41v. 
Línies genealògiques dels Cardona més properes a la Baronia de Serra

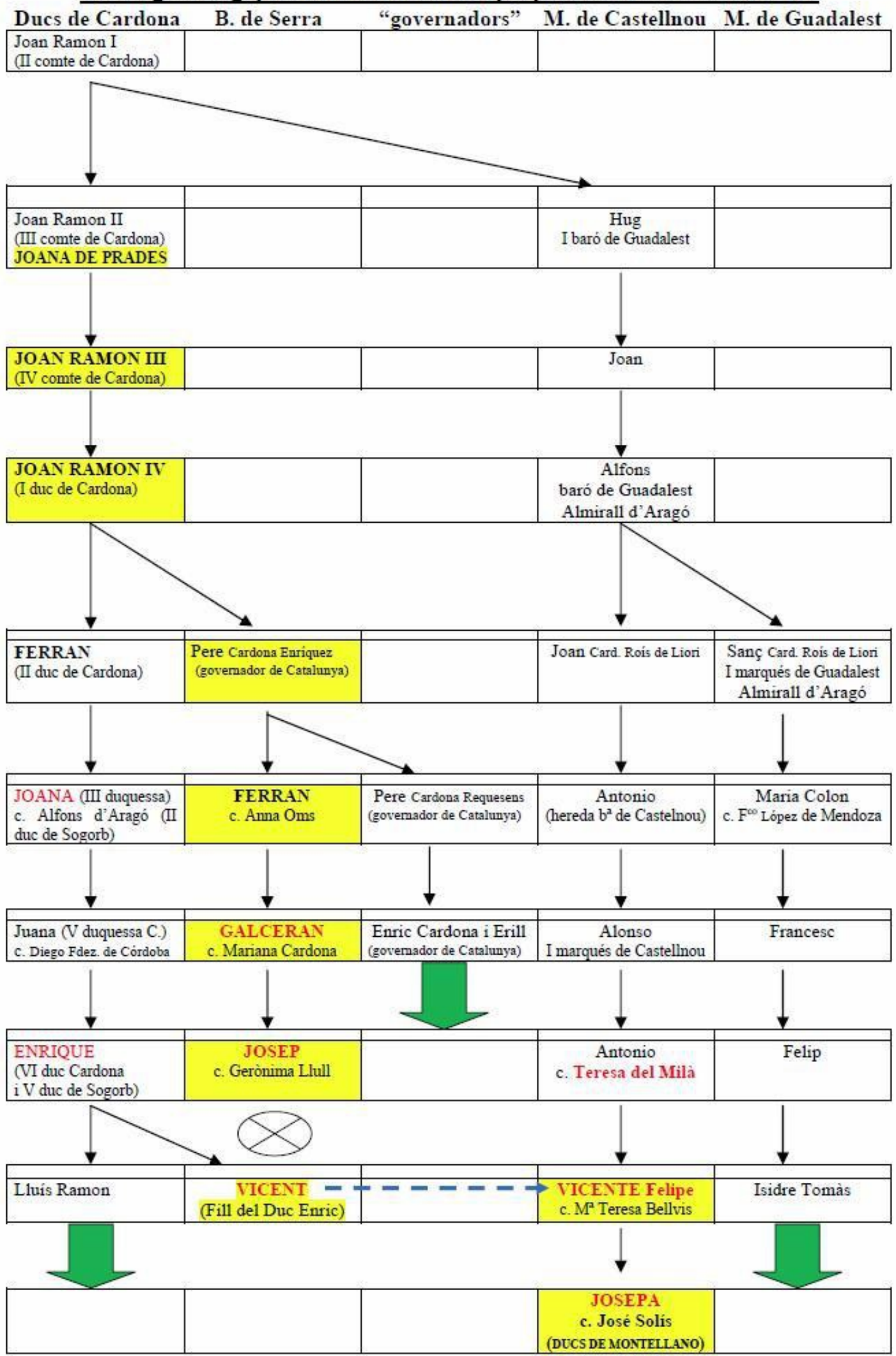

En groc indiquem els que van ser senyors de Serra i en lletra roja aquells que pledejaren.

Elaboració pròpia. 
La causa d'aquell plet era fonamentalment l'acte d'agregació que havia fet Joana de Prades en 1444 i que, inacceptablement des del punt de vista jurídic, el primer duc no havia fet respectar. Entenia que prevalia l'agregació feta per Joana de Prades i que per tant la baronia de Serra li pertanyia per ostentar ella el títol de la casa de Cardona i de Prades.

En 29 de gener de 1603 (havia transcorregut més de mig segle!) es dictava, pel magnífic Dr. Jeroni Torner, sentència en favor de Joana d'Aragó i Cardona, confirmantla com a V duquessa de Cardona. Però cinc anys desprès moria aquesta, succeint-la el seu nét Enric; i poc desprès, el mateix any, moria també el seu cosí Galceran, sent succeït aquest, com sabem, pel seu fill, Josep, que sembla tornaria a plantejar plet sobre el ducat. El nou duc, Enric d'Aragó Folch de Cardona, tenia la seua residència a Andalusia, on havia practicat com a marquès de Comares $\mathrm{i}$ on vivia amb la seua segona esposa ${ }^{47}$, Catalina Fernández de Córdoba i Figueroa, i les seues filles. Però en 1618 decidí canviar la seua residència al principat de Catalunya, i per a fer el viatge d'ell i sa família sol-licitava als diputats de la Generalitat de Catalunya les galeres de dita institución ${ }^{48}$. Des de Catalunya, el duc prengué cada vegada major presència tant en les seues possessions catalanes i valencianes com també en la cort reial, traslladant-se cada vegada amb més freqüència a Madrid. Durant els anys vint i trenta del segle XVII, el duc de Cardona tingué un paper rellevant en la vida política catalana. Al mateix temps, la seua esposa anava prenent notorietat en els ambients nobiliaris, on conegué i congenià estretament amb la comtessa de Montagut, Jerònima Lull, l'esposa de qui precisament portava pledejat llarg temps contra Enric. No obstant, en 1624 era el duc qui continuava plet, aportant una "substancial" davant la Reial Audiència de València, sobre la demanda contra Josep sobre la possessió de "las baronías de Asueva, Soneja, Pellunes, Mosquera, Sierra, Armell y Ría, situadas en el Reyno de Valencia, que se intentó a instancia de la Duquesa doña Juana de Aragón, Aqüela del Duque que oy la prosigue, contra don Galceran de Cardona, padre de don Iusepe possehedor respectvamente de dichas Baronias y Lugares". 49

Aquesta amistat de la duquessa (consort) de Cardona i la comtessa de Montagut, així com el fet de que en l'any 1627 Enric aconseguia una nova sentència confirmatòria de la de 1603, tot designant-lo a ell en el seu dret sobre la possessió del títol de Duc de

47 Havia estat casat primer, en $16 \mathrm{amb}$, però quedà prompte vidu i sense descendència. 48 Pere Molas Ribalta: La Duquesa de Cardona den 1640. Cuad. Historia Moderna, 29: 133-143. 2004. $49 \mathrm{ADM}, 115, \mathrm{n}^{\circ} 2798$, f. 612 i ss. 
Cardona, ${ }^{50}$ sembla que van determinar un acabament cordial a les demandes. Desconeixem si va haver sentència sobre la demanda del duc reclamant les dues baronies, però no podem descartar ni que aquesta fora finalment retirada, ni la possible incidència que a l'efecte poguera haver tingut l'amistat i intercessió de les esposes dels litigants. En tot cas, i des d'aquell moment, la relació entre les dues famílies va ser excel·lent, fins al punt de què, els fills del duc serien contemplats en els testaments de Josep de Cardona i de Jerònima Lull com a candidats a succeir-los en la possessió de les baronies de Serra i de Soneixa.

Al poc d'haver embarcat cap a Casale Monferrato en Josep (com he referit en el capítol segon), també el duc de Cardona era mobilitzat, però no arribaria a embarcar, en ser nomenat abans virrei de Catalunya, càrrec que va exercir en dues etapes: de $1630 \mathrm{a}$ 1632 i de 1632 a 1638. Finalment, en 1640, durant una altra missió, ara al Rosselló, el duc moriria, concretament el 22 de juliol d'aquest any. Des d'aquell moment començà per a la duquessa una etapa difícil, en la que, durant uns quants mesos, li tocà fer de diplomàtica, mediadora i interlocutora del Braç Reial davant les institucions catalanes, com ara la Generalitat i el Consell de Cent. Enmig d'aquella situació, cap a finals de 1640 vingueren a Barcelona, per tal d'estar amb sa mare i consolar-la per la falta de duc, dos dels seus fills menors: Pere Antoni (marqués de Povar) i Antoni (membre del consell de la Inquisició), els quals es convertiren en segrestats quan el 4 de gener de 1641 van ser arrestats i ingressats en les presons reials de Barcelona. Pocs dies desprès, la duquessa hagué de deixar el seu palau per la tensa situació i les amenaces que rebia, refugiant-se a sagrat en el convent de les carmelites descalces ${ }^{51}$, sota gran risc de les monges i priora d'aquell convent i de manera que aquella reclusió es convertiria també en una mena de segrest a disposició de la Generalitat i del Consell de Cent.

Mentre tant, el nou duc de Cardona (Lluís d'Aragó, el fill primogènit de la duquessa) romania com a conseller de la Cort reial, a Madrid, on, per altra banda, estaven també retinguts, des de feia prop d'un any, els ambaixadors de la Generalitat ${ }^{52}$. Açò propicià la negociació d'un intercanvi d'hostatges en el mes de maig, però la cort trigà en decidir-se i l'acord no es produiria fins al mes de novembre d'aquell any 1641. Segons

50 Sentència dictada pel magnífic Dr. Francesc Aguilò, segons l'opuscle Consultación en derecho sobre la sucesión del ducado de Cardona, imprés en Barcelna, en 1711 (http://books.google.es).

51 Molas Ribalta, Pere: La Duquesa de Cardona en 1640. Cuadernos de Historia Moderna: 29: 133-143. 2004.

52 Es tractava d'un grup format pel conseller tercer Joan Rosell, tres canonges i altres cinc cavallers, tots ells ambaixadors, ciutadans honrats de Barcelona, que en març de 1640 havien sigut enviats per la Generalitat de Catalunya a parlamentar amb sa majestat. 
els Dietaris de la Generalitat de Catalunya ${ }^{53}$, el dijous dia 8 de novembre tragueren de la presó als fills del duc, i trobant-se amb sa mare iniciaren el viatge cap a Montblanc, amb una nombrosa escolta de cavalleria i d'infanteria. La duquessa viatjava en un cotxe amb llitera i la seguien altres quatre cotxes amb les seues criades i algunes senyores de Barcelona, esposes de fugitius del bàndol reial, entre les quals es trobava Jerònima Lull, la comtessa de Montagut, que així iniciava també el seu exili personal cap a Soneixa, on esperaria l'arribada del seu marit per a fixar allí definitivament la seua residència.

Els ambaixadors que havien de ser canviats romanien des de feia dies a Tarragona. Així que la comitiva es desplaçà per Constantí fins a Tarragona, on finalment es va fer el canvi, el dia 15 de novembre de 1641. Allí, l'exèrcit de Felip IV va rebre a la duquessa Catalina amb tots els honors. Degué de ser un encontre especialment emotiu, destacant també la figura de Vicent d'Aragó, un altre dels fills menors de la duquessa, que amb 21 anys d'edat havia format part de les tropes reials que rebien en aquell moment a sa mare i els seus germans. Entenc que la comtessa de Montagut degué quedar impactada per aquell encontre, fins al punt que aquell jove, Vicent Agustí d'Aragó i Folch de Cardona, per diverses circumstàncies acabaria convertint-se, pels testaments dels comtes de Montagut, en l'hereu i posseïdor de les baronies de Serra i de Soneixa.

\subsection{NOU PLET SUCCESSORI CONTRA JOSEP FOLCH DE CARDONA, EN 1641}

Quan els conflictes successoris que heretà Josep Folch de Cardona semblaven ja un passat llunyà i els comtes de Montagut anaven a iniciar un nova etapa de tranquil·litat i retir en la seua residència de Soneixa, desprès d'haver patit una guerra i haver fugit de les convulsions que tant havien agitat la seua vida a Barcelona, un cosí d'en Josep, Vicent (Alons Vicent Milan i Cardona), li va presentar en 1641 una demanda per a la successió de les baronies de Serra i de Soneixa. El demandant era fill de la seua tia Joana (la germana de Galceran) i el seu marit Alonso del Milà.

El plet el plantejava per la particular interpretació que feia Vicent del Milà d'una clàusula que forma part del d'un document signat el 4 d'abril de 1560: les capitulacions matrimonials que signaren els avis paterns d'en Josep (Ferran Folch de Cardona i Anna Oms), per una part, i els avis materns del demandant (Maria Anna Carrós ${ }^{54}$ i Alfons del

53 Volum V (1623 a 1644), pàg. 1219 i ss.; obra dirigida per Josep M $M^{a}$ Sans i Travé. Ed. Gen. Catalunya. 1999.

54 També era vídua de Don Marc Antoni Borja i de Pallàs. 
Milà), per altra, amb motiu del casament de Joana, la filla dels primers (germana d'en Galceran) amb Alonso Milà, fill dels segons i pare del demandant. ${ }^{55}$ Concretament, en el capítol 4 d'aquestes capitulacions matrimonials, en Ferran Folch de Cardona manifestava i es comprometia al següent:

Item: es pactat, avingut, e concordat entre les dictes parts, que lo dit don Fernando de Cardona si és tingut i obligat fer, segons que amb los presents capítols fa, donació de les dites Baronies e llocs de aquelles à la dita Joana, fills, e descendents de aquella, e del dit don Alonso de Milà, aquell, o aquells que ella voldrà, o elegirà, donantli facultat, com amb los presents capítols li dona, de poder variar la dita electio tantes voltes, quantes aquella voldrà, e ordenarà.

La qual donació haja lloc tan solament en cas, que lo dit don Fernando de Cardona muira sens fills, e descendents de aquell, e de la dita dona Anna; è los fills de aquell, e de la dita dona Anna moriren sens fills, e descendents alguns, legítims, e naturals, e de legítim matrimoni nats, e procreats.

Com sabem, en morir en Ferran, va succeir-li Galceran, i a aquest en Josep, l'actual (per aquell temps) baró de Serra. El plet el planteja Vicent del Milà perquè en Josep "és ja major (tenia 57 anys) i no té fills, ni previsible és que en tinguen ell i la seua dona”. És fàcil imaginar l'efecte tan negatiu que aquest conflicte pogué causar-li al demandat, plantejant-li en vida una exigència de drets per al moment en que ell morís.

En síntesis, els parentius existents són els que mostra l'esquema següent:

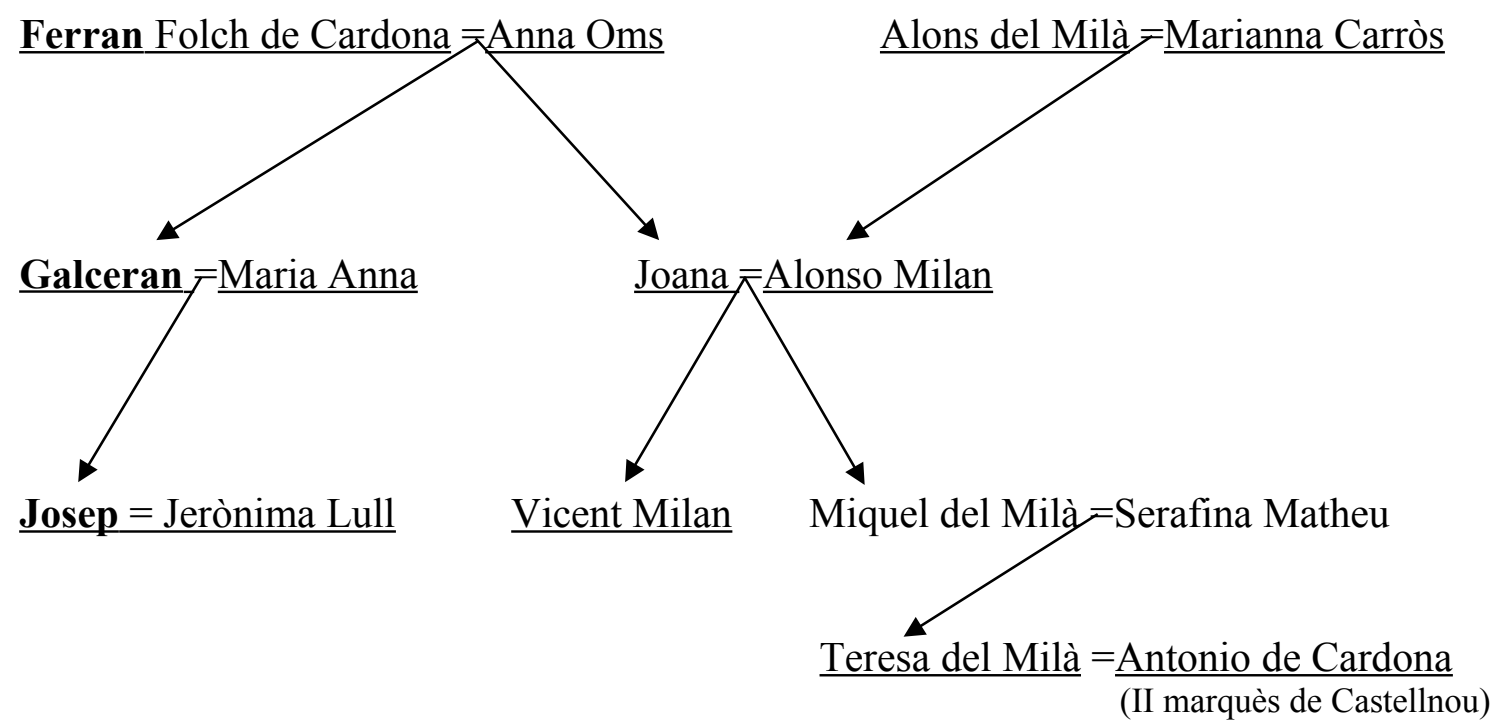

55 AHN-Montellano, leg. 1369/13 
Josep Folch de Cardona pledejà de manera ferma defensant el seu honor, com ho mostra ja en un primer memorial de data 1 de febrer de $1645^{56}$. En un segon memorial ${ }^{57}$ la defensa de Josep Folch de Cardona augmenta encara més encara l'argumentació jurídica i acabava concretant:

De manera que la duda deste pleito se reduze a ver, si por haver muerto don Fernando con hijos; y su hijo don Galceran tambien con hijo, se cumplió aquella condicion, o verdaderamente si dura, en el caso de la muerte de don Joseph sin hijos (que oy no los tiene,) la condicion de restituirse a don Vicente". I finalment remata: "Y es fuerça dezir que esta condicion, puesta en esta donacion o capitulacion espiró, particularmente quando ambos grados de llamamientos se han verificado de hijos, e hijos de hijos. ${ }^{58}$

En aquest punt les coses, resulta interessant observar que els Milà, noble branca de cavallers catalans que primer s'emparentaren amb els Borja (Joan del Milà es casà amb Caterina de Borja, germana de Calixte III), s'emparentaren també, diverses vegades, amb els Cardona, com són els casos de Coloma del Milà i Cardona, a qui va concedir el rei Felip III el títol de Marquesa d'Albaida en 1605; i d'Alfons de Cardona Borja i Milà d'Aragó, que seria nomenat en 1639 marqués de Castellnou. Tanmateix, el matrimoni amb Joana de Cardona, la germana d'en Galceran, li suposava a la nissaga d'Alfons del Milà clars beneficis potencials, com eren, a més dels drets per les baronies de Serra i de Soneixa, certs drets sobre la casa i ducat de Cardona. D'aquest matrimoni nasqueren el primogènit, Miquel, i el ara litigant, Alons Vicent del Milà i Cardona, que fou cavaller de l'hàbit de Calatrava.

El plet iniciat contra Josep Folch de Cardona no em consta que tinguera prompta sentència, sinó que va acabar, o bé quedà en suspens, de sobte, degut primer a la mort de Josep Folch de Cardona (desembre de 1645) i, poc desprès de la del demandant, que moria també sense fills. Aquest precedent, però, seria només l'inici d'una reivindicació que continuaria pocs anys desprès amb la neboda del demandant (filla de Miquel), Teresa del Milà (senyora de Massalavés), tan prompte com va morir la comtessa de Montagut.

56 BV, Gregori Mayans, 722(10). 


\subsection{TESTAMENTS DE JOSEP FOLCH DE CARDONA I DE JERÒNIMA LULL}

En el testament que va fer en Josep Folch de Cardona el dia de Nadal de 1645, la vespra de la seua mort, trobant-se greument malalt a bord de la galera Santa Àgueda, designava com a hereva universal de tots els seus bens a la seua esposa, Jerònima Lull i li donava plena facultat per a que "ella puga nomenar com a successors dels llocs de Serra, Soneixa, Ria i Assuévar, en el Regne de València, amb tot allò pertanyent a dits llocs, tant de jurisdicció com de privilegis i rendes, a la persona que bé li pareixés a la senyora comtessa, sa muller". El testament original està redactat en italià ${ }^{59}$ i el va publicar Iquino Parra (1982: 77) traduït per ell al castellà.

Només en el cas de que la seua dona faltés sense haver testat, preveia i designava també altres persones com a següents successors dels seus bens, drets i títols. Així, en aquest supòsit de que la comtessa arribara a morir sense haver testat ni nomenat altre successor, designa com a hereva legítima dels dits llocs a la senyora comtessa donya Catalina Pons de León, neboda seua, i per mort d'aquesta a don Manuel Pons de León, nebot seu, i si dits nebots moriren sense hereus, en tal cas vol que siga hereu don Pere d'Aragó, nebot seu.

Però, a més de les seues pròpies possessions (les baronies de Serra i Soneixa) contempla també els drets que té sobre la casa de Cardona (el ducat) i vol que els herete directament la seua dóna, la comtessa, i en cas de que aquesta morís sense haver nomenat a cap successor en aquests drets, vol que succeeixen, en aquest ordre, els següents: Pere d'Aragó i Cardona, i per mort d'aquest Antoni d'Aragó i Cardona, i que per manca d'aquests dos que entrés en aquests drets Vicent d'Aragó i Cardona, i per mort d'aquest últim Pasqual d'Aragó i Cardona.

Per altra part, no deixa de ser sorprenent que, entre la resta de beneficiaris i disposicions (liquidació de deutes, pensions, atencions, donatius i almoines per a obres pies, etc.) li llegara a Teresa de Milà i de Mateu, esposa d'Antoni de Cardona (el marquès de Castellnou), 3.000 escuts que se li havien de donar desprès de la mort de la comtessa, sa muller. Tanmateix, manà que se li donaren, desprès de la mort de la comtessa, 1.000 ducats, per una sola vegada, a Vicent del Milà i Cardona. Recordem que es tracta dels dos germans, cosins seus, que li disputaven la successió de les baronies de Serra i Soneixa. Així, sorprèn que en el testament els deixa fora, triant altres hereus, però, en canvi, els llega unes quantitats en diners que no es podran satisfer fins a desprès de la

59 ARV, Manaments i empares, any 1646, t. 4, m. 49, f. 33. També: AHN-FN, leg. 1167/18 (i 22 a 32) 
mort de la comtessa de Montagut. Queda palès, també, que cap a Teresa mantenia un poc més de simpatia o tolerància que no cap a Vicent del Milà.

Com a marmessors, per a que facen complir el seu testament, designa al duc i la duquessa d'Arcos, a Vicent d'Aragó i Cardona (no deixa de ser curiós: per què Vicent i no els seus germans?) i a Catalina Pons de León.

Catalina i Manuel Pons de León eren nebots polítics d'en Josep, nebots carnals segons de la comtessa; d'ells tornaré a parlar més avall. Observem abans que els diversos "Aragó i Cardona" que cita són tots ells germans de Lluís, el VII duc de Cardona (i VI de Sogorb), i fills dels difunts Enric de Cardona i Catalina Fernández de Còrdova i Figueroa. Per tant, si la comtessa de Montagut no disposava altra cosa, l'herència possessòria de les baronies de Serra i Soneixa podria passar, finalment, als successors directes dels qui havien estat tan de temps litigant contra Josep, son pare i el seu avi. Abans, no obstant, havien de recaure, si vius foren, en un dels germans Pons de Lleó, però la tercera opció era ja Pere d'Aragó i Cardona, "candidat" a poder-se convertir en VIII duc de Cardona, si bé, aquest Pere optà pel Braç Reial, on fou president del reial consell d'Aragó; capità general de la cavalleria de Catalunya, virrei de Nàpols i virrei d'Aragó.

Pel que fa al dret sobre el ducat de Cardona, Josep venia a posar certa pau, designant com a successors, en el remot cas de que alguna vegada (cosa ja molt improbable) li fora adjudicat a la seua línia genealògica aquest dret, el cedia als germans menors de l'actual duc. Recordem que Pere (1611-1690) i Antoni (1616-1650) eren els dos germans que en 1641 van ser permutats a Tarragona, junt a la duquessa Catalina, pels ambaixadores de la Generalitat Catalana. I Vicent (1620-1676), germà menor d'aquests, va ser també protagonista d'aquell fet. Tots tres eren cavallers de l'orde d'Alcàntera. En quan a Pasqual (1626-1677), el menor dels germans, va prendre hàbit religiós i arribà a ser Cardenal, a més d'Arquebisbe de Toledo ${ }^{60}$.

No obstant, desprès de la mort d'en Josep i tal com havia disposat, Jerònima va exercir d'única senyora de les baronies de Serra i Soneixa, a més del seu títol de comtessa de Montagut, fins a la seua mort, ocorreguda en octubre de 1649. Però en el seu testament, ${ }^{61}$ dictat dies abans de morir, davant d'Antoni Masó, notari de Sogorb, deixà molt clara la seua voluntat successòria, tant de les dues baronies com de les altres seues possessions i títol de comtessa.

60 Esténaga, 1929: Pascual d Aragón; Arellano García: Limpieza de sangre del Cardenal Aragón. 61 ARV, Manaments i empares, any 1705, t. 2, m. 4ª f. 3 i ss.; AHN-FN, leg. 1339/8. 
Jerònima Lull va nomenar per marmessors, per aquest ordre, als següents: Vicent d'Aragó i Cardona, Bernardo Pons i Catalina Mendoza, (comtes de Robles), Miguel Saler i sa muller Jerònima, Pedro Caspe i Francisco Villagrasa, canònic de Sogorb. I nomena, per a les seus diverses possessions (les que venien del seu marit més les seues pròpies) diferents hereus.

En primer lloc, nomena i fa hereu de les baronies de Soneixa i Serra a Vicent d'Aragó i Cardona, però amb pacte vincle i condició de que si aquest morira sense fills legítims i naturals, de legítim i carnal matrimoni, nascuts, batejats i procreats, i tanmateix, si els seus fills i descendents no els tingueren legítims i naturals, nascuts de carnal matrimoni, en tal cas, vol i és sa voluntat que succeeixa en elles, enterament i sense detracció alguna de legítima falcídia trebel·liànica, ni cap altre dret, donya Teresa Milà, si viva fos, i si no els seus fills i descendents, mantenint, entre ells, l'ordre de primogenitura, precedint sempre els homes a les dones; i amb pacte també de que dit senyor en Vicent d'Aragó ni la dita senyora, na Teresa, ni els fills i descendents dels dos, puguen alienar, vendre ni empènyer dites baronies, i que "tinguen obligació de sustentar la casa de Soneixa en que al present visc per haver-me emparat en ella quan vaig vindre de Catalunya".

La comtessa va decidir que les baronies havien de quedar en mans dels Cardona, i no en mans dels nebots d'ella, com en principi havia donat opció en testament el seu marit. La designació dels hereus és molt més clara i concreta en aquest testament. En primer lloc, les seus baronies del regne de València (Serra i Soneixa) eren per a Vicent d'Aragó i Cardona, un dels marmessors en el testament de en Josep i ara el principal marmessor del testament de Jerònima. A més d'una possible predilecció per aquest i no cap altre dels germans Aragó i Cardona, supose que podria haver sospesat la comtessa, per a la seua decisió, que Antoni ${ }^{62}$ i Pasqual havien fet carrera eclesiàstica i Pere ocupava càrrecs reials de gran responsabilitat fora del Regne de València.

No obstant, també preveu que, si Vicent d'Aragó morís sense descendents (cosa que realment va ocórrer, molts anys desprès) hauria d'haver-hi un altre hereu alternatiu, també Cardona, designat per Jerònima Lull. I així nomena, com a tercer "aspirant" a posseir les baronies de Serra i Soneixa, a Vicent de Cardona i Milà, el fill de Teresa del Milà i del marquès de Castellnou, son marit. En aquest cas, l'herència seria de transició, a través de Teresa, si viva fóra encara, però amb certes condicions o pactes encaminats a 62 Antoni d'Aragó arribà a ser nomenat Cardenal diàcon pel papa Inocenci III, però moriria molt poc desprès, el 8 d'octubre de 1650, amb només 34 anys d'edat. 
preservar tant la propietat jurisdiccional com fins i tot la casa o palau residencial de Soneixa, on la comtessa visqué la darrera etapa de la seua vida.

Pel que fa als 1000 ducats que en Josep designà per a Vicent del Milà "desprès de la mort de la comtessa" ja no tenien sentit, en haver mort aquest destinatari, i respecte als 3000 escuts per a Teresa del Milà quedava ara tot més clar quan Jerònima disposa que “els 3000 ducats que Josep deixà a Teresa del Milà, esposa d'Antoni Cardona, té obligació de pagar-li'ls l'hereu de les baronies de Soneja, Assuévar, Serra i Ria". Desconec si aquest pagament es va lliurar finalment per Vicent d'Aragó, quan prengué possessió de les baronies en successió i herència de Jerònima Lull.

Està clar que per a Jerònim Lull, Teresa del Milà era més una amiga i familiar (neboda) que no una contrincant -com va ser-ho el seu oncle- per l'herència de les baronies d'en Josep. De fet, és a ella (i a través d'ella al seu fill Vicent de Cardona i Milà) a qui li deixa les baronies, sens dubte preveient que Vicent d'Aragó, el primer adjudicatari, era o havia sigut religiós, i cabia la possibilitat de que no tinguera descendents directes. A més a més, li llega a Teresa dues de les seues joies més valuoses: un anell gran de robins fins i una -la que ella triara- de les dues comptes grans d'ambre guarnit d'or que tenia Jerònima; l'altra compta seria per a Pedro Caspe. Una altra valuosa joia que tenia era la famosa "brotxa de diamants" que li havia regalat el rei Felip IV durant una recepció, estant a Barcelona. Aquesta li la deixa a sa germana, Isabel de Cabrera

També recorre a Vicent d'Aragó per a que es faça càrrec d'un parell de deutes, com són 1000 ducats que li deu al Duc d'Arcs, que li'ls havien prestat, i l'encàrrec de que als Cardona (ducs) “se'ls hi pague de seguida allò que se'ls degués, que creu que són 170 lliures, de les quals ja estan pagades unes 107 més allò que els haguera pagat Pedro Caspe". A canvi li llega també a Vicent d'Aragó, la meitat de tot allò que li deuen en les illes de Mallorca i de Serdenya, sent l'altra meitat per a "l'hereu que baix dirà" i que seria la persona que heretés el títol del comtat de Montagut. I en tal sentit disposa que "en tots els demés drets, deutes, accions i bens" deixa per hereua a Catalina Salvia i Pons, filla de Miquel Salvia i Villagomera (sic.) i de Jerònima Pons i Turell (cosina de Jerònima), amb pacte de que, si morís sense fills legítims, li succeira Bernat Mendoza i Pons, fill de Bernat Pons i Turell (cosí de Jerònima) i de Caterina de Mendoza (comtes 
de Robles)";63 i que si aquests moriren sense fills, els hi succeira Isabel de Cabrera i Pons (germana de la testant) si viva fos i si no els seus fills.

Tant Josep com Jerònima coincidiren en que l'hereva principal (en primera instància) del comtat de Montagut havia de ser la seua neboda Caterina Salvà i Pons (Caterina Pons de León, segons la cita el testament d'en Josep). Aquesta era filla, com he avançat, de Miquel Salvà i Vallgornera i de Jerònima Pons i Turell (cosina de na Jerònima). El pare de Caterina seria nomenat pel rei Carles II, en 1682, marquès de Vilanant, però morí un any desprès, succeint-lo la seua filla Caterina, que era ja comtessa de Montagut.

El segon candidat triat per Jerònima Lull també es convertiria en comte de Montagut, no per substitució de Caterina, sinó pel fet d'haver-se casat amb ella. Efectivament, el fill dels comtes de Robles, "Bernat Mendoza i Pons" segons el testament de a Jerònima, el trobarem generalment com a marit de Caterina i comte de Robres, amb el nom d'Agustí-Bernat López de Mendoza i Pérez de Pomar (ometent de vegades el Pons patern). Caterina i Bernat eren cosins germans, la qual cosa podria explicar els canvis i omissió que feien en l'ordre dels seus cognoms.

\subsection{VICENT D'ARAGÓ I CARDONA, SENYOR DE LA BARONIA DE SERRA ENTRE 1650 I 1676}

Finalment, el nou senyor de les baronies de Serra i Soneixa, en haver mort la comtessa de Montagut, serà Vicent-Agustí d'Aragó i Cardona, el setè dels fills d'Enric (VI duc de Cardona) i Caterina Fernàndez de Còrdova (la qual moriria a Saragossa en 1646, als 57 anys d'edat).

Vicent (Vicent-Agustí) va nàixer a Sogorb el 30 d'agost de 1620. Va ser cavaller de l'orde d'Alcàntera, canònic de Toledo, ardiaca ("arcedià") de Calatrava i, des del 1650 senyor de les baronies de Serra i de Soneixa, tot prenent possessió d'elles aquell any.

Tampoc la vida de Vicent amb la possessió de Serra i de Soneixa estigué exempta de plets. A penes una setmana desprès de morir Jerònima Lull, Teresa del Milà presentava una súplica judicial, concretament el 27 d'octubre de 1649, per a la possessió de les baronies de Serra i de Soneixa, atenent, novament, al capítol quart de les

63 el comtat de Robres va ser concedit en 1646, pel rei Felip IV a Bernat de Pons i Turell, succeint-lo el seu fill Bernat-Agustí Pons i López de Mendoza. 
capitulacions matrimonials atorgades pel seu avi Ferran en favor de sa mare, Joana i son pare, Alons del Milà.

Tres dies més tard (30 d'octubre) serà Vicente Felipe de Cardona i Milà (II marquès de Pons, des de 1642), fill de Teresa i del seu marit Antoni de Cardona (marqués de Castellnou) qui sol·licitarà davant l'Audiència que li reconega aquest dret successori per tal de poder prendre la possessió de les dues baronies.

Cal tenir en compte que Teresa del Milà era senyora de la baronia de Massalavés (Parranchet i Massalavés), per herència paterna, i a més a més esposa d'Antoni Folch de Cardona, el II marquès de Castellnou. De tal manera que el seu fill, Vicent, era el primogènit $\mathrm{i}$ ara mateix l'hereu natural d'aquests títols.

L'esmentada petició xocarà frontalment amb la designació de Vicent d'Aragó i Cardona com a hereu testamentari de les dues baronies, tal com havien designat els seus últims posseïdors. Aquest serà per tant un conflicte de successió entre dos Vicents: l'hereu testamentari, Vicent-Agustí d'Aragó i Cardona (un germà menor del duc de Cardona i Sogorb) i el demandant, Vicent-Felip de Cardona i del Milà qui arribarà a ser, amb el temps, marquès de Castellnou.

El 29 de novembre i a petició de Vicent d'Aragó, es dicta una Reial Provisió encaminada a resoldre el conflicte sobre aquesta possessió. Teresa del Milà suplica i, el 15 de gener de 1650 és cridada per a que presente al·legacions. El 12 de febrer presenta súplica de provisió i, encara, el 30 de març, Teresa suplica per a que Vicent d'Aragó i Cardona siga interrogat. La súplica de la marquesa de Castellnou serà denegada.

Per fi, el 15 de juny de 1650, és dictada per la Reial Audiència una Regia sententia favorable a Vicent d'Aragó i Cardona en el juí seguit sobre la possessió de la baronia de Serra, contra Teresa del Milà i Cardona. ${ }^{64}$

El 4 de juliol següent, Vicent d'Aragó i Cardona envia, a través del seu procurador, Pau Visedo, un agutzil per a prendre possessió de "les quatre baronies". Des d'aquest moment és cada vagada més freqüent comprovar que els documents no es refereixen només a les dues baronies i els seus llocs, sinó que tracten els llocs, a sovint, com si cadascun d'ell fora una baronia.

La possessió de Serra i Ria, per les persones expressament designades pel seu nou senyor, tindria lloc el dia 9 de juliol de 1650, mentre un dia abans havia tingut lloc la presa de possessió de Soneixa i Assuévar.

64 Biblioteca del Col·legi del Corpus Christi: GM/537 (62). 
Vicent d'Aragó i Cardona va ser el nou senyor de les dues baronies fins a la seua mort, ocorreguda a Madrid, on residia habitualment, el dia 29 de maig de 1676 (abans de complir el 56 anys). Va morir sense fills i les seues restes reposen en el reial monestir de Santa Maria de Poblet.

\subsection{ELS MARQUESOS DE CASTELLNOU SENYORS DE SERRA (TERESA DEL MILÀ I EL SEU FILL, VICENT FOLCH DE CARDONA) \\ De la mateixa manera que va sol·licitar Teresa del Milà, en 1649, la possessió de} les baronies de Serra i de Soneixa només produir-se la mort de Jerònima Lull (en 1649), tornava a fer-ho ara novament, 26 anys desprès, concretament el dia 8 de juny de 1676, pràcticament una setmana desprès de morir Vicent d'Aragó i de Cardona. La petició tindria ara major fonament, doncs, pel fet d'haver mort en Vicent sense descendència, era ella la que es convertia ara en hereva de les baronies, en virtut de la clàusula de pacte i vincle estipulada per na Jerònima Lull en el seu testament. De la mateixa manera, si ella haguera mort, el següent hereu testamentari havia de ser el seu fill, Vicent Felip de Cardona i Milà.

Teresa del Milà va ser, de fet, la nova senyora de les baronies de Serra i de Soneixa fins a la seua mort, en $1680^{65}$. Abans ja era senyora de la baronia de Massalavés, que heretà de son pare, Miquel del Milà i Cardona, nebot aquest (per via materna) de Galceran, l'antic senyor de Serra i pare d'en Josep. A més d'això era la marquesa de Castellnou per ser la dona d'Antoni Folch de Cardona i Borja, el segon d'aquest títol.

Però aquesta tan llargament esperada i desitjada possessió tampoc va ser tranquil·la ni fàcil, perquè en 1677 va presentar una demanda contra ells, contra Teresa del Milà i el seu fill, la X duquessa de Cardona, Caterina Antònia d'Aragó i Folch de Cardona (16351696), pel dret a la successió de les baronies de Serra i de Ria. La demandant, a més de duquessa de Cardona i de Sogorb ho era també de Medinaceli. Reclamava les baronies atenent, entre altres raons històriques, a que ella era la descendent familiar més directa de l'últim posseïdor, Vicent d'Aragó i Cardona. En 26 de maig de 1679, per a la determinació d'aquest plet, el consell d'Aragó nomenava jutges oficials a don Alonso d'Olea i a don Joseph de Salamanca ${ }^{66}$, en substitució de Marcos Roig, anterior jutge de la

65 L'Audiència de València i el Consell d'Aragó declararen a Teresa del Milà posseïdora de les dues baronies en virtut de les clàusules del testament de Jerònima Lull. M. A. Rodríguez (2012).

66 ACA, consejo de Aragón, lg. 0576, núm. 034. 
causa a qui la duquessa havia acusat de possible imparcialitat. Aquesta causa quedà parcialment interrompuda per la mort de la marquesa, però continuà en ella, encara durant molts anys, el seu fill primogènit.

Vicent Felip Folch de Cardona i Milà, nascut el 28 de març de 1656, heretà les baronies de Serra i Soneixa amb 24 anys, per la mort de sa mare. Va ser III marquès de Pons i, desprès, pe la mort d son pare, en març de 1694, es convertí també en III marqués de Castellnou. Es va casar amb Teresa Bellvís de Montcada, amb qui tingué tres filles: Teresa, Josefa i Sinforossa. Josepa seria la successora en tots els títols i possessions.

Tot el temps que va ser senyor de les baronies, fins que va morir el 24 de març de 1704, Vicent el passà pledejant per aquestes possessions i, més tard també per altres a les que va aspirar, com eren les pertanyents al marquesat de Guadalest, a partir de que, en 1699 morira sense descendència el seu titular Isidre Tomàs Folch de Cardona. Però en aquest plet van ser prou més les parts en litigi, com el marquès d'Ariza (Juan Antonio de Palafox), el marquès de la Casta (Juan Pardo de la Casta) i el futur "Príncep de Cardona" (Josep de Cardona i Erill), de qui tornaré a parlar més avall.

El mateix any 1699, en que moria el marquès de Guadalest, Vicent-Felip Folch de Cardona, Milà, Borja i Alagón, marquès de Castellnovo, baró de Massalavés, Serra i Soneixa... Presentava al rei un memorial ${ }^{67}$ sol·licitant ser nomenat Almirall d'Aragó, dignitat que, exposava, havien ostentat "tots els barons Cardona, sent ell l'únic que queda de dita casa". El cert és que aquest era un títol exclusiu d'homes i, per tant, no haguera pogut tindre continuïtat a través dels seues descendents, en ser totes dones.

\subsection{NOU CONFLICTE INICIAT EN 1711 PEL COMTE DE CARDONA DEL SACRE IMPERI.}

Josep Folch de Cardona Ruiz de Liori, Erill i Borja (1651-1729), important personatge austracista, a qui Carmen Pérez Aparicio (2002) va dedicar un interessant treball, va ser virrei de València, en 1706, i per concessió de Carles d'Àustria rebé, entre d'altres, els títols d'Almirall d'Aragó (1707), Gran d'Espanya (1709), Príncep de Cardona (1717) i Gran d'Espanya de 1a classe (1722).

67 Aquesta petició ve referida en el memorial citat en el Indice de la Colección de don Luis de Salazar y Castro (llibre publicat el 1957, com a volum XIX de Obras Genealógicas. Real Academia de la Historia; format en Baltasar Cuarterao i per Antonio de Vargas-Zúñiga). 
A principis de 1706, desprès de la mort del seu nebot Vicent Felip Folch de Cardona (marqués de Castellnou i baró de Massalavés, Serra i Soneixa) el virrei Josep Folch de Cardona reclamà per a si mateix el títol de marqués de Castellnou, perquè el seu nebot havia mort sense descendència masculina. Poc abans -com ja he comentat- també s'havia personat en el plet per la successió del marquesat de Guadalest, on ja estaven en litigi alguns parents seus (entre ells el seu ara difunt nebot) des de la mort sense fills, en 1699, del VII marqués, Isidre Tomàs Folch de Cardona. D’aquesta manera, i com a virrei de València també s'autotitulava (malgrat estar sub iudice i no haver recaigut encara cap sentència) com a marqués de Guadalest, títol que finalment, la justícia borbònica adjudicà al marquès d'Ariza (Juan Antonio de Palafox Zuñiga y Folch de Cardona), segons reial cèdula de 20 de juny de 1707, en la qual també se li concedia a aquest marquès el títol d'Almirall d'Aragó, dins el domini borbònic (no així en l'austriacista, en que aquest mateix títol li va ser concedit a Josep Folch de Cardona a finals de 1707) ${ }^{68}$.

També va reclamar l'Almirall austracista d'Aragó, en 1711, l'adjudicació del Ducat de Cardona, segons sabem pel memorial de 118 pàgines que va editar amb gran luxe de detall sobre els antecedents familiars nobiliaris. ${ }^{69} \mathrm{Cal}$ dir que en aquest pretensió no inclou, en principi, les baronies de Serra i Soneixa, sinó que es centra en els títols que aleshores anaven més directament lligats al del Ducat.

Anys desprès, Josep Folch de Cardona seria també reconegut per la part borbònica com a Gran d'Espanya de 1a classe, mitjançant Reial Cèdula de 28 d'octubre de $1727 .{ }^{70}$ Això seria, evidentment, desprès d'haver-se signat el tractat de Viena, entre l'emperador Carles VI i el rei Felip V (el 30 d'abril de 1725), que suposà el reconeixement de la corona borbònica d'Espanya i establia amnistia i perdó per als seguidors de l'un i l'altre bàndol, com també el reconeixement dels béns, drets i títols anteriors al conflicte. Com que en Josep no tingué descendents per línia directa, els conflictes successoris dalt esmentats no prosseguirien després de la seua mort.

\subsection{ELS DUCS DE MONTELLANO, SENYORS DE LA BARONIA DE SERRA}

L'hereva i successora de Vicent Felip, tant en els marquesats de Castellnou i Pons com en les baronies de Massalavés, Soneixa i Serra, serà la seua filla Josepa Folch de

68 Perez Aparicio (2002), pàg. 441.

69 CONSVLTACION en derecho, sobre la sucesión del ducado de Cardona, marquesado de Villamur y demás estados unidos, y adyacentes. Obra impresa a Barcelona per Rafael Figuerò, amb llicència del Rei. Any 1711. (exemplar de la Biblioteca Central de Barcelona; digitalizat en http://books.google.com). 70 Carmen Pérez Aparicio (2002), pàg. 447. 
Cardona i Bellvís. Però, a més dels títols i la possessió dels llocs "heretaria" també els conflictes que suportava son difunt pare, particularment el que mantenia per la possessió de les baronies de Serra i Soneixa amb la duquessa de Cardona i Sogorb (Catalina d'Aragó i Cardona, esposa del duc de Medinaceli), conflicte que va continuar després del 1696 (a la mort de la duquessa) el seu fill i successor, Luis Francisco de la Cerda (ara triple duc: Cardona, Sogorb i Medinaceli).

En aquest plet, els ducs insistien no solament en que Serra i Soneixa havien sigut possessions pròpies de l'oncle de la duquessa (de qui ella es considerava hereva), sinó que insistirien novament en un argument que encara no havia sigut suficientment aclarit $\mathrm{i}$ sentenciat, com era el fet de l'agregació que en 1444 havia fet Joana de Cardona de les baronies d'Entença, Serra i Soneixa al comtat de Prades, del qual comtat era ella la titular. La rèplica argumental dels marquesos de Castellnou era sempre la mateixa: la inacceptable donació particular que el I duc de Cardona havia fet al seu fill Pere (secundogènit) com a bé lliure i desvinculat dels altres títols.

Josepa Folch de Cardona i Bellvís va nàixer a València el 26 de maig del 1682 i tindria per tant uns 22 anys quan, per la mort de son pare, hagué de fer-se càrrec de l'herència com a IV marquesa de Castellnou i IV marquesa de Pons. ${ }^{71}$ Però, el seu casament, aquell mateix any 1704, amb Josep Ignasi de Solís i Gante (Gand-Vilain), comte de Salduenya i futur duc de Montellano (es convertiria en el III duc d'aquest títol per la mort de son pare, en 1717) facilitaria enormement la seua capacitat de litigar.

Pérez Aparicio (1998) fa referència a la complicada situació que de vegades havien de suportar els vassalls de les baronies de Serra i de Soneixa davant la dualitat i confrontament que per la seua possessió mantenien en aquelles últimes dècades del segle XVII les dues parts en litigi. En la pràctica eren els marquesos de Castellnou els posseïdors habituals i efectius de la baronia de Serra, però les protestes i peticions a l'Audiència per part dels ducs no van ser poques. De fet, a pesar de les repetides inhibicions ordenades des de 1697 per la Reial Audiència al marqués de Castellnou i als vassalls, sembla que aquests no dubtaren en permetre la possessió a Josepa de Cardona en 1704, només morir son pare. Davant aquesta desobediència, el procurador fiscal de Sa Majestat i el procurador del duc sol·licitaren la nul·litat d'aquesta possessió i el càstig per als actors. ${ }^{72}$

71 Cfr. AHN-FN, lg. 1419/8: "Autos relatius a la possessió de les baronies de Massalavés, Prada i Paranchez, en favor de Josepa de Cardona i Bellvís, primogènita i successora del marquès de Castellnou". 
Desprès d'haver presentat Josep de Solís i la seua esposa Josepa de Cardona, com a marquesos de Castellnou i de Pons, un memorial sobre la possessió de "les baronies d' Assuévar, Soneixa i d'altres" en el regne de València ${ }^{73}$, també presentava una rèplica el duc de Medinaceli. ${ }^{74}$

Novament, en juny del 1711, els marquesos de Castellnou presentaven un escrit d'al·legacions davant el consell de Castella demanant que fóra notificat sobre l'estat del plet el nou representant de la part contrària, que en aquell moment era el jove Nicolau Fernández de Còrdova, successor en els ducats de son pare, mort aquell mateix any. Per fi, el Consell de Castella va emetre sentència el 2 de juny del 1712 a favor dels marquesos de Castellnou, als qui manava que prengueren possessió de les baronies. El nou duc de Medinaceli presentà recurs contra la sentència, i això forcà a que el dia 28 de març de 1713 es dictara nova sentència, ara de revista però confirmatòria de l'anterior.

D’aquesta manera, Josepa de Cardona, prengué possessió els dies 19, 20 i 21 d'abril de 1713, a través del seu apoderat, Josep Sánchez i Olivar, dels llocs de Soneixa, Assuévar, Serra i Ria (aquest totalment despoblat); a més va preguntar pel 1loc d'Armell, en la baronia de Serra, sense que ningú del presents vassall poguera donar-li notícia ni raó d'aquell lloc que ni havien conegut ni sabien on hauria estat ubicat. ${ }^{75}$

El 4 de febrer de 1716, el Reial i Suprem Consell de Castella va adjudicar a Josepa Folch de Cardona, per reial carta executòria ${ }^{76}$, la possessió de "les baronies d'Assuévar, Soneixa, Serra, Pellunes, Mosquera, Armell i Ria”. No obstant, la marquesa moriria sobtadament aquell mateix any (amb només 34 anys d'edat), mentre que el duc Nicolau Fernández de Còrdova continuaria pledejant encara molts anys més. D’entrada, ara al·legava judici contradictori, tot demanant un grau de vista i revista ${ }^{77}$.

Josepa deixava tres fills: Alfons (l’hereu dels títols nobiliaris i que va ser també virrei de Navarra), Francesc (arquebisbe de Sevilla) i Josep (virrei de Nueva Granada). El

72 Pérez Aparicio (1998, p. 261), referint les següents fonts: ARV, Real, 1.302, f. 144v $-145 \mathrm{r}^{\mathrm{o}}$; 1303 , f. $220 \mathrm{r}^{\mathrm{o}}-221 \mathrm{v}^{\mathrm{o}} ; 1304$, f. $47 \mathrm{r}^{\mathrm{o}}-48 \mathrm{v}^{\mathrm{o}} ; 1306$, f. $130 \mathrm{v}^{\mathrm{o}}-132 \mathrm{r}^{\mathrm{o}} ; 140 \mathrm{r}^{\mathrm{o}}-140 \mathrm{v}^{\mathrm{o}} ; 246 \mathrm{r}^{\mathrm{o}}-248 \mathrm{v}^{\mathrm{o}} ; 1307,42 \mathrm{r}^{\mathrm{o}}-44 \mathrm{v}^{\mathrm{o}} ; 269 \mathrm{r}^{\mathrm{o}}$ i v ; 1308 , f. $12 \mathrm{r}^{\mathrm{o}}-13 \mathrm{v}^{\mathrm{o}}$; 1310 , f. $45 \mathrm{r}^{\mathrm{o}}-46 \mathrm{r}^{\mathrm{o}}$.

73 AHN-FN, lg. 2323/10.

74 Per veure l'argumentació de la part contrària hi ha encara una adició al memorial ajustat, que havia presentat pel mateix temps el duc de Medinaceli, Lluís Francesc de la Cerda, poc abans de morir (AHNFN, lg.1569/7).

75 ARV, Escrivanies de cambra, 1713, exp. 89; document també citat per Rodríguez (2012) i per Ferrer Taberner (1996): El lugar de Armell, un despoblado mudéjar en el señorio de Serra. També en AHN-FN, c. $1648 / 2$.

76 AHN-FN. C. 1167/1 a 6: executòries del plet mantingut pel duc de Feria i el comte de Salduenya per la propietat de les baronies de Serra, Soneixa,,, i presa de possessió d'aquestes per dit comte.

77 AHN-FN, caixa 263, doc. 38.; referit també per Rodríguez (2012). 
comte de Salduenya, Josep Ignasi de Solís i Gante es convertia, al poc d'enviduar, en III duc de Montellano, fent-se càrrec, igualment, d'administrar tots els títols i llocs de la difunta marquesa. Va ser un home culte i cultivat, com ho demostra el fet de ser en 1713 un dels acadèmics fundadors de la Reial Acadèmia Espanyola de la Llengua" (ocupant la butaca lletra J). Morí el 1765, amb 82 anys d'edat (havia nascut el 19 d'abril de 1683), i va ser succeït pel seu fill primogènit, Alons Vicent.

Respecte al plet que mantenia la difunta marquesa (iniciat pel seu pare en 1699) per la successió en el marquesat de Guadalest, s'havien pronunciat el 1704 i el 1712 sengles sentències a favor del marquès d'Ariza. Nogensmenys, el 1737 es tornà a dictar nova sentència, ara en favor del duc de Montellano (i marquès de Castellnou per mort de la marquesa). Però aquesta sentència va ser recorreguda pel principal afectat, que finalment la guanyaria en sentència de revista ${ }^{78}$. Aquest segon plet sembla que hauria sigut reprès per la presentació en la causa de la il·lustre senyora Maria del Patrocinio Aremberg, Princesa de Brabançon i vídua de qui va ser marquès de Guadalest, Isidre Tomàs Ruiz de Liori Cardona $(+1699)$. I la causa sembla que tindria una clara relació amb el fet de que aquell any 1737 contragueren matrimoni Maria Augusta Wignacourt, filla d'aquesta il·lustre senyora (i filla del seu tercer marit: Henry August de Wignacourt, comte de Roche) i Alons Vicent Folch de Cardona i Solís (observem aquest canvi intencionat en l'ordre dels cognoms), fill de Josepa Folch de Cardona i del III duc de Montellano.

Alons Vicent de Solís i Folch de Cardona nasqué en 1708 i es convertiria en el IV Duc de Montellano, entre la resta de títols. En 1737 es va casar en segones noces ${ }^{79}$ amb Maria Augusta Teresa Wignacourt Arenberg i Manrique de Lara, IV comtessa de Frigiliana. Aquesta senyora aportaria al matrimoni nous títols i possessions que transmetria al seu fill, addicionalment als altres títols i possessions que ja acompanyaven al del ducat de Montellano. Entre aquestes possessions estava la senyoria de Dave (prop de Namur, a Bèlgica). ${ }^{80}$

78 Memorial ajustat que va presentar el 2 de novembre de 1737, Thomàs Fernández de Mesa, en nom del marquès d'Ariza; dipòsit digital Universitat de Navarra (http://dadun.unav.edu/handle/10171/30912).

79 En 1732 es va casar amb Maria Manuela Centurión Ayala i Velasco, de qui no tingué fills. Desprès d'haver enviduat tornaria a casar-se, en l'any 1737.

80 Capitulacions matrimonials d'Alfons amb M. Augusta Wignacourt, comtessa de Frigiliana i princesa de Barbanzón (AHN-FN, lg. 201). 
Pel seu registre en la insigne ordre del Toisó d'Or, trobem que Don Alonso Vicente de Solís, Folch de Cardona, Rodríguez de Varillas, Valderábano, Dávila, Milán, Borja y Alagón, era tot açò:

Duc de Montellano, Gran d'Espanya de primera classe, Avançat Major de Yucatán, comte de Salduenya, Frigiliana i Egremont, marquès de Castellnou i Pons, Vescomte de Dave, duc d'Aremberg, príncep de Barbanzón, baró d'Assuévar, Soneixa, Serra, Massalavés, Mosquera, Prada, Parrancher, Aneff, Ria, Armell i Ronchines, senyor de la Casa Carrillo i de la de Milán, Zemprón i Bernoy, villas del Retortillo, la Granja, Peralejos de Solís, Narros de Salduenya, la Puebla, Villar del Profeta i Santa Catalina de Berjamunyós, alcaid de l'Alcazaba, Gibralfaro, torre de Genoveses i altres fortaleses de la ciutat de Màlaga, cavaller de la insigne ordre del Toisó d'Or (des del 22 d'octubre del 1771), comanador de l'Obreria Major, Dignitat en la Militar de Calatrava, Gentilhome de S.M. amb exercici, Tinent General dels Reials Exèrcits, Virrei i Capità General del Regne de Navarra, i Capità de la Reial Companyia d'Albarders. A més hi consta que estigué casat (i ací trobem l'origen d'alguns dels títols esmentats) amb Doña Maria Agustin de Wignacourt, Ligne d'Aremberg, Manrique de Lara, Princesa de Barbanzón i del S.R. Imperio, Duquesa de Aremberg, Vizcondesa de Dave y Ronchines, Señora de Anneff y de la Casa Carrillo, Alcaydesa de la Alcazaba, Gibralfaro, torre de Genoveses, y demás fortalezas de la ciudad de Málaga, Condesa de Frigiliana, y Grande de España de primera clase.

I acaba aquest registre amb la data de la defunció del duc. ${ }^{81}$

Al llarg del segle XVIII, la demanda dels ducs de Cardona i alguns conflictes per la successió de les baronies de Soneixa i de Serra es manté latent, com es comprova en un memorial ajustat de 1760 sobre el plet seguit per Lluís Antoni Fernández de Còrdova, duc de Medinaceli, contra el marquès de Castellnou ${ }^{82}$ (duc de Montellano), o en un memorial posterior (en grau de revista), de 1764, sobre el mateix plet en haver-se dictat una sentència favorable al segon ${ }^{83}$. En el seu estudi sobre aquests conflictes, Rodríguez (2012) fa notar que si bé la possessió oficial recau sempre en els ducs de Montellano, que són els que l'exerciten, també hi ha diversos moments en que el duc de Cardona (i de Sogorb, Medinaceli i ara també de Feria) arriba a "adjudicar-se" oficiosament i unilateral, la possessió dels llocs de les baronies de Serra i de Soneixa. Així, el nou duc, Pere d'Alcàntera (fill de Lluís Antoni Fernández de Còrdova i Spínola: 1704-1768)

81 Julián de Pinedo y Salazar (1787): Historia de la insigne orden del Toyson de Oro. Imprenta Real. 
declarava ser seus, entre altres, els llocs de Serra i Soneixa l'any $1769 .{ }^{84}$ Igualment, en 1772, seguia declarant el duc Pere d'Alcàntera Fernández de Còrdova (1730-1789) estar en possessió dels llocs de Serra, Soneixa, Assuévar i Ria. ${ }^{85}$

Alons Vicent va morir el dia 3 d'agost de 1780, sent successor en els títols el seu fill primogènit Alfons Aleix de Solís Wignacourt i Folch de Cardona (1756-1806), que es convertia en V duc de Montellano en prendre possessió del ducat i les seues pertinences aquell mateix any, ${ }^{86}$ no sense abans haver atès un despatx requisitori sobre diligències $i$ testimonis de les escriptures de possessió de les baronies de Massalavés, Serra i Soneixa, com també de la vila de Castellnou. ${ }^{87}$

Alfons es va casar amb $\mathrm{M}^{\mathrm{a}}$ Andrea Antònia Lasso de Vega i Silva (1756-1788), IV Duquessa de l'Arco, XI marquesa de Miranda d'Anta i VII comtessa de Puertollano, i tingueren com a única filla i hereva de tots els títols a Maria Vicenta de Solís i Lasso de Vega, de qui tractaré en el següent apartat.

En el cas de Serra, el període del govern d'Alfons de Solís es caracteritza perquè hem pogut disposar de major informació documental que en altres èpoques, doncs, bona part de l'activitat del notari Miquel Conejos (continuada fins a 1820 pel seu fill, d'igual nom) abasta aquesta època. Alfons posà en ordre el govern de les seues possessions $i$, particularment de la baronia de Serra. Ell ordenà que es fera la delimitació de tot el terme de la baronia, el 1788 (del que he parlat en el capítol primer), com també el capbreu de veïns de Serra, del 1779, (que hem estudiat en el capítol quart d'aquesta tesi).

També va redimir Alfons de Solís tres censos que sobre les baronies de Serra i de Soneixa havia carregat el seu avi, Josep Ignasi (amb presència del fill d'aquest, AlonsVicent). Aquesta redempció dels censals la va fer l'any $1786^{88}$. Dos anys després de redimir els censos realitzaria un arrendament dels drets dominicals de la baronia, per període de quatre anys, a Joaquim Modrego, un mestre de seda veí de València. ${ }^{89}$

84 Josep Berní i Català (1769): Creación, antigüedad y privilegio de los títulos de Castilla. Valencia; citat per Rodríguez (2012).

85 Pedro Angel de Tarazona "suceso del dia" (29 de juliol), en Diario curioso, històrico, erudito, comercial, civil y económico. Impremta de Juan Forns. Barcelona; també citat per Rodríguez (2012). 86 AHN-FN, c. 263/24 i 25.

87 AHN-FN, c. 2191/11.

88 AHN-FN, c. $263 / 38$.

89 AHN-FN, c. 263/39 a 42. 


\subsection{MARIA VICENTA DE SOLÍS, VI DUQUESSA DE MONTELLANO.}

En 1780, el mateix any que moria Alons Vicent Solís, el IV duc de Montellano, naixia la seua néta i única hereva del títol: Maria Vicenta de la Soletat Solís Wignacourt y Lasso de la Vega. Maria Vicenta va nàixer a Madrid el 27 d'octubre ${ }^{90}$, en un vell palau del barri de Sant Andreu, on vivia la seua família. Va ser batejada a la parròquia d'aquell barri. Es va casar el 29 d'octubre del 1798, en la mateixa església, amb Carlos Gutiérrez de los Ríos, que en aquell moment era el setè comte de Fernán-Núñez (des de la mort de son pare, en febrer de 1794) i anys més tard arribaria a ser el primer duc de FernánNúñez, per una disposició de Fernando VII, de qui era $\operatorname{amic}^{91}$. Ell havia nascut a Portugal, per ser son pare ambaixador en aquell regne; mantenien, però, la residència espanyola al palau ducal del poble de Fernán-Núñez (Còrdova). Segons Valverde $(1975)^{92}$ aquella va ser una boda trista, perquè el nuvi havia de partir l'endemà cap a la seua ambaixada en Londres, on estava destinat, mentre que ella restava sola a Madrid. A més a més, el propi marit diria anys després, en el seu testament, que quan es casaren la seua dona ja sabia que el seu cor era d'una altra (referint-se a Fernanda Fitz-James Stuart, filla dels ducs d'Alba).

De l'any 1803 són dos retrats dels comtes de Fernán-Núñez que va pintar Francisco José de Goya y Lucientes. ${ }^{93}$ Aquella jove comtessa consort s'havia de convertir prompte en la duquessa de Montellano (FIGURA 7.1)

Carlos Gutiérrez de los Ríos i Sarmiento de Sotomayor (3/01/1780-27/11/1821), comte de Fernán-Núñez des de la mort de son pare en 1794, esdevindria el 1817 en el I duc del mateix títol. A més va ser VI marqués de Castel-Moncayo, $\mathrm{X}$ marqués de l'Alameda, XI comte de Barajas i IV marqués de Villanueva de las Achas.

90 José Arlandis Rubio: Una señora de los lugares de Serra y Ria pintada por Goya. Serra festes. 1992. 91 Fou home de confiança de Fernando VII durant la guerra del Francès, tot participant com a diplomàtic en les jornades de Baiona davant Manuel Godoy, i posteriorment com ambaixador a Anglaterra plenipotenciari al Congrés de Viena. També fou responsable en las negociacions que donarien lloc a la intervenció dels "Cent Mil Fills de Sant Lluís" contra Riego. A més de la seua trajectòria política i es seues dots negociadores, va destacar per ser un home culte, amb una excel·lent formació diplomàtica i amb una gran sensibilitat literària. El títol de comte de Fernan-Nuñez va ser concedit al seu avantpassat, Alonso Estacio Gutiérrez de los Ríos y Angulo, en 1639, per Felip IV.

92 José Valverde Madrid: El retrato de la primera duquesa de Fernán-Núñez, por Goya. Revista de la Feria de Fernán Núñez.Año 1975.

93 José Valverde (1975) op. cit.; José Arlandis (1992) op. cit.; Fortún Paesa, Antonio (s.a.) Retrato de la condesa de Fernan Núñez (http://www.almendron.com/artehistoria/arte/pintura/goya-realidad-eimagen/retrato...); Jose Manuel Arnaiz: Nuevas andanzas de Goya. A los 250 años de su nacimiento. Galeria Antiquaria, 135: 30-34. 1996; 
FIGURA 7.1.- Retrat de la comtessa de Fernán-Núñez (futura duquessa de Montellano).

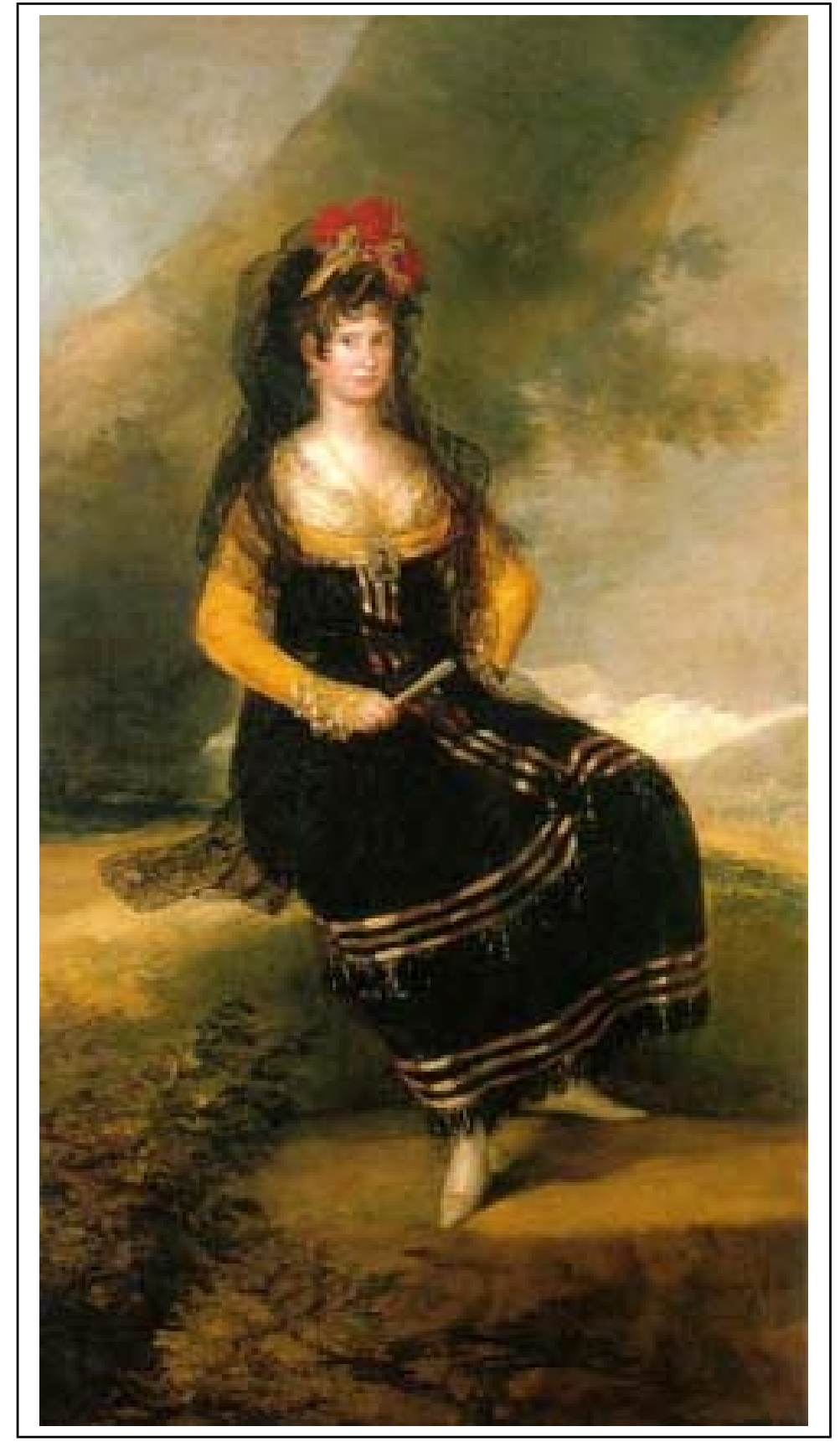

Quadre pintat per Goya el 1803, quan la comtessa tenia 23 anys. Pertany a la col·lecció particular de la família. Ha estat reproduït en nombroses publicacions (cites en el text).

Per la mort de son pare, Maria Vicenta es convertia, el 1806, en la VI duquessa de Montellano, a més de molts altres títols: duquessa d'Arco, marquesa de Miranda d'Anta, marquesa de Castellnou, marquesa de Pons, comtessa de Salduenya, comtessa de 
Frigiliana, senyora de Dave o senyora de les baronies de Massalavés, Serra i Soneixa. El títol de duc de Montellano li havia sigut concedit en 1705 pel rei Felip V a José Solís y Valderrábano Luzón y Guzmán, fins aleshores comte de Montellano, conegut també per haver sigut Adelantado Mayor de Yucatán.

El matrimoni de Maria Vicenta i el comte de Fernán-Núñez tingué dues filles. A la primera li posaren el nom de Casilda de la Esclavitud, un nom molt al·lusiu a la situació personal i de soledat en que es trobava sa mare. Va morir essent encara una xiqueta. La segona filla fou Francisca Gutiérrez de los Ríos y Solís (1801-1836) que va heretar tots els títols familiars de son pare, es va casar amb Felipe Osorio de la Cueva, comte de Cervelló ${ }^{94}$.

El 23 d'agost de 1817, Carlos Gutiérrez de los Ríos era nomenat Duc de FernánNúñez pel rei Ferran VII "como premio a los servicios prestados"; cinc anys després, però, concretament el 27 de novembre del 1822 (1821 segons algunes fonts), moria a París (on havia sigut ambaixador) com a conseqüència d'una caiguda del cavall. La notícia de la mort degué de ser terrible per a M. Vicenta, pel fet afegit del testament del seu marit, ja que li va llegar a Fernanda Stuart (aleshores duquessa d'Híjar) joies i fins i tot el cotxe, quedant-li a M. Vicenta determinats deutes i la declaració -adés citada- de que quan es va casar la seua dona ja sabia del seu enamorament per l'altra.

Sens dubte, aquesta mort també va ser un alliberament per a la duquessa, que relativament jove encara, noble i rica es va tornar a casar, ara amb un tinent d'artilleria, uns deu anys més jove que ella, don Filiberto José Mahy, que va exercir com a Senyor de Serra, fins $\mathrm{i}$ tot desprès del traspàs de la duquessa (esdevinguda el 4 de juny del 1840) $\mathrm{i}$ fins a la seua pròpia mort, el 3 de gener del 1887.

\subsection{TESTAMENT I HEREUS DE LA VII DUQUESSA DE MONTELLANO.}

A la mort del duc de Fernán-Núñez, els títols nobiliaris d'aquest havien passat a la seua jove filla Francesca, de 20 anys, la qual morí a l'edat de 35 anys (el 1837), tot sobrevivint-la, per tant, sa mare, Maria Vicenta, qui conservava els seus propis títols familiars. D'aquesta manera, la tercera persona en la que recaigué el títol del ducat de Fernán-Núñez (com a III duquessa, a l'edat de set anys) seria la jove Maria del Pilar

94 Felipe Ossorio i de la Cueva, a més de VII comte de Cervelló, va ser el V Marqués de la Mina, comte d'Aroca i XII comte d'Elda. 
Loreto Osorio Gutiérrez de los Ríos Solís i de la Cueva (10/12/1829-1/09/1921), néta de la duquessa de Montellano.

Si bé en el seu testament, Maria Vicenta nomenava com a única, legítima $\mathrm{i}$ universal hereva a la seua amada néta, Maria Pilar, contemplava també que "en el triste caso, lo que Dios no permita, de que mi amada nieta y sucesora actual faltase antes que yo, declaro que es mi voluntad legar a mi esposo Don Filiberto Mahy y Brauly todos mis bienes libres, habidos y por haber". De fet, abans d'aquest testament, el seu espòs havia ja rebut de la duquessa la quarta part de tots els seus bens de Dave, Nanines i Bonchines, a la província de Namur (Bèlgica), donació que havia fet el 15 d'octubre de 1835 “con arreglo a las leyes de dicho país", segons manifesta en el testament. De la mateixa manera, el testament deixava clar que llegava també a Filibert Mahy la cinquena part de tots els béns lliures que ella posseira a Espanya en el moment de la seua mort, i a compte d'aquesta cinquena part li deixava ja al seu espòs totes les seues joies, brillants, perles i demés, amb excepció de tres, que just abans havia reservat per a la seua néta, i afegia que era la seua voluntat que a més a més se li seguira completant l'haver i pagament d'aquesta cinquena part amb els béns que li havien quedat a Bèlgica després de la donació. ${ }^{95} \mathrm{O}$ siga, que la voluntat de la duquessa era que finalment -si ho acceptava l'altra part- el seu espòs acabara posseint plenament (i entre altres coses) totes les possessions de Dave, d'on era originària la seua família.

Com a marmessors testamentaris nomenava, si ella morís a Espanya el seu espòs, Filibert Mahy, i el seu fill (polític), el comte de Cervelló (pare i curador de la seua néta), a més d'altres dues persones: el seu cosí, comte de Santa Coloma, i el seu amic, el marquès de Sant Martí. I si ella morís en qualsevol punt de l'estranger (com de fet passaria), els marmessors serien els dos primers (espòs i fill polític) i "el seu germà" (cunyat) Camil Gutiérrez de los Ríos i "altra persona que nomene el primer".

Nou dies després de la mort de la duquessa, el seu testament hològràf, en un plec tancat i lacrat amb cinc segells li va ser lliurat al cònsol d'Espanya en París, José López Bustamante, pel marquès de Miraflores, ambaixador de S.M. en el regne de França. Aquest plec va ser obert en presència de diverses persones coneixedores de la difunta que davant el cònsol juraren reconèixer la lletra i signatura de la difunta. Així donaren lectura

95 Li deixava expressament a la seua néta una agulla de brillants units que va ser regal de la reina Maria Lluïsa, una de les cinc flors de brillants (la que té una sement d'or en forma de gira-sol) i un petit medalló rodó guarnit de brillants petits que conté cabells dels pares de Maria Pilar. 
a dit testament el 13 de juny de 1840, signant-lo i posteriorment diligenciant-lo l'esmentat cònsol.

En 8 de novembre de 1880, una nota del Ministeri d'Estat afegida al testament indica que la translació de domini que tingué lloc en 1840, d'herència directa d'ascendent a descendent legítim no reporta drets ni impostos a la Hisenda pública en l'esmentada data. Seguidament, una segona nota dóna fe de la inscripció com a titular hereva de Maria del Pilar Loreto Osorio Gutiérrez de los Ríos, com a duquessa de Montellano i de Fernán-Núñez, inscripció feta en l'administració econòmica de la província de Màlaga, el 6 d'octubre de 1881. Aquesta inscripció ve a confirmar que la possessió completa del llegat de Maria Vicenta per la seua néta es va produir o almenys completar únicament desprès que Filibert Mahy va entrar en una edat molt avançada (moriria el 3 de gener de 1887, amb 96 anys d'edat), tot havent actuat fins aleshores com a ple usufructuari del títol de duc de Montellano, amb consentiment del comte de Cervelló i de la pròpia Maria Pilar, desprès de cert litigi que mantingueren en els anys immediats a la mort de la duquessa, del que parlem tot seguit.

El 20 de juny de 1840, el comte de Cervelló escrigué des de Madrid al Tribunal de Namur (Bèlgica), demanant que correguera per compte de Filibert Mahy el pagament del llegat que la duquessa, en la clàusula 10a del seu testament, havia deixat a Marià d'Agustín (el seu inspector dels béns de Bèlgica), consistent en la continuació, fins als dies de sa vida i per via de pensió, del sou que actualment gaudia, de 12.000 rals de billó. Al respecte cal recordar que la duquessa, en la clàusula 18a, havia expressat la voluntat que el seu espòs poguera acabar posseint plenament totes les seues possessions de Bèlgica, per un possible bescanvi que es podria haver negociat a partir de la cinquena part dels béns lliures d'Espanya que li deixava al duc. Al respecte, el duc responia als legataris que s'havien adreçat a ell recordant-los allò que establia la clàusula $8 \mathrm{a}$ del testament: "En atención á que mi amada nieta la Duquesa de Fernan-Núñez es mi sucesora y heredera de los bienes (á excepción de los que me reservo disponer con arreglo a las leyes vigentes) dejo á su cargo y durante su menor edad á su padre y curador el Conde de Cervellón, para que se cumplan las mandas siguientes..." (ja he dit que la referent a Marià d'Agustín era una clàusula posterior). En aquesta causa compareixia també Marià d'Agustín el 5 de març de 1841.

Per altra part, el 14 de juliol de 1840, Filibert Mahy citava el comte de Cervelló, en qualitat de tutor de la seua filla (menor) davant el Tribunal de Namur, per a veure la 
manera de que per experts convinguts per les dues parts o bé imposats d'ofici pel tribunal, es procedira a delimitar i amollonar les terres i immobles que la duquessa ja li havia donat (donació entre vius) en 15 d'octubre de 1835. Al respecte, la postura del comte era que aquella donació podria ser superior a la quarta part del total de les possessions de la duquessa al seu vescomtat de Dave, Nanines i Ronchines. La qüestió de fons en aquesta part de la demanda era que l'article 1098 del Codi civil del regne belga limitava a $1 / 4$ les donacions lliures quan hi havia també fills descendents. ${ }^{96}$

Finalment, sobre tots aquests assumptes, la Cort de Namur fallava el 10 d'agost de 1842 declarant-se competent per a conèixer i resoldre en darrera instància sobre els assumptes en qüestió, però venint a dir que , en principi, no era competent per a altres aspectes més immediats i que haurien de ser resolts primerament pels tribunals espanyols. És el cas de la pensió o sou vitalici d'Agustín, doncs les dues parts són espanyols i residents a Espanya, on hi ha un procés obert de successió. I pel que fa a l'assumpte de si la donació supera o no la quarta part del total, també és un assumpte encara pendent i negociable, tal com deixa obert el testament.

Al marge d'aquestes qüestions, de les que no coneixem gaire altres detalls, tornarem a parlar del duc vidu de Montellano en el capítol novè d'aquesta tesi, tractant ja del procés de dissolució del règim senyorívol pel que fa a la baronia de Serra.

Maria Pilar es va casar a Madrid el 14 d'octubre de 1852, amb Manuel Falcó i d'Adda, marqués d'Almonesir. Ella era filla de M. Vicenta Solís i ell nét d'una íntima amiga d'aquesta, M. de la Concepción Valcàrcel i Pascual del Povil, filla de la IX marquesa de Castel-Rodrigo i Princesa Pio de Saboya, la que fou enterrada l'any 1800 al creuer del temple parroquial de Serra.

96: Journal du Palais. Recueil la plus compléte de la Jurisprudence Belge, par Ledru-Rollin. Publié par F-F Patris. Année 1843. Paris.Bureau, rue des Grans-Austins, $n^{\circ} 7$.

(http://books.googleusercontent.com/books/content?req) 


\section{CAPÍTOL 8}

\section{MORIR I NÀIXER A SERRA: VIDA SOCIAL, DEVOCIONS, COSTUMS...}

\subsection{ASPECTES QUOTIDIANS EN LES PRIMERES DÈCADES DEL XVII}

Mitjançant els protocols del notari Joan Font (APCC), que abasten el període de 1611 a 1632 hem pogut conèixer alguns detalls de la vida quotidiana dels colons i del desenvolupament de la colònia repobladora en aquelles dues primeres dècades de la seua existència.

En aquesta sèrie notarial hi trobem des d'algun arrendament del lloc o de les seues regalies, ${ }^{1}$ fins a l'acord d'un consells de veïns per tal de prendre diners del pòsit per a comprar a Sogorb la llavor de blat necessària per a sembrar a Serra, ${ }^{2}$ passant per rebudes o publicacions de testaments, nomenaments de procuradors amb diverses finalitats, traspassos o arrendaments sobre béns immobles, un inventari de béns, acords sobre curadors de menors i sobre dots matrimonials; especialment, però, sovintegen contractes de compra i venda d'èquids (habitualment rossins o mules), etc. Una selecció i mostra d'aquests actes ha estat recollida dins l'apèndix documental d'aquesta tesi. Cal indicar que hi ha molts actes que semblen incomplets i altres resulten difícils d'entendre degut al mal estat que de vegades presenten els originals. La llengua dominant és amb diferència el llatí, si bé també hi ha alguns actes que estan escrits en valencià i encara en castellà. El lligalls estan enquadernats i amb cobertes de pell i no solen anar paginats, però sí ordenats cronològicament, per la qual cosa indicarem normalment la data com a referència del document.

Entre els testaments enregistrats en els protocols de Joan Font ens crida l'atenció que hi predominen els de dones sobre els d'homes. Quan confrontem açò amb les dades inscrites en el llibre dels difunts parroquial observem que el més habitual, entre els homes, son els testaments nuncupatius, o siga, els que es fan directament de paraula per la persona que és conscient que pot estar a prop de morir; en tal cas, qui rep les darreres

\footnotetext{
${ }^{1}$ Antoni Massó, mercader de Soneixa i com a procurador general de Josep Folch de Cardona fa àpoca de 65 lliures que corresponen al lloc de Serra i Ria, en presència dels seus jurats (APCC, 21049, data 3/11/1630). Antoni Esteve i Pere Navarro arrenden el forn per 30 rals (APCC, 21047, data 17/11/1624).

${ }^{2}$ Acte del 8 de gener del 1617 que ja hem esmentat en el capítol cinquè (APCC, 21045, f. $1 \mathrm{r}^{\mathrm{o}} \mathrm{i} \mathrm{v}^{\mathrm{o}}$ ).
} 
voluntats o bé la comunicació d'haver-hi testament, sol ser el rector parroquial. Entre els testaments localitzats en els protocols de Font estan els de les següents dones: Bàrbara Mateu (APCC, 21044, data 1/01/1615) esposa de Baptista Català, el de Peronella Hernández (APCC, 20584, data 24/02/1632) esposa d'Antoni Pérez, un de complementari de Paula Serra (APCC, 20584, data 13/10/1632) esposa de Joan Donya (el batlle de Serra) i el de Beatriz Muñoz (APCC, 20584, data 18/10/1632) esposa de Domingo Moreno. També hem localitzat el de Jeroni Sastre (APCC, 21048, data 2/11/1621) rector de la parròquia de Serra i Nàquera.

Especialment interessant, com a exemple referit a l'època i els detalls humans que l'envoltem, ens ha resultat el testament de Miquel Sáez (APCC, 21047) fet públic en data 4/03/1623) que havia sigut rebut pel franciscà fra Gil Herrero poc abans de la mort del testador, ocorreguda el 22 de febrer de 1623. Realment $-\mathrm{i}$ ja ho hem comentat en altra ocasió- no és un cas aïllat el de confiar aspectes de l'ànima als franciscans, sens dubte pel seu comú lligam a la Mare de Déu dels Àngels, patrona de Serra. El cas és que, només produir-se la mort de Miquel Sáez, el testament escrit de la mà del franciscà però en presència de quatre testimonis, va ser posat en mans del notari Joan Font per indicació del rector, Jeroni Sastre (el rector d'origen morisc, de qui parlàrem en el capítol segon) qui a més era nomenat marmessor en dit testament. El registre notarial inclou, primer la inscripció del testament rebut, desprès pren nota de les declaracions de cadascun dels testimonis $\mathrm{i}$, finalment, recull la publicació del contingut del testament (4 de març de 1623) feta davant els interessats i amb presència del Justícia de Serra, Antoni Èpila i del seu lloctinent de Justícia, Jaume Pérez. Segueixen, quasi dos anys després, alguns actes relatius a la custòdia de la filla menor del difunt, com també un inventari dels béns a petició del curador dels fills i en presència de la vídua.

En el seu testament, Miquel Sàez deixava la seua dona, Isabel Domingo, com usufructuària de tota la seua hisenda i béns, mentre que no es tornés a casar, tot afegint que si es casés de nou "de la mateixa hisenda li donen 50 escuts per la companyia i serveis" però salvant sempre la casa i un bancal (d'horta) que està Baix la Torre, que confronta amb terres de Joan Font (el notari), per dos costats, i amb la senda que va a Nàquera. ${ }^{3}$ Pel Quinque Libri sabem que la vídua es tornà a casar, en juny de 1624, amb Joan Mallach.

\footnotetext{
${ }^{3}$ APCC, 21047, data 4/03/1623.
} 
Del paràgraf anterior queda clar que el notari posseïa terres d'horta a Serra, en l'esmentada partida de Baix la Torre, com també tenim clar que, a més de la seua casa de València (prop del carrer de Morvedre), posseïa també una altra casa a Serra. Així ho indica quan escriu el testament de Peronella Hernández, dient que el va rebre "en lo present lloc de Serra i en la casa que tinc en aquell”, en 24 de febrer de $1632 .{ }^{4}$

Un altre aspecte habitual és el dels nomenaments de procuradors. Els motius dels nomenaments poden ser diversos però no sempre -per les dificultats trobades en els manuscrits- ens ha quedat clar l'objectiu final. Destaquem, no obstant això i com a mostra, el que fa Antoni Pérez, agricultor de Serra, en nomenar en 31 d'octubre de 1614 procurador seu a Miquel Pasqual "picador de tapins" de València, per a que li cobre una sèrie de quantitats pendents que li deuen a València (no les concreta). El 14 d'octubre anterior havia fet un altre nomenament de procurador, en aquell cas a Atanasi Herrero, agricultor de les Alcubles, per a que s'encarregara de la liquidació dels béns que tenia en aquell lloc. En un altre cas (APCC, 20584; data 3/06/1632) trobem a Domingo Cavaller, rector de Serra, donant poders i autoritzant a fra Vicent Carlos, ministre del convent de la Font de Llíria, per a que li cobre la mensa arxiepiscopal i la paga del passat any i de l'any corrent. Per altra part, Josep Domènec, apicultor i habitador de Serra, va ser nomenat per Pedro Pancrudo, ciutadà de València, procurador seu per a que rebera i li recuperara sis alnes i un pam de "llana de mescla València" corresponents a una comanda (APCC, 21048b).

A banda dels béns de les Alcubles liquidats per Antoni Pérez, la venda de possessions (en domini emfitèutic) dels repobladors que vingueren de les Alcubles a Serra també la trobem referida en altres ocasions, com és el cas de Violant Valle, dues vegada vídua, esposa que fou de Jaume Moreno i esposa abans del repoblador Antoni Sanchis (originari de les Alcubles) qui va vendre, en 4 de març de 1620, la seua casa d'aquell lloc a un tal Joan Estaca. ${ }^{5}$

La venda i els arrendaments de terres són també objecte de diversos actes notarials, com és el del 8 d'agost de 1632, en que Martí Tortajada, llaurador de Serra (realment de Nàquera, segons el Quinque Libri de Nàquera) "ven i traspassa" a Joan Ibáñez una fanecada i mitja de terra (d'horta), per preu de 20 lliures, en rals de València, fent constar també que està subjecta a cens de 20 sous sots directa senyoria de D. Josep de Cardona. ${ }^{6}$

\footnotetext{
${ }^{4}$ APCC, 20584, data 24/02/1632.

${ }^{5}$ APCC, 21046, data 4/03/1620.

${ }^{6}$ APCC, 20584, dates 8 i 20/08/1632.
} 
La confrontació de dades entre diferents actes permet reconstruir algunes situacions que resulten interessants (o com a mínim curioses). Així sabem, per un altre acte, ${ }^{7}$ que Miquel Pasqual, el "picador de tapins", de València, a qui Antoni Pérez, en 1614, havia nomenat procurador seu, per a certs assumptes a València, en 1623 residia i tenia una casa a Serra, junt a la de Joan Donya (el fill del batlle) "en el carrer que va cap a la font"; i en 2 de setembre de 1620 va arrendar-li unes terres (dos bancals d'horta "en lo collao de les Eres de Ria") a Pere Joan Ribes, per preu 15 lliures. ${ }^{8}$ Practicava un ofici artesà, com era fer tapins, una mena de sandàlies de suro folrades amb pell i tela. En alguna altra referència i fins a 1632 el trobem citat (en llatí) com a "Miquel Pasqual sandalium" (i sandalorum). El fet d'haver-se instal·lat a Serra bé podria respondre, al menys en part, a un millor accés o aprofitament directe del suro, la seua principal matèria prima, però tampoc poder descartar que fora per assumptes o negocis administratius, doncs trobem que Pere Martínez li devia el 20 d'agost de 1632 “per regalies i drets de senyoria" $14 \mathrm{~L} .17 \mathrm{~s} .4 \mathrm{~d} .{ }^{9}$

L’inventari dels béns de Miquel Sáez és l'únic, almenys clar i més o menys complet que hem identificat d'aquella època. El seu contingut és una mostra (no sabem fins a quin grau poc o ben representativa) de la humilitat, les limitacions i la discreció dels aixovars i possessions mobles amb les que vivien aquells repobladors veïns de Serra. La següent relació de béns entenem que resulta força expressiva sobre aquest aspecte.

Un altre inventari, fet el 12 d'abril de 1623 per Antoni Esteve, curador dels fills del difunt, es fa en la que va ser la seua casa "situada i posada en lo present lloc de Serra, afronta amb casa de Miquel Pasqual, de la ciutat de València, amb casa de Joan Baptista Donya, batlle, carrer públic enmig i amb camí que va a la font” (per la seua situació i veïnat bé podria ser una de les cases bones del poble). El contingut era el següent: a l'entrada de la casa 3 cafissos de calç sens pastar, una pastera de bugades vella, 40 vasos ("ab rusc") de tenir abelles, una caixa de coure vella, una paella de ferro vella, dos (...) d'espasa velles, dos cadires de costura velles, una taula d'alzina vella de mode de banca, dos banquets molt vells, una dotzena d'escudelles, sis plats i dos olles, tres "joals" de cera i mel buides cabent a 10 arroves cascuna, una llegona i una aixada, un aladre amb sa rella i son "sorbell”, un aixó vell, una caixa de pi sens pany ni clau buida, un rastell, un llit de pi molt vell que amb penes sí aprofita, una màrfega vella, dos llençols vells, una

\footnotetext{
${ }^{7}$ APCC, 21047, data 12/04/1623.

${ }^{8}$ APCC, 2145, data 2/09/1620.

${ }^{9}$ APCC, 21049, data 24/09/1630.
} 
flassada vella, un vestit de dit difunt de pebret de València nou i llis ("ço és, capa, saragüells i copilla"), altre vestit de dit difunt de cordellat molt vell, unes alforges velles, dos "odels" buits de portar mel, un davant de 1lit vell, una "albosca", dos "caboals" de ferro molt vells, una camisa d'home molt vella, una caldera de coure cabrit, un setrill de vidre i un llibrell..., Dos davalles de taula velles, dos "talegues" velles... Tot açò dins la casa.

A més a més, inclou aquest inventari: "dues mules, una vella, de pèl blanc, i l'altra jove, de pèl castany, totes dues amb ses paeres i tots sos aparells vells i dues campanetes de dites mules; 15 cabres amb cinc cabrits; 191 "colmenes" plenes amb ses abelles, les quals estan en lo terme de Serra i d'Altura; dotzena i mitja de capaços de dites coplmenes, un cedàs vell”, i també tota una sèrie de parcel·les agrícoles. ${ }^{10}$

Les constitucions de dots matrimonials són tanmateix objecte d'actes notarials, com en el cas de Bàrbara Esteve, que junt amb el seu pare, Antoni Esteve, llaurador, acorden en 28 d'agost de 1632 que, per al seu casament amb Macià Cabo, ella aportarà com a dot 26 lliures, que seran 6 d'elles en robes i les altres 20 en el producte d'un conjunt de terres que són: tres bancals en l'horta de Ria, altres tres en la de l'Ombria de Ria, dos trossos de terra amb garrofers, un en la Misèria i l'altre prop de Ria, un garroferal a Xarxant, sis jornals i un altre separat, tots set junt al camí de Portaceli, i una "barrancada" a Tòixima. ${ }^{11}$

La dot de la dona, per a casar-se, és un element clau per a la formació d'una nova família i per al sustent i començament de la nova convivència familiar, quedant evidenciat aquest objectiu des de la primerenca edat de totes les xiquetes. Quan les condicions dels pares ho permeten, aquests van reservant i preparant des de ben joves les dots de les seues filles. Però quan són pobres o orfes, la solució habitual és que les xiques vagen a servir, com a donzelles o criades, a alguna casa, moltes vegades només a canvi d'aliment (i estança, potser) però sempre amb la condició de que quan arriben a l'edat adient rebran de cop una ajuda o una dot dels senyorets o curadors. L'edat per a poder anar a servir una xiqueta era de 9 anys. Així ho comprovem en el cas de la filla menor (Caterina) del difunt Miquel Sàez. El seu padastre, Joan Mallach (nou marit de la mare de la xiqueta; casats en 2 de juny de 1624) va protestar davant el Justícia de Serra i Ria que no volia prestar a la xiqueta "que té poc més de 3 anys" (nasqué el 7 d'abril de 1621 i

${ }^{10}$ APCC, 21047, data 13/02/1625.

${ }^{11}$ APCC, 20584, data 28/08/1632. 
morí son pare en 22 de febrer de 1623) els aliments necessaris, ni tenir-la en sa casa, si no és rebent (compensació) per poder-li pagar els aliments necessaris. Per a tal menester reclama la tercera part dels béns de l'herència del difunt pare de la xiqueta; però, desprès de fer-se un inventari es veu que la part que recauria a la menor no aniria més enllà de 30 lliures, mentre que es calcula que caldrien 100 lliures per a cobrir les necessitats de la menor en els propers 6 anys, en que arribaria a "l'edat competent per a poder servir" (els esmentats 9 anys d'edat). ${ }^{12}$ Aquest costum d'enviar i prendre xiquetes a servir a alguna casa el trobem molt estès entre les òrfenes de l'hospital General, amb edats des de vuit anys, a canvi de que "quan siga gran" o "prometent-li per a son matrimoni" la soldada acostumada (generalment unes 50 lliures i, de vegades també, un vestit. ${ }^{13}$

Finalment, el curador de Caterina seria Antoni Esteve, que era també curador dels altres dos fills del difunt: Joan i Francesca, que aleshores tenien uns 15 i 12 anys d'edat, respectivament. Ell manifesta que s'encarregarà d'educar i sustentar a Caterina per temps de 6 anys "prestant-li los aliments necessaris de beure i menjar, vestir, calçar i tot el que és necessari i de gran profit per a dita menor". Antoni Esteve era un dels repobladors de Serra, com el pare de la xiqueta i ambdós alcublans d'origen. És el mateix que hem citat dos paràgrafs més amunt, atorgant la dot d'una de les seues filles majors. A més, sabem que estava casat amb Joana Romero i eren pares d'una xiqueta (Vicenta) de la mateixa edat que Caterina i un xiquet menor que elles, a més d'altres cinc fills prou més majors (entre ells Bàrbara, abans esmentada).

Les nombroses transaccions comercials sobre compra i venda d'animals de tir i de càrrega, molt abundants en la sèrie notarial de Joan Font, posen de relleu aspectes que considerem especialment remarcables. En primer 1loc, la seua abundància és un clar indicador dels tipus d'oficis i modes de vida dels serrans d'aquella època, doncs el cavall/rossí/mul és l'element principal del treball dels llauradors (aquest és l'ofici més recurrent que hi trobem sempre citat, tant en la documentació notarial com en la parroquial); per altra part, el transport amb èquids ha sigut sempre fonamental per als serrans: la distribució de les collites, però sobre tot de la llenya i el carbó, l'aigua de les fonts, etc. A més a més, cal tenir en compte que el transport amb carros va ser molt tardà, no essent possible fins a la dècada de 1870 , quan la projectada carretera provincial de “Burjassot-Torres Torres” aconseguí arribar fins a Serra (Martínez Aloy, 1924: 163-164).

\footnotetext{
${ }^{12}$ APCC, 21047, data 13/01/1625.

${ }^{13}$ Hem tingut ocasió d'esbrinar molts exemples (cap d'ells relacionat amb de Serra, però si amb Morvedre, Burjassot i altres) en la sèrie del "llibre de bords del Espital General" (ADPV, Hospital, signatura II-4/1).
} 
Recordem, al respecte, com hem referit abans (testament de Miquel Sàez) la "senda que anava a Nàquera" (que no camí). Un altre aspecte cridaner de les operacions de compra $\mathrm{i}$ venda de mules i de rossins és que les operacions solen fer-se amb forasters (sovint els que vénen els èquids als serrans); també es pot apreciar que, de vegades, un mateix serrà el podem trobar com a comprador i com a venedor en actes relativament propers en el temps, indistintament. La variabilitat de preus entre els diferents animals arriba a ser considerable, tal com es veu en el QUADRE 8.1. Si bé el preu mig en la mostra de 7 animals és de 23 lliures, trobem que el preu d'una mula pot arribar a quadruplicar-se.

QUADRE 8.1.- Compra-venda d'èquids en les primeres dècades del segle XVII.

\begin{tabular}{l|l|c|c|c|c|c|}
\multicolumn{1}{c}{ Comprador } & \multicolumn{1}{c}{ Venedor } & \multicolumn{1}{c}{ Objecte } & \multicolumn{1}{c}{ Preu Data } & Document \\
\hline Pere Martínez & Francesc Morell & Mula & $16 \mathrm{~L}$ & $1 / 01 / 1615$ & APCC, 21044 \\
\hline Francesc Ibáñez & Agustín Crespo & Mula & $25 \mathrm{~L}$ & $26 / 07 / 1617$ & APCC, 21045 \\
\hline Pere Ibáñez & $\begin{array}{l}\text { Vicent Castel } \\
\text { (de Les Alcubles) }\end{array}$ & Mula & $16 \mathrm{~L}$ & $16 / 06 / 1617$ & APCC, 21045 \\
\hline $\begin{array}{l}\text { Antoni Pérez, Jaume } \\
\text { Pérez i Bertomeu Pérez }\end{array}$ & Prior de Portaceli & Dues egües & $30 \mathrm{~L}$ & $3 / 11 / 1624$ & APCC, 21047 \\
\hline Antoni Pérez & Pere Martínez & Rossí & $15 \mathrm{~L}$ & $9 / 08 / 1632$ & APCC, 20584 \\
\hline Antoni Ėpila & Antoni Pérez & Mula & $60 \mathrm{~L}$ & $12 / 11 / 1626$ & APCC, 21050 \\
\hline
\end{tabular}

Dades basades en els protocols del notari Joan Font (APCC).

La forma de pagament es realitza normalment en diners, concretament pagant les lliures pactades en rals de València o altra moneda corrent, $i$ generalment en dos lliuraments aproximadament semestrals. Però, curiosament, hi ha un cas, el primer del quadre, en que el pagament es fa en espècie. Pere Martínez promet pagar, les 16 lliures del valor de la mula que ha comprat i rebut, de la següent manera: per Sant Joan del mes de juny vinent li donarà a Francesc Morell sis barcelles de bon forment i, per al dia de la festa de la nativitat de la Mare $\mathrm{d}$ Déu Maria (8 de setembre) li donarà, com a segon termini del deute, trenta arroves de fusta (lignetum) de garrofer. Recordem que Francesc Morell, de professió fabricant de panys de llana (pannorum primi) va ser un dels signants de la carta-pobla de Serra del que a penes trobem més referències a Serra, per la qual cosa suposem que la venda d'aquesta mula -i suposadament dels béns immobles que 
rebé en emfiteusi- podria formar part de la seua decisió de seguir vivint a València, d'on era originari.

Trobem també en els protocols de Joan Font (cap al final del lligall APCC, 21048) un lot de "contractes" preparats per a la venda d'almenys una dotzena de cavalls que tenen disponibles Pere Bonanat, comerciant (de Burjassot) i Rafel Arinyo (sempre va seguit de civi absenti), tots dos junts com a venedors. El notari Font té llestes les corresponents apoques per a concretar la venda de cadascun dels animals, indicant el nom dels venedors (Bonanat i Arinyo absenti), una breu descripció de cada l'animal i els preus que els hi correspon, quedant pendent de posar (està en blanc) el nom del comprador i la data que correspondran arribat el moment. No obstant, la data de confecció d'aquest conjunt de documents calculem que pot ser de juliol de 1622 o poc de temps després. El QUADRE 8.2 recull les característiques i preus dels animals, que assoleixen un preu mitjà unitari de 31 lliures, si bé amb gran variació entre uns i altres, que pot anar de 10 i 46 lliures, segons aquesta mostra. Entenem que són tot cavalls (equus), si bé, l'antagonisme "potro senil" no ens queda gens clar. En apoques posteriors hi consta que altres cavalls ("potro senil") van ser venuts per 33 i 29 lliures a Antoni Badia i a Jacobo Abadia, llauradors de Xirivella, i una mula de pèl "rucio" la comprà per 45 lliures Joan Gregori, agricultor de la vila de Torres Torres.

Totes aquestes dades, i el fet de que Joan Font tinguera sa casa (a més de la de Serra) junt al carrer de Morvedre, apunten a que aquests animals podrien formar part del mercat o fira d'animals que tradicionalment (i fins als anys 60 del segle XX) tenia lloc baix del riu junt al portal dels Serrans. No sabem si algun d'aquests cavalls acabaria sent venut a serrans (pot ser que no); en tot cas, però, la referència de preus ens resulta certament interessant com a aportació general i com a element de comparació amb els casos adés exposats i altres posteriors que n'aportarem.

Abans de concloure aquest epígraf basat en la documentació notarial de Joan Font, val la pena destacar un parell de detalls relacionat amb aspectes culturals i de la convivència en aquells anys. Un dels detalls que ens ha cridat l'atenció és que alguns joves no saben exactament l'edat que tenen. Per exemple, dos dels testimonis del testament de Miquel Sáez, quan han de ratificar dit testament, escriu el notari: Francesc Moreno, llaurador del lloc de Nàquera, "atrobat en lo lloc de Serra, d'edat que deu ser de vint-i-cinc anys, poc més o menys, lo qual jura”, etc.; i també Joan Donya (menor, el fill del batlle de Serra) "que dix ser de vint-i-un anys poc més o menys". Aquest diu l'edat que té "poc més o 
menys", mentre que el primer sembla que és el notari qui li la calcula, perquè ell no la sap dir. ${ }^{14}$

QUADRE 8.2.- Èquids preparats per a la venda, en 1622 i tal com apareixen en llatí.

Descripció de l'animal preu

\begin{tabular}{|c|c|}
\hline Potro senil pili andrino & $46 \mathrm{~L}$ \\
\hline Equi sive rossí senil pili castany & $41 \mathrm{~L}$ \\
\hline Potro senil pili andrino & $10 \mathrm{~L}$ \\
\hline Equi senil pili seni & $38 \mathrm{~L}$ \\
\hline Potro senil pili andrino & $27 \mathrm{~L}$ \\
\hline Potro senil pili andrino & $40 \mathrm{~L}$ \\
\hline Potro senil pili castany & $33 \mathrm{~L}$ \\
\hline Potro senil pili castany & $40 \mathrm{~L}$ \\
\hline Potro senil pili vallo & $24 \mathrm{~L}$ \\
\hline Equi pili blanc i roig & $15 \mathrm{~L}$ \\
\hline Potro senil pili castany & $33 \mathrm{~L}$ \\
\hline Potro senil pili vayo & $29 \mathrm{~L}$ \\
\hline
\end{tabular}

Dades tretes dels protocols del notari Joan Font (APCC, 21048).

D'altra banda, els actes notarial també aprofiten per a conciliar a les persones, dirimir diferències i signar "paus duradores per temps de cent i un anys", que és el que fan Antoni Pérez i Francesc Martínez (observe's la mescla de llatí i valencià):

Die xviii mensis octobris anno 1614.

Ego Franciscus Martines velluterii civies Sugurbi nunc in loco de Serra repertus ex una et Anthonius Peres, dicti loci habitatore ex altera, per si parents amics i valedors fermen pau duradora per temps de cent $\mathrm{i}$ un anys en mà i poder de Josep Domènech, Justícia del present lloc de Serra i en virtut i sacrament $i$ homenatges en mà i poder de dit Justícia, Josep Domènech, prestats prometent la una part a l'altra i la altra a l'altra ad invicem et vicissim que no es faran mal ningun, ni fer-lo faran, ans bé, si algú els ne voldria fer s'avisaran o avisaran faran, sots pena de boí i traïdor que els pena de mort natural i de cent florins d'or d'Aragó aplicadors, etiam sotsmeterense etiam renunciaren etc. a tot dret civil y criminal proquibus etc. obligaren etc. a un de juliol. A Serra.

\footnotetext{
${ }^{14}$ APCC, lg. 21047, data 4 de març de 1623.
} 
Testes huius rei funt Joannes Baptista Borras pharmacipola, civis Valencie et Baptista Donya, agricultor dicti loco. ${ }^{15}$

Al llarg d'aquestes línies hem observat alguns oficis i accions lligades al ram de la roba o calcer i teixits: aquest Francesc Martínez, velluter de Sogorb), Francesc Morell (pannorum primi), el sandalier Miquel Pasqual (picador de tapins) o l'encàrrec que li feia a Josep Domènch el ciutadà de València Pedro Pancrudo per a una comanda de sis alnes $\mathrm{i}$ un pam de "llana de mescla València". Observem aquestes referències però, a penes hi trobem continuïtat significativa en etapes posteriors que també hem esbrinat. Més interessant, podria ser, destacar-hi la pràctica de l'apicultura ja en la Serra del segle XVII, amb l'exercici de l'ofici d'apicultor, de Josep Domènech, i les arnes o rucs (duescentes "colmenes" entre els termes de Serra i d'Altura) i abundant utillatge apícola de Miquel Sáez.

\subsection{ORIGEN DE LA PARRÒQUIA I NOTÍCIES DEL PRIMERS TEMPLES (SEGLES XVI a XVIII).}

Quan Senís (1954) tracta dels rectors parroquials en el seu llibre, comenta haver pogut consultar, a més dels llibres de la parròquia, una nota presa d'un expedient de visita pastoral de 1562, segons la qual, Serra amb Ria i Nàquera formaven part de la mateixa rectoria que Torres Torres fins a l'any 1535, quan se separava Serra (i els seus annexes, Ria i Nàquera) per a formar una rectoria pròpia. ${ }^{16}$

El rector de Serra aquell any 1562 era mossèn Benedicto, resident al poble d'Altura, des d'on havia de desplaçar-se cada diumenge fins la rectoria de Serra per a celebrar dues misses: una a Nàquera (on sembla que hi havia alguns cristians vells entre la majoria morisca) i l'altra, alternativament, a Serra o a Ria, que eren llocs exclusius de nous convertits. És coneguda certa resistència de la minoria morisca que mantenia tant costums i religió com l'ensenyament de la seua pròpia llengua, i que tenia connexions clandestines entre els moriscos del Camp de Túria i els de les terres de l'Espadà, ${ }^{17}$ però

\footnotetext{
15 APCC, 21044.

16 Suposem que aquesta nota podria ser deguda a Ambrosio Cebrian, quan consultà el contingut d'aquesta visita pastoral bé d'un original que en algun temps degué existir en l'arxiu parroquial o bé del registre de l'arxiu de l'arxidiòcesi (Palau Arquebisbal de València).

${ }^{17}$ Llibret de l'exposició "Quatre-cents anys de l'expulsió". Inst. Estudis comarcals Camp de Turia, 2009.
} 
també es conegut que molts moriscos mantenien la devoció religiosa cristiana. ${ }^{18}$ Una mostra, en el cas de Serra, és la donació que de tots els seus bens mobles i eines, valorats en més de 200 lliures, realitzà a la Cartoixa de Portaceli "per la molta voluntat i amor que li tenien" el matrimoni format per Antoni Ramí i la seua dona Grayda Curcuja, moriscos de Serra, al poc de ser publicat el decret d'expulsió del 1609. ${ }^{19}$

A diferència de Serra, de Ria i de Nàquera, que eren llocs de moriscos, la població de Torres Torres estava formada per 80 cases de cristians vells, en les quals vivien 240 persones de confessió i comunió, estant la seua església dedicada a la Mare de Déu; tot això segons la visita pastoral de l'any 1570 a la que hem tingut accés. ${ }^{20}$ Per fonts posteriors sabem que l'advocació de l'església de Torres Torres sempre fou a la Mare de Déu dels Àngels, si bé és també venerada i té gran tradició la Mare de Déu de la Llet, que és la patrona de Torres Torres. Aquesta tradició és atribuïda a una troballa, en el segle XVII, d'una imatge d'aquesta mare de déu (una talla atribuïda al segle XV) que aparegué en una fornícula, a prop del castell de Torres Torres (probablement relacionada amb l'antiga església que allí existia antigament, posada de manifest, recentment, per Juan Corbalán de Celis, cronista de Torres Torres). En el lloc on va ser trobada aquesta imatge es va fundar una ermita que encara cita Cavanilles (1795-1798), si bé després desaparegué.

Aquest antecedent permet entendre que l'església de Serra també tinguera des d'un principi la dedicació a la Mare de Déu dels Àngels, en procedir d'una segregació administrativa de la seua església mare (la de Torres Torres), tot això en temps dels moriscos. En canvi, l'església de Nàquera tingué ja una dedicació diferent,: Nostra Senyora de l'Encarnació, ${ }^{21}$ si bé sempre formà part de la mateixa parròquia i rectoria de Serra fins a l'any 1897, en que es desmembrà definitivament, desprès d'haver passat també una llarga etapa com a vicaria, des de 1771.

\footnotetext{
$18 \quad$ Molts d'ells moriren a Àfrica apedregats o degollats, per no haver volgut renegar del cristianisme $\mathrm{i}$ haver-se negat a entrar a les mesquites, segons exposa Luis Cabrera de Córdoba (1559-1623) cronista reial, en la seua obra "Relaciones de las cosas sucedidas en la corte de España desde 1599 hasta 1614" (obra no publicada fins a 1857).

19 "Llibre de Benefactors", publicat en Tarín y Juaneda (1897).

20 Visites pastorals de Sant Joan de Ribera (1569-1570). Arxiu diocesà (ADV), Seció I, Fons XXXI. No he pogut localitzar, però, la visita pastoral que un any abans (1596), el mateix visitador, Tomàs d'Espinosa havia fet a les esglésies de Serra i de Nàquera (segons cita d'Emili Lluch, 2002: 301).

${ }^{21}$ Inicialment seria de l'Anunciació, passant després a l'Encarnació (comunicació personal i aclariment fet per Alexandre Navarro).
} 
Tal com observa i conta Senís (1954), els diferents rectors de la Parroquial de Serra i Nàquera estaven generalment assistits, o bé ajudats o substituïts en els oficis, per frares de diferents ordres, però principal i predominantment franciscans procedents del monestir de Sant Esperit (de la vall de Toliu, a Gilet). A més a més, durant llargues etapes, en les que no trobem enregistrat cap rector titular, s'encarrega plenament de l'administració dels oficis i de les inscripcions en el Quinque Libri, com a suplent o com a vicari, algun pare franciscà.

És significatiu el fet de que precisament, el primer rector de Serra i Nàquera que trobem en els Quinque Libri parroquials, des de que comencen els registres en l'any 1619 (deu anys desprès de l'expulsió) va ser el ja esmentat sacerdot d'origen morisc Jeroni Sastre (Garay, 2012: 329), que continuà fins al mes de maig de 1623. El va seguir durant un any Francesc Pérez (fins al juny del 1624) i després, sembla que per vacant o absència de titular, trobem com a "regent" un franciscà de Sant Esperit: Baltasar Artiaga, que seguí un any mes al càrrec de la parròquia i tornà a ocupar interinament el lloc en altres ocasions posteriors. Em crida l'atenció que, mentre que els titulars (rectors oficials) empren sempre la llengua castellana quan escriuen en els llibres parroquials (i habitualment amb valencianismes, que denoten que són persones valencianoparlants), en canvi, els franciscans fan generalment totes les inscripcions en valencià.

El fet de trobar-se freqüentment pares franciscans a Serra no és exclusiu del segle XVII sinó una qüestió llargament arrelada i que perdurarà llargament en el poble, on algunes persones majors encara recorden les freqüents visites i peregrinacions que es feien (fins als anys trenta del segle passat) des de Serra a Sant Esperit i en determinades ocasions; per exemple, quan anaven a confessar-se quadrilles d'homes, durant la Setmana Santa, o bé quan acudien en la festa de Sant Francesc (Santamarina i Bodí, 2014). Al llarg del segle XVII (i també del XVIII) trobem al Quinque Libri molts casos de serrans que en els seues testaments i darreres voluntats demanen ser enterrats vestint amb un hàbit franciscà. Al respecte, tinguem present que la Mare de Déu dels Àngels és la que representa la particular devoció mariana dels franciscans. ${ }^{22}$

En una visita pastoral de 1579, segons se cita en el volum quart del Quinque Libri de Serra (f. 111-114) se manava allargar el temple parroquial de Serra per a que caberen tots els feligresos, de set anys amunt, dels dos llocs (Serra i Ria), evitant així que alguns

\footnotetext{
22 Devoció lligada al somni de Sant Francesc d'Assís en que va veure a Maria amb el nen Jesús al braç i acompanyada d'uns àngels (açò donaria origen a la basílica de Porziuncola, on es va fer aquesta fundació, església mare dels franciscans)-
} 
d'ells hagueren de romandre al carrer per manca d'espai. En un altre expedient de visita pastoral, ara de 1619, Ambròs Cebrián (Lluch i Cebrián, 1935) va trobar una curiosa referència: que Serra només comptava amb 22 cases de cristians vells, havent-ne en elles 75 persones de confessió (majors de 7 anys) i d'aquestes 50 de comunió (majors de 10 anys), afegint que Ria està ja pràcticament despoblada.

Un segle desprès, la població de Serra (desapareguda ja Ria) havia crescut notablement i era necessari procedir a una nova ampliació o reconstrucció del temple. El dia 14 de maig de 1677 es va posar la primera pedra d'aquella obra, sent beneïda pel llicenciat Josep Tarrasa, rector de Godella, en presència del rector de Serra i Nàquera, que en aquell temps era Bartolomé Greses, qui malauradament moriria just 6 mesos després. En aquell temps era senyora de la baronia de Serra Teresa del Milà Mateu.

Aquell temple ampliat no és encara l'actual, sinó una part d'ell: tenia l'entrada pel la plaça de l'Església (l'actual porta lateral) i l'altar quedava recte al fons, on hui és la capella de la Mare de Déu del Carme. ${ }^{23}$

Les obres realitzades l'any 2003 permeteren trobar l'antic vas existent junt a aquella entrada. Aquest vas és un element important per a entendre determinats aspectes de les confraries, doncs va ser el destí de molts cossos de difunts al llarg del segle XVII i encara durant el XVIII i fins que es va prohibir a principis del XIX aquest costum de soterrar dins de les esglésies. Aquell vas, situat justament a l'entrada dels antics temples, es mantingué en ús dins del nou temple (l'actual) però ara separat de la porta principal.

\subsection{CONSTRUCCIÓ DEL NOU TEMPLE (FINALS DEL SEGLE XVIII).}

L'actual església es construiria un segle després que l'anterior i fent una notable ampliació d'aquella. Quan el pare Onofre Reig arribava a Serra per a fer-se càrrec de la parròquia, el 1784, observà que hi havia una gran manca d'espai en el temple, atès el gran creixement que havia experimentat la població al llarg de les darreres dècades, tal i com hem vist en el capítol quart. El rector Reig convocà els veïns per a estudiar el tema,

23 "Este templo, fabricado según la arquitectura y gusto antiguo, era seguramente muy capaz y proporcionado al número de vecinos, constaba de dos capillitas por bando y la Torre, con buenos ángulos de piedra sillar, o picada, y de lo mismo las basas de las pilastras. Tenía su Coro alto. Dos cubiertas o techos, el primero de bóveda pintada de flores, y el segundo de madera. La puerta de la Placeta era la única, el Tabernáculo y Altar Mayor estaba colocado donde hoy la Capilla del Santo Cristo y la pila Bautismal frente a esta Puerta; no era más grande su latitud regular. Estaba dedicada esta Iglesia a Nuestra Señora de los Ángeles" (nota inserida en "el Llibre de Fàbrica", de l'APS). 
tots coincidien en que calia construir una església molt més gran encara que aprofitant l'existent. Alguns veïns consideraven que era millor allargar l'església un poc cap a l'est, tot mantenint la porta d'accés on estava, en la plaça de l'Església; altres, en canvi, opinaren que seria millor allargar-la també cap a l'est però molt més, tot cobrint el carrer de Sant Josep; finalment, segons consta en el Llibre de Fàbrica parroquial, el rector Reig va proposar la solució que finalment es prengué, que consistia en comprar les cases que confrontaven amb l'església pel Sud i fer en aquest sentit l'ampliació, obrin una nova porta principal pel nord, en l'actual carrer de l'Església, tot i mantenint la porta de la plaça de l'Església com a segon accés.

El projecte del nou temple va ser encarregat a Francesc Pechuan, que el redactà tot rebent l'aprovació de l'Acadèmia de Sant Carles i de l'arquebisbe de València, que per aquell temps era Francesc Fabián y Fuero. Se li feia aquest encàrrec a Pechuan el mateix any 1784 en que acabava el seu grau acadèmic. Les obres començarien el $1789 \mathrm{i}$ serien beneïdes el 1795, encara que no conclourien definitivament fins a 1802 .

Aquest temple parroquial acusa l'empremta de les fórmules arquitectòniques desenvolupades per Gilabert (un dels mestres de Pechuan), amb la tradicional disposició barroca en creu llatina inscrita en un rectangle amb cúpula de mitja taronja en el creuer, capelles laterals comunicades entre sí i presbiteri pla, on a ambdós costats situa la capella de la comunió i la sagristia. A la part posterior del presbiteri disposà Pechuan un rerasagrari cobert també amb cúpula de mitja taronja sense tambor. Tanmateix, Pechuan tenia un enfocament diferent als pressupostos decoratius de Gilabert i va saber modular les superfícies murals fins a una pura expressió arquitectònica que dista elegantment de l'èmfasi excessivament delimitant i barroc de Gilabert.

En efecte, Pechuan dins de la pauta del moment evoluciona cap a un classicisme més sever que, a l'església de Serra, se resol en modular la nau amb un equilibrat ordre de pilastres jòniques de capitells amb volutes angulars unides per garlandes, d'ascendència romana i que sembla havien estat introduïdes a València pel pare Tosca a principis del segle XVIII. Pechuan cobria així una aspiració acadèmica de recuperar un lèxic eminentment classicista. ${ }^{24}$

Per a posar la primera pedra es va convidar al senyor de la baronia, Alons-Vicent de Solís i Folch de Cardona, duc de Montellano, però aquest, que residia a Madrid, va delegar en el seu apoderat, Pedro Verges, qui el va representar en aquell acte, celebrat el

\footnotetext{
${ }^{24}$ Sobre l'estil arquitectònic del temple de Serra i l'obra de l'autor veure l'article de Banyuls (1993).
} 
dia 10 de maig de 1789, amb assistència de Joan Val, rector d'Algímia, els pares franciscans Pere Melis “visitador de la Tercera Orde de Sant Esperit” i Antoni Aznar "de Vall de Jesús" i altres molts. Segons el rector Onofre Reig va ser aquell dia per a Serra "uno de los mayores de su júbilo, como acreditó la grande fiesta y abundante comida pública a todo vecino y forastero de que se llenó el lugar".

L'obra del temple va ser una enorme mostra de durs i continuats treballs personals i col·lectius de tots els serrans de l'època, fet possible per una extraordinària devoció i fervor, segons expressen els rectors de l'època que també treballarien dur alentant a la gent que sempre es mostrà disposada. Va ser una empresa que en la que posaren moltes il·lusions però també un inusitat sacrifici personal i d'algunes vides. Del treball personal en parlarem en posterior apartat. Seguint el llibre de fàbrica, escrit pel rector Tormo, trobem que les obres de la construcció, pròpiament dita, del temple parroquial, desprès d'onze durs anys de treball voluntari van concloure oficialment el 16 de juliol de 1800, any en que es va pintar també el frontal de l'edifici. No obstant això, els treballs d'ornamentació, complements, imatgeria i altres detalls, així com el mobiliari, no conclourien fins passar altres cinc anys.

L'esmentat dia 16 de juliol de 1800 va ser el designat per a celebrar oficialment la finalització de les obres, tot preveient l'assistència de nombrosos convidats i entre ells, com a personatge més destacat, la jove M. Vicenta de Solís, futura duquessa de Montellano (filla única del duc) i futura senyora de la baronia de Serra. Quatre dies abans, però, d'aquella data, una de les nobles dames assistents a l'acte, enmalaltí greument i va morir a Serra. La difunta era Tomasa Pasqual del Povil i Sannazar, comtessa (consort) de Castel-Rodrigo i, entre altres títols, princesa Pius de Saboia, pel seu matrimoni. Tan fatídic esdeveniment va ser aprofitat, per decisió familiar, per a que la tomba de "la princesa" fóra finalment disposada en el creuer de l'església, fent així honor al temple. Aquesta noble havia nascut a Alacant en desembre del 1754 i s'havia casat el $1772 \mathrm{amb}$ Antonio Valcárcel y Pío de Saboya, que es convertiria després en IX marqués de Castel-Rodrigo. Ella tenia, per tant, 45 anys i mig quan va morir a Serra. Aquesta notícia de la mort i posterior enterrament en el creuer del nou temple parroquial queda recollida en el Quinque Libri i va també ressenyada, per una aportació d'Ambròs Cebrián, dins la veu "Serra" de l'Enciclopèdia Universal Il-lustrada (Espasa-Calpe; any 1927): “En el crucero (del temple parroquial) está enterrada la princesa Pío, marquesa (sic.) de Castel-Rodrigo, fallecida en 1800”. Segons fonts orals, fent testimoni d'aquell 
sepulcre hi hagué, fins a les remodelacions posteriors a la darrera guerra civil, una gran llosa de pedra negra amb la corresponent inscripció.

En 1801 van ser estucats els sòcols i les pilastres de l'església. En 1802 va ser pintat el rerasagrari i la capelleta de la Comunió; també va ser posat el retaule de la Purísima, que va costar 100 lliures, pagades de les almoines que s'avien fet per a aquesta imatge; i el retaule de Sant Francesc el va costejar la Tercera Orde franciscana i el Crist el pagà la Fàbrica, costant cadascun 100 lliures. En 1803 van ser posats els bancs, que costaren també 100 lliures; es va dur també la imatge de la Mare de Déu dels Dolors, que costà 130 pesos i 18 les andes; aquesta imatge la va esculpir l'escultor Francesc Pérez, deixeble de Josep Esteve Bonet, qui ja havia fet personalment el Nen poc abans de morir. Aquesta imatge va ser portada pels mossos de Serra des de València en andes "en un domingo de invierno, el más frío y tempestuoso". També va ser Josep Esteve Bonet (1741-1802) l'autor de la imatge de la patrona, la Mare de Déu dels Àngels, obra destacada del famós escultor, la qual es perdé durant el incendi del temple parroquial de 1933, que es va originar per un curtcircuit elèctric. ${ }^{25}$

El retaule major, el preu del qual s'ajustà per 950 pesos, no va poder ser acabat fins a 1805, any en que també es va pintar el sagrari (tabernacle) i s'incorporà al temple el Salvador, que costà 175 lliures i va ser obra de Vicent Lluc. Amb tot açò va culminar definitivament el temple amb tota la seua esplendor.

\subsection{REPARTIMENT DE TREBALL COMUNAL I "FATIGUES” DELS SERRANS}

En els més de deu anys que trigaren en ser executades les obres del temple parroquial, els veïns de Serra, a més d'aportar braços i nombrosos jornals voluntaris dels homes, aportaren també l'esforç de tot el poble (amb dones i xiquets) que es va abocar transportant materials, fent col·lectes, recollint almoines, elaborant productes per a la venda, etc. Com hem dit adés, un enorme esforç voluntari digne de ser ben recordat.

Potser la condició al final de la clàusula tretzena de la Carta Pobla de Serra i Ria, en el sentit d'estar els vassall obligats a fer-se càrrec de les reparacions de la sèquia del

\footnotetext{
25 Segons nota d'Ambròs Cebrián (en Cebrián i Lluch, 1935) el dia 18 de juny de 1933 es va declarar l'incendi per un curtcircuit elèctric, que destruí l'altar major i la imatge de la Mare de Déu. L'escultor Josep $\mathrm{M}^{\mathrm{a}}$ Ponsoda Bravo va fer la nova imatge idèntica a l'anterior, però seria destruïda durant la guerra.
} 
molí i el seu assut, posant el senyor "mestre i calç" i els vassalls tota la resta, o bé algun altre costum comunal aportat a Serra pels repobladors, pogué ser l'origen de les derrames de mà d'obra gratuïtes per a la realització de treballs comunals. Es tracta d'un costum molt arrelat que no solament trobem reflectit durant la construcció del temple parroquial, en les darreres dècades del XVIII i principis del XIX, sinó que tornarem a trobar-lo en la construcció dels calvaris de Serra i molt desprès encara, amb el nom "fatigues" són encara recordats els treballs voluntaris llargament aplicats fins a finals del segle XX (anys setanta) per al manteniment dels camins i sendes rurals: eren treballs de repartiment de tasques, on cada propietari havia de dedicar a l'any cert nombre de jornals (proporcionalment a l'extensió de les seues propietats) per a la reparació i conservació de camins i sendes comunals, o altres infraestructures comuns, com les sèquies, i qui no volia treballar-los havia de pagar dits jornals per a que es pogueren contractar a altres que ho feren per ells.

Però també hem trobat referències a les "fatigues" dels serrans en la relació de comptes de fäbrica de Serra de l'any 1769, que el rector parroquial, Joan Baptista Costa, rendeix i remet, amb còpia a la Seu arquebisbal, atenent així un "Reial Acord de la Ciutat", de 4 d'abril de 1769, que exigeix aquesta mena de comptes a tots els rectors fabriquers i Juntes d'Electes de totes les esglésies parroquials de l'arquebisbat de València. El rector, a més del detall de tots els càrrecs recollits, any per any, en el quinquenni de 1764 a 1768 , on destaquen els ingressos per arrendament de terres de la parròquia, fruits dels arbres que no estan arrendats, almoines que es feren cada any, la primícia, etc.; i confronta açò amb les despeses, entre les quals està els delmes pagats, la còngrua per al sosteniment del rector i el manteniment d'una haca que utilitza per a anar al seu annexe Nàquera. A més explica que disposa d'un obrer que cada any nomena conjuntament el rector i l'ajuntament per a fer i coordinar treballs de construcció, generalment extraordinaris, com són la caiguda d'algun mur i teulat de l'església, reparació de caixons que ja estan vells, parets del cementeri, etc. Per a fer aquest treball "ni el dicho obrero ni demás parroquianos gastan de su casa y propios caudales ningún dinero, ni se haze ningún repartimiento", segons es estil i costum immemorial, conclou. Signen el certificat de comptes el rector, el Justícia de Serra, Baptista Domènech i "por los fatigueros el fiel de fechos" que era l'escrivà Miquel Conejos. ${ }^{26}$

${ }^{26} \mathrm{ACV}, \lg .4689$, f. $35 \mathrm{r}^{\circ}$. 
El que també ens queda clar és que l'arrendament de les terres de l'esglèsia era habitual i les feia una Junta de la Fàbrica de l'Església de Serra molts anys abans de començar a ser construït el nou temple. Així, en 1777 sabem que es van arrendar dites terres (16 fanecades d'horta de moreres, altres 2 d'horta i una petita porció de secà) a 6 veïns de Serra per 4 anys i preu global de 70 lliures. ${ }^{27}$

En la fabricació de les campanes de la torre, en l'any 1780, participaren els veïns de Serra Vicent Arnal, Baltasar Sanchis, Jeroni Romero i Llorenç Garay, que aquell any li devien a Bertomeu Ros 67 lliures amb 11 sous i 4 diners "pel metall que els vengué a fiat per a les campanes de la torre de l'església". ${ }^{28}$

Tornant a la construcció del temple de Serra, cal dir que la primera pedra es va posar (en 1789, recordem) sota el tabernacle de l'altar major, però, quan començaren a excavar per afermar i fonamentar els ciments es trobaren amb la dura sorpresa que el substrat rocós ferm es trobava a més de 20 pams de profunditat en la part de llevant. Desprès de feta l'excavació calia omplir fonaments, i diu el retor Tormo que tot el poble aportava materials però tot pareixia escàs per a omplir el fonament; fins i tot s'aportaren grans pedres de fins a 200 arroves que en arrossegades, fins a quedar sepultades, amb una galera de Portaceli. Tot seguit afegeix:

"Como esto era en los principios, todo se hacía con fervor y nada cansaba, pero ¿con qué fondos se dio principio a obra tan costosa?. No reconozco otros que la Providencia de Dios Nuestro Señor, y la caridad de los fieles. El Señor del Lugar debiera tomar esta Obra bajo su protección; mas los procuradores no siempre son animados del espiritu de caridad que su (principal), y los beneficios de éstos bajan a los vasallos a medida de la voluntad de aquéllos. Pero no se entibie el fervor ni falte la Unión en el Pueblo, que nada importa. Hace el cura sus pláticas y anima al Pueblo; nada menos hacen los Padres de Santo Espíritu, particularmente el Padre Domingo Pérez, y el P. Pedro Melis. El cura no deja arbitrio que no se valga; compra y reparte cáñamo, las mujeres hilan, se fabrican y venden telas. Se pide en el horno y lugar limosna para la fábrica. La dan los vecinos abundante en tiempo de cosecha de los principales frutos; pero la mejor limosna es la seda. El cura reparte simiente de Capullo verde y aunque hay tan poca hoja en el término, hace la fábrica la más grande de sus limosnas habiendo pasado algún año de 50 libras de seda fina, no llegando ningún vecino a 30 de cosecha propia, lo que advierto para que el cura cuide no se pierda este arbitrio en lo sucesivo, y la Iglesia tenga este producto en sus necesidades, no fiándole

\footnotetext{
27 ARV, lg. 3625; data 8/06/1777.
}

8 ARV, lg. 3627. 
nadie el cuidado de sacar la simiente, y sobre todo de repartirla a las casas por el mes de marzo con su prudencia y buen celo; porque si esto se deja al cuidado de otro que del cura, podrá perderse. Tanto pues importa su asistencia en esta como en las demás limosnas añales de otros frutos". ${ }^{29}$

Amb les anteriors paraules, el rector deixa constància de que la construcció del temple és una obra popular i gens o molt escassament recolzada, econòmicament, pel Senyor de la Baronia. És, doncs, el fruit d'un admirable fervor popular al qual s'abocaren decididament els serrans.

Passem a l'any 1893: el rector de Serra, Manel Portaña, parlant de la construcció del nou calvari (inaugurat en 1893) fa també referència a la llarga tradició del treball voluntari dels serrans per a fer possibles importants obres pies. En aquest cas, el rector comenta que en la construcció d'aquest calvari participaren moltes famílies, les més acomodades, costejant els casilicis, que recolliren els noms de les famílies que els costejaren, però seguidament afegeix que "hubo muchos pobres que, no obstante no estar sus nombres puestos en el calvario, si les hubiera de haber pagado su trabajo hubiese ascendido a muchos duros, sus nombres no los olvida el Señor". Fins els xiquets participaven, doncs, en el llibre de comptes consta que en els quatre anys que duraren les obres se gastaren més de 30 duros en comprar estampetes per tal de tindre'ls contents i regalar-les als xiquets que acudien a transportar terra d'una andana a l'altra.

Encara en temps recents, el cinema d'hivern i el cinema d'estiu i trinquet de pilota van ser també grans obres comuns (en aquests cas propietat de l'església) construïts per aquest sistema de fadigues en les primers dècades del franquisme (Senís, 1978 i Santamarina i Bodí, 2012).

\subsection{CREACIÓ DE LA CONFRARIA DE LA VERGE DELS ÀNGELS (SEGLE XVII).}

Un fet notable de la vida religiosa dels serrans del segle XVII va ser la fundació $i$ constitució de la Confraria de Nostra Senyora dels Àngels. La data que sembla oficial de la constitució de la confraria és 1698, any en que comença el llibre dels Confrares de Nostra Senyora dels Àngels (APS), recollint en ell la següent acta constituent:

En 27 de julio del año 1698 se juntaron lo Rector y vecinos del lugar de Serra en la Iglesia de dicho lugar y concordaron todos el poner en uso y en execución la Cofadría

\footnotetext{
${ }^{29}$ Llibre de fábrica, escrit pel rector Francesc Tormo en 1806 (Annex VI).
} 
de $N^{a} S^{a}$ de lo Ángeles, y se inscribieros cofrades pagando cada vecino un dieciocheno de entrada por cada familia y constituyeron que en adelante los que quisieran entrar cofrades pagasen de entrada un tres y ocheno. Los de la Junta fueron Mossén Gaspar Sellés, presbitero, Bautista Doménech, Bayle, Lorenzo Navarro, Justicia, Jayme Pérez, Jurado mayor, Martín Romero, Jurado menor, Estevan Rubio, Mayordon(¿??), Domingo Moreno, Macià Cabo, Pedro Garay, Francisco Romero, Vicent Arnal, Domingo Pérz, Christóbal Rubio, Juan Navarro, Bautista Català, Pere Joan Navarro, Jusepe Rubio, Jusepe Cabo, Batista Ros. En fe d lo qual lo firmo yo el dicho R., en dicho día, mes y año. $\mathrm{M}^{\mathrm{n}}$ Gaspar Sellés, retor de Serra i Nàquera.

És indubtable, però, que degué haver-hi una fundació anterior de la Confraria, almenys de l'any 1676, si no prou anterior, doncs d'aquell data la butlla papal per la qual són donades certes indulgències als membres d'aquesta Confraria de la Mare de Déu dels Àngels del poble de Serra. El papa Clement X va signar la seua butlla o Breu, de concessió d'indulgències en favor dels confrares de Serra, el dia 22 de febrer de 1676. Quatre mesos desprès moria aquest Papa de fructífer pontificat, sent succeït per Innocenci XI. El text de la butlla ve recollit en escrits que es conserven a l'APS.

La Santa Croada va dictar més tard la suspensió d'aquesta i moltes altres concessions semblants, inclosa la butlla de la Santa Croada, per la qual també Clement X havia concedit indulgències als portadors de corones, rosaris, imatges, creus i medalles que hagueren estat beneïdes amb ocasió de la canonització dels sants confessors Caietà, Francesc de Borja, Felip Benici, Lluís Bertran i Santa Rosa de Lima (verge de Perú).

El 1682, però, l'Arquebisbe Reial i Comissari General de la Santa Croada, des de Madrid, alçava totes aquestes suspensions anteriors de la Santa Croada, validant de nou, entre altres, la concessió pontifícia del poble de Serra. D'aquesta manera, mitjançant un escrit de data 29 de juliol de 1683, que reproduïm en l'apèndix documental d'aquesta Tesi, en que es dóna fe i raó de quines eren les indulgències concedides a Serra.

No tenim del tot clares les circumstàncies o raons per les quals va ser concedida expressament a Serra aquesta butlla, però, més bé que els franciscans potser serien els cartoixans els que gestionarien o mitjançarien per a que el Papa Clement X l'atorgara a la parròquia de Serra. Diem açò per una sèrie d'indicis o casualitats: si mirem altres butlles del mateix papa trobarem que en son diverses les que tenen relació amb els cartoixans i, més concretament, amb la Cartoixa de Portaceli que, no oblidem, va ser durant segles un gran centre de poder i influència en assumptes tant terrenals com espirituals. ${ }^{30}$

\footnotetext{
${ }^{30}$ Garay, 2004: 7.
} 
Així, el 12 de maig de 1675, Clement X havia signat una indulgència per a l'orde dels Cartoixants: Concessio indulgentiarum sacri anni iubilaei MDCLXXV per Sanctissimum D. Clementem Papam X sacro Ordini Carthusianorum, mitjançant la qual, eren concedides certes indulgències a aquells cartoixans que durant quinze dies seguits freqüentaren quatre altars cartoixans diferents; aquestes visites no deixaven de tindre el seu mèrit, tenint en compte els modes de retir i aïllament d'aquests frares. Anteriorment, el mateix Papa havia canonitzat a Sant Lluís Beltran (12 d'abril de 1671), un sant valencià ben conegut en el monestir de Portaceli.

Malgrat la butlla de Clement X de 1676 i la data de creació de la confraria en 1698, hi ha raons fonamentades per considerar que la confraria de la Mare de Déu dels Àngels existira ja en la primera meitat del segle XVII. De fet, la constitució feta en 1698 està clar que és una refundació o reconstrucció de la confraria desprès d'alguns anys d'inactivitat. Per altra part, hi ha constància a l'APS que hi hagué també a Serra una altra confraria anomenada del Santíssim Sagrament i que va ser creada el 3 d'octubre de 1658.

Tornant al punt anterior i observant amb detall els assentaments $\mathrm{i}$ despeses (càrrecs i descàrrecs) de l'esmentat llibre de la confraria de la Mare de Déu dels Àngel, al llarg del segle XVIII, trobem que són conformes amb el propi títol del llibre, que és: “Libro de los Cofrades de Nuestra Señora de los Ángeles y de los derechos a fábricas y sepulturas, y de los censales y arrendamientos de la Iglesia de Serra". O siga, que una de les missions o objectius principals d'aquesta confraria sembla clar que era la de donar assistència als difunts i familiars dels difunts, honrant-los en els sepelis i complint les seues darreres voluntats que, a sovint, passaven per rebre sepultura en un lloc determinat (com el vas de l'església) i freqüentment amortallats amb determinats hàbits, com el de Sant Francesc. Trobem que aquesta pràctica era freqüent a Serra, al menys des de principis dels anys vint del segle XVII. Recollim, al respecte, una breu selecció de casos trets del primer volum del Quinque Libri):

- Miquel Sáez morí el 22 de febrer de $1623 \ldots$ deixà una novena amb assistència d'un religiós "según se acostumbra en las Alcublas", amb ofrenes de pa i de vi i cera de sa casa... Va ser enterrat en el vas de l'església amb llicència oficial... Deixà per a l'església un llegat de 12 lliures: 10 per a daurar el sagrari i les altres 2 per a una creu a l'altar conforme al manament de la visita pastoral (potser la de 1619?).

- Pere Navarro, marit de Vicenta Donya, morí el 8 de novembre de 1637. Rebé tots els sagraments i "lo enterré en el cimenterio de Serra, con tres misas cantadas, de cuerpo presente". Havia fet testament, pel qual deixava per a la seua ànima 12 lliures, nomenant per marmessor sa muller. 
- Francesca Cavaller, fadrina (i germana del rector titular, Domingo Cavaller), morí el 21 de maig de 1638. Rebé tots els sagraments "los cuales le administré yo". Fou enterrada en el vas de l'església de Serra, amb tres misses cantades acostumades, de cos present i amb l'assistència d'un religiós de Sant Francesc... En ser pobra, el seu germà aportà 10 lliures per la seua ànima $i$ les despeses.

- Baptista Domènech morí el 24 de juliol de 1647 amb tots els sagraments... Deixà per la seua ànima 100 ducats i aquesta disposició: "que quiere ser enterrado en Santo Espiritu" i deixà, a més a més, llegat de 5 lliures per a un frontal a l'església de Serra.

- Isabel Mànyez, muller que fou de Miquel Èpila, morí el 27 de juliol de 1669 havent disposat en el seu testament que "el dia de su entierro se cantasen dos misas amortajando su cuerpo con el hábito d San Francisco".

- Pere Garay morí per malaltia el dia 1 de juliol de 1702, i fou enterrat en el vas de l'església amb hàbit de Sant Francesc del convent de Sant Diego d'Alfara, amb assistència de tres religiosos d'aquest convent.

- Joan Arnal morí d'una escopetada el dia 11 de maig de 1707 i "quiso fuese su cuerpo enterrado con el hábito de San Francisco, de los Capuchinos de la Madalena, lo qual no se pudo hacer por haver soldados en la tierra y no haver ningún hombre que se atreviese a ir por el hábito".

El sosteniment $\mathrm{i}$ funcionament de la confraria queda més o menys explicat $\mathrm{i}$ justificat analitzant la relació de "comptes de l'obreria del lloc de Serra" (QUADRE 8.3) que aquell mateix any de la refundació (any 1698) fa el nou Obrer electe, Josep Rubio. Observem que els ingressos o "càrrecs" abasten el producte dels arrendaments de les terres de l'església, mentre que les despeses o "descàrrecs" inclouen partides que, en principi no semblen pròpies o exclusives de la confraria, essent-ho més del conjunt de l'església i el seu manteniment i ornat. Aquest “Obrer de l'església" havia rebut del seu antecessor en el càrrec els comptes de l'exercici anterior, del mateix mode que ell passava ara els presents comptes al que seria el seu successor, Domingo Pérez.

D'aquests comptes resta un balanç positiu de 14 lliures, 11 sous i 9 diners, que seria el import o "alcance" que l'Obrer li passaria al seu successor. En quant a les diferents referències que es fa a un monument $\mathrm{i}$ les despeses relatives a millorar aspectes del temple (nova corda de campana, calç, manteniment de la llanterna, etc) tot fa indicar que la confraria començava novament amb força i efecte, i una de les despeses fetes és, precisament, per a comprar (per 10 sous) el llibre de la confraria, el mateix que hem consultat en l'APS per a traure aquestes notes. 
QUADRE 8.3.- Comptes que fa Josep Rubio, com Obrador de l'església de Serra, per a l'any 1698, al seu successor, Domingo Pérez.

\begin{tabular}{|c|c|}
\hline \multicolumn{2}{|l|}{ CÀRREC } \\
\hline Conceptes & Quantitat ingressada \\
\hline El Alcance de su antecesor, Bautista Ros & $22 L-s 9 d$ \\
\hline ..Del arrendamiento de las tirras de la Iglesia & $31 \mathrm{~L} 8 \mathrm{~s}-\mathrm{d}$ \\
\hline ..De las limosnas que se recogieron en el horno & $15 \mathrm{~L} 2 \mathrm{~s} 2 \mathrm{~d}$ \\
\hline ..Por la fábrica de Madalena Èpila (defunció) & $1 \mathrm{~L}-\mathrm{s}-\mathrm{d}$ \\
\hline ..De la fábrica de un albat de Tomàs Català & $-\mathrm{L} 10 \mathrm{~s}-\mathrm{d}$ \\
\hline ..Cera, se recogió para el monumento & $2 \mathrm{~L} 7 \mathrm{~s}-\mathrm{d}$ \\
\hline ..De los cofrades que se ajuntaron a $N^{a} S^{a}$ de los Ángeles & $1 \mathrm{~L} 15 \mathrm{~s} 3 \mathrm{~d}$ \\
\hline .De la limosna del trigo & $2 \mathrm{~L} 9 \mathrm{~s}-\mathrm{d}$ \\
\hline ..De les garrofes de la Iglesia & $-\mathrm{L} 13 \mathrm{~s}-\mathrm{d}$ \\
\hline ..Del aforro de la capa d la Iglesia & $-\mathrm{L} 12 \mathrm{~s} 12 \mathrm{~d}$ \\
\hline ..Se sacó del Sepillo & $-\mathrm{L} 4 \mathrm{~s} 4 \mathrm{~d}$ \\
\hline
\end{tabular}

Todo el CARGO: $\quad$ 78L 1s $6 \mathrm{~d}$

\section{DESCÀRREC}

Conceptes

Quantitat ingressada

...Seis@ de aceyte en el curso del año para lámpara del Santísimo

..Cera y insienso en el discurso del año, para la Iglesia

$11 \mathrm{~L} 8 \mathrm{~s}-\mathrm{d}$

..De aliñar la llanterna

..Palmes, agulles claus y recado... tres papeles para el monumento $24 \mathrm{~L} 18 \mathrm{~s}-\mathrm{d}$

..Se va Singulo Blanco

L $3 \mathrm{~s}-\mathrm{d}$

..De los olores para el monumento

$1 \mathrm{~L} 13 \mathrm{~s} 6 \mathrm{~d}$

.De los ramilletes

.Del gasto de los óleos sanctos

$-\mathrm{L} 6 \mathrm{~s}-\mathrm{d}$

..Cal para la Iglesia

$1 \mathrm{~L} 9 \mathrm{~s} 2 \mathrm{~d}$

..Corda de les campanes

L $8 \mathrm{~s}-\mathrm{d}$

..Paga al fuster dels frontals del niño de su noche y el frontal mayor ...y de aliñar atre frontal y el Sagrari y xxx claus de palo

\begin{tabular}{|l|c|}
\hline.. De aliñar dos albes & \\
\hline.. Salario del lumbrero & $2 \mathrm{~L} 10 \mathrm{~s}$ \\
\hline.. Pago de siete misereres al reverendo & $-\mathrm{L} 10 \mathrm{~s} 6 \mathrm{~d}$ \\
\hline..$D e$ 52 misses y salves al $R^{d o}$, a 5 s, són & $13 \mathrm{~L}$ \\
\hline.. De pasar las cuentas al Retor & \\
\hline.. De un llibre nou & -L $10 \mathrm{~s}-\mathrm{d}$ \\
\hline
\end{tabular}

Todo el DESCARGO:

$1 \mathrm{~L} 5 \mathrm{~s} 2 \mathrm{~d}$

$1 \mathrm{~L} 16 \mathrm{~s} 6 \mathrm{~d}$

-L $6 \mathrm{~s}-\mathrm{d}$

3L 5s 4d

63L 9s 9d

Font: Llibre de la cofraria de la Verge dels Àngels (APS). 
Si tal com hem dit, la de 1698 va ser una refundació de la confraria, no seria l'última. Al menys hi trobem evidència d'una altra refundació ocorreguda en 1822, en ple trienni lliberal, la qual ve citada al mateix llibre amb un nou llistat de confrares i el següent encapçalament:

Memoria de los cofrades que se alistaron en la Cofradia de $N^{a} S^{a}$ de los Ángeles en el año 1822, cuya Cofradia, olvidada muchos años, la publicó el nuevo Dr José Vicente Durá, Rector de esta Parroquia. Por este año y para fomentar la devoción, no se exigió de ningún cofrade limosna alguna en el acto de su alistamiento. ${ }^{31}$

\subsection{CEMENTERIS, CALVARIS I L'ERMITA.}

En la primera defunció del Quinque libri s'indica que el difunt, Joan Guillem, que morí sobtadament el dia 21 de febrer de 1620, hagué de ser enterrat en el cementeri de Nàquera per no estar encara beneït el de Serra. Senís (1954) recull aquesta notícia i també indica que aquell cementeri estava situat junt a l'església, en l'actual plaça de la Constitució, fins que va ser construït un nou cementeri prop de l'Era Alta en l'any 1816, fent-se el primer enterrament en ell el dia 11 d'agost d'aquell any. Posteriorment es construiria l'actual en l'any 1901.

A banda, però, del cementeri (referit generalment com a fossar al llarg del Quinque Libri dels primer segles) hi havia a Serra el vas de l'església, on eren enterrats els clavaris o les persones que pagaven o oferien un diners per la fàbrica. Aquest vas, situat antigament sota la mateixa porta d'accés al temple (avui la porta lateral que dona a la plaça de l'Esglèsia, des de l'any 1800) va ser trobat fortuïtament durant les obres realitzades en el paviment del temple l'any 2003. Vaig tindre l'oportunitat d'examinar aquell espai i alçar un croquis, tot posant de manifest que es tracta d'un soterrani de base $2 \times 1$ x metres i un nivell de culminació situat a 1'8 metres per sota la superfície actual del paviment de l'església. Aquest nivell de culminació és el dels enterraments que degueren fer-se fins als primers anys de segle XIX, fins que van ser prohibits els enterraments dins de les esglésies. Mitjançant els llibres parroquials serà possible fer una relació dels cossos dipositats en aquell vas, tasca que per ara no hem abordat. En tot cas,

31 APS, Libro de los Cofrades de Nuestra Señora de los Ángeles y de los derechos a fábricas y sepulturas, y de los censales y arrendamientos de la Iglesia de Serra. 
desconeixem la profunditat inicial del vas. El lloc va quedar perfectament identificat i cobert amb una gruixuda làmina de vidre que permetria, si arribara el moment, poder fer una excavació i un estudi arqueològic adients.

A partir del primer cementeri (on avui hi és la plaça de la Constitució i el carrer de la Mare de Déu dels Àngels) i seguint vessant amunt per l'actual carrer del Dr. Ros, estigué el primer calvari, construït el 1620 (Senís, 1954). L’expansió, però, de la població va obligar a traslladar-lo cap al carrer de les Eres on començava. Segons una nota escrita pel rector Jaume Sanchis Palop en el Quinque Libri (llibre de casaments, any 1746) aquell calvari va ser acabat de construir de pedra i morter durant la quaresma del 1744. Senís (1954), que també refereix aquesta nota, indica que algunes casetes o casilicis van quedar incorporades en les cases i murs dels carres que avui formen aquest sector.

En la seua "Nota del Calvario de Serra", el rector Francisco Tormo Vidal fa relació de com va ell plantejar i vetllar per a que el calvari de Serra fóra una realitat al temps que s'estava acabant de construir el temple parroquial amb el sacrificat treball de diverses dècades dels serrans. Diu que el poble tenia un calvari molt modest, format per creus de fusta, però que en 1748 un pare franciscà que vingué a predicar la Quaresma animà el poble $\mathrm{i}$, en lloc de les creus construïren catorze casetes de pedra "de poco gusto e inferior material".

Ocupat el poble en la fàbrica de l'església no es pensava, però, en el calvari que, entre tant anava quedant malmès i molt derruïdes les casetes, mentre que el poble creixia i anava estretint el terreny. Sembla que tampoc no es reconstruïa fent despeses perquè ja sen havia parlat, feia molt de temps, de la possibilitat de construir un nou calvari més còmode i desplaçat cap al voltant de l'Era Alta. ${ }^{32}$

Novament van ser els pares franciscans de Sant Esperit, i especialment el pare Josep Garcia, durant la missió que realitzaren a Serra en 1803, els qui suggeriren i van fer veure la necessitat que Serra tinguera un calvari en condicions. I així va ser com el rector, segons ell mateixa afirma, va prendre la determinació de construir el Calvari a l'Era Alta, desprès de meditar els inconvenients que aquells que havien treballat en l'obra de l'església posaren per mantenir-lo en la muntanya on estava. I afegeix el rector que allí es va mamprendre l'obra però sense que li mancara contradicció, perquè: "parte de dicha montaña y terreno ya lo habían establecido para casas, ya había cimientos y ya iban a cerrar la subida a dicha montaña; pero llegado el cura a tiempo (que fue permisión de

\footnotetext{
${ }^{32}$ (APS, Libro de Cuenta i Razon de la Obra i fabrica de la Yglesia de Serra; any 1806).
} 
Dios) y acordando lo antiguo, lo inmemorial del sitio del Calvario etcétera, dejaron el terreno expedito".

L'obra degué ser realment dura perquè -segons escriu el rector- es tractava d'una muntanya escarpada $\mathrm{i}$ amb unes sendes entre la malesa, però "reunits els diumenges $i$ festes el poble, arrancant penyals i sota la direcció del rector" acabarien sent traçats els carrerons i els ribassos. A continuació, el rector expressa clarament com va viure i sentir l'obra:

"Pensé al principio hacer las paredes de cal y canto, pero no ha podido ser ahora ni tampoco hacerse con la mayor perfección por ser obra de tantas manos. Luego que estuvieron los ribazos, se emprendieron las casitas y, si no tienen más gusto es por falta del albañil. La construcción y casitas se distribuyeron entre vecinos pudientes, es decir, dar comer al albañil y servir de peón, que el jornal y materiales es de la Iglesia y, aún de esta manera han contribuido pocos; pero el afán y trabajo grande del cura todo lo ha suplido, de modo que el Calvario es obra del Cura, porque los señores alcaldes han hecho tan poco en esta parte, que rara vez, sino por curiosidad se les ha visto en dicha maniobra".

El toc i remat del rector va ser que, en lloc de plantar xiprers o altres arbres decidí plantar-ne moreres, que "con la bondad del terreno y en poco más de un año han tomado gran incremento". Amb elles esperava que, amb la cura dels seus successors, hi hauria gran goig i profit en pocs anys. La justificació de per què no va plantar xiprers la deixa també clarament escrita: "Sé muy bien que en los calvarios suelen plantarse cipreses, mas decía un señor Obispo que de estos árboles no debía haber sino uno en el mundo para que se supiese que tal árbol había, porque no dan fruto alguno".

L'Ermita de Sant Josep i la Creu, que és l'actual que trobem a la part alta del Calvari i molt prop de la Torre medieval avui coneguda com torre del Calvari o de l'Ermita (desconeixem quin seria el seu topònim anterior al segle XIX) no seria edificada fins la darrera dècada del segle XIX, però tingué en aquesta època un intent precursor. El rector Tormo parla d'una excavació que s'havia fet a la part alta del calvari per a construir una "capella que devia tindre la seua façana com d'Ermita". En ella devia ser posat, quan estiguera en condicions, "el Crist pintat que estava en la sagristia" i, finalment, desprès de destacar també el decent i divertir passeig que suposaria seguir el calvari fins arribar a l'ermita, el rector expressava de la següent manera, tan eloqüent, la seua esperança per a l'ús d'aquest espai de devoció: 
"Fecho todo bendígase, y el cura los domingos y fiestas por la tarde puede reunir la gente en la Yglesia y luego en procesión, cantando el rosario, subir al calvario y concluidos los Pasos, arriba, acomodada la gente en aquella plaza, y bancos que puede haber, el cura... puede hacer su plática. Y seguramente acudirán más que a la Yglesia por el buen estar, comodidad y conveniencias, y no se excusarán en el verano con el calor y pulgas".

El cert és que encara s'havia de construir un nou calvari prolongant aquell de principis del segle XIX. Aquest quart, definitiu i actual calvari seria oficialment obert $\mathrm{i}$ beneït el 10 d'abril de 1893, sent rector parroquial Manel Portaña (Senís, 1954). L'ermita de Sant Josep i la Creu va ser construïda pels mateixos anys.

No tots els difunts de Serra, però, foren enterrats en sagrat, en el cementeri o en el vas de l'església. Hi hagué també algú que renegà del rituals oficials i acabà sent excomunicat o enterrat en lloc fora de sagrat. Així, en el primer volum del Quinque Libri, hi trobem un sol cas: Tomàs Casànada, de Morella, habitant a Serra, va ser “descomulgat" perquè no es va confessar ni comulgà dins el temps senyalat pel concili i sínode diocesà, havent sigut advertit en 14 de juny, en 20 de juny i en 28 juny...

També ens resulta expressiu el cas d'un impiu que, desprès d'insistents esforços per part de mossèn Vicent Segarra (rector parroquial entre 1727 i 1742) i d'altres persones notables de la població "per a fer-lo entrar en raó" va morir sense haver acceptat ser confessat ni voler rebre els sagraments, essent tot això causa i trastorn que motivà la decisió final d'enterrar-lo en un lloc allunyat del poble. Senís (1978: 61) ho explica de la següent manera:

"El 11 de marzo de 1739, ocurrió un hecho insólito que no conocemos se haya repetido en Serra, Y es la muerte de un impio de 90 años de edad, viudo y forastero por cierto, que falleció sin querer confesar ni comulgar, pese a las exhortaciones que en presencia del Alcalde y del cirujano del Lugar le hizo el Cura y un fraile de Santo Espiritu que a la sazón se encontraba en Náquera y al que se invitó a venir a Serra con dicho exclusivo objeto, llegando incluso el cirujano a hacerle varias pruebas por ver si es que no estaba en su sano juicio. Hubo que consultar con las autoridades de Valencia, quienes prohibieron su sepultura en sagrado, por lo que careciendo de cementerio civil fue enterrado en un barranco de la partida de Alcalá".

Però el text complet que recull el Quinque Libri, també transcrit per Ferran Martínez Navarro (Pérez Casado et al., 1992: 71 i 72), tot el que transmet és la 
resistència d'un home a l'administració d'un ritual religiós que no està disposat a acceptar per la força. Realment, a més de la seua indevoció en els darrers moments de la seua vida, el que diu contra ell el rector és que va ser sempre molt pervers per haver estat tota la vida jurant i blasfemant, i tan indevot que quan tocaven a missa els dies festius se'n anava i, per a fer-lo confessar per la quaresma era menester, cada any renyir amb ell. Aquests comentaris del rector Segarra venen a demostrar el caràcter pràcticament obligatori que tenia la religió i la pràctica religiosa, i com, al menys una vegada a l'any, per la quaresma, era obligatori que tots els homes es confessaren. Açò explica la tradició, encara recordada en els anys 50 del segle XX, d'anar tots els anys (per a quaresma) una gran quadrilla d'homes de Serra a confessar-se a Sant Esperit (lluny de l'enteniment del rector parroquial de Serra). Aquest costum el tenien també els homes d'Olocau (comunicació personal de Ferran Zurriaga), que anaven, per la mateixa raó i tradició, a confessar-se fins a Sant Esperit, quan no a Portaceli. I tanmateix els de Nàquera, en ple segle XX i quan no hi anaven a confessar-se als pares franciscans de l'església de Sant Llorenç (comunicació personal d'Alexandre Navarro).

\subsection{MORALITAT EN TEMPS DE L'ARQUEBISBE MAYORAL}

Un dels textos més llargs que trobem escrits en els llibres parroquials de Serra és, més enllà d'una simple visita pastoral, el que correspon i acompanya a una Reial Ordre i Provisió de data 16 d'octubre de 1758 i un posterior i consegüent Decret d'Andreu Mayoral, arquebisbe de València, decret que es titula "Sobre otorgados". Allò que més crida l'atenció d'aquestes disposicions és, per una part, la gran importància concedida tant per l'arquebisbe com pel rei Ferran VI a aquest assumpte tan concret de moralitat, com és el dels "atorgats" i, per altra part, la insistència moral i la càrrega sancionadora abocades en aquest decret, que més enllà de ser una qüestió simplement moral i de caire religiosa es converteix en un assumpte de govern per al qual l'administració reial, a petició de l'arquebisbe (cal dir també), va preveure la imposició de severes càrregues penals als infractors i també a les autoritats (municipals, reials o eclesiàstiques) que per passivitat consentiren aquests "atorgaments".

El text sobre "otorgados" ocupa setze denses pàgines del volum II del Quinque Libri de Serra, justament abans del llibre de difunts d'aquest segon volum que abasta el 
període de 1710 a 1758. Comença amb una Reial Provisió de Ferran VI, de 16 d'octubre de 1758, sobre els atorgats, la qual utilitza com a pròleg les paraules del Fiscal de la Cort on diu que malgrat les diferents ordres expedides a les Justícies de tot el Regne $\mathrm{i}$ altres providències que s'han adoptat per a contenir el detestable abús d'aquell tracte familiar que amb el nom de galanteo tenen entre si els atorgats abans del matrimoni, res no ha sigut suficient per a moderar aquestes "comunicacions" que, al contrari, haurien anat a més, experimentant cada dia "funestes resultes en aquella relaxació que contrau la gent jove acostumant-se a l'ociositat i a la vida llicenciosa", atès que en les trobades que solen oferir-se per aquest motiu es produeixen llastimosos estralls patits per l'honestedat de les dones i que arriben amb massa freqüència als tribunals.

Per això -diu la disposició- que si d'ara en avant agafaren atorgats "comunicant-se a soles" o justificaren haver-ho executat, ja siga en el camp, ja en les seues cases o finestres, o ja en les cases d'altres veïns, parents o confidents, procedeixen les autoritats in continenti contra ells i contra els encobridors, imposant-los les multes i penes que "determine aquesta Reial Sala".

Després de la Reial provisió queda inserit el text del Decreto del $I^{\text {lmo. }}$ y $R^{\text {evmo. }}$ Señor Don Andrés Mayoral, Arzobispo de Valencia, del Consejo de su Magestad ETC, sobre Otorgados, donat en "el nostre Arquebisbal Palau de la ciutat de València" a 13 de gener de 1759. Aquest decret comença adreçant-ho als rectors parroquials que tenen encomanada "la cura espiritual dels súbdits d'aquest el nostre arquebisbat"; tot seguit justifica "por cuanto no han sido suficientes los edictos, decretos $i$ mandatos de anteriores Visitas pastorales..." i determina que el decret és per a corregir "l'abominable abús de comunicar-se i visitar-se en ses cases i fora d'elles aquells als que diuen atorgats i atorgades, consentint-ho moltes vegades els seus pares i persones sota la tutela i empara dels quals n'estan".

De tot allò que diu la reial ordre i el consegüent decret de l'Arquebisbe Mayoral podem entendre que "atorgats i atorgades" serien aquells xics i xiques (i homes i dones) que sense estar casats intimen d'alguna manera (sense necessàriament arribar a cap tipus de relació sexual). Evidentment, en aquestes disposicions legals hi ha una enorme càrrega moral i moralitzant adreçada a educar els joves en els principis i la fe cristians, reprimint els instints i les actituds amatòries abans del matrimoni i molt més enllà de la sexualitat. Per altra part, però, en aquesta repressió, educació i disposicions legals pre-conjugals hi ha també un objectiu real que no és gratuït fora del aspecte moral i religiós, sinó que 
respon clarament a un greu problema social del moment, determinat per certa proliferació d'actes de violació i abusos sexuals, violència de gènere i, en general, cert llibertinatge, a voltes amb resultats de sang i quasi sempre en perjuí de la dona. Així sembla quedar palès amb la insistència i reiteració de la norma en utilitzar expressions com la ja esmentada dels "llastimosos estralls que pateix l'honestedat de les dones, arribant amb massa freqüència als tribunals" o quan, en altres punts de l'ordenança, incideix en la necessitat de que es facen rondes per a detectar aquesta mena de pecats públics reconeixent $\mathrm{i}$ identificant als presumptes atorgats $\mathrm{i}$ atorgades, com també (o diu cap al final de la norma) per a que siguen regirats i es comprove si duen armes, reduir-los en aquest cas a la presó fins que presenten la llicència que tingueren per al seu ús i, en cas de no tindre-la o de ser armes curtes, tant blanques com de foc, els hi formen autos d'ofici indagant el seu mode de viure, costums i designis que pogueren tindre al respecte... "a cuyo fin se les examine cuydadosamente sobre los pasos y comunicación que hayan tenido en aquella noche y se evacuen sus citas para averiguar la verdad, dando cuenta a la Sala de lo que resulte". I encara que foren trobats sense armes, preveu l'ordenança que els hi facen aquelles preguntes que paregueren adients "segons la qualitat dels subjectes" per a esbrinar el motiu de trobar-se fora de ses cases a hores intempestives com són les de després de tocada la campana de queda.

Respecte de les penes, se n'estableixen no solament per als atorgats i les atorgades, sinó també contra els consentidors i encobridors (“en cas d'omissió o culpable dissimulació") i encara, contra els alcaldes i autoritats que per passivitat o omissió no hagueren ordenat les rondes $\mathrm{i}$ bans públics informant la població de manera adient en la lluita contra aquests "abusos i desordres". Concretament, la Reial Ordre establia que s'haurien de lliurar reials provisions circulars a totes les Justícies del Rei, per a que la publicaren dins el termini de 6 dies després d'haver-la rebut, i tornaren certificació d'haver-ho fet, sota pena de 20 lliures si no ho feren. També disposa que es remeteren ‘copies a tots els Ajuntaments per a que es fera pública l'ordre i es poguera repetir la seua publicació cada any i tanmateix que se li llegira a tots els nous alcaldes cada vegada que prengueren possessió del càrrec, anotant-ho així en els llibres de Cabildo amb diligència signada pel propi alcalde i l'escrivà de l'Ajuntament, i no ho feren incorrerien cadascú d'ells en pena de 100 lliures exigides mancomunadament a tots dos.

La pena per als atorgats, la primera vegada que siguen trobats en "comunicació que puga ser sospitosa bé pel lloc o bé per l'hora" havia de ser de 15 dies de presó i 4 
lliures de multa, aplicades per meitats a penes de càmera i despeses judicials; i si no pogueren pagar-la se'ls hi condemne en altres 15 dies més de presó. I a les atorgades se les apercebrà per la primera vegada que si reincideixen seran formalment processades. I per les segones vegades, tant a atorgats com a atorgades "se les fulmine causa de Oficio" i feta que siga la sumària en que se justifiquen les seues contravencions, es procedeixa a la presó i embargament del bens d'ambdós i siga donat compte a la Sala per a prendre la providència corresponent.

Pel que fa als pares i mares, curadors i curadores, i amos al càrrec dels quals estigueren els atorgats i les atorgades, podran condemnats, per la primera vegada amb 10 lliures de multa, aplicades en la forma ordinària, i no podent-les pagar amb un mes de presó, tot això si es justificara que no havien adoptat les precaucions i mesures adients per evitar les "escandaloses familiaritats", prenent totes les precaucions necessàries per "al recogimiento de los mosos ó mosas" que tinguen dins de llurs cases i ses famílies. I si són reincidents se'ls hi forme causa d'Ofici tractant-los com a encobridors d'aquells excessos.

Per la seua part, l'Arquebisbe determina en el seu decret la possibilitat de castigar els rectors i assistents per les omissions que tingueren en fer allò que se'ls ordena i en donar notícia puntual als Justícies, multant-los amb 20 lliures per la primera vegada i amb 40 per la segona, i encara a partir de la tercera amb altres penes majors i "a nuestro arbitrio". I també manen als rectors que publiquen en el púlpit aquell edicte en un dia festiu i en altres que els pareguera oportú i, almenys, cada any en el dia que publicaren els nascuts i difunts en ell "y le coserán o fixarán al principio o fin del Quinque-Libri". Aquesta entenem que és la raó (i la prova de publicació) per la qual hem trobat aquests afegits dins del segon volum del Quinque Libri de Serra.

\subsection{Altres disposicions de l'arquebisbe Mayoral.}

A més de la reial ordre de 16 d'octubre de 1758 i del decret de l'Arquebisbe Mayoral, de 13 de gener de 1759, l'afegit del Quinque Libri de Serra conté també un altra disposició del mateix arquebisbe, de data 25 d'agost de 1760, la qual la realitza atenent una reial cèdula expedida en Aranjuez el 24 d'abril del mateix any, que regula $i$ impulsa la necessitat de que els seglars aporten assistència i esbrinaments per al càstig dels delictes "cuyo conocimiento privativo nos toca" d'adulteri, concubinatge, (amancebamiento), sacrilegis, usures, blasfèmies i perjurs... En que "per ser de mixt fur 
hi ha prevenció" entre ambdues jurisdiccions, eclesiàstica i seglar. Tot tenint en compte aquesta disposició reial, l'arquebisbe dicta també la seua: que no podent assistir ell ni el seu Provisors i Vicari General a totes les poblacions de la arxidiòcesi, per a l'esbrinament i càstig dels esmentats delictes, i sent per tant necessari destinar-hi altres subjectes que d'això s'encarreguen, nomena per comissaris als degans, plebans, rectors $\mathrm{i}$ regents $\mathrm{i}$ curadors d'ànimes de les ciutats, viles i llocs del seu arquebisbat "para que cada uno en el territorio de parroquia pueda proceder y proceda a la averiguación de cualesquiera delitos que van insinuados, recibiendo sumarias y practicando cuantas diligencias convengan a este fin, y resultando por ellas al delito y delincuente" i afegeix que invocant aleshores l'auxili del braç seglar passen a la seua captura i empresonament, donant compte al Vicari General per a que quan faça visita puga procedir al càstig i penes pertinents... I així ho anota i fa constar el rector parroquial de Serra, Pedro Sellés.

Un article de Cárcel i Trenchs (1981-82), referit a la visita pastoral que dit arquebisbe va fer a la parròquia d'Ondara en 1774, posa també de manifest el seu característic zel dictant normes morals d'una claredat contundent. En aquella visita, més enllà dels assumptes litúrgics que solen ser, generalment, el principal objecte de les visites pastorals, l'arquebisbe entra de ple en "normes de comportament" i aspectes de moralitat per als feligresos, com són: la prohibició d'entrar els nuvis en les cases de les seues promeses o núvies; la decència que cal tindre en el vestir de les dones ("sin salir públicament por las calles y plazas con solas enaguas blancas, de que se siguen muchas ofensas a Dios..."); l'observança estricta de dormir els pares en llits separats dels seus fills, o també "la reunió del rector i dels beneficiats per a tractar casos de consciència".

En qüestió de possibles atorgats escriu sobre el gran abús que hi ha que els promesos entren en les cases de les que han de ser les seues mullers, contra les repetides prohibicions que per evitar els grandíssims inconvenients, escàndols i ofenses a Déu estan publicades en "nostres constitucions" i especialment en la primera del títol primer de De sacramento matrimonii, com també entre les sinodals de l'il·lustríssim senyor Rocabertí "nuestro antecesor". ${ }^{33}$ Després de fer l'anterior preàmbul resol amb contundència:

33 Cárcel i Trenchs (op. cit.) corregeixen que no és el títol sisè i no el primer: Cfr Constituciones sinodales del Arzobispo de Valencia hechas por el Ilmoy Exmo Sr. D. Fr. Juan Tomàs de Rocabertí... en el sínodo que se celebtó en dicha ciudad (Val.) en 22 de junio de 1687. Tit. VI: De sacramnto matrimonii Const.: Que los que se conciertan de casar por palabras de futuro no cohabiten antes de desposarse. 
(Per això...) ...mandamos a todos y cualesquiera otorgados de este nuestro arzobispado y especialmente a los que al presente hay y en adelante huviese en esta villa de Ondara... bajo la pena de excomunion mayor lata sententia, que no entren en las casas de sus prometidas ni éstas en casa de aquéllos.

Per la seua sepultura, que hem vist a la catedral de València, coneixem que Andreae Mayoral Zamorano (l'arquebisbe Andreu Mayoral Alonso de Mella, nascut al poble zamorà de Molacillos) nasqué l'any 1685, prengué possessió de l'arxidiòcesi valentina en 1738 (el va proposar Felip V l'any anterior) i mantingué aquest càrrec fins a la seua mort, el 6 d'octubre de 1769. Llin Cháfer (s.a.) ha destacat la tenacitat d'aquest arquebisbe en renovar pastoralment tota l'arxidiòcesi, de la qual va visitar totes les parròquies, i les va dotar de tot allò que pogueren necessitar per a litúrgia però exigint també del clergat molta disciplina. Va disposar que els llibres parroquials foren sempre escrits en castellà.

Però, sobre tot, és recordat aquest arquebisbe per les fundacions que va fer d'escoles, com la gran Casa d'Ensenyament per a xiquetes sense recursos (València). ${ }^{34}$

En tot cas, el que cal posar de relleu respecte a aquest poderós personatge és que tingué una forta influència sobre els monarques, des de Felip V fins a Carles III, tant en el sentit de forçar les normes de moralitat exposades com de rebre grans facultats $\mathrm{i}$ prerrogatives, fins i tot del papa Clement XIII, segons observem en les recopilacions realitzades per Calabuig (1897). Tots aquests són aspectes que ens sembla es van fer notar clarament en el període central i segona meitat del segle XVIII, i evidentment no sols a Serra.

$34 \quad$ Aquest gran edifici, la Real Casa de Enseñanza de Niñas, seria construïda entre els anys 1758 i 1763, i en ell seria ubicat l'actual ajuntament de València desprès del incendi que el 1854 va afectar a l'anterior edifici consistorial que estava situat en la plaça de la Seu, cantó carrer de Cavallers (Calabuig (1897). També va donar aquest arquebisbe una gran ajuda a la casa de la Misericòrdia, a l'Hospital General o a l'acadèmia de Belles Arts (convertida en 1768, per Carles III, en Reial Acadèmia de Sant Carles.

Calabuig (1897), comentant sobre la Casa d'Ensenyament de xiquetes, destaca de l'arquebisbe que "anticipant-se a les exigències de la cultura i de la vida moderna" comprengué tota la importància del problema de l'educació cristiana de la infantesa i va ser per això que consagrà la seua poderosa iniciativa i els seus notables recursos en posar-ne solució i eficàcia "al problema". No obstant, Gregori Mayans dóna de l'arquebisbe una visió de persona ambiciosa, que no renunciava als diners per a aconseguir tot allò que pretenia, que era enemic d'homes ingenus i apreciador dels aduladors; ambiciós en deixar nom de si mateix, pensant que les fäbriques el farien memorable i gastant en elles el que fora precís en el foment de la pietat i de les lletres; però també venjatiu contra tots aquells que el contradigueren. 


\subsection{CÀRRECS PÚBLICS I PREUS, SEGONS ELS PROTOCOLS DE CONEJOS (SEGLE XVIII a XIX).}

Per a finals del segle XVIII i principis del XIX disposem d'un altre ampli registre d'actes notarials que ens permeten novament aproximar-nos a detalls de la vida comú i quotidiana de Serra i dels serrans. El volum d'informació és molt més ampli que en el cas anterior (el de principis del XVII, amb el notari Joan Font), però el nostre interès, en aquest moment de la tesi, comença a concentrar-se més en un dels nostres objectius bàsics: esbrinar com va ser realment la fi de la baronia i de l'Antic Règim a Serra. Per això, deixem per a una altra ocasió aprofitar amb més profunditat els nombrosos aspectes que sobre la "vida social" dels serrans ens pot brindar aquest recurs.

No obstant, hem volgut fer amb aquest epígraf una aportació complementària a la que férem per a les primeres dècades del segle XVII i, de pas, aportar i destacar algunes dades que ens han semblat interessants sobre aquest període i aquest valuós recurs documental que tantes vegades hem aprofitat i citat al llarg dels capítols precedents.

La sèrie de protocols de Miquel Conejos comença en 1773 i continua fins a 1821 amb un canvi que cal posar de relleu: en els darrers anys de la sèrie el notari és substituït en l'ofici pel seu fill major, del mateix nom, de manera que serien dues sèries continuades en les que, per altra banda, amb penes sí notem canvis perquè el fill és fidel continuador de l'escrivania, tant en la part pública com en la que presta serveis al duc de Montellano per als assumptes de la baronia. A diferència del que passava amb el notari Font (de principis del segle XVII), en que quasi la totalitat dels actes eren transaccions de particulars i assumptes més o menys privats, els protocols de Conejos contenen també cert volum d'actes i qüestions públics relacionats amb la baronia, d'alguns dels quals (com els relatius a les delimitacions del terme i amollonaments) ja hem tractat en capítols anteriors.

L'abast de carn de Serra va ser arrendat (sempre per termini d'un any) en 1774 a Miquel Ribelles, de Serra; en 1776 a Vicent Ribelles, d'Alfara; en 1777 a Francesc Ribelles "cortante" i veí de Serra, i en 1779 a Francesc Ribelles, de la vila de Morvedre. Per a l'any següent, el 5 de març de 1780 és arrendat l'abast de carn de Serra a Francesc Ribelles “cortante”, de Serra, i l'abast de Nàquera, el 24 de març, a Vicent Ribelles. Desconeixem els possibles lligams familiars d'aquests tres, quatre o cinc individus, però sembla evident que es tracta d'un grup familiar o nissaga de professionals especialitzats 
en el comerç carnisser. Trobem que també va ser el mateix Vicent Ribelles, arrendador de l'abast de carn de Serra en 1776, qui va arrendar el de Nàquera en el mateix any.

El preu oficial que s'ha de pagar per la carn en aquells anys, segons les clàusules dels arrendaments, era el següent (les lliures de pes són sempre de 36 unces):

\begin{tabular}{|l|c|c|c|}
\hline \multicolumn{1}{|c|}{ CARN } & any 1774 & any 1776 & any 1780 \\
\hline Lliura de carner de 36 unces & 3s. 8d. & 4 s. & 4s. 8d. \\
\hline La de matxo de 36 unces & 3s. 6d. & & 4s. \\
\hline La de cabra & 2s. 6d. & & \\
\hline La d'ovella & & & 3s. 6d. \\
\hline Les tandes de matxo & 2s. 10d. & & \\
\hline Les tandes de carner i cabra & 2s. 4d. & & \\
\hline
\end{tabular}

Aquests Ribelles són clarament carnissers i compradors de carn, segons constatem per tota una sèrie de compres realitzades a ramaders. Així, Miquel Ribelles li comprava a Josep Alemany, llaurador de Xilxes, el 1774, 50 carners al preu de una lliura i deu sous cadascun. En 30 de setembre de 1782, Vicent Ribelles "cortante" de Serra, li compra a Tomàs Bonillo, de Macastre, una porció de ramat llanar d'ovelles i carners per 178 lliures i 16 sous.

En 1 de gener de 1784, l'adjudicació de l'abastiment de carn se li fa a Josep Nebot, que aporta com valedor a Vicent Ribelles. ${ }^{35}$ Vicent Ribelles serà adjudicatari el 1787, però de nou Josep Nebot ho serà en anys següents.

A més del piló i la venda oficial de carn (normalment ovi-caprina) sabem que era habitual criar gallines i pollastres en les cases, però també hi hem trobat evidència de que hi havia criança de porcs en els corrals de les cases i una "setmana de la matança". Així es desprèn de l'oferiment que fa el 15 de desembre de 1782 un tal Miquel Roca, de Puçol, a qui la "porcada de la setmana del porc" li adjudica "el empleo de carnicero o butrero de los cerdos".

Per alguns d'aquests actes de l'abast de carn coneixem el nom de les persones que anaven ocupant, en diversos anys, els càrrecs de l'ajuntament. Per exemple, en 1774 era alcalde Ventura Cabo i "diputats" Manel Navarro, Manel Domingo, Vicent Navarro, Francesc Dolz, Tomàs Cabo, Josep Català i Josep Iranzo (7 “diputats”). En 1776, l'equip municipal ("los que componen el ayuntamiento") ha canviat completament: l'alcalde és ara Joaquim Arnal; de "diputats" només hi ha dos, Pere Puig i Jeroni Romero; i a més

\footnotetext{
${ }^{35}$ ARV, protocols de Miquel Conejos, lg. 3629.
} 
estan Joan Pérez, tinent d'alcalde; Lluís Cabo i Andreu Cabo, regidors; Francesc Català, "síndico procurador personal"; Josep Gimeno, síndic personer, i Miquel Ros, “amotasén" (mostassaf). En 1780 és alcalde de Serra Blai Dasí.

També trobem al llarg dels protocols arrendaments de Peses i Mesures fets pel municipi. Concretament, el 7 de gener de 1780, Blai Dasí “alcalde ordinari” i "els que composen l'ajuntament" arrenden per un any aquest servei a Josep Domènech, de Serra, per 30 lliures i 5 sous. Quasi un any desprès (el 31 de desembre de dit any) l'adjudicatari serà Bernat Izquierdo, ara per a 4 anys i per preu de 37 lliures i 10 sous cadascun any, però, sorprenentment, el 8 de gener de 1781 trobem que ha quedat sense efecte l'anterior adjudicació i es torna a fer de nou, ara a Josep Domènech per un sol any i per un preu major: 41 lliures i 4 sous. El 13 de gener de 1782 es fa l'arrendament, també per un any, a Ventura Calvo, però el preu torna a ser 30 lliures, com era dos anys abans.

En 1 de gener de 1784 "l'ajuntament i la junta general d'arrendaments" li adjudica el servei de Peses i Mesures a Francesc Romero, de Serra, per 34 lliures, 1 sou i 3 diners; i el 1792 se li arrenda a Llorenç Garay per la mateixa quantitat.

De vegades hem trobat protocols de subarrendaments ("rearriendos" i "subarriendos") de regalies. Per exemple, el que fa Vicent Bellver, comerciant de Serra i arrendador dels drets dominicals de la baronia, del molí fariner, el primer de gener de 1777, a Josep Peiró, tractant i veí de Montanejos, per 4 anys al preu de 170 lliures anuals.

Inclou en la concessió una mula, els arreus necessaris, la casa d'habitació, la bassa i altres. ${ }^{36}$ Com que l'anterior contracte no tingué èxit, el 6 de desembre de 1778 (dos anys desprès) torna Vicent Bellver a subarrendar el molí, ara a Joan Carbonell, mestre moliner, per dos anys, al preu de 110 lliures anuals. ${ }^{37}$.

En 27 de desembre de 1780, el mateix Joan Carbonell, moliner, veí de Massamagrell i arrendador ara dels drets dominicals de la baronía de Serra, subarrenda a Iside Ferrara, de Serra, la regalia de la "tenda de venda de vi" (taverna) per 4 anys. Uns dies desprès, 31 de desembre, Manel Martínez, de Massamagrell (podria ser soci de Carbonell) subarrenda a Francesc Puig, de Serra, el forn, per 4 anys i preu de 167 lliures cada any, i a Cristòfol Arnal el molí fariner, per 4 anys i a raó de 120 lliures anuals. ${ }^{38}$

Aquests tipus de subarrendaments de les regalies els podem trobar encara alguns anys de la primera dècada del segle XIX, però més no.

\footnotetext{
${ }^{36} \mathrm{ARV}$, protocols de Miquel Conejos, lg. 3625.

${ }^{37}$ ARV, protocols de Miquel Conejos, lg. 3626.

${ }^{38} \mathrm{ARV}$, protocols, de Miquel Conejos, lg. 3627.
} 
Els comerç d'èquids torna a ser en els protocols de Conejos un dels punts forts, com elements bàsics i fonamentals que són tant del treball en el camp i en la muntanya com per al transport. El mateix que férem anteriorment, també presentem a continuació una taula recopilatòria sobre preus $\mathrm{i}$ característiques d'aquests animals de càrrega $\mathrm{i}$ de força i transport (QUADRE 8.4). De la comparació d'aquesta taula amb les que presentàvem en els quadre 8.1 i 8.2 es veu que hi cert augment bàsic dels preus de les mules (per utilitzar un patró de referència) però continua havent una gran variació entre els animals, sens dubte ateses les seues característiques particulars i, com no, a les lleis del mercat i les circumstàncies en cada moment dels compradors i dels venedors.

El que sí que queda clar amb aquests quadres és que els preus eren notablement més baixos que les més de 100 lliures que se solien pagar al monestir de Portaceli, al llarg del segle XVIII, per cadascuna de les seues famoses mules de criança que en els segles XVII i XVIII constituïen un dels negocis de major renom de la cartoixa. Eren molt preades i buscades no solament pel llaurador (de l'horta de València, principalment) sinó també per cavallers de la ciutat, que es valien d'elles per a muntar-les o per al tir de les carrosses (Garay, 2004). Les mules de la cabanya de mules de Portaceli eren "les primeres de la seua classe en el País" i tenien fama "por su estampa y hagilidad" (Tarín y Juaneda, 1897).

Finalment, destacarem que sobre aprofitaments de llenyes i drets de fer carbó també hom troba en aquests protocols diverses referències, com un conveni del 25 de gener de 1778, pel qual Eleuteri Alfaro, procurador del duc de Montellano, fa cessió a Jaume Navarro, Francesc Català, Eusebi Arnal i Jeroni Català, tots llauradors de Serra, d'una autorització per a poder tallar i reduir a carbó els pins de la "Roja del Castell" (la reserva o bovalar del Senyor, segons la carta pobla) que són dèbils, "nodosos" o "xaparros", i que suposarien unes 20 galerades (xifra respectable, doncs la galerada és la càrrega que pot transportar una galera). Tanmateix, als veïns de Nàquera Tomàs Tortajada i Vicent Arnal i Blasco, el duc de Montellano els vengué, en juny de 1783, "matorral y leña de monte bajo", per preu de 40 lliures, d'un tros de terra comprès entre el camí de les Vinyetes i el collao de la fonteta del Manyo, seguint el barranc del Moncúdio cap al terme de Nàquera i fins arribar al barranc Major. ${ }^{39}$

\footnotetext{
${ }^{39}$ ARV, protocols de Miquel Conejos, lg. 3628; data 6 de juny de 1783.
} 
QUADRE 8.4.- preus d'èquids comprats per serrans cap a finals del segle XVIII.

\begin{tabular}{|c|c|c|c|c|c|}
\hline Comprador & Venedor & Objecte & Preu & Data & Document \\
\hline Tomás Cabo & Fco. Ginesta (Sogorb) & Matxo & $99 \mathrm{~L}$ & $21 / 07 / 1778$ & ARV, lg. 3626 \\
\hline Lluís Cabo & Fco. Ginesta (Sogorb) & Mula & $40 \mathrm{~L}$ & $10 / 10 / 1778$ & ARV, lg. 3626 \\
\hline Carles Tomàs & Josep Blasco (Altura) & Matxo & $33 \mathrm{~L}$. & $1 / 02 / 1781$ & ARV, lg. 3627 \\
\hline Maria Arnal & F. Givert (Sogorb) & Matxo & $105 \mathrm{~L}$ & $15 / 02 / 1782$ & ARV, lg. 3628 \\
\hline Josep Martínez & Jaime Pujol (Sogorb) & Ase & $26 \mathrm{~L}$ & $11 / 09 / 1782$ & ARV, lg. 3628 \\
\hline Vicent Ros & F. Ginesta (Sogorb) & Matxo & $35 \mathrm{~L}$ & $15 / 12 / 1782$ & ARV, lg. 3628 \\
\hline Josep Arnal & Juan Labat (Sogorb) & Matxo & $60 \mathrm{~L}$ & $17 / 12 / 1782$ & ARV, lg. 3628 \\
\hline Josep Català & Juan Labat (Sogorb) & Matxo & $95 \mathrm{~L}$ & $17 / 12 / 1782$ & ARV, lg. 3628 \\
\hline Blai Dasí & Juan Labat (Sogorb) & Mula & $120 \mathrm{~L}$ & $4 / 04 / 1787$ & ARV, lg. 3630 \\
\hline Joaquim Arnal & Juan Labat (Sogorb) & Mula & $125 \mathrm{~L}$ & $4 / 04 / 1787$ & ARV, lg. 3630 \\
\hline Francesc Arnal & Fco. Ginesta (Sogorb) & Mula & $125 \mathrm{~L}$ & $17 / 05 / 1787$ & ARV, lg. 3630 \\
\hline Tomàs Verge & Juan Labat (Sogorb) & Somera & $20 \mathrm{~L}$ & $3 / 11 / 1787$ & ARV, lg. 3630 \\
\hline Jaume Forner & Juan Labat (Sogorb) & Potro & $36 \mathrm{~L}$ & $3 / 11 / 1787$ & ARV, lg. 3630 \\
\hline
\end{tabular}

Hem respectat la forma matxo (mul) per ser ací l'habitual Dades tretes dels protocols de Miquel Conejos (ARV).

\subsection{OFICIS, OCUPACIONS I CÀRRECS PÚBLICS, SEGONS EL CENS DE 1857.}

El de llaurador és l'ofici que trobem més habitualment en els registres, tant el parroquial com els notarials (agricultor loci de Serra, quan ho posa en llatí) de Joan Font (segle XVII), Miquel Conejos (segle XVIII) o Soriano (segle XIX), si bé són molts altres els que hi trobem, per exemple el de carboner (especialment en els biscaïns del segle XVII) i altres que hem nomenat en l'apartat primer d'aquest capítol.

Evidentment, al llarg dels registres de qualsevol dels arxius consultats, però especialment de l'arxiu nobiliari dels ducs de Montellano, hi trobem sovint tots els oficis i càrrecs esmentats en la carta-pobla de 1609: batlle, justícia, lloctinent de Justícia, jurats, mostassaf, escrivà... I encara alfarrassador i els oficis propis dels arrendaments de l'hostal, taverna, piló de carn i carnisseria, molí fariner, forn i fleca, almàssera i tenda, alguns dels quals hem citat oportunament quan pertocava. 
Però l'única ocasió en que hem pogut trobar per a un període concret un nombre significatiu de persones $\mathrm{i}$ els seu oficis ha sigut en el cens del 1857. Es tracta d'una autèntica instantània feta en un moment molt concret (la nit de Nadal d'aquell any). És així que podem trobar representant de tots els oficis que exercien els habitants de Serra. Per una part hem considerat oportú diferenciar els oficis dels caps principals de cada casa (de cada cèdula) i considerar a banda la resta de persones treballadores que vivien amb ells. En el primer cas és on trobem les principals ocupacions dels serrans, mentre que en el segon hi trobem oficis diferents als primers, com són criats, pastors o llauradors.

Els oficis dels caps de cèdula (QUADRE 8.5) són, principalment tres: "propietaris" (els principal terratinents), "propietaris-jornalers" (tenen terres i les cultiven per compte propi però també fan jornals) i "jornalers" (treballen principalment conreant a jornal per a altres). En el primer grup estan els més rics, i això es posa de relleu perquè són els únics que de vegades tenen criats o servents al seu càrrec, mentre que els "propietaris-jornalers" no en tenen mai. Molts dels oficis especialitzats (obrers, fusters, carreter...), com també oficis artesans i càrrecs públics, els solen exercir persones que també són propietaris de terres (però no jornalers). També alguns propietaris emparen amb la seua cèdula a alguns pastors aragonesos que, suposadament, estan passant l'hivern a Serra amb els seus ramats, probablement en els corrals dels corresponents "propietaris".

També està entre el grup dels propietaris un dels principals: Simeón Domingo Navarro, de 61 anys d'edat, amb el seu fill de igual nom però de 33 anys d'edat i professió "propietari industrial". Aquests eren els propietaris del Colador d'aiguardent.

L'ofici de llaurador, que tan estès trobàvem en segles anteriors, es reserva ací únicament als fills fadrins que ja han deixat els estudis i es dediquen a treballar la terra amb els seus pares. Molts d'ells sembla clar que seran els hereus terratinents.

Per completar les 277 cèdules del quadre anterior cal tenir en compte que dues d'elles pertanyen a persones que per "professió, ocupació o posició social figura que són “mendigos". Una d'elles (cèdula 227) és Magdalena Martínez, vídua de 66 anys, que viu amb el seu fill Mateu Cabo, de 26 anys i de professió jornaler. L'altra és la cèdula 88 , que comparteixen quatre germanes fadrines i analfabetes, de cognom Arnal Navarro i edats de 36 a 17 anys. 
QUADRE 8.5.- Oficis dels 277 caps de cèdula del cens de 1857.

Oficis

Nombre o Titular

Altres en la mateixa cèdula

\begin{tabular}{|c|c|c|}
\hline $\mathrm{P}$ (propietaris sense més) & $\begin{array}{l}78 \text { caps de cèdula } \\
\text { ( } 5 \text { en són dones vídues) }\end{array}$ & \\
\hline PJ (propietaris-jornalers) & 110 caps de cèdula & \\
\hline $\mathrm{J}$ (jornalers) & 61 caps de cèdula & \\
\hline $\mathrm{P}$ i ferrer & $\begin{array}{l}\text { Falomir } 4 \\
\text { Falomir } 5\end{array}$ & 1 ferrer \\
\hline $\begin{array}{l}\text { P i obrers (de vila) } \\
\text { P, obrer i campaner: }\end{array}$ & $\begin{array}{c}\text { Joan Arnal Cabo } \\
\text { Josep Arnal Cabo } \\
\text { Francesc Arnal Cabo }\end{array}$ & $\begin{array}{l}1 \text { labrador } \\
1 \text { obrer }\end{array}$ \\
\hline PJ i obrer (de vila) & Blas Arnal Cabo & \\
\hline $\mathrm{P}$ i fusters & $\begin{array}{c}\text { José Saera Gayano } \\
\text { Miguel Pérez Navarro }\end{array}$ & \\
\hline $\mathrm{P}$ i teixidor & Hilari Arazo Cabo & \\
\hline $\mathrm{P}$ i artista (teixidor) & Ramon Peña Sancho & 1 serventa i 2 teixidors-artistes \\
\hline Jornaler de taller (sastre) & Tomás Arazo Rubio & \\
\hline Espardenyer & Esteve CatalàCabo & \\
\hline $\mathrm{P}$ i cirurgià & Pee Esteve Jordan & 1 serventa \\
\hline Metge & Tomàs Ferrando Tormo & \\
\hline Rector parroquial & Vicente Aguilar Ramón & \\
\hline PJ i sagristà & Josep Cabo Pérez & \\
\hline $\mathrm{P}$ i agutzil & Francesc Rubio Jenaro & 1 llaurador \\
\hline P i secretari d'ajuntament & Joan Domingo Navarro & \\
\hline Forner & Josep Navarro Aernal & 2 llauradors \\
\hline Carnisser & Constantino Aliaga Navarro & 1 carnisser \\
\hline $\mathrm{P}$ i estanquer & Francesc Dolz Domingo & \\
\hline $\mathrm{P}$ i arrier & $\begin{array}{c}\text { Salvador Navarro Martínez } \\
\text { Vicent Navarro Gamon }\end{array}$ & $\begin{array}{l}1 \text { llaurador } \\
1 \text { mendigo (captaire). }\end{array}$ \\
\hline $\mathrm{P}$ i carreter & Josep Navarro Arnal & Mestressa \\
\hline Mestre & Josep Garay Falomir & \\
\hline Pastor & Joaquín Faulí Gamon & $1 \mathrm{P}$ vídua (la sogra del pastor) \\
\hline
\end{tabular}

Elaborat a partir de les dades del cens de 1857 (ADPV). 
El terme "mendigo" (captaire) se sol aplicar en el cens a persones d'edat avançada (pares i sogres, generalment) i que suposem tenen limitades les seues capacitats de treballar. En altres casos trobem, com si d'ofici o posició social es tractés, algunes persones amb discapacitats: coix, cec.... En el QUADRE 8.6 recollim, complementàriament al quadre anterior, la distribució d'oficis de totes les persones que no són caps de cèdula.

QUADRE 8.6.- Oficis de les persones que no són caps de cèdula ni població infantil.

\begin{tabular}{|c|c|c|}
\hline Ofici o condició & nombre & observacions \\
\hline Llauradors & 112 & són majoritàriament fills de cada casa. \\
\hline Jornalers & 20 & \\
\hline Servents (criats) & 19 & una dona de 20 anys; 14 tenen menys de 30 anys. \\
\hline Pastors & 10 & tots aragonesos (ramats transhumants?). \\
\hline Propietaris & 6 & 3 vídues, 1 vidu, 1 P. industrial i ... \\
\hline "mendigos" & 13 & 9 tenen 60 o més anys, i els altres més de 41. \\
\hline (Discapacitats) & 7 & 4 coixos, 2 cecs i un "tonto". \\
\hline Altres & 4 & 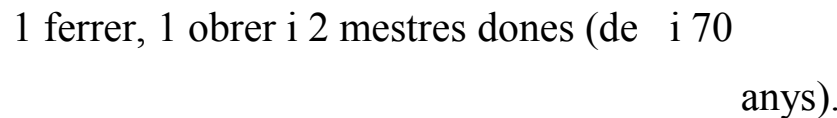 \\
\hline
\end{tabular}

Elaborat a partir de les dades del cens de 1857 (ADPV).

\subsection{L'ENSENYAMENT I LES ESCOLES}

La gran fundació de la casa d'ensenyament per a xiquetes (construïda entre els anys $1758 \mathrm{i}$ 1763) que va fer a la ciutat de València l'arquebisbe Mayoral és una bona mostra de l'auge que aniria prenent l'ensenyament i la creació d'escoles per a xiquets en la segona meitat del segle XVIII, empreses que la Corona potenciaria decisivament en les dècades següents, com ho demostra l'ordre del Consell de Sa Majestat enviada en 1790 al Corregidor de la ciutat de València per tal de vigilar i informar-li sobre l'ensenyament d'infants en les escoles de la seua jurisdicció. Així ho veiem en un expedient relatiu a la dotació dels mestres de primeres lletres de València. ${ }^{40}$

$\overline{40}$ RSEAPV, 1790, C-20, III Educación, nº 1. 
Però, en general, no tenint les famílies recursos per enviar els seus fills a estudiar o formar-se fora de Serra, l'única opció que tenien molts joves d'apropar-se a poder llegir i escriure o aprendre algun ofici diferent als que podien trobar al seu poble era entrar de criats o aprenents en Portaceli. Per al cas de la vall d'Olocau, Zurriaga (2003) va fer una aproximació a aquesta casuística, tot posant de manifest que l'explotació de les terres i els recursos de la cartoixa de Portaceli necessitava de molta mà d'obra i aquesta era en bona part complida per joves dels pobles de l'entorn que entren a treballar, contractats com a criats, fent generalment de llauradors, pastors o carreters, si bé alguns passen també a tasques més especialitzades en treballs de la casa: cuiners, ferres, sastres, fusters, guardes i altres oficis.

La contractació de joves com a criats i jornalers de Portaceli va ser habitual en totes les èpoques del monestir (així es pot comprovar al llarg de les obres de Tarín i Juaneda, 1897; Ribes, 1998, o Fuster, 1993). De l'administració de tota aquesta mà d'obra (dita la Majoralia) s'encarregava el pare Conrer (aquest és el nom del càrrec). Hi havia magatzem i tallers (corretger, ferrer, sabater, sastre...) al costat occidental del pati de les Obediències i, a més d'això estava el corral dels Frares (amb diverses habitacions i cuina per als pastors, al sud del monestir, a prop de l'ermita del Sant Sepulcre (desprès coneguda com de Santa Bàrbara). ${ }^{41}$

En el nostre cas hem prestat especial atenció al "Llibre de la Soldada dels Mossos" que venien a la cartoixa de Portaceli (ARV, Clero, lg. 4015), que conté una detallada relació de centenars de mossos que passaren per aquella institució en la primera meitat del segle XVIII. A més del nom i de la data d'arribada, se sol indicar (no sempre) la procedència del jove, el destí laboral que se li dóna, el temps que passa en aquell lloc de treball i si va passar a altres diferents, la soldada o sou (a mode de liquidació final) que li correspondria cobrar per tot el seu treball en tot aquell temps i, seguidament les detraccions aplicables: descompte de quantitats avançades, despeses per assistència mèdica $\mathrm{i}$ medicines dispensades, roba neta que se li dona i possibles faltes comeses al llarg del seu període laboral. Entre les raons de quantitats avançades solen ser del tipus "visitat a sa mare que es troba greument malalta" o assistències al soterrar patern, etc.

No tenim certesa del percentatge de serrans que participaren d'aquelles plantilles de joves treballadors, formades generalment per diverses desenes (de vegades mig

\footnotetext{
${ }^{41}$ El 1480 hi havia 30 criats (per a treballar les terres i en obres de la casa), el 1487 eren 18 homes i 4 mossos com a criats al monestir, i en 1824 n'eren 85 i en 1831 n'hi havia no menys de 60.
} 
centenar o més) però, pels cognoms que sabem que són característics de l'antiga baronia de Serra podem suposar que generalment hi eren prop d'una desena de joves serrans els que hi treballaven. En les primeres dècades del segle XVIII també trobem a sovint joves de Bétera, Nàquera, Olocau, Gàtova, Altura, Alcubles, Gilet, Sogorb, Teresa, alguns pobles de l'Horta Nord... També ,però, de llocs més allunyats (El Cuervo, Catí, Saragossa...).

Com diem, al llarg del segle XVIII, però especialment en la segona meitat del segle, molts criats (generalment xiquets) de la Cartoixa de Portaceli solien aprendre a llegir i a escriure en el monestir, al temps que mantenien la seua relació laboral com a criats i treballadors. Un original mètode per a donar a conèixer als xiquets les lletres, els números i els signes de puntuació, així com ensenyar-los a fer síl·labes i la pronúncia corresponent, era el joc de la Perinola, o el dels daus, que havia ideat el pare Jaume Roig i Benet, vicari de la reial Cartoixa de Portaceli. ${ }^{42}$

Un cas ben conegut és el de Roc Romero i Puig, nascut a Serra en 1811, fill de Tomàs Romero, natural de Serra i nét de Francesc Romero, natural de Marines. Va ser enviat com a criat a Portaceli, on va aprendre a llegir i escriure, amb bona aplicació. Per aquell temps, el comte d'Olocau buscava un escrivà de suport $\mathrm{i}$ sembla que des de Portaceli li van recomanar al jove Roc, que acabà instal·lant-se a Olocau, on es va casar i arribà a ser secretari de l'Ajuntament durant molts anys. ${ }^{43}$

A través dels comptes generals que per als anys 1778 i 1779 li presentava al duc de Montellano el seu procurador i tresorer Pedro Verges Salafranca, coneixem que en aquell temps se li pagava a Pere Domènech, mestre de xiquets, 12 lliures pel seu salari anual. Per altres pagues fraccionades constatem que, efectivament, se li pagava a raó d'una lliure pel seu treball de mestre d'ensenyament. En els comptes de 1799 i 1800 (vint anys desprès), el mestre d'escola és José Cabo, que continua cobrant un salari de 12 lliures a l'any; en canvi, hi ha també, aleshores, una mestra de xiquetes, Rosa Sánchez, a la que se li paga prou més: 20 lliures anuals.

Per a construir la primera escola de xiquetes que tindria Serra es va restaurar, com ja hem explicat, una antiga casa "inhabitable i mig enrunada" que havia sigut casa de l'Ajuntament i presidi. La notícia del rector diu que com a Serra no hi havia Casa de Ensenyament de xiquetes i a tots els resultava molesta la companyia d'aquestes, que

${ }^{42}$ Sobre aquest mètode fa un interessant informe Joan Rubio: RSEAPV, 1790, C-20, III Educación, $\mathrm{n}^{\circ} 2$.

${ }^{43}$ Zurriaga (2003: 393). 
havien estat ocupant diferents llocs, van decidir que aquella que anaven a habilitar hauria de ser escola permanent i exclusiva per a que només pogueren ocupar-la la mestra i les xiquetes. A l'efecte -expressa el rector- es va fer una escriptura pública que és "la que consta al principi del Quinque Libri corresponent", en la qual diu que seria facultat privativa del rector la de posar a la mestra. Es va gastar en aquesta obra més de 100 pesos. $^{44}$

Però recordem que la construcció d'aquella primera escola de xiquetes, tal com indicava el rector Tormo, va ser possible desprès de que en 1799 el consell local haguera decidit que les 100 lliures que havia donat el duc de Montellano per a ajudar a construir un pou de neu es destinaren, millor, a posar en marxa una escola de xiquetes.

En aquell temps, l'ensenyament és sobre tot moral i religiós, estant les escoles a càrrec o sota la tutela dels rectors parroquials. Precisament tenim notícia de que en 1801 era tinent o mestre de l'escola de xiquets de Serra mossèn Jacint Vivas, clergue aragonès incorporat a la parròquia amb l'obligació de dir la missa matinal i tindre l'escola dels xiquets (Senís, 1978: 63).

Mig segle desprès, pel diccionari de Madoz (1845) sabem que Serra tenia una escola de xiquets i una altra de xiquetes; a la primera hi concorrien 30 alumnes i a la segona 40. Estaven dotades, respectivament, amb 1.500 i 1.200 rals (sous del mestre i de la mestra). Aquestes escoles s'han d'entendre amb un caràcter més clarament laic, a diferència de les anteriorment referides.

El cens oficial de l'any 1857 (un decenni i escaig posterior a les dades de Madoz) ens aporta una magnífica informació nominal de tots els veïns de Serra amb les seues característiques d'edat, sexe, ocupació i grau d'alfabetització. Així, hem pogut elaborar una sèrie de gràfiques i quadres que mostren interessants aspectes sobre l'escolarització $i$ les taxes d'analfabetisme general i per grups d'edats. Per a aquesta anàlisi hem partit només de les 1.251 persones censades al poble de Serra, excloent-hi, per tant, les 98 persones que habitaven en les tres colònies o nuclis rurals de Portaceli, La Pobleta i La Torre, formats majoritàriament per adults treballadors.

D'aquestes 1.251 persones en sabien llegir 267 (però una trentena d'aquestes només llegirien, sense saber escriure). Per tant, podem dir que al voltant d'un $79 \%$ de la

\footnotetext{
44 APS, Llibre de comptes de la fàbrica de l'església de Serra, fetes pel rector Francesc Tormo, en
} 1806: ANNEX VI. 
població és totalment analfabeta, mentre que la taxa dels que saben llegir i escriure es situa per baix del $19 \%$.

Si excloem la població de menors (350 xiquets i xiquetes que no en passen dels 12 anys), la població adulta, que inclouria gent jove de 13 i més anys (edat de treballar), es queda en 901 persones, de les quals saben llegir 122 (15 d'elles, com hem dit adés, no sabrien escriure, només llegir). Vist així, l'analfabetisme dels adults puja al 86 '5 \% i la taxa dels que saben llegir i escriure es queda encara per baix del $12 \%$ de la població adulta (incloent-hi joves de 13 o més anys). Entre les persones que saben llegir i escriure es troben la major part dels que exerceixen oficis especialitats més enllà dels de llaurador i jornaler; per exemple, l'obrer (de vila), el fuster, l'agutzil i, evidentment, el metge, el rector, dues mestresses (una de 70 i l'altra de 30 anys) i encara cinc estudiants d'entre 17 i 22 anys que, per l'edat podem suposar que siguen universitaris o almenys batxillers. Però també saben llegir i escriure al menys vuit de la quinzena de pastors aragonesos que resideixen a Serra en el moment de fer-se el cens (la nit de Nadal d'aquell any 1857). Per sexes resulta que 95 són els homes que saben llegir i només 27 les dones que en saben. Per edats, el grau d'alfabetització queda distribuït segons el QUADRE 8.7).

QUADRE 8.7.- Distribució per grups d'edats dels adults (13 o més anys) que saben llegir, segons els cens de l'any 1857.

\begin{tabular}{|l|c|c|c|c|c|c|c|c|}
\hline EDAT: & $13-20$ & $21-30$ & $31-40$ & $41-50$ & $51-60$ & $61-70$ & $>70$ anys & Totals: \\
\hline Homes: & 33 & 18 & 16 & 18 & 5 & 3 & 2 & 95 \\
\hline Dones: & 6 & 9 & 6 & 2 & - & 3 & 1 & 27 \\
\hline TOTAL: & 38 & 27 & 22 & 20 & 5 & 6 & 3 & 122 \\
\hline
\end{tabular}

Dades basades en el cens de 1857 (ADPV).

A la vista d'aquest quadre s'observa, en primer lloc, que la clara diferència global d'alfabetització entre homes i dones es manté en tots els grups d'edat. A més a més, podem afegir que de les 15 persones que sabien llegir però no escriure només dos són homes i les 13 restants dones, de les quals quatre estan en el grup més baix d'edat (13 a 20) i altres quatre en el següent (21 a 39), detall que ja sembla indicar que la discriminació per sexes continua activa en les dècades més recents de la sèrie, tal com 
anem a constatar desprès. Per altra part, es nota una bona diferència del percentatge d'alfabetització entre els majors i els menors de 50 anys ( o de 40 a 50 anys, més bé); i això podria significar que al voltant dels anys vint del segle XIX s'hauria pogut donat un major impuls a l'escolarització i l'ensenyament dels xiquets. Una possible explicació d'açò podem trobar-la, pot ser, en la política educativa del trienni liberal i el Reglament General de la Instrucció Pública de 1821, encara amb les seues vicissituds i derogació, però havent marcat, molt probablement una nova tendència en el camp de l'ensenyament públic i laic, desprès de que fins aquell moment haguera sigut sempre l'església la principal dipositària de l'educació dels més joves.

Tornant a les dades del cens de 1857 encara podem extreure un interessant perfil sobre la població infantil i jove en edat d'escolarització. Dels 350 xiquets i xiquetes trobem que estan escolaritzats 104, concretament 59 són "niños de escuela" i altres 45 "niñas de costura". Per tant, els xiquets anaven a l'escola i les xiquetes a costura. En el QUADRE 8.8 mostrem per edats la distribució de xiquets i xiquetes, així com el nombre dels que ja saben llegir o llegir i escriure. A la vista del quadre deduïm que l'edat d'escolarització és a partir de quatre anys, si bé hi ha ja un parell de xiquetes amb aqueixa edat; mentre que pràcticament deixarien l'escola a partir dels 12 anys. El fet de trobar alguns xiquets i xiquetes de tretze anys podria significar que estarien rebent un reforç, bé per acabar d'aprendre matèria bàsica o bé per a preparar-los en un accés a estudis superiors. En tot cas, com explicàvem abans, hi ha molts joves de 13 i més anys treballant, ells com a jornalers i elles sense indicació d'ofici (tampoc posa cap ofici el cens amb les que suposem que son mestresses).

En ocasions trobem famílies (cèdules) amb xiquets que saben llegir i escriure mentre que no en saben les seues germanes majors. Per exemple, dels germans Arnal Inglés (cèdula 185), Francesca i Dolors (13 i 11 anys) no en saben, mentre que Ramón (9 any) llig i escriu; o els germans Cabo Sanchis (cèdula 157), en que Ramona (12 anys) no sap llegir però el seu germanet Joan (10 anys) llig i escriu. La raó d'aquesta aparent discriminació podria estar simplement en un sistema educatiu en que els xiquets són ensenyats més prompte a llegir i escriure (en 8 o 9 anys ja tots en sabrien, segons les dades del quadre 8-6, apartat A), mentre que les xiquetes sembla que rebrien un altre ensenyament en els primers anys (la costura) i només dominarien la lectura i escriptura cap al final del seu període d'escolarització (cap als 11 anys, segons les dades d'aquest quadre). 
QUADRE 8.8.- Distribució per edats dels xiquets i xiquetes escolaritzats a Serra (A) i dels no escolaritzats que declaren saber llegir i escriure (B), segons el cens de 1857.

A) ESCOLARITZATS

\begin{tabular}{|l|c|c|c|c|c|c|c|c|c|c|c|}
\hline EDAT: & 4 & 5 & 6 & 7 & 8 & 9 & 10 & 11 & 12 & 13 & Totals: \\
\hline Xiquets & - & 1 & 9 & 9 & 9 & 11 & 10 & 2 & 6 & 2 & 59 \\
\hline (llig/escriu): & - & - & $2 *$ & 2 & 7 & 11 & 10 & 2 & 6 & 1 & 41 \\
\hline Xiquetes & 2 & 2 & 3 & 4 & 9 & 7 & 2 & 10 & 4 & 2 & 45 \\
\hline (llig/escriu): & & & & $2 *$ & $1^{*}$ & $3^{*}$ & 1 & 9 & 4 & 2 & 22 \\
\hline
\end{tabular}

B) NO ESCOLARITZATS PERÒ QUE DIUEN SABER LLEGIR I ESCRIURE

\begin{tabular}{|l|c|c|c|c|c|c|c|c|c|c|c|}
\hline EDAT: & 4 & 5 & 6 & 7 & 8 & 9 & 10 & 11 & 12 & 13 & Totals: \\
\hline Xiquets & - & - & 5 & 18 & 2 & 3 & 1 & 5 & 3 & - & 37 \\
\hline Xiquetes & - & - & 6 & 9 & 4 & 7 & 5 & 2 & 9 & - & 42 \\
\hline
\end{tabular}

L'asterisc indica que saben llegir però no escriure encara.

Dades basades en el cens de 1857 (ADPV).

El grup dels xiquets i xiquetes no escolaritzats (que arriben a la xifra de 246) inclou 76 xiquets i 69 xiquetes que serien d'edat pre-escolar (edat de quatre anys o inferior), metre que dels restants infants no escolaritzats però en edat d'estar-ho (entre 5 i 12 anys) hi ha una clara majoria que si que saben llegir i escriure; concretament 37 xiquets i 42 xiquetes (apartat B del quadre 8-6). Suposem que es tractaria de casos en que els xiquets han de dedicar-se a ajudar en el treball dels seus progenitors (per necessitat o per opció, una vegada saben llegir i escriure) i les xiquetes ajudar en les tasques domèstiques o bé anar a servir (a partir dels 9 anys). Per últim, els infants restants 9 xiquets i 13 xiquetes que no estan escolaritzats i tampoc saben llegir i escriure són tots de 'edat de 5 anys, per la qual cosa deduïm que aquesta seria realment l'edat obligatòria per a ser escolaritzats (haver complit els 5 anys, podem suposar).

En conclusió, podríem dir, a la vista de totes aquestes dades, que la taxa d'analfabetisme tindria una clara tendència a desaparèixer en aquesta recent començada segona meitat del segle XIX.

\subsection{LA PRESÓ I LES FORQUES}

L'immoble esmentat en la "notícia de la casa d'ensenyament de Serra", de la que parlarem adés, podem identificar-lo clarament amb el de l'antic Ajuntament que hem conegut a Serra fins els anys setanta del segle XX. Aquell edifici havia sigut durant 
temps immemorial la casa Ajuntament, l'escola de xiquets i de xiquetes (al primer pis) i la presó: un petit quartet, de gruixuda porta de fusta, situada als baixos de l'edifici. Sobre aquest immoble, l'esmentada nota diu:

"Habia en la calle que llaman del Consejo (Consell del municipi), una tramada muy arruinada que antiguamente había sido Casa del Ayuntamiento y servido de cárcel. Más en el día se estaba cayendo y era inhabitable. Solo servía para guardar la madera de la fábrica (de l'església), las garrofas en algunos años y toda ella causaba miedo. En esta intención,el Dr. Francisco Tormo, cura actual, hizo demanda de dicha tramada al Govierno actual y señores que en los años anteriores habian sido alcaldes, con el fin y objeto de construir en dicha tramada una casa de enseñanza". ${ }^{45}$

Com que aquesta notícia és dels començaments dels segle XIX, i per una altra notícia que a continuació veurem i els comentaris fets més amunt, resulta evident que aquella casa Ajuntament, amb presó i ara també amb les escoles va ser reconstruïda al complet per a tots els esmentats usos i funcions.

En l'any 1815, els corregidors de València, de Sant Felip i d'Alzira ordenaven a tots els pobles de les seues jurisdiccions que informaren sobre l'estat de totes les corresponents presons. En el cas de Serra va ser el seu alcalde ordinari de la baronia, Vicent Fabregat, qui informava així:

Certifico, en cumplimiento de lo mandado por el Sr. Corregidor de la ciudad de Valencia, en su despacho del veinte y uno del corriente, en que se manda remita testimonio de todas las noticias que pidieron en la orden de 20 de Diciembre del año 1814 relativa a las de 26 de noviembre del mismo año, expedida por el supremo Consejo: Que en este pueblo solo hay una cárcel con dos divisiones de corta extensión, construidas por el dueño territorial de esta Baronía. Su construcción y puertas no es de lo más sólido y por lo mismo, solo pueden servir para custodia y seguridad a los reos de poca entidad, pues cuando á resultado alguno de delitos grandes se ha trasladado a las cárceles de la ciudad de Valencia. El número ordinario de presos no puede decirse porque raras veces los hay. Revistas para su subsistencia no las hay, y se mantiene de sus propios bienes y en su defecto a expensas del pueblo. Y por consiguiente no hay administración alguna.

No hay en el pueblo otras cárceles ni casas de corrección.

Y para que conste doy el presente en esta baronía de Serra a los 30 días de agosto de 1816. Valga.Vicente Fabregat, Alcalde, y de su orden, por no saber escribir, Vicente Conejos, Fiel de Fechos". ${ }^{46}$

Si bé sembla evident que la presó estigué en aquest mateix lloc des de finals del segle XVIII, almenys. Hi trobem també evidències de que hi hagué abans presó en un altre lloc que ens resulta ben conegut: la Torre del Senyor, una torre medieval, de fàbrica andalusina, junt a la qual estigué sempre ubicada la Casa del Senyor. A més del testimoni

\footnotetext{
45 Aquesta noticia ocupa una página al final del Llibre de Fàbrica (APS, llibre de fäbrica del temple parroquial de Serra).

${ }^{46}$ ADPV, sg. A.8.1, caja 1, f. 103. (Secció A central, Subsecció "Cárceles y correcciones públicas").
} 
documental que tot seguit exposarem, altres dues són les raons per las quals enteníem que va existir aquella presó: per una banda la memòria viva en forma de topònim urbà, doncs l'habitacle de la torre, tradicionalment el lloc que feia de corral per a les tradicionals festes de bous al carrer, era i és conegut encara com a "la presó"; per altra banda, els gravats que hom pot apreciar junt al finestró de la torre, en la seu part interior, òbviament; formes esquemàtiques i amb traços paral·lels que ens recorden els que hem pogut també observar (suposadament segles XVI a XVII) en el diminut presidi del castell de Benissanó.

Dins d'aquella presó (esmentada ara com a la Torre de la Presó) va passar una estona el llaurador Francesc Rubio, per ordre d'en Enric Villagrasa, procurador d'en Vicent d'Aragó i Cardona (nou Senyor de la baronia de Serra), justament el dia en que estava prenent possessió d'ella en nom del dit senyor jurisdiccional. Era el dia 9 de juliol de 1650 i el procurador acabava de fer una crida pública (i la va preconitzar ) per la qual prohibia jugar a les cartes i qualsevol altre joc (d'aposta), com també portar armes o renyir uns amb altres, en el dit lloc i baronia de Serra i termes d'aquella, sota pena de seixanta sous i de presó. Desprès d'haver-se publicat aquella crida seria trobat l'esmentat Rubio portant un "punyal sense espasa, contravenint la dita crida i manament", per la qual cosa, el senyor procurador manà prendre i capturar a aquell i posar-lo dins la presó, tot exercint així la seua jurisdicció.

Va ser per la mediació d'algunes persones que, el procurador va accedir a manar traure i "excarcerar" al reu, però volgué, aleshores, executar aquell amb la pena de la crida (el pagament de les 60 lliures), la qual pena li fon remesa, finalment, a precs $\mathrm{i}$ intercessió d'algunes persones. ${ }^{47}$

Podem suposar que en aquesta mateixa presó de la Torre passaria algun temps Francesc Ros, que ser acusat de la mort de la seua esposa, Josepa Arnal, esdevinguda en la matinada del dia 3 d'octubre de 1778. El Justícia de la baronia de Serra ordenà que fora "assegurat en les presons ordinàries". Des d'elles va ser traslladat a les presons de València, on va ser jutjat, però mentre esperaven la sentència va arribar una orde de perdó i alliberament, de data 25 de febrer de $1779 .^{48}$

En un altre acte de presa de possessió de la baronia de Serra, el que va fer el 21 d'abril del 1713 en Josep Sánchez, com a procurador de Josep de Solís i de Josepa Folch

${ }^{47}$ AHN (FN), c. 1357, doc. 3 (8).

48 Cas citat pel notari Miquel Conejos (ARV, protocols, lg. 3626; data 25/02/1779) i del que no coneixem molts més detalls ara dignes de consideració. 
de Cardona, marquesos de Castellnou (nous senyors de la baronia de Serra desprès de la sentència recaiguda al seu favor aquell any), novament es pren possessió de les cases de l'Ajuntament i la presó, entre molts altres elements i regalies. Però, en aquest cas, el procurador pregunta també per la forca de la baronia i així és conduït a la muntanyeta que avui coneixem com a Puntal de les Forques "en donde al presente están levantados de calicanto (dos murs), y algunos vecinos del lugar que iban asistiendo a su merced, manifestaron haber estado siempre alli la horca". Desprès de prendre possessió, en la forma acostumada, va ordenar que els dits pilars foren reparats i que d'un a l'altre se travessés un pal per a que romanès per sempre una forca, en senyal de la jurisdicció criminal d'aquest lloc.

No hem trobat en la documentació examinada cap cas de condemnes a pena major ni sentències amb penes de presó, sinó únicament algunes penes pecuniàries, com els 450 rals de billó imposats en nom del senyor de la baronia a Francesc Català en 1799 com a "condemna de despeses i multa" per tallada de pins en el terme de la baronia de Serra. 


\section{CAPÍTOL 9}

\section{EXTINCIÓ I REVERSIÓ DE LA BARONIA DE SERRA A LA CORONA. FORMACIÓ DE L'AJUNTAMENT CONSTITUCIONAL}

Vam veure al capítol setè com els senyors de la baronia de Serra en el segle XIX van ser els ducs de Montellano i, particularment Maria Vicenta Solís y Lasso de la Vega, des del 1806 fins a la seua mort, esdevinguda a París el 1840. Continuà usufructuàriament en l'exercici del ducat el seu segon marit, Filibert Mahy i Branly, com a duc de Montellano i senyor de Serra, entre altres possessions i títols. Per tant, seria aquest noble qui hagué de protagonitzar la dissolució fàctica de la baronia de Serra com a tal i dins el procés de la seua reversió a la Corona formant un municipi constitucional. També va ser ell qui va negociar i liquidar amb els serrans la venda i traspàs de les seues possessions lliures fins que passaren plenament a mans del nous propietaris, que serien els veïns i l'ajuntament de Serra.

Per altra part, hem vist en els capítols cinquè i vuitè com en 1834 els vassalls de Serra pagaven encara tots els seus tributs emfitèutics al duc de Montellano, mentre que en els tres anys següents del mateix període d'arrendament de drets dominicals (1834 a 1837) es produïa una forta baixada i quasi total anul'lació dels tributs degut a la negativa veïnal. Aquell va ser, de fet, el darrer quadrienni del que tenim notícia que foren arrendats els drets dominicals de la baronia de Serra.

Tanmateix, vam explicar en el capítol sisè com també aquell any de 1835 deixaven de pagar-se delmes per part dels delmari parroquial de Serra i Nàquera, en ser decretada per aquell temps la derogació d'aquest dret secular.

Per últim, ja havíem parlat també, en el capítol primer, que va ser el 1835 i arran d'aquell any, per la dissolució de les ordes monàstiques i el procés desamortitzador de Mendizábal, que el terme de Serra quedaria ampliat amb el territori que fins aquell moment havia sigut terme del priorat de Portaceli, recuperant així una segregació que entenem que s'havia fet en el segle XIII, primer amb les donacions de Jaume I durant el Repartiment $\mathrm{i}$ desprès amb les maniobres del bisbe Albalat per crear aquell estratègic enclavament cartoixà. En tot cas, també hem pogut deixar palès en l'esmentat capítol primer i altres posteriors que al llarg dels segles transcorreguts des d'aquella suposada 
segregació, els plets territorials entre la baronia de Serra i el monestir de Portaceli havien sigut gaire continus pels límits d'afrontació dels dos termes, particularment en el sector més proper a la font del Llentiscle.

En el present capítol intentem explicar la manera i fets que envoltaren tota aquesta etapa final de la dissolució efectiva del règim senyorívol a Serra i de com va adquirir el poble el nou estatus municipal al voltant del que seria l'ajuntament constitucional de Serra.

Abans d'entrar en el cas particular de Serra convé deixar clar el context legal en el que quedarà emmarcat tot el procés de supressió del règim senyorial i de les senyories com a tals. Si el punt de partida era el Decret de 6 d'agost de 1811, que en el seu article primer incorpora a la Nació totes les senyories jurisdiccionals però en el seu article cinquè deixa fora d'aquesta incorporació a les senyories territorials i pairals. La posterior alternança d'etapes liberals i constitucionals amb altres clarament absolutistes, al llarg del segle XIX, complicaren encara més les interpretacions confuses i l'aplicació d'aquesta norma legal. Caldrien altres disposicions complementàries posteriors per a poder aclarir aquesta diferència bàsica entre senyories jurisdiccionals versus senyories territorials.

Intentant dissipar dubtes en la intel·ligència d'aquell decret es promulgaren dues lleis aclaridores sobre la seua interpretació i aplicació: la llei de 3 de maig de 1823 i la llei de 26 d'agost de 1837, però aquell esperit aclaridor sembla que només donà peu a estimular complicades retòriques $\mathrm{i}$ allargar, en definitiva, molts processos judicials al respecte. S'ha escrit molt al respecte, però desprès de les valuoses i ja clàssiques aportacions de García Ormaechea (1932) i de Moxó (1965), com també una llarga producció historiogràfica posterior plena de grans coincidències però també certes diferències $\mathrm{i}$ alguna que altra controvèrsia, hem trobat en el treball de Hernández Montalbán (1999) una perspectiva realment analítica i aclaridora de l'assumpte.

Per altra part i sabent, com sabíem per un document de l'arxiu ducal de FernánNúñez, que en el cas de Serra s'havia arribat a incoar un expedient judicial de demanda per a la reversió de la baronia a la Corona, vam cercar una possible sentència al respecte. La recerca realitzada va resultar finalment infructuosa per al cas concret de Serra, però ens va permetre tindre un accés clar i fiable a molts altres casos de sentències, recursos $i$ execucions en aquesta matèria. ${ }^{1}$

1 Hem cercat en els 8 primers volums de la col-lecció JURISPRUDÈNCIA CIVIL, obra publicada en 1860 i que se subtitula com "Colección completa de las decisiones sobre competencias y de las 
D'aquesta experiència volem destacar la continua al·lusió que en tot moment hem observat que es fa per determinar el caràcter de la jurisdiccionalitat/territorialitat de les senyories i baronies; aquest és sempre el quid de la qüestió (tal i com defensa Moxó, 1965) o, almenys, el fil argumental en resolucions i en recursos (a més de les sentències a les que fan referència però no s'acompanyen per ser anteriors a la sèrie). Com diem, no hem trobat cap referència a Serra, però l'acumulació de casos observats ens duu a entendre que Serra era un típic cas de senyoria jurisdiccional (donacions reials del segle XIII) i desprès baronia del mateix caràcter (concessió del segle XIV). Els ducs de Montellano no podrien haver argumentat el contrari, en un principi. Però la compra que van fer Felip Boïl i Agnès de Vallterra a principis del segle XV va ser per diners $(80.000$ sous) i la posterior compra a tots dos pels comtes de Prades cal suposar que també ho fou. No dubtem que aquestes compra-vendes, degudament argumentades pels senyors de la baronia de Serra, podrien haver complicat considerablement el procés jurídic de reversió a la Corona; açò, però, no deixa de ser una apreciació personal, no exempta d'interès però si mancant d'evidència real.

No obstant, el que també ens sembla evident és que una bona part dels casos s'allargaren tant en el temps que finalment quedaren superats per la pràctica i per la realitat social del país, restant en una mena d'etern llimbs jurídic.

\subsection{ELS DUCS DE MONTELLANO SENYORS DE SERRA EN EL SEGLE XIX.}

Hem vist en el capítol setè com els ducs de Montellano van ser senyors de la baronia durant la major part del segles XVIII i tot el que resta de reminiscències de l'antic règim durant el segle XIX.

El 1800 era senyor de la baronia de Serra el V duc de Montellano, Alfons Aleix de Solís Wignacourt i Folch de Cardona, que ho era des de la mort de son pare, el 1780, i seguiria sent-ho fins al 13 de novembre del 1806, en que morí a l'edat de 50 anys. Li succeiria en el ducat la seua única filla, Maria Vicenta, de qui hem parlat amb més detall en el capítol setè.

Recordem que M. Vicenta de la Soledat Solís i Lasso de la Vega heretà de son pare, Alfonso Alejo de Solís (1756-1806), els títols que coneixem, del ducat de Montellano, marquesat de Guadalest i diverses baronies, entre elles la de Serra, a més de

sentencias en recursos de nulidad, casación e injusticia notoria". Digitalitzada per Google. 
certes possessions a Bèlgica, i de sa mare, $\mathrm{M}^{\mathrm{a}}$ Antònia Lasso de la Vega i Silva (17561788), que va ser IV Duquessa de l'Arco, XI marquesa de Miranda d'Anta i VII comtessa de Puertollano, tots aquests títols.

Per la mort del primer marit de M. Vicenta Solís, Carlos Gutiérrez de los Ríos (11780-822), esdevinguda a París, on era ambaixador, la filla d'ambdós, Francesca (aleshores de 20 anys d'edat) heretaria els títols paterns del ducat de Fernán-Núñez, als que la duquessa de Montellano no va mostrar cap interès desprès del dolent testament del difunt marit, que reconeixia el seu amor cap a una altra dona, Fernanda Stuart, a qui li llegava totes les joies i altres coses.

Així, mentre que el ducat de Fernán-Núñez quedava en mans de Francesca (II duquessa d'aquest títol), el de Montellano seguiria en mans de M. Vicenta i, després de la seua mort, en les del duc consort, el seu segon marit i hereu usufructuari en Filibert Mahy i Branly, qui continuaria exercint plenament com a duc de Montellano, almenys a nivell administratiu i fins a la seua tardana mort.

Maria Vicenta Solís va morir a la ciutat francesa de Tours el dia 4 de juny de 1840, a l'edat de 60 anys. Les seues restes mortals van ser traslladades al panteó dels Montellano, situat en la Sacramental de Sant Isidre, a Madrid. Tres anys abans, estant a París, en 2 de maig de 1837, al poc d'haver faltat la sua filla, havia escrit el seu darrer testament hològraf (veure apèndix documental), al qual ja hem dedicat certa atenció en el capítol setè.

Per tant seria aquest noble, Filibert Mahy, qui hauria de viure de manera més directa tot el procés de la pèrdua efectiva de possessió baronia de Serra i la posterior liquidació dels bens que li restaren en aquesta.

Quan en la segona meitat del segle XIX havia ja desaparegut la baronia de Serra com a possessió jurisdiccional i territorial, el títol de la mateixa, com a reminiscent però legal títol nobiliari, continuaria en mans dels mateixos llinatges que la posseiren abans.

Vam veure al capítol setè, amb més detall, com la filla de Maria Vicenta Solís i el seu primer marit, convertida en II duquessa de Fernán-Núñez, havia mort en 1837 amb només 35 d'edat, casada, però, amb Felipe Osorio de la Cueva, comte de Cervelló, havia tingut una filla, Maria del Pilar Loreto Osorio Gutiérrez de los Ríos Solís y de la Cueva (10/12/1829-1/09/1921), la qual heretaria molt jove tots els títol nobiliaris de Fernán- 
Núñez (com a III duquessa) i també, amb el temps, els de la seua àvia i aviastre: els del ducat de Montellano (VII duquessa) amb la llarga llista de títols que duia adjunts.

FIGURA 9.1.- Esquela mortuòria de la baronessa de Serra, Ria i Armell (i altres títols).

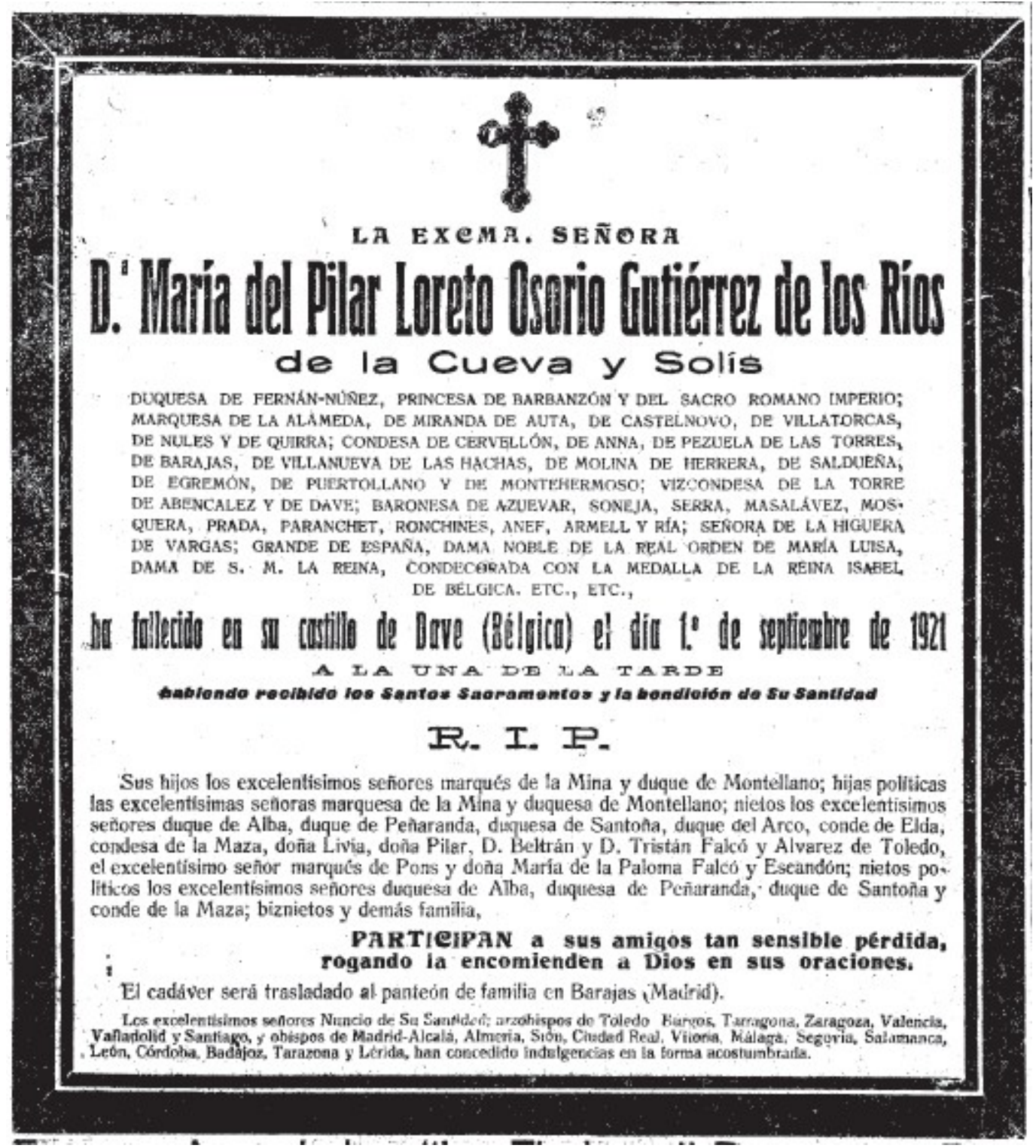

Esquela publicada en diversos rotatius de l'època.

Maria del Pilar es va casar a Madrid el 14 d'octubre de 1852 amb Manuel Falcó i d'Adda, marqués d'Almonesir. Malgrat la desaparició de l'antic règim, el títol de baronessa d'Assuévar, Soneixa, Serra, Massalavés, Mosquera, Prada, Paranchet, Ronchines, Anef, Armell i Ria... el trobem encara en la seua esquela mortuòria, en setembre del 1921 (FIGURA 9.1). La duquessa moria en el seu castell de Dave (Bèlgica), 
poc abans de complir els 92 anys d'edat. Curiosament, en l'esquela no hi consta el títol de duquessa de Montellano, per haver-lo donat en vida a un dels seus fills, tal com hem explicat al final del capítol setè. D'aquesta manera, entenem que actualment, el títol de la baronia de Serra, Ria i Armell ja no es troben lligats a la persona titular de que ostenta el títol del ducat de Montellano, sinó al de Fernán-Núñez.

\subsection{FILIBERT MAHY, DARRER POSSEIDOR DE LA BARONIA DE SERRA.}

Filiberto José Mahy Branly Romo Gamonales, originari d'una distingida família de Namur (regió de Valònia, Bèlgica), va nàixer el juliol de 1790 a Madrid. Els seus pares havien d'embarcar cap a Nueva Espanya tres mesos abans del seu naixement, però l'estat de la mare, embarassada de risc, amb hemorràgies uterines des del tercer mes de l'embaràs (segons certificat mèdic) aconsellaren posposar el viatge i així li ho concediren. $^{2}$

Son pare, Filiberto Mahy Martín, sent cadet de la $7^{\mathrm{a}}$ Companyia Flamenca de Reials Guàrdies de Corps (guàrdia reial) s'havia casat amb Josepa Branly sense disposar de la pertinent llicència reial, cometent així una falta que el mantenia suspès de la paga a la que aspirava per haver-se-li conferit el càrrec de Capità de Dragons de l'exèrcit de Nova Espanya. D’aquesta falta va ser indultat pel Rei, segons consta en la notificació que va rebre el virrei de Nova Espanya, tramesa des d'Aranjuez en data 28 de maig de $1790 .^{3}$ El dia 11 de juliol del mateix any, poc abans de nàixer el seu fill, aquest capità de Dragons exposa al rei la seua situació familiar i personal i suplica que se li comence a pagar el sou del seu càrrec de Capità $\mathrm{i}$ que se li reconega a la seua esposa el dret de viduïtat al que tindria dret si arribés el cas. El 16 d'agost se li ratifica l'indult i el dret de paga però no el de viduïtat perquè ho prohibeix el Reglament del Montepio militar. ${ }^{4}$

Finalment, el capità i la seua família obtindran el 4 d'abril de 1791 el passatge per a viajar a Veracruz amb el seu criat, Antonio Pérez González, natural de Llanes i fadrí de

\footnotetext{
2 Maria Teresa Díez Martín (2.011): Viajeras al servicio de su majestad. Un discurso colonialista de género en el siglo XVIII. In Viajeras entre dos mundos, de Sara Beatriz Guardia (ed.). (http://maytediez.blogia.com/2011/092202-viajeras-al-servicio-de-su-majestad.-un-discurso-colonialista-de-genero-en-el-si.php).

3 Archivo General de Simancas, SGU, lg. 7224, núm. 52, f. 244. (accès en portal PARES).

${ }^{4}$ Archivo General de Simancas, SGU, lg. 6957, núm. 17, f. 58 a 63. (accès en portal PARES).
} 
38 anys, a bord de la fragata Nuestra Señora del Rosario. ${ }^{5}$ Suposem que a Mèxic i al Carib pogué haver passat Filibert Mahy Branly la seua infància i primera formació, doncs un oncle seu, Nicolás Mahy, era Capità General de Cuba en 1821. No obstant això, sembla clar que el pare, Filibert Mahy Martín, en la segona dècada del segle XIX estava ja destinat en la Península. En 1814 hauria arribat a ser coronel de Dragons de Lusitania, quan el trobem en un procés en que és acusat de francmaçó davant el tribunal de la inquisició de $\mathrm{Cort}^{6}$. Dos anys desprès trobem el testimoni agraït d'una persona que hagué d'allotjar en sa casa al coronel don Filiberto Mahy (pare) quan entrà prop de Lorca el regiment de cavalleria que dirigia: "le cedi la habitación principal y él así por eso como por su buena educación, se portó con mucho decoro mientras estuvo en casa, que fue poco más de un mes". En 1821 també trobem al coronel com a Comandant d'Armes de la ciutat de Burgos.

Filibert Mahy Branly es va casar el 12 de febrer de 1824 amb la duquessa de Montellano, Ma Vicenta Solís. Com sabem la duquessa era vídua del duc de FernánNúñez (que havia mort cap a 1822) i tenia per tant 43 anys quan contragué el seu segon matrimoni, mentre que el seu marit, Filiberto Mahy era un Tinent d'Artilleria deu anys més jove que ella. Algunes fonts indiquen que el casament hauria sigut el 12 de febrer de 1834 (deu anys després), ${ }^{7}$ però hem de dissentir perquè en els anys vint hi trobem de vegades referida la figura de Mahy com duc de Montellano. Per exemple, la llicència que en 28 de juny de 1827 concedeix el duc de Montellano, Filibert Mahy Branly, a dos veïns de Massalavés per a que puguen vendre uns camps d'arròs a un altre veí d'Alzira. ${ }^{8}$

En l'arxiu ducal de Montellano i Fernán-Núñez (AHN, secció noblesa) no he trobat constància de que aquest matrimoni tinguera descendència, sinó tot el contrari, tres anys abans de morir (juny de 1840), la pròpia duquessa escrivia en el seu testament “declaro que me hallo actualmente casada con el Exmo. Señor Don Filiberto Mahy y Brauly, de cuyo matrimonio no tenemos hijo alguno". " Però altres fonts "oficioses" asseguren que Vicenta havia tingut cap a 1822 una filla, Maria de Mahy i Solís de

\footnotetext{
${ }^{5}$ Archivo General de Indias, Arribadas, 516, N.33. (accès en portal PARES).

6 "Alegación fiscal del proceso de fe de Antonio Bernard, comandante del Regimiento de Algarbe; Filiberto Mahy, coronel de Dragones de Lusitania y Ramón Villalba, exinspector de Caballería, seguido en el tribunal de la Inquisición de Corte, por francmasones, propagandistas en Vigo". (ES-AHN-28079UD-178103).

${ }^{7}$ Entre altres: www.geneanet.org.

${ }^{8}$ BV, Manuscrits, Ms. 303, f. 74.

${ }^{9}$ AHN-FN, c. $438 / 1$.
} 
Wignacourt, la qual es casaria amb Pere de Zea, donant a la comtessa de Montellano un nét: Philbert Zea Mahy (1843-1904), prestigiós almirall de l'Armada espanyola i suposadament emparentat amb el comtat de Clonard $^{10}$; qüestió que simplement comente ací com a curiosa anècdota que no té més transcendència als nostres efectes. En tot cas, la boda de la duquessa amb Filiberto Mahy no s'hauria produït fins al 12 de febrer de 1824 . A banda de l'opció adés apuntada de que Filibert Mahy i Branly poguera haver viscut els primers anys de sa vida a Amèrica, el cert és que era un militar de llarga tradició familiar, procedent com hem apuntat abans, de la província belga de Namur, on precisament els ducs de Montellano posseïen la senyoria de Dave, de la que fou titular Maria Augusta de Wignacourt, àvia paterna de M. Vicenta Solís.

En tot cas, en 1822 trobem esmentat a Madrid el brigadier D. Filiberto Mahy (entenem que seria novament el pare de Mahy Branly) comandant la Columna de Sigüenza. ${ }^{11}$ També aquell any, concretament el 22 de juliol, moria a l'Havana, per la malaltia del vòmit negre, l'oncle de Filiberto (germà major de son pare), Nicolás Mahy Martín Chenu i Romo (nascut a Madrid, el 1757), que era Capità general de Cuba des del 3 de març del 1821. Pels expedients de noblesa de sang (fidalguia) d'aquest oncle (registre 1524; Exp. 1206.- aprovat en 1 d'agost de 1803) i del pare d'aquest (registre1523; Exp. 121, aprovat en 23 febrer de 1782), hem pogut conèixer una bona part de la línia genealògica ascendent de Filibert Mahy Branly: ${ }^{12}$

Avi: Nicolas Mahy Chenu Monget y Jacquet, nascut a Namur l'11 desembre de 1719, va ser Tinent graduat i ajudant de la Companyia Flamenca de Reials Guàrdies de Corps. Es va casar a Madrid el 3 de desembre de 1756, amb Francesca Martín (nascuda a Jadraque en 1735). Tingueren cinc fills: Nicolàs, Rafaela, Filibert, Antoni i Francesc. Morí en 1782.

Besavi: Nicolás Filibert Mahy, nascut a Namur, el 30 de gener de 1671, conseller de la ciutat de Namur entre 1705 i 1727; casat el 20 de gener de 1715, amb Maria Isabel Chenu (també nascuda a Namur, el 7 de gener de 1685, i vídua de Pedro Flories).

Rebesavi: Corneli Mahy, també nascut a Namur, el 20 de gener de 1640; casat en $1661 \mathrm{amb}$ Caterina Monget (nascuda també a Namur, el 20 de febrer de 1649).

\footnotetext{
${ }^{10} \mathrm{http}: / \mathrm{gw}$. geneanet.org/iraird?lang=fi\&p=vicenta\&n=solis+de+vignancourt. Segons aquesta font: "Este es otro incomprensible error de algunas controvertidas genealogías españolas, que aparentemente han preferido "favorecer o dar por válidas" lo que afirman las genealogías de los Falcó y más recientemente la de los Fitz-James. Es decir omitir la descendencia de la Duquesa de Montellano con Philibert de Mahy". Veure també: www.suttonclonard.com/PicJoe.htm.

${ }^{11}$ citat a la Gaceta extraordinària de Madrid del diumenge 11 de juliol de 1822.

${ }^{12}$ Vicent de Cadenas y Vicent (1985) Extracto de los expedients de la Orden de Carlos III (1771-1847). Inst. Salazar y Castro. CSIC.
} 
Trebesavi: Francesc Mahy, nascut a Namur el 5 de maig de 1615; fill de José Mahy i Maria de la Ruelle. Va ser conseller de S.M.; casat el 20 de juliol de 1633 amb Maria Cuvelier (nascuda a Namur l'11 de febrer de 1613).

Sembla clar que Filibert Mahy Branly, en casar-se hauria deixat la seua trajectòria militar per dedicar-se sencerament a l'administració del ducat de Montellano i la resta de possessions nobiliàries de la seua esposa i sempre junt amb ella. Així, els trobem a sovint fora d'Espanya; en 1839 a Bordeus, com veurem desprès; en altres moments a Bèlgica, on freqüentaven el seu castell o palau de Dave; el seu darrer testament l'escrigué M. Vicenta Solís a París, on tenia casa i, en fi, la mort li sobrevindria a la duquessa estant a Tours, el dia 4 de juny de 1840 .

A més de en els assumptes judicials $\mathrm{i}$ administratius de les baronies $\mathrm{i}$ altres pertinences del ducat de Montellano, hem trobat al "Sr. duque viudo de Montellano y del Arco" fent una donació de 2.000 rals a l'Associació de la Creu Roja en l'any $1874 .{ }^{13}$

El duc de Montellano continuaria ocupant-se dels assumptes propis del ducat i la resta de possessions que havien sigut de la duquessa, i que en certa manera havien passat a ell plena i francament, fins a la seua mort, que li vingué el 12 de febrer de 1887 (amb 96 anys d'edat).

\subsection{PRESSIÓ TRIBUTÀRIA AL LLARG DEL SEGLE XVIII I ENCARA EL XIX.}

Van veure en el capítol cinquè com les, en principi no massa dures condicions i quotes de partició reflectides en la carta-pobla de Serra i Ria (si les comparàvem amb altres cartes-pobles coetànies i posteriors) acabaren fent-se realment dures quan, al llarg, sobre tot, de la primera (i també la segona) meitat del segle XVII en altres llocs eren assolides concòrdies i pactes que assuaviren llurs condicions inicials. El malestar dels serrans es va manifestar aleshores amb declaracions incompletes de les produccions, estratègies d'ocultació, tal com observàrem en el cas de les vinyes i del vi.

Per fi, a finals dels XVII començarien a canviar les coses amb certes mercès $i$ concessions per als vassalls aleshores fetes per Vicent Folch de Cardona i Milà. Realment serien concessions més forçades per la seua pròpia estratègia de consolidar la

${ }^{13}$ Diari polític "La Época", del 9 de juliol de 1874. 
fidelitat dels vassalls, davant a altres contrincants per la possessió de la baronia, que per raons benvolents. Aquestes concessions en concretarien per escrit en una sèrie d'actes notarials nomenats com "Establiments" que tot seguit resumim: ${ }^{14}$

- Dos establiments fets i fermats en 30 de març de 1697 pel marqués de Castellnou i de Pons... concedint als Justícia, jurats, pròcers i universitat de Soneixa: (1r) concessió per a ampliar la casa del consell local (aula consiliarii) i (2n) el dret de poder hostatjar i donar alberg en "El Mesó" de la baronia (concessió d'aquesta regalia).

- Un establiment del mateix marquès i senyor, fet i fermat el 16 de juny de l'any 1700 a favor del Justícia, jurats i “demés particulars” del lloc de Serra i Ria, per tal d'afermar les gràcies, establiments i concessions que Josep Vidal, el seu procurador generals, els hi va fer al temps de prendre possessió de la baronia de Serra i Ria (suposem que açò es remunta a l'any 1680).

Les concessions i gràcies a que fa referència l'establiment de 1700 consistien, en primer lloc, en la facultat donada als esmentats jurats i consell de Serra per a poder arrendar el forn de coure pa "situat en dit lloc de Serra" i cobrar la renda, pagant no obstant al Senyor directe 12 diners de lluïsme i fadiga pagadors tots els anys "en lo dia $\mathrm{i}$ terminis en que es paguen la resta de censos". Però (atenció!) feia açò “a canvi de que no puguen dits veïns ni sons successors elegir, reconèixer i proclamar altre Senyor directe que no siga el dit il·lustre Marquès, senyor de dit lloc i sons successors en aquell, sots pena de comís".

Tanmateix, redimia tots els veïns del dit lloc de Serra que pagaren, així com pagaven per cadascuna casa, 15 rals de cens, lluïsme i fadiga, anualment. I d'ara en avant pagarien només 10 rals a dit il·lustre marquès. A partir d'aquell moment tampoc haurien de pagar més per divisions o particions de cases: "no hagen de pagar més ni tinguen fer pagar sinó lo cens que els tocarà a cascú de la part de casa en que es dividiran, per raó dels 10 rals d'aquella".

La concessió anterior modifica la clàusula cinquena de la carta-pobla, com també la següent concessió feta: que cada casa que els veïns edificaren de nou no hagueren de pagar pel "siti" on s'establiran sinó únicament un cens anual de 4 sous. Aquesta nova condició i gràcia ens ajuda ara a millor interpretar els dubtes i qüestions que plantejarem en el capítol quart sobre els censos tan baixos de les cases partides i "les cases de Ria".

\footnotetext{
${ }^{14} \mathrm{ARV}$, escrivanies de càmera, any 1714 , expt. 21 , f. $11 \mathrm{r}^{\mathrm{o}}$ a $91 \mathrm{v}^{\mathrm{o}}$.
} 
Però les majors concessions seran, per fi, la rebaixa efectiva de les particions de tots els grans i fruits. Per una banda, els de l'horta passen de pagar la sisena a pagar només la vuitena part "i no més, per redimir-los, com els redimeix, les dos que van de sis a vuit". I pel que fa al secà "que del dia de hui en avant los veïns del referit lloc de Serra hagen de pagar a dit il·lustre Marquès a raó del fruits i grans del secà lo mateix que paguen els veïns del lloc de Soneixa" (no concreta numèricament quant, però la casuística és ampla i variable: vinyes tradicionals, vinyes de noves transformacions $i$ altres diferents fruits).

A partir del govern de Vicent Folch de Cardona i Milà en la baronia de Serra tot podria haver sigut més tranquil i cordial pel que fa a les relacions entre senyors i vassalls i al sentiment d'opressió que havia dominat en els vassalls durant la major part del segle XVII patint una pressió senyorívola prou més dura que l'existent a la propera baronia de Nàquera o davant les millores que havien assolit, tenint al mateix baró, els vassalls de Soneixa.

Però la realitat va ser una altra més dolenta quan, desprès de la mort de Vicent Folch de Cardona (en 1704), les concessions que havia fet a Serra començaren a ser oblidades, i més encara desprès de les sentències que Josepa Folch de Cardona acabava de guanyar en el plet que mantenia contra el duc de Sogorb i que li adjudicaven definitivament la possessió de les baronies de Serra i de Soneixa, de les que prendrien ràpidament possessió ella $\mathrm{i}$ el seu marit, aleshores comte de Salduenya (futur duc de Montellano), entre els dies 19 i 21 d'abril de 1713, per mans del seu apoderat, Josep Sánchez i Olivar. Recordem que en aquella presa de possessió s'interessaren per deixar molt clara la jurisdicció, mer i mixt imperi que tenien, fent reconstruir la forca i fent posar un home dins de la presó per dur una espasa (com hem vist al capítol vuitè).

El dia 6 de juliol de 1713, el sacerdot Ignasi Lavarias (rector parroquial de Massalavés), com a procurador generals de Josep de Solís i Gante i Josepa Folch de Cardona, marquesos de Castellnou i de Pons i "Senyora de la presente baronia..." es reunia a Soneixa amb els representants i consell d'aquest lloc per a reclamar-los que devien pagar la sisena part dels fruits de les hortes... i complir amb la resta de censos $\mathrm{i}$ drets que pagaven els seus antecessors "de conformitat amb la sentència definitiva que dita molt il·lustre senyora ha guanyat en el plet que seguia..." (entenem que la sentència deu de fer referència a la carta-pobla/cartes-pobles). Els regidors, tinent d'alcalde, síndic, etc., de Soneixa, expressaren que els veïns no devien pagar més de la vuitena part de 
fruits ni pagar més d'allò que fou convingut amb l'anterior molt il·lustre senyor marquès en Vicent Folch de Cardona y Milà, pare de dita senyora en Josepa, "al temps que dit lloc donà la possessió del lloc, de ses regalies i de tots altres drets dominicals al dit senyor marquès per la mort de l'Exma. senyora Caterina d'Aragó, duquessa de Sogorb". ${ }^{15}$

El document anterior recull de manera clara i ferma la protesta i reclamació dels vassalls i universitat de Soneixa, però està clar que aquest no seria més que l'inici d'un llarg plet entre vassalls i futurs ducs de Montellano. Per la seua part, en 14 d'abril de 1714, el procurador Francesc Alfonso, en nom i representació de "les baronies i llocs de Soneixa, Serra i Assuévar" aportava a l'audiència escrit acompanyat de còpies de les diferents escriptures dels establiment pels quals reberen les esmentades gràcies i concessions les expressades baronies. A més de les ja citades, de 30 de març de 1697 (Soneixa) i de 16 de juliol de 1700 (Serra), cita una altra de 20 de febrer del mateix 1697, que potser parle de la reducció de la partició de fruits feta prèviament a Soneixa. ${ }^{16}$

Un any desprès, el conflicte continuava ben latent segons coneixem per un document de 1715 existent a l'arxiu dels ducs de Montellano: un "Memorial ajustat del plet seguit per D. José Solís y Gante y Josefa Folch de Cardona, marqueses de Castellnou i Pons... contra els veïns de llurs baronies de Soneixa, Serra i Assuévar, sobre les gràcies que els hi concedí l'apoderat de dits senyors sense ordre ni consentiment dels marquesos". No hem trobat l'acabament d'aquest litigi ni cap sentència al respecte però, amb l'anterior text com a "assumpte" del memorial no ens resulta massa estrany que el conflicte no es resolguera a favor dels vassalls, sinó que aquells, per contra, en el cas de Serra continuaren estant sotmesos als capítols inicials de la carta pobla. Així ho hem vist, per exemple, en el conflicte del vi, que hem exposat en el capítol cinquè i que, com sabem, desprès d'un dilatat procés arrossegat al llarg del segle XVII no es resolgué fins a $1808 \mathrm{amb}$ una sèrie de sentències a favor sempre del Senyor.

Com sabem, la marquesa moriria jove $\mathrm{i}$ de sobte en 1716, poc desprès de que el Reial i Suprem Consell de Castella li haguera confirmat novament la possessió de les baronies de Soneixa i Serra. Poc desprès, el seu marit, Josep Ignasi de Solís i Gante (que va viure fins al 1756) es convertia, per la mort de son pare, en el III duc de Montellano i continuava, ara com a tal, fent-se càrrec de tots els títols i possessions de la difunta marquesa, en companyia del fill primogènit d'ambdós, Alons Vicent. Serien, per tant, els

\footnotetext{
${ }^{15}$ Ibidem, f. $35 \mathrm{r}^{\mathrm{o}}$ a $39 \mathrm{v}^{\mathrm{o}}$.

${ }^{16}$ Ibídem, f. $90 \mathrm{r}^{\mathrm{0}}$ a $91 \mathrm{v}^{\mathrm{o}}$.
} 
ducs de Montellano (III, IV i V ducs) els que seguiren sotmetent els vassalls serrans a les mateixes dures particions de la carta pobla de 1609. Pel capbreu de 1779 sabem que els censos emfitèutics de les cases tampoc no es rebaixaren respecte al que deia la cartapobla, si bé, almenys en el tema menor de les noves cases i les cases dividides van ser més tolerants.

El problema creat per la negativa de la marquesa de Castellnou i els seus marit, fill i nét, ducs de Montellano, a reconèixer les gràcies i concessions que Vicent Folch de Cardona i Milà havia concedit l'any 1700 als serrans no trobà cap solució al llarg del segle XVIII, com hem vist, ni la trobaria tampoc en el segle XIX, com veurem en l'epígraf següent. El problema, però, va originar en els serrans un sentiment de frustració i d'injustícia que es prolongaria al llarg de diverses generacions, i arriba de vegades a certa desobediència i encara rebel·lia. De fet, molts veïns i encara la corporació local i alguns càrrecs públics, com és el cas dels justícies de la baronia, mostraren de vegades una gran mancança de rigor, fermesa $\mathrm{i}$ sentit del deure quan de temes contributius $\mathrm{i}$ pecuniaris es tractava. Desconeixem casos i detalls de certes actituds dels justícies, però ens consta que en diverses ocasions van ser condemnats i amonestats. Concretament, en maig de 1761, el comte de Saldueña (Alons Vicent Solís), mitjançant de l'escrivà de València Cristòfol Fornas, denunciava els subjectes que havien exercit els càrrecs de justícia de Serra entre els anys 1736 a 1760, per les seues omissions i la mala administració de la justícia, motiu pel qual foren condemnats la major part d'ells a penes pecuniàries imposades per una sentència del Dr. Manuel Román, jutge comissionat per a la causa. ${ }^{17}$

També per les seues “omissions i negligència en la bona administració de justícia” serien comdemnats a penes pecuniàries altres dels individus que havien exercit l'ofici de justícia de la baronia de Serra entre els anys 1761 i 1775, tot açò segons sentència resultant del procés iniciat el 16 de juliol de 1776 pel duc de Montellano amb assistència del llicenciat Eleuteri Alfaro i davant l'escrivà Miquel Sarrió. Podem suposar que hi haurien més denúncies o amonestacions senyorívoles al respecte, perquè l'any 1792, l'ajuntament de Serra traslladava al duc de Montellano una sèrie de propostes de conciliació referides als veïns que havien exercit els càrrecs de justícia entre els anys 1725 i $1785 .{ }^{18}$

17 "Yndice general de los instrumentos..." (Annex 5): doc. 62.

18 "Yndice general de los instrumentos..." (Annex 5): doc. 71 i 79. 
Però, aquesta mena de fets no seria exclusiva de Serra, sinó que també els van patir els ajuntaments de Soneixa i d'Assuévar, doncs observem que també es van produir accions semblants del duc contra els justícies negligents d'aquells pobles i posteriors respostes semblants de dits ajuntaments buscant fórmules de perdó i conciliació, suposem que en la mateixa línia plantejada pels de Serra. ${ }^{19}$

\subsection{ALGUNS CASOS DE CONFLICTE DOMINICAL EN EL SEGLE XIX.}

Tenint en compte que la situació de Serra era propícia a que s'haguera produït alguna mena de protesta o d'insubmissió activa al pagament de drets dominicals, i vist que al voltant de l'estiu de 1801 es van viure per bona part del País Valencià una sèrie d'avalots en tal sentit, sota la figura anònima d'un tal "Pepet de l'Horta" (Ardit, 1969 i 1977), que a Estivella i altres pobles adoptava el nom de "Pepet de la Muntanya" (Mesa, 2014), hem repassat les sèries dels avalots, ${ }^{20}$ recercant algun possible conflicte o indici que tinguera referències a Serra o a serrans, sense trobar cap resultat positiu malgrat que la revolta arribà amb força fins poblacions properes a Serra, com l'esmentada Estivella, Albalat de Segart i Montcada.

No obstant això, en els primers anys del segle XIX, els ànims dels serrans sabem que eren més bé d'insubordinació i rebel·lia. Per una banda ho recordem amb el conflicte del vi, del què parlàrem en el capítol cinquè i que es trobava ben latent en 1806. Per altra hi trobem que entre finals de 1807 i principis de 1808, Francesc Rubio, com a procurador de l'excel·lentíssim comte de Fernán-Núñez, duc de Montellano i de l'Arc, observava que havien sigut construits cert nombre de forns de coure pa en cases particulars, sent això una pràctica expressament prohibida pel capítol 13 de la Carta-Pobla de Serra i Ria, que deia que els pobladors i llurs successors no podien fer hostal, posar taverna, piló... Ni fer forn algun, encara que siga per al seu propi ús, ni molí, ni almàssera... perquè totes aquestes eren regalies reservades per al senyor i, a més a més, els pobladors tenien deure i obligació de coure en el forn de la baronia.

La primera denúncia que interposa Francesc Rubio, que a més d'actuar com a “procurador de l'amo territorial d'aquesta baronia” és d'ofici moliner i veí de Serra, va contra Josep Navarro a qui li comunica haver tingut notícia de que ha disposat la

\footnotetext{
19 "Yndice general de los instrumentos..." (Annex 5): doc. 63, 64, 69, 70, 78 i 80.

${ }^{20} \mathrm{AHN}$, Consejos, lg. 51.531 a 51.552.
} 
construcció d'un forn de coure pa en sa casa i per això insta a ell i al mestre i operaris que "entenguen en l'obra" que la paralitzen, sots pena de 200 lliures. El següent escrit és ja la demanda fiscal en que el procurador afirma que el forn de "pan cocer" ha estat construït en el corral de la casa del dit Josep Navarro fa pocs dies i en ell ja ha sigut cuit pa. Li adverteix que en ell no poc coure pa "sots pena de 25 lliures d'irremissible exacció" i li ordena que procedeixa a la seua demolició. ${ }^{21}$

L'anterior denúncia era del 14 de desembre de 1807 , però darrere d'ella i en el mateix expedient, venen afegides altres denúncies posteriors: una de 15 de febrer de 1808 contra Joan Valls, cuber i aladrer, veí d'aquesta baronia, per construir en sa pròpia casa un forn de coure pa; una altra, pel mateix motiu i en la mateixa data, contra Roc Pérez, doctor en medicina i veí de la baronia, i una altra més contra Josep Ros, llaurador i veí de la baronia.

En 17 de juny del mateix any, el comte de Fernán-Núñez actua contra "el consell, junta i regiment de la baronia i altres veïns", per haver consentit que alguns veïns hagueren fabricat clandestinament forns en les seues propietats. Mentre se tramita la nova denúncia, l'escrivà dona notícia de que també un altre veí, Vicent Domingo, ha fabricat un altre forn en sa casa. En un requeriment posterior s'exigeix als infractors que enderroquen dits forns, sots pena de 100 lliures cadascun d'ells. La denúncia arriba per fi a la Reial Audiència, la qual mana notificar personalment a cada infractor. Intentada la notificació resulta que tots estan absents de ses cases: Joan Valles està a València, diu la seua dona, Josepa Català; Josep Ros està en la muntanya, diu la seua dona, Josepa Català i Fabregat; Roc Pérez (el metge) tampoc està en sa casa, la qual està tancada; Vicent Domingo també està absent, diu la seua dona, Teresa Navarro, i Josep Navarro està treballant fora de sa casa, diu la seua dona, Bàrbara Fabregat.

Consten desprès, en l'expedient, la petició de ratificacions i petició de preguntes als veïns; com també hi consta certa insistència contra la rebel $\cdot$ lia de propi ajuntament $\mathrm{i}$ veïns en general. Finalment es produeix una sentència en data 22 d'agost del 1809, la qual es pronuncia en el sentit de que els veïns han d'enderrocar els seus forns $i$ en tot cas abstenir-se de coure pa en ells.

No sabem si es produïren més actes sobre ratificació i execució d'aquesta sentència i dubtem que les penes pecuniàries que s'anunciaven en les propostes arribaren a efecte. Tampoc no hem d'oblidar que en data 27 d'abril del 1808 s'havia produït la ${ }^{21}$ ARV, Escribanías, any 1808 , exp. 45. 
sentència sobre la discòrdia de la partició del vi, de manera favorable al senyor (la sentència determinava que tocava complir tot allò que al respecte recollia la carta-pobla).

En un altre ordre de coses però cronològicament molt proper a la data que estàvem referint, cap destacar un conflicte extern que si va tindre clara repercussió entre la població de Serra, la guerra del francès. Recordem que a finals de 1808 Serra devia designar a 10 "veïns honrats"segons el "Reglament per a la formació de companyies de veïns honrats del regne de València" que havien de defensar a la població contra a possibles infiltracions franceses, tal com exposàrem en el capítol quart. Front a aquesta milícia honrada i de caràcter passiu, però, a principis d'aquell mateix any el saguntí Josep Romeu ja estava organitzant un exèrcit guerriller actiu per a evitar que els francesos "estigueren tranquils ni un sol dia en les terres valencianes". Aquest exèrcit, que prompte assoliria els 2.000 homes armats per la ciutat de Morvedre, començà amb el reclutament que Marià, oncle i lloctinent de Romeu havia iniciat pels pobles de les rodalies: Almenara, baronia de Torres Torres, Canet de Berenguer, Massamagrell, la Pobla de Farnals, la Vall de Segó... I acabant en els pobles de Serra i Nàquera. ${ }^{22}$

La cruenta batalla de Sagunt, del 25 d'octubre de 1811 (Andriani, 1834; Arcón, 2004) s'estengué realment per una bona part del sector oriental de la serra Calderona. Un any i escaig abans de la batalla, els francesos havien controlat el territori per a fer una definitiva invasió i conquesta de València, i també, setmanes abans d'aquella batalla les tropes franceses procedents d'Aragó, per la vall del Palància, i de Morella, s'havien estat posicionant prop de la plaça de Sagunt, on havien posat setge a una guarnició espanyola que s'havia fet forta en el seu castell. Per altra part, pocs dies abans de la batalla, els exèrcits espanyols comandats pel general Blake també anaven prenent posició al voltant de Sagunt i del vessant sud de la serra Calderona. El tercer dels tres exèrcits espanyols, que des de Llíria anava cap a Rafelbunyol estava dirigit pel general Nicolàs Mahy, oncle del que anys desprès arribaria a ser duc )consort) de Montellano i senyor de la baronia de Serra. El mariscal de camp José Obispo, amb uns 4.000 homes es va establir a l'est de Nàquera, prop de la font de l'Oró i del Puntal de Mateu (també conegut des d'aleshores com Puntal dels Francesos). Al nord de Serra i voltants de Torres Torres, segons observem en diferents plànols de la batalla (ops. cit., a més de Valicourt, 1906), hi havia un destacament dels francesos. No tenim notícies concretes sobre successos esdevinguts a Serra aquells dies, però el Quinque Libri, tal com va posar de manifest Senís (1978:

\footnotetext{
${ }^{22}$ Veure http://gie1808a1814.tripod.com/persones/romeu.html, i també García Guijarro (1908).
} 
43), recull al menys quatre morts violentes ocorregudes a Serra alguns dies abans de la batalla de Sagunt i causades violentament pels soldats francesos; una d'elles ocorregué el dia 13 d'octubre de 1811 i les altres tres al dia següent.

En aquells moments i esdeveniments podríem situar certes dades que coneixem al voltant de l'avenc del Puntal de Mateu, un pou natural de $32 \mathrm{~m}$ de caiguda (Fernández et al., 1980: 59 i 60) que sembla que podria haver sigut el destí dels cossos d'un parell de soldats francesos que moriren prop d'allí, segons un borrós testimoni oral que va recollir Emili Lluch i les troballes de restes d'un fusell i baioneta francesa que va reconèixer José Donat Zopo (comunicació personal) en la primera exploració espeleològica a l'avenc, realitzada el dia 2 de agost de 1954.

Els tres ajuntaments, conjuntament, de Serra, Soneixa i Assuévar, van escriure el dia 11 de març de 1815 al Rei, demanant-li la seua intervenció contra els abusos del duc, dient-li al rei que no poden suportar l'enorme pes de les prestacions i gabel·les que els exigeix el duc... Es tracta d'una extensa carta, el contingut resumit de la qual trobem en Iquino (1982: 141-143). Signaven l'escrit els alcaldes i càrrecs dels tres ajuntaments, que per la part de Serra n'eren: Francesc Dolz (alcalde), Vicent Romero (regidor degà) i Francesc Cabo (síndic procurador).

L'efecte va ser el contrari del desitjat perquè el duc, assabentat d'aquesta actuació, va reaccionar amb un escrit de resposta dient "que no poden administrar-se en Justícia els pobles que són revoltosos i no paguen ni respecten honor, hisendes ni vides, sent els de Soneixa, Assuévar i Serra dels més exaltats, fins a l'extrem d'haver-lo injuriat i haver cremat un forn que hagué de rectificar"' (no sabem a quin dels tres pobles es refereix amb aquest forn). I sol-licita l'establiment d'Alcaldes majors, lletrats... adduint també el fet de que, si bé, les Corts, en 6 d'agost del 1811 havien abolit les senyories, el Rei les havia restablert en 15 de setembre de 1814, sense que els tres pobles compliren ni obeirien allò que no els hi convenia (Iquino, 1982: 144).

La represa de l'activitat de les Corts de 1814, desprès de signada la pau amb França i encara sota el mantell de la Constitució de 1812 degué de ser una etapa adient per a permetre el foment i la permissió d'algunes iniciatives privades. Suposem que aquest seria el marc en que el veí de Serra Francesc Arnal va sol·licitar autorització governamental per a construir un molí fariner de dues moles junt al barranc de Marianet 
aprofitant cabals procedents d'un aflorament d'aigua excavat prop d'allí (possiblement la font de l'Horteta). De l'expedient d'un plet que en 1848 mantindria aquest moliner amb els regants de la zona sabem que el molí el va construir en 1815 desprès d'haver-se-li reconegut el Domini Major i haver pagat el cens que aleshores corresponia al Reial Patrimoni. Si bé la data de construcció del molí ratlla la tornada al absolutisme de Ferran VII i el restabliment que va fer de les institucions de l'Antic Règim, aquest cas bé podria ser exemple d'una actuació legal en un moment en que la jurisdicció senyorívola estava abolida i, per tant, res podia reclamar la duquessa de Montellano sobre els seus drets de regalies.

Per entendre millor la situació caldria tenir en compte, en primer lloc, el decret de les Corts de Cadis de 6 d'agost de 1811 que havia suprimit el domini eminent de les senyories sobre les aigües de particulars, que passaren a ser de domini general. Però, posteriorment, tal com fa notar Maluquer de Motes (1983) hi haurà un detall particularment interessant de la Reial Cèdula de 1814, de reintegració de les senyories, i és que va exceptuar d'aquesta reintegració les rendes i censos que tingueren "notòriament el seu origen de la jurisdicció i privilegis exclusius", i en tal cas es trobava precisament l'aigua. Per això manifestava Arnal en aquell plet que se li havia reconegut el Domini Major amb el pagament de cens anual que per aquell temps venia pagant al Reial Patrimoni. En tot cas, si l'aprofitament de l'aigua era legal, entenem que el molí com a tal seria incompatible amb els drets de regalies de la duquessa de Montellano que regulava el capítol tretzè de la carta-pobla de Serra i Ria. Desconeixem, nogensmenys, si açò va ser objecte d'alguna actuació administrativa o judicial concrera, tal com havia passat amb el cas dels forns en 1807 i 1808. El cas és que el molí i la bassa que l'alimentava, construït a expenses del moliner en terreny propi i d'una altra persona, van funcionar des d'aquell moment i els cabals d'aigua van ser objecte, cap a l'any 1831, d'un conveni entre l'Ajuntament, els regants i el moliner. ${ }^{23}$

Recordem que havíem parlat també, en el capítol cinquè, d'altres plets d'aquesta època, i concretament al voltant de 1848, relatius a conflictes en matèria de captació i usos privatius de cabals d'aigua. Per ubicar tots aquests casos i expedients administratius en el moment i context legal adient, recordem que el procés de l'abolició de la condició patrimonial de l'aigua es va produir de manera gradual en la primera meitat del segle XIX, tal com explica i analitza encertadament el professor Maluquer de Motes (1983). El ${ }^{23}$ ADPV, E-3.1, c. 82, exp. 1491. 
privilegis del Reial Patrimoni en matèria d'aigua acabarien desapareixent arran de la promulgació del Reial Decret de 19 de novembre de 1835, que eximia del pagament de qualsevol ús de l'aigua i donava llibertat per a la seua utilització seguint les normes generals sobre la qüestió i concedint també lliure facultat per a la construcció de tota mena d'enginys hidràulics, com els molins i batans. Tanmateix, la llei donava llibertat per a que els propietaris de les terres pogueren fer i aprofitar captacions d'aigües subterrànies com podin ser pous, rases o galeries. Entenem que aquesta és la principal norma que donaria peu a cert proliferació de treballs d'excavació que hem observat a Serra entre els anys trenta i quaranta.

Davant el reconeixement de la propietat privada de l'aigua subterrània que feia aquest decret de 1835, el govern dictà, complementàriament, una Reial Ordre de 14 de març de 1846 que implícitament establia com a bens de domini públic totes les aigües que no estigueren encara apropiades pels particulars. Aquest, concretament, entenem que degué ser el motiu pel qual alguns veïns de Serra s'afanyaren en buscar i consolidar cabals d'aigua que acabarien en els conflictes que va rebre en 1848 el govern provincial. En tot cas, observem que aquestes disposicions i les experiències aportades per la seua aplicació van ser la base de les posteriors lleis d'aigües, tant la de 3 d'agost de 1866 com la definitiva de 13 de juny de 1879, que es mantindria plenament vigent en l'ordenament jurídic espanyol durant més d'un segle. ${ }^{24}$

Un altre veí de Serra, Francesc Taroncher, no tingué tanta sort amb el forn de fabricar algeps que havia construir en 1819 junt als algepsars de Serra i prop del terme de la cartoixa de Portaceli. Ell manifestà que el terreny era seu, però el representant del Comte de Fernán-Núñez (sic.; ja era duc des del 23 d'agost de 1817) defengué que es trobava dins dels límit de la mina d'algeps de la baronia. El forn va ser enderrocat però, l'expedient també explica com al cap d'un mes el forn tornà a ser construït i a més es va crear una gran tensió entre el infractor, els jornalers, que no cobraven, i la mediació de l'alcalde intentant posar ordre i concert. Finalment aquells no cobrarien. ${ }^{25}$

Entre els assumptes que l'ajuntament de Serra administra sense a penes intervenció ni ingerència de la senyoria trobem el de la "llenya de carro", que seguidament veurem de què es tracta. El dia 31 de maig de 1832, el secretari municipal,

\footnotetext{
$24 \quad$ Fins a la promulgació de la nova Llei 29/1985 d'Aigües, que té com a trets més distingits la declaració del domini públic hidràulic i el reconeixement, per primera vegada, del cicle hídric.

25 ARV, Escribanías, any 1819, exp. 81.
} 
Francesc Ros, certifica que els "senyors de l'ajuntament": Joaquim Cabo (alcalde), Joaquim Arazo (regidor primer), Francesc Navarro (síndic procurador), Bartomeu Català (síndic personer), Manuel Navarro (diputat) i Francesc Rubio (mostassaf), havien determinat prohibir fer llenya en un determinat sector del terme, concretament el que queda al nord del camí de Serra a Portaceli i fins al terme de Sogorb, i també amunt (cap a l'est) del camí d'Alcalà. La raó d'açò és "la ruïna que causen els que tenen actualment l'arbitri de la llenya de carro" en el mode d'arrancar la llenya de tot el terme sense conservar cap forest per a una necessitat, i per això prenen aquest acord "desitjant conservar certa part del terme per a conveniència dels actuals veïns com dels que vindran". ${ }^{26}$

En aquell acte també es trobava present el notar Miquel Conejos, “col·lector” del duc de Montellano, que li remeté al "senyor territorial" una còpia del certificat d'aquest acord $\mathrm{i}$ un dictamen on explica que el capítol 10 de la carta-pobla de Serra conté l'absoluta i general llibertat en que quedaren els veïns de la baronia per a fer carbó de la llenya de garriga (o "monte bajo") sense més restricció que els arbres (de cap arbre) i d'haver de pagar al senyor territorial un sou per cada càrrega gran que feren i sis diners per cada xicoteta de jument. Per altra part, l'única restricció de fer llenya i arrancar rabasses seria la que imposa el capítol onzè: no poder fer-ho en la reserva de la Xara. Per tant, amb l'extracció de llenya no troba més perjuí als interessos del senyor que el fet de que aquesta siga extreta en carros i no s'aprofite per a fer carbó dins del terme. Per altra part, opina que la mesura adoptada és laudable i encaminada a una millor conservació de la forest. ${ }^{27}$

Per tant, queda clar que la "llenya de carro" era la manera d'aprofitar un recurs eludint qualsevol pagament al senyor. El destí de la llenya bé podia ser per a fer carbó fora dels límits de la baronia o bé per als diversos usos que també eren habituals $\mathrm{i}$ demanats (forns de calç, forns ceràmics, forns de coure pa, tec.). Per altra part, ens crida l'atenció les reiterades referències que fa el notari del duc de Montellano al seu "senyor territorial", com volent emfatitzar aquest caràcter "territorial" de la possessió que en aquells anys era la clau que havia de permetre conservar com a propis del senyors els termes de les baronies i senyories, tal com hem exposat al principi d'aquest capítol.

\footnotetext{
${ }^{26}$ AHN (F-N), c. 1357, Doc. 3 (11).

${ }^{27}$ AHN (F-N), c. 1357, Doc. 3 (12).
} 
Un altre tema certament interessant és que el quarter protegit en 1832 coincideix clarament amb el quadrant nord-oest del terme de la baronia, i això concorda amb el criteri que durant molts anys es va seguir a Serra per a subhastar els aprofitaments tant de fusta com de llenyes i fornilla. Segons ens explicava un pràctic de Serra fa alguns anys, la forest de l'Ajuntament (Alt del Pi i agregats) se subhastava antigament per quartes parts, dividint-la segons dues línies (una vertical N-S i una altra horitzontal E-O) de manera que cada any es treia a subhasta només un quart de la forest amb un criteri rotatiu; així, cada quarter explotat tenia desprès tres anys per a recuperar-se abans de tornar a ser subhastat. ${ }^{28}$

A petició del veí de Serra Simeon Domingo, en 9 de novembre de 1829 és incoat expedient per a que se li concedeixa un suplement de títol per a una fàbrica de colar aiguardent que havia construït en el terme de Serra, partida del camí de Nàquera. A aquesta petició es va oposar en principi el duc de Montellano, però desprès, vista la bona fe del sol·licitant i vist també que la construcció d'aquesta fàbrica no perjudicava els seus interessos, el duc va decidir no mantindre cap oposició, reservant-se únicament el dret de cobrar-li els censos que li corresponien com a senyor territorial de la baronia pels terrenys on estava enclavada l'esmentada fàbrica. En vistes de que no hi hagué major oposició se li va concedir a Simeon Domingo el suplement de títol que sol-licitava, assenyalant-li un canon de 15 rals i 2 maravedís. ${ }^{29}$

\subsection{SERRA CONSTITUEIX EL SEU AJUNTAMENT CONSTITUCIONAL}

Boix (1847), quasi com a cronista d l'època, i Sebastià (2000), com a veterà investigador dels fets més d'un segle desprès, transmeten una clara sensació de que el moviment revolucionari forjat a València en 1935 i en certa manera iniciat l'any anterior amb la formació de la milícia urbana encarregada de combatre el còlera mòrbid i acatar les desamortitzacions, anava creixent conforme la guerra carlista capitanejada per Ramón Cabrera i estesa pel nord del País Valencià s'apropava, cada vegada més a l'entorn de València com una onada de preocupació i incerteses. Al mateix temps, eren nombroses les famílies que des de la Plana de Castelló i fugint dels carlistes arribaven en carros buscant asil en la capital valenciana.

${ }^{28}$ Comunicació personal de Benjamí Ros Domingo, en 15/11/2001.

29 ARV, Bailia Gen. Sala 4, exp. 3516, any 1829. Citat també per Lluch i Cebrián (1935). 
En la seua publicació original de 1976, el professor Enric Sebastià (2000) expressava, molt suggeridorament, que en 1834 estaven pràcticament presents a València una mena de versió lliure del “Quatre Genets de l'Apocalipsi”, que per a una situació històrica posterior assenyalaria el gran novel·lista valencià Vicent Blasco Ibáñez: guerra (carlista), epidèmia (còlera), fam i expropiació (desamortitzacions). El cas és que la Milícia urbana, la Junta General Consultiva, els esdeveniments bèl·lics i les notícies arribades sobre moviments perifèrics de tropes estrangeres estimularen, encara més, una exaltació popular que el 4 de setembre de 1835 donaria pas a la Junta de Govern del Regne de València, la que va decretar, entre altres mesures, l'abolició de totes les prestacions senyorívoles de qualsevol tipus (Sebastià, 2000: 217). Aquesta junta revolucionària seria una més de les diverses que es van constituir a la resta del territori espanyol.

La sisena mesura de l'edicte de 5 de setembre del 1835, de la Junta de Govern del Regnes de València i de Múrcia ordena que "cessarà el pagament dels drets o cànon de senyories" i relleva d'aquest gravamen als pobles que comprèn la Capitania General, ínterim se n'ocupa d'aquest interessant assumpte "la representació nacional" (Gómez Benedito (2009: 380, doc. 30). En una nota manuscrita, de data de 20 de juny del 1835, trobem el següent text, referit al que seria, probablement, el darrer pagament de cens emfitèutic : "Ha recibido el $\mathrm{Sr}$. don Lorenzo Muriel, Apoderado Genaral del Exmo. Sr. Duque de Montellano y del Arco, la cantidad de 179 reales de vellon, y son por segundo trimestre de contribución que le ha correspondido en el presente mes. Por mandato del Sr. Alcalde y de su orden: Francisco Rubio (rubricat)" ${ }^{30}$

Garrido (2004) recull l'opinió de que la Junta Revolucionària de València, que incloïa a militars, canònics, propietaris, terratinents i títols nobiliaris, semblava una nòmina més pròpia de l'Antic Règim que d'una revolució, però clar està que "una representació d'aquesta mena mai no permetria que els revolucionaris cometeren grans excessos"; i sabent això és que Mendizábal acabaria decretant la conversió de les Juntes de 1835 en diputacions provincials, passant així a ser integrades en la legalitat vigent les institucions creades per la revolució, "sense cap esgarrapada".

L'any següent, l'Ajuntament de Serra, com la major part del pobles de la província de València, va jurar la Constitució de 1812 seguint una Reial Ordre que havia ${ }^{30}$ DP-ADN, 12. 
sigut publicada en la Gazeta extraordinària de Madrid del dilluns 15 d'agost de $1836 \mathrm{i}$ que el ministre de Governació, Ramon Gil de la Quadra, havia remès al governador (“Jefe político de València”) per a la seua publicació i efectes. Es tracta d'un Decret expedit dos dies abans per Sa Majestat, la Reina Governadora, pel qual, mitjançant la seua concessió i l'efectiu jurament de la "Constitució política de la Monarquia de l'any de 1812" pels ajuntaments i les administracions espera el cessament de tota "l'escissió" i l'alteració del bon govern. Pretén així assolir una estreta unió "entre els amants del tro i de la llibertat contra l'enemic comú que combat sota el pendó de l'absolutisme". ${ }^{31}$

El secretari de l'Ajuntament de Serra, Francesc Ros, amb escrit de data 4 de setembre del 1836, tramés al governador de la província "en cumplimiento de lo mandado" certifica que en data 18 d'agost, els senyors que formen l'ajuntament de Serra decidiren comunicar-li el contingut de dita circular al rector parroquial i als oficials de la Guàrdia nacional i convocar seguidament a tots els veïns per a que el present dia 4 de setembre acudiren tots a la missa major celebrada a l'objecte. Conclosa la missa es va posar una taula completament adornada al peu de l'altar major i sobre ella el llibre dels Sagrats Evangelis, procedint el rector parroquial a jurar en primer lloc la Constitució del 1812, desprès ho feren els senyors que composaven l'Ajuntament i els oficials de la Guàrdia Nacional, i per últim tots els veïns que havien acudit a l'acte. A continuació es va cantar un solemne tedèum que va concloure amb gran volteig de campanes i molts vives "observándose entre los vecinos un singular regocijo".

Els representants de l'Ajuntament que acudiren a aquell acte de proclamació i jurament de la "Constitució política de la Monarquia espanyola de l'any 1812" i signaren l'acta van ser Francesc Navarro (alcalde), Francesc Dolz (regidor tercer), Manel Cabo (síndic) i l'esmentat Francesc Ros (secretari), que també diu signar pels que no saben ferho.

El governador provincial de València, tal i com va fer amb tots els ajuntaments $i$ altres demarcacions de la seua jurisdicció provincial, també remeté a "la pedania de Portaceli" la seua circular per la que instava a jurar i acceptar la Constitució. Però, a diferència de Serra i altres ajuntaments, el seu alcalde pedani informava que no podia fer complir allò que es manava perquè no existia com a tal un poble ni ajuntament, sinó únicament tres "cases de camp" o masies en les que "no hi ha més veïns que els majorals,

\footnotetext{
${ }^{31}$ ADPV, Govern Civil, C1, caixa 33 (Jurament de la Constitució; any 1836).
} 
criats i jornalers, tots pobres i tenint la major part d'ells el seu domicili en diferents pobles" de les rodalies.

L’esmentat alcalde pedani, José Cortina, li recordava també al governador que en tres oficis diferents, tramesos al temps de liquidar els comptes del ram de Policia de Portaceli, ja li havia fet saber que en dit territori havia sigut suprimida la "Comunitat de la Cartoixa de Nostra Senyora de Portaceli" i que per tant ja no existia aquesta i els que eren els seus criats "no consumeixen ja passaports ni paperetes". I aprofita per demanar-li al governador que el relleve del càrrec d'Alcalde perquè diu que ja duu exercint-lo des de fa tres anys, quan era encara criat de la comunitat cartoixana. Com que l'alcalde no sap signar, escriu de la seua ordre i signa per ell Gabriel Martí, el dia 20 d'agost del $1836 .{ }^{32}$

Cada ajuntament va organitzar aquell acte de jurament com ho va considerar més adient, alguns també a través de les esglésies i altres fora d'elles. Per exemple, en el de Torres Torres, segons certifica el seu secretari municipal, el 18 d'agost d'aquell any, la Constitució va ser proclamada i jurada per la corporació local (no esmenta res de l'església), havent a continuació repic de campanes, descàrregues de fuselleria pels Nacionals (la Guàrdia) i lluminàries per la nit. A Nàquera decidiren fer crida als paratges acostumats per a que acudira la gent a la plaça Major, on reunits l'Ajuntament, els oficials de la Guàrdia Nacional i la major part dels veïns va ser llegida l'ordre reial i seguidament entraren a l'església, on es va combregar i jurar la Constitució, per a desprès cantar un solemne tedèum i fer voltejar les campanes. ${ }^{33}$

\subsection{INTERPOSICIÓ DE DEMANDA POPULAR I FISCAL EN 1839}

Des de la negativa a pagar les rendes de 1835 fins a la promulgació de la nova llei de 26 d'agost de 1837, aclaridora de l'abolició senyorívola, passant per la supressió del priorat de Portaceli i la incorporació del seu terme al del municipi constitucional de Serra, entre altres esdeveniments, podem suposar que la vida dels serrans degué de ser un poc més animada i excitada que en els anys previs al 1835. Una mostra d'açò està en el contingut del procés de demanda que el 3 de gener de 1839 interposava el promotor Fiscal de l'estat contra els ducs de Montellano per a la reversió de la baronia de Serra a la

32 ADPV, Govern Civil, C1, caixa 33; No 93.

${ }^{33}$ ADPV, Govern Civil, C1, caixa 33; No 107 i 13, respectivament. 
Corona. ${ }^{34}$ En el seu primer escrit, el fiscal recull "los clamores del común de vecinos y terratenientes del pueblo de Serra, relativos a que el dueño territorial, titulado hasta ahora del mismo, carece del derecho a la percepción de dichas prestaciones dominicales $y$ demás derechos de enfiteusis" i que per això li demanen a l'ofici fiscal que els escolte sense indiferència, com a assumpte molt propi del seu deure i fins a aconseguir el segrest de la baronia. ${ }^{35}$

El que assumeix el fiscal, recollint el clamor popular dels serrans i vetllant pels interessos de l'Estat, és una petició al Jutge de Sagunt per a que mane als escrivans del jutjat que certifiquen si el senyor de la baronia de Serra o el seu legítim representant han presentat davant l'esmentat jutjat el títols d'adquisició del poble o baronia de Serra dins el termini de dos mesos que li concedia la llei per a fer-ho. Davant aquesta suposada manca de títols acreditats del domini territorial i pairal sobre Serra, el fiscal sol-licita que li siga degudament comunicat el resultat de la seua petició per tal de donar els següents passos, consistents en el segrest de la baronia i la interposició formal de la demanda contra els ducs de Montellano.

La base legal i l'estratègia d'aquesta futura demanda queden recollides millor en un segon escrit del Fiscal, text que reberen els ducs de Montellano i que quedà salvaguardat en el seu arxiu. Diu així:

"El Promotor fiscal del Juzgado dice que la solicitud del Tribunal de Providencia del dia 24 de enero último (1838) tuvo a bien acordar el secuestro de todos los predios derechos y prestaciones que resulte haber percibido el Señor Duque de Montellano o sus antecedores en el pueblo de Serra, habiendo nombrado en su virtud en Depositario a Francisco Dolz menor, vecino de la misma población, quien en el día 18 de febrero próximo pasado aceptó el encargo en debida forma, según se deduce de la diligencia en su razón extendida.

Dado pues ya este paso legal, es indispensable poner en ejecución el ofrecimiento que hizo este Ministerio en su censura del día 3 de enero ya citado concretivo a proponer la competente demanda de incorporación a la Corona con arreglo a loo dispuesto en la última parte del artículo quinto de la Ley de 26 de agosto del pasado año 1837.

Las Cortes, al dictarla tuvieron muy presentes los requisitos que deben preceder a la instauración de dicha demanda, reducido otro de ellos a no haber verificado los dueños territoriales la presentación de títulos dentro del preciso término de dos meses prefijados en la propia ley, como consiguiente la cesación de la percepción de las prestaciones dominicales y demás derechos de enfiteusis en el modo y términos que lo disfrutaron hasta el pasado año 1835, debiendo ser ya S.M. o el Estado la única persona

\footnotetext{
${ }^{34}$ La fórmula d'incorporació (reincorporació) a la Corona d'antigues senyories jurisdiccionals no era nova; hi trobem casos precursors fins i tot en el segle XVIII, com és el de Catadau (Ardit, 1998). No obstant, el decret de 6 d'agost de 1811 era ara contundent i general en tal sentit (article 1r del decret).

35 AHN (FN), c. 1438/3.
} 
legítima para continuar exigiéndoles a los pueblos las indicadas prestaciones sin la menor alteración ni novedad. Por consiguiente, hallándose el dueño territorial del expresado pueblo de Serra en el caso ya manifestado de no haber llenado la obligación que le impuso el citado decreto de las Cortes, es preciso pesen sobre el mismo los resultados que en el se previenen, esto es, el del Secuestro y el de la incorporación a la Corona, en pena de su descuido, por no tener al efecto Títulos legítimos que le autoricen para denominarse en lo sucesivo dueño territorial... etc. ...Asi que, proponiendo la demanda, que más bien corresponda como protesta de enmendarla, corregirla o variarla si conviniere, PIDE se sirva U. declarar que el señorío o pueblo de Serra corresponde a la Corona y, por consiguiente que es incorporable a la misma... etc. ...Sin embargo acordará U. como siempre lo que le parezca más conforme a Justicia, por la que únicamente se interesa l oficio fiscal.

\section{Murviedro, 4 de marzo de 1839. D. José Galmes i Moltó". ${ }^{36}$}

Aquest expedient va ser incoat pel jutge Antonio Álvaro Campaner, del Jutjat de Primera Instància i Instrucció de la vila i partit de Morvedre, actuant com a escrivà judicial Salvador Vicent Gascó. La seua instrucció ens permet seguir de prop detalls sobre les diferents notificacions i intents de fer-les, així com les dificultades trobades fins a la interposició formal de la demanda judicial. ${ }^{37}$

En primer lloc van ser incorporats a l'expedient certificats dels escrivans del jutjat Marià Larcada, Joaquim Soriano i Hipòlit Martínez, fent constar que en el jutjat de Sagunt i fins a gener de 1839 no s'havia presentat cap títol territorial per part dels senyors de Serra ni llurs representants. Posteriorment va ser intentada la notificació al Senyor de la baronia de Serra de totes les actuacions fetes, mitjançant els seus apoderats i procuradors. En tal sentit se li va fer lliurament de les mateixes el dia 8 de març a Lluís Arnau, Administrador del duc de Montellano per a Serra i altres de les seues possessions valencianes.

En acte de data 22 de març de 1839 el notari Francesc de Paula Furió, escrivà públic de València, dona fe que el senyor Llorenç Muriel és Apoderat General del duc de Montellano i li ha aportat carta pública per la qual, en data 10 d'octubre de 1827, l'excel-lentíssim Senyor en Filibert Mahy Branly Romo y Gamonales, duc de Montellano, li va atorgar poders, davant l'escrivà de València Rafel Cano, per a que en el seu nom i el de la duquessa poguera comparèixer en juí davant de qualsevol tribunals, ja siguen eclesiàstics com seculars majors $\mathrm{i}$ menors que corresponga, en els que interpose $\mathrm{i}$ responga demandes, presente escrits i documents, demane execucions, presons, embargaments i desembargaments de bens, faça vendes, aranzels, remats, recusacions,

\footnotetext{
${ }^{36} \mathrm{AHN}(\mathrm{FN})$, c. 1438 , núm. 3.

${ }^{37}$ Ibidem. Cal fer notar que aquest sembla ser un expedient original del Jutjat (amb notes, assentaments, certificats, diligències i signatures), el qual trobem, en canvi, a l'arxiu de la duquessa de Montellano.
} 
jure, escolte autos i sentències, etc. Per això entenem que degué ser emplaçat aquest home per a comparèixer davant del Jutjat. Però, només dos dies desprès, el 24 de març, Luis Arnau compareix amb un escrit davant el jutjat de Sagunt "en nom i virtut del poder i substitució que presente i jure, del Sr. duc de Montellano" i diu que respecte al poder que ha presentat Llorenç Muriel, en qualitat d'Apoderat general de l'esmentat duc, que dit poder no es suficient per a la causa en aquest plet, i que deurà ser citat expressament l'esmentat duc en persona, el qual viu a Madrid junt a la duquessa.

Desprès d'haver intentat la notificació, sense èxit, a través dels jutjats de Madrid, novament el promotor fiscal s'adreça al jutge, el 6 de juny, per a demanar-li que intente novament la notificació als ducs però enviant-los ara l'exhort a Bordeus, de França, que és on estan residint realment. Mentre tant, diu el fiscal que no es pot prendre cap resolució alienant-li la possessió de Serra al ducs en base al decret de 1837 si abans no se li notifica la causa als ducs de manera expressa i personal; en cas contrari podria recórrerlo en qualsevol moment i fer-lo nul.

En data 10 de juny de 1839 el jutjat envia l'esmentat exhort per correu al Sr. Cònsol de Sa Majestat a Bordeus, amb el prec de que li siga notificat als ducs de Montellano. Des del consolat d'Espanya a Bordeus va arribar al jutjat de Sagunt la certificació, signada per Mateu Durou (secretari de Sa Majestat i Cònsol d'Espanya a Burdeus) fent-li saber que el dia 3 de juliol de 1839, a l'Exc. Sr. Duc de Montellano li havia sigut degudament notificat l'exhort i així ho signava (el document inclou la signatura original del duc: "el Duque de Montellano").

En octubre del mateix any, el procurador fiscal li comunica al Jutge que els procediments traslladats en el mes de març a Lluís Arnau, el "procurador causídico" (procurador en aquesta causa de Serra) els reté aquest senyor en son poder, sense haverlos tornar encara al jutjat; i per això sol·licita al jutge que li ho reclame i apresse. Desprès de rebre aquest requeriment, l'esmentat Lluís Arnau escriu al jutjat el 31 de desembre de 1839 expressant que, al seu parer, no seria correcta ni vàlida la notificació feta a Bordeus per no haver-la executat un òrgan judicial adient, i que caldria fer-ho bé perquè si no és així, per qualsevol escletxa legal que ell trobe hi entrarà. En fi, es tracta d'un escrit de caire prepotent i que planteja continues objeccions, per concloure manifestant que ell vetllarà tot el que siga precís per defensar els interessos del seu Senyor. El promotor fiscal no trigarà en actuar i així, el 28 de gener de 1840 interposa per registre un escrit 
rebatent i justificant que Arnau està totalment equivocat en allò que ha dit. No obstant, el mateix procurador diu al Jutge, en un altre escrit de 21 de març de 1840, que no té inconvenient a l'apel·lació que havia fet Lluís Arnau.

En aquest punt de la instrucció cal tenir en compte que la duquessa va morir el dia 4 de juny de 1840, estant a Tours, França. Assabentats el fiscal i el jutge de Sagunt de que l'hereua de la duquessa és la seu néta, la duquessa de Fernán-Núñez, seran traslladats novament exhorts, en agost del mateix any, als jutjats de Madrid ("a cualquiera de los Señores Jueces de primera instancia de la Villa y Corte de Madrid") on resideix la jove hereua, per a que li ho notifiquen. El jutge de Primera Instància de La Plaza comunica al de Sagunt que ha tramés l'exhort al Jutge de San Francisco. Però, per alguna mena de complicació passarà prop d'un any fins que tornem a trobar en l'expedient noves actuacions. I arribem així al primer de març de 1841, en que el jutge torna a insistir davant els jutjats de la Vila i Cort de Madrid. Aquesta vegada, l'escrit va seguit d'aquest reconeixement de fedataris:

"Legalización: los escribanos de la Reyna Nuesta Señora, públicos con residencia en esta Villa de Murviedro que abajo signamos y firmamos, Certificamos y damos fe: Que D. Antonio Álvaro Campaner y D. Salvador Vicente Gascó, por quienes va librado, firmado y refrendado el anterior exhorto, son el primero juez de primera instancia de esta Villa y su Partido y el segundo otro de los escribanos de dicho Juzgado, fieles, leales y de confianza. Que las firmas puestas al pie de dicho exhorto son las que acostumbran poner en todos sus escritos, a los cuales siempre se les ha dado y da entera fe y crédito, asi judicial como extrajudicialmente. Y para que conste damos la presente en Murviedro, a quince de Marzo mil ochocientos cuarenta y uno.

Joaquín Soriano; Mariano Larcada".

Quan va dur la notificació a casa de la jove duquessa, l'escrivà judicial Sr. Algarra va ser informat per don Angel Taboada i Ulloa de ser dita senyora menor d'edat i filla del comte de Cervelló, el seu curador ad bona. A continuació, el comte va ser informat del despatx aportat i respongué que la seua filla tenia nomenat un menor curador ad litem que era don Pedro Jiménez Navarro, si bé el mateix comte va signar la notificació en 1 d'abril de 1841 (hi consta la signatura: "el Conde de Cervellón”). Seguidament trobem en l'expedient la notificació feta un dia desprès a l'esmentat curador ad litem. Com a resposta, el comte de Cervelló, Felipe María Osorio y de la Cueva, presentaria una apel·lació en nom de la seua Principal, adduint una sèrie de suposats defectes observats $i$ l'agravi que podia haver causat l'anterior duc (Mahy) per no haver contestat (afegint que 
tampoc no se li havia verificat la citació i emplaçament per poder-ho fer) i, sobre tot, desprès haver mort la senyora, a la que ha succeït la nova duquessa, etc. Per tot això pretén que el procediment es retrotrega i torne al jutjat de primera instància de Sagunt.

El darrer document observat en els 78 full numerats que formen aquest expedient judicial correspon a un certificat de José Antonio Albelda, "notari de Regnes" i Escrivà de Càmera de S.M. la Reina Nostra Sra. Donya Isabel Segona, interí en la Sala Segona de l'Audiència Territorial (de València), el qual certifica -desprès d'una llarga exposicióque la Sala va acordar el decret que diu així: "Hecha cuenta de la Apelación interpuesta por el Duque de Montellano devuélvanse los autos al juzgado de primera instancia, según lo propone el fiscal de Su Magestad". Com a colofó afegeix que "por ahora (l'expedient) queda en mi poder y oficio de Cámara". Y per al seu compliment pel jutge de primera instancia de Morvedre ho signa ell. València, 24 de gener de 1842 (signat: José Antonio Albelda).

Aquest procés és molt provable que mai no fora resolt i quedara pràcticament oblidat. Dubtem que fóra finalment tramés de nou al Jutjat de Sagunt, i si així fou degueren ocórrer desprès circumstàncies excepcionals que puguen explicar per què l'expedient acaba finalment en l'arxiu dels ducs de Fernán-Núñez. Tot sembla indicar que per alguna circumstància i autoria l'expedient hauria sortit de l'Audiència de València sense arribar mai a Sagunt. Amb sentència o sense ella, però, de qualsevol manera, la que s'havia creat era una situació sense retorn, en el sentit de que amb el temps el nou estatus municipal de Serra anava afermant-se i consolidant-se dins els paràmetres del nou règim liberal i burgès. ${ }^{38}$

\subsection{SOBRE L'EVOLUCIÓ DEL CONFLICTE I LA LIQUIDACIÓ DE LA BARONIA.}

El procés de desaparició efectiva de l'Antic Règim, en Serra està marcat per una sèrie de circumstàncies $i$ fets particulars que s'emmarquen, òbviament, en els esdeveniments polítics, socials i d'instrumentació legal que caracteritzen l'agitat segle XIX espanyol.

\footnotetext{
38 En tot cas hem de dir que tant si arribà a haver-hi cap sentència com si no, el cert és que no hem tingut la sort de trobar-la malgrat els esforços i gran quantitat de temps invertits per aquest doctorand $\mathrm{i}$ persones a les que hem recorregut sense més èxit.
} 
En epígrafs anteriors hem posat de relleu el prolongat descontent i malestar arrossegat pels serrans des del segle XVII per la negativa dels nous senyors en reconèixer les concòrdies anteriors que havien rebaixat i suavitzat els tributs i censos que devien de pagar a la senyoria. Les situacions de desobediència, d'ocultació de la producció real, de resistència i encara rebel·lia, a pesar de les sentències judicials en contra, ja hem comprovat que no mancaren ni el segle XVIII ni en el XIX. Però la primera vegada que observem una postura més ferma i absoluta de desobediència i encara aparent insolència cap al Senyor és quan en 1835 els serrans es neguen a pagar al senyor les rendes per partició de fruits, tal i com hem explicat en el capítol cinquè. Quinze anys abans podria haver passat el mateix, amb l'inici del trienni lliberal, però aleshores contribuí a evitarho, sense dubte, el Decret de 19 d'abril de 1820 que va publicar pel comte d'Almodóvar, Capità General de València, que manava expressament als alcaldes constitucionals de les baronies de Soneixa, Assuévar i Serra, i també la de Castellnou, que no impediren a l'excel·lentíssim duc de Fernán-Núñez, de Montellano i de l'Arc, ni tampoc als seus representants i arrendadors, la percepció dels drets que no estaven abolits, sota la responsabilitat i rigorosa multa a la que s'enfrontarien. ${ }^{39}$ En els anys que estigué en marxa aquest període constitucional, la presència dels oficials de la Senyoria sembla que va ser major que en altres èpoques. Per exemple, hi trobem que en novembre de 1821 es realitza en la baronia de Serra un dels pocs inventaris de béns que hem pogut localitzat, referit a les eines $\mathrm{i}$ utensilis per al servei dels molins d'oli i de farina, dels cellers de vi i d'oli, del forn de pa, de la fonda (“el mesón”) i la carnisseria... Tot i això amb objecte de fer-li el degut lliurament a Lluís de Luca, el nou arrendador dels drets dominicals. ${ }^{40}$

Pot ser que el preu de l'arrendament de les rendes de la baronia de Serra haguera sofert alguna rebaixa (ho desconeixem) en aquest període, del mateix mode que es rebaixaren els preus dels arrendaments dels delmes durant el Trienni. En tal cas, però, tampoc romandria massa temps la rebaixa perquè, rematant el trienni constitucional, la regència absolutista presidida pel duc del Infantado signaria, el 15 d'agost de 1823, una cèdula ordenant que foren reintegrats als senyors territorials els seus drets $\mathrm{i}$ el gaudiment de la percepció de totes les rendes, prestacions i emoluments que els hi corresponien. ${ }^{41}$ Aquesta cèdula, que va circular per la Reial Audiència de València tres dies després,

\footnotetext{
39 "Yndice general de los instrumentos..." (Annex 5): doc. 114

40 "Yndice general de los instrumentos..." (Annex 5): doc. 115.

41 "Yndice general de los instrumentos..." (Annex 5): doc. 116.
} 
sabem que va ser notificada expressament al poble d'Assuévar (podem suposar que igualment a Serra i Soneixa) el dia 20 del mateix mes, per a que no deixaren de pagar " $a$ su Dueña la Exma. Señora Duquesa de Montellano, y del Arco, viuda de Fernán Núñez, los Derechos y Prestaciones que le devían". Evidentment, aquestes disposicions venien a deixar sense efecte l'aplicació de la recentment promulgada llei de 3 de maig de 1923, aclaridora del decret de 1811 de supressió de les senyories.

En 1835 la situació va ser ben diferent, perquè en lloc d'una ordre del capità general (com en 1820), el que suposadament degueren rebre el serrans va ser la consigna de que s'abstingueren de pagar més tributs als senyor, consigna que emanaria de la Junta Revolucionària de València formada en aquell any de decisius canvis, canvis que continuarien produint-se encara al llarg de 1836 i fins culminar, des del punt de vista que ara ens interessa, en la llei de 26 d'agost de 1837, tercera i pràcticament definitiva disposició supressora del sistema senyorívol abans abolit en 1811 i ratificat en 1823.

Cal tindre present, especialment per al cas de Serra, que paral-lelament a la irregular aplicació de les disposicions antisenyorívoles de 1811, 1823 i 1837 s'havien donat altres disposicions que minvaven el poder econòmic i polític dels ordes religiosos $\mathrm{i}$ en general de l'església espanyola, com eren el decret de 29 de juny del 1821, que retallava a la meitat els delmes i primícies (i que seria anul·lat per una ordre circular de 6 de juny del 1823); el decret d'11 d'octubre del 1835, de dissolució dels ordes religiosos; el decret de 19 de febrer del 1836, de desamortització dels ordes religiosos, i el decret de 29 de juliol del 1837, de supressió dels delmes i primícies. Per les dades que hem manejat i tingut a l'abast, sembla molt clar que va ser el decret de 1835 el que donaria peu a que definitivament el terme del que havia sigut fins a aquell moment priorat de Portaceli quedara ara recollit i integrat (novament), des d'aquest mateix any, dins del terme de Serra, ara un terme constitucional que, com hem vist en epígraf anterior, ratificarà tal condició jurant en setembre del 1836 la Constitució del 1812.

La duquessa de Montellano tenia ben assumit i sabia bé, abans encara de la promulgació de la segona llei (la de 29 de juliol de 1837) aclaridora del d'abolició del règim senyorívol de 1811, que ja no era propi parlar de vassalls i que la negativa dels veïns de la baronia de Serra i altres a pagar les rendes emfitèutiques des de l'any 1835 significava, pràcticament, la definitiva desaparició de l'Antic Règim, de manera que tot el que li quedava era defensar i aplicar la facultat legal que li concedia la legislació 
sectorial, en el sentit de poder disposar únicament dels seus béns propis i lliures que li quedaren en les seues baronies. Així ho va expressar clarament en el seu testament, de 2 de maig de 1837, fet a París poc desprès d'haver mort la seua filla. En aquest testament (veure Apèndix Documental) fa concreta referència als decrets de les Corts de 27 de setembre de 1820 i de 19 de juny de 1821 (no cita la llei "aclaridora" de 23 de maig de 1823), dient que han sigut establerts amb tota la seua força i rigor, per a seguidament afegir: "es mi voluntad usar de la facultad que los mismos (decrets) me conceden de disponer, como dispongo, de la mitad de mis bienes vinculados como propios y libres, y por consiguiente quedan libres desde ahora, y por tanto serán comprendidos en el cuerpo de bienes libres al tiempo de mi fallecimiento". Tot seguit continua disposant el seu testament fent valer aquesta premissa.

Notem que en aquest testament no solament reconeixia que assumia la llei antisenyorívola, sinó que està també dient $\mathrm{i}$ afermant que des d'aquell mateix moment ja declara com a béns lliures i propis aquells que li pertanyeren arribada la seua mort.

Sabent açò podem entendre per què quan reberen els ducs de Montellano la notificació de la demanda del promotor Fiscal i del poble de Serra, primer el 1839 (potser a Madrid i comunicada pel seu procurador), i desprès el 1840, estant ells en un lloc tan llunyà com Bordeus (França), ni la duquessa de Montellano ni el seu marit interposaren cap al·legació. Sembla que la duquessa tindria clar que aquell era un acte previsible i que s'havia de produir més prompte que tard, que la demanda no deixava de ser un requisit legal necessari i que, l'opció de poder presentar ella títols d'adquisició de tan secular domini no deixava de ser un formalisme de garantia legal dins del procés judicial. No sabem fins a quin grau era coneixedora d'allò que apuntàvem al principi d'aquest capítol, de que "la clau de l'assumpte", segons els juristes de l'època, estava en la suposada diferència entre senyories territorial i jurisdiccionals. En tal cas, ella devia saber molt bé que la senyoria i baronia de Serra procedien d'una donació jurisdiccional i no d'una simple compra que poguera emparar-la en la consideració de ser un mer domini territorial. Podria haver pledejat en tal sentit, mitjançant la presentació de documents sobre la "compra de la baronia" feta a Felip Boïl a principis dels segle XV, doncs els documents que referien aquella compra els tenia a l'abast des de que el seu primer marit, Carlos Gutiérrez de los Ríos va disposar que s'ordenaren i classificaren tots els documents de l'arxiu referents a les baronies de Serra i Soneixa. ${ }^{42}$ No ho va fer, però,

\footnotetext{
${ }^{42}$ Fruit d'aquest treball va ser el "Yndice general de los instrumentos..." que transcrivim com Annex VII.
} 
potser conscient de que això només prolongaria innecessàriament un procés que realment ja no tenia retorn.

A banda d'aquestes consideracions i suposicions que fem respecte al pensament de la duquessa, cal no oblidar tampoc que encara hi havien plets, no definitivament resolts o tancats, pel dret a la successió de les baronies de Serra i de Soneixa, plets contra l'eterna part contraria que, en els darrer segle havien sigut els ducs de Medinaceli, tal com hem comprovat al llarg del capítol setè d'aquesta tesi.

Per altra part, si ens atenem únicament als continguts de l'expedient del Jutjat de Primera Instància de Sagunt, resumidament el veiem com una reclamació dels veïns de Serra que farà seua el promotor fiscal i la presentarà en gener del 1838 davant el jutge. La incoació de l'expedient duia aparellat el segrest de la baronia per part de la Corona i la designació d'un Dipositari que s'havia de fer càrrec dels tributs locals mentre romania el segrest. Per a exercir aquest càrrec va ser nomenat, previ jurament i formalisme, Francesc Dolz menor, veí de Serra. La notificació als que fins aleshores havien sigut posseïdors de la baronia resulta ser la part més llarga i complicada que hem vist en tot el procés degut a les esquives, demores, retards i altres subterfugis dels Administradors i procuradors dels ducs i més tard del comte de Cervelló. Per altra part, ni el jutge ni el fiscal volen prendre cap decisió precipitada; són diligents i eficients en la presa de decisions mentre dura la instrucció però mostren una gran cautela sempre, doncs saben també el poder que tenen tots aquells als qui s'enfronten.

Efectivament, quan se li fa la notificació de la demanda al comte de Cervelló, en el seu palau de Madrid, aquest adopta una postura més bel-ligerant que la dels ducs respecte a la pèrdua de la baronia de Serra, potser per un sentiment de responsabilitat $i$ defensa dels interessos de la seua filla, de menor edat i hereua i neta de M. Vicenta Solís. Com hem explicat, el que va fer el comte és comparèixer en el procés amb la intenció d'introduir en ell una estratègia dilatòria, com era la petició de retrotaure la causa tornant l'expedient novament a Sagunt. Desconeixem fins a quin punt tenia present o pesava en el seu ànim allò que havia expressat la duquessa en el testament però, sembla evident que el comte de Cervelló seguia la seua pròpia estratègia. En tot cas, la publicació cap a finals de 1840 del testament de la difunta comtessa de Montellano ens aporta l'evidència de que el matrimoni, i desprès el duc vidu no tenien en el seu ànim oposar massa resistència al 
procés, ni tampoc, evidentment, s'esforçaren en aportar al jutjat els títols de propietat que tenien sobre la baronia de Serra.

Finalment, la data del 24 de gener de 1842, que és la del decret de l'Audiència Territorial que ordenava que l'expedient d'incorporació de Serra a la Corona havia de tornar al jutjat de Primera Instància de Morvedre, sense que aparentment açò es complira, es converteix en una altra fita destacada en el procés d'allunyament de les reminiscències feudals pel poble de Serra.

Malgrat aquella intervenció del comte de Cervelló en el procés de la baronia, ens consta que la persona que va liquidar els béns lliures de la baronia de Serra va ser Filibert Mahy, en qualitat de duc de Montellano, al llarg de vàries dècades i prop encara de l'any 1860. Sobre la major part d'aquestes vendes hi ha constància entre la documentació senyorívola de l'arxiu de Fernán-Núñez. Per exemple, de data 30 de juny de 1854 és l'escriptura de venda del solar i la casa "Mesón" del poble de Serra, atorgada pel duc de Montellano a favor de l'Ajuntament de dit poble, per preu de 2.000 rals de billó; escriptura atorgada davant el notari Joan Genovés i Cause, de la ciutat de València. ${ }^{43}$

Quatre anys després també va vendre el duc de Montellano, ara a un particular, Francesc Dolz i Català, veí de Serra, altres béns situats en dit poble, concretament el forn de "pan cocer", situat en el carrer del Forn, la carnisseria, situada en la plaça del Cementeri Vell, el molí fariner, en terme del poble, i un petit solar destinat antigament a forn de coure teula que es va utilitzar en la construcció de l'església parroquial. Tots quatre immobles al preu conjunt de 38.000 rals, segons escriptura feta davant Timoteu Liern, escrivà de València, el 18 de juliol de $1859 .{ }^{44}$

Per la mateixa època $i$ anys posteriors també venia el duc altres immobles situats en els pobles de Soneixa i d'Assuévar, entre ells l'anomenada “casa d'ensenyament (abans Mesó)" situada en la Plaça Major de Soneixa, venuda a un particular per 600 escuts, en 24 de març de $1868 .^{45}$

Davant aquestes dades concretes i plenament confiables, en una nota d'Ambròs Cebrián recollida en el manuscrit inèdit de Lluch i Cebrián (1935), diu que: “El solar para escuelas y Casa Ayuntamiento lo vendió el Exmo. Sr. Don Manuel Pascual Luis Sales D'Adda al Ayuntamiento. La escritura de venta de un solar que fue mesón lo

\footnotetext{
43 "Yndice general de los instrumentos..." (Annex VII): doc. 164.

44 "Yndice general de los instrumentos..." (Annex VII): doc. 166.

45 "Yndice general de los instrumentos..." (Annex VII): doc. 165, 167 i 168.
} 
vendió también el mismo Duque de Fernán González" (sic.). Tot i sabent les imprecisions d'aquesta cita, la recollim per ser quasi coetània (potser basada en transmissió oral o en alguna anotació de l'època). Per la mateixa font trobem un interessant assumpte, com és la "donació de l'algepsar de Serra". Al respecte, Senís (1954: 12), tot seguint textos de Cebrián, destaca que les mines d'algeps de Portaceli (i part en l'antiga baronia de Serra) eren d'excel·lent qualitat i el seu producte industrial enduria molt ràpidament, per la qual cosa, abans d'utilitzar-se el ciment, era un producte molt preat, estès $\mathrm{i}$ indicat en obres "atrevides" com escales, voltes, voladissos, etc..., i afegeix (ara citem literalment a Cebrián): “Estas minas y los montes en que están enclavadas fueron cedidos verbalmente al pueblo por su señor territorial don Filiberto Mahy Branly Romo Gamonales, Duque de Montellano, en 1834, inscribiéndose en el Registro de la Propiedad en 1 de agosto de 1877, a nombre de Serra".

Aquestes aportacions d'Ambròs Cebrián respecte al duc i la transmissió d'alguns béns lliures donen sensació de respecte i correcció per part del cronista i condescendència i bones atencions per part d'en Filibert Mahy. El fet d'haver cedit oralment el duc l'algepsar en 1834 (les mines i la muntanya on estan enclavades) no deixa de ser una mostra d'atenció i cordialitat; i encara que haguera sigut una cessió puntual i transitòria va adquirir continuïtat en el temps, fins ser inscrita definitivament a nom del poble (ajuntament) sense cap oposició. El forn de teula referit en el lot que comprà Francesc Dolz Català és el Rajolar, forn de coure rajoles que es van fer servir per a construir tota la part superior del temple parroquial (forn de finals del segle XVIII, segons veurem oportunament), i que amb aquesta referència entenem que s'hauria destinat també a fabricar desprès la teula de la coberta del temple.

En aquestes dades no hem trobat referits alguns altres béns que de segur també serien venuts, potser a particulars, en aquells anys i posteriors. Tal seria el cas de la tenda, la taverna i l'almàssera de l'oli. Entenem, per altra part, que el celler de vi i de l'oli, que són citats en alguns documents anteriors, devien formar part de la "casa del Senyor", que seria el immoble que en els documents més recents, del segle XIX, venim trobant generalment com a "Mesó" i que en el record viu seria "la Fonda". 
Hem trobat que el mateix any que el duc Mahy venia la casa-ajuntament de Serra, la Corporació publicava anunci per a la provisió d'una plaça de Secretari, per estar aquesta vacant. L'anunci, publicat en 23 de desembre del 1854, té el següent contingut:

"ALCALDIA CONSTITUCIONAL DE SERRA

Hallándose vacante la Secretaría de este Ayuntamiento, con la dotación anual de 1.350 reales vellón por renuncia del que la tenía, se anuncia al público para que los aspirantes a ella dirijan sus solicitudes, francas de porte, a esta corporación dentro del término de 30 días contados desde el que aparezca inserto este anuncio en el Boletín Oficial de la Provincia.

Serra 12 de octubre de 1854. De su orden. El Secretario interino Juan Domingo", ${ }^{46}$

En anys posteriors seguim trobant altres anuncis de l'alcaldia i de l'ajuntament Constitucional de Serra i encara de l'alcaldia Popular de Serra, com és el que es fa en 24 de juny de 1869 per a la provisió d'una plaça de metge-cirurgià titular de tercera classe, dotada amb el sou anual de 400 escuts, per l'assistència "de una fins a cent famílies pobres". ${ }^{47}$ Per altra part, també els expedients de pressupostos municipals de l'Ajuntament Constitucional de Serra per als anys 1846 a 1855, que hem consultat a l'arxiu històric de la Diputació, reflecteixen una administració municipal totalment consolidada i experimentada. ${ }^{48}$

Definitivament, podem dir que ha partir de 1835 l'ajuntament constitucional de Serra es manté com una institució afermada en el rang d'administratiu local d'un Estat de dret i així es manté sense a penes interrupció a partir d'aleshores.

Únicament ens resta considerar si cada veí es va fer directament propietari ple de les terres i cases del seu antic domini útil, una vegada abolit el sistema emfitèutic i el règim senyorívol o si, pel contrari va fer falta alguna mena d'acords de compra o concòrdies. Del mateix mode ens podem preguntar què passaria realment amb els terrenys comunals de l'antic Senyor, tant els que foren directament reservats a la senyoria (el bovalar, dit la Xara en la carta pobla de 1609) com la resta de terrenys forestals que, no per estar incultes deixaven de ser una important font d'ingressos per als serrans (no oblidem allò de "la llenya de carro"). ${ }^{49}$ Se n'ocuparem d'açò en el següent i darrer epígraf.

\footnotetext{
46 Gaceta de Madrid, num. 721, de 23 de desembre de 1854.

47 Gaceta de Madrid no 175 , de 24 de junio de 1869.

48 ADPV, sg. H1, caixa 436, exp. 6785 a 6794.

49 Veure notes de peu de pagina 26 i 27, d'aquest capítol.
} 


\subsection{FINQUES PARTICULARS I FORESTS PÚBLIQUES DEL TERME DE SERRA}

Per donar resposta a la primera de les dues qüestions plantejades en el darrer epígraf, duem a collació la que ens sembla una interessant observació i reflexió de Gómez Benedito (2009: 332 i 333) referida al cas de Sogorb i en la línia del que estem plantejant-nos en aquest mateix sentit per a Serra. Diu que els emfiteutes de Sogorb mantingueren el domini útil sobre les propietats que tenien establertes, però que no ha trobat documentació que permeta corroborar si la propietat plena l'adquiriren per compra del domini directe als senyors i a títol individual (com va passar en Nàquera) ${ }^{50}$ o bé mitjançant alguna concòrdia. Aquests serien els dos procediments habituals, però, en el cas de Sogorb, la transformació de la propietat útil en plena entén que se pogué gestar en un lent procés en el que s'ajuntava la resistència dels emfiteutes a seguir pagar censos i la impotència de la casa ducal per a defensar uns drets cada vegada menys estables i més llunyans. I afegeix que, a més de negar-se a pagar els censos, els emfiteutes eludien qualsevol esment a la qüestió de l'emfiteusi cada vegada que feien declaracions de béns, protocolitztació de documents notarials o inscripcions registrals.

El mes de juliol de 1842 recaigué resolució judicial favorable al duc de Medinaceli en vista de primera instància, la qual permetia el cobrament de les prestacions feudals. En el seu dictamen, els lletrats recomanaven a l'Ajuntament de Sogorb que presentara una apel·lació (Gómez Benedito, 2009: 384, doc. 33), cosa que sembla no va fer. La casa de Medinaceli, en haver presentat diversos títols d'adquisició de les seues senyories obtingué diverses sentències judicials favorables als seus interessos. Els pobles, que no presentaren apel·lacions a les sentències, estaven determinats, però, en no pagar cap prestació feudal. Aquesta ferma voluntat de no pagar acabaria per doblegar l'actuació de la casa ducal, cada vegada més mancada de recolzaments oficials i d'autoritat efectiva per a exigir el compliment de les resolucions judicials, fins i tot la publicació de les

\footnotetext{
${ }^{50}$ Els veïns de Nàquera, desprès de diferents sentències judicials (anys 1838, 1878 i 1884) recaigudes en favor del Marquès de Boïl i de Sardanyola, que li reconeixien el dret del domini directe sobre la baronia, signaren amb el Senyor un conveni del 7 de maig de 1879 (Lluch, 2002: 439, doc. XIX): els propietaris del domini útil podrien obtindre la propietat plena de les cases pagant al Senyor 50 rals en el termini de 4 mesos, 80 rals al cap d'un any, o bé, en tercer lloc, 90 rals al cap de dos anys. Si no ho feien en aquests terminis seguirien pagant indefinidament una pensió anual de 20 rals. Per a les terres cultivades (tant d'horta com de secà) podien fer-les franques pagant 4 rals per fanecada, o bé 5 rals en el termini d'un any o 6 rals arribat el segon any. Si no ho feien pagarien sempre 1 ral de pensió anual, si bé, en qualsevol moment i sense límit temporal podrien comprar el ple domini per 8 rals/fanecada. Resulta molt cridaner que entre els veïns i propietaris compareixents en Nàquera, hi havia, entre els propietaris útils, 56 persones de Nàquera i 27 de Serra, a més de quatre de València i dos més de Massamagrell.
} 
ordres $\mathrm{i}$ disposicions de la seua comptadoria acabà sent una càrrega econòmica que no aconseguia efectes. Per això, finalment, deixaren d'exigir els pagaments (Gómez Benedito, 2009: 331).

En el cas de Serra entenem que aquesta és la opció que millor s'ajusta a la realitat del que va passar després del 1842. I diem açò perquè, per una part sabem que Filibert Mahy no havia adoptat una postura bel-ligerant ni agressiva cap a Serra; i per altra part, a través d'arxius personals i particulars de veïns de Serra hem tingut accés a un cert nombre d'escriptures de compra i venda de finques particulars que es remunten a finals del segle XIX (concretament les darreres tres dècades) i en cap moment hem trobat referències a qüestions emfitèutiques ni possibles adquisicions a l'antic senyor territorial. Més bé al contrari, s'arriba a parlar de possessions immemorials i generalment hom omet tota classe de detalls i referències al tema. ${ }^{51}$

Completant aquestes observacions també cal dir que entre els protocols del notari Joaquim Soriano, de l'any 1837, hem trobat certa quantitat d'actes referits a serrans, i entre ell algunes vendes de parcel·les i immobles. En alguns fan referència (encara) al lluïsme, però en altres no es fa cap referència al domini directe ni cal altre dret dominical. Entre els primers tenim, per exemple, el 4 de maig i el 4 de juny, respectivament:

José Català, labrador de esta vecindad, con protesta de obtener la licencia del Exmo. Sr. Duque de Montellano, y pagarle el correspondiente luismo, a cuyo dominio mayor se halla tenida su finca... vende a Mateo Cabo, presbitero, vecino de la ciudad de Valencia... dos hanegadas tierra secana, plantada de olivos y algarrobos... término de Serra, partida del Molino... por 210 reales de vellón... ${ }^{52}$

Luís Ros Navarro vende, con protesta de obtener la licencia del Exmo. Sr. Duque de Montellano y pagar el correspondiente luismo, a cuyo dominio mayor y directo se halla tenido... un jornal de tierra secana, que perteneció a su padre, Miquel Ros... partida Barranco de la Ombría, por 60 libras... ${ }^{53}$

En canvi, el mateix 4 de maig, Domingo Navarro li ven (sense cap referència senyorívola) a Lluís Ros part d'un corral situat junt a la casa del comprador, en el carrer de la Font, per 585 rals. Més interessant ens resulta la següent venda, que no refereix cap llicència ni dret dominical però si el consentiment de marit, exigit per dret per a que una dona casada puga vendre:

\footnotetext{
51 El doctorand troba oportú afegir que va intentar accedir al Registre de la Propietat de Massamagrell, amb l'esperança de trobat entre les primeres inscripcions de finques registrades de Serra possibles referències a concòrdies, sentències, etc.; però l'intent va resultar infructuós, doncs l'arxiu havia sigut destruit durant la darrera guerra d'Espanya, segons ens van informar els responsables d'aquest organisme.

${ }^{52}$ ARV, protocols notarials, 4007, f. 74 r ${ }^{\circ}$. (notari Joaquim Soriano).

${ }^{53}$ Ibídem, f. 90r ${ }^{\circ}$.
} 
En la baronia de Serra, a los 4 días del mes de mayo de 1837, se pasa por esta pública escritura cómo Teresa Ros y Francisco Català, consortes, labradores de esta vecindad, previo el permiso de Marido á lugar prevenido por derecho,qu d haber sido pedido, concedido y aceptado, yo el Escribano doy fe, asi en sus nombre propios como en el de sus herederos y sucesores, Otorgan: Que venden y dan en venta real por juro de heredd, para siempre jamás, a Luis Ros, labrador de esta vecindad, y a los suyos, dos jornales, poco más o menos de tierra secana plantada de viña e higueras, situada en este término de Serra, partida de Les Viñetes... por precio de 140 reales de vellón.... ${ }^{54}$

Més llarg i interessant ens resulta l'esdeveniment dels terrenys forestals de l'antiga baronia de Serra i especialment els comunals fins arribar a la seues declaracions com a forests d'utilitat pública pertanyents, finalment, a l'Ajuntament de Serra.

En una nota d'Ambròs Cebrián, dels primers anys del segle XX (citada en el manuscrit de Cebrián i Lluch, 1935) trobem aquesta afirmació: “Los montes de Serra no consta de quien fueron adquiridos ni tampoco el tiempo que el pueblo lleva de posesión de los mismos, por datar de tiempo inmemorial. Se inscribieron a favor del común de Serra en 1864". A continuació diu (text posterior, degut a Emili Lluch): “Estos montes estaban cubiertos, en gran parte, por espesos pinares, hoy bastante mermados a causa de los repetidos incendios que han destruido la gran riqueza forestal de los tiempos pasados". Aquesta afirmació contrasta, en principi, amb l'estat deplorable que transmetien les decisions adoptades per l'ajuntament de Serra en $1832 .{ }^{55}$ No obstant, es pot entendre aquesta aparent disparitat si es considera la capacitat de regeneració del pinar i el fet de que, des del 1832 i en poques dècades les zones conservades per aquella disposició municipal podrien haver format boscos de pi (Pinus halepensis) de certa entitat.

En la presentació de l'obra col·lectiva Bienes Comunales: propiedad, arraigo y apropiación, Piqueras (coord.; 2002) mostra una senzilla però clara visió històrica sobre l'evolució que generalment experimentaren els terrenys comunals:

Los usos y la propiedad comunal de la tierra formaron parte esencial del régimen económico y social de la sociedad de Antiguo Régimen, convirtiéndose durante siglos en factores de equilibrio en la reproducción de las actividades humanas. El proceso de disolución comunal a partir del siglo XVIII se acentuó con las transformaciones liberales del siglo XIX para llegar al siglo XX un volumen limitado de bienes de titularidad pública -municipal o estatal- que por lo general constituyen eriales, dehesas pecuarias y masas forestales.

\footnotetext{
${ }^{54}$ Ibídem, f. $76 \mathrm{v}^{\mathrm{o}} \ldots$

55 AHN (FN), c. 1357, doc. 3.
} 
No conec la magnitud d'aquesta limitació de bens comunals en molts altres llocs, però, en el cas de Serra podem avançar que va ser molt notable, com veurem cap al final d'aquest epígraf.

Seguint a Piqueras (2002: 17 i 18) la despossessió de terres i drets comunals practicada en el segle XIX respon generalment a tres procediment: les disposicions legals, les apropiacions per part dels antics senyors en el curs de la dissolució de l'antic règim i les intrusions i usurpacions. En el "segon procediment" trobem que es troba un cas molt proper a Serra: la baronia de Nàquera, les forests de la qual, desprès d'haver sigut inscrites a nom del poble en 1863 hagueren de tornar a reconèixer el domini compartit amb el Marquès de Boïl i Sardanyola, al que devien pagar 750 pessetes anuals pels aprofitaments forestals, fins que arribaren a un definitiu acord en 1908, pagant encara 6.217 pessetes per poder cancelar i redimir el dret dominical (Lluch, 2002).

Sobre les disposicions normatives obviarem fer una relació extensa que, per altra part, es pot trobar fàcilment en reculls de legislació i nombrosos estudi sectorials. La gestió dels boscos sabem que es remunta a temps immemorial, especialment pel seu valor estratègic militar $\mathrm{i}$, particularment des del segle XVIII per la marina espanyola (de la Croix, 1801; Ferrer Pérez, 2001). Les alienacions de propios y baldios comencen durant la guerra del Francès $\mathrm{i}$ junt a altres ocupacions són regulats en diverses disposicions posteriors; però, a efectes d'administració forestal com a tal, vull destacar el R. Decret de 30 d'abril de 1835 pel qual s'ordena la creació dins del Cuerpo de Ingenieros civils d'una Inspección de Montes, la qual rebrà els encàrrecs posteriors de classificar i catalogar les forests de tot el territori espanyol.

El decisiu pas legal, en matèria de gestió i administració de les forests, arranca de la coneguda Llei Madoz de desamortització general, d'1 de maig de 1855, que en el seu article primer estableix la venda de tots els predis rústics i urbans de l'Estat però en el seu segon article exceptua diversos grups de béns, entre ells els boscos. Per concretar aquesta excepció es dicten la $\mathrm{R}$. Ordre de $5 \mathrm{~d}$ maig següent, ordenant que siguen catalogades les forests, la R. Ordre de 10 de maig, que suspèn la venda de forests fins que siguen catalogats, i el R. Decret de 26 d'octubre de 1855 que prefixa les forests excloses. Molts pobles, per temor de perdre els seus aprofitaments comunals, arribaren a acords amb els antics senyors, donant-se gran nombre de concòrdies d'aquesta naturalesa a partir de la llei general de desamortització de 1855. Entre altres exemples cita Martínez 
Gallego (2002: 183) els casos dels set pobles del Comtat de Xelva, amb el duc de Villahermosa; Olocau i Marines, amb el comte d'Olocau; Picassent i Bétera, amb el marqués de Dos Aigües, o Enguera amb el comte de Cervelló.

En el cas de Serra trobem la situació especial, ja referida, de que els aprofitaments principals, més que de fusta solien ser els de la "llenya de carro" (fornilla, bàsicament) que administrava directament el comú, l'ajuntament, amb coneixement i consentiment (impotent, potser) del Senyor, tal com hem referit que va passar en l'any $1832 .{ }^{56}$ Açò mateix ens permet ja intuir que en el cas dels comunals de Serra pogué passar el mateix que hem comentat adés per a les propietats i predis particulars.

De fet, la Classificació general de forests públiques "exceptuades de la desamortització", feta en compliment del R. Decret de 16 de febrer de 1859 i l'Ordre del 17 del mateix mes, aprovada de nou per R. Ordre de 30 de setembre del mateix any, inclou com pertanyent al comú de Serra la forest anomenada Alto del Pino y agregados, amb una cabuda de 199 hectàrees, tenint com a espècie dominant el "pi carrasco" i com a espècie subordinada l'argelaga. També defineix que aquesta forests confina amb termes d'Estivella, Segart, Nàquera... I amb la forest de Portaceli.

A partir d'aquest catàleg, tot tenint en compte els posteriors treballs de delimitació de la forest iniciats en 1861, en virtut de decret de 14 de setembre del mateix any, així com el R. Decret de 22 de gener de 1862 i diverses ordres que desenvoluparien aquest decret, es va aprovar un Catàleg de Forests Públics exceptuats de la desamortització, que trobem publicat en el B.O.P. de València números 141 i 142, de data 17 i 18 de juny de 1862. Poc desprès seria promulgada la Llei de Forests, de 24 de maig de 1863, desenvolupada pel seu reglament aprovat mitjançant un R. Decret de 17 de maig de 1865. En aquest catàleg, la forest "Alt de Pi i agregats" ve catalogada en el lloc 77 de les forest públiques de la província de València, amb una cabuda de "199/3.872”. Entenem que aquesta nova xifra correspon a la superfície inscrita en la delimitació perimetral realitzada, que inclou una gran superfície d'enclavats de propietat particular.

Per això i considerant la resta de dades que venim exposant, no cabria posar cap objecció a l'afirmació del cronista Ambròs Cebrián quan deia que "la forest comunal de Serra va ser inscrita a favor del comú (Ajuntament) el 1864", una vegada s'havia publicat oficialment l'esmentat Catàleg dos anys abans. No entrarem en més detalls sobre les posteriors revisions del Catàleg ni sobre noves disposicions en matèria normativa ${ }^{56}$ Veure nota a peu de pàgina 26 , d'aquest capítol. 
forestals per no eixir-nos massa del interval temporal i l'objecte concret de la present Tesi doctoral; al respecte es pot consultar, entre molts altres estudis sectorials, la publicació de Calvo Sánchez (2001). Però paga la pena destacar la Rectificació del Catàleg de 18771896, perquè l'Alt del Pi i agregats es converteix ara en la $\mathrm{N}^{\circ} 105$ (M.U.P. 105 és encara avui la referència oficia) de les Forests Públiques que, a més a més van ser declarades d'Utilitat Pública en aquell moment. Tanmateix, trobem molt interessant que en el nou Catàleg de 1901, aquesta forest de l'Ajuntament de Serra passa a tindre (oficialment) una cabuda total de 2.801 ha, de les quals n'eren públiques 1.361 ha (escassament un $49 \%$ ). La resta serien enclavaments de finques particulars, pot ser que agrícoles en una gran majoria.

El 4 de juliol de 1941, Ramón Caparrós, enginyer de la $1^{\text {a }}$ Secció del Districte Forestal de València, informava, com a prolegomen al projecte i acte de delimitació de la forest pública $\mathrm{n}^{\mathrm{o}} 105$, del Catàleg dels d'Utilitat Pública de la província de València, denominat Alto del Pino y Agregados, dels propis i terme de l'Ajuntament de Serra, de que en l'arxiu municipal de Serra, "entitat a la que el Catàleg assigna la pertinença d'aquesta forest", no hi havia document ni dades algunes concretes per les que bé per adquisició, donació o transmissió poguera comprovar-se i confirmar-se dit estat legal. Únicament diu haver vist una còpia d'una antiga carta-pobla, l'original de la qual va ser informat que s'havia destruï en el passat "moviment revolucionari". Diu seguidament que tampoc en l'arxiu del centre administratiu (Districte Forestal de València) on pertanyia aquest enginyer hi havia cap indici de com passà a formar part dels béns dels propis de l'Ajuntament de Serra aquest predi. No obstant, continua dient que pels més antics plans d'aprofitament "per aquest Districte confeccionats", com pels expedients de denúncies per aquest òrgan tramitades, hi ha documentació que prova "de manera fefaent i sense cap reserva" l'acció tutelar, fiscal i administrativa de dit Districte Forestal sobre aquesta forest pública que, mitjançant el Reial Decret de data 22 de gener de 1862 ja apareix com classificada i definida dins del Catàleg de les d'utilitat pública i com a pertanyent i propi de l'ajuntament de Serra, amb una cabuda de 199 hectàrees. Seguidament, però, esmenta que en el Catàleg rectificat del 1897, aquesta forest apareixia ja amb molta més superfície deguda a que incloïa ara nombrosos enclavats particulars. ${ }^{57}$

\footnotetext{
57 Informe inclòs entre els antecedents històrics d'aquesta forest, en l'arxiu territorial de la Secció Forestal de València (edifici Prop I): Forest $n^{\circ} 105$, caixa ${ }^{\circ} 3$, doc. $\mathrm{N}^{\circ} 77$.
} 
L'anterior informe duu per annex un manuscrit que recull la relació dels enclavaments d'aquesta forest, manuscrit signat en data 11 de maig de $1884 \mathrm{i}$ en el que ve a dir que el perímetre de la forest segueix els límits del terme municipal de Serra exceptuant per l'oest, on el límit correspon a la forest de Portaceli, del mateix terme de Serra però “propietat de l'Estat". A més a més, diu el manuscrit que aquesta forest número 105 inclou fins a onze finques o "suertes" de terreny enclavades, que sumen 1.439 ha 78 a i 51 ca. Hem vist que els onze enclavats venen indicats amb numeració romana i cadascun d'ells agrupa un gran nombre de propietats i propietaris, veïns de Serra.

Finalment afegirem que la forest de Portaceli (actualment M.U.P. 5), reconeguda com pertanyent al terme de Serra des de l'any 1835, havia quedat declarada a favor de l'Estat $\mathrm{i}$ inclosa entre les "Forests Nacionals" en 1838, mitjançant una R. Ordre de 24 de febrer que donà tal atribució a totes les forests que fins aleshores administrava la Marina i també (en un principi) les que gaudien el comú dels pobles mentre que aquells no presentaren documents justificatius de la seua propietat. Per a la venda de Portaceli es van fer diferents lots. Un d'ells era el de la Pobleta, que els frares havien arribat a vendre en 1820, però recuperaren per manca de compliment de l'acord econòmic. En 1835 Vicent Bertran de Lis aconseguia comprar a l'Estat la Pobleta. El mateix comprador, per escriptura de 24 de juliol de 1844 comprava també a l'Estat la masia de la Torre; i uns dies desprès comprava Portaceli (la majoralia amb el monestir i tota la forest i pinar). Per mort del propietari, en 14 d'abril de 1858 heretaven tota la propietat Manuel i Rafael Bertran de Lis; aquest últim era ja propietari de la Casa Blanca, la masia que els cartoixans havien posseït en el terme de la Pobla de Vallbona. Degut, però, a problemes amb la hisenda pública, aquests propietaris perderen tota la possessió de Portaceli, inclosa la Casa Blanca. Totes les propietats, embargades, passaven de nou a l'Estat en novembre del 1865 (Fuster, 1994).

El primer acte que hem localitzat sobre delimitació de la forest de Portaceli i dels seus enclavats (inicialment la Pobleta, la Torre i Monestir amb la majoralia) correspon a any $1844 \mathrm{i}$ el segon al 1855, sent en les dues dates propietari de la forest i dels enclavats l'esmentat Vicent Bertran de Lis, un important personatge de l'època, conegut comerciant, polític liberal i "banquer" de la Casa Reial. ${ }^{58}$

${ }_{58}$ ADPV, Diputació, sg. 2.1., c. 21, exp. 3. 


\section{CONCLUSIONS}

Les successives donacions del castell i la vila de Serra fetes pel rei Jaume I a diversos cavallers al llarg del segle XIII són l'origen de la senyoria cristiana i mudèjar de Serra. Anteriorment, el castell de Serra/Axerra hauria sigut un districte castral musulmà de major extensió, que seria fragmentat pel rei Jaume I en almenys tres parts o senyories: Nàquera, Lullén i Serra, conservant aquesta el castell, la vila i les alqueries de Ria i d'Armell. En les darreres dècades del mateix segle, la senyoria de Serra tornaria a estar en mans de la Corona (reialeng), fins a la definitiva donació, en 1270 a Bertran de Bellpuig; donació que es va fer conjunta amb la de Torres Torres.

Com a baronia, la de Serra tindria el seu origen arran de les concessions jurisdiccionals, de mer i mixt imperi, que en 1345 Pere IV li va concedeix Galceran de Bellpuig. Poques vegades hem trobat que es fera referència al "baró de Serra" com a tal, sinó que el més habitual ha sigut sempre "el Senyor de la baronia" o qualsevol dels títol de superior rang que sempre tingueren els barons de Serra: comte de Montagut, marqués de Castellnou o comte de Montellano han sigut els habituals des del segle XVII.

En el moment de l'expulsió dels moriscos, el senyor de la baronia de Serra i, conjuntament de la de Soneixa, era un jove de vint-i-quatre anys, Josep Folch de Cardona, que no tenia més possessions nobiliàries que les citades. La seua carrera militar, molt prop de la cort reial en els moments previs a la decisió de decretar l'expulsió, entenem que va ser fonamental per a que decidira un repoblament ràpid $\mathrm{i}$ eficaç de les seues baronies tan prompte com van quedar desertes a primers d'octubre de 1609. El 26 de novembre d'aquell any atorgava carta de poblament a 30 nous vassalls, als que es referim al llarg de la Tesi com a "repobladors", per a que repoblaren 20 d'ells el poble de Serra i els altres 10 el poble de Ria, estant separat un de l'altre 1,5 km. El dia següent, 27 de novembre, atorgava també carta de poblament a altres vassalls que repoblarien l'altra baronia, la de Soneixa amb Assuévar.

D'aquesta manera, la carta-pobla de Serra i Ria, seguida de la de Soneixa i Assuévar, es convertia en la primera d'aquest tipus que s'atorgava amb èxit en el Regne 
de València desprès de l'expulsió dels moriscos, tenint en compte, no obstant, que l'única que hem trobat anterior (del despoblat de Pujol, junt a ) no prosperà.

Una de les aportacions de la Tesi es pot concretar i resumir en el següent quadre, que recull la llista dels diferents senyor i senyores que van ser-ho de la baronia de Serra, Ria i Armell des de l'any 1609 i fins a la completa desaparició de l'Antic Règim.

\begin{tabular}{|c|c|c|}
\hline Període & Senyors de Serra & altres títols nobiliaris \\
\hline $1608-1645$ & \begin{tabular}{|c|} 
Josep Folch de Cardona iCardona \\
Barcelona, 18 gener(1584-1645) 26 desembre, Còrsega \\
Casat amb Jerònima Lull
\end{tabular} & $=>$ comtessa de Montagut \\
\hline 1645-1649 & $\begin{array}{l}\text { Jerònima Lull i Cabrera } \\
(15-1649) 17 \text { octubre, Soneixa }\end{array}$ & Id. \\
\hline $1650-1676$ & \begin{tabular}{|c|}
$\begin{array}{c}\text { Vicent Agustí d'Aragó i Cardona } \\
\text { Sogorb, } 30 \text { agost (1620-1676) Madrid, } 29 \text { maig }\end{array}$ \\
\end{tabular} & \\
\hline 1676-1679 & $\begin{array}{c}\text { Teresa del Milà i Mateu } \\
(1625-1679) \\
\text { Casada amb el Antoni Folc de Cardona }\end{array}$ & $\begin{array}{l}=>\text { baronessa de Massalavés } \\
=>\mathrm{m} . \text { de Castellnou i de Pons }\end{array}$ \\
\hline $1680-1704$ & $\begin{array}{c}\text { Vicent Felip Folch de Cardona i Milà } \\
28 \text { març (1656-1704) } 24 \text { març } \\
\text { Casat amb Teresa Bellvís de Montcada }\end{array}$ & Marquès de Castellnou \\
\hline fins a 1765 & $\begin{array}{c}\text { Josepa Folch de Cardona i Bellvís } \\
\text { València (1682-1716) } \\
\text { Casada amb José Ignacio Solís i Gante }(+3 \text { juny } 1765) \\
\end{array}$ & $\begin{array}{c}\text { Id. } \\
\Rightarrow>\text { III duc Montellano / c. Salduenya }\end{array}$ \\
\hline $1765-1780$ & $\begin{array}{c}\text { Alons Vicent Solís i Folch de Cardona } \\
4 \text { octubre }(1707-1780) 3 \text { agost } \\
\left(1^{\text {er }} \text { matrimoni amb } \mathrm{M}^{\mathrm{a}} \text { Manuela Centurión Ayala i Velasco }\right) \\
\text { Casat amb } \mathrm{M}^{\mathrm{a}} \text { Augusta Wignacourt i Aremberg } \\
\end{array}$ & $\begin{aligned} & \text { IV duc de Montellano } \\
& \text { (m. Castellnou, m. Pons, etc.) } \\
&=> \text { IV comtessa de Frigiliana } \\
&\end{aligned}$ \\
\hline 1780-1806 & $\begin{array}{c}\text { Alfonso Alejo de Solís Wignacourt } \\
19 \text { juliol (1756-1806) } 3 \text { novembre } \\
\text { Casat amb } \mathrm{M}^{\mathrm{a}} \text { Andrea Lasso de la Vega }\end{array}$ & $\begin{aligned} & \text { V duc de Montellano } \\
\Rightarrow & \text { IV duquessa de Arco, etc. }\end{aligned}$ \\
\hline $1806-1840$ & \begin{tabular}{|c|} 
M$^{\text {a }}$ Vicenta de Solís V. i Lasso de la Vega \\
Madrid, 27 octubre (1780-1840) 4 juny, Tours \\
Casada en 1798: Carlos Gutiérrez de los Ríos \\
i després amb Filiberto José Mahy \\
\end{tabular} & $\begin{aligned} & \text { VI duquessa de Montellano } \\
&=>\text { comte/ I duc de Fernan Núñez }\end{aligned}$ \\
\hline $1840-18$ & $\begin{array}{r}\begin{array}{r}\text { Filiberto José Mahy Branly } \\
\text { juliol (1790-1887) } 3 \text { gener }\end{array} \\
\end{array}$ & VI duc de Montellano (vidu) \\
\hline ----- & $\begin{array}{c}\text { Francisca Gutiérrez de los Ríos i Solís } \\
4 \text { octubre (1801-1836) } \\
\text { Casada amb Felipe Ossorio de la Cueva }\end{array}$ & $\begin{aligned} & \text { II duquessa de Fernan Núñez } \\
& \text { (però no de Montellano) } \\
&=>\text { comte de Cervelló }\end{aligned}$ \\
\hline 1848-1923 & $\begin{array}{c}\mathrm{M}^{\mathrm{a}} \text { del Pilar Osorio Gutiérrez de los Ríos } \\
10 \text { desembre (1829-1923) Dave, } 1 \text { setembre } \\
\text { Casada amb Manuel Falcó d'Adda }\end{array}$ & $\begin{array}{l}\text { VII duquessa de Montellano i } \\
\text { III duquessa de Fernan Núñez } \\
=>\text { marquès d'Almonacir }\end{array}$ \\
\hline
\end{tabular}

En lletra negreta, dins del quadre, hem destacat aquelles persones que foren directament titulars directes i generalment hi prengueren possessió formal de la baronia de Serra (Serra, Ria i Armell), però també aquelles persones que en qualitat de consorts 
i de vidus-consorts exerciren com a vertaders senyors i actuaren com a tal, perquè així ho hem comprovat en documents $\mathrm{i}$ actes als que hem tingut accés al llarg de les recerques realitzades.

La possessió nobiliària de la baronia de Serra estigué sempre caracteritzada per haver de suportar tota una sèrie de plets i demandes que, en bona part venien motivats per qüestions i successos ocorreguts molt abans de l'any 1609. Entre els principals motius estava l'agregació que Joana de Prades va fer en 1444 de les baronies de Serra i d'Entença vinculant-les per a sempre amb el comtat de Prades. Una altra decisió llargament qüestionada en el futur va ser la que va adoptar a principis del segle XVI el I duc de Cardona, de separar les baronies de Serra i de Soneixa de la resta de possessions que arrossegava el seu títol comtal, desprès ducal, de Cardona. Per això, els principals contrincants que reclamaven la possessió de Serra i de Soneixa als seus "qüestionats" titulars van ser els ducs de Cardona, desprès com a ducs de Sogorb i ducs de Medinaceli.

Un altre conflicte llargament arrossegat és el va encara patir Josep Folch de Cardona, en el que ell i abans son pare i el seu avi reclamaren la titularitat del ducat de Cardona, en ser ells els hereus agnats mentre que el títol i les possessions de Cardona anaven passant per mans de dones. Finalment ens resolgué aquest assumpte en el segle XVI a favor dels ducs de Sogorb-Cardona, en vida de Josep Folch de Cardona que, junt a la seua dona, Jerònima Lull travaren una bona relació amb els aleshores duc i duquessa de Cardona i Sogorb, fins al punt de que un fill dels ducs seria el seu successor testamentari en la baronia d Serra.

Les bones condicions que en principi, comparativament amb altres cartes-pobla dels primers anys del repoblament postmorisc, tingueren els vassalls de Serra, es convertiren en roïnes quan en el transcurs del segle XVII molts llocs i baronies anaven millorant les seues inicialment dures condicions, mitjançant acords i concòrdies, mentre que els de Serra a penes aconseguirien millores. Els referents més propers a Serra, com podien ser Soneixa (del mateix amo) o la propera Nàquera aconseguiren sensibles millores que no arribaren als serrans.

Per fi, al voltant de 1700, els serrans aconseguiren, per mig d'establiments, noves concessions i gràcies que els equiparaven a certes concessions de regalies que ja gaudien els de Soneixa, a més d'equiparar amb les d'aquella baronia les particions de 
fruits i grans. Aquestes concòrdies i pactes es van fer per part de Vicent Folch de Cardona i del Milà (marquès de Castellnou) per tal de guanyar-se la simpatia i recolzament dels vassalls, que així li juraren fidelitat. Allò va ser també un cop d'efecte decisiu en la pugna que mantenia amb els ducs de Sogorb per la successió de les baronies de Serra i de Soneixa.

El problema gran va ser que els successors d'en Vicent, començant per la seua filla, Josepa, i el seu gendre, el duc de Montellano, no volgueren mai reconèixer aquestes establiments i seguiren exigint -sobre tot a nivell de particions- les condicions pactades en la carta-pobla de 1609. Al llarg del segle XVIII tant els vassalls de Serra com els de Soneixa i Assuévar, conjuntament, pledejaren contra els ducs de Montellano, obtenint per resposta només resolucions judicials favorables als Senyors de les baronies.

Front a les resolucions desfavorables i les negatives i intransigències dels senyors, els serrans seguiren adoptant una postura d'ocultació de produccions, iniciada ja en la primera meitat del segle XVII, i que hem constatat de manera especial i reiterada en el cas de la producció del vi.

En les darreries del segle XVIII i, sobre tot, en les primeres dècades del XIX trobem també, per part dels serrans, casos creixents de desobediència i encara rebel·lia respecte a les sentències judicials i els manaments senyorívols. Els censos, les particions i la resta de drets dominicals es continuaren pagant, amb certa irregularitat però, fins a l'estiu de l'any 1835, en que la Junta revolucionària de València va donar als pobles instruccions per a que deixaren de fer-ho.

El fet de jurar formalment la Constitució de Cadis de 1812, el dia 20 d'agost de 1836, va fer que l'Ajuntament de Serra quedara constituït com a Ajuntament Constitucional. Els esdeveniments socials i polítics de l'època, i la promulgació de la llei de 26 d'agost de 1837 van conduir a que el 3 de gener de 1839 s'obriren diligències en el Jutjat de Sagunt una demanda popular i fiscal que exigia la reversió a l'Estat de la baronia de Serra.

A diferència del que va passar en molts altres casos, els senyors d la baronia de Serra no aportaren documents acreditatius de la seua possessió. El jutge va insistir reiteradament, fent notificacions que arribaren fins a Tours (França) on estaven residint els ducs de Montellano. La duquessa va morir en 1840, estant obert aquell procés judicial, però en el seu testament, que estava fet en 1837, sorprenentment deixa clara, 
respecte a les seues possessions nobiliàries, la seua acceptació de les lleis liberals i la seua determinació de disposar sobre els seus bens lliures.

A pesar de que el duc encara vivia i havia sigut notificat, les notificacions arribaren també a Madrid, dirigides a la hereua de la duquessa, aleshores una xiqueta, el pare i curador de la qual va presentar apel-lacions a la causa. Per acceptació del físcal, l'expedient, que es trobava ja la Sala $2^{\mathrm{a}}$ de l'Audiència Territorial de València, havia de ser tornar al Jutjat de Sagunt, per decisió de la Sala i del "notari de regnes" José Antonio Albelda. Açò passava ja el 24 de gener de 1842; però, sembla que mai no va arribar a Sagunt i quedà, finalment dipositat en l'arxiu dels ducs de Fernán-Núñez.

En les dècades següents, el duc vidu de Montellano, Filibert Mahy va liquidar els bens lliures de la baronia de Serra, respectant algunes concessions que havia fet anteriorment.

Desconeixem que hi haguera cap sentència sobre la demanda del fiscal i del poble de Serra. Tampoc hem pogut localitzar cap acord ni conveni regulador entre el duc de Montellano, ni el comte de Cervelló (en qualitat de tutor de la duquessa hereua), amb els veïns de Serra. No obstant, a diferència del que va passar a Nàquera, Olocau i altres pobles de les rodalies, a Serra no ens consta que els veïns arribaren a pagar quantitat alguna al Senyor ni per les seues cases i terres ni per la forest comunal que tant la Classificació general de forests públiques de 1859 com el Catàleg de 1862 havien adscrit al municipi de Serra i el seu ajuntament inscrigué al seu nom en 1864. 


\section{BIBLIOGRAFIA}

APARICI MARTÍ, Joaquín (2001). El Alto Palancia como polo de desarrollo económico en el siglo XV. El sector de la manufactura textil. Col. Maria de Luna, VIII. Ayuntamiento de Segorbe.

AGUIRRE, Domingo de; i SUELVES ARANGUREN, Ioseph Cayetano de (1711). Consvltacion en derecho, sobre la sucession del ducado de Cardona, marquesado de Villamur, y demàs estados unidos, y adjacentes. Obra feta per encàrrec de Josep Folch de Cardona (príncep de Cardona) i impresa a Barcelona per Rafael Figuerò, amb llicència del Rei. (Biblioteca Central de Barcelona; exemplar digitalitzat en http://books.google.com).

ÁLVAREZ VÁZQUEZ, J.A. (1984). Los diezmos en Zamora (1500-1840). Universidad de Salamanca.

ANDRIANI, general (1914). Memoria justificativa de la defensa de Sagunto en 1811 por el General Andriani. Imprenta de don Eusebio Aguado. Madrid. Facsímil publicat per Librerías París-Valencia, any 1994. València.

ARCÓN DOMÍNGUEZ, José Luis (2004). Sagunto: la batalla por Valencia. Ed. Museo Histórico Militar. València.

ARDIT LUCAS, Manuel (1969). "Los Alborotos de 1801 en el Reino de Valencia". Hispania, 113: 526-542.

--- (1975). "El govern del general Elio a València i les conseqüències econòmiques i socials de la guerra del francès". Arguments, 2: 7-33. Ed. l'Estel.

--- (1977). Revolución liberal y revuelta campesina. Un ensayo sobre la desintegración del régimen feudal en el País Valenciano (1793-1840). Ed. Ariel. Barcelona.

--- (1987). "Expulsió dels moriscos i creixement agrari al País Valencià”. Afers, 5-6: 273316.

--- (1989). "Recaudación y fraude diezmal en el siglo XVIII". En Estructuras agrarias y reformismo ilustrado en la España del siglo XVIII: 391-410. Ministerio de Agricultura, Pesca y Alimentación.

---- (1993). Els homes i la terra del País Valencià (segles XVI-XVIII), 2 vols. Ed. Curial. Barcelona.

--- (1994). “Crisi i transformacions desprès de l'expulsió dels moriscos". Col·loqui Internacional sobre la Segona Germania: 23-42. Ed. Diputació de València.

--- (1998), "El plet d'incorporació a la Corona de Catadau (1740-1806)". Estudis, 24: 391-414. València.

ARDIT LUCAS Manuel, BADENES MARTÍN Miquel Àngel i BERNAT MARTÍ Joan Serafí (2001). El País Valencià en el Cens d'Aranda (1768). Pub. UJI-UV. València. 
BANYULS i PÉREZ, Antoni (1993). "Del classicisme al neoclassicisme: l'arquitectura de Francesc Pechuan (1758 - 1819)". Aguaits, 9: 71-82. Inst. d'Est. Comarcals Marina Alta.

BERNAT MARTÍ, Joan Serafí (1980). “Aportació a l'estudi de la p oblació valenciana del segle XVIII. El cas de la Serra d'En Galceran (la Plana Alta)". Estudis d'Història Contemporània de País Valencià, 1: 43-74. Universitat de València.

--- (1990). Crecimiento de la población y crisis demográficas en el País Valencià (siglos $X V I I-X I X)$. Tesi doctoral, 1.486 p. Universitat de València.

BERNAT i MARTÍ, Joan Serafí i BADENES MARTÍN, Miquel Àngel (1994). Crecimiento de la población valenciana. Análisis y presentación de los censos demográficos (1609-1857). Col. Arxius i documents, 11. Ed. IVEI. València.

BRINES BLASCO, Joan (1978) "Reforma agraria y desamortización en la España del siglo XIX”. Estudis, 7: 125-154.

BONET ROSADO, Helena i MATA PARREÑO, Consuelo (2002). El Puntal dels Llops. Un fortín edetano. Serie de Trabajos Varios, 99. S.I.P, Diputació de València.

BORONAT BARRACHINA, Pascual (1901). Los moriscos españoles y su expulsión. 2 vols. Ed. F. Vives y Mora. (edició facsímil de L. París-Valencia, 1998). València.

CABANES PECOURT M D, FERRER NAVARRO R i HERRERO ALONSO A (1981). Documentos y datos para un estudio toponímico de la región valenciana. València.

CALABUIG i CARRA, Vicente (1897). La Casa Enseñanza, fundación del Arzobispo Mayoral. Informe presentado al Excmo. Ayuntaminto. Imp. Talleres Emilio Pascual. València. (Edició accessible a travès de BIVALDI, Biblioteca Valenciana).

CALVO SÁNCHEZ, Luis (2001) La génesis histórica de los montes catalogados de utilidad pública (1855-1901). Ministerio de Medio Ambiente. Madrid.

CÁRCEL ORTÍ, Ma Milagros i TRENCHS ODENA, José (1981-82). "Visita pastoral de Andrés Mayoral, arzobispo de Valencia, a la villa de Ondara (1744)". Estudis, 9: 131155. Univ. de València.

CARSÍ I GIL, Pau (2011). Cosas particulares y usos y costumbres de la ciudad de Valencia. Dietario de Pau Carsí i Gil; estudi i transcripció de Rafael Solaz Albert. Ed. Soc. Biblográfica Valenciana "Jerónima Gales". València.

CASEY, James (1981). El regne de València al segle XVII. Ed. Curial, Barcelona.

--- (1994). "La Segona Germania: perfil d'una revolta camperola”. Col·loqui Internac. sobre la Segona Germania: 133-160. Ed. Diputació de València.

CASTAÑEDA y ALCOVER, Vicente (1919) Relaciones geográficas, topográficas e históricas del Reino de Valencia, hechas en el siglo XVIII a ruego de don Tomás López. Tipogr. Revista de Archivos, Bibliotecas y Museos. Madrid.

CASTILLO SÁINZ, Jaume (2012) Alfons el Vell, duc reial de Gandia (1342-1412). Ed. CEIC Alfons el Vell; anys 1999 i 2012 (edició digital). Gandia.

CATALÁ i GORGUES, Miguel Àngel (2000). "Notícies de la casa Procura de Porta-Coeli (extrapolades d'un imaginari llibre de memòries, el MS De Rebus Monasterii, 1766, i d'altres dietaris apòcrifs)". En L'arqueologia fa ciutat: Les excavcions de la Plaça de Cisneros, pàg. 41-47. Galeria del Tossal. Pub. Ajuntament de València. 
CAVANILLES PALOP, Josep Antoni (1795-1997) Observaciones sobre la Historia Natural, Geografia, agricultura, población y frutos del Reino de Valencia. Madrid

CEBRIÁN y SANTOS, Ambrosio i LLUCH ARNAL, Emilio (1935). Apuntes y notas para la historia de Serra. Manuscrit inèdit ordenat i ampliat per E. Lluch a partir d'originals d'A. Cebrián. Arxiu Municipal de Serra.

CÍSCAR PALLARÉS, Eugenio (1977). Tierra y señorío en el País Valenciano (15701620). Ed. Del Cenia al Segura. València.

--- (1993). Moriscos, nobles y repobladores. Col. Estudios Universitarios, 58. Ed. Alfons el Magnànim. València.

CONDESA D’AULNOY (1892). Relación que hizo de su viaje por España la señora Condesa d'Aulnoy en 1679. "Traducció anònima i primera edició en espanyol" (Facsímil de Librerías Paris-València).

CONTELL TERUEL, Rafael (2005) "La Prehistoria en los orígenes de Serra". Festes Patronals: 49-54. Serra.

CORBALÁN DE CELIS y DURÁN, Juan (1997) La repoblación en la baronía de Torres Torres. Cartas de nueva población de Alfara y Algimia (1609-1611). Ajt. d'Algímia d'Alfara.

CROIX VIDAL, Joaquín de la (1801). "Memoria premiada que contiene la indicación de los montes del Reyno de Valencia: clase calidas uso y abundancia ó escasez de sus maderas". Junta Pública de la Real Sociedad Económica de Amigos del País de Valencia: 163-267. València.

CRUZ OROZCO, Jorge i SEGURA MARTÍ, Josep Ma (1996). El comercio de la nieve. La red de pozos de nieve en las tierras valencianas. Generalitat Valenciana, Dir. Gral. de Patrimoni Artístic. València.

DIAGO, Francisco (1613). Anales del Reino de Valencia. 2 vols. Facsímil de Librería París-València, any 1981.

DÍEZ PÉREZ, Joaquín (2004) Torres Torres. Luces y sombras. València.

DOMÉNECH PALAU, Amparo (1998). Bétera, un pobles per a tots. Ed. Ajuntament de Bétera-Coop. Agrícola de Bétera.

DOMÍNGUEZ ORTIZ, Antonio (1962) “La Sociedad Española en el siglo XVII”. En La Historia de España, de Ramón Menéndez Pidal, t.XXIII.

EIRAS ROEL, Antonio (1993). Estructura demográfica, diversidad regional y tendencias migratorias de la población española a finales del antiguo régimen. En: Le Migrazioni in Europa Secc. XIII-XVIII. Ed. Inst. Internazionale di Storia Economica F. Datini Prato. Firenze.

ESPINALT y GARCÍA, Bernardo (1784) Atlante Español ó Descripción General Geográfica, Cronológica e Histórica de España, por Reynos y Provincias. (Tomo 8: Reyno de Valencia). Edició facsímil del IVEI: Descripción del Reyno de Valencia, 3 volums. València.

ESTELLÉS ZANÓN, Emilio (1996). Buñol: sus gentes y su història. Ayuntamiento de Buñol. 
FELIPO ORTS, Amparo (1985a). "Producción y consumo de vino en el País Valenciano durante el siglo XVII: los manifiestos de 1627-1631". Saitabi, 35: 1-24. Univ. València.

--- (1985b). Control de la producción vinícola en el País Valenciano durante el siglo XVII: los manifiestos de 1627-1631. ESTUDIS, 11: 41-82. València.

FERRER PÉREZ, Vicente (2001). "Els boscos valencians i la construcció naval en la segona meitat del segle XVIII". Cuad. De Geografia. 69/70: 23-52. Universitat de València.

FERRER TABERNER, Andrés (1995). "Repobladores moriscos en el deshabitado lugar de Ponera". Actes del Ier. Congrés d'Estudis sobre el Camp de Morvedre. Braçal, núm. 11-12. Sagunt.

--- (1996). "El lugar de Armell: un despoblado mudéjar en el Señorío de Serra". Serra en festes: 29-32. Ajuntament de Serra.

--- (1988) "El testamento de un morisco de Ría: un documento de 1595 que arroja nuevos conocimientos de la historia de Ría". Serra en Festes. Ajuntament de Serra

--- (1999). "Una carta puebla inédita: la capitulación de los moros de Serra en 1365". Saitabi, 49: 363-374. Univ. València.

FERRI, Marc (2000). "Molins i moliners al segle XIX. Notes entorn al cens de Molins de la província de València de 1847”. En: Els molins hidràulics valencians. Tecnologia història i context social (Tomàs Glick, Enric Guinot i Luis P. Martínez, Eds.): 451483. Institució Alfons el Magnànim. Colección Estudios Universitarios, 81. València.

FLUVIÀ i ESCORSA, Armand de (1979) "Els comtes i el comtat de Prades". Annals de l'Institut d'Estudis Gironins, 25: 155-165.

FONSECA, Damián (1613). Justa expulsión de los moriscos de España.

FRANCH BENAVENT, Ricardo. (1994). "La producción de seda en el País Valenciano durante el siglo XVIII: distribución geográfica y evolución". Noticiario de Historia Agraria, 8: 67-98. Murcia.

--- (2003). "El cultivo de la morera y las iniciativas para la mejora de la hilatura y el torcido de la seda en el siglo XVIII. El crácter pionero de la fábrica de Vinalesa". Actes del II Congrés d'estudis de l'Horta Nord: 19-45. Vinalesa.

FUSTER SERRA, Francisco (1994). Cartuja de Portaceli. Historia, vida, arquitectura y arte. Col. Estudis, 5. Ajuntament de València.

--- (2003) Cartuja de Portaceli. Historia, vida, arquitectura y arte. Col. Estudis, 5. Edició revisada i ampliada de la de 1994. Ajuntament d València.

GARAY MARTÍN, Policarp (2000) El dominio triásico Espadán-Calderona; estudio geológico e hidrogeológico. Publ. en microficha. Tesi Doctoral. UVEG. València.

--- (2001). "Primeres dades sobre l'emplaçament i característiques del poblat sarraí d'Armell o Almuelle (terme municipal de Serra)". III Congrés Comarcal del Camp de Túria. Lauro, 10: 81-88. Llíria.

--- (2004). "Aprofitament de recursos naturals en l'antic priorat de Portaceli". Axerra, 1: 40. Ajuntament de Serra. 
--- (2009) "Corrals i tradició ramadera al terme municipal de Serra". Jornades sobre Arquitectura tradicional valenciana. Paterna.

--- (2012). "Onomàstica de moriscos de la vessant sud de la serra Calderona (Bétera, Gàtova, Marines, Nàquera, Olocau i Serra”. Crònica de la XXVIII Assemblea de Cronistes del Regne d València: 321-333. València.

GARAY MARTÍN, Policarp i PERIS GIMÉNEZ, Immaculada (2001). “Ambrosio Cebrián y Santos (1863-1933) autor de les Notes Geogràfiques i Històriques de Serra". III Congrés Comarcal del Camp de Túria. Lauro, 10: 89-95. Llíria.

GARAY MARTÍN P, GARAY IBÁÑEZ R, GARAY IBÁÑEZ A i NAVARRO TOMÀS A (2010) Estudi toponímic del terme municipal de Serra a partir de la documentació històrica. Treball becat per l'Acadèmia Valenciana de la Llengua. Novembre de 2010. Inèdit.

GARCÍA MERCADAL, J. (1952). Viajes de extranjeros por España y Portugal, desde los tiempos más remotos hasta finales del siglo XVII. 3 vols. Madrid.

GARCÍA ORMAECHEA, Rafael (1932) Las supervivencias feudales en España. Estudio de legislación y jurisprudencia sobre señorios. (Edició a cura de de Pedro Ruiz, 2002).

GARCÍA EDO, Vicente (1987). Segorbe en el siglo XIII. Ed. Ayuntamiento de Segorbe.

GARRIDO MURO, Luis (2004). "El final del arca de la alianza: alternancia y exclusivismo durante el reinado de IsabelII". En Violencia y legitimidad, politicas y revoluciones en España y América Latina, 1840-1910 (Carlos Matamud i Carlos Dardé Eds): 21-42.. Universidad de Cantabria.

GIL OLCINA, Antonio (2012). Singularidades del régimen señorial valenciano. Expansión, declive y extinción de la señoría directa. Publ. Universidad de Alicante.

GIL, Francesca i NAVARRO, Alexandre (1997). Toponímia rural de Nàquera. Ed. IDECO Camp de Túria. Llíria.

GIMÉNEZ FONT, Pablo (2008). Las transformaciones del paisaje valenciano en el Siglo XVIII. Col. Estudis Universitaris, 112. Inst. Alfons el Magnànim. València.

GUERRERO CAROT, Francisco José (2004). El Palancia: nacer y emigrar. La evolución de la población (siglos XVI al XIX). Universitat Jaume I - Diputació de Castelló. Castelló de la Plana.

GUERRERO CAROT, F.J. i CORBALÁN DE CELIS, L. (2002). Repblar para vivir. Sot de Ferrer. Un ejemplo de poblamiento en el Palancia (ss. XIV a XVIII). Ayuntamiento de Sot d Ferrer.

GUINOT RODRÍGUEZ, Enric (1991) Cartes de poblament medievals valencianes. GENERALItat Valenciana. València.

--- (1997). "La creació de les senyories en una societat feudal de frontera: el Regne de València (segles XIII-XIV)". Revista d'Història Medieval, 8: 79-108. Universitat de València.

GÓMEZ BENEDITO, Vicente (2009) Conflicto antiseñorial y abolición del régimen feudal en Segorbe. Col. María de Luna, 11. Ayuntamiento de Segorbe.

GUAL CAMARENA, Miguel (1989). Las cartas pueblas del reino de Valencia. Generalitat Valenciana. València. 
GUERRERO CAROT, Francisco J. (2005). El Palancia: nacer y emigrar. La evolución de la población (siglo XVI al XIX). Universitat Jaume I. Castelló de la Plana.

GUIA MARÍN, Lluis (1982). "La revolta dels llauradors de 1'Horta de 1663”. Estudios dedicados a Juan Peset Aleixandre, vol. II: 304-326. Universitat de València.

HALPERIN DONGHI, Tulio (1980). Un conflicto nacional. Moriscos y cristianos viejos en Valencia. Ed. Inst. Alfons el Magnànim. Diputació de València.

HAMILTON, Earl J. (1975). El tesoro americano y la revolución de los precios en España, 1501-1650. Ed. Ariel. Barcelona.

--- (1988). Guerra y precios en España (1651-1800). Alianza Ed.

HERNÁNDEZ GARCIA, Ricardo i PÉREZ ROMERO, Emilio (2008). "La evaluación del producto agario en Castilla y León durante la edad moderna. Problemas y posibilidades para su estimación a partir de fuentes diezmales". IX Congreso Asociación Española de Historia Económica: 1-36. Murcia.

HERNÁNDEZ MONTALBÁN, Francisco J. (1999). La abolición de los señorios en España (1811-1837). Col. Història, 10. Biblioteca Nueva-Universitat de València.

IQUINO PARRA, Félix (1982). Historia de Soneja. Ed. Caja de Ahorros y Monte de Piedad de Segorbe.

LAPEYRE, Henry (1986). Geografía de la España Morisca. Col. Història i societat, 4. Diputació de València.

LARIO RAMÍREZ, Dámaso de (1973) Cortes del reinado de Felipe IV. Cortes valencianas de 1626. Monografías y Fuentes, 9. Universitat de València.

LLIN CHÁFER, Arturo (s.a.). “Andrés Mayoral Alonso de Mella (1738-1769)” (listado cronológico/resenya biogràfica). Pàgina web de l'arquebisbat de València. Consulta feta en 2014: http://www.archivalencia.org/contenido.php? $\mathrm{a}=1 \& \mathrm{pad}=100 \&$ modulo=67\&epis $=53$.

--- (2007): <www.archivalencia.org/episcopologio>. 20-02-2013.

LLORET, Paz (2002). "Los intentos repobladores del Señor de Olocau tras la expulsión de los moriscos. La carta puebla de 1609". Estudis, 28: 345-365.

LLUCH ARNAL, Emilio (2002). El señorío y baronia de Náquera. Ed. Ajuntament de Nàquera. Edició millorada de la reproducció de 1983; original de 1945. Nàquera.

MADOZ, Pascual (1845-50) "Diccionario geográfico-estadístico de España y sus posesiones de ultramar". Edició del IVEI (1987): "Alicante, Castellón y Valencia", 1987. Inst. Alfons el Magnànim. València.

MARES, padre Vicente (1681) La Fénix Troyana. 2a edició de l'any 1931. Teruel.

MARTÍNEZ ALOY, José (1924). "Provincia de Valencia". Tomo I de la Geografia General de Alicante, Castellón y Valencia, dirigida per F. Carreras Candi. Ediciones Valencianas.

MARTÍNEZ GALLEGO, Francesc A. (2002). "Los envites contra el comunal: boalres, baldíos y montes valencianos durante el proceso revolucionario (1834-1868)". En Bienes Comunales: propiedad, arraigo y apropiación (J.A. Piqueras, coord.): 155188. Ministerio de Agricultura, Pesca y Alimentación. Madrid. 
MARÍ I BRULL, Gerard (2009) "Perpinyà Hipòlit, beneficiat i administrador de l'Hospital del Coll de Balaguer (s. xiv-Xv)". Gimbernat (Rev. Catalana d'Hist. de la Medicina i de la Ciència), 51: 43-59. ISSN: 0213-0718.

MARTÍNEZ NAVARRO, Ferran (1976). "Estudi epidemiològic de la mortalitat infantil i pre-escolar a Serra des de 1620 a 1679". Primer Congreso de Historia del País Valenciano, vol. III: 361-370. Ed. Universitat de València.

--- (2013). "La repoblació a Serra desprès de l'expulsió dels moriscos (1609-1759)". Mirades, 4-5: 36-47.

MAS I FORNERS, Antoni i MONJO I MASCARÓ, Joan-Lluis (2002). Per poblar lo regne de valentia. L'emigració mallorquina al País Valencià en el segle XVII. Col·lecció Els Camins de la Quimera, 5. Conselleria de Presidència. Consell de les Illes Balears.

MENJÓN RUIZ, M. (1992). "DIEZMO”, en Gran Enciclopedia de España, t. 7. Ed. Enciclopedia de España, S.A.

MESA REIG, Lluís (2009). Quinque Libri d'Estivella 1619-1678; Índex i Comentaris. Col. El Nostre Patrimoni, 2. Ajuntament d'Estivella.

--- (2014). "L'avalot de Pep de la muntanya a Estivella l'any 1801”. Crònica de la XXIX Assemblea de Cronistes Oficials del Regne de València: 365-393.

MESTRE SANCHIS, Antonio (1976). "La recolección de diezmos en la diócesis valenciana según la encuesta capitular de 1758". Primer Congreso de Historia del País Valenciano, vol. III: 631-642. València.

MIRET I SANS, Joaquim (1918) Itinerari de Jaume I el conqueridor. Inst. d'Estudis Catalans. (Edició facsímil de 2007, Inst. d'Estudis Catalans, Memòries de la Secció Històrico-arqueològica, LXV, amb Pròleg de Maria Teresa Ferrer i Mallol).

MOLAS RIBALTA, Pere (2004) La Duquesa de Cardona en 1640. Cuadernos de Historia Moderna, 29: 133-143.

MOLINS MARCH, Honorato J. (1978). Escritos biográficos sobre Inés de Moncada. Museu Municipal de Moncada - Diputació de València.

MOXÓ, Salvador de (1965). La disolución del régimen señorial en España. CSIC. Madrid.

MUÑOZ Y RIVERO, Jesús (1917). Manual de Paleografía Diplomática Española de los siglos XII al XVII. Ed. Daniel Jorro. Madrid.

NAVARRO GARAY, Antonia (1985) "Recordant coses antigues de Serra". Serra en festes. Ajuntament de Serra.

PALOP RAMOS, José Miguel (1982). "El producto diexmal valenciano durante los siglos XVII y XVIII. Aproximación a su estudio". En: Prestations paysannes, dîmes, rente fonciere et mouvement de la production agricole a l'époque préindustrielle, I: 407-416 (Goy J i Le Roy Ladurie E, ed.). Paris-La Haya-New York.

PÉREZ APARICIO, Carmen (1998). "Reivindicaciones antiseñoriales en el País Valenciano. De la segunda Germanía a la guerra de Sucesión”. Estudis, 24: 247-279.

PÉREZ CASADO R, MARTÍNEZ NAVARRO F i ZURRIAGA AGUSTÍ F (1992). Del Carraixet al Palància. Editat pels autor. València. 
PÉREZ PUCHAL, P. (1972). "La población del País Valenciano hasta la época estadística". Cuadernos de Geografia, 10: 1-30. Univ. de València.

PIQUERAS ARENAS, J.A. (1996) "La evolución burguesa española. De la burguesía sin revolución a la revolución sin burguesía". Historia Social, 24: 95-132. Valencia.

--- (2002). "Presentación" i “Aprovechamiento y nostalgia del comunal". En Bienes Comunales: propiedad, arraigo y apropiación. (J.A. Piqueras, coord.): 9-10 i 11 a 60, respect. Ministerio de Agricultura, Pesca y Alimentación. Madrid.

PIQUERAS HABA, Juan (1980) "La vid y el vino en el País Valenciano (Geografía económica: 1564-1980)". Institución Alfonso el Magnánimo. Diputació de València.

--- (1986) "Historia y guía de los vinos valencianos". Conselleria d'Agricultura i Pesca. $267 \mathrm{pp}$.

RIBES TRAVER, Ma Estrella (1998). Los Anales de la Cartuja de Portaceli. Inst. Alfons el Magnànim. València

RODRÍGUEZ RODRÍGUEZ, Miguel Angel (2009). La carta puebla de Soneja y Azuébar. Ed. Ayuntamiento de Soneja.

--- (2012). "Plets successoris a la casa de Cardona i a les seves baronies valencianes (1576-1679)". Pedralbes, 32: 157-194.

ROMERO TALLAFIGO, Manuel, i PALLET PLAJA, Ma Teresa (1991). Documents de la Baronia d'Entença (Vandellòs, Coll de Balaguer, l'Hospitalet de l'Infant).

Ajuntament de Vandellòs i l'Hospitalet de l'Infant.

ROYO MARTÍNEZ, Josep (1998). "Estat general de tots els pobles en 1789 segons les seues respectives justícies". Crònica de la XXI Assemblea de Cronistes Oficials del Regne de València: 347-374. València.

SALA, Juan ((1820). Ilustración del derecho real de España. J. del Collado. Madrid.

SALA GINER, Daniel (1999). Viajeros franceses por la Valencia del siglo XVII. Ed. Ajuntament de València.

SARTHOU CARRERES, C. (1918) Geografía General del Reino de Valencia: provincia de Valencia. Tomo II. Barcelona.

SANCHIS SIVERA, José (1923). Nomenclátor geográfico-histórico de los pueblos de la diócesis de Valencia. Valencia.

SEBASTIÀ DOMINGO, Enric (2000). Crisis d los factores mediatizantes del régimen feudal. Feudalismo y guerra campesina en la Valencia de 1835. Clásicos de historia social de España. Una selección crítica. P. Sánchez León y J. Izquierdo (comps.): 193-217. Col.: Biblioteca Historia Social, 5. Valencia.

--- (2001). La revolución burguesa. La transición de la cuestión señorial a la cuestión social en el País Valenciano. (amb Prefacio de Javier Paniagua i Estudi preliminar de José A. Piqueras), Col.: Biblioteca Historia Social, 10; 2 vol. Inst. Historia Social. València.

SEBASTIÀ, E. i PIQUERAS, J. A (1987) Pervivencias feudales y revolución democrática. Institució Valenciana d'Estudis i Investigació. Ed. Alfons el Magnànim. València.

SENÍS DOMINGO, José (1954). Serra. Apuntes para su historia. Imp. Laguarda. Serra. 
--- (1978). Serra. Apuntes para su historia ( $2^{a}$ edición corregida y aumentada). Ed. Asociación de Amigos de los Ancianos. Serra.

--- (1981) “La verema”. Serra en festes. Ajntament de Serra.

TARAÇONA, Pere Hieroni (1580). Institucions dels furs i privilegis del Regne de València. Ed. facsímil de Librerías París-Valencia, any 2005. València.

TARÍN y JUANEDA, Francisco (1897). La cartuja de Porta-Coeli (Valencia). Apuntes istóricos. Imp. M. Alufre (edició facsímil de Librerías París-Valencia, any 1986) València.

TEROL GRAU, Vicent (1994). "Migracions i creixement demogràfic endògen al País Valencià (segles XVII-XX)". La población valenciana; pasado, presente, futuro, vol. I: 187-210. Institut de Cultura Juan Gil-Albert-Diputació Provincial d'Alacant. Alacant.

TORRES MORERA, Juan Ramón (1969) Repoblación del Reino de Valencia tras la expulsión de los moriscos. València.

VALICOURT, Charles de (1906). La conquête de Valence par l'armée française d'Aragon 1811-1812. Ed. R. Chapelot et Ce. Paris.

VIDAL PLA,Jordi (1981) "La crisi social dins de la classe dirigent catalana, elements bàsics de l'estudi sobre els exiliats filipistes a la guerra dels segadors (1640-1652)". Pedralves, 1: 377-380.

--- (1984) Guerra dels segadors $i$ crisi social. Els exiliats filipistes (1640-1652). Edicions-62. Barcelona.

VILA MORENO, Alfonso (1983). La lengua valenciana en la administración parroquial (siglos XVII a XIX). Ed. del Cenia al Segura. Valencia.

ZURRIAGA AGUSTÍ, Ferran (1987) "Introducció a l'estudi de la Carta-Pobla de la Vall d'Olocau, Marines i Gàtova”. Boletín de la Sociedad Castellonense de Cultura, vol. LXIII: 223-233.

--- (1994). "Els malnoms i els llinatges d'Olocau". II Congrès d'Estudis Comarcals Camp de Turia, actes: 127-132. Benaguassil.

--- (2003-a). Olocau, cau de somnis. Tòpica edetana, 2. Llíria.

--- (2003-b). "Els criats de Portaceli i la seua relació amb la vall d'Olocau". Actas del Congr. Internac. de las Cartujas Valencianas, t. I: 387-394. E1 Puig.

--- (2005). “El lledoner, l'arbre de les forques”. Revista Mètode, 45.

--- (2007). "Olocau, cau de somnis"; el resum digital. Mirades, 3: 88-91. Ed. Institut d’Estudis Comarcals del Camp de Túria. Llíria.

\section{DOCUMENTS PUBLICATS}

El Fuero, Privilegios, Franquezas y Libertades de los Cavalleros hijos dalgo del Señorío de Vizcaya. Confirmados por el Rey don Felipe III, Nuestro Señor, y por los Señores Reyes sus ptredecesores. Con licenci Real. En Medina del Campo impresso por Francisco del Canto. A costa del Señorío de Vizcaya. Por orden de Antonio de Zaballa, Vizcayno vezino de Medina del Campo. Año MDLXXV: 
(http://www.liburuklik.euskadi.net/handle/10771/8568). (La $3^{\text {a }}$ edició va ser impresa a Bilbao, per Pedro de Huydobro "impressor del dicho Señorío. Año 1643”).

Tarifa dels preus i pesos de les mercaderies per a millor exacció i cobrança de la cisa de Pas que es col·lecta en les Taules de la Contribució de la present ciutat i llocs situats d'aquella. (Facsímil d'un original de 1671, inclòs en Documents històrics valencians del segle XVII. Comerç, mesures $i$ oficis. Ed. Ajuntament de València. Col-lecció 9 d'octubre, núm. 3. Any 1995).

Novísima recopilación de la Leyes de España, dividida en XII libros en que se reforma la Recopilación publicada 'por el Señor Don Felipe II en el año 1567, reimpresa últimamente en el de 1775: Y se incorporan las pragmáticas, cédulas, decretos, órdenes y resoluciones Reales y otras providencias no recopiladas y expedidas hasta el de 1804. Mandad formar por el Señor Don Carlos IV. Impresa en Madrid. Año 1805. (http://fama2.us.es/fde/ocr/2006/novisimaRecopilacionT1.pdf; (https://books.google.es/...)

Colección de la Leyes, Decretos y Declaraciones de las Cortes y de los Reales Decretos, Órdenes, Resoluciones y Reglamentos Generales expedidos por la Secretarías del Despacho desde el $1^{\circ}$ de julio hasta fin de diciembre de 1837. Tomo XXIII. De orden de S.M. Madrid. En la Imprenta Nacional. Año de 1838. (https://books.google.es/...).

$$
++
$$




\section{RELACIÓ DE QUADRES I FIGURES}

\section{$\underline{\text { FIGURES }}$}

1.1.- Ubicació del Castell (estrela) i la vila de Serra quadrat) amb llurs alqueries (cercles). .17

1.2.- Mapa de termes, seglars i religiosos, de la serra Calderona a principis del segle XVII. ................19

1.3.- Delimitació del terme municipal de Serra segons la cartografia cadastral de 1938. ....................23

1.4.- Restes malmesos del molló MT9 (Sogorb, Torres Torres i Serra), construït en 1788. ..................24

1.5.- Molló MT9 (triangle groc) sobre el visor cartogràfic de la GV. ...............................................25

1.6.- Molló M39, antic trifini entre de Portaceli i les baronies de Serra i Nàquera. ..............................26

1.7.- Molló M39 (triangle groc) sobre el visor cartogràfic de la GV. Desajustos existents. ..................27

1.8.- Ubicació de mollons i fites en la muntanya del Reixo, amb el Puntal de Ferrer. .........................38

1.9.- Antic molló divisori entre Serra i Portaceli. Avui divisori entre les forests públiques. ...................39

2.1.- Fragment del mosaïc ceràmic que hi hagué en la Casa del Senyor de Serra. ...............................68

3.1.- Evolució dels casaments registrats a Serra en el segle XVII, agrupats per dècades. ...................103

4.1.- Restes arqueològiques recollides i estudiades per Nicolau P. Gómez Serrano, en 1920. .............121

4.2.- Torreta de Ria, amb evidències d'haver estat lluïda i emblanquinada. .....................................123

4.3.- Camí d'Estivella al seu pas per Ria i restes de paret d'una antiga casa. ......................................123

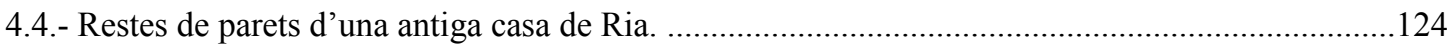

4.5.- Ortofoto i parcel·lació en l'entorn de Ria. ..........................................................................125

4.6.- Esquema que mostra el desplaçament de Ria per a formar el Bàrio. ............................................128

4.7.- Pont del Bàrio, sobre el barranc de la Font del poble. ..................................................................129

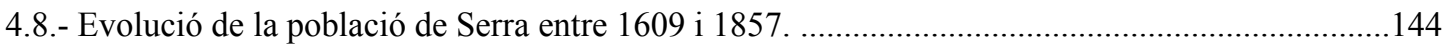

4-9.- Funcions gràfiques de l'evolució de la població de Serra entre 1609 i 1857 .............................145

4.10.- Evolució del nombre de batejats i de difunts entre 1620 i 1745 ..............................................149

4.11.- Augment net acumulat de població (batejats-difunts) entre 1620 i 1745 ................................151

4.12.- comparació de la mortalitat infantil a Serra (1619 a 1708), front a la resta de defuncions. ........152

4.13.- comparació entre la corba demogràfica (negre) i l'evolució de taxes de natalitat i mortalitat. ..153

5.1.- Ventisquer de Rebalsadors, construir junt al terme de la baronia de Serra. ................................161

5.2.- Molí de Marianet, junt a la Casa $\mathrm{n}^{\circ} 1$, poc abans del ser enderrocats casa i molí (anys 60). ........166

5.3.- Restes del Molí de la baronia de Serra, avui ocult per la vegetació. ..........................................167

5.4.- Restes del molí de La Pobleta. .............................................................................................168

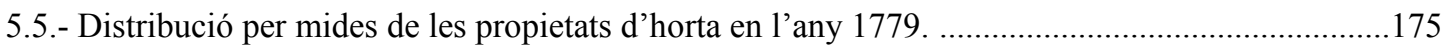

5.6.- Distribució de propietats d'horta en 1779, segons la seua cabuda. ..........................................177

5.7.- Distribució de propietats de secà en 1779, segons la seua cabuda. ............................................178

5.8.- Distribució de la superfície de secà (en jornals) entre els contribuents (any 1779). ...................178

5.9.- Fotografia actual de la bodega del segle XVII de la masia de La Torre. .....................................191

5.10.- Lledoners de Serra (A: horta de Ria; B: horta de l'Ombria) amb les típiques perxes. ...............202

6.1.- Evolució d'arrendaments de delme de Serra i Nàquera abans i desprès de 1609 ......................219 
6.2.- Diagrama de l'evolució dels arrendaments de delmes en baronies properes a la de Serra. .221

6.3.- Delmes de Serra i Nàquera (1611-1837) del Contrallibre (Arquebisbat de València). .................223

6.4.- Comparació de preus (dalt, en blau) i dels arrendament de Serra i Nàquera (en roig). ................225

6.5.- Comparació d'arrendament dels delmes de Serra-Nàquera, Segart-Albalat i Torres Torres. .......227

6.6.- Esquema de les càrregues suportades pels vassalls de la baronia de Serra. ................................233

7.1.- Retrat de la comtessa de Fernán-Núñez (futura duquessa de Montellano). ................................281

9.1.- Esquela mortuòria de la baronessa de Serra, Ria i Armell (i altres títols). ....................................342

\section{QUADRES:}

1.1.- Relació d'actes de delimitació de termes que afecten a Serra i/o Portaceli. ................................22

2.1.-Llistat dels repobladors de Serra i Ria segons diferents versions de la carta-pobla. .......................57

2.2.- alguns càrrecs públics de la baronia de Serra i Ria en el darrer terç del segle XVII. ....................71

3.1.- Freqüència dels principals cognoms de batejats de Serra entre els anys 1619 i 1709 ...................76

3.2.- Expansió del llinatge dels Domingo en la Serra del segle XVII. ...................................................79

3.3.- Llinatge i expansió del cognom Rubio en Serra durant el segle XVII. ........................................82

3.4.- Comparació entre veïns d'Alcubles (1598) i de Serra (1609). ......................................................85

3.5.- Resum de llocs de procedència dels primers 30 repobladors de Serra i Ria. ...............................88

3.6.- Relació de repobladors de Serra i Ria (novembre de 1609) i de Nàquera (desembre de 1609). ....90

3.7.- "Caps de Casa" del cens de 1646 corresponent al lloc de "Serrayria" (sic.). ................................91

3.8.- Aveïnaments ones en la ciutat de València entre 1604 i 1611, segons l'origen. .........................107

3.9.- Padrins biscaïns registrats en el llibre de Batejats de Serra (segle XVIII). .................................111

3.10.- Distribució per dècades dels biscaïns citats com a padrins (segle XVII). ..................................113

3.11.- Altres padrins forans del llibre de batejats de Serra. .................................................................116

4.1.- Variació del nombre de cases en llocs moriscos de la Serra Calderona (segles XVI i XVII. ........118

4.2.- Tipologia de pobladors i adscripció de poblacions de l'entorn de la Serra Calderona. .................119

4.3.- Relació de veïns del cens de 1646, completats amb llurs conjuges i fills. ........................131 i 132

4.4.- Altres matrimonis i fills registrats en l'Arxiu Parroquial de Serra, però no censats en 1646.......135

4.5.- Relació de fillols del francès "Domingo de Surdaña". ...............................................................136

4.6.- Diversitat de preus que es pagaven pel “cens de casa de Ria” (1779). ......................................140

4-7.- Dades censals de la població de Serra entre 1609 i 1857 ..........................................................143

4.8.- Distribució per edat, sexe i raó, de la població de Serra en 1768. ...............................................147

4.9.- Cens de veïns de diversos pobles i nombre d'urbans que havien d'aportar en 1808. .................148

5.1.- Ingressos que tingué Serra destinats a la fàbrica de l'església en 1799 . .......................................163

5-2.- Distribució de parcel·les d'horta i secà segons la cabuda i distribució la superfície total. ...........176

5-3.- Produccions agrícoles segons Cavanilles, en les baronies de Nàquera, Serra i Torres Torres. ....181

5.4.- Drets dominicals de les produccions agrícoles de Serra l'any 1834 (últim que es tributaria). .....183

5.5. Càntirs de vi produïts per diferents pobles de l'entorn de Serra. ..................................................186

5.6. Producció de vi de diverses baronies a finals del segle XVIII. .....................................................188 
5.7.- Delme obtingut del carnatge de Morvedre de l'any 1679/1680

5.8.- Inventari de corrals de ramat del terme municipal de Serra. .....................................................199

6-1.- Repartiment del delme de Serra i Nàquera per a l'any 1797-98. ..............................................213

6.2.- Referències al documents explicatius del repartiment de delmes al voltant de 1795 .................214

6.3.- Arrendadors dels delmes de Serra i Nàquera abans i desprès de l'expulsió morisca. .................217

6.4.- Arrendaments dels drets dominicals de Serra entre finals del XVII i principis del XVIII. ..........237

7.1.- Senyors de la senyoria de Serra entre els segles XIII i XIV. ...................................................247

7.2.- Senyors de la baronia de Serra al llarg del segle XV. $\quad \ldots . .256$

7.3.- Els Folch de Cardona, senyors de la baronia de Serra en el segle XVI. ...................................258

7.4.- Diferents branques dels Cardona que pledejaren per la possessió de Serra. ..............................260

8.1.- Compra-venda d'èquids en les primeres dècades del segle XVII. ..............................................293

8.2.- Èquids per a la venda en Burjassot, al voltant de 1622 i tal com venen descrits en llatí. ............295

8.3.- Comptes que fa Josep Rubio (Obrador de l'església de Serra) al seu successor, en 1698. ..........309

8.4.- Preus d'èquids comprats per serrans cap a finals del segle XVIII. ..............................................323

8.5.- Oficis dels 277 caps de cèdula del cens de 1857 .................................................................325

8.6.- Oficis de les persones que no són caps de cèdula ni població infantil, en el cens de 1857 ..........326

8.7.- Distribució per grups d'edats dels adults que saben llegir, segons el cens de 1857 ....................330

8.8.- Distribució per edat d'infants escolaritzats (A) i no escolaritzats que lligen i escriuen (B). .........332 


\section{ANNEX I \\ RELACIÓ DELS MOLLONS HISTÒRICS QUE DELIMITEN EL TERME MUNICIPAL DE SERRA}

Es fa ací relació dels 63 mollons històrics que són la base per a la delimitació del terme municipal de Serra i coincideix amb el mapa cadastral de 1938, a escala 1:25.000 (FIGURA 1.3). Per una part es troben recollits el mollons del priorat de Portaceli segons les renovacions de 1649 (amb Sogorb) i de 1722 (amb la resta de baronies, excepte la de Serra). No es recullen els 8 mollons que tenia Portaceli amb Serra per haver sigut suprimida aquesta confrontació amb l'agregació feta en 1835. Per part de l'antiga baronia de Serra es recullen tots els mollons de la delimitació manada fer pel duc de Montellano en 1788, com també els afegits posteriorment en les revisions amb Torres Torres i amb Nàquera. Es diferencien com a MT el mollons trifinis (entre tres termes municipals) de la resta, els $\mathrm{M}$ que serveixen de divisòria únicament entre dos termes.

MT1: molló trifini entre els termes municipals de Gàtova, Sogorb i Serra. És el molló 7 de l'amollonament de l'any 1737, situat enmig del talveg d'un barranc que hi ha entre Montemajor i la "Rodana Sobirana" (topònim desaparegut).

M2: junt al Collao Roig (antigament dit d'Arrianos); és el molló n 6 de l'amollonament de 1737.

M3: molló $\mathrm{n}^{\mathrm{o}} 5$ de l'amollonament de 1737: "en un morron de la serra Falaguera"; anomenat "Puntal del Sapo" en el projecte d'ordenació de la forest de Portaceli de l'any 1905. A 20 passes hi ha una creu d'un pam gravada a terra, en "roca rodena".

M4: molló nº 4 de l'amollonament de 1737: “en el puntal de la Serra Falaguera”, hui també conegut com “el Sapo" i "les Penyes Imargues".

M5: molló no 3 de l'amollonament de 1737: en la “ceja de la solana del Llentiscle".

M6: molló no 2 (entre Sogorb i Portaceli) de l'amollonament de 1737, sobre unes penyes (i junt a una que tenia forma de llosa) "a un tir d'escopeta de la font del Llentiscle".

M7: (antic MT): molló $\mathrm{n}^{\mathrm{o}} 1$ de l'amollonament de 1737, i que en aquell temps es prengué com a trifini entre Sogorb, Portaceli i Serra. 
M8: molló no 2 (ara entre Sogorb i Serra) del següent tram de l'amollonament de 1737, en la part que confrontava Sogorb i Serra.

MT9: molló trifini entre els termes municipals de Sogorb, Torres Torres i Serra. Correspon a l'Alt de la Nevera, i n'és el no 1 (trifini) de l'amollonament de 1737. També equival al molló $\mathrm{n}^{\circ} 7$ de l'amollonament de 1847, i al nº 5 del de l'any 1788.

M10: en un Rodeno" un poc més alt que el M11. Correspon al $n^{\circ} 6$ de l'amollonament de 1847.

M11: en el Rodeno de Tasaro (topònim desaparegut) o Rodeno de Banyet. Correspn al molló $\mathrm{n}^{\mathrm{o}} 5$ de l'amollonament de 1847. O bé aquest molló o bé l'anterior (M10) correspondria al $\mathrm{n}^{\mathrm{o}} 4$ de l'amollonament de 1788, anomenant-se Puntal de la Moleta o Cinglo Benarta (sic.).

En un barranquet que queda entre el M11 i el M12: "fondo de la partida de Banyet" estava el molló $\mathrm{n}^{\circ} 3$ de 1788.

M12: Lloma de Banyet, equivalent al molló nº 4 de 1847.

M13: cim del "Puntal de Pablo", a unes 15 passes del camí. És el n 3 de 1847 i el no 2 de 1788. El Puntal de Pablo (així era conegut pels de Torres Torres) era també conegut com la Lloma del Camí Nou pels de Serra.

M14: molló $n^{\circ} 2$ de 1847, en la part mitjana de la lloma “coneguda com Camí Nou pels de Serra".

MT15: molló trifini entre els termes municipals de Torres Torres, Estivella i Serra. A unes 200 passes del barranc d'Alcalà; correspon al molló $n^{\circ} 1$ de 1788 , que és també el $n^{\circ}$ 1 de 1847.

M16:

M17:

M18:

M19:

MT20: molló trifini entre els termes municipals d'Estivella, Segart i Serra.

M21:

M22:

MT23: molló trifini entre els termes municipals de Segart, Nàquera i Serra. Situat a uns 350 m d'altitud, dins del barranc de Meliquet. 
M24: (nº 20 de 1938): uns 500 m d'altitud, en el Moncudio.

M25: (nº 19 de 1938): uns 500 m d'altitud, en el Moncúdio.

M26: (nº 18 de 1938): uns 350 m d'altitud; a un costat del barranc del Manyo.

M27: (n 17 de 1938): uns 344 m d'altitud, a l'altre costat del barranc del Manyo.

M28: (nº 16 de 1938): uns 292 m, en el crestó de la torreta de Nàquera.

M29: ( ${ }^{\circ} 15$ de 1938): a un marge de la carretera.

M30: (nº 14 de 1938): a l'altre marge de la carretera.

M31: ( ${ }^{\circ} 13$ de 1938): dalt de Monteamor, a uns 350 m d'altitud.

M32: (nº 12 de 1938): en vessant, a uns 330 m d'altitud.

M33: (nº 11 de 1938): en un "puntalet".

M34: ( $\mathrm{n}^{\mathrm{o}} 10$ de 1938): prop de la confluència de les actuals carreteres a Portaceli des de Serra i des de Nàquera.

M35: (nº 9 de 1938 i no 5 de 1788): En el "puntal inferior del Rodeno" i prop d'on s'ajunten els camins de Nàquera a Portaceli i de Serra als Algepsars.

M36: (nº 8 de 1938 i n 4 de 1788): partida l'Empeltà; junt a la carretera actual, camí de Portaceli.

M37: ( $n^{\circ} 7$ de 1938 i no 3 de 1788): Puntal de la Basseta.

M38: (nº 6 de 1938 i n 2 de 1788).

M39: (antic MT) molló trifini ( $\mathrm{n}^{\mathrm{o}} 4$ de 1455) que partia els termes de Portaceli, Nàquera i Serra. Partida de la basseta de la Contenda. (nº 5 de 1938):

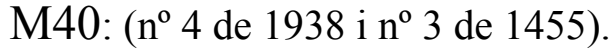

M41: (nº 3 de 1938 i n 2 de 1455). Molló Foradat.

M42: (nº 2 de 1938).

MT43: molló trifini entre els termes municipals de Nàquera, Bétera i Serra. En la delimitació feta en 1771 entre Nàquera i Bétera (Lluch, 2002, p. 33 i 34) el lloc es conegut com "cap de la canyada d'Èpila" pels de Nàquera i "dalt de l'heretat de Broseta" pels de Bétera.

M44: en el "tancat de Portaceli”, enmig del pla; a l'est del barranc de Portaceli.

M45: en lloc pla, a l'oest del barranc de Portaceli. 
M46: en la "muntanya Foradada", a uns 240 m d'altitud.

M47: al peu del vèrtex geodèsic "Guarda", a uns 262 m d'altitud.

M48: en línia recta entre M47 i MT49; junt a la carretera CV-333, pK 6.6.

MT49: molló trifini entre els termes municipals de Bétera, la Pobla de Vallbona i Serra

MT50: molló trifini entre els termes municipals de la Pobla de Vallbona, Olocau i Serra.

M51: molló de la Pedra o "llosa blanca" (any 1325); a la vora esquerra del barranc de Pedralvilla.

M52: molló de la carretera o "canyada de Llíria" (any 1844), prop del barranc de Pedralvilla.

M53: molló dels Esparters o "llomica de la Seu” (any 1844); a uns 215 m d'altitud.

M54: molló de la Seu, en la Vinya de la Seu "a unes 40 passes de la senda de La Torre a Olocau (any 1844); a uns 235 m d'altitud.

M55: molló del Jueu (248 m d'altitud) o tossal Pelat, sobre la cova del Colom.

M56: molló del tossal del Pinar, a 291 m d'altitud.

M57: molló de la clotxa del Mangraner o tossal del Portitxol; a 395 m d'altitud.

M58: molló de la penya del Rellotge (prop del mirador de l'Abella); uns $523 \mathrm{~m}$.

MT5:9: molló del "rodeno de l'Horteta"; trifini entre els termes municipals d'Olocau, Gàtova i Serra; a uns 482 m d'altitud.

M60: segons l'amollonament de 1844 seria aquest el molló trifini amb Gàtova; prop de la font del Llop, junt a la marge esquerra del barranc.

M61: junt al camí (al sud d'ell) que anava de La Rosa i El Berro a Brihuela (a Olocau diuen Bolillola); segons altres actes en el mateix Cabeço Roig (535 m d'altitud) o prop del coll que forma aquest amb Penyes Altes.

M62: molló baix de les Penyes Altes, a uns $650 \mathrm{~m}$ d'altitud; baix la penya i cova dels Carboners.

M63: molló suposadament ubicat a la "punta sobirana" $(827 \mathrm{~m})$ de Penyes Altes. Passant per ell però seguint la mateixa línia que portàvem s'arribaria al fons del barranquet on està el MT 1, arribant així al terme de Sogorb 


\section{ANNEX II}

\section{TAULA DELS BATEJATS A SERRA ENTRE 1619 i 1709 \\ (Quinque libri de Serra- APS, volum I)}

\section{PARES \\ Antonio Épila (labrador)/ Isabel \\ Manyeç \\ (Antón Èpila)}

Jaime Pérez/

Catalina García

Bartolomé Pérez

Juana Ana García

Pedro Navarro

(labrador)/ Vicenta

Doña
FILLS

1619: Antonio Diego

1622: Francisco Domingo

1625: Policarpa Catalina

1627: Úrsola Catalina

1629: Catalina Águeda

1632: no posa nom, es

moria...

1635: Francisco Pasqual

1635: Madalena Merina (beso)

1638: Vicente Domingo

1640: Jusepe Diego

1620: Jaime Antonio

1623: Domingo Agustín 1626: Catalina Agueda

1623: Bartolomé Tomás

1625: Besucristo $(+)$

1620: Juana Vicenta

1621: Estevan Juan

1624: Rafela Vicenta

1625: Lucía Rafela

1627: Catalina Lucía

1629: Vicenta Francisca

1631: Agustina Rafaela

1633: Jusepe Joan Ambrosio

1621: Vicenta Clara

Clara Cavaller

(Pedro Juan Ribes i 1623: Angela Clara

Clara Cavaller)

\section{PADRí}

Juan épila(tío)/

Sebastián Pérez/

Vicente Arnal/

Estevan Moreno/

Pedro de Lera (vizcaino)/

Francisco lasierra, criado de Francisca Cavaller los padres de Porta Coeli

Domingo Diago, mancebo Madalena Estevan,

Jusepe Domenec

Diego Hernandez, pastor

Antonio Salvador/

Agustín Cavaller/

Pedro Juan Ribas/

Domingo Diago/

Juan Doña (su tío)/

Juan Doña (su tío)/

Martín Herrando (vizcaino)

Martín de Hernando

(vizcaino)/

Juan Doña (su tío)/ Catalina Borrasa

(Valencia)

Miguel de ¿merloiy??? / Francisca ¿Monsanada?

Bautista Domenec/

Joan Doña, vecino de

Valencia/

Antonio Salvador/

Juan Doña, mancebo/ muger de Domingo Navarro

MADRINA

Catalina Abril (abuela)

Vicenta Cavaller

(València)

Ursula Girbes, ¿retora?

(Benaguassil)

Catalina Abril

Angela Ribas

Marianna Ribas, doncella

Clara Cavaller

Vicenta Cavaller

Vicenta Cavaller

Vicenta Cavaller

Rafaela Doña (su tía)

Rafaela Doña (su tía)

Rafaela Doña

Rafaela Moreno

(València)

Agustina Puig

Raffaela Doña, vecina de

Serra

Catalina García

Vicenta Cavaller
Rafaela Doña 
1625: Catalina Merenciana

1627: Pere Juan Vicent

Sàez

1621: Catalina Ansina?

Antoni Esteve-an/

Juana Romera

Juan Rubio/ Maria 1621: Felicia Bárbera

Siprer

1624: Vicenta Emerenciana

1627: Juana Anna

1627: Jusepha Marianna

Francisco Rubio/

Vicenta Cavaller

1628: Joan Bautista
1630: Margalida Francisca
1632: Felicia Francisca

1634: Esperança Francisca

1635: Francisco Joan Pedro

1637: Cathalina Leocadia

1639 Buenaventura

1641: Pedro Joset Patricio

Joan Rubio/ Visenta 1645: Jusepa Agustina

Cavaller (iii $i$ ? !!!) Angela

$\begin{array}{ll}\begin{array}{ll}\text { Bautista Catalan/ } \\ \text { Bárbera Matheu }\end{array} & \text { 1622: Juan Vicente } \\ \begin{array}{ll}\text { Bautista Catalan } \\ \text { menor/ Juana Anna }\end{array} & \text { 1627: Juan Jusepe } \\ \text { Estevan } & \\ & \begin{array}{l}\text { 1628: Francisco Bruno } \\ \text { 1632: Magdalena Josepa }\end{array} \\ & \begin{array}{l}\text { 1636: Policarpia Jucepa } \\ \text { 1638: Jusepe Joachim }\end{array} \\ & \text { 1622: Francisco? Cristóval } \\ \begin{array}{l}\text { Domingo Diago/ } \\ \text { Isabel Morell }\end{array} & \text { 1626: Catalina María }\end{array}$

Domingo Ramos/ 1622: Domingo

Francisca Moles
Vicent Cavaller/

Domingo López/

Catalina Gorrisa

(Valencia)

Paula Serra de Doña (C)
Vicente Cavaller/

Vicente Airnodiz

(Montcada)

Domingo Sanz (vizcaino)/

Domingo Diago/

Pedro Juan Ribas/

Francisco Rubio/

Miquel Domingo/

Vicente Cavaller, llaurador

del lugar de Carpesa/

Pedro Ricart, vecino de

Albalate de Segart/

Joan Mañez

Martín Domingo

Francisco Cavaller, vecino de Valencia

Sebastian Garcia, de

Valencia, garbillador de oficio

Juan Ibañez

Juan Doña menor/

Francisco Rubio/

Francisco Sanz/

Josepe Domenech,mancebo/

Simon Falcon, ciudadano!

Bautista Catalan major

Cristóval de GraciaDei

(vizcaino)/

Cristóval de Graciategi (vizcaino)/

Francisco Rubio/
Rafaela Doña

Felicia Colissa

Vicenta Cavaller

Catalina Borras

(Valencia)

Marianna Vallsuar

(Albalat de Segart)

Joana Romero (Nàquera)

Bárbera Estevan

Francisca Cavaller, de

Carpesa

Francisca Cavaller, donzella del lugar de

Carpesa

Francisca Cavaller, donzella de Serra

Jusepa Domcarsur?, donzella

Patricia Duch (ver

Cavaller1639), de

Valencia

Patricia Duch, doncella, de Valencia

Angela Ribas

y su hna. Rafaela Doña

Úrsula Girbes

Catalina Garcia

Madalena Estevan, donzella

Jusepa Domenech

Jusepa Domenech

Rafaela Doña

Catalina P. Borrasa

(Valencia)

Isábel Gimeno 
Jusephe Doménech/ 1623: Pedro Vicente

Agustina Puig

Domingo Moreno menor/ Rafaela

Doña

"padres ocultos y secretos"

Joan Mallach/

Isábel Domingo

\begin{tabular}{|c|c|}
\hline $\begin{array}{l}\text { Juan Mallach/ } \\
\text { Ángela Guillem }\end{array}$ & 1631: Angela Clara \\
\hline Bartolomé & 1628: Joan Agustín \\
\hline Domingo/ Maria & \\
\hline $\begin{array}{l}\text { Catalan } \\
\text { (ací posa la mare } \\
\text { Maria Català) }\end{array}$ & 1633: Jusepha Luysa \\
\hline \multirow{4}{*}{$\begin{array}{l}\text { Juan (Joan) } \\
\text { Ibànyes/ Catalina } \\
\text { Garcia }\end{array}$} & 1630: Vicenta Clara \\
\hline & \\
\hline & 1637: Joan Romualdo \\
\hline & 1641: Victoria Ninfa \\
\hline Joan Ibañez/ Paula & 1643: Agostina Siurana \\
\hline Domenech & $\begin{array}{l}\text { Jusepa } \\
\text { Lauro }\end{array}$ \\
\hline \multirow{2}{*}{$\begin{array}{l}\text { Juan Ibañez/ } \\
\text { Francisca Matheu }\end{array}$} & 1648: Pere Joan Esteve \\
\hline & $\begin{array}{l}\text { 1650: Felisia Pasquala } \\
\text { 1652: Maria Francisca } \\
\text { Valera } \\
\text { 1654: Catalina Sesilia }\end{array}$ \\
\hline
\end{tabular}

1624: Domingo Hieroni

1629: Juana Rafela

1631: Domingo Aniceto

1633: Violant Melgora

Rafela

1640: Theodosia Paula

1645: Pedro Pau

1624: Martín Juan

1628: Vicenta Feliciana
Hier. Sastre (el cura)/

Ledas? Navarro/

Hirónima Doménec

(Vda.)

Rafaela Doña (abuela)

1627: Juan Bta. Domingo

1634: Francisca Theodora

1636: Domingo Salvador

1638: Jusepe Joan Bautista

1643: Barbara Victoriana

1632: Pere Joan (n. En Val.) Jusepe Domenech,

mancebo/

Juan Bta. Doña/

Juan de Layola (és

viscaino!)/

Jusepe Doménec, mancebo/

Joanes de Loiola, de nación

vizcaino/

Francisco Moreno, natural de Nàquera

Joañes de Loiola, vizcaino

Sebastian Garcia, de

València

Joanes de Balatsiar vizcaino Vicenta Sastre, muger de

Vicente Arnal Juan Doña

Jaime Peres, labrador, natural de Sierra

Barbara Mateu

Ursola Moreno, de Serra

Agustina Puig, muger de J. Bta. Doña

Juan Espelet (franchu)/

Joan Ferrer (Barcelona)/

Clara Cavaller

Juan de Guale (vizcaino)/

Migel Miglotc, vizcaino/

Jusepha Ursola

Domenegh, de Serra

Pedro de Casanova

(vizcaino)/

Bautista Doña, Bayle de

Sierra

Joan Font, vecino de Torres

Torres

Jerónima Mesquita (vec.

De Nàquera)

Pedro Juan Maro?, sirujano natural de Liria

Joan Font, labrador natural de Torís

Gaspar Borgadà, de Bètera

Macià Cabo

Mossen Jaume Marí, rector

d'Estivella

Pedro Asnar, de Alfara
Clara Cavaller

Francisca Cavaller, doncella

Geronima Garcia, de Valencia

Jusepa Domenech, donzella nat. Serra

Agostina ¿Puig? i Domenech, la major

Catalina Peres, de

¿Yàtova???

Fe'lia Burgos

Felisia Burgos

Sisilia Cabo, de Serra 
Miguel Domingo/ 1631: Miguel Vicente Clara Cavaller

1633: Francisco Mathias

1635: Agueda Dominga

1637: Agustin Vicente 1639: Andres Mauro

1642: Pedro Joan Alejo

Joan Saez/ Mariana Tortaxada

Vicente Arnal/ Violant (Violante) Ruvio

Vicente Arnal/ Jusepa Domenec

Mathias Cabo/

Bàrbara Estevan

1636: Angela Jusepa

1638: Miguel Joan 1640: Olalia Cathalina

1632: Teudora Catalina

1636: Romualdo Vicente

1639: Joan Crisostomo

1641: Felix

1653: Margalida Lloïsa

1633: Maria Francisca
Martín Domingo, mancebo/

Francisca Mesquirda? muger de Miguel

Pascual.

Francisco Cavaller/

Francisca Cavaller, naturales de Sierra!.(en altre posava de Carpesa; Rubio,1632)

Vicente Cavaller, y...

Mariana Vallabar, su muger.

Vicente Cavaller, y... Francisco Cavaller, y Anna Duch, vecinos de Valencia

Bautista Domenech

Marianna Vallovares?

Anna Duch, de Valencia

Jusepa Domenech

Bautista Domenech/

Augustina Puig, muger del bayle

Joan Salvà, moço, de nación catalan y criado de los frayles de Portaceli

Baltasar Salvà, criado del convento de Portaceli

Miguel Navarret

Lorenço de Nasallur, vizcaino

Jusepa Domenech

Bautista Domenech/

1634: Francisco Hysidoro

Bautista Domenech, mancebo/

Bautista Domenech

Miquel Roca

Mateo Estevan

Jusepa Domenech

Jusepa Domenech

Catalina Garcia, muger de Joan Ibañez

Catalina Garcia, muger de Juan Ibañez

Catalina Garcia, muger de Joan Ibañez

Chatalina Garcia, muger de Joan Ibañez

Ursola Roca

Madalena Estevan

Bautista Sipres?, de Valencia Angela Morenca i Sipres, de Valencia Mariana Ribes, nat de Serra

Clara Cavaller, de Serra

i Lloïsa $<$ santamaria, habitadores de Valencia

¿g...ynèn?....(ver

Domingo1653)

1655: Andrés Bartista T. Tomàs Guacs (Guasch?)

Esperanza Domenec

1635: Cecilia Catalina

Gertrudis

1638: Joana

1640: Casimiro Jusepe

1642: Joan Bta. Josep

Bernardo

1644: Jusepe Gil

1647: Angela Jesussa

Simón Cabo, mozo vecino de Valencia, tinturero/

Domingo Moreno

Vicente Cabo

Bautista Domenech Joan Bautista Cathalan mayor

Jusepe Suastre, natural de Aldaja Jusepe Herrero, mosso Angela Domingo i Ribas, labrador, nat de las Alcublas nat de Serra Juan Ibañez
Francisca Cavaller, vecina de Serra. Francisca Cavaller, vecina de Serra. Francisca Cavaller Jusepa Domenech Jusepa Domenech

Madalena Estevan, hija de Sierra Felisia Burgos, ambos
Fat de Serra 
Barbera Esteve

1652: Juan Pau

Matías Cavo/

Barbara Esteve

Domingo Navarro/ 1634: Ana Maria Catalina

Madalena Estevan

1635: un hijo que murió £63e/g1Pddro Joan 1640: Vicenta Jusepa 1642: Domingo Jusepe 1644: Joan Domingo

1647: Filisia Siledonia Jusepa

1649: Antonio Pablo

Melchiades

Domingo Navarro/ 1652: Juan Miguel Pedro Madalena Esteve

\author{
Martín Torajada/ 1634: Laurena Salvadora \\ Innes Donet? \\ Joan Arnal/ \\ 1637: Francisco Joan Jusep \\ Dorhothea Valles \\ Francisco Cavaller/ 1639: Innes Geronima \\ Anna Duch?-Dasí \\ (vecinos de Val.) \\ Estevan Moreno/ \\ Dorothea Cesarii \\ 1639: Esteban Leandro \\ 1641: Felix Symon \\ Antonio \\ 1638: Gregorio \\ Correcha(Correga)/ \\ Isabel Epila \\ Joanes de Loyola/ 1639: Vicenta Isabel Teresa \\ Isabel Epila
}

Matheo Estevan/ 1641: Domingo Matheo

Dionysia Sanches (- Cristoval

is?)

Matheu Esteve/

1643: Vicent Andreu

Donisa Sanches

Matheo Estevan/

Dionisia Sanchis

Mateu Estevan/

Dionisia Sanchis

1647: Matheu Felip

1650: Juana Agueda

Mateu Estevan/

1655: Tomàs Juan Mateu

Ysabel Ortís

1645: Felicia Catalina
Juan Ibañez

Francisco Rubio

Matheo Estevan/

Vicente Arnal

Matias Cabo

Vicente Arnal

Jusepe Yuastre, mosso

natural d'Aldàja

Esteve Navarro

Jusepe Domenec

Domingo Verge, de Serra

Joan Bta. Doña, Bayle de Sierra

Juan Tortajada

Francisco Nadal, platero

Gerónima Garcia, vda. De Luis Duhc?

Simon Aleman, de Valencia Ursola Roca y de Dolz

Simon Aleman

Luisa Rollo?(Bollo?)

Vicente Arnal

Jusepa Domenech

Maria Roca, i-? De

Bètera

Agueda Domingo de Serra.

Jusepa Domenech

Jusepa Domenech

Jusepa Domenech

Paula Domenech i de

Ibañez., de Serra

y Jusepa Domenec

Jusepa Domenech

Vicenta Epila
Catalina Garcia, vecinos

Jusepa Roys, de Valencia

Felisia Burgos, de Serra natural d'Aldaia

Joan Estevan Navarro, mosso labrador i natural de Serra

Jusepe Domenech

Vales???? Catalan

Matias Cabo 


\begin{tabular}{|c|c|c|c|}
\hline & 1658: Mateu Juan Telesfori & Francisco Rubio & Madalena Estevan \\
\hline & 1660: Mateu Juan Domingo & Juan Navarro & Madalena Cata? \\
\hline $\begin{array}{l}\text { Mateu Esteve/ } \\
\text { Hisabel Hortís }\end{array}$ & 1663: Jasinta Isabel Maria & Francisco Rubio & Maria Lorente \\
\hline $\begin{array}{l}\text { Mateu Estevan/ } \\
\text { Isabel Ortíz }\end{array}$ & 1670: Vicenta Juana G. & Pedro Juan Navarro & Vicenta Arnal \\
\hline \multirow{5}{*}{$\begin{array}{l}\text { Bautista Domenech/ } \\
\text { Marianna Ribas }\end{array}$} & 1642: Jusepe Hylario & Miguel Domingo & Paula Domenech \\
\hline & 1643: Agustina Celedonia & Miguel Domingo & Agustina Puyg \\
\hline & 1644: Jusep Visent Juan & $\begin{array}{l}\text { Pedro Mactheng?, mosso de } \\
\text { cación francés }\end{array}$ & $\begin{array}{l}\text { Agustina Puig, de } \\
\text { Valencia }\end{array}$ \\
\hline & 1646: Juan Bautista Thomàs & Jusepe Domenech, natural de & Felisia Burgos, nat de \\
\hline & & Carpesa & $\begin{array}{l}\text { Val., y muger del } \\
\text { anterior }\end{array}$ \\
\hline $\begin{array}{l}\text { Pedro Salinas/ } \\
\text { Joana Arnau }\end{array}$ & 1642: Paula Joana & Matias Cabo & $\begin{array}{l}\text {...la (Rafaela?) } \\
\text { Domenech }\end{array}$ \\
\hline \multirow[t]{8}{*}{$\begin{array}{l}\text { Martín Domingo/ } \\
\text { Angela Ribas(-es) }\end{array}$} & 1642: Jusepa Glaudiana & Agustin Salvador & $\begin{array}{l}\text { Anna Puch, vecina de } \\
\text { Valencia }\end{array}$ \\
\hline & 1644: Ana Maria Llorença & Miguel Domingo, Bayle & $\begin{array}{l}\text { Mariana Ribas, natural } \\
\text { de Carpesa y hbte. en } \\
\text { Serra }\end{array}$ \\
\hline & 1646: Jusep Tomàs & $\begin{array}{l}\text { Pedro Macthesig, de nación } \\
\text { francés }\end{array}$ & $\begin{array}{l}\text { Catalina Peres i Català, } \\
\text { nat de Serra }\end{array}$ \\
\hline & 1648: Nadala Tomasa & Estevan Navarro & Teresa Rodríguez \\
\hline & 1650: Jusepe Joan Martín & $\begin{array}{l}\text { Jusep Gallac, natural de } \\
\text { Valencia }\end{array}$ & $\begin{array}{l}\text { Josepa Navarro, naturales } \\
\text { de Valencia }\end{array}$ \\
\hline & 1652: Joan Jusep Llois & Juan Davit, nat de Valencia & $\begin{array}{l}\text { Lloïsa Santamaria, } \\
\text { naturales de Valencia }\end{array}$ \\
\hline & 1654: Martín Mauro Andres & Matias Cabo & Agueda Domingo \\
\hline & 1656: Engrasia Maria Sesilia & $\begin{array}{l}\text { Estevan Soler, de nación } \\
\text { francés }\end{array}$ & $\begin{array}{l}\text { Agueda Domingo, } \\
\text { doncella de Serra }\end{array}$ \\
\hline $\begin{array}{l}\text { Jaime Peris/ Ursola } \\
\text { Moreno }\end{array}$ & $\begin{array}{l}\text { 1645: Pasquala Simona } \\
\text { Catalina }\end{array}$ & $\begin{array}{l}\text { Simon Aleman, hornero } \\
\text { mallorquín }\end{array}$ & $\begin{array}{l}\text { Catalina Peris (ó Peres), } \\
\text { de Sierra }\end{array}$ \\
\hline $\begin{array}{l}\text { Jaime Peres/ Ursola } \\
\text { Moreno }\end{array}$ & 1646: Rafela Andrina & $\begin{array}{l}\text { Simó Aleman, hornero de } \\
\text { nación mallorquín y vive en } \\
\text { Val. }\end{array}$ & $\begin{array}{l}\text { Rafela Doña i Morina??, } \\
\text { de Serra }\end{array}$ \\
\hline \multirow{7}{*}{$\begin{array}{l}\text { Jaume Peres/ Ursola } \\
\text { Moreno }\end{array}$} & 1649: Perpetua Tomasa Fca. & Esteve Moreno & Rafela Doña \\
\hline & 1650: Rafaela Maurisia & Esteve Moreno & Rafela Doña \\
\hline & 1653: Leandra Teresa & Estevan Moreno & $\begin{array}{l}\text { Rafaela Doña, todos de } \\
\text { Serra }\end{array}$ \\
\hline & 1655: Jaime Domingo P. T. & Domingo Moreno & $\begin{array}{l}\text { Rafaela Doña, vecinos de } \\
\text { Sierra }\end{array}$ \\
\hline & 1658: Eugenia Arcangela & Domingo Moreno & Rafaela Doña \\
\hline & 1660: Ursola Catalina & $\begin{array}{l}\text { Diego Cebrian de Aragon, de } \\
\text { Culla }\end{array}$ & Rafaela Doña \\
\hline & 1663: Teresa Maria & Francisco Verge & Teresa Rodrigues \\
\hline $\begin{array}{l}\text { el "guardam" Jaime } \\
\text { Perez/Ursola }\end{array}$ & 1665: Matias Domingo & Matias Cabo menor & $\begin{array}{l}\text { Catharasia (és Catalina) } \\
\text { Perez coniuges }\end{array}$ \\
\hline
\end{tabular}

Miguel Rovella?, labrador habitador de Nàquera
Jusepa Suastre, natural de Aldaja
Jusepe Suastre

1646: Policarpa Jusepa

Maria Diago 
Antonio Arnal/

Ursola Epila

Jusepe Català/
Catalina Peres
Jusepe Catalan/
Catalina Peres

Agustin Salvador/ Mariana Rubio

Vicente Rubio/

Vicenta Navarro

Nadal Camps/

Ysabel Juana Raga

(Nadal Camps:

nintor/ coinges nats

Josep Rubio/

Vicenta Navarro

Josep Rubio/

Vicenta Doña

Francesc Verge/

Teresa Rodrigues

Esteve Navarro/

Marianna Ribes

Estevan Navarro/

Mariana Ribes
1646: Josep Juan Anastacio

Prudencia

1646: Jusepa Agueda

1648: Juan Batiste Valentin

1650: Jaume Andreu

1646: Joan Jusep Berthomeu Melchor Tortaxada, mosso nat de Nàquera

1649: Jaume Francés Agustí Francesc Rubio

1651: Jusepa Vicenta Agna Visente Estevan?, de Serra $\mathrm{M}^{\mathrm{a}}$

1654: Agustín Antonio

1657: Francisca Dorotea

Baptista Catalan

Francisco Rubio

1646: Vicente Nadal Estevan Estevan Navarro, mosso de Serra

1652: Tomàs Pere Juan

Juan Ibañez

1655: Pedro Juan Matías

Juan Ibañez

1656: Pedro Juan Pasqual

1657: Jusepe Basilio

Juan Ibañez

Jusepe Navarro

1647: Joana Baptista Lloysa

Domingo Diago maior, del lloc de Serra

Juan Ibañez

Baptista Siprer?

1650: Juan Bautista

Cristoval

1649: Tomás Juan Francesc Juan Ibàñez

1652: Arcangel Felisia Maria Macià Cabo

1654: Alexandro Pere

Domingo Moreno

Domingo

1656: Euguerio Basilio F. Matias Cabo

1658: Manuel Estevan Juan

1649: Pere Juan Esteve

Josep Domenech

1651: Jusep Esteve Llorens

1653: Ambrosio Pedro Juseph

1656: Tomasa Maria Clara
Martín Domingo

Pedro Carvios???....i

Jusep Domingo, de las Alcublas
Juana Martínez, natural de Puebla de Valverde, muger de Durà.

...Juana Martínez, vecinos de Nàquera

Paula Domenec i Ibañez, nat y habtdra de Serra

Angela Ribes, vecinos de Serra

Ysabel Ximeno, habitadores de Serra

Jusepa Valles?, nat i hab de Nàquera Catalina Salvador, vda.de Bertomeu Sebnes???

Josepa Navarro, de Valencia Agueda Domingo, doncella de Serra Agueda Domingo, doncella de Serra

Felicia Burgos i

Domenech, nat de

Valencia

Francisca Mateu, habitadores de Sierra Francisca Mateu, vecinos de Serra

Francisca Mateu

Teresa Rodrígues

Geronima Anolla?, de Valencia

Felisia Burgos, ambdos hbabitadors de Serra Josepa Domenec

Angela Ribes

Felisia Burgos, todos de Serra Angela Ribes

Teresa Terasona Francisca Mateu

Felisia Burgos, hbtdres de Serra Clara Cavaller Jusepa Navarro, habitadores en Valencia Agueda Domingo, de Serra 


\begin{tabular}{|c|c|c|c|}
\hline $\begin{array}{l}\text { Juan Cisuerga (?)/ } \\
\text { Teresa Rodrigues }\end{array}$ & 1651: Catalina ¿? & Esteve Moreno, de Valencia & $\begin{array}{l}\text { Teresa Tarasona, de } \\
\text { Valencia }\end{array}$ \\
\hline $\begin{array}{l}\text { Agustín del Oyo/ } \\
\text { Catalina Peres }\end{array}$ & $\begin{array}{l}\text { 1654: Visenta Policarpia } \\
\text { Paula }\end{array}$ & Juan Ibañez & $\begin{array}{l}\text { Carpia Catalan, donsella } \\
\text { de Serra }\end{array}$ \\
\hline \multirow{3}{*}{$\begin{array}{l}\text { Domingo Verge/ } \\
\text { Felisia Cavo } \\
\text { Domingo Verge/ } \\
\text { Sesilia Cavo }\end{array}$} & $\begin{array}{l}\text { 1654: Domingo Pablo } \\
\text { Matias }\end{array}$ & Matias Cabo & Francisca Cabo \\
\hline & 1656: Visenta Francisca & Matias Cabo & Francisca Cabo \\
\hline & $\begin{array}{l}\text { 1658: Dorotea Teresa B. } \\
\text { 1660: Domingo Matias } \\
\text { Joseph }\end{array}$ & $\begin{array}{l}\text { Vicente Servera, de Líria } \\
\text { Matias Cabo }\end{array}$ & $\begin{array}{l}\text { Teresa Rodrigues } \\
\text { Teresa Rodrigues }\end{array}$ \\
\hline \multirow{5}{*}{$\begin{array}{l}\text { Domingo Verge/ } \\
\text { Sisilia Cavo } \\
\text { Domingo Verje/ } \\
\text { Cicilia Cabo (amb B } \\
\text { per primera vegada) }\end{array}$} & 1662: Jusepe Matias Urbano & Tomas Castellano & Angela Cabo \\
\hline & 1664: Angela Barbara & Jusepe Cathalan & Angela Cabo \\
\hline & 1666: Cicilia Luisa J. & $\begin{array}{l}\text { Jacinto Tallada, cirujano y } \\
\text { habit. En Moncada }\end{array}$ & Felicia Cabo \\
\hline & 1667: Juan Bautista & $\begin{array}{l}\text { Juan Fuster, nat. de la calle } \\
\text { de Murviedro, baut en la } \\
\text { parroq de San Lorenço de } \\
\text { Val. }\end{array}$ & Catharina Perez de Jaime \\
\hline & 1670: Cicilia Maria & Miguel Escrich, y su muger: & Francisca Ibañez \\
\hline \multirow{4}{*}{$\begin{array}{l}\text { Vicente Català/ } \\
\text { Vicenta Royo } \\
\text { Vicente Catalan/ } \\
\text { Vicenta Roya } \\
\text { Vicente Catalan/ } \\
\text { Vicenta Royo }\end{array}$} & 1654: Hisabet Elena & Visen Renau? ... i ... & $\begin{array}{l}\text { Hisabet Guerola, de } \\
\text { Beselga }\end{array}$ \\
\hline & 1656: Tomàs Juan & Juan Arnal & $\begin{array}{l}\text { Car??? Català, vecinos de } \\
\text { Serra }\end{array}$ \\
\hline & 1664: Juan Bautista J. & $\begin{array}{l}\text { Juan Dolse (Dolz?), } \\
\text { mancebo y nat de la villa de } \\
\text { Chelva }\end{array}$ & Selidonia Navarro \\
\hline & 1667: Maria Jacinta Isabel & Batista Catalan & $\begin{array}{l}\text { Carpia Catalan, hija de } \\
\text { dicho Bautista }\end{array}$ \\
\hline \multirow[t]{9}{*}{$\begin{array}{l}\text { Juan Arnal/ } \\
\text { Francisca Cabo }\end{array}$} & 1655: Maria Francisca & Francés Arnal..., i & $\begin{array}{l}\text { Merina Arnal, vecinos de } \\
\text { Nàquera }\end{array}$ \\
\hline & 1658: Agña? Maria Dorotea & $\begin{array}{l}\text { Carlos Arcriso?, de nación } \\
\text { francés }\end{array}$ & Meresia Arnal \\
\hline & 1660: Manuela Francisca J. & Matias Cabo & Catalina Arnal \\
\hline & 1663: Marcela Antonia & Matias Cabo & Dorotea Valero \\
\hline & 1665: Mauricia Andrea C. & $\begin{array}{l}\text { Macian Cabo maior, agüelo } \\
\text { de dicha bautizada }\end{array}$ & $\begin{array}{l}\text { Felicia Cabo, doncella, } \\
\text { hija de dicho Macian }\end{array}$ \\
\hline & $\begin{array}{l}\text { 1668: Gregorio Francisco } \\
\text { M.B. }\end{array}$ & $\begin{array}{l}\text { Mossen Marcos Diago, retor } \\
\text { del lugar }\end{array}$ & $\begin{array}{l}\text { (no posa madrina). } \\
\text { Signa: Pedro Domenech, } \\
\text { de la orden de S. } \\
\text { Francisco }\end{array}$ \\
\hline & 1671: Juan Caietano V. A. & Miguel Domingo & Catalina Arnal \\
\hline & 1673: Vicente Casimiro J. & Juan Domingo & Vicenta Arnal \\
\hline & 1677: Tomasa Fransisca L. & Llois Cabo, fadrí & Agna Arnal \\
\hline \multirow[t]{3}{*}{$\begin{array}{l}\text { Vicente Estevan/ } \\
\text { Vicenta Ramon }\end{array}$} & 1656: Pasqual Jusepe V. & Jusepe Domenech & $\begin{array}{l}\text { Felisia Burgos, vecinos } \\
\text { de Serra }\end{array}$ \\
\hline & 1659: Juan Batiste & Francisco Domingo & Jusepa Domenec \\
\hline & 1662: Isabel Esperança & Thomàs Castellano & Felisia Burgos \\
\hline Miguel Ros/ & 1658: Juan Bautista & Batiste Català & Francisca Mateu \\
\hline
\end{tabular}




\begin{tabular}{|c|c|c|c|}
\hline Carpia Català & $\begin{array}{l}\text { Pantaleon } \\
\text { 1660: Evaristo Baptista } \\
\text { 1663: Miguel Andres Jusepe }\end{array}$ & $\begin{array}{l}\text { Baptiste Catalan } \\
\text { Joseph Catalan }\end{array}$ & $\begin{array}{l}\text { Francisca Mateu } \\
\text { Francisca Mateu }\end{array}$ \\
\hline $\begin{array}{l}\text { Domingo Herrero/ } \\
\text { Visenta de Layolo }\end{array}$ & 1658: Ursola Catalina V. & $\begin{array}{l}\text { Juan Martínez ¿eroy-pe?, } \\
\text { vizcaino de nacion }\end{array}$ & Felisia Burgos \\
\hline $\begin{array}{l}\text { Domingo Herrero/ } \\
\text { Visenta Gamba? }\end{array}$ & 1661: Maria Jusepa & Martin? Martínes & Jusepa Arnal \\
\hline $\begin{array}{l}\text { Martín Moreno/ } \\
\text { Mariana Rubio }\end{array}$ & 1659: Domingo Casimiro & Francisco Rubio & Francisca Mateu \\
\hline \multirow{2}{*}{$\begin{array}{l}\text { Jusepe Domingo/ } \\
\text { Teudosia Moreno }\end{array}$} & 1659: Catalina Clara Maria & Juan Moreno & Clara Cavaller \\
\hline & $\begin{array}{l}\text { 1660: Clara Maurisia } \\
\text { 1663: Francisco Gaspar T. }\end{array}$ & $\begin{array}{l}\text { Francesc Domingo } \\
\text { Francesc Domingo }\end{array}$ & $\begin{array}{l}\text { Clara Cavaller } \\
\text { Catalina Arnal }\end{array}$ \\
\hline \multirow[t]{4}{*}{$\begin{array}{l}\text { Jusepe Domingo/ } \\
\text { Maria Moreno }\end{array}$} & $\begin{array}{l}\text { 1664: Juan Bautista } \\
\text { Domingo }\end{array}$ & Jasinto Tallada, sirujano & Rafela Doña, viuda \\
\hline & 1668: Jusepe Casimiro & Domingo Moreno, su tio & $\begin{array}{l}\text { Jusepa Domenech, de } \\
\text { Arnal }\end{array}$ \\
\hline & 1671: Pablo Juan D. & Domingo Moreno & Mariana Ribas \\
\hline & 1673: Maria Ursola P. & Macian Cabo maior & $\begin{array}{l}\text { Ursola Moreno, vda. de } \\
\text { Jaime Perez }\end{array}$ \\
\hline $\begin{array}{l}\text { Jusep Domingo/ } \\
\text { Orosia Moreno }\end{array}$ & 1676: Carlos Joan B. & Carlos Frenco? & Maria Arnal, doncella \\
\hline \multirow{5}{*}{$\begin{array}{l}\text { Pedro Garay/ } \\
\text { Madalena Epila }\end{array}$} & 1659: Maria Ursola F. & Bernat Garay, vizcaino & Ursola Epila \\
\hline & $\begin{array}{l}\text { 1662: Pedro Antonio Josepf } \\
\text { 1664: Catalina Florentina } \\
\text { 1666: Angela Isabel }\end{array}$ & $\begin{array}{l}\text { Jusepe Duran } \\
\text { Macian Cabo } \\
\text { Hernando Garneche? menor, } \\
\text { vizcaino nat de Aroa }\end{array}$ & $\begin{array}{l}\text { Catalina Arnal } \\
\text { Petronila Gonzalez } \\
\text { Angela Cabo, doncella }\end{array}$ \\
\hline & 1669: Juan Antonio J. & Juan Gambó & Jusepa Arnal \\
\hline & 1673: Ant. Bautista Baltasar & Batista Domenech, i & $\begin{array}{l}\text { Maria Lorente, conjuges } \\
\text { i habit de Serra }\end{array}$ \\
\hline & 1674: Isabel Polinaria & Vicente Arnal & Polinaria Arnal, germans \\
\hline $\begin{array}{l}\text { Estevan Soler/ } \\
\text { Angela Ribes } \\
\text { Angela la vda? De } \\
\text { Domingo) }\end{array}$ & 1660: Tomasa Juana M. & $\begin{array}{l}\text { Carlos Arcriso?, de nación } \\
\text { francés }\end{array}$ & Llorensa Domingo \\
\hline \multirow[t]{4}{*}{$\begin{array}{l}\text { Martín Romero/ } \\
\text { Mariana Rubio }\end{array}$} & $\begin{array}{l}\text { 1661: Martín Francisco } \\
\text { Philipe }\end{array}$ & Francisco Rubio & Lorensa Domingo \\
\hline & 1664: Pedro Pasqual & $\begin{array}{l}\text { Pedro Romero, natural de } \\
\text { Riodeva }\end{array}$ & $\begin{array}{l}\text { Angela Rubio, doncella y } \\
\text { tia del bautizado }\end{array}$ \\
\hline & 1666: Francisco Pablo & Francisco Rubio, su tio & Marianna Ribas \\
\hline & 1671: Esperanza Catalina & Domingo Moreno & Catalina Arnal \\
\hline \multirow{3}{*}{$\begin{array}{l}\text { Juan Lazaro/ } \\
\text { Angela Ribas }\end{array}$} & 1664: Juan Bautista Jayme & Jayme Peres & Marianna Ribas \\
\hline & 1665: Vicente Batista Barth. & $\begin{array}{l}\text { Vicente Pons, natural de } \\
\text { Vexis (Begís?) }\end{array}$ & Maria Lorente \\
\hline & 1668: Manuel Jusepe & $\begin{array}{l}\text { Manuel Arnau, de Torcas } \\
\text { (Villatorvas?) }\end{array}$ & Francisca Ibañez \\
\hline \multirow{2}{*}{$\begin{array}{l}\text { Mathias Cabo } \\
\text { (menor)/ Catharina } \\
\text { Perez }\end{array}$} & 1666: Mathias Jaime & Mathias Cabo, y ... & $\begin{array}{l}\text { Ursola Moreno, abuelos } \\
\text { del bautizado }\end{array}$ \\
\hline & 1668: Jusepe Jaime Diego & Jusepe Thomàs, $\mathrm{y}$ & Rafaela Pérez, \\
\hline
\end{tabular}


Macian

1671: Maria Ana Jusepa G. Estevan Rubio

habitadores de Sierra

Cabo/Catarina Perez

1672: Maria Isidora

1675: Marianna Secilia

Luysa

1678: Agna Maria Ursola
Isidoro Linares, habitador en Mariana Ribas Valencia y receptor de las limosnas que se plegan para el hospital general de dicha ciudad de Val..

Sabastian Romero, de Marianna Ribas

Gatava

Joseph Avariat, de Alcalà de Ursola Peres, donsella

Chivert, habitador de

Valencia

Mathias Cabo/

1680: Catalina Teresa Ursola Jayme Peres, de Serra
Catalina Peres, de Serra

Catalina Peres

Estevan Navarro, y ...

(menor)/ Maria

Lorente

Vicente Epila/

Petronila Gonzalez

Josep Navarro/

Pascuala Saez

Jusepe Navarro/

Pascuala Says

Jusepe Chillida/

Agustina Mañez

Jusef Chillida/

Agustina Ivañez?

Juan Dolz/

Celidonia Navarro

1667: Juana

1670: Pedro Juan Gregorio

Joseph Rodriguez

Jusepe Duran, bayle de

Nàquera, y su muger:

1672: Vicenta Agustina M. Domingo Moreno

1674: Bautista Juan T. Domingo Moreno

1679: Fransisco Visente B. Visente Arnal

1681: Juana $\mathrm{M}^{\mathrm{a}}$ Rosa Blasia Juan Domingo

1683: Maurisia Viviana F.

1666: Antonio Vicente F. Juan Ibañez, i....

1668: Miguel Caretano

Olmiche el baxo

1670: Pedro Francisco A. Pedro Garay de Campanar

1669: Dorotea Ines F.

Pedro Juan Navarro

1671: Josef Domingo

de Noxa

1673: Jusepa Miria-ana L. Lorenço Navarro

1675: Andreu Juan Joseph Joan ¿?(¿dols?)

1685: Pedro Martín

Valencia habitador en Sra.

1670: Paula Catarina E. Estevan Rubio
Miguel Escrich, natural de

Marianna Ribas, coniuges.

Jusepa Arnal

Merina Arnal

Felicia Burgos

Maria Anna Ribas

Mariagna Ribes

Juana Agna Matheu

Francisca Garcia Matheu, coiuges

Jusepa Arnal

Madalena Epila

1667: Orosia Miguela M. A. Gerónimo Bellohc, habitador Maria Gómez, hab de

Val. y sobrina de Jusepe

Hiranço

Francisca Pérez

Vicente Pérez, de iglesia

vizcaino y natural de la villa

Maria-ana Ribas

Andrea Pérez y de

Navarro

1678: Juan Joseph Chr. Christoval Ruvio, mansevo

1680: Juan Policarpio Jayme Mos. Policarpio Mallac, de

Ursola Perez, donsella

Teresa Peres, de Serra

1668: Francisca Melchora A. Pedro Alvarez, arendador y Francisca Mateu y de Bayle de Sierra, mercader y Mañez

Francisca Mateu

1668: Juan Domingo Josef Domingo Navarro (tio)

Felicia Cabo 


\begin{tabular}{|c|c|c|c|}
\hline \multirow{5}{*}{ /Silidonia } & 1670: Francisco Juan D. & Batista Domenech & Maria Lorente \\
\hline & 1673: Maria Jusepa C. & $\begin{array}{l}\text { Pedro Alvarez, bayle y } \\
\text { arrendador deste lugar }\end{array}$ & Jusepa Domenech \\
\hline & 1676: Visente Pedro S. & $\begin{array}{l}\text { Visente Dols, de la villa de } \\
\text { Chelva }\end{array}$ & Catalina Arnal, Vda. \\
\hline & 1679: Juan Fransisco Jayme & Juan Navarro & Ursola Peres \\
\hline & $\begin{array}{l}\text { 1682: Tomàs Andreu Juan } \\
\text { 1686: Maria Manuela }\end{array}$ & Bautista Ros & Eusebia Peres \\
\hline \multirow{6}{*}{$\begin{array}{l}\text { Juan Navarro/ } \\
\text { Andrea Pérez } \\
\text { /Andreua }\end{array}$} & 1669: Juan Domingo J.C.M. & Domingo Moreno & $\begin{array}{l}\text { Rafaela Pérez, donzella, } \\
\text { tíos del bautizado }\end{array}$ \\
\hline & 1671: Josef Domingo J. G. & Domingo Navarro & Francisca Pérez \\
\hline & 1674: Ursula Eusebia A. A. & Pedro Juan Navarro & Eusebia Pérez \\
\hline & 1676: Maria Francisca V. & Christòfol Ruvio & $\begin{array}{l}\text { Ursola Moreno, vda de } \\
\text { Pérez, madre de Andreua }\end{array}$ \\
\hline & 1679: Domingo Salvador J. & Juan Dols & Eusebia Peres \\
\hline & $\begin{array}{l}\text { 1682: Teresa Andreua P. } \\
\text { 1684: Jayme Diego }\end{array}$ & Bautista Ros & Teresa Peres \\
\hline \multirow{8}{*}{$\begin{array}{l}\text { Domingo Moreno/ } \\
\text { Angela Cabo }\end{array}$} & 1669: Juana Catarina & Juan Arnal & Rafaela Pérez \\
\hline & 1670: Domingo Protho B. & Baltasar Moreno & Ines Andreu \\
\hline & 1672: Francisco Matias & Matias Cabo, agüelo & Catalina Arnal \\
\hline & 1675: Gaspar Melchor B. & Joan Navarro & $\begin{array}{l}\text { Catalina Arnal, vda de } \\
\text { Francisco Domingo }\end{array}$ \\
\hline & 1677: Masià Jaume J. & Masià Cabo & Catalina Domingo \\
\hline & 1679: Josepa Refela E. & Bautista Domenech & Eusibia Peres \\
\hline & $\begin{array}{l}\text { 1682: Simona Àngela y F. } \\
\text { 1685: Teresa Ángela Agueda }\end{array}$ & Mathias Cabo menor & Simona Aguilar \\
\hline & 1688: Maria Angela Agnasia & Domingo Vidal & Angela Garay \\
\hline $\begin{array}{l}\text { Jusepe Rodriguez/ } \\
\text { Lorença Domingo }\end{array}$ & 1670: Maria Ana Jusepa & $\begin{array}{l}\text { Francisco Garcés, natural de } \\
\text { Camarena, moço }\end{array}$ & Mariana Ribas \\
\hline $\begin{array}{l}\text { Mateu Micó/ } \\
\text { Madalena Catalan } \\
\text { (cojuges que tienen } \\
\text { su domicilio en }\end{array}$ & 1670: Francisca Jusepa M. & Domingo Moreno & Francisca Pérez \\
\hline $\begin{array}{l}\text { Francisco Domingo/ } \\
\text { Catarina Arnal }\end{array}$ & 1670: Clara Francisca G. & $\begin{array}{l}\text { Miguel Domingo Merina } \\
\text { Arnal }\end{array}$ & \\
\hline $\begin{array}{l}\text { Miguel Eslich/ } \\
\text { Francisca Ibañez }\end{array}$ & 1671: Maria Catalina V. V. & $\begin{array}{l}\text { Pedro Álvarez, bayle de } \\
\text { Sierra y habitador en } \\
\text { Valencia }\end{array}$ & Catalina Ibañez, doncella \\
\hline $\begin{array}{l}\text { Miguel Escrich/ } \\
\text { Francisca Ivañez }\end{array}$ & 1673: Pedro Juan Miguel & $\begin{array}{l}\text { Pedro Sanz, moço nat de } \\
\text { Molina, en Castilla } \\
\text { (Obispado de Sigüenza) }\end{array}$ & $\begin{array}{r}\text { Catalina Arnal, vda de } \\
\text { Francisco Domingo }\end{array}$ \\
\hline \multirow{2}{*}{$\begin{array}{l}\text { Miguel Escrix/ } \\
\text { Francisca Ivañez }\end{array}$} & 1676: Francisca Catalina & Pedro Scrig & Catalina Arnal \\
\hline & 1679: Fransisco Julian G. & $\begin{array}{l}\text { Julian Piamonte (és de } \\
\text { Sogorb), y }\end{array}$ & Ursola Ivañes \\
\hline \multirow{4}{*}{$\begin{array}{l}\text { Miguel Escrig/ } \\
\text { Francisca Ivañez }\end{array}$} & 1681: Bautista Miguel & Bautista ¿¿¿Lvos??? & Teresa Peres \\
\hline & $\begin{array}{l}\text { 1682: Juan Bta. Miguel } \\
\text { 1685: Teresa Francisca } M^{a}\end{array}$ & Bautista Ros & Teresa Peres \\
\hline & 1689: Bautista Jerónimo & $\begin{array}{l}\text { Mos.Geronimo Garsia, } \\
\text { beneficiado en la Seo }\end{array}$ & Agustina cillida \\
\hline & 1691: Juana Florentina & Jusepe Cabo & Florentina Garay \\
\hline
\end{tabular}


1693: Ynésd Anna Maria

1671: Josef Juan Matias

El guardan: Jusepe

Thomàs/ Felicia

Cabo

( ...haver quedado

preñada cuando

Đơnîngo Navarro/ 1672: Domingo Juan J.

Francisca Pérez

el Guardan (nou!):

Domingo Navarro/ 1697: Juanna Francisca

Esperansa Romero Maria

1700: Maria Theresa

Esperansa

1702: Bibiana Felicia

Manuela

Domingo Navarro/ 1704: Vte. Jaime Domingo Josepa Salvador

1707: Juan Francesc Juseph Agustí Regular

1708: Anna $\mathrm{M}^{\mathrm{a}}$ Josepha Agustín Regulat

Domingo Navarro 1706: Jusepa Maria Juana

maior/ Jusepa Arnal

1708: Theresa $\mathrm{M}^{\mathrm{a}}$ Fabiana

Francisco

1673: Francisco Josef J.

Calataiud/ Maria

Arnal

Bautista Catalan/

Petronila Gonzalez

Bautista Català

menor/ Petronila

Gonçales

Bautista Català/

Polinaria Arnal

Bautista Catalan/

Polinaria Arnal

Bautista Català/

Polinaria Arnal

Vicente Estevan/

Catalina Ibañez

Vicente Esteve/

Catalina Ivañez

Visente Esteve/

Anna Roxas

Visente Estevan/

Anna Rojas

Joseph Navarro

Joseph Rubio

Lois Cabo

Lluis Cabo

1678: Josepa Eusibia B.

1679: Juan Jusepe Martín

1682: Catalina Geltrudis P. Thomàs Català

1684: Luysa Donisa J.E.

1687: Francisca $\mathrm{M}^{\mathrm{a}} \mathrm{Jasinta}$

1694: Jayme Visente Juan

Jayme Perez

1676: Joan Batiste Macià

Juan Domingo carpintero

1698: Dionicia Margarita

Ofres.
Bautista Domenech, Bayle

de Sierra

y su muger Maria

Lorente

Macian Cabo menor

Maria Lorente
Pedro Escrig, mancebo

Domingo Navarro, moço

Jusepe Rodrigues

Miguel Domingo

Josef Calataiud, de Bètera

Pedro Juan Navarro

Lorenso Navarro

1674: Vicente Juan Melchor Domingo Moreno

Jusepe Chillida, de Beselga

Domingo de Suldaña,

Roch Fos

Ursula Navarro, viuda

Maria Ruvio, donsella

Felisia Moreno

Ursola Perez

Josepa Català

Francisca Salvador

Josepha Rubio

Maria Domingo

Ana Arnal, domitela

Esperança Catalan

Maria Lorente

Eusibia Peres

Margarita Sesé

Geltrudis Gil

Francisca Arnal

Celidonia Navarro

Maria Lorente

Agustina Chillida

Rosa Navarro

1701: Manuel Bautista

Roque
$\mathrm{M}^{\mathrm{a}}$ Rosa Domenech 


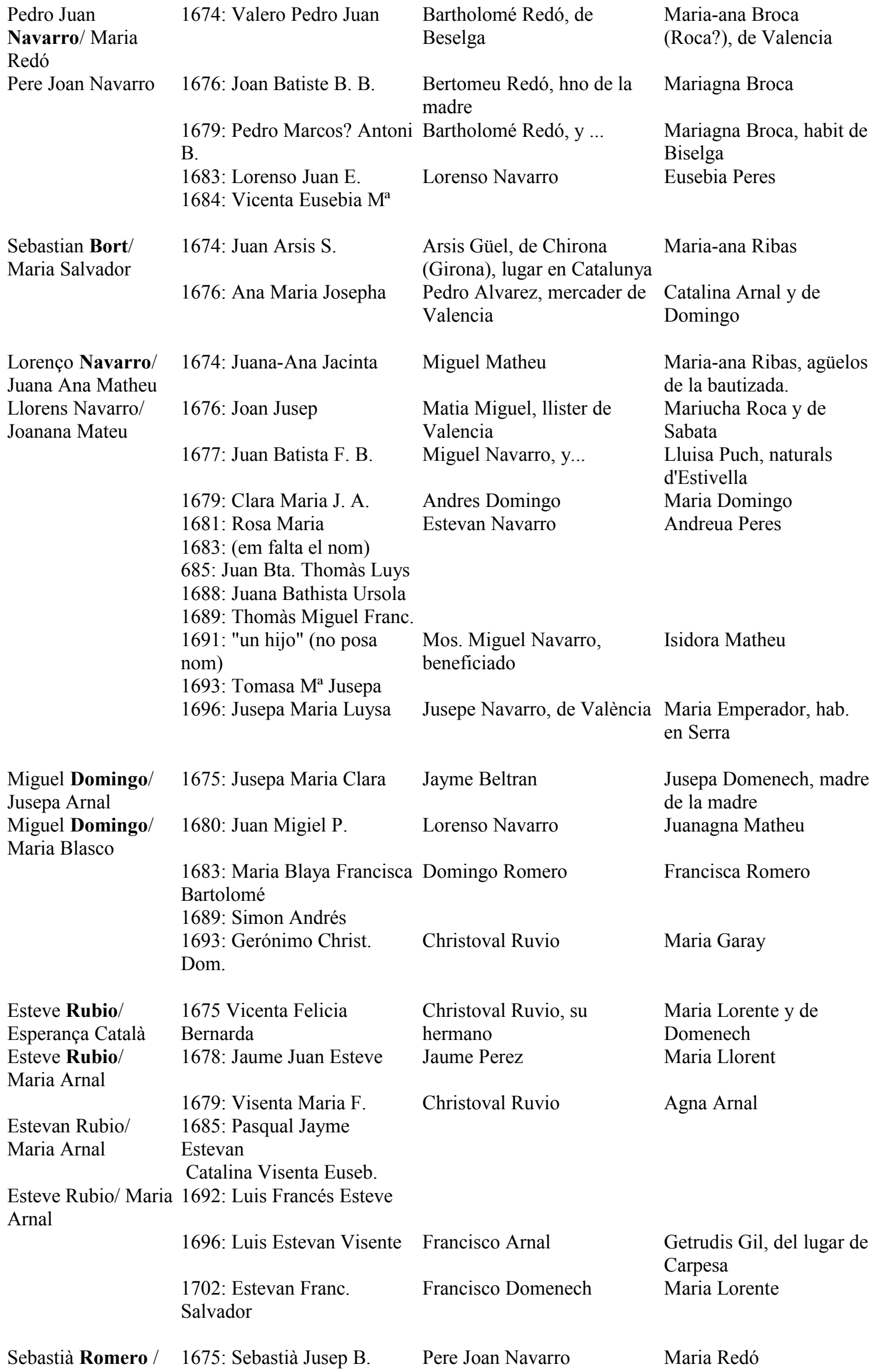


Francisca Pérez

(ell de Gatova)

Manuel Salvador/

Ana Maria Arnal

Joan Domingo/

Getrudis Gil

Salvador Bigs

(Vich?)/ Maria

Domingo

Pau Verge/

Christina Torres

Pablo Verge/

Christina Torres

Pau Verge/

Christina Torres

Vicente Arnal menor/ Josepha

Gonzalez

Vicente Arnal/

Maria San Juan

Visent Arnal, de Nàquera/ Maria San

Juan

\begin{tabular}{|c|c|c|c|}
\hline & 1694: Joseph Pablo & Pablo Domingo & $\begin{array}{l}\text { Jusepa San Juan, } \\
\text { doncella natural de } \\
\text { Beselga }\end{array}$ \\
\hline $\begin{array}{l}\text { Visente Arnal/ } \\
\text { Josepa Gonzales }\end{array}$ & $\begin{array}{l}\text { 1700: Salvador Ambrosio } \\
\text { Bta. }\end{array}$ & Salvador Navarro & $\mathrm{M}^{\mathrm{a}}$ Rosa Domenech \\
\hline $\begin{array}{l}\text { Jayme Salvador/ } \\
\text { Visenta Arnal }\end{array}$ & $\begin{array}{l}\text { 1680: Jusepa Maria } \\
\text { 1683: Salvadora Francisca P. }\end{array}$ & Domingo Moreno & Jusepa Gonsales \\
\hline $\begin{array}{l}\text { Christoval Ruvio/ } \\
\text { Maria Garay }\end{array}$ & $\begin{array}{l}\text { 1680: Visenta Maria } \\
\text { Magdalena }\end{array}$ & Llorens Navarro & Juana Agna Matheu \\
\hline
\end{tabular}

Eusibia Peres

Maria Garay

Maria Escuder, de

Aragón

Florentina Garay

1690: Jusepe Visente Roque Roque Guashc Florentina Garay

... lunch mancebo...

1678: Maria Jusepha Juliana Julian Viamonte (en Geronima Ogeria, Escrig1679 pone Piamonte), naturales de la ciudad de y

1681: Visente Gregorio Bta. Pedro Garay

Segorbe

Florentina Garay

1684: Gregorio Diego J.B.

1686: Maria Manuela

A688sid

Barthol.

1694: Violant Visenta Esper. Juan Garay

1697: Francisco Jusepe Francisco Doménech

Esperansa Navarro?, donsella

Isidora Cabo

Dionic.

1689: Visente Gabriel Gabriel San Juan Isabel Juan

1690: Grabiel Jusepe

1692: Jusep Grabiel Lluis Jusep Llopiz Jusepa Sent Juan

$\begin{array}{ll}\text { retor!), de Catí } & \text { Florentina Garay }\end{array}$

1686: Maria Jusepa Cesilia

...batejat per necessitat, en sa

casa...

rcángela $\mathrm{M}$

el joven ¿Juashoan? Arnal Anna Maria Arnal, filla

Llorens Navarto

e


1682: Pedro Juan Christoval Pedro Garay

1685: Jusepa Madalena V. Francisco Bollot?, milanés

1688: Teresa Angela Esteve Ruvio

Florentina

1691: Francisca Isabel Man.

1694: Rosana Florentina Fr. Juan Arnal, mancebo

$\begin{array}{ll}\text { 1696: Thomasa Cathalina } & \text { Pere Escrig } \\ \text { Rosa } & \\ \text { 1700: Francisco Xavier } & \text { Francisco Arnal, i } \\ \text { Christ. } & \\ \text { 1703: Juan Manuel Nadal } & \text { Pedro Navarro }\end{array}$

Juan Libros/

Polinaria Arnal

Tomàs Domingo/

Eusibia Peres

Juan Balada/

Catalina Domingo

Juan Balada/

Francisca Rubio

Joan Balada,

albañil/ Francisca

Rubio

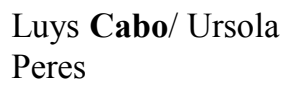

Luis Cabo/ Ursula

Pérez

\section{Andrés Catalan/}

Thomasa Torres

Andrés Català

Maria Esteve
1680: Agna Maria Margarita Juan Navarro

1683: Ana Maria Margarita

1685: Jusepa Manuela M.

1688: Juan Jusepe Tomàs

1691: Matheu Pere Grabil

1693: Domingo Juan Jusepe

Grabiel San Juan, de

Estivella

Domingo Duserdaña, fuster

1680: Thomàs Andreu

Juan Dols

Jayme

1685: Visente Melchor Ant. Antonio Marín, de Moncada

1687: Antonio Pedro Tomàs

1689: Ma Francisca Pasq. M. Miguel Arlés, de Burxasot

1681: Jusepe Juan Christóval Jusepe Rubio

1687: Isabel Teodosia Em.

1690: Ynés Juana Ana

1692: Ynés Paula Juanna

Anna

Domingo Moreno maior, tunch Jurado Maior

1695: Juan Cristoval Asensi

Cristoval Rubio

Francisco Navarro

1684: Jusepe Bta. Luys

1686: Felicia Frca. Manuela Bautista Domenech, Bayle Eusebia Peres

1688: Jayme Francisco Luys

1690: Barbara Ursola Franc.

1693: Pasqual Jusepe

Mathias

1682: Jusepe Thomas

Bautista Catalan

Andreu

1684: Manuel Jusepe Dom.

1688: Jusepe Andrés Dom.

1690: Miguel Andrés Dom.

1691: Tomàs Domingo

1693: Domingo Nicolàs Silv. Domingo de Sordaña,
Ursola Navarro, donz. hab. de Serra

Esperansa donzella

Teresa Peres

Andreua Marín, de Moncada

Francisca Épila, de Nàquera

Eusibia Peres

Juanna Matheu

Juana Matheu

Teresa Peres

Girtrudis Gil

Madalena Epila

Rosana Emperador, de Juan Navarro germans.

hermanos.

Clara Navarro

Margarita Arnal

Ana Maria Navarro, 
Batiste

1696: (no tinc el nom)

1698: Maria Francisca

Jusepa

1701: Cecilia Dorotea Ursula Domingo de Surdaña, y hab. De Serra

1703: Theresa Felicia Maria Inacio Gutierres

1704: Carpia Andreua Maria Andrés Català menor, su

$\begin{array}{ll}\begin{array}{l}\text { Jayme Peres/ Agna } \\ \text { Arnal }\end{array} & \text { 1682: Ursola Teresa B. } \\ & \text { 1688: Francisca Ma Eusebia } \\ & \text { 1690: Cathalina Francisca } \\ \begin{array}{l}\text { Jayme Peres/ Anna } \\ \text { Arnal }\end{array} & \text { 1693: Cathalina Francisca } \\ & \text { 1696:Jayme Josepe Mathias } \\ & \text { 1699: Teresa Asensia } \\ & \text { Vicenta } \\ & \\ \text { Blay Gasch/ Angela } & \text { 1682: Juana Agna Cecilia } \\ \text { Verge } & \\ & \text { 1684: Maria Mariana Sesilia } \\ & \text { 1686: Maria Sesilia Angela } \\ & \text { 1688: Juana Anna M Ursola } \\ & \text { 1691: Jusepa Maria }\end{array}$

Blas Gasch/Angela

Berge

T690alAnagela Pasquala

Blas Gasch/Angela Frsnc.

Verge

1695: Baltasar Joseph Blay

1697: Jusepa Maria Teresa Juan Arnal

1700: Mateu Thomàs Miguel Jusepe Navarro de Juan

Blas

Guarsch/Angela

1704: Angela Theresa Franc. Francisco Dolz

Verge

Blay Garht/ Angela 1706: Maria Vicenta Angela Jusep Navarro menor

Verge

\section{Mathias Cabo \\ (menor)/ Simeona}

1683: Jasinta Teresa B.

Aguilar

/ Simona

Mathias Cabo

(maior)/ Simona

Aguilar

Matias Cabo/ Maria 1697: Jusepe Macian Miguel Jusepe Navarro Gil carpintero, hijo de Benisanó hermano

donzella

Catalina Escrig, lunch

donsella

Francisca Arnal

Ursola Perez

Felicia Moreno

Carpia Ros

Maria Lorente

Estevan Ruvio tunch, Jurado Cathalina Arnal tunch, donsella

Rafaela Moreno, donsella lunch

Maria Mateu

Juana Agna Matheu

Maria Emperador

Maria Emperadora

Maria Emperador

Theresa Moreno

Jusepa Emperador

Florentina Garay

Maria Emperador

Rosa Navarro, hermanos

Felicia Cabo

Clara Navarro 


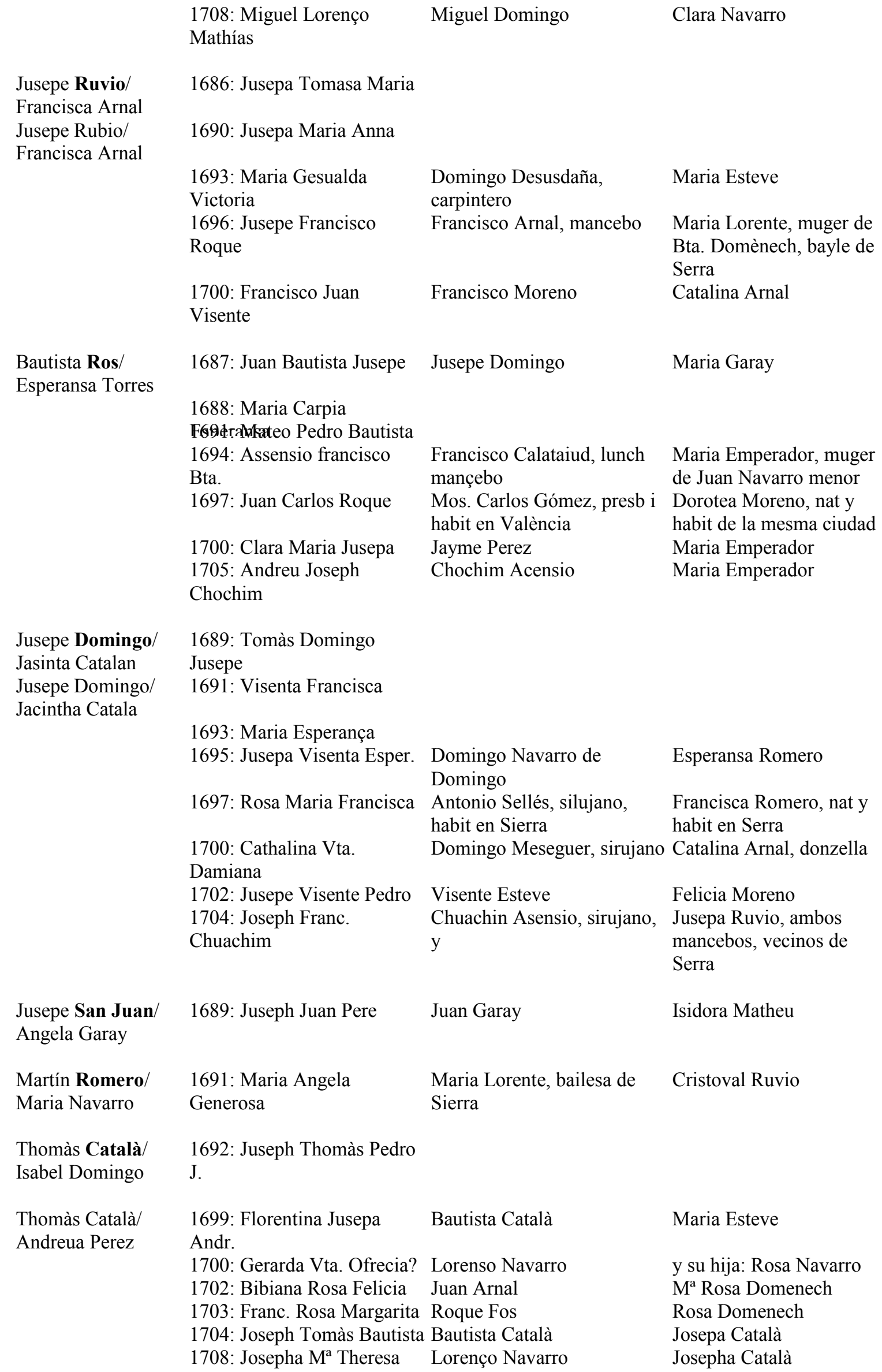


Fr.

Domingo Perez/ Maria Dolz
1692: Ursula Maria Rosalea

\begin{tabular}{|c|c|c|}
\hline 1695: ...lola Teresa & Domingo Navarro de & Florentina Fgaray \\
\hline & & \\
\hline $\begin{array}{l}\text { 1698: Domingo Jusepe } \\
\text { Jayme }\end{array}$ & $\begin{array}{l}\text { Domingo de Surdaña, } \\
\text { carpintero habit en Serra }\end{array}$ & $\begin{array}{l}\text { Maria Anna Navarro, } \\
\text { donsella }\end{array}$ \\
\hline $\begin{array}{l}\text { 1701: Ursola Theresa } \\
\text { Visenta }\end{array}$ & Domingo Meseger, cirujano & Maria Emperador \\
\hline 1703: Jayme Franc. Vte. & Vte. Esteve & Manuela Dolz \\
\hline 1705: Maria Manuela Jusepa & Josep Cabo & Manuela Arnal \\
\hline $\begin{array}{l}\text { 1707: Ursola Selidonia } \\
\text { Maria }\end{array}$ & Francés Arnal & Manuela Arnal \\
\hline 1709: Joseph Viçente Juan & Juan Dolz & $\begin{array}{l}\text { Carpia Ros, ambos de } \\
\text { Serra }\end{array}$ \\
\hline
\end{tabular}

\section{Jusepe Alcayde,} cirujano/ Ursola

Navarro

1693: Maria Rosa Andreua Juan Navarro maior

1696: Juan Jusepe Miquel

Juan Alcayde

Maria Lorente, muger del bayle de Serra

Maria Emperador

Roche (roque) Fos/ 1693: Jusepa Ma Ynacia Juana Esteve

1696: Jacintha Maria

Theresa

1703: Theresa Bernarda

Man.

1706: Roc Franc. Juseph

Juan

Matheu Fos, nat i habit. de Nàquera

Antonio Sellés, de

Cocentayna

Francés Arnal

Maria Cabo, de Serra

Jusepa Arnal

Francisca Salvador

Domingo Verge/

Pasquala Torres

1693: Thomasa Esperansa V.

1699: Visenta Maria

Domingo Perez

Francisca

1702: Gerónimo Bautista

Dom.

Bautista Ros, vecino de

Serra

1704: Thomasa Manuela

Pasq.

1708: Josepha Maria Teresa

Agustín Regulat, y

Joseph Català maior

1694: Maria Teresa

Josep Blasco, de Beselga

1696: Jusepe Miguel

Massian

1698: Salvador Macià

Domingo

1701: Serafina Angela

Leandra

Geroni Blasco, de Beselga

Domingo Moreno

Pablo Domingo, moço

1694: Francisca Maria

Ursula

Joseph Sebastian/

Maria Garcia

Francisco Romero/ 1695: Juana Maria Antònia

Jusepa Vila-nova

1698: Francisco Tomás

Pedro

Joseph Rubio

Pedro Escrich, moso

Domingo Verge

Pedro Garay, agüelo de
Francisca Yvañes

Margarita Muñoz, de Castilla y habit de Serra

Manuela Arnal, mancebos

Teresa Escrig

Maria Lorensa

Cathalina Blasco, de Beselga Rafaela Moreno

Rosa Blasco, dons nat de Beselga

Ursola Navarro

Francisca Arnal

Margarita Muñoz, habit en Serra

Esperansa Romero, lunch 
Cabo

Martín Romero/

Maria Navarro

\begin{tabular}{|c|c|}
\hline & dicho bautizado \\
\hline $\begin{array}{l}\text { 1698: Maria Madalena } \\
\text { Theresa }\end{array}$ & Baltasar Moreno, moso \\
\hline 1701: Rosa Maria Getrudis & Salvador Navarro \\
\hline 1703: Juan Franc. Bautista & Francisco Arnal \\
\hline 1706: Pere Thomàs Fermí & Josep Cabo \\
\hline
\end{tabular}

1696: Esperansa Anna Cath. Jayme Perez

1699: Martín Jusepe

Francisco

1702: Visenta Pasquala

Franc.

1704: Joseph Pasqual

1709: Vicenta Pasquala

Man.

Juan Arnal/ Jusepa Emperador (de Segart)

Miguel Gil/ Maria
Cabo
Joseph Blasco/
Merina Arnal
Roch Gil/ Juana
Esteve
Pere Escrig/

Thomasa Rico

Inacio Gutierres/

Manuela Dolz

Francisco

Domenech/ Ursola

Perez menor

1701: Isidro Francisco

Matías

1702: Bacilia Ursola Rofina Francisco Arnal

1704: Vta. Ursola Rosalea Francisco Arnal

1699: Pedro Miguel Jusepe Visente Esteve, moso

1699: Jusepa Maria Pasquala Juan Blasco, y

1699: Rosa Theresa Isabet

Francés Arnal

1701: Pedro Baltasar

Salvador

1703: Miguel Thomàs

Salvador

1704: Salvador Franc. Pedro Salvador Navarro

1707: Josepha $\mathrm{M}^{\mathrm{a}}$

Bonaventura

Josep Garcia, del lugar de Petrés

\section{Salvador Navarro}

Salvador Navarro, mancebo

1704: Franc. Ignacio Joseph Joseph Cabo

1708: Salvador Antonio Juan Salvador Navarro

1704: Franc. Mathías Jayme Bautista Domenech

1708: Ma Rosa Luisa

Generosa

Luis Cabo

1704: Tomàs Joseph Franc.

Francisco Dolz

Felicia Moreno

Pablo Domingo/

Ana Maria Català
1707: Rosa Augustina

Simona

1706: Rosa Maria Juana
Bautista Domingo, beneficiado

Agustín Domingo

Joset Cabo doncella, habts.

Jacintha Navarro,

donsella

Rosa $\mathrm{M}^{\mathrm{a}}$ Navarro

Felicia Moreno

Catalina Arnal

Anna Arnal, coniuges.

Beatris Rodrigues, nat y hab de Gatoba Maria Emperador

Catalina Arnal, de Serra a Catalina Arnal, de Serra

Catalina Fauli?, su muger

Ursola Perez

Ursola Perez

Ursola Perez

Catalina Arnal, donsella

Merina Arnal, todos de Nàquera

Isabel Domingo

Maria Ruvio

Rosa Domenech

Rosa Domenech

Teresa Escrig, donz., nat de Serra

Theresa Moreno

Manuela Arnal

Anna Arnal

$\mathrm{M}^{\mathrm{a}}$ Lorente

Theresa Moreno

Rosa Casanova

Maria Emperador 
Paulo Domingo/ Ana Maria Català

1707. Juan Francisco Juseph Juan Domingo

Jerónimo Lasaña/

Vicenta Muñoz

Miguel Escrig

menor/ Clara

Navarro

Joan Esteve/

Josepha Bort

Jochim Assensi/

Jusepa Ruvio
1709: Theodosia Vta.

Josepha

8-5-1707: Maria Teresa

Rufina

Miguel Domingo

Domingo Bondia, de Masarroches

1708: Rosa $\mathrm{M}^{\mathrm{a}}$ Fr. Bta. Clara Lorenço Navarro

1708: Ja $\mathrm{M}^{\mathrm{a}}$ Fr. Augustina V. Agustín Regulat, y

1709: Jaime Jusepe Jochim Jusepe Cabo
Damiana Perez

Vicenta Navarro

Rufina Granell, (de Masarroches, tots 4)

Bautista Navarro, donzella

Francisca Salvador, ambos de Serra

Ana $\mathrm{M}^{\mathrm{a}}$ Arnal 


\section{ANNEX III \\ LLIBRE DELS CONFIRMATS (segle XVII) \\ (Quinque libri de Serra. APS)}

\section{ANY 1619}

En 9 de noviembre del año 1619 el Ilmo. y Reverentísimo Sr. D. Fr. Isidoro Aliaga, Arzobispo de Valencia, estando en la visita de los lugares de Serra y Nàquera administró el Sacramento de la Confirmación a los siguientes:

- Juan Bautista Domenech (10 anys); fill de Josep Domènech i d'Agustina Puche; padrí Antonio Masson de Soneja, bayle de dit lloc.

- Juan Rubio (3 anys); fill de Juan Rubio i Anna Ruvia; padrí Josep Domènech menor.

- Domingo Diago (4 anys); fill de Domingo Diago i d'Isabel Morell; padrí Juan Donya, del lugar de Sierra.

- Bautista Chatalà (12 anys); fill de Bautista Català i de Bàrbara Mateu; padrí Pere Juan Ribas, veí i habitador d'aquest lloc.

- Martín Esteve (12 anys); fill d'Antoni Esteve i de Joana Romera; padrí: Anton Salvador, habitador i veí d'aquest lloc.

- Juan Sáez (9 anys); fill de Miquel Sáez i d'Isabel Sayal; padrí

- Agustín Salvador (4 anys); fill d'Antoni Salvador i d'Eufemia Teruel; padrí Miquel Pascual, retor de València.

Dones confirmades en la mateixa visita:

- Àngela Domènech (4 anys); filla de Josep Domènech i d'Agustina Puche; padrina Vicenta Sastre, donzella.

- Francesca Sáez (6 anys); filla de Miguel Sáez i d’Isabel Sayas; padrina Vicenta Paula??, donzella i habitant d'aquest lloc.

- Maria Chathalan (sic.) (11 anys); filla de Bautista Català i de Bàrbara Mateu; padrina: Rafaela Donya, donzella habitant d'aquest lloc.

\section{$\underline{\text { ANY } 1634}$}

En 14 de enero del año 1634 el Señor Obispo (Auxiliar) D. Vicente Clavería estando en la visita de los lugares de Sierra y Nàquera con Comisión del Señor Arzobispo de Valencia don fray Isidoro Aliaga, confirmó a los siguientes: 
- Josep Catalan (13 anys); fill de Bautista Catalan i Bárbara Mateua; padrí Domingo Moreno, d'aquest lloc de Serra.

- Vicente Catalan (12 anys); fill de Bautista Catalan i Bárbara Mateu; padrí Domingo Moreno, del lloc de Serra.

- Francesc Bru (5 anys); fill de Bauthista Catalan i de JoanaAnna Estevan; padrí fue Maties Cabo, del lloc de Serra.

- Pere (10 anys); fill de Josep Domènec i d'Agustina Puig; padrí Antoni Masó, Batlle del lloc de Soneixa. ${ }^{1}$

- Miguel Domingo (3 anys); fill de Miquel Domingo i Clara Cavaller; padrí Vicente Cavaller, de Carpessa.

- Francisco Domingo (1 any); fill de Miquel Domingo i Clara Cavaller; padrí Mossèn Salines, escrivà de la Visita.

- Melchior Tortajada (12 anys); fill de Martín Tortajada i Agnès Domènec; padrí: Jusepe Domènec, del lugar de Sierra.

- Jucepe Tortajada (1 any i mig); fill de Martín Tortajada i Agnès Domènec; padrí: mosén Salines, de València.

Dones confirmades:

- Úrsola Èpila (1 any); filla d'Antón Ėpila i d'Isabel Mañez; padrina Francisca Cavaller de Carpesa.

- Caterina Ramon (2 meses); filla de Bernat Ramon i Esperança Domènec; padrina Agustina Puig.

- Ángela Ribes (10 anys); filla de Pere Joan Ribas i Clara Cavaller; padrina Esperança Domènec del lloc de Benimaclet.

- Rafela Moreno (1 any); filla de Domingo Moreno i Rafaela Donya; padrina Esperança Domènec del loc de Benimaclet.

- Maria Diago ((8 anys); filla de Domingo Diago e Isabel Morell; padrina...

- Nicasia Tortajada (8 anys) filla de Martín Tortajada i Isabel Domènec; padrina Agustina Puig.

- Maria Francesca (1/2 any); filla de Mathias Cabo i Barbara Arnal; p. Isabel Mañez.

\footnotetext{
${ }^{1}$ Iquino (1982: 69-73) cita a Antoni Marso, mercader habitador de Soneixa i en altre moment a Antonio Masó, criat de Don Juseph Folc. En tots els casos es tracta de la mateixa persona o bé de pare i fill (tots dos, del mateix nom, arribaren a ser batlles de Soneixa).
} 
- Mariana Rubio (1 any); filla de Francisco Rubio i Vicenta Cavaller; padrina Francesca Cavaller, del lugar iCarpesa.

- Magdalena Català (2 anys); filla de Bautista Català i Joana Anna Estevan; p. Marianna Ballovar, del lloc de Carpesa.

- Catalina Pérez (8 anys); filla de Jaume Pérez i Caterina García; p. Francesca Pastor, de València.

$\underline{1646}$

En 14 días de Maio de 1646 el Sr don Jasinto Minvarte, Obispo de Maronea, estando en la Vissita de los lugares de Sierra i Nàquera, con licencia del Sr Arzobispo de Valencia don fr. Hissidoro Aliaga, confirmó a los siguientes

Homes

- Domingo Moreno; fill de Domingo Moreno i Rafaela Donya; padrí Jaime Pérez.

- Juan Moreno, fill de Domingo Moreno i Rafaela Donya; padrí Jaime Pérez.

- Pere Pau, fill de Domingo Moreno i Rafaela Donya; padrí Jusepe Domènec.

- Josep Català, fill de Batista Catalan menor i Juanana Esteban; padrí Bautista Catalan Major de dies.

- Francesc Rubio, fill de Francesc Rubio i de Vicenta Cavaller; padrí Miguel Domingo, batlle.

- Pere Patrici, fill de Francesc Rubio i de Vicenta Cavaller; padrí Agostí Salvador.

- Domingo Esteban, fill de Mateu Esteban i de Donissa Sanchis; padrí Domingo Diago major de dies.

- Pere Juan, fill de Miquel Domingo, batlle i de Clara Cavaller; padrí Agostí Salvador.

- Andreu Domingo, fill de Miquel Domingo, batlle i de Clara Cavaller; padrí Leonard Herrero, batlle de Nàquera.

- Agostí Domingo, fill de Miquel Domingo, batlle i de Clara Cavaller; padrí Leonard Herrero, batlle de Nàquera.

- Pere Joan, fill d Domingo Navarro i Magdalena Esteban; padrí Artoni Arnal.

- Josep Navarro, fill de Domingo Navarro i Magdalena Esteban; padrí Josep Domènec.

- Domingo Navarro, fill de Domingo Navarro i Magdalena Esteban; padrí Juan Massó.

- Macià Cabo, fill de Macià Cabo i Bàrbara Esteban; padrí Esteban Navarro.

- Josep Cavo, fill de Macià Cabo i Bàrbara Esteban; padrí Bautista Català menor. 
- Francesc Èpila, fill d'Antón d'Èpila i d'Isabel d'Èpila; padrí Vicent Arnal.

- Juan Arnal, fill de Vicent Arnal i Violante Rubio; padrí Josep Durà.

- Félix Arnal, fill de Vicent Arnal i Violant Rubio; padrí Domingo Moreno.

- Juan Arnal, fill de Vicent Arnal i Violant Rubio; padrí Domingo Moreno.

- Juan Ibáñez, fill de Juan Ibáñez i Paula Domènec; padrí Leonardo Herrero, batlle de Nàquera.

- Josep Domènec, fill de Bautista Domènec i Mariana Ribas; padrí Esteban Navarro.

- Josep Navarro, fill de Pere Navarro i Vicenta Donya; padrí Bautista Domènec.

\section{Dones}

- Teodòsia Moreno, filla de Domingo Moreno i Rafela Donya; padrina Laura Jaume.

- Ursola Moreno, filla de Domingo Moreno i de Rafela Donya; padrina Francesca Giberto.

- Caterina Pérez, filla de Jaume Pérez i Úrsola Moreno; padrina Laura Jaume.

- Llorença Domingo, filla de Martín Domingo i Ángela Ribas; padrina Vicenta Sastre.

- Josepa Català, filla de Josep Català menor i Caterina Pérez; padrina Paula Ibáñez.

- Càrpia Català, filla de Bautista Català i de Juanana Estevan; padrina Josepa d'Arnal.

- Ventura Rubio, filla de Francesc Rubio i de Vicenta Cavaller; padrina Mariana i de Salvador.

- Àngela Rubio, filla de Francesc Rubio i de Vicenta Cavaller; padrina Francesca Giberto.

- Àgueda Domingo, filla de Miguel Domingo, batlle, i de Clara Cavaller; padrina Felícia i de Domènec.

- Vicenta Ramon, filla de n. Ramon i Esperança Domènec; padrina Felícia i de Domènec.

- Cecília Cabo, filla de Macià Cabo i de Barberà Esteban; padrina Clara Cavaller.

- Magdalena Èpila, filla d'Antón Ėpila i Isabel Màñez; padrina Mariana Domènec.

- Agostina Ibáñez, filla de Juan Ibáñez i Paula Domènec; padrina Agostina Puix i Domènec.

- Vicenta Navarro, filla de Pere Navarro i Vicenta Donya; padrina Maria Ribas i Domènec. 


\section{ANNEX IV \\ PROSOPOGRAFIA DELS COGNOMS DELS QUE VAN REPOBLAR SERRA I RIA EN 1609}

Aquest annex recull i repassa tot allò que hem pogut esbrinar a nivell prosopogràfic de cadascun dels repobladors de 1609. Com que no hem trobat les actes individuals de vassallatge que suposadament devien formar part del protocols del notari Gregori Tarrasa, hem hagut d'escorcollar en altres fonts, sobre tot en el Quinque libri de Serra (APS, volum I). Constatarem que bona part dels colons procedien de Les Alcubles. En la major part les dades han quedat resumides en els annexos precedents (II i III), però també hem tingut en compte altres fonts, tal com hem fet constar al llarg de la memòria d'aquesta Tesi. També farem alguna referència al cens prosopogràfic d'Aparici (2001), malgrat que és d'una època anterior (segles XV i XVI) i referit a la comarca de Sogorb, doncs hem tingut en compte que Alcubles mantenia certa relació de mobilitat amb aquesta comarca a través de la propera cartoixa de Valdecrist, a la qual pertanyia.

\section{Domingo DIAGO (repoblador en Serra)}

Sabem de Domingo Diago que estava casat amb Isabel, de la qual trobem en 1622 que el seu cognom és Morell (potser fora filla del repoblador Francesc Morell). Però en canvi, en al menys altres quatre ocasions posteriors -i sense que conste que Diago enviduara ni es tornara a casar- ve recollida com a Isabel Simón (també Simona). Hi consta que en 1622 tingueren un nou fill: Francisco Christoval, el qual va morir en 1630, amb només 8 anys d'edat; també en 1621 havia mort una xiqueta de 2 anys, filla del matrimoni. Per últim, en 1626 nasqué una xiqueta que anomenaren Cathalina Maria.

Un altre fill i una altra filla de Domingo Diago i d'Isabel Simón o Morell van nàixer abans de 1619, i es casaren a Serra. Domingo Diago menor es va casar en 1640 amb Isabel Gimeno, veïna de Vaselga (Beselga, prop de Serra, terme d'Estivella), però quedà vidu en 1642. No obstant, el trobem com a veí en el cens de 1646, compartint casa amb Domingo Diago major. La filla era Maria Diago, que es va casar en 1645 amb Josep Sastre (Jusepe Suastre), natural d'Aldaia, qui també consta en el cens de 1646, com a 
"tierrateniente". Maria Diago va morir en 1646, desprès d'haver tingut una filla: Policarpa Jusepa.

El repoblador Domingo Diago va morir en 1651. També l'he trobat com a padrí de dos xiquets: Bartolomé Pérez (1623) i Joana Anna Rubio (1627); i com a testimoni de l'enllaç entre Joan Ibáñez i Catalina Garcia (1627).

\section{Miquel DOMINGO de Martí i}

\section{Miquel DOMINGO de Bartolomé (repobladors en Serra)}

De tots els cognoms de repobladors de Serra i Ria, el de Domingo és gairebé l'únic que ha perdurat clarament i extensa fins els nostres dies, sent molts els serrans que duen aquest antic cognom.

De Miquel Domingo de Martí no trobem cap referència en el quinque libri, però si de l'altre Miquel Domingo, el de Bartolomé, que estava casat amb Margarida Ximenes (de vegades li posen per cognom Gimeno, erròniament). Al menys tres dels seus fills barons es casen a Serra: Bartolomé, Miquel i Martín.

En l'acta de casament del primer fill, Bartolomé, posa que és "natural y habitador de Las Alcublas". Es casa en 1626 amb Maria Català, filla del repoblador de Nàquera Batista Català (però que en el certificat consta ja com a veí de Serra).

El segon fill, Miquel, també hi consta que és natural de Les Alcubles. Es casa en 1630 amb Clara Cavaller, la vídua de Juan Ribes, mort en 1628 i provablement fill d'un dels dos repobladors amb aquest cognom (Sebastià, de Serra o Miquel, de Ria).

El tercer fill, Martí, també consta com a "llaurador natural de Alcublas". Es casa amb Àngela Ribes, en 1640.

En 1624 es casa Isabel Joana Domingo, amb Juan Mauricio Mallach "llaurador de Serra”. No hi consta l'ascendència d'Isabel, però sembla que poguera ser filla d'un dels dos Miquel Domingo, repobladors. En 1630 mor aquesta Isabel Domingo, esposa de Joan Mallach.

En 1641 trobem que Miguel Domingo era el batlle de Serra. Així consta com a testimoni de l'enllaç entre Batista Domènech i Mariana Ribas.

El quadre 3.2 (Capítol 3) permet observar que, a més de la branca dels germans Bartolomé, Miquel i Martín (fills del repoblador Miquel Domingo i de Margarida Ximenes) hi ha una segona branca del cognom Domingo a Serra: la que correspon a Jusepe Domingo "natural de Las Alcublas", fill de Juan Domingo y de Catalina 
Domingo, que es casa en 1657 a Serra, amb la serrana Teodosia Moreno, filla de Domingo Moreno y Rafaela Donya. Les dos branques s'expandiran àmpliament en el temps.

El cognom Domingo també l'hem trobat ja present en l'economia tèxtil de l'Alt Palància de finals del segle XV i començaments del XVI ${ }^{1}$. Concretament hi ha referència d'un tal Bartolomé Domingo, pelaire, veí de Viver o Xèrica, com també dels germans Joan i Domingo, pelaires en Sogorb, i Joan Domingo, cordeller. També la Carta Pobla de Soneja i Assuévar recull dos repobladors de cognom Domingo, Martín i Pedro.

\section{Antoni ESTEVE (repoblador en Serra)}

Anton o Antoni Esteve estava casat amb Joana Romero (sovint està escrit "romera", una pràctica freqüent de feminitzar els cognoms quan s'apliquen a una dona). Abans de 1619, aquest matrimoni tenia almenys quatre fills: Martín, Joana Anna, Magdalena i Mateu², i desprès en tingueren dos fills més: Vicenta Agustina (“Austina”), en 1621, i Vicente Antonio, en 1623.

La filla major, Joana Anna, es casarà en 1626 amb Joan Batista Català, i en la inscripció es fa constar que ella és natural de Las Alcublas. Sembla evident, per tant, que el cognom Esteve o Esteban (al llarg del registre el trobem escrit d'ambdues formes, indistintament, per a les mateixes persones) procedeix també d'Alcubles. L'altra filla major, Magdalena, es casà en 1633 amb Domingo Navarro.

El repoblador Anton Esteve consta també com a testimoni dels enllaços matrimonials de Francesc Rubio ("llaurador de Les Alcubles") i Vicenta Cavaller (en 1625), i els de Donya-Puig (1628) i Mallach-Guillem (1630). Ell va morir en 1647, i la seua dona, Joana Romera, en 1656.

El fill menor, "Vicente Esteban" es va casar amb Vicenta Ramon i tingueren tres fills: Pasqual (n. 1656), Joan Batista (n. 1659) i Isabel (n. 1662). Desprès va morir violentament (“de un escopetaso") en 1663.

El cognom Esteve és un altre dels que arribaran a penetrar en el segle XVIII, i ho farà mitjançant Vicent (n. 1643), un nét d'Anton, i fill de Mateu.

\footnotetext{
${ }^{1}$ J. Aparici (2001)

${ }^{2}$ No sabem quin era l'ordre d'edat, però hi consta que Martín tenia 12 anys quan va ser confirmat en 1619 (per tant nasqué cap a 1607).
} 
Aquest cognom el trobem també present en l'economia tèxtil del Segle XV a la comarca de Sogorb: Bernat Esteban, sastre i habitador en Viver, i Joan Esteban, pelaire, veí de El 1 Toro ${ }^{3}$.

Recordem que en el capítol 3 d'aquesta Tesi hem presentat (uadre 3.2) l'expansió d'aquest cognom a Serra durant el segle XVII.

Jaume FONFRIA (repoblador en Serra),

Miquel GARRUÉS (repoblador en Ria) i

Miquel GRANELL (repoblador en Ria)

No hi he trobat cap rastre d'aquests tres repobladors en tot el quinque libri de Serra. No obstant, el primer i el tercer són cognoms que actualment es troben presents $i$ són habituals en diverses poblacions de l'Horta Nord, mentre que el segon podria ser d'origen navarrès o biscaí.

En el cas de Fonfria, el que si he trobat es que en 1631 o 1632 es casa a Nàquera ${ }^{4}$ Magdalena Fonfria, natural i habitadora en Alcàsser, filla de Miguel Fonfria i Vicenta Guardiola. També es troben persones amb aquest cognom en l'entorn de Sogorb i durant el segle XV (Joan Fonfria és un veí de Mançanera, ramader que ven llana a un veí de Xèrica $)^{5}$. No queda clar si l'origen del repoblador Jaume Fonfria es podria relacionar amb aquest entorn de la vall del Palància, o encara amb l'esmentada població de l'horta sud.

\section{Joan GUILLEM (repoblador en Ria)}

De Joan Guillem sabem que dues filles seues es van casar a Serra i una tercera a Nàquera. En 1623 va ser Bàrbera-Llorença Guillem "habitadora a Serra” qui contrau matrimoni amb Miquel Cavo (Cabo), de Nàquera. En 1630, Àngela Guillem es casà amb Juan Mallach, que era el vidu d'Isabel Domingo. I en 1634 es casà a Nàquera, amb el francès Domingo Naturille, Vicenta Guillem "natural de Serra i habitadora en Olocau", filla de Juan Guillem i Bàrbera Serret.

Potser també fora filla de Joan Guillem una tal Maria Guillem, que era difunta en 1637, doncs, el seu vidu, Francesc Rubio es casa dit any a Nàquera, amb Maria Navarro, també vídua.

\footnotetext{
${ }^{3}$ J. Aparici (2001).

${ }^{4} A P N$, llibre de casaments, primer volum del Quinque libri de Nàquera.

${ }^{5}$ J. Aparici (2001).
} 
Joan Guillem és el primer difunt registrat en el Quinque libri de Serra. Morí el 21 de febrer de 1620 "molt pobre". El van soterrar en el cementeri de Nàquera per no estar beneït encara el de Serra.

En 1618 trobem a Soneja un veí de nom Joan Guillem ${ }^{6}$, que no seria estrany fora fill o tinguera algun altre grau de parentesc amb el repoblador de Serra, si tenim en consideració la pertinença de Soneja al mateix Senyor i que Serra era sens dubte lloc habitual de pas dels veïns de Soneja cap a València.

En el segle XV, a la comarca de Sogorb ${ }^{7}$, hi ha constància del pelaire Antoni Guillem, i de Violant Guillem, que en 1518 era vídua d'un tal Pere-Gil Català.

\section{Pere IBÁÑEZ (repoblador en Serra)}

En 1624 trobem a Pedro Hivanes com a testimoni dels enllaços entre Joan Mallach i Isabel Domingo, per una part, i de Domingo Moreno con Rafela Donya, per altra. En el segon s'indica que Pero Yvanyeç és natural de Saragossa.

Pere estava casat amb Catalina Muñoz, i eren pares de Joan Ibáñez, nascut a Alcubles, qui és l'origen del llinatge dels Ibáñez de Serra i de Nàquera. Joan va estar casat tres vegades, per haver enviduat en dues ocasions. Primer es casà amb Catalina Garcia (1627), amb qui tingué tres fills; les amonestacions prèvies al casament les van fer a Alcubles. Desprès es casà amb Paula Domènech, en 1642, i tingueren dos fills. I per fi es va casar amb Francesca Mateu (vídua de Joan Ros), en 1647, i tingueren altres quatre fills.

Joan Ibáñez va morir en 1661, i aparenta haver sigut un personatge prou popular i estimat, ja que el trobem com a testimoni de diversos casaments i com a padrí d'almenys una desena de xiquets i xiquetes, tant de famílies del poble com d'alguns forasters.

\section{Menau LLANES (repoblador en Serra)}

De Menau Llanes sabem molt poca cosa, i encara que el cognom sembla d'origen asturià i el nom té certa afinitat "cantàbrica", hi trobem en el registre parroquial un tal Anton Llanes que procedia de València, i va ser testimoni de l'enllaç matrimonial entre Domingo Moreno menor i Rafela Donya, en 1624.

\footnotetext{
${ }^{6}$ És un dels signants del nou pacte i concòrdia, de l'any 1618, entre vassalls de Soneja i el Senyor, per tal de reduir les càrregues sobre les vinyes (veure $\mathrm{F}$. Iquino, 1982).

${ }^{7}$ J. Aparici (2001).
} 
En el testament de Miquel Saes $(1623)^{8}$ es troba com a testimoni un veí de Serra que es diu Antoni Llanes. No sé quina relació poguera haver-hi entre el dit Antoni i el Menau Llanes repoblador. Caldrà també recordar que aquest repoblador signà la carta de poblament (o siga, el seu jurament de fidelitat $\mathrm{i}$ vassallatge) tres dies desprès que la resta de repobladors, o siga, el dia 29 de novembre de 1609.

En els protocols del notari Joan Font ${ }^{9}$ trobem encara un altra referència a aquest repoblador, deixant clar que Perau Llanes (per Menau) va ser propietari d'un bancal que en 1620 pertanyia a Jaume Peres ${ }^{10} \mathrm{i}$ encara abans havia sigut del morisc Corcuix.

\section{Domingo MÁÑEZ de Miquel (repoblador en Serra)}

Totes les pistes de l'Arxiu Parroquial de Serra sobre aquest cognom es centren en Isabel Manyes, possible filla de Domingo Manyes.

La primera referència, cronològicament, és de 1624, en que morí un fill d'Anton Épila i Isabel Manyes; però en 1626, 1631 i 1632 moren també sengles fills d'aquest matrimoni. Antoni Èpila va morir en 1640, i 12 dies desprès de la seua mort morí encara un albat de dos mesos, també fill del difunt i d'Isabel Manyes.

Sembla que Isabel va tornar a casar-se potser dues vegades més, perquè en 1648 consta una inscripció nupcial d’Isabel Manyes "vídua de Martín Épila" (germà d'Anton?), amb Domingo Ripoll, natural de Caudiel.

El 27 de juliol de 1669 mor Isabel, “muger que fue de Domingo Ripoll”. Havia fet testament davant el notari Antoni Armengol, d'Algímia, i nomenà per marmessors a Pere Garay i a Francesc Épila (son fill). Demanava que el dia del seu soterrar "se cantassen dos missas amortajando su cuerpo con el hábito de San Francisco".

Finalment, en acte notarial de 1631 trobem que Miquel Manyes (potser fos fill del repoblador Domingo Manyes de Miquel) deu 70 lliures al matrimoni format per Anton Épila i Isabel Manyes (probablement la seua germana), en concepte de "lluïsme i quitament de censals".

\section{Francesc MORELL (repoblador en Serra)}

En 1619 és confirmat Domingo Diago, un xiquet de 4 anys fill de Domingo Diago major i de Isabel Morell.

\footnotetext{
${ }^{8}$ APCC, 21047; Font, 4/03/1623.

${ }^{9}$ APCC, 21045; Font, 21/11/1620.

${ }^{10}$ APCC, sg. 21047; Font, 20 de febrer de 1623.
} 
En 1622 s'inscriu el bateig d'un xiquet, Francisco Christoval, fill també de Domingo Diago i d'Isabel Morell, però podria haver-hi alguna confusió o errada, si tenim en compte -ja ho he referit- que en altres registres del quinque libri (un cas anterior $\mathrm{i}$ altres quatre posteriors), aquesta dona apareix amb un altre cognom (o apel·latiu, o malnom): Isabel Simón (o "simona").

Aquesta confusa referència és l'única que he trobat en el quinque libri sobre el cognom del repoblador Francesc Morell. Observe's, no obstant, la coincidència entre el primer nom del batejat i el del repoblador; tanmateix, el segon nom del batejat coincideix amb el del seu padrí: el biscaí Christoval Graciatey.

Segons acte del notari Joan Font, un tal Francesc Morell pannorum primi, habitador de la ciutat de València, li ven, per 16 lliures, una mula a Pere Martines menor, agricultor habitador en el lloc de Serra, en l'any 1615.

També a Sogorb trobem aquest cognom en el segle XVI ${ }^{11}$ : Bartomeu Morell, sastre, i fill del també sastre (difunt en 1488) Joan Morell.

\section{Joan MUÑOZ (repoblador en Serra)}

Del repoblador no he trobat cap referència en els registres parroquials, però si de Chathalina Munyoz, qui consta vàries vegades com a dona de Pere Ibáñez, també repoblador, i mare de Joan Ibáñez. Desconec el possible grau de parentesc entre aquesta dona i el repoblador Joan Munyoç, però bé podria ser la seua germana o la seua filla.

A Sogorb trobem en el segle XVI al mestre sastre Martí Munyoç ${ }^{12}$.

\section{Jaume NOGUERA (repoblador en Serra)}

L'única referència d'aquest cognom correspon a Bartolomé Noguera -de qui no es fa constar el seu origen- que es casa en 1629 amb Juanna Anna Cyprer, que indica ser vídua de Joan Rubio. Però també hi ha una situació confosa, doncs, la dona de Joan Rubio era realment Maria Siprer, segons consta en els batejos de tres dels seus fills, en els anys 1621, 1624 i 1627.

En els segles XV i XVI hi ha a l'alt Palància diversos personatges de cognom Noguera $^{13}$ : els pelaires de Sogorb Jaume (1480-1512) i Francesc (1503-1531), el teixidor, també de Sogorb Joannes (1414), i el pelaire de Xèrica Vicent (1455-59). No obstant, hi

\footnotetext{
${ }^{11}$ J. Aparici (2001).

${ }^{12}$ Ibidem.

${ }^{13}$ Ibídem.
} 
ha una altra opció, potser més clara i inerassant per al primer Noguera de Serra, i es que, segons fonts mallorquines ${ }^{14}$, en 1610 hi ha un mallorquí, anomenat Joan Noguera, natural de Lluch Major, residint al Regne de Velència, suposadament a Serra "devora la baronia d'Olocau, el feu de Joan de Vilaragut, virrei de Mallorca" (Mas i Forners, 2002; p. 61).

\section{Marc PALACIO i}

\section{Joan PALACIOS (tots dos repobladors en Serra)}

De cap dels dos repobladors trobem cap referència en el registre parroquial. No obstant, cal indicar que el cognom Palacio es troba instal lat en la comarca de Sogorb ja en el segle $X V^{15}$, per la qual cosa, tampoc seria estrany que haguera arribat fins a Serra des d'aquell entorn, tenint en compte la relació tan directa que existia, per proximitat, entre la ciutat de Sogorb i la cartoixa de Val de Crist, la qual posseïa, com ja he dit abans, els llocs d'Altura i d'Alcubles. Així, Bartomeu Palacio és un sastre que al voltant de 1415 participa en operacions comercials, una d'elles relacionada amb un censal "al piquero de Valencia Pere Balaguer". Però més tard trobem a un personatge dit, com el repoblador de Serra: Marco Palacio, pelaire que, entre 1445 i 1449, és obligat a tornar certa quantitat que devia.

De Joan Palacios ja hem vist, en parlar de la carta pobla, que no hi consta de manera fefaent la seua signatura; doncs el dia 26 de novembre estava absent de Serra $\mathrm{i}$ desprès ja no es fa constar quin dia va signar (si es que arribà a fer-ho).

\section{Sebastià RIBES (repoblador en Serra) i Miquel RIBES (repoblador en Ria)}

Són diverses les referències al cognom Ribas o Ribes, que tan prompte apareix escrit d'una manera com de l'altra, referint-se a la mateixes persones i llinatge. Però totes les referències de Serra se centren en Pere Joan Ribes i llurs descendents. No hi cap pista que demostre si Pere Joan era fill de Miquel o bé de Sebastià, però el que si deixen clar diversos assentaments és que era llaurador i de Serra. Estava casat amb Clara Cavaller i va morir -sembla que prou jove- en 1628. La vídua es tornà a casar, en 1630 amb Miquel Domingo, natural d'Alcubles, i tingué encara altres sis fills (l'últim nascut en 1642).

\footnotetext{
${ }^{14}$ Estudis de Bartomeu Font, citat per Antoni Mas i Forners: Per poblar lo regne de Valentia. L'emigració mallorquina l País Valencià en el segle XVII. Col·lecció Els Camins de la Quimera, 5. Ed. Conselleria de Presidència. Govern de les Illes Balears. 2002.

${ }^{15}$ Ibidem.
} 
Del matrimoni de Clara Cavaller amb Pere Joan Ribes, hi consten quatre inscripcions de batejats: Vicenta (1621), Àngela (1623), Caterina (1625) i Pere-Joan (1627). A més devien tenir al menys una altra filla, nascuda abans de l'inici del quinque libri, de nom Marianna, qui es va casar en 1641 amb Batista Domènech, natural de Carpesa. També trobem a Pere Joan com a testimoni dels enllaços entre Joan Mallach i Isabel Domingo (en 1624) i entre Francisco Rubio (d'Alcubles) i Vicenta Cavaller (la seua cunyada, natural de Carpesa), en 1625.

També la seua filla Àngela Ribes, es casa en 1640 amb un altre alcublà, Martín Domingo, encara que enviduà dues vegades i tornà a casar-se, primer amb el francès Esteve Soler (1641) i desprès amb Juan Lázaro (1663). Amb el primer marit tingué 8 fills, un amb el segon i altres tres amb el tercer.

Amb totes aquestes dades sembla provable la possible ascendència, o bé certa estreta relació, de Pere Joan amb Alcubles, i de la seua dona Clara Cavaller, amb Carpesa.

\section{Joan RUBIO (repoblador en Ria)}

En el Llibre de Batejats, el matrimoni format per Joan Rubio i Anna Siprer (o Cyprer) té inscrits tres fills: Felicia (1621), Vicenta (1624) i Joana Anna (1627), però també tenien almenys altres dos fills anteriors: Joan, que va ser confirmat en 1619 (amb només 3 anys d'edat), i Vicent Rubio, que es va casar en 1464 amb Vicenta Navarro, continuant així el llinatge dels Rubio de Serra, que entra per aquesta branca en el segle XVIII i fins i àdhuc fins el present.

Poc desprès trobem encara un altre veí a Serra, Francisco Rubio, que duu aquest cognom, però que és "llaurador de Les Alcubles i habitador en Nàquera", fill de Francisco Rubio i de Caterina Romero. En 1625 es casa aquest alcublà resident en Nàquera amb Vicenta Cavaller, natural de Carpesa, i seran pares de deu fills nascuts $i$ batejats a Serra entre i 1627 i 1645 . Però aquest llinatge no tindrà continuïtat a Serra.

Com en altres casos, en el registre parroquial s'empra i alterna, indistintament, la grafia Ruvio (dominant) amb la de Rubio, encara tractant-se d'una mateixa persona.

Per les dades anteriors, resulta suggeridora la possibilitat de que també els Rubio procediren d'Alcubles. I abundant en aquesta idea també trobem el cognom Rubio en el ram tèxtil de l'Alt Palància, durant el segle $\mathrm{XV}^{16}$.

\footnotetext{
16 Domingo Ruvio, veí de Mançanera, ven llana a un peraire de Xèrica, en 1488 (APARICI, 2001; pàg. 32)
} 
En el quadre 3.3 hem mostrat la nissaga dels Rubio en la Serra del segl XVII.

\section{Miquel SÁEZ (repoblador en Serra)}

Miquel Sáez estava casat amb Isabel Sayas o Sayal, i en 1619 van ser confirmats dos fills seus: Juan (9 anys) i Francesca (6 anys). No obstant, en una referència de $1631^{17}$ consta que Joan Sáez, veí de Serra, és fill de Miquel Sáez i Isabel Domingo.

Miquel Saeç va morir el 22 de febrer de 1623, desprès d'haver fet testament davant fra Gil Herrero (franciscà) i haver-lo donat al notari Joan Font. Nomenà per marmessors al rector de Serra i Nàquera, Hieroni Sastre, i a Joan Català, veí d'Alcubles.

Pel seu testament ${ }^{18}$ coneixem que realment tenia més fills, sense que sapiam exactament quants; i coneixem també la relació dels seus bens, posant-se de manifest que aquest home era apicultor, a més de viticultor i colliter de cereal. De fet, en el seu testament expressa la seua voluntat de que per als oficis fúnebres es dispose de pa, vi i cera de sa casa. A més, llega a l'església 12 lliures, que serien 10 per a daurar el sagrari i les altres 2 per a una creu en l'altar.

Sembla que només continua a Serra el seu fill Joan Saeç, casat en 1631 amb Mariana Tortaxada (cognom de Nàquera), i que foren pares dels següents batejats: Isabel (1632), Jorge Vicente (1634), Àngela (1636), Miquel Joan (1638) i Olàlia Caterina (1640). En 1635 mor un albat del matrimoni (cal suposar que seria Jorge).

Encara en l'any 1636 es casà un altra filla de Miquel, Francesca Sáez “natural de Serra i habitadora en Montcada", amb Marco Boya, natural de Montcada.

Com a últim registre del cognom Sáez en els llibres parroquials, hi consta que en 1664 es casa a Serra la seua filla menor, Caterina, amb Antoni Blasco, de Beselga (lloc d'Estivella).

Antoni SALVADOR (repoblador en Serra), Lluch SALVADOR (repoblador en Ria) i Joan SALVADOR (repoblador en Ria)

Les escasses dades trobades sobre aquest cognom en el registre parroquial no sempre deixen clar que es tracte dels propis repobladors, de llurs fills o d'alguna altra

\footnotetext{
${ }^{17}$ Arxiu Parroquial de Nàquera, Quinque libri, acta de casament amb Mariana Tortaxada, 8 d'octubre de 1631.

${ }^{18}$ APCC, 21047; Font, 4/03/1623.
} 
persona, de la qual no queda clar el possible grau de parentesc amb els repobladors, encara que sembla, el més provable, que hi tingueren tots ells certa relació familiar directa. En tot cas, com veurem tot seguit, són sempre referències que apunten la possibilitat de que el cognom procedira de la ciutat de València.

Així trobem que en 1623, Juan Salvador (bé podria ser el propi repoblador de Ria, o un fill seu) "mercader de València", consta com a un dels testimonis de l'enllaç entre Miquel Cabo i Bàrbara Guillem (una de les filles d'un altre dels repobladors de Ria, Joan Guillem).

A Antoni Salvador "habitador en Serra" (possiblement el repoblador) també el trobem com a testimoni dels enllaços Català-Esteve i Ibàñez-Garcia, tots dos en 1626.

Per altra part trobem, com a testimonis de l'enllaç Domingo Català, també en l'any 1626, al Doctor Vicente Salvador "cavallero, veçino de Valencia", i a Gaspar Salvador, "vesino de Valencia".

L'única descendència del cognom Salvador que continua a Serra passant la barrera del segle XVII, és la d'Anton Salvador (supose que es tracta del repoblador de Ria, Anton Lluch Salvador), que estava casat amb "Eufemia Terguel” (Eugènia? Teruel). Una filla d'aquest matrimoni, Josepa "natural de Serra y habitadora en València" es va casar en 1639 amb Miquel Bou, de València. Un altre fill del matrimoni, Agustí Salvador, que havia nascut cap a 1615 (va ser confirmat en 1619, amb 4 anys) es casà amb Marianna Ruvio, a Serra, l'any 1645.

Anton Salvador va morir a Serra el 15 de maig de 1631, i en el seu testament, entre altres disposicions, encomana que es celebren vuit misses per la seua ànima en "San Salvador de València". Catorze dies abans (el primer de maig) havia mort la seua dona Heufemia Teruel.

Agustí Salvador i Mariana Rubio tingueren al menys sis fills: Joan Josep Bartomeu (n. 1646), Jaume Francés Agustí (1649), Josepa Vicenta (1651), Agustí Antoni (1654), Francesca Dorotea (1657) i Maria (no hi consta batejada, però es casa a Serra, en 1673 amb Sebastià Bort, de Traiguera).

Jaume Salvador, fill d'Agustí i Mariana, es casa en 1674 amb Vicenta Arnal, amb qui tindrà almenys dues filles abans d'acabar el segle. Un tal Manuel Salvador, l'ascendència del qual no queda ben clara, també es casaria, pel mateix temps amb Anna Maria Arnal, sent pares d'una xica, Apolinaria Josepa, en 1676. 
Malgrat que el cognom Salvador "de Serra" arriba al segle XVIII, acabarà extingint-se, doncs no el trobem ja en un capbreu de l'any $1779^{19}$.

\section{Bertomeu SALVATERRA (repoblador en Serra)}

En el quinque libri no es troba cap referència sobre aquest repoblador ni sobre el seu cognom. No obstant, sembla un cognom d'origen toponímic que tindria el seu més probable origen en una població de la província d'Osca pegada a la de Navarra: Salvatierra de Esca, en la vall del Roncal (Navarra). Recolzant la possibilitat de que estiguérem d'avant un repoblador d'origen navarrés, hi trobem que Joan Bautista Donya, el batlle de Serra, resident a València, té relacions comercials amb aquest llister d'origen basc, anomenat Pere Joan Salvaterra, amb qui coincideix en nombrosos actes comercials $^{20}$.

Miquel SANCHIS (repoblador en Serra), Joan SANCHIS (repoblador en Serra) i Antoni SANCHIS (repoblador en Ria)

Les referències a aquest cognom són molt escasses. Pràcticament es redueixen a Donisa Sanchis "natural $i$ habitadora en Gàtova", qui es casa en 1639 amb Matheo Estevan. Tenen cinc fills, batejats a Serra, i ella mor en 1653. En la inscripció del casament, Donisa apareix amb el cognom "Sangez", en la resta d'assentaments hi consta també "Sanches" i més encara "Sanchis", que és la forma que consta en la seua defunció. Encara que en 1666 hi trobem l'enllaç entre Cristòfol Cabo i Inés Sánchez, ell de Cantoria (Almeria) i ella de Carcaixent, i filla de Juan Sánchez i Florentina Sánchez, no sembla que aquesta tinga cap relació amb els Sanchis de Serra.

Informació prou més interessant es troba en el testament de Violant Vallés ${ }^{21}$, muller de Jaume Moreno, però que va ser-ho abans d'Antoni Sanchis, el seu primer marit, que era natural d'Alcubles. Aquell, en marxar d'Alcubles per a vindre a Serra, va vendre en aquell poble la casa que tenia.

\section{Vicent Sarigó RIBERA (repoblador en Ria)}

\footnotetext{
${ }^{19}$ AHN/SN, Montellano, 2220/1.

${ }^{20}$ APCC, sg. 20584, Not ${ }^{\circ}$ Font, 10/02/1631

${ }^{21}$ APCC, 21046, Font, 4/03/1620.
} 
No hi consta cap referència a aquest cognom en el quinque libri de Serra.

\section{Joan TERUEL (repoblador en Serra)}

L'única referència del quinque libri a aquest cognom a Serra correspon al cas d'Eufèmia (Eugènia?) Teruel, la dona d'Anton Salvador, un dels repoblador de Ria. Ja he comentat que aquest matrimoni va tindre, al menys dos fills, Jusepa i Agustí. Probablement aquesta dona fora germana de Joan Teruel i aquest morira abans de 1619, i potser sense descendència.

En l'Arxiu Parroquial de Nàquera també he trobat una inscripció de bateig de l'any 1627, en que hi consta un tal Pedro Teruel, veí de València, com a padrí de Joana Catalina Falbres (filla del batlle de Nàquera, Miquel Falbres).

Una informació certament interessant és que Eufèmia Teruel va morir a Ria, el primer de maig de 1631. Això significa la darrera referència cronològica concreta que ve a demostrar com Ria encara estava habitada en dit any (al menys devia quedar encara una casa en peu!).

Pocs mesos abans d'aquesta defunció, la mare d'Eufèmia Teruel, Petronila Hernández, sembla que d'edat avançada i trobant-se malalta, va fer testament ${ }^{22}$, pel qual sabem que aquesta dona estigué casada amb Bartomeu Teruel (el seu primer marit) amb qui tingué dues filles, l'esmentada Eufonia i Isabel Teruel (en 1631 era vídua de Sancho). Potser el repoblador Joan Teruel fora també germà d'aquestes dues dones.

\section{Domingo VILANOVA (repoblador en Ria)}

Tampoc no hi consta cap referència a aquest cognom en el quinque libri de Serra.

\footnotetext{
${ }^{22}$ APCC, sg. 20584, Font, 24/02/1631
} 


\section{ANNEX V \\ CENSOS I DOMINIS ÚTILS SEGONS EL CAPBREU DEL 1779}

Font: AHN (FN), c. 2.220, doc. 1)

La present relació ha estat elaborada a partir del cabreu anomenat "Apeo, empadronamiento, o Cabrebe general de los vecinos terratenientes de la Baronía de Serra, que por las Casas y tierras que tenían, pagaban sus respectivos censos anuales". No es tracta per tant d'un autèntic cens de veïns, sinó d'una relació de persones i béns que paguen censos al senyor directe de la baronia. Aquest instrument permet conèixer el nombre de cases de Serra i "de Ria", com també particions de cases i acumulació de vàries en un mateix propietari útil. També permet elaborar un cens de veïns separant-ne els que són propietaris de cases d'aquells que no ho són (però podrien tindre-la arrendada). Les dades corresponen a l'època en que era Senyor de la baronia de Serra Alons de Solís Folch de Cardona, V duc de Montellano.

Abans d'exposar les dades es fa necessari introduir alguns aclariments i consideracions:

- La llista és realment de contribuents, que no necessàriament de veïns vassalls, per això està com a tal l'Ajuntament (que paga pel cens de la casa-ajuntament, comuna), el retor (recent difunt, Joan Batiste Costa), el "curato de Serra" que té només un jornal de secà, el metge (Dr. Roque Pérez) i, podem preveure que fins i tot algunes persones que no foren realment residents a Serra però si propietàries de terres.

- En la columna de les CASES venen referides únicament les del "lloc de Serra".

- La columna de les HORTES recull la superfície total en fanecades de cada veí, seguida entre parèntesi del nombre de parcel·les en que es repartia dita superfície.

- La columna SECÀ està feta amb el mateix criteri que la de les hortes però la superfície ve ara indicada en jornals.

- Les Cases a Ria (en la columna ALTRES) entenem que són cases d'habitació ubicades en el raval annex a Serra, més conegut com El Bàrio. Sembla evident que es manté el nom de Ria per coherència y en consonància amb el contingut de la cartapobla, doncs, com ja sabem, l'antic lloc de Ria ja es trobava totalment deshabitat en el segon terç del segle XVII.

\begin{tabular}{|c|c|c|c|c|c|}
\hline NOM & COGNOM & CASA & HORTA & SECÀ & ALTRES \\
\hline & Ajuntament & 1 & & & \\
\hline Antoni & Arazo & 1 & & 1 & \\
\hline Abdó & Arnal & 1 & 1 & $2.5(2)$ & \\
\hline Antoni & Arnal & & & 1 & \\
\hline Cristòfol & Arnal & 1 & $5(4)$ & $16(8)$ & casa Ria \\
\hline
\end{tabular}




\begin{tabular}{|c|c|c|c|c|c|}
\hline Eusebi & Arnal & & 1 & $7.5(6)$ & casa Ria \\
\hline Francesc de Francesc & Arnal & 1 & & $8.5(4)$ & \\
\hline Francesc de Josep & Arnal & & & 1 & \\
\hline Francisca & Arnal & 1 & $3.75(4)$ & $6(4)$ & casa Ria \\
\hline Joaquin (major) & Arnal & 1 & $7.5(6)$ & $30.25(13)$ & casa Ria + paller \\
\hline Joaquim de Francesc & Arnal & 1 & 0.25 & $6.5(3)$ & \\
\hline Josepa & Arnal & 1 & 0.5 & $5(2)$ & \\
\hline Manuel & Arnal & & & $3(3)$ & \\
\hline Maria & Arnal & & 0.75 & $3.5(2)$ & casa Ria \\
\hline Mariana & Arnal & & $2(2)$ & $5(5)$ & casa Ria \\
\hline Vicent de Vicent & Arnal & 1 & $6(4)$ & $6.25(7)$ & casa Ria + corral + era \\
\hline Vicente de Salvador & Arnal & $1+1$ & $4(4)$ & $31.5(10)$ & Paller \\
\hline Andreu & Cabo & 1 & 0.5 & $10(3)$ & \\
\hline Batista de Josep & Cabo & 1 & 2 & $14(6)$ & casa Ria \\
\hline Batista de Marià & Cabo & 0.5 & 1 & $9(3)$ & casa Ria \\
\hline Batista de Luis & Cabo & 1 & $4.25(3)$ & & \\
\hline Casimir & Cabo & & 0.75 & & \\
\hline Cebrià & Cabo & 1 & $2(2)$ & $19(7)$ & casa Ria \\
\hline Cristòfol & Cabo & 1 & $2.25(3)$ & $14(7)$ & casa Ria \\
\hline Francesc de Martí & Cabo & & 0.75 & & \\
\hline Francisco & Cabo & 1 & 2 & $24.5(8)$ & casa Ria \\
\hline Gertrudis & Cabo & & & 2 & \\
\hline Josepa & Cabo & & 3 & & \\
\hline Lluís (major) & Cabo & 1 & $4(3)$ & $25.5(9)$ & Era \\
\hline Lluís (menor) & Cabo & 0.5 & & $5.5(4)$ & \\
\hline Marià & Cabo & 1 & $3.25: 3$ & $22.5(11)$ & casa Ria \\
\hline Martí & Cabo & 1 & & $5(2)$ & \\
\hline Mateo & Cabo & & & 1 & \\
\hline Maties de Josep & Cabo & 1 & $3.75(4)$ & $10(7)$ & \\
\hline Maties de Miguel & Cabo & & 1 & 3 & \\
\hline Miguel & Cabo & 1 & $3(2)$ & $13.5(13)$ & casa Ria \\
\hline Pascual & Cabo & 1 & & $7(4)$ & casa Ria \\
\hline Teresa de Martin & Cabo & & 1.5 & 0.25 & casa Ria \\
\hline Tomás de Francesc & Cabo & 1 & $3(2)$ & $16(3)$ & casa Ria \\
\hline Tomás de Luis & Cabo & 1 & 1 & $9(5)$ & casa Ria \\
\hline Tomás de Tomás & Cabo & & & 1 & \\
\hline Ventura & Cabo & $1+1$ & $3.75(4)$ & & casa Ria \\
\hline Vicente de Luis & Cabo & 0.5 & & $4.5(3)$ & \\
\hline Vicente de Miquel & Cabo & 1 & 1 & $7(6)$ & \\
\hline Vicente de Pascual & Cabo & 1 & 1 & $11.5(3)$ & \\
\hline Jeroni & Català & & 0.75 & $8.5(4)$ & \\
\hline Josepa & Català & 1 & 1 & $12(4)$ & casa Ria \\
\hline Francesc de Francesc & Català & & & $7(3)$ & \\
\hline Batista & Català & 1 & $3.5(2)$ & $17.5(7)$ & casa Ria \\
\hline Francesc de Josep & Català & 1 & 1.5 & $14.5(8)$ & casa Ria \\
\hline Josep de Josep & Català & 1 & 2 & $18.5(9)$ & casa Ria \\
\hline Pedro & Català & 1 & $2(2)$ & $22.5(15)$ & Casa Ria + $1 / 2$ corral \\
\hline Teresa & Català & $1+1$ & $1.25(2)$ & $4.25(3)$ & casa Ria \\
\hline Vicenta & Català & $1+1$ & 2 & $20.5(7)$ & casa Ria \\
\hline Vicente de Francesc & Català & & & $6(3)$ & \\
\hline Vicente de Josep & Català & & & $9(2)$ & \\
\hline Francisco & Catalan & 1 & $2.75(2)$ & $15.25(8)$ & casa Ria \\
\hline Francisco & Caudete & 1 & & $5(2)$ & \\
\hline
\end{tabular}




\begin{tabular}{|c|c|c|c|c|c|}
\hline Joan Batista (difunt) & Costa (retor) & 1 & $6.5(2)$ & $14(6)$ & Era \\
\hline "curato de Serra" & & & 1 & & \\
\hline Blai & Dasí & 1 & $11.5(5)$ & $35(5)$ & casa Ria + corral + era \\
\hline Agustí & Dolz & 1 & & 1 & \\
\hline Andreu & Dolz & & & $2.25(3)$ & \\
\hline Batista & Dolz & 1 & $2(2)$ & $22.5(9)$ & \\
\hline Francisco & Dolz & $2 / 3+1 / 3$ & 2 & $18(9)$ & casa Ria +era \\
\hline Pascual & Dolz & & & 1.5 & \\
\hline Batista & Domènec & 0.5 & $8.25(4)$ & $2(3)$ & Corral + era \\
\hline Francisco & Domènech & 0.5 & $11(6)$ & $9.75(6)$ & \\
\hline Josep & Domènech & 1 & $3.5(3)$ & $4.75(5)$ & casa Ria \\
\hline Roque & Domènech & 1 & $6.5(2)$ & $32(11)$ & paller + corral \\
\hline Vicente & \multicolumn{2}{|l|}{ Domènech } & 1 & $4(2)$ & \\
\hline Joaquin & Domingo & $1+1$ & $2.75(4)$ & $24.25(12)$ & casa Ria \\
\hline Manuel & Domingo & 1 & 1 & $13(7)$ & casa Ria \\
\hline Batista & Escrig & 1 & 1.5 & $1.5(2)$ & \\
\hline Francisco & Escrig & & 1 & $10.5(5)$ & casa a Ria \\
\hline Joaquin & Escrig & 1 & 1 & $3.5(4)$ & \\
\hline Josep (major) & Escrig & 1 & 1.5 & $13.5(3)$ & casa a Ria \\
\hline Josep (menor) & Escrig & & $1(2)$ & 3 & \\
\hline Josepa & Escrig & 1 & $7.25(4)$ & $10.5(6)$ & casa Ria + paller +2 corrals \\
\hline Juan & Escrig & & 0.5 & 2 & \\
\hline Lorenzo & Estela & & 1 & $3(2)$ & \\
\hline Domingo & Esteve & $1+1+1$ & $10.5(7)$ & $23.75(15)$ & Corral \\
\hline Bàrbara & Fabregat & & & $1.75(2)$ & \\
\hline Domingo & Fabregat & & 1.5 & 2 & \\
\hline Francisco & Fabregat & & 0.25 & $9.25(4)$ & \\
\hline Pascual & Fabregat & 1 & 1 & $8.5(4)$ & casa Ria \\
\hline Vicente & Fabregat & & & $3.25(2)$ & \\
\hline Josep & Falomir & & & $3.5(2)$ & \\
\hline Juan & Falomir & 1 & $2(2)$ & $21.75(10)$ & casa Ria \\
\hline Vicente & Fenollosa & & 1 & $2(2)$ & \\
\hline Isidro & Ferrara & & 0.75 & $6.5(3)$ & \\
\hline Melcior & Ferrara & 1 & & $3(2)$ & \\
\hline Francisco & Ferrer & & & 1 & \\
\hline Roque & Fos & 1 & 1 & $5.25(5)$ & casa Ria + era \\
\hline Vicente & Fos & & 0.5 & $8.5(5)$ & \\
\hline Lorenzo & Garay & $1+1$ & 1 & $14.75(9)$ & \\
\hline Josep & Gimeno & $1+1$ & $1(2)$ & $16(10)$ & \\
\hline Vicente & Inglés & 1 & $3.5(3)$ & $4(2)$ & casa Ria \\
\hline Josep & Iranzo & & & $4(3)$ & \\
\hline Josep & Laparra & 1 & & & \\
\hline Batista & Lluch & 1 & $2.25(2)$ & $12(3)$ & Era \\
\hline Inés & López & 1 & 0.5 & $2.25(3)$ & casa Ria \\
\hline Josep (major) & Martínez & & $2(2)$ & $4(3)$ & \\
\hline Josep (menor) & Martínez & $1+1 / 3$ & & $7.5(6)$ & \\
\hline Tomassa & Mico & 1 & & 2 & \\
\hline Ramón & Montero & 1 & & $5(2)$ & casa Ria \\
\hline Francisco & Muñoz & 1 & & $15.5(4)$ & \\
\hline Manuela & Muñoz & & 1.5 & $2(2)$ & \\
\hline Batista de Vicent & Navarro & 1 & 1 & $4(2)$ & \\
\hline Bernat & Navarro & $1+1$ & $5(4)$ & $22(11)$ & \\
\hline Francesc de Batista & Navarro & 1 & $1.5(2)$ & $16.75(12)$ & casa Ria \\
\hline
\end{tabular}




\begin{tabular}{|c|c|c|c|c|c|}
\hline Francesc de Domingo & \begin{tabular}{|l|} 
Navarro \\
\end{tabular} & $1+1$ & $3(2)$ & $37.75(9)$ & Era \\
\hline Francesc de Francesc & Navarro & & $1.5(2)$ & $4.5(2)$ & \\
\hline Francesc de Vicent & Navarro & 1 & $2.5(2)$ & $25.5(10)$ & \\
\hline Jaume & Navarro & 1 & $6(3)$ & $19.5(10)$ & casa Ria \\
\hline Josep de Batista & Navarro & 1 & 0.25 & $6.75(7)$ & \\
\hline Josep de Domingo & Navarro & 1 & $3.5(4)$ & $13.5(9)$ & \\
\hline Josep de Pasqual & Navarro & 0.5 & 1.25 & $11(4)$ & casa Ria \\
\hline Josep de Salvador & Navarro & 1 & 0.5 & $11.5(4)$ & \\
\hline Juan Batista & Navarro & $1+1$ & 1.5 & $63.5(19)$ & casa Ria + corral + era \\
\hline Manuel de Vicent & Navarro & 1 & 2 & $15.25(10)$ & \\
\hline Pedro & Navarro & 1 & 2 & $21(7)$ & \\
\hline Teresa & Navarro & 1 & & $3.5(2)$ & casa Ria \\
\hline Ventura & Navarro & 1 & $2(3)$ & $12.5(6)$ & casa Ria \\
\hline Vicente de Esteban & Navarro & 1 & 3 & $17.25(8)$ & casa Ria \\
\hline Vicente de Josep & Navarro & 1 & 1 & $6.5(4)$ & \\
\hline Vicente de Pascual & Navarro & 0.5 & $2.25(2)$ & $7(4)$ & casa Ria \\
\hline Vicente de Salvador & Navarro & 1 & $4.5(3)$ & $16(7)$ & \\
\hline Francisco & Palma & & & 3 & \\
\hline Felix & Panach & & & 2 & \\
\hline Maties & Pasqual & 1 & $4(4)$ & $13(5)$ & casa Ria \\
\hline Francisco & Pérez & 0.5 & $2.5(2)$ & $18.75(11)$ & casa Ria \\
\hline Francisco (menor) & Pérez & & 1 & $5(3)$ & \\
\hline Domingo & Pérez & 1 & 1 & $10(3)$ & casa Ria \\
\hline Dr. Roque & Pérez & 1 & $1.5(2)$ & $5(2)$ & \\
\hline Joaquin de Cristòfol & Pérez & 1 & 1.5 & $12.5(4)$ & corral (Cova Gran) \\
\hline Joaquin de Jaume & Pérez & 1 & $2.5(3)$ & $25.25(11)$ & Paller \\
\hline Juan & Pérez & 0.5 & 1.5 & $13.75(6)$ & casa Ria \\
\hline Valero & Pérez & 0.5 & $2.5(2)$ & $16.5(8)$ & casa Ria \\
\hline Francisco & Puig & 1 & $2(2)$ & $18.5(11)$ & casa Ria \\
\hline Josep & Puig & 1 & $2.25(3)$ & $12(6)$ & casa Ria + era \\
\hline Maria & Puig & $1+1$ & $2(2)$ & $3(4)$ & casa Ria \\
\hline Pedro (major) & Puig & 1 & $2.5(2)$ & $9(8)$ & casa Ria \\
\hline Pedro (menor) & Puig & 0.5 & & $5(2)$ & \\
\hline Batista & Regulat & 1 & $1.75(2)$ & $7(5)$ & \\
\hline Francesc de Francesc & Romero & 1 & & $7(3)$ & \\
\hline Jeroni & Romero & 1 & $2(2)$ & $11(6)$ & \\
\hline Manuel & Romero & & 1 & 0.5 & \\
\hline Pasqual & Romero & & & 1.5 & \\
\hline Tomàs & Romero & & 0.5 & 0.5 & \\
\hline Bertomeu & Ros & $1+1$ & $9.5(6)$ & $15(7)$ & casa Ria + paller + era \\
\hline Batista de Batista & Ros & 1 & $7(4)$ & $19(12)$ & \\
\hline Batista de Josep & Ros & & & 1 & \\
\hline Batista d'Andreu & Ros & & & $3,5(2)$ & \\
\hline Francesc d'Andreu & Ros & 1 & $2(2)$ & $15.5(7)$ & \\
\hline Francesc de Bertomeu & Ros & & 2 & $5(2)$ & \\
\hline Francesc de Batista & Ros & & & $5(5)$ & \\
\hline Josep de Andrés & Ros & & & $4.25(3)$ & \\
\hline Josep de Pere & Ros & 1 & $2.5(2)$ & $7.5(7)$ & \\
\hline Juan & Ros & 1 & 1 & $8.5(5)$ & casa Ria \\
\hline Manuel & Ros & & 1 & $4.5(3)$ & casa Ria \\
\hline Miguel & Ros & 1 & $1.5(2)$ & $12.5(11)$ & casa Ria \\
\hline Pere de Batista & Ros & 1 & 2 & $5.75(6)$ & \\
\hline Pere de Pere & Ros & 1 & $3.75(3)$ & $7.5(6)$ & casa Ria \\
\hline
\end{tabular}




\begin{tabular}{|l|l|c|c|c|l|}
\hline Vicente & Ros & 1 & $3(2)$ & $17.5(9)$ & casa Ria \\
\hline Francesc de Josep & Rubio & 1 & 1 & $12.5(9)$ & casa Ria \\
\hline Francesc (major) & Rubio & 1 & 4 & $4(3)$ & \\
\hline Josep & Rubio & $1+1$ & $4(2)$ & $23.5(7)$ & casa Ria \\
\hline Josep de Josep & Rubio & & 1 & $15(10)$ & \\
\hline Josepa & Rubio & 1 & & 1 & \\
\hline Baltasar & Sanchis & 1 & $2(2)$ & $13(7)$ & \\
\hline Joaquin & Sanchis & 1 & $1+1$ & $7.5(4)$ & \\
\hline María & Sanchis & 1 & & 0.25 & \\
\hline Vicente & Sanjuan & 1 & 1 & $13(9)$ & \\
\hline Francisco & Tamborero & 0.5 & & $2.75(2)$ & \\
\hline Carles & Tomàs & 1 & 0.2 & $7(4)$ & \\
\hline Francisco & Tomàs & & & $12(5)$ & \\
\hline Josep & Torrente & & & 6 & \\
\hline Tomás & Verche & 1 & $1+1$ & $10(4)$ & casa Ria \\
\hline
\end{tabular}




\section{ANNEX VI \\ LLIBRE DE COMPTE I RAÓ DE L'OBRA DEL TEMPLE PARROQUIAL DE DE SERRA}

(APS, llibre escrit fins a 1806 pel rector Francesc Tormo)

Recull aquest Annex VI la transcripció del quadern titulat "Libro de Cuenta y Razón de la Obra y fábrica de la Yglesia de Serra", que va ser escrit pel rector Francesc Tormo Vidal (rector titular entre 1796 i 1807), amb el subtítol següent: "Motivos que dieron ocasión á la fabrica de la nueva Iglesia, principio que tuvo, progresos, y total terminación con otras noticias dignas de memoria. Ano 1806.":

f. $1 v^{o}$

Este lugar de Serra en tiempo del Beato Patriarca Ribera, y como consta de las Visitas de su tiempo no se componía más que de 18 Casas de Cristianos nuevos, y 17 el lugar de Ría, oy despoblado. En la visita del año 1579 se manda alargar la Iglesia de modo que quepan los Vecinos de los dos Lugares de siete años arriba, que forme el Cura un Padrón y los nombre al tiempo del Ofertorio, toda esta disciplina era necesaria a los recién convertidos, y los ejecute a los que faltaren á la Misa con las penas de la Constitución. Esta primitiva Iglesia, ò Capilla, que se manda alargar, estaría situada a al entrada de este nuevo templo, ya por ser lugar más proporcionado; ya también por haberse hallado en los cimientos indicios de ello. Creció la población, y pareciendo corta la Iglesia, trataron hacer nuevo templo: Se puso en ejecución, y se colocó la primera piedra en 14, de Mayo de 1677. que bendijo el Ldo. Mossèn Josef Tárraga Rector de Godella, en presencia del Mossèn Bartolomé Greses Cura actual de esta parroquia. Todo consta de una apuntación de dicho Cura en el Quinque Libri de entonces.

f. $2 \mathrm{r}^{\mathrm{o}}$

Este templo, fabricado según la arquitectura y gusto antiguo, era seguramente muy capaz y proporcionado al número de vecinos, constaba de dos capillitas por banda y la Torre, con buenos ángulos de piedra sillar, o picada, y de lo mismo las basas de las pilastras. Tenia su Coro alto. Dos cubiertas ó techos, el primero de bóveda pintada de flores, y el segundo de madera. La puerta de la Placeta era la única, el Tabernáculo y Altar Mayor estaba colocado donde hoy la Capilla del Sto. Cristo, y Pila Bautismal frente 
esta Puerta; no era más grande su latitud regular. Estaba dedicada esta Iglesia á Nuestra Señora de los Ángeles. No pareció a los antiguos moradores construcción de Templo más capaz, pero en estos tiempos se ha considerado precisa, y necesaria; pues en un siglo se ha aumentado el vecindario en tal conformidad, que no cabiendo sino una tercera parte de gente se quedaba la demás en la Placeta á las inclemencias de los tiempos, y rigores de la Estación.

\section{f. $2 v^{o}$}

Tratose pues engrandecer el templo y hacerlo más capaz, pero ante todas cosas se trató derribar la Casa Abadía por ser muy mala y mal forjada, y más por haberla habitado el Cura Giner con sospechas y circunstancias de tísico, aunque murió en el Hospital de Pobres Sacerdotes de Valencia, no quiso pues habitarla el Cura Reig y, derribándola, se construyó ésta en el mismo sitio, con la ayuda de vecinos y dirección de dicho Cura; se construyó en el año 1787. Luego se trató empezar la obra de la Iglesia, pero ¿cuántas dificultades y pareceres no se originaron? Unos querían alargar el Templo viejo, tomando de la Placeta; otros, al contrario, alargándole de la Testera, formando Arco párale tránsito de las gentes, y todos eran de parecer que la Iglesia vieja se aprovechase la mayor parte de sus paredes, porque lo demás parecía mucho gasto; pero gracias a Dios, que sin desagradar à nadie, se abrazaron el dictamen del Cura Mosén Onofre Reig, que pensó lo mejor, y comprando casas y terreno, la extendió hacia el medio día. Formose la planta y Diseño, que lo es del Maestro Arquitecto Francisco Pechuán, de Valencia, y con...

\section{f. $3 r^{\circ}$}

...la aprobación de la Academia de San Carlos, del Señor Arzobispo Don Francisco Fabián y Fuero y con universal satisfacción de todo el Pueblo, se decretó dar principio á la obra; mas ante todas las cosas se hizo un(a) Junta General de Parroquia en 9 de abril de 1787, con asistencia del Cura, Ayuntamiento y demás vecinos que componen el lugar. Aquí se trató el modo de hacer esta fábrica con la mayor equidad, y después que cada uno voluntariamente ofreció según su posibilidad la cantidad que le pareció, todos se obligaron con Escritura ante Miguel Conejos el Viejo, á acopiar y conducir materiales a la obra, servir de Peones siempre que les mandasen, y contribuir con Limosnas en tiempo de las cosechas, lo que han cumplido exactamente bajo el cuidado del Cura y Señores del Ayuntamiento. Considerando pues que a tan grande y magnífica obra correspondia un buen Patrón, dieron la honra y honor de colocar la primera Piedra... 
...a Don Alonso de Solís, Duque de Montellano, Señor de este Lugar Sc.(¿?) lo cual ejecutó por medio de su apoderado y Procurador Don Pedro Verges, con asistencia pues de Mosén Onofre Reig, Cura actual de esta Parroquia, de Don Juan Val, Cura de Algimia, de los Padres Fr. Pedro Melis, Visitador de esta Tercera Orden del Colegio de Santo Espíritu, del P. Fr. Antonio Asnar, de Vall de Jesús, de otros muchos, y todo el lugar presente; se colocó y puso con todas las ceremonias la Primer Piedra para el caso prevenida con la memoria del Papa, Arzobispo y Rey que gobiernan, del Señor del Lugar, del Cura, Alcalde y demás que, a la sazón, componen el Ayuntamiento. Se practicó esta solemnísima ceremonia en el día diez de mayo del Año del Señor mil setecientos ochenta y nueve, día de la Virgen de los Desamparados. Predicó el R. P. Fr. Antonio de Muro, Ex Provincial Capuchino, tío del Cura Reig. Puede contar Serra entre los mayores de su júbilo este día, así lo acreditó en la grande fiesta y en abundante comida pública a todo vecino...

\section{f. $4 r^{\circ}$}

... y forastero de que se llenó el lugar.

Ya pues tenemos colocada la Primera Piedra bajo el Tabernáculo del Altar Mayor; ya está principiada la obra. Algunas dificultades se vencieron hasta aquí pero todas eran especulativas y se reducían a unir dictámenes; ¿quién vencerá las que siguen en la práctica?. Pero buen ánimo que es obra de Dios y este Señor lo allanará todo. Ábrense cimientos y, quien ha de creer que en la parte de levante el piso de la Iglesia se abrieron en más de 20 palmos de profundidad ¡hasta encontrar piso firme! Considérelo mejor el que se asomare al Balcón de la Sacristía. Su latitud correspondiente y de más de 12 palmos.

Todo el pueblo aportaba materiales, todo parecía escaso para llenar cimientos. Piedras de 200 arrobas se arrastran en una galera de Portaceli para sepultarlas. Como esto era en los principios, todo se hacía con fervor y nada cansaba, pero ¿con qué fondos se dio prin...

$$
\text { f. } 4 v^{0}
$$

...principio a obra tan costosa?. No reconozco otros que la Providencia de Dios Nuestro Señor, y la caridad de los fieles. El Señor del Lugar debiera tomar esta Obra bajo su protección; mas los procuradores no siempre son animados del espíritu de caridad que su (principal), y los beneficios de éstos bajan a los vasallos a medida de la voluntad de 
aquéllos. Pero no se entibie el fervor ni falte la Unión en el Pueblo, que nada importa. Hace el cura sus pláticas y anima al Pueblo; nada menos hacen los Padres de Santo Espíritu, particularmente el Padre Domingo Pérez, y el P. Pedro Melis. El cura no deja arbitrio que no se valga; compra y reparte cáñamo, las mujeres hilan, se fabrican y venden telas. Se pide en el horno y lugar limosna para la fábrica. La dan los vecinos abundantes en tiempo de cosecha de los principales frutos; pero la mejor limosna es la seda. El cura reparte simiente de Capullo verde...

\section{f. $5 r^{\circ}$}

... y aunque hay tan poca hoja en el término, hace la fábrica la más grande de sus limosnas habiendo pasado algún año de 50 libras de seda fina, no llegando ningún vecino a 30 de cosecha propia, lo que advierto para que el cura cuide no se pierda este arbitrio en lo sucesivo, y la Iglesia tenga este producto en sus necesidades, no fiándole nadie el cuidado de sacar la simiente, y sobre todo de repartirla a las casas por el mes de marzo con su prudencia y buen celo; porque si esto se deja al cuidado de otro que del cura, podrá perderse. Tanto pues importa su asistencia en esta como en las demás limosnas anuales de otros frutos.

Empiézase la obra, se trabaja con gusto y afán. Dios la bendice y en pocos años se adelanta sobremanera. Entre tanto acontece la muerte del cura Reig en 22 de julio de 1791 á los 42 años de sus edad. Lloró Serra esta desgracia, y lo fue grande para la obra, en circunstancias de que nadie del pueblo era capaz...

\section{f. $5 \mathrm{v}^{\mathrm{o}}$}

... de suplir ni encargarse de este cuidado y mareo. Hallárase ya cubierto el crucero, hecha la media naranja, lucida y pintada por dentro. Los cuatro Evangelistas y Virtudes son del pintor Juan Bautista Suñer, de Valencia. Pusiéronse por entonces los intereses de la fábrica en manos del Alcalde y, en poco tiempo se hubiera todo perdido si no trataran de ponerlo en poder del Ecónomo Dr. Mariano Cervera, de Liria, y en esta ocasión y muerte del cura desapareció y perdiose el Libro de Cuenta y Razón de dicha obra, descuido y falta sensible. Y no falta quien lo atribuya a la malicia. De todos modos, es inconveniente al objeto y fin de esta relación.

Quince meses se mantuvo dicho ecónomo en esta Parroquia, en cuyo tiempo se lució y dio de tintes al crucero. Hecho esto trató dicho ecónomo hacer la traslación de su Majestad... 
... a la nueva Iglesia, y el Señor Arzobispo dio comisión al Cura de Bétera, Don Miguel Ortiz, el cual, el día 27 de diciembre de 1795 bendijo e hizo la traslación del Señor á la Iglesia nueva. Cantó la misa dicho cura y predicó el Ecónomo; por la tarde se hizo una muy lucida Procesión del Señor por todo el lugar.

Al otro día cantó la Misa el Padre Domingo Pérez de arriba; predicó el M.R.P. Fr. Antonio de Muro ref ${ }^{\circ}$ ( ¿?). Y el día tercero cantó la Misa dicho Ecónomo; predicó un capuchino.

Los tres días hubo música de Liria, siendo alcalde Francisco Rubio, regidor Francisco Navarro de Francisco; síndicos: Blas Dasí y Cipriano Cabo; diputados: Juan Falomir y Josef Navarro de Bernardo.

En este estado de cosas entró a regentar este Curato el Dr. Francisco Tormo, natural de Albayda, Vicario Perpetuo de la Parroquial Iglesia de Santiago de la misma Ciudad de Orihuela. Tomó posesión de este Curato en el día 17 de febrero...

\section{f. $6 v^{\circ}$}

... febrero del año del Señor 1796, precisado de la necesidad se encargó de la fábrica del nuevo templo. Providencia singular del Señor en que le venga de genio y agrade la obra para concluirla; de otro modo suelen pararse las grandes obras de caridad como ésta.

Reanima al pueblo cansado, va delante en las maniobras, busca limosnas, lleva las cuentas de todo y se constituye Sobrestante de modo tan particular que, a nada hace falta. Para continuar la obra y nave de la Iglesia se hace preciso derribar la vieja, que venía al través. Cerrose de barandas de arriba abajo el crucero del nuevo templo para evitar polvo y aguas; determinose por el cura el día para demoler el viejo y, dada la orden, cada serrano con su azada, en poco más de un día, lo llenaron todo de escombros y aún segregaron los materiales, poniéndolos en su lugar. Esta maniobra anduvo por instantes, pues todos los serranos son hábiles maestros en deshacer y arrancar piedras. Al echar en tierra uno de los Arcos principales casi se llevó detrás un...

\section{f. $7 \mathrm{r}^{\mathrm{o}}$}

... oficial de Albañil. En otra ocasión se descolló por la talla al tiempo de agarrar y recibir una piedra Josef Gutiérrez, vulgo Maño, pobre que hacía de peón, y con caer muy alto, juntamente con la piedra, no recibió notable daño, y no sólo en éstas, sino que en muchas otras ocasiones durante la obra se ha experimentado y visto visible la singular protección de Dios Nuestro Señor de que todos son buenos testigos. 
Todo el pueblo creyó al principio que se aprovecharía una grande parte del Templo viejo, y este discurso, seguramente, les empeñó en obra tan larga y costosa; pero, a excepción de la testera del viejo y media torre, nada ha aprovechado y servido de embarazo a la obra del nuevo y motivo de alguna imperfección, como es de ver en el plano de dicha obra. Esta demolición de la Iglesia vieja se ejecutó en 12 de marzo de 1797. Como toda la Iglesia nueva está trabada de obras por bajo, se abrieron cimientos en más...

\section{f. $7 v^{0}$}

... de 20 palmos de profundidad. Se sacaron los cuerpos de los curas Benavent y Costa, y se colocaron ante la subida del Coro: el cura Reig está en medio (de) la Iglesia, á la entrada de la puerta de la Placeta. En 7 de noviembre de 1796 se volvió a emprender la obra, es decir, llenar los cimientos de la nave, y el cura puso la primer(a) piedra. En 6 de marzo de 1797 se replanteó dicha nave por el referido Director y maestro Pechuán y aunque hasta ahora trabajaron en dicha Iglesia otros oficiales, en adelante el oficial principal que la llevó hasta el fin fue Pasqual Feases, maestro albañil del Puig. Levantose algunas andamiadas y se la dejó hacer aciento (=asiento). Las pilastras y todos los arcos de la nave y capillas son de atova (=toba; o adobe?) o ladrillo. Este material hubiera sido costoso, pero se hizo un horno aquí en el lugar en Toxima. ${ }^{1}$ El pueblo conducía la tierra y leña, y la fábrica pagaba las manos por millares, y de este modo se ha gastado tanta obra, que...

\section{f. $8 \mathrm{r}^{\mathrm{o}}$}

... que sólo en mi tiempo pasarían de cien millares. En 8 de marzo de 1798 volvió a emprenderse la obra. La obra del campanario empezó en 20 de mayo de 1799. En octubre de dicho año se colocó el Reloj en la torre.

En 27 de mayo 1717, el cura Benavent bendijo las dos campanitas, que se harían por entonces. El año 1777, de estas dos, añadiendo metal, el cura Ros fabricó cuatro, que son las que hay en el día.

En 23 de octubre 1798 se puso la Puerta principal de la Iglesia y en 26 del mismo la de la Placeta. Su importe, dichas dos: 300 pesos en corta diferencia. Se aforraron (=forraron) de hoja delata en 31 de julio de 1802. En 16 de julio de 1800 se concluyó la obra de la Iglesia, en cuyo año se pintó el frontis. En 1801 se dieron de estuco los zócalos y pilastras de la Iglesia. En 1802 se pintó el tras-sagrario y capillita de Comunión y se

\footnotetext{
1 Aquest forn, conegut com "El rajolar" estava situat per damunt del Molí de la Baronia, on està actualment el magatzem de construcció de Pepito el Cirilo.
} 
puso el retablito de bonitas piedras. En dicho año se hizo y colocó el Retablo de la Purísima que...

$$
\text { f. } 8 \mathrm{v}^{\mathrm{o}}
$$

...costó cien libras que se pagaron de limosnas a dicha imagen. El inmediato retablo de San Francisco lo costeó la $3^{a}$ Orden, y el del Sto. Christo la Fábrica, á cien libras cada uno de madera. En el año 1803 se hicieron los bancos y antepecho; costaron cien libras. Dicho año se hizo y trajo la Virgen de los Dolores con el Señor en los brazos; costó 130 pesos, y 18 las andas, diadema y toalla de la Cruz. La hizo el escultor Francisco Pérez, discípulo de Esteve, y el mismo hizo el Niño. La Virgen se pagó del producto de la Cuaresma del año 180(¿) que por evitar etiquetas predicó el mismo cura, de lo que recogieron las Dolorosas y, lo demás, la Fábrica. Se trajo por los mozos desde Valencia en andas, en un domingo de invierno el más frío y tempestuoso.

En mayo de 1805 se colocó el Retablo Mayor de esta Iglesia. Se ajustó por 950 pesos de madera sólo. Pintar el Sagrario o Tabernáculo y el Salvador costó 175 libras, y es obra de Vicente Lluc.

\section{f. $9 \mathrm{r}^{\mathrm{o}}$}

Dorar y pintar el nicho principal y dar de blanco o color de fábrica costó 130 pesos.

El lienzo grande de la Virgen de los Ángeles es del pintor Josef Zapata; costó ciento diez pesos, cuyas cantidades, unidas a los gastos de conducción de dicho retablo, colocación pavimento de azulejos del Presbiterio, etc. hacen la suma de mil y quinientos pesos, si no pasan, y esta es otra de las maravillas del Señor de la Providencia, haberse ya pagado todo en tan corto espacio de tiempo, (y) en años tan estériles. Bendito sea Dios!.

Pensábamos que el Señor Duque hubiera costeado esta obra tan propia de su Persona, y han sido menester todas las diligencias del Cura para lograr cien libras, pero ahora, el Señor Duque, colocado en nuevo Estado protesta no puede hacer, ya lo que antes, por las mayores obligaciones de su Casa, pero su carácter es piadoso y benéfico.

$$
\text { f. } 9 \mathrm{v}^{\mathrm{o}}
$$

\section{Nota del Calvario de Serra}

Este lugar tenía calvario en la montaña donde está hoy. Había tan solamente unas cruces de madera que aún han visto los viejos del día. En el año 1748, un padre franciscano Predicador de la Cuaresma animó al pueblo y se construyeron, en lugar de cruces catorce casitas que todos han visto, mas de poco gusto e inferior material. Ya 
derruidas y arruinadas casi todas se proyectaba hacer Calvario nuevo, y se pensaba hacerlo más cómodo al rededor de la Era Alta.

Ocupado el pueblo en la fábrica de la Iglesia, no se pensaba en (el) Calvario.

Entre tanto crecía el lugar se estrechaba el terreno.

En el año 1803 hubo misión de los padres de Santo Espíritu y, encareciendo la necesidad de Calvario, especialmente el Padre Josef García, determiné emprender dicha obra, desembarazada ya la gente de la de la Iglesia, y meditando algunos inconvenientes de hacerlo en la Era Alta, y las ventajas de la montaña donde estaba, determiné hacerlo allí mismo. Efectivamente, se emprendió dicha maniobra, y aunque con buen fin y buen celo, no le ha faltado contradicción.

Parte de dicha montaña y terreno ya lo habían establecido para casas, ya había cimientos. Ya iban a cerrar la subida a dicha montaña; pero llegado el cura...

\section{f. $10 \mathrm{r}^{\circ}$}

... a tiempo (que fue permisión de Dios) y acordando lo antiguo, lo inmemorial del sitio del Calvario etcétera, dejaron el terreno expedito. Este era una montaña escarpada, con unas sendas por entre la maleza y, reunido los domingos y fiestas el pueblo, arrancando peñascos, con dirección del cura, se fueron trazando las calles, ribazos y demás.

Pensé, al principio, hacer las paredes de cal y canto, pero no ha podido ser ahora ni tampoco hacerse con la mayor perfección por ser obra de tantas manos. Luego que estuvieron los ribazos, se emprendieron las casitas y, sino tienen más gusto falta es del albañil. La construcción y casitas se distribuyeron entre vecinos pudientes, es decir, dar comer al albañil y servir de peón, que el jornal y materiales es de la Iglesia y, aún de esta manera han contribuido pocos; pero el afán y trabajo grande del cura todo lo ha suplido, de modo que el Calvario es obra del Cura, porque los señores alcaldes han hecho tan poco en esta parte, que rara vez, sino por curiosidad se les ha visto en dicha maniobra. Fecho todo el cura de consejo de algunos labradores experimentados ha plantado moreras que con la bondad del terreno en poco más de año han tomado tanto incremento, que espera que con el cuidado de los sucesores, hayan mucho gozo y provecho dentro de pocos años y desde ahora destina todo el interés, y producto temporal del Calvario y montaña para las benditas almas del Purgatorio, que con este fin, y objeto pío, mirarán los feligreses por su aumento debiéndose arrendar la hoja y lo demás, para que de este modo el arrendador cuide de que no le quiten... 
... nada. Sé muy bien que en los calvarios suelen plantarse cipreses, mas decía un señor Obispo que de estos árboles no debía haber sino uno en el mundo para que se supiese que tal árbol había, porque no dan fruto alguno, sea lo que se fuese. Este terreno es capaz de todo árbol y todo crecerá mucho si se cuida y riega de cuando en cuando con el agua de la Miseria. Conclúyase la acequia y la tendrán cada día causando el mayor gusto con el murmullo y despeño. El Sr. Cura y cualquier vecino de gusto puede servirle al calvario de decente paseo y diversión y luego que se concluya la Casita Grande en el sitio de la excavación, deberá subirse á dicha Casa o Capilla por ocho a diez gradas con su pretil, dicha capilla debe tener su fachada como de Ermita, dentro su mesita de Altar, y el Cristo pintado que está en la sacristía debe cubrirse con su media naranja. Fecho todo bendígase, y el cura los domingos, y fiestas por la tarde puede reunir la gente en la Iglesia y luego en procesión cantando el rosario, subir al calvario, y concluidos los Pasos arriba, acomodada la gente en aquella plaza, y bancos que puede haber; el cura desde dicho Pretil puede hacer su plática, y seguramente acudirán más que a la Iglesia por el buen estar, comodidad y conveniencias, y no se excusarán en el verano con el calor y pulgas.

Este ha sido mi fin y objeto, en obra tan costosa y el renovar el Cristiano la memoria de la Pasión, lo que no he tenido el gusto de lograr y conseguir en mis días. Dios Nuestro Señor bendiga dicha obra y a los que se ocupen en ella, y todo ceda á mayor honra y gloria suya. Luego que esté hecha la capillita, cuide el Sr. Cura que el Calvario se cierre por los dos lados, que costará poco y no entraran caballerías y animales. 
P. Garay

2015 


\section{ANNEX VII \\ ÍNDEX D'INSTRUMENTS PÚBLICS DE LES BARONIES DE SERRA I DE SONEIXA}

(DP-PGM)

En aquest annex transcrivim el contingut bàsic d'un volum titolat: Yndice General de los Instrumentos públicos pertenecintes a las baronias de Soneja, Serra, Azuébar, Armell, Mosquera, Pellunes y Ría, en el Reino de Valencia, obra original de 1818 adquirida per llibreria de llanç i antiquari. Es tracta d'un volum de 36x26 cm, enquadernat en rústica, amb tapes de cartró i 358 fulls numerats, dels quals només estan escrits els 75 primers i els tres últims. Va ser escrit per l'escrivà de Salamanca Tomàs d'Almeyda, cap a 1818, seguint un encàrrec escrit que li va fer Carlos José Gutiérrez de los Ríos, comte de Fernán-Núñez i espòs de Maria Vicenta Solís, la duquessa de Montellano i de l'Arco. A tal efecte li va ser enviada al seu despatx de Salamanca tota la documentació dispersa que sobre les baronies de Serra i de Soneixa es trobava en diferents ubicacions, com ara Massalavès, Madrid i altres llocs. En primer lloc, l'escrivà hauria procedit a identificar, classificar i ordenar tots els documents sobre Serra i Ria, per a desprès catalogar-los i donar una signatura a aquells que no la tingueren encara.

El volum conté la descripció de 168 instruments públics numerats i ordenats cronològicament, dels quals únicament els primers 109 són anteriors a 1818 i la resta continuen l'ordre cronològic arribant fins a l'any 1868. Això vol dir que el llibre va ser continuat encara mig segle desprès de la mort del I duc de Fernán-Núñez (antic comte) esdevinguda a finals de 1821. A partir de la descripció del instrument 142 (any 1830) l'escriptura canvia lleugerament, evidenciant un canvi de mà. També les descripcions 163 a 165 estan escrites per un altra mà diferent (anys 1831 a 1854) i, encara més clar ocorre el mateix en les darreres descripcions, on la lletra és ara molt més menuda i de diferent estil fins arribar així a l'instrument 168 (anys 1859 i 1868). Cadascun dels instruments descrits es pot identificar pel número del seu assentament (numeració entre 1 i 168) i per la data del propi instrument, però en cap moment s'aporten signatures, localitzadors, referències ni descriptors altres de cap tipus. Això indica que no ens trobem davant d'un catàleg per a la localització dels documents en l'arxiu, sinó més bé d'un nou inventari indexat $\mathrm{i}$ agrupat en set grans apartats o lligalls que se citen al final 
del llibre i a mena d'índex (referit com Apéndice). En els documents que hem tingut ocasió de consultar en el fons documental del ducat de Fernán-Núñez a Toledo (AHN, Secció Noblesa) observem que, a més de les signatures de referència en ús, hi ha generalment una una segona referència numèrica i moltes vegades també la referència "Papelera $\mathrm{N}^{\circ}$...". Però, ni en els documents de l'AHN trobem referències als números del nostre "Yndice" ni viceversa. Això ens fa creure que si bé els documets van ser degudament ordenats $\mathrm{i}$ tornats per l'escrivà de Salamanca als ducs, junt amb el llibre Yndice, una vegada en l'arxiu degueren seguir un criteri de classificació i integració diferent en l'arxiu nobiliari general. El 1libre, no obstant, seria continuat (potser no exhaustívament) com a registre correlatiu de posteriors documents al llarg del segle XIX i fins la definitiva pèrdua de propietat sobre les darreres possessió de Serra i de Soneixa $i$ Assuévar. Tot açò fan les 75 fulles (els 168 assentaments descriptors d'altres tants “instruments").

Els últims escrits del llibre (desprès de centenars de pàgines en blanc) són el de l'Apéndice, en la darrera fulla del llibre (f. 358), que cita els set grans apartats anomenats "legajos" (els lligalls que degué confeccionar l'escrivà de Salamanca per a tornar la documentació). Els cinc primers lligalls fan referència al conjunt de les 168 inscripcions o Ynstrumentos, separades amb un criteri cronològic, mentre que el lligall sisé diu que són "arbres genealògics i paper simples" i el lligall setè agrupa diferents documents comptables de rendes corresponents a les possessions dels ducs en el Regne de València, des de 1742 a 1800 "i successives" (suposem que fins a 1829). D’aquests lligalls hi ha sengles breus resenyes justificatives en les fulles 356 i 357 del Yndice. Però no hi ha cap referència ni cap altra relació dels ducuments que debien formar aquells dos últims lligalls.

Que aquest llibre tingué una intencio i un caràcter clarament d'ordre jurídic no en tenim dubte. El preàmbul del llibre dóna a entendre els conflictes jurídics suportats pels marquessos de Castellnou per no haver tingut, en cada moment, llestos i ordenats els títols de pertanyença de les diferents cases i possessions; i en aquesta línia va l'ordre que li dona el comte de Fernán-Núñez a l'escrivà, per a que ordenara els instruments. Per això mateixa, en la nota que sobre el lligall sisè fa l'escrivà (f. 356) indica que en ell estan també els papers que per no ser autèntics "ni merèixer fe en judici" no han sigut enumerats en la relació dels Ynstruments. 


\section{f. $2 r^{\circ}$}

Desde que las Baronías de Soneja, Serra, Azuebar, Armell, Mosquera, Pellunes, y Ria, recayeron en la excelentissima Señora Doña Josefa Folch de Cardona, tercera Duquesa de Montellano, andubieron sus títulos de pertenencia embueltos y confundidos con los del Marquesado de Cxastelnobo, y Barona de Mazalavez, que poseía dicha Señora, y asi estaban llamados con numeración progresiva de unos con otros en los Yndices sucintos e incompletos que gobernaban entonces; hasta que el Excelentisimo Señor Don Alfonso de Solis Wignacourt, quinto Duque de Montellano, nieto de aquella Señora, trató de remediar tal confusion y la que generalmente habia en los Ynstrumentos de todos los Mayorazgos de su Casa.

A este fin los remitio a Salamanca, y encargó esta operación a Don Tomas de Almeyda, quien procedio a ella en la forma que explica en os tomos primero y segundo Yndice de los Ynstrumentos del Marquesado de Castelnovo, que ocupan las Papeleras diez y ocho y diez y nuebe de este Archivo. En el se vé la claridad con que quedan dividido unos y otros Mayorazgos, por haber aplicado a cada uno los Ynstrumentos que le pertnecen, con notas de los que conducen en lo venidero para evitar dudas; y asi ha procedido en el arreglo d los de estas Baronias, extractandoles en castellano y numerandoles por el oden cronologico que manifiesta su cubierta de papel, ultimament puesta a cada Documento para resguardarle y conserbar su autoridad, cuyo total extracto se vertera a qui a plana seguida, y por el se bendra en conocimiento no se conservan mas Ynstrumentos que desde la ultima expulsion de los Moros sucedida en el reinado de Don Felipe tercero, por haberse presentado los anteriores en los pleitos seguidos con la Casa de Medina-Celi por espacio de siglo y medio, y su Apendice se pone al folio último.

$$
\text { f. } \left.3 r^{\circ} \ldots \text { (fins a f. } 75 r^{\circ}\right)
$$

\section{BARONIAS DE SONEJA, SERRA, AZUEBAR, ARMELL, MOSQUERA, PELLUNES, Y RIA.}

\section{LEGAJO $1^{\circ}$ YNSTRUMENTOS DE SU PERTENECIA DESDE 1609 A 1712}

1. Concordia otorgada entre D. Josef Folch de Cardona, Caballero de la orden de Alcántara Gentilhombre de boca del Rey d. Felipe $3^{\circ}$, y Señor de las Baronias de Serra, y Ria, y 31 sugetos, por la qual entre los 20 Capitulos que comprende, acordaron que los primeros 21 sugettos poblarian de nuevo dicho./. lugar de Serra, y los 10 últimos el de Ria, que quedaron desiertos por haber echado a África los moros que los habitaron en virtud de orden de dicho monarca, publicada en Valencia á 22 de septiembre del año de la fecha; que á este fin se avecindarian en dichos Lugares sujetandose a la jurisdiccion y 
vasallaje del citado D.Josef, y sus sucesores; que este señor les daba todas las casas, heredades, y demás que dejaron los moros, y que por cada casa le habian de contribuir cada año con 30 sueldos y luismo y fatiga, dos sueldos por cada fanega de tierra, la sextaparte de todos los Granos, y su Diezmo y Primicia, la octaba parte de frutas, pasas y ganado lanar y cabrio, y un sueldo por cada carga de carbón, y otras regalias a favor del Señor, según costumbre y fueros de la Valencia, cuya Escritura pasó ante Gregorio Tarrasa, Notario en Valencia, a 26 de Noviembre de 1609. Dada en traslado por Ildefonso Serrano su sucesor. Sobre la compra de Serra.

2. Escritura de capitulación de nueva poblacion de la Baronia de Serra, otorgada entre D. Josef Folch de Cardona, su dueño, y los nuevos pobladores; su fecha en Valencia, ante Gregorio Terrasa, Cescribano en ella a 26 de Noviembre de 1609; trasladada por Juan Antonio Espada, igual Cescribano, a 25 de mayo de 1767. Dicha capitulacion se colocaria bajo esta cubierta y número, luego que sea enviada por S.E, por haberse remitido al contador D. Manuel Gutierrez Bustilbo en 11 de Diciembre de 1802, folio 78 del Libro de salidas, y se apuntará lo mas que de ella resulte, sin hacer merito del numero 1656 que tenia según el metodo anterior. Devuelta.

3. Concordia otorgada entre D.Josef Folch de Cardona, cavallero de la Orden de Alcantara, Gentil hombre de boca del Rey D. Felipe $3^{\circ}$, Señor delas Baronias de Soneja y Azuebar, y 45 sugetos, por la qual entre los 24 capitulos que comprende, acordaron que los primeros 39 sugetos poblarian de nuevo el lugar de Soneja y los seis ultimos el de Azuebar, que dejaron yelmos los moros expulsados a Africa, por orden de dicho monarca, publicada en Valencia a 22 de septiembre del año de la fecha; que a referido D.Josef, y sus suscesores; que este señor les daba todas las casas, heredades y demás que dejaron los moros y que por cada casa le habian de contribuir cada año con 30 sueldos, y luismo, y fadiga, dos sueldos por cada fanega de tierra, la sexta parte de todos los granos, con diezmo y primicia, la octava parte de frutas, pasas, y ganado lanar y cabrio, y un sueldo para cada carga de carbón, y otras regalias a favor del Señor, según costumbre y fueros de Valencia, quedando unida a dichas dos nuebas poblaciones la huerta y redondez de Mosquera, sus Alcornoques, y cuebas, cuya Escritura pasó ante Gregorio Tarraza, Notario en Valencia, a 27 de nobre de 1609. Dada en primero traslado por Juan Antonio Torrella, su sucesor, en 21 de mayo de 1676. A continuación del Instrumento Num. ${ }^{\circ} 805$. Legado 13 del Marquesado de Castelnovo, Papelera 19 de este Archibo, sehallan unidas diferentes Instrucciones relatibas a esta nueba población, utilisimas por las buenas noticias que dan.

4. Concordia Otorgada entre D.Josef Folch de Cardona, Cavallero dela orden de Alcantara, Gentil hombre de voca del Rey D.Felipe $3^{\circ}$, y Señor de las Baronias de Soneja, y Azuebar, y 45 sugettos, por la qual entre los 24 capitulos que comprende, acodaron que los primeros 39 sugetos poblarian de nuevo el lugar de Soneja, y los 6 ultimos el de Azuebar, que dejaron yermos los moros expulsos a Africa, por orden de dicho Monarca, publicada en Valencia a 22 de septiembre del año dela fecha; que a este fin se avecindarian en dichos lugares, sugetandose a la jurisdicion y vasallaje del referido D. Josef, y sus sucesores: que este señor les daba todas las casas, heredades, y demas que dejaron los moros, y que por cada casa le habian de contribuir cada uno con 30 sueldos, y luismo y fadiga, dos sueldos por cada fanegada de tierra; la sextaparte de todos los granos, con Diezmo y primicia; la octaba parte de frutas, pasas, ganado lanar, y cabrio; y un sueldo por cada carga de carbon; y otras regalias a favor del Señor según costumbre y fueros de Valencia, quedando unida a dichas dos nuevas poblaciones, la huerta y 
redondez de Mosquera, sus alcornoques y cuevas; cuya escritura pasó ante Gregorio Tarraza, Notario en Valencia, a 27 de Noviembre de 1609, dada en traslado $2^{\circ}$ por Juan Antonio Espada, sucesor del anterior Notario, a 25 de mayo de 1767.

5. Reconocimiento otorgado por D. Josef Folch de Cardona, Conde de Monteagudo, y Señor delas Baronias de Soneja, y Azuebar, a favor del Ilustre Cabildo de la Sta. Iglesia Catedral de la Ciudad de Segorbe, de dos censos que le habia cedido su deán D. Pedro Ramírez, contra las Aljamas delos moros de dichas dos Baronias, el uno de 75 libras de principal, y el otro de 370 libras, cuyos reditos quedaron reducidos a 445 sueldos anuales desde la expulsión; ante Geronimo Ruiz de Ripodas, Notario de Valencia, fecho en Soneja a 4 de mayo de 1618. Dado en traslado por Josef Torrent, Cescribano del Ayuntamiento y Cabildo de Segorbe año de 1724.

6. Testamento otorgado por $\mathrm{D}^{\mathrm{a}}$ Geronima Lull y Cabrera, Condesa de Monteagudo en el Principado de Cataluña, por el qual declara estava viuda de D. Josef Folch de Cardona, Señor delas Baronias de Azuebar, Soneja, Ria, Serra, y agregadas, de las que le había dejado heredera dicho su marido, de cuyo matrimonio no tenia hijos, por cuya causa nombra sucesor delas citadas Baronias a Dn. Vicente de Aragon y Cardona, y en su falta sin hijos, a $\mathrm{D}^{\mathrm{a}}$ Teresa del Milá, y Cardona, muger de D. Antonio de Cardona, sus hijos y descendientes. Nombra heredera de los restantes bienes que tenía en Cataluña a otras partes, a $D^{a}$ Catalina Salba y Fonz, y en su falta a D. Bernardo de Mendoza y Sanz, hijo de los Condes de Robles, con condicion de pagar los legados particulares que hace a la misma $\mathrm{D}^{\mathrm{a}}$ Teresa del Milá, y otros, y manda enterrarse al lado de su marido en la Iglesia Parroquial del Lugar de Soneja, donde le otorgó, ante Antonio Maso, Notario de Segorbe, a 16 de octubre año de 1649. Dado en traslado por Florentin Marco, regente el oficio del anterior Notario, en Segorbe a 19 de enero de 1705.

7. Testamento y ultima voluntad de $\mathrm{D}^{\mathrm{a}}$ Geronima Lull y Cabrera, Condesa de Monteagudo, y Señora delas Baronias de Soneja, Azuebar, Serra y Ria, viuda de D.Josef Folch de Cardona, havitadora en el Lugar de Soneja, ante Antonio Maso, Notario en Segorbe, a 16 de octubre año de 1649. Dicho testamento se colocará vajo esta cubierta y numero, luego que se remita por la contaduria de S.E. a donde se embio en 7 de agosto de 106, folio 81 del Libro de salidas, y se apuntará lo mas que de el resulte, sin hacer mérito del número 1836 que tenia según el mettodo anterior.

8. Demanda original entablada en la R Audiencia de Valencia, a 22 de octubre de 1649, por Da Teresa del Mila, Señora de la Baronia de Mozalabez, y Paranchet, muger de D. Antonio de Cardona, Marqués de Castelnovo, contra D. Vicente de Aragón y Cardona, Caballero de la Orden de Alcantara, hijo delos Duques de Segorbe y Cardona, sobre derecho al goce y posesion delas Baronias de Soneja, Serra, Azuebar y Ria, qe poseyó D. Josef de Cardona, Conde de Monteagudo, quien las dejo a su muger $D^{a}$ Geronima Lull y Cabrera, y esta las legó a dicha $\mathrm{D}^{\mathrm{a}}$ Teresa, luego qe murisese sin hijos dicho D. Vicente de Aragón, pretendiendo dicha $\mathrm{D}^{\mathrm{a}}$ Teresa, le pertenecian dichas Baronias en virtud del testamento de dicha $\mathrm{D}^{\mathrm{a}}$ Geronima, como hija de D. Miguel de Milá, y D ${ }^{\mathrm{a}}$ Serafina Mateu, nieta de D. Pedro del Milá, y D ${ }^{a}$ Juana de **** (segunda nieta) de D. Pedro del Mila, y $\mathrm{D}^{\mathrm{a}}$ Aloya del Mila, segunda nieta de D. Alfonso del Mila Borsa y Corraz, y $\mathrm{D}^{\mathrm{a}}$ Juana de Cardona su muger, esta hija de D. Fernando de Cardona, y D $\mathrm{D}^{\mathrm{a}}$ Ana Oms, su muger, señores de dichas Baronias, según capitulaciones matrimoniales, ante Luis Valleriola, año 1560, que se presentan, con otros algunos instrumentos, en virtud delos quales por los señores dela citada Real Audiencia, se dio sentencia en 15 de junio de 1650, publicada por Esteban de Calba, Exmo de Camara, en la que declararon y 
mandaron dar posesion de dichas Baronias al citado D. Vicente de Aragon y Cardona, para lo qual libraron despacho a 5 de Julio del mismo año, y la tomó dos días despues, de que se pidio vista $\mathrm{p}^{\mathrm{a}}$ seguir La Inst ${ }^{\mathrm{a}}$.

9. Cinco sentencias dadas por la real Audiencia de Valencia, una de ellas ante su Esmo de Camara Gaspar Mascaro, en 15 de junio de 1650, por la qual mando meter en posesion delas Baronias de Soneja, Azuebar, Serra, y agregadas a D.Vicente de Aragón, Cavallero dela Odn de Alcantara, como heredero que quedó de $\mathrm{D}^{\mathrm{a}}$ Geronima Lull y Cabrera, Condesa de Monteagudo, ultima posehedora, que le disputaba $\mathrm{D}^{\mathrm{a}}$ Teresa del Milá, y su marido, cuyos sucesores son los actuales señores de Soneja; aunque no estan autorizadas seles da este lugar por las importantes noticias que dan.

10. Ordenanzas formadas por los Jurados y Concejo de la Baronia de Soneja, para el mejor orden y metodo de aprobechar y guardar los frutos de su termino, imponiendo penas y multas a sus contrabentores: aunque no tienen fecha, se aplicaran despues del año 1650, en que parece las aprobó D. Vicente de Aragon y Cardona, Cavallero de la orden de Alcantara, que fue Señor de dichas Baronias desde dicho año adelante.

11.Genealogia dela Casa y apellido de Cardona, en Cataluña, dedicada al Exmo Señor D. Luis Ramón Folch de Cardona, Duque de Segorbe y Cardona, Marqués de Comares, y Pallars, Conde de Empurias y Prades, señor delas ciudades de Lucena, y Solsona, y muchas Baronias; escrita por Bernardo Josef Llobet, Not $^{0}$ de la Villa de Castellon, e impresa por Antonio Lacaballeria, en Barcelona, año de 1665; es mui interesante por el enladce y parentesco que justifica delos señores de Soneja, Castelnovo, y Mazalabez, con los citados Duques de Cardona, y otras ilustres Casas de España, y sus Reyes Catolicos.

12.Despacho librado por D. Fr. Juan Tomás de Rocaberti, Arzobispo y capitan general de Valencia, para que las Justicias y Jurados delos Lugares de Soneja, Serra, Azuebar, Ria, y agregados, no dieran laposesion de ellos al Marq. De Cogolludo, primogenito dela Duquesa de Segorbe, por ser emperjuicio de la marquesa de Castelnovo, suscrito de Eusebio de Benavides, secretario de Cam.ra en Valencia a 30 de junio de 1678.

13. Provision librada por el Regente y s. ** del Consejo de Aragon, reinando D. Carlos $2^{\circ}$ paa que un Cescribano de Camara dela Real Audiencia, diese ala IH marquesa de Castelnovo, testimonio del estado del pleytto que en ella seguia, con la IH Duquesa de Segorbe y Cardona, sobre derecho alas Baronias de Soneja, Azuebar, Ria y otras; su fecha en Madrid, y refrendada de Luis Boher, Secretario de Camara, a14 de Septiembre de 1678 .

14. Solicitud hecha por D. Vicente de Carmona y Mila, ala Real Audiencia de Valencia, en 9 de Agosto de 1686, para que sele admitiese y tubiese por parte en la demanda que $\mathrm{D}^{\mathrm{a}}$ Teresa del Mila Folch de Cardona, Marquesa de Castelnovo, su madre, seguia con la

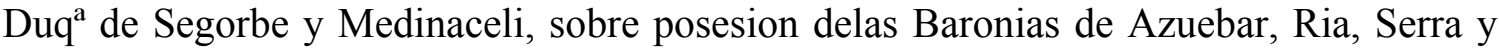
Soneja; de que se dio traslado, en cuyo estado quedó sin signar del Esmo Marcos Mansonis, ante quien paso.

15. Arrendamientos delos Derechos dominicales del Lugar de Azuebar, y heredad de Jayar, hecho por la Justicia, Jurados, y vecimos de dicho lugar, a favor de D. Vicente Folch de Cardona y Milá, Señor de el, y Marques de Castelnovo y Pons, por tiempo de seis años, y renta en cada uno de 130 libras; ante Fran.co Tarrega, Notario en la villa de Jerica, a 25 de junio de 1699. 
16. Despacho librado por el Marques de Villagarcia, Conde de Barrantes, Virrey y Capitan general de Valencia, para que los Arrendatarios delos Derechos dominicales delas Baronias de Soneja, Serra, Azuebar, Ria, y otras, pusieran enla tabla de cambios de Valencia las Rentas que de ellas estaban dbiendo, según lo solicitaba el Duque de Medinaceli, Segorbe, Cardona, Alcala, y Lesma, Conde de Prades ** que las disputaba; refrendado de Vicente Pareja Esmo de Camara, en Valencia a 25 de Agosto de 1704. Dado en traslado con sus intimaciones por Josef Torrent, a 13 de Septiembre del mismo año.

17. Sentancia dada por el Supremo Consejo de Aragón, en el articulo suscitado por el Duque de Medinaceli, de haverse excedido los oficiales de Justicia delas Baranias de Soneja, Azuebar, y Ria, en haver dado posesion de ellas $\mathrm{aD}^{\mathrm{a}}$ Josefa Folch de Cardona, hija primogenita del Masques de Castelnovo; por la qual declararon nula la citada posesion, y sepusieron las cosas del pleytto que la motibaba a suprimer estado, pronunciada por Vicente Saboya, en lugar de Vicente Pareja, Esmo de Camara, en Valencia a 10 de febrero año de 1705. Notada por Miguel Pajaron, Notario dela Cancelaria, y roborada dicha Nota por el Conde de Carlet, Justicia Civil de Valencia, y ttodo está duplicado.

18. Sentencia dada por el Real y supremo Consejo de Aragón, en el pleytto q*. en el pendia entre el Duque de Medinaceli, y $\mathrm{D}^{\mathrm{a}}$ Josefa Folch de Cardona, hija primogenita de D. Vicene de Cardona, Marques de Castelnovo, sobre derecho al goce y posesion de las Baronias de Soneja, Azuebar, Serra, y Ria, y otras, que quedaron vacantes en el Reyno de Valencia, por muerte del Conde de Monteagudo; por laqual declararon nula la posesion que de dichas Baronias havia tomado la referida Marquesa de Castelnovo; publicada por Vicente Soboya, en lugar de Vicente Pareja, Esmo de Carmara en Valencia, a 10 de febrero de 1705.Notada de Miguel Pajaron, Notario dela Cancelaria, y suscripta por el Conde de Carlett, Justicia Civil de dicha Ciudad, y esta todo duplicado.

19. Libro Judiciario, o mano de **** donde sentaban sus providencias civiles y politicas, los Alcaldes dela Baronia de Soneja, desde el año de 1698, hasta el de 1707. Contiene varias particularidades, y entre ellas las paces hechas entre algunos de sus vecinos, por las quales costaban sus desavenencias y riñas, por tiempo de 101 años y un dia.

20. Diez y nuebe exemplares del Memorial Ajustado del pleyto pendiente en el Real Consejo de Aragón, entre D. Nicolás Fernandez de Cordoba, Marques de Priego, Duque de Feria y Medinaceli con $\mathrm{D}^{\mathrm{a}}$ Josefa Folch de Cardona, Marquesa de Castelnovo y Pons, muger del Exmo Señor Dn. Josef de Solis y Gant, Duque de Montellano, sobre la mision enposesion delas Baronias de Azuebar, Soneja, Pellunes, Mosquera, Serra, Armell, y Ria; formado por el Dr. D. Pablo Montestauch, e impreso en Madrid, a16 de Noviembre de 1711 .

21. Quatro exemplares dela adiccion al Memorial ajustado del pleytto que pendio en el Real Consejo de Aragón, entre D.Nicolas Fernandez de Cordoba, Marques de Priego, Duque de Feria, y Medinaceli, y D ${ }^{\mathrm{a}}$ Josefa Folch de Cardona, Marquesa de Castelnovo y Pons, muger del Exmo Señor D. Josef de Solis y Gant, Duque de Montellano, sobre la mision en posesion delas Baronias de Azuebar, Soneja, Pellunes, Mosquera, Serra, Armell, y Ria; formada por D. Francisco Reguilon y D. Pablo Montestruch, e impresa en Madris, a 3 de Agosto del año de 1712. 
22. Memorial ajusttado formado por partte del Excelentisimo Señor Don Josef de Solis y Gant, y Doña Josefa Folch de Cardona, Duques de Monttellano, Marqueses de Castelnovo y Pons, en el Pleytto que seguian con Don Nicolás Fernandez de Cordoba, Marqués de riego, Duque de Feria y Medinaceli, sobre la inimisión enposesion delas Baronias de Azuebar, Soneja, y ottras, sitas en el Reyno de Valencia; aunque no tiene fecha sele aplica a fines del año de 1712, por cuyo tiempo se conjetura se imprimio.

\section{LEGAJO $2^{\circ}$ YNSTRUMENTOS DESDE EL AÑO DE 1713 AL DE 1756.}

23. Egecutoria librada por los Señores del Consejo del Rey D. Felipe quinto, el año de 1713, en el pleyto que havia cerca de doscientos años seguian en la Audiencia deValencia, y Consejo de Aragón, los Duques de Medinaceli y Segorbe, con los antecesores de $\mathrm{D}^{\mathrm{a}}$ Josefa Folch de Cardona, Marquesa de Castelnovo, muger de D. Josef de Solis y Gant, Duque de Montellano, sobre derecho ala posesion y goze delas Baronias de Soneja, Serra, Azuebar, Armell, Mosquera, Pellunes, y Ria, en el Reyno de Valencia, que habian quedado vacantes por muerte de D. Josef de Cardona, y D ${ }^{\mathrm{a}}$ Geronima Lull y Cabrera, su muger, Condes de Monteagudo, en la qe. Declararon pertenecer dichas siete Baronias ala citada $\mathrm{D}^{\mathrm{a}}$ Josefa Folch de Cardona, y sus sucesores. Aunque está simple e incompleta, ocupa estte lugar por incluir el testamento de dicha $\mathrm{D}^{\mathrm{a}}$ Geronima Lull y Cabrera, en que dejó heredero a D.Vicente de Aragón y Cardona, y a falta de este sin hijos, ala contenida $\mathrm{D}^{\mathrm{a}}$ Josefa del Mila, y Cardona, Abuela de la referida $\mathrm{D}^{\mathrm{a}}$ Josefa Folch de Cardona, Marquesa de Castelnovo, y por ottros importantes Ynstrumentos que se copian en ella.

24. Posesiones generales delas Baronias de Soneja, Azuebar, y sus agregadas Pellunes, Mosquera, y Jayar, Sierra y su aprogada Ria, sitas en el Reyno de Valencia, con sus Jurisdiciones, terminos, casas, carnicerias, tabernas, molinos, y patronatos de sus Iglesias; tomadas a nombre delos Ilustres Señores D. Josef de Solis y Gant, y D Josefa Folch de Cardona, marido y muger, Marqueses de Castelnovo y Pons, en virtud de Sentencia de vista y revista, dadas en favor de dicha señora por el Consejo de Aragón en $1^{\circ}$ de Junio de 1712, y 28 de Marzo de 1713, en contraditorio juicio seguido con el Marqués de Priego, Duque de Feria y Medinaceli, por muerte sin hijos de D. Vicente de Aragon y Cardona, su ultimo posehedor: Dadas por la Justicia dela villa de Murviedro, en virtud de comision articular que sle dio para ello; ante Francisco Antonio Gallego, Esmo de Camara dela $\mathrm{R}^{*}$ Audiencia de Valencia, a 18 y siguientes dias de Abril del citado año de 1713. Dadas en traslado por Fran.co Exulbe, igual Esmo de Camara, y originario delos Auttos, a 20 de Mayo del referido año.

25. Memorial ajustado formado a instancia delos Exmos. Señores D. Josef de Solis y Gant, y D ${ }^{a}$ Josefa Folch de Cardona, su muger, Duques de Montellano, Marqueses de Castelnovo y Pons, en el pleytto que seguian con los vecinos de sus Baronias de Soneja, Serra, y Azuebar, sobre que fuesen nulas e invalidas las gracias que les concedio el Apoderado de ottros señores, sin orden ni consentimiento de ellos; formado por el D.Gaspar del Castellar, e impreso en Valencia a 10 de noviembre de 1715. Sigue su arrendamiento en dicho año.

26. Egecutoria librada por los señores del Consejo del Rey D. Felipe quinto, en Madrid a 4 de febrero de 1716, refrendada de D. Josef de Bordonaba, Secretario de Camara, por la que declararon pertenecer al Exmo Señor D. Josef de Solis y Gant, Duques de 
Montellano, como marido dela Sra. $\mathrm{D}^{\mathrm{a}}$ Josefa Folch de Cardona, Marquesa de Castelnovo, la posesion delas Baranias de Azuebar, Soneja, Pellunes, Mosquera, Serra, Armell, y Ria, en el Reyno de Valencia, que le disputaban los Señores Duques de Medinaceli; Dicha Egecutoria se colocará vajo esta cubierta y numero, luego que sea remitida por la contaduria de S.E. Ala que se envio en 11 de Diciembre de 1802, Folio 78 y 81 del Libro de Salidas, y se apuntará lo mas que de ella resulte, sin hacer merito del numero 1725 que tenia según el mettodo anterior. Debuelta y colocada aquí con una copia simple.**

27. Sentencias de vista y revista dadas por el Real y Supremo Consejo de Castilla, ante su Esmo de Camara D. Josef Bordonaba, en Madrid, a 4 de febrero de 1716, en el pleytto que en el seguia el Duque de Feria y Medinaceli, con D. Josef de Solis y Gant, D ${ }^{\mathrm{a}}$ Josefa Folch de Cardona, su muger, Condes de Saldueña, y Frigiliana, Marqueses de Castelnovo, sobre la sucesion, y mision en posesion delas Baronias de Azuebar, Soneja, Pellunes, Mosquera, Serra, Armell, y Ria, sitas en el Reyno de Valencia, por las quales mandaron dar la posesion de ellas ala citada $\mathrm{D}^{\mathrm{a}}$ Josefa Folch de Cardona, como sucesora de su Abuela $\mathrm{D}^{\mathrm{a}}$ Teresa del Milá, en quien havian recibido por muerte de D. Vicente de Aragón; dadas en traslado en virtud de mandato Judicial, por Juan Nabarro, Cescribano en Madrid, a 7 de junio de 1743, duplicadas**.

28. Pososion del termino y Jurisdicion de Serra, tomada por parte del Exmo. Señor D.Josef de Solis y Gant, ante Juan Bautista Paris, Cescribano en Valencia, a 19 de Marzo de 1716. Dicha posesion se colocará vajo esta cuvierta y numero, luego que se remita por la contaduria de S.E, ala que se embio en 11 de Diciembre de 1802, Folio 78 y 81 del Libro de Salidas, y se apuntará lo mas que de ella resulte, sin hacer merito del numero 1769 que tenia según el metodo anterior. Debuelta.

29. Posesion particularmente tomada de la Baronia de Soneja, y todos sus derechos y regalias territoriales y Jurisdicionales, por parte del Exmo Señor D. Alonso de Solis Folch de Cardna, por haver sucedido en ella por muerte dela Exma Señora Da Josefa Folch de Cardona, Duquesa de Montellano, y Marquesa de Castelnovo, su madre; ante Juan Bautista Paris, Cescribano en Valencia, a 23 de Marzo de 1716.

30. Posesion tomada particularmente dela Baronia de Azuebar, y las de Pellunes, y Mosquera, sus agregadas, y todos sus derechos y regalias territoriales y jurisdicionales, por parte del Exmo Señor D. Alonso de Solis y Folch de Cardona, que havia sucedido en ellas, por muerte de la Exma. Señora $\mathrm{D}^{\mathrm{a}}$ Josefa Folch de Cardona, Duquesa de Montellano, y Marquesa de Castelnovo, su madre; ante Juan Bautista Paris, Cescribano en Valencia, a 23 de Marzo de 1716.

31. Recibo dado por D. Francisco Exulbi, Cescribano de Camara dela Real Audiencia de Valencia, de treinta y dos piezas de Autos de que constava el pleytto del Duque de Medinaceli, con el Marques de Castelnovo, sobre derecho al goze de las Baronias de Soneja, Serra, Azuebar, Mosquera, Armell, y Ria, hasta inclusive las sentencias de vista y revista, en que se amparó en la posesion de ellas a dicho Sr. Marques; su fecha en Valencia, a 4 de Julio de 1716. Dado en traslado por D. Juan de Penuelas, Secretario de Camara del Consejo de Castilla, en Madrid a 5 de octubre de 1753.

32. Carta de pago otorgada por el Administrador delas Rentas del Cavildo dela Catedral dela ciudad de Segorbe, de 255 libras, 11 sueldos y 8 dineros que havia recivido del 
Arrendador dela Baronia de Soneja, mitad delas que los Señores de ella le debian por pensiones atrasadas; ante Josef Torrent, Cescribano en Segorbe, a 26 de Julio de 1717.

33. Carta de pago dada por el Administrador delas Rentas del Cavildo de la Santa Iglesia de la Ciudad de Segorbe, de 255 libras 11 sueldos y 8 dineros que habia recivido del Arrendatario del lugar de Soneja, por cuenta de 511 libras que sele restaban de atrasos de pension sobre dicho Lugar, según convenio del año de 1716; ante Josef Torrent, Cescribano en Segorbe, a 27 de enero de 1718.

34. Carta de pago dada or el Dean y Cavildo dela Santa Iglesia Catedral dela Ciudad de Segorbe de 255 libras 11 sueldos y 8 dineros que habian recivido del Arrendador de Soneja por pension atrasada y corriente por mitad que los Barones del dicho Lugar les pagaban; ante Josef Torrent, Cescribano en Segorbe, a16 de Agosto de 1718.

35. Concordia hecha entre el Apoderado del Exmo Señor D. Josef de Solis y Gant, Duque de Montellano, Padre y lexitimo Administrador de D. Alonso de Solis Folch de Cardona, Marques de Castelnovo, y Juan Vidal, molinero de la Villa de Liria, por la qual se obligó este, afabricar a su costa un molino arinero, en el mismo sitio donde estubo el antiguo en termino del lugar de Serra, entre el Barranco y camino para Valencia; y que despues de siete años que le aprovechase el molinero, quedase para dicho D. Alonso de Solis Folch de Cardona, como Señor del Lugar y termino en que se fundaba, y para sus sucesores, con varias condiciones; ante Mateo Condomina, Cescribano en la Villa de Murviedro, a 18 de Marzo de 1719. Dada en traslado por dicho excribano a11 de junio de 1720 .

36. Certificacion dada por el Reverendo Luis Vicente de Cuencabuena, canonigo dela Catedral de Segorbe, de estar satisfecho su cavildo delas pensiones que le pagaba el ilustrisimo Marques de Castelnovo, sobre su Lugar de Soneja, hasta fin del año 1715; su fecha en el Archibo de Segorbe, a12 de Junio de 1719.

37. Carta de pago dada por el tesorero y canonigo del Cavildo de la Santa Iglesia de la Ciudad de Segorbe, de 255 libras 11 sueldos y 8 dineros que habian recivido del Arrendador del Lugar de Soneja, por pension corriente y atrasada que el Barón y Señor de dicho Lugar les pagaba; ante Josef Torrent, Cescribano en Segorbe a 2 de octubre de 1719 .

38. Obligacion con sus condiciones para hacer el molino del Lugar de Serra, en el año de 1719. Dicha obligcion se colocará vajo esta cuvierta y numero, luego que sea remitida por S:E, aquien se envio con otros en 7 de Agosto de 1806, y se apuntará lo mas que de ella resulte, sin hacer merito del numero 1624 que tenia según el metodo anterior. Dicha obligacion se otrogó ante Mateo Condomina, Cescribano de Murviedro.

39. Carta de pago dada por el tesorero y canonigo de la Catedral de la Ciudad de Segorbe, de 511 libras 3 sueldos y 4 dineros que havian recividod del Arrendador del Lugar de Soneja, por pensiones arasadas y corriente que el Baron y Señor de dicho Lugar les pagaba; ante Josef Torrent, Cescribano en Segorbe, a1 ${ }^{\circ}$ de Julio de 1720.

40. Carta de pago dada por el Administrador de las Rentas del Cavildo de la Santa Iglesia Catedral de la Ciudad de Segorbe, de 390 libras, por reditos de tres años de la pension que gozaba sobre las Rentas del Lugar de Soneja en virtud de Escritura otorgada ante el Cescribano de esta carta, que lo fue Josef Torrent, quien la firmó y signo en Segorbe a 29 de Julio de 1720. 
41. Poder ottorgado por D. Josef Galindo y Zayas, a favor de D. Pedro Esles, para que en su nombre administrara y cobrara las Rentas que le pertenecian en Madrid por los mayorazgos que gozaba de los Zayas, y Alonso de Herrera, y Elvira Nieto; ante Francisco Ignacio Ramirez Pantoja, Cescribano en Toledo, a11 de febrero de 1721.

42. Libro que se destinaba para la cuenta y razon de las Rentas de las Baronias de Soneja, Serra, y Azuebar, desde el año de 1722 en adelante, y luego le ocupan la maior parte las memorias de Mazalabez; resultando por el, lo que producia en aquel tipo y las cargas que se pagaban sobre Serra.

43. Carta de pago dada por el Dean y Cabildo de la Santa Iglesia Catedral dela Ciudad de Segorbe de 2044 libras 13 sueldos y 4 dineros que habian recivido de los Arrendadores de los Lugares de Soneja, Azuebar, Serra y Ria, por cuenta de la pension anual que les pagaba el Baron y Señor de ellos, el Ilustre D. Josef de Solis y Gant, Conde de Saldueña como padre de D. Alonso Vicente de Solis Folch de Cardona; ante Jayme Torrent, Cescribano en Segorbe, a 24 de septiembre de 1723.

44. Carta de pago dada por el colecttor de las Rentas del Cavildo de la Catedral de Segorbe, de 35 libras, un sueldo y dos dineros que habia recivido del Arrendador del Lugar de Soneja con las quales le habian complettado D. Josef de Solis y Gant, y suhijo D. Alonso, Barones y Señores de dicho Lugar, las 255 libras 11 sueldos y 8 dineros que le pagaban de pension, y por la perteneciente al año de 1723; ante Jayme Torrent, Cescribano en Segorbe, a 25 de Abril de 1724.

45. Residencia tomada alos sugettos que egercieron los oficios de Justicia en la Baronia de Soneja, desde el año de 1707 hasta el de 1723, la que resulta sentenciada, y condenados muchos de ellos apenas pecunarias por los descuidos y omisiones que tuvieron en la administracion de Justicia; hecha por D. Pedro Esles, campero, comisionado para ella por el Padre del Exmo Señor D. Alonso de Solis Folch de Cardona, Dueño de dicha Baronia; ante Pedro Olano y Aparicio, Cescribano de Segorbe, a 27 y siguientes dias de Julio de 1724 .

46. Residencia tomada alos sugettos que egercieron los oficios de Justicia en la Baronia de Azuebar, desde el año de 1707 hasta el de 1723, en la que se dio sentencia, y por ella se condenó ala mayor parte en pena pecuniaria, por sus descuidos y omisiones en la recta administracion de Justicia, y de los derechos del Exmo. Señor D. Alfonso (sic.) de Solis Folch de Cardona, Dueño de la citada Baronia, donde fue agecutada ante Pedro Olano, Cescribano de Segorbe, $\mathrm{a} 1^{\circ}$ y siguientes dias de septiembre de 1724.

47. Residencia tomada alos sugetos que egercieron los oficios de republica en el lugar de Serra, desde el año de 1707 hasta el de 1723, en la que se dio sentencia y condenó a todos ellos en penas pecuniarias, por sus omisiones y descuidos en la Administracion de Justicia; hecha de orden del padre del Exmo Señor D. Alonso de Solis Folch de Cardona, Conde de Saldueña, Marques de Castelnovo y Pons, señor del referido Lugar; ante Pedro Olano, Cescribano de Segorbe, a 25 y siguientes dias de Septiembre de 1724. Está con la informalidad de faltarle las firmas del Juez que la tomó.

48. Cesion hecha por el Apoderado del Exmo. Señor D. Josef de Solis y Gant, Duque de Montellano, como padre y legitimo Administrador de la persona y vienes de D:Alonso de Solis Folch de Cardona, Conde de Saldueña, Marques de Castelnovo, y Baron de Sierra, a Pedro Libera, vecino del Lugar de la Puebla de Farnals, de un sitio de 100 palmos de largo y 50 de ancho, en dicho lugar de Serra, para fabricar un molino de Aceyte, en que 
los vezinos de el molieran la Aceytuna de su cosecha, pagando en cada año, el citado Libera, y sus sucesores, al referido Señor Conde de Saldueña, y los suyos, 30 sueldos valencianos, ante Pedro Olano, Cescribano de Segorbe, a10 de octubre de 1724.

49. Disposiciones y apuntaciones testamentarias que el Exmo. Señor D. Josef Foch de Cardona y Eril, hizo en viena, desde 10 de octubre de 1720, hasta 5 de Julio de 1726, por las quales declaro havia estado en servicio de los Emperadores de Alemania, que en aquel Imperio le havian cedido la Ciudad de Wirobitisa (??) que posehia el Amirantazgo y Principado de Cardona, la Encomienda de Alcalá de Xibertt, y otros vienesen España, delo qual nombra heredero a D. Francisco de Silba Foch de Cardona, Marques de la Vega de la de la Sagra, su sobrino, hijo de la Marquesa de Monte Mayor, hermana del testador; y hace algunos legados al Conde de Montesanto; Marques de Villasor, su suegro; ala Condesa de

50. Desaucio hecho por Juan Vidal, vecino de la villa de Liria, del Molino del Lugar de Sierra, propio del Exmo Señor Conde de Saldueña, Duque de Montellano, respecto a tenerle en subarriendo, y no poder cumplir con lo capitulado. Dado por testemonio de Josef Aragó Serra, **** en dicha villa, a16 de febrero de 1727

51. Certificado dado por el cura Rector de la Iglesia Parroquial del lugar de Soneja, de haber recivido sus mayordomos de fabrica 25 libras *** que les entregó el Procurador del señor de dicho lugar, por censo sobre el correspondiente al año de 1729; firmado y sellado a 27 de marzo de 1730 .

52. Padron de los ochenta y un vecinos que tenía el lugar de Serra, sus haciendas y productos vasadas cargas; hecho en virtud de orden del Yntendente general de Valencia, en Soneja a15 de Abril de 1730.

53. Libro del repartimiento delas casas, y tierras del lugar de Serra, y su unido Ria, en el Reyno de Valencia, hecho entre los 61 vecinos que tenia el año de 1714, y continuado entre los 77 que tenia en el año de 1737, expresando lo que cada uno pagaba cada año por laposicion que gozaba al Dueño territtorial.

54. Residencia tomada alos sugetos que egercieron los oficios de justicia en el lugar de Serra, desde el año 1723 hasta el de 1729, enla que se dio sentencia condenando a muchos de ellos en pena pecuniaria por sus omisiones y falta de administracion de justicia; tomada de *** del Exmo Señor D. Alfonso de Solis Folch de Cardona (Alonso), Conde de Saldueña, Marques de Castelnovo y Pons, Señor del citado lugar ante Onofre Candas, Cescribano en Valencia, a16 y siguientes dias de mayor de 1737. Lo equivoco el Cescribano poniendo veinte años antes, y dejando de firmar del Juez las diligencias. Se unen dos arrendamientos en 1738.

55. Residencia tomada alos sugetos que egercieron los oficios de justicia en la Baronia de Soneja, desde el año de 1723 hasta el de 1738, en la que se dio sentencia condenando en penas pecuniarias ala mayor parte de ellos, por sus descuidos y omisiones en la administracion de Justicia; hecha de orden del Exmo. Señor D. Alonso de Solis Folch de Cardona, Conde de Saldueña, Marques de Castelnovo y Pons, Señor de dicha Baronia, ante Onofre Candas, Notario de Valencia, a 8 y siguientes dias de Enero de 1739, faltandole el esencial requisito de las firmas del Juez que lo tomo.

56. Carta de pago dada por el Cura Rector y Aministradores de la Iglesia del Lugar de Soneja, de 175 libras ** que habian recivido del Exmo. Señor Conde de Saldueña, 
Maques de Castelnovo, Señor de dicho lugar, por censo que sobre el se pagava, pertenecientes a siete años cumplidos en el de 1738; ante Felipe Tarrega, Cescribano de la ciudad de Segorbe a19 de Enero de 1739. Dada en traslado tres años despues.

57. Ynformacion sumaria, hecha del Real Oficio de Justicia del lugar de Soneja, por la que se acredita que muchos de sus vecinos se tumultuaron por no querer igualarse con medico, cirujano y botticario, como habia acordado su Ayuntamiento, para cuya oposicion habian repartido algunos sueldos; esta original sin determinar, ante Felipe Tarrega, Cescribano en dicho lugar, a 21 de Abril y siguientes dias de Mayo de 1739.

58. Recibo dado por el parroco y Mayordomo de fabrica de la Baronia de Soneja, de 20 libras n**, que habian recivido del Exmo Señor Duque de Montellano, Señor de dicha Baronia, para la amplificacion de su Yglesia Parroquial; su fecha a19 de mayo de 1740.

59. Convenio hecho entre el Apoderado del Exmo. Señor D. Alonso de Solis Folch de Cardona, Conde de Saldueña, Marques de Castelnovo, Baron de Soneja, Villa y Cavildo de la Yglesia Parroquiel de la Ciudad de Segorbe, por el qualse obligó el primero pagar al segundo en seis años 550 libras que sele estaban deviendo por pensiones atrasadas de tres censos a su favor sobre ** lugar de Soneja, cesando la egecuacion que por ellas havia entablado; ante Joaquin Medina, Cescribano en Valencia, a12 de Noviembre de 1746. Dado en traslado por Raymundo Gomez, igual Cescribano, a10 de diciembre de 1752. Sigue una Nota interesante.

60. Testimonio del arrendamiento hecho ante Pedro Rodrigo, escrivano en Valencia, a 25 de octubre de 1756, de todos los dias dominicales del lugar de Serra, perteneciente al Exmo Señor D. Alonso de Solis Folch de Cardona, Duque de Montellano, por tiempo de quattro años, y renta en cada uno de nuebecientas libras. Dado por el mismo Cescribano, a 27 de corriente mes y año.

\section{LEGAJO $3^{\circ}$ YNSTRUMENTOS DESDE EL AÑO 1757 AL DE 1764}

61. Seis ejemplares del memorial ajustado del pleytto seguido en grado de rebista en la Real Audiencia de Valencia, por D. Luis Fernandez de Cordova, Marques de Priego, Duque de Feria y Medinaceli, con D. Alonso de Solis Folch de Cardona, Duque de Montellano, Marques de Castelnovo y Pons, sobre la sucesión en propiedad de las Baronias de Azuebar, Soneja, Pellunes, Mosquera, Serra , Armell, y Ria, formado por tres lettrados, y procuradores de las partes, e mpreso en Valencia, a13 de Julio de 1760.

62. Residencia tomada alos sugettos que egercieron los oficios de Justicia en la Baronia de Serra, desde el año de 1736 hasta el de 1760, en la qual se halla dada sentencia or el Dr. D. Manuel Roman, Juez comisionado de ella, por la qual condenó ala mayor parte de ellos en penas pecunarias, por sus omisiones y mala administracion de Justicia; hecha en virtud de orden del Exmo. Señor D. Alonso de Solis Folch de Cardona, Conde de Saldueña, Marques de Castelnovo y Pons, Señor de dicha Baronia, ante Cristobal Fornas, Cescribano en Valencia, a13 y siguientes dias de Mayo de 1761; consta de quatro piezas originales, estendidas con la mejor formalidad.

63. Residecia tomada alos sugettos que egercieron los oficios de replublica en la Baraonia de Azuebar, en el Reyno de Valencia, desde el año de 1740, hasta el de 1760, en la que se condenó a varios de ellos con multa pecuniaria or sus omisiones en la 
administracion de Justicia; hecha en virtud de comision del Exmo Señor D. Alfonso de Solis Folch de Cardona (Alonso), Conde de Saldueña, Marques de Castelnovo, y señor de la citada Baronia, por el Dr. D. Manuel Roman, Abogado delos Reales Consejos, ante Cristoval Fornas, Cescribano a 21 de Enero de 1762. Está original, y consta de quatro piezas.

64. Residencia tomada alos sugettos que egercieron los oficios de republica en la Baronia de Soneja, en el Reyno de Valencia, desde el año de 1741 hasta el de 1760, en la que se condenó a muchos de ellos en multa pecunaria por sus omisiones en la administracion de Justicia; hcha en virtud de comision del Exmo. Señor D. Alfonso de Solis Folch de Cardona (Alonso), Conde de Saldueña, Marques de Castelnovo, y Señor de otra Baronia, or el Dr. D. Manuel Roman, Abogado de los Reales Consejos; ante Cristobal Fornas, Cescribano a14 de Marzo de 1762, Esta iriginal y consta de tres piezas.

65. Quatro exemplares de la adiccion al memorial ajustado del pleyto que en la Real Audiencia de Valencia, seguia en rebista D. Luis Fernandez de Cordoba, Duque de Medinaceli, con D. Alonso de Solis Folch de Cardona, Duque de Montenllano, Marqués de Castelnovo y Pons, sobre la sucesion en propiedad de las Baronias de Azuebar, Soneja, Pellunes, Mosquera, Serra, Armell, y Ria; formada por tres Letrados de Valencia, e impresa en esta ciudad a 21 de Mayo de 1764.

66. Trece Arboles genealogicos impresos, que manifiestan los posehedores de esta Baronia, de Soneja, y sus unidas, hasta la Exma Señora $D^{a}$ Josefa Folch de Cardona, Maquesa de Castelnovo, que las ganó en contraditorio Juicio con el Duque de Medinacili, que se las disputaba. Se aplican al año de 1764 como en justificacion de los momoriales ajustados y adicciones que les preceden.

67. Otros trece Arboles genealogicos impresos, que manifiestan los posehedores de esta Baronia de Soneja, y sus unidas, hasta la Excelentisima Señora Daña Josefa Folch de Cardona, Marquesa de Castelnovo, que las ganó en contradictorio juicio con el duque de Medinaceli, que las dispottava. Se aaplican al año de 1764, como en justtificacion de los memoriales ajusttados, y adcciones que les preceden.

\section{LEGAJO $4^{\circ}$ YNSTRUMENTOS DESDE EL AÑO DE 1765 al de 1800}

68. Egecutoria de sentencia de rebista dada por los señores Governador Capittán general, Presidente, Regente y oydores de la Real Audiencia de Valencia, en el pleytto seguido en ella por D. Alonso de Solis Folch de Cardona, Duque de Montellano, y Marques de Castelnovo, y el Arrendador de los derechos dominicales de su Baronia de Soneja, contra el Consejo y vecinos de la misma Baronia, subre que esttos le pagasen el derecho delas Aceytunas que cogian, con arreglo alos capitulos 7 y 13 de su nueba poblacion; por la qual rebocaron la de primera instancia dada por el Alcalde de Soneja, y la de vista dada por dicha Real Audiciencia, y declararon que dicho Consejo y vecinos no fuesen mantenidos en la posesion de no pagar dicho Derecho de Aceytuna; refrendada de D. Luis Oller y Borja, Cescribano de Camara en Valencia, a10 de Diciembre de 1767.

69. Residencia tomada a los sugettos que egercieron oficios de republica en la Baronia de Azuebar, en el Reyno de Valencia, desde el año 1767 hasta el de 1775, en la que se hicieron algunas condenaciones pecuniarias a muchos de ellos por sus omisiones en la adminsitracion de Justicia; hecha en virtud de Comision del Exmo Señor D. Alfonso 
(Alonso) de Solis Folch de Cardona, Duque de Montellano, Marques de Castelnovo, y Sñor de dicha Baronia, por el licenciado D. Eleuterio Alfaro, Abogado de los Reales Consejos; ante Ignacio Torres y Selma, Cescribano, a 24 de Mayo de 1776. Está original, y consta de tres piezas.

70. Residencia tomada alos sugettos que egercieron oficios de repubica en la Baronia de Soneja, en el Reyno de Valencia, desde el año de 1762, hasta el de 1775, en la que resulta se condeno a muchos de ellos en penas pecunarias por sus omisiones en la administracion de Justicia y buena politica; hecha en virtud de mandato del Exmo Señor D. Alfonso (Alonso de Solis Foch de Cardona, Duque de Montellano, Marqués de Castelnovo, y Señor de dicha Baronia, por el Licenciado D. Eleuterio Alfaro, Abogado de los Reales Consejos; ante Cosme Galbis, Cescribano, a 4 de Junio de 1776. Esta original y consta de tres piezas.

71. Residencia tomado alos sugetos ue egercieron oficios de republica en la Baronia de Serra, en el Reyno de Valencia, desde el año 1761 hasta el de 1775, en la que aparece se condenó a muchos de ellos en pen pecuniaria por sus omisiones y descuidos en la buena administracion de Justicia; hecha en virtud de nombramiento del Exmo Señor D. Alfonso (Alonso) de Solis Folch de Cardona, Duque de Montellano, Marques de Castelnovo, y Señor de dicha Baronia, por el Licenciado D. Eleuterio Alfaro, Agogado de los Reales Consejos; ante Miguel Sarrio, Cescribano, a16 de Julio de 1776. Está original, y consta de tres piezas $\mathrm{Y}$ un arrendamiento.

72. Apeo, empadronamiento, ojabrebe general, de los vecinos terratenientes de la Baronia de Serra, que por las Casas y tierras que tenian, pagaban sus respectibos censos anuales al Exmo. Señor D. Alonso de Solis Folch de Cardona, Dueño de dicha Baronia, en la ue se egecutó el año de 1779.

Posesion tomada por parte del curador ad litem del Exmo Señor D. Alfonso de Solis Wignacourt, Duque de Montellano, Marques de Castelnovo i Sr. de la Baronia de Soneja, en el Reyno de Valencia, y todos sus derechos dominicales de Jurisdicion y terrazgo, que havia quedado vacante por muerte de su padre el Exmo Señor D.Alfonso (Alonso) de Solis Folch de Cardona; dada en virtud de despacho requisitorio de D. Mariano Colon, Juez Delegado del Real y Supremo Consejo de Castilla; ante Vicente Ignacio de Atucha, Cescribano de Valencia, a 25 de Agosto de 1780. Y el Requis.rio lo refrendó Pedro Balladares.

Posesion tomada por parte del curador ad litem del Exmo Señor D. Alfonso de Solis Wignacourt, Duque de Montellano, Marques de Castelnovo, de los derechos dominicales de Jurisdicion y terrazgo de la Baronia de Azuebar, en el Reyno de Valencia, que havia quedado vacante por muerte del Exmo Señor D. Alfonso (Alonso) de Solis Folch de Cardona, su padre: dada en virtud de Despacho de D. Mariano Colon, Delegado del Real y Supremo Consejo de Castilla, ante Vicene Ignacio de Atucha, Cescribano de Valencia, a 25 de Agosto de 1780, y la de Serra.

75. Arrendamiento de la heredad titulada de Jayar, situada en el Monte del Lugar de Soneja, propio del Exmo. Señor D. Alfonso de Solis Wignacourt, Duque de Montellano, hecho por Josef Soriano, vecino del citado Lugar, por tiempo de seis años, y renta en cada uno de 130 libras Reales, ante Ignacio Fornes y Selma, Cescribano de Castelnovo, en Soneja, a 21 de Noviembre de 1782, y dio en traslado el año siguiente de 1782 . Y otro Arrendamiento en 1788. 
76. Testemonio del arriendo hecho por Josef Soriano y Piquer, y Salbador Ribas y Bojo, vecinos de la Baronia de Soneja, de los derechos dominicales de esta, y la de Azuebar, correspondientes a su dueño el Exmo Señor D. Alonso de Solis Wignacourt, Duque de Montellano, por tiempo de seis años, y Renta en cada uno de ellos de 3.700 libras valencianas, según escritura ante Vicente Francisco Magdalenes, Cescribano en Valencia, a 8 de enero de 1782, quien asi lo testifica, en 7 de Diciembre de 1783, Se le ha unido la Escritura Literal.

77. Representacion hecha al Rey D. Carlos $3^{\circ}$ por D: Pascual Mercader de Calatayud, Marques de la Vega, y Baron de Cheste, y Montichelbo, delos servicios que el y sus antecesores havian hecho a dicho Monarca y los suyos, para que por ellos le concediera la gracia que le pedia; son interesantes las explicaciones que hace de las servidumbres de Palacio, Titulo de Baron y sus privilegios y otras curiosidades dignas de trasmitirse como recopiladas de los mejores escritores españoles; formada por Josef Mariano Ortiz, Cescribano de la Alcaldia del Real Palacio de Valencia, e impresa en Madrid, año de 1783.

78. Trece propuestas hechas por el Ayuntamiento del Lugar de Soneja, de las personas que egerciesen la Justicia en el, y nombrase su Señor el Marques de Castelnovo, y son pertenecientes a varios años, desde el de 1716 al de 1785 .

79. Cinco propuestas hechas por el Ayuntamiento del Lugar de Serra, de las personas que egerciesen la Justicia en el, y eligiese su Señor el Marques de Castelnovo, desde el año de 1725 al de 1785; y otras dos de Soneja de 1792 y 93.

80. Ocho propuestas hechas por el Ayuntamiento del Lugar de Azuebar, de las personas que egercieran Justicia en el, y eligiera su Señor el Maqués de Castelnovo, desde el año de 1722 , al de 1785 .

81. Testimonio de tres notas puestas a continuacion de la Egecutiva que en 4 de febrero de 1716 libró el Real y Supremo Consejo de Castilla, adjudicando la posesion de las Baronias de Azuebar, Soneja, Serra, Pellunes, Mosquera, Armell, y Ria, en el Reyno de Valencia, Da Josefa Folch de Cardona, muger de D. Josef de Solis y Gant, Condes de Saldueña, y Marqueses de Castelnovo, por las quales resultaba que por dicho Señor Marques de Castelnovo, y su hijo D. Alonso, se impusieron tres censos sobre dichas Baronias, y luego los redimio su nieto el Exmo Señor D. Alfonso de Solis Wignacourt, quinto Duque de Montellano, y también Marques de Castelnovo, como resulta en el Legajo de vienes libres que estte Señor dejó, y queda notado enlos Cabrebes de Mozalabez. Dado dicho testimonio por Felipe Benicio Harraiz, Cescribano en Madrid, a 14 de Agosto de 1786.

82. Arredamiento de los derechos dominicales de las Baronias de Soneja, y Azuebar, propieos del Exmo. Señor D.Alsonso de Solis Wignacourt, Duque de Montellano, hecho por Josef Soriano y Piquer, Salbador Ribas, y Juan Carbonell, por tiempo de quatro años, y renta en cada uno de 3.930 libras Rs, ante Vicente Francisco Madalenes, escribir en Valencia, a 4 de septiembre de 1787; sigue unido un *** de horno de cocer pan en Azuebar, hecho por aquel tiempo, y ottro del Palacio de Soneja, poco anterior a el, y otro del Meson de Soneja.

83. Informacion practicada a instancia del poder haviente del Exmo Señor D.Alfonso de Solis Wignacourt, Duque de Montellano, y Señor de la Baronia de Serra, por la queal se justifico que el Procurador, o conrrer, del Convento de la Cartuja de Portaceli, havia 
tomado un pedazo de terreno al puntal de la ferrea de dicha Baronia y lo havia agregado a dicha Cartuja; lo cual visto por el Dr. D. Josef Luis Marco, Alcalde Mayor de Serra, mando devolver incomporar a su termino el citado terreno, lo que así hizo; ante Miguel Conejos, excribano en ella, a19 de Abril de 1788.

84. Renovacion de los limites y mojones que dividen el termino de la Baronia de Serra, propia del Exmo Señor D. Alfonso de Solis Wignacourt, Duque de Montellano, y Señor de ella, de los Pueblos comarcanos que son Segorbe, Albalat, Torres Torres, Estibella, Naquera y Real Cartuja de Portaceli; practicada por el Dr. D. Josef Luis Marco, Alcalde mayor de dicha Baronia de Serra; ante Miguel conejos, Cescribano en ella, a 3 y siguientes dias de Junio de 1788.

85. Arrendamiento otorgado por Joaquin Modrego, maestro de seda en Valencia, de todos los derechos dominicales de la Baronia de Serra, perteneciente a su Dueño el Exmo Señor D:Alfonso de Solis Wignocourt, Duque de Montellano, por tiempo de quatro años, y Renta en cada uno de 1.660 libras reales y diez arrobas de Aceyte, ante Vicente Francisco Madalenes, Cescribano en Valencia, a10 de diciembre de 1788. Le sigue otra copia.

86. Arrendamiento ottorgado por Pedro Pasqual Sanz, Salbador Gil, y Josef Soriano, de los Derechos dominicales de las Baronias de Soneja, y Azuebar, porpias del Exmo Señor D. Alfonso de Solis Wignacourt, Duque de Montellano, por tiempo de quatro años y Renta en cada uno de 6.100 libras Reales, 15 arrobas de Aceyte, y 150 arrobas de paja, y 100 arrobas de algarrobas; ante Carlos Vicente de Segui y Rodriguez, Cescribano en Valencia, a 8 de Agostto de 1795, que dio en traslado dos años despues. Se le ha unido otra copia.

87. Arrendamiento ottorgado por D.Mariano Mauricio de Algarra, vecino de la Ciudad de Valencia, de los Derechos dominicales de la Baronia de Serra, pertenecientes al Exmo Señor D. Alfonso de Solis Wignacourt, Duque de Montellano, por tiempo de quatro años, y Renta en cada uno de 2.320 libra y media Reales, y 50 arrobas de paja, y 50 arrobas de Algarrobas; ante Carlos Vicente de Segui y Rodriguez, Cescribano en Valencia, a 3 de ocrubre de 1796, que dio en traslado el año siguiente.

88. Arrendamiento ottorgado por Salbador Ribas, y Gaspar Juan, vecinos y labradores del Lugar de Soneja, de todos los derechos dominicales de dicho Lugar, y del de Azuebar, propios del Exmo Señor D. Alfonso de Solis Wignacourt, Duque de Montellano, por tiempo de quatro años, y renta en cada auno de 7.200 libras, y varias adealas de Aceyte, Paja y Algarrobas; ante Carlos Vicente de Segui y Rodriguez, Cescribano en Valencia, a13 de Septiembre de 1799. Se le une una copia de el, y otra del año 1803.

\section{LEGAJO $5^{\circ}$ YNSTRUMENTOS DESDE EL AÑO DE 1801 ADELANTE}

89. Testimonio autentico, que deverá ponerse esta cuvierta, de los Ynstrumentos que expresa la Nota que esta dentro de ella, relatibos a acreditar los sucesores y posehedores de estas Baronias hasta yo; y en seguida se colocaran los que sucesibamente se otorguen, con numero progresibo. 
90. Posesiones tomadas por parte del Exmo. Señor D. Carlos de los Rios, Conde de Fernannuñez y de Barajas, Duque del Arco ** de la Baronia de Soneja, su jurisdiccion, nombramiento de oficiales quela ejercieron, carcel, poblacion, palacio, Casa de la Señoria, Patronato de su Iglesia, casa de su Parroco, tienda, taberna, panaderia, carniceria, y su pilon, dos Huertos, Almacera, Bodega, meson, horno, molino de Harina, Venta nueva, Algarroferal, cuatro pedazos de tierra, y de su termino general que quedó por muerte del Marques D. Alfonso de Solis Wignacourt, Duque de Montellano ett. Padre de la Exma Sra. Da Maria Vicenta de Solis Laro de la Vega esposa de dicho Exmo. Señor Conde de Hernan-Nuñez: ante D. Pedro Ibañez de Lara y Herraez Cescribano del num. ${ }^{\circ}$ de Valencia a 20 de Noviembre de 1806.

91. Posesiones tomadas por parte del Exmo. Señor Don Carlos de los Rios, Conde de Fernan-Nuñez, y de Barajas, Duque del Arco, * de la Baronia de Azuebar, su Jurisdicion, nombramiento de Oficiales que las egercieran, Carcel, Casa de Ayuntamiento, Poblacion, Patronato de su Yglesia, tienda, taberna, Panaderia, Carniceria y su Pilon, Almazara, Meson, Horno, Carrascal, su termino general, y el de su heredad del Jayar, que quedaron por muerte del Exmo. Señor Don Alfonso de Solis Wuignacourt, Duque de Montellano, * y padre de la Exma. Sra. Doña Maria Vicenta de Solis Wignacourt Laso de la Vega, esposa de dicho Exmo. Señor Conde de Fernan-Nuñez: ante D. Pedro Ybañes de Lara y Herraez, Cescribano del Numero de Valencia, a 21 de Noviembre del año de 1806.

92. Posesiones tomadas por parte del Exmo Señor Don Carlos de los Rios, Conde de Ferna-Nuñez, y de Barajas, Duque del Arco *, de la Baronia de Serra, en Jurisdicion, Nombramiento de Oficiales que la egercieran, Carcel, Poblacion, Palacio, Casa de la Señoria, Patronato de sus Yglesia, Horno, Panaderia, tienda, taberna, Carniceria y su Pilon, Meson, telar, Pedrera de Yeso, Molino arinero, y su termino general, y de el de su desplablado Ria, que quedaron por muerte del Exmo Señor Don Alfonso de Solis Wuignacourt, Duque de Montellano, * , Padre de la Exma Sra. Doña Maria Vicenta de Solis Laso de la Vega, esposa de ** Exmo Señor Conde de Fernan Nuñez: ante D. Pedro Ybañez de Lara y Heraez, Cescribano del Numero de Valencia, a 23 de Noviembre del año de 1806.

93. Arrendamiento otorgado por Vicente Navarro, de los derechos Dominicales de la Baronia de Serra, con sus Censos de Casas, Tierras, particion de frutos, Hervajes, Molino , Horno, Tienda, Pilon, Panaderia, Cantera de Yeso, Luismos de Rentas, y demas, por tiempo de 4 años, y precio en cada uno de 2.402 libras y 10 sueldos, 15 arrobas de Aceyte, 50 arrovas de Paja, y 50 de Algarrobas: ante D. Pedro Ybañez de Lara y Herraez, Cescribano en Valencia, a 22 de diciembre de 1806. todo a fabor del Exmo Señor D. Carlos de los Rios, como marido y conjunta persona de la Exma Señora Da Maria Vicenta de Solis Laso de la Vega, sucesora en dicha Baronia, como hija y heredera del Exmo Sr. D. Alfonso de Solis Wignacourt, Duque de Montellano. Se le unen la Aclaracion y fianza.

94. Arrendamiento en copia simple, hecho por Jose Sorriano Gil, y Manuel Aparicio y Soriano, de los Derechos Dominicales de las Baronias de Soneja y Azuebar, con los censos de Casas, tierras, particiones de frutos, herbajos, Molino, Horno, Tienda, Pilon, Panaderia, Cantera de Yeso, y demas, según capitulaciones de Poblacion, por tiempo de 4 años, y precio en cada uno de 7.600 libras, 15 arrovas de Aceyte, 10 de higos, 150 arrobas de Paja, y 100 de Algarrobas, ante D. Pedro Ybañez de Lara y Herraez, Cescribano en Valencia, a 21 de Agosto de 1807. 
95. Arrendamiento otorgado por D. Luis Luca, de los derechos Dominicales de la Baronia de Serra, que comprenden los citados anteriormente pertenecientes a la Exma Señoa Da Maria Vicenta de Solis Laso de la Vega, Condesa de Fernan-Nuñez, Duquesa de Montellano, y del Amo, que governaba y regia por si, en virtud de poder que le dio en el Puerto de Santa Maria su Esposo el Excelentisimo Señor Conde, y Duque de los mismos titulos, por tiempo de cuatro años y precio en cada auno de mil setecientas libras, y 10 arrobas de Aceyte; ante Jose Vicente Garcia, Cescribano en Valencia, a 17 de Junio de 1811. Se le une copia, y otra de la Yesera.

96. Arrendamiento hecho por Gaspar Juan y Miguel Piquer Rubio, de los Derechos Dominicales de los Lugares de Soneja y Azuebar, esplicados ya en los anteriores, por tiempo de tres años, y precio en cada uno de siete mil y quinientas libras, que habian de entregar a sus plazos al Administrador de Bienes Nacionales de Valencia, nombrado por el General Frances Souchet, por quien estaban intervenidas otras rentas: ante el Licenciado Felipe Olano, Cescribano en Segorbe a 27 de Febrero de 1812. Se le une una copia firmada del propio Cescribano, y otra simple.

\section{(nota de l'escrivà):}

Hasta aquí se fue guardando el orden analitico en la colocacion de los Documentos de pertenencia de estas Baronias; pero teniendo noticia de que en poder del Administrador a cuyo cargo estan en Valencia, existian muchos antiguos y modernos, relatibos a las mismas, y aun a la de Mazalabez, y Marguesado de Castelnovo, se le mandó por S.E. Embiase Ymbentario de ellos, lo que asi hizo, y por el Archibero se señalaron los útiles, los que remitió en seguida, y se pasaron al Archivo con orden de S E de 6 de Julio de 1829.

De aquel cúmulo de Ynstrumentos unos se han aplicado a la Baronia de Mazalabez, otros al Marquesado de Castelnovo; y a estas Baronias de Soneja y unidas, se han destinado los que les son referentes, muchos de los cuales se han colocado a continuación de sus originales, duplicados de ellos, como se advierte por las adicciones puestas en muchos lugares de este Yndice; y los que no han podido llevar aquel método siguen aquí en esta forma.

97. Sentencia dada por la Real Audiencia de Valencia, siendo su Presidente y Capitan gral., D. Pedro Jose de Silba, Conde de Cifuentes, Marques de Alconchel, y Juez de Alzadas de Toledo, en la disputa suscitada entre el Duque de Medinaceli, la Ciudad de Segorbe, el Sindico del Lugar de Serra, y el Combento de la Cartuja de Portaceli, sobre a cual de ellos pertenecia la fuente llamada Lantisco, y las Heredades contiguas a ella; por la cual declaró que los terminos de Segorbe, Serra, y Portaceli, acaban se unen en dicha fuente del Lantisco, que es el mojon trifinio o divisorio de dichas tres poblaciones, que por lo mismo son comunes a sus habitantes las Aguas de la misma fuente; que desde esta por la cueba de la plata adelante, corre la division de los terminos de Serra, y Portaceli; y que se pusiesen los mojones oportunos para evitar dudas en lo sucesibo: publicada y refrendada por Eusebio de Benabides, Cescribano de Camara, en Valencia, a 24 de Diciembre de 1686. Dada en traslado a instancia del Exmo Señor Duque de Montellano, Señor de Serra, por D. Pedro Belasco, Abogado y Archibero general de los Archibos de la Ciudad de Valencia, a 19 de Octubre de 1805.

98. Apeo y renobacion de mojones de la raya divisoria de los términos de la Baronia de Serra, propia del Señor Marques de Castelnovo, y del Real Convento de la Cartuja de 
Portaceli; hecho a instancia del Prior y Monges de dicho Convento, por el Dr. José Ynsa, Prelator y Comisionado de la Real Audiencia de Valencia, ante Miguel Calbo, su escribano de Camara, a 21 y siguientes días de Marzo de 1735. Por él resulta se levantó Mapa del terreno, y que tuvieron presentes los Apeos practicados los años de 1686, y 1722 , y por ellos principió dicho Juez la renovacion de mojones de dicha raya por el $1^{\circ}$ situado sobre la fuente del lantisco, el que mandó reedificar. A distancia de 1.200 palmos valencianos del anterior renovó el Mojon $2^{\circ}$, nombrado la Foya de Martín de Cuenca. A distancia de 1.900 palmos del anterior renovó el $3^{\circ}$, llamado el segundo de la Foya. A distancia de 2.300 palmos del anterior renovó otro mojón llamdo Cueva de la Plata, y primero de los Jurados. A distancia de 4.100 palmos del anterior, renovó otro mojón llamado de los Rebalsadores, segundo de los Jurados. A distancia de 4.090 palmos del anterior mandó renovar otro mojón llamado $3^{\circ}$ de los Jurados. A distancia de 3.484 palmos del anterior mandó renovar otro mojón llamado La Rodana. A distancia de 2.068 palmos del anterior mandó renovar otro mojón llamado de Milep. A distancia de 4.400 palmos del anterior mandó renovar otro mojón llamado Fosalet. A distancia de 1.480 palmos del anterior mandó renovar otro mojón de Algepsars. A distancia de 1.800 palmos del anterior mandó renovar otro mojón llamado el Collado, sierra de Balseta. Y de éste siguió a la Peña de la Risela, hacia Segorbe, en la que concluían vestigios del mojón antiguo divisorio de ambos términos. Dado en traslado con aprobación de la Real Audiencia, por D. Pedro Blasco, abogado y archivero general de los Reales Archivos de Valencia, a 17 de Octubre de 1805.

99. Dictamen dado por Vicente Pardo, y Mauro Minguet, Arquitectos en Valencia, por el cual aseguran que aunque el Portillo o Boguet, de piedra azul, que riega la Huerta del Lugar de Sot y de Ferrer, le habian sacado de su primitibo sitio, por bajo de la Fuente de la Azequia, y mudado a igual distancia por cima de dicha Fuente, no recibian agrabio alguno los de Sot, por tragar la misma agua de un modo como de otro, y que haciendo algunos cortos reparos se taparian las roturas de Azequia y Rio, y regarian igualmente los vecinos del Lugar de Sot, propio de la Sra. Condesa de las Amayuelas, y los del Lugar de Soneja, propios del Señor Duque de Montellano a cuya presencia lo firmaron en el Molino arinero de Soneja, a 1 de Noviembre de 1775.

100. Arrendamiento hecho por D. Gerónimo Gil, presbítero, vecino de la Villa de Soneja, de un huerto cerrado en ella, lindante con camino de Almedijar, propio del Exmo Señor Duque de Montellano, Baron y Señor de dicha Villa, por tiempo de cuatro años, y renta en cada uno de sesenta libras: ante Ygnacio Torres y Selma, Cescribano de Castelnovo, a 3 de diciembre de 1779.

101. Auto dado por D. Pedro Villanueba, Juez comisionado por el Ministerio de Marina, para la visita de los Montes de la Costa de Valencia, por el cual mandó que los Alcaldes del Lugar de Serra, cuidasen que por Noviembre de cada año se siembren Nueces, Bellotas de Roble y Encina, Alamos negros, y Piñones, cuidando bien de sus semilleros, y Biberos, para plantar anualmente a tres Arboles por vecino de los 106 que tenía; que no se corte ningun arbol aun con licencia del propietario, sin licencia del Ministro del Departamento; y en fin dictando otras providencias para la conserbacion de sus Montes y aumento de plantios, con arreglo a la Reaal ordenanza de 1748, y su Adiccional de 1751; refrendado dicho auto de Manuel Jose Sanchez, Cescribano de dicha comision en Portaceli, a 17 de Setiembre de 1781. Dado en traslado por su Sucesor Joaquin Gil Alarcon, en Cartagena, a 21 de Junio de 1798. 
102. Solitud hecha por parte del Exmo Señor Duque de Montellano, a la Justicia de su Baronia de Soneja, para que los Repartidores del Real equibalente, cargado a aquel Pueblo, declarasen en que forma haian hecho el repartimiento en el año de la fecha, pues se creia perjudicado; lo que asi se mandó, y principiadas las declaraciones tubieron que suspenderlas a motibo de impedirlas con alboroto algunos indibiduos de Justicia el dia 23 de Abril de 1784.

103. Solicitud hecha por parte del Exmo Señor Duque de Montellano, al Corregidor o Yntendente de Valencia, para que moderase las licencias que habia dado a Tomas Peris, vecino de Vilanesa, y otros, para cortar Leña en el termino de su Baronia de Serra, para la fabrica de Ladrillos, Teja, y Cales para aquella Ciudad, en virtud de los pribilegios que tenia, para evitar los abusos y perjuicios que cometian dichos tejeros; su fecha 20 de Abril de 1791. Simple, y se le une a su continuacion un Arrendamiento de Soneja del mismo año.

104. Quatro arrendamientos hechos por diferentes sugetos, de todos los Derechos Dominicales de la Baronia de Serra, pertenecientes a los Exmos Señores D. Alonso de Solis Folch de Cardona, Duque de Montellano, y su hijo D. Alonso de Solis Wignacourt; el $1^{\circ}$ ante Vicente Ygnacio de Atucha, Cescribano en Valencia, a 26 de Agosto de 1776: el $2^{\circ}$.ante el mismo Cescribano a 25 de Enero de 1781: el $3^{\circ}$ ante $* * * * *$ Cescribano a 18 de Nobiembre de 1784; y el $4^{\circ}$ por Joaquin Modrego, en 1560 libras anuales, ante Carlos Viente de Segui y Rodriguez, igual Cescribano a 10 de Diciembre de 1792 . El $3^{\circ}$ duplicado.

105. Oficio del Ministro de Marina del Departamento de Cartagena D. Alejandro Teran, noticiando al Exmo Señor D. Alonso de Solis Wignacourt, Duque de Montellano, la resolucion del Rey D. Carlos $4^{\circ}$, en orden a que no diese licencias para Arboles en sus montes de Serra, sin interbencion del Ministro de la Marina de Valencia, como estaba acordado en el Auto de Visitas dado por D.Pedro Villanueba, año de 1781: cuyo ofício tiene la fecha en Cartagena, a 21 de Julio de 1798.

106. Correspondencia seguida entre el Administrador de las rentas del Exmo Señor Duque de Montellano, $;$, y el Probeedor de utensilios en Valencia, dirigida a tratar este la compra de Pinos y Leñas del Monte de Serra, para dicha provisión, haciendo su corta por la marca o Argolla de Marina, la cual señala que puesta al Arbol y no corriendo por él no puede cortarse aquel, y sí por el que corra. Contiene informes curiosos acerca del estillo de estas ventas. Dice que cada carreta de carbon haze 80 capazos; cada Bolleta de Pinocha hace 112 garbones; y señala a cada clase el precio que tenia entonces, que fue el año 1804.

107. Siete inventarios de las herramientas y otros utensilios de los molinos de harina y aceite, horno, bodegas, mesón, y otras oficinas de la Baronia de Serra, entregadas a sus respectivos arrendadores: el $1^{\circ}$ ante Miguel Conejos, escribano en ella a 20 de Agosto de 1781: el $2^{\circ}$ ante el mismo a 12 de setiembre de 1785: el $3^{\circ}$ ante el propio en 15 de Febrero de 1797; el $4^{\circ}$ ante el citado en 7 de Enero de 1798; el $5^{\circ}$ ante el referido en $1^{\circ}$ de Enero de 1801; el $6^{\circ}$ ante el dicho en 12 de Enero de 1805; y el $7^{\circ}$ ante otro Miguel Conejos, en 14 de Abril de 1807.

108. Ymbentario de los Bienes muebles que contenia la Benta nuebamente edificada junto al camino real en la Baronia de Soneja, y erramientas en su Horno, Carniceria, 
Bodega, y Molinos de Arina y Aceyte; como tambien los otros dos iguales en Azuebar; hecho ante Ygnacio Torres y Selma, Cescribano en Castelnovo, a 26 de Octubre de 1808.

109. Sentencia de rebista dada por el Presidente y Oidores de la Real Audiencia de Valencia, a 22 de Noviembre de 1808, en el pleito seguido en sus Estrados por el Exmo Señor Conde de Fernan Nuñez, Duque de Montellano, Dueño de la Baronia de Serra, contra los vecinos de esta, sobre que no estraygan el vino del Lugar sin abisar al Arrendador, o Colector para medirle y separar su $8^{\mathrm{a}}$ parte de particion para dicho Duque; por la cual confirmaron la de vista en que declararon que los vecinos Cosecheros de la Baronia de Serra, cumpliesen puntualmente el Capitulo $8^{\circ}$ de la Escritura de Encartacion: ante Antonio Tarrasa, en 26 de Noviembre de 1609. Dada en traslado con dicho Capitulo $8^{\circ}$ por el Abogado D. Lorenzo Martinez, Excribano de Camara de dicha Real Audiencia, a 20 de Setiembre de 1815 .

110. Padron de las Casas, tierras, Viñas, y fincas de toda clase, que poseia cada uno de los 403 vecinos de la Barronia de Soneja, sugetas a la paga anual de censo, particion de frutos, y demas acordado en la Escritura de Encartacion o nueba poblacion del año de 1609 a fabor del Exmo Señor Duque de Montellano, dueño de dicha Baronia; y tambien de las que S.E posee en ellas, y su termino, y otros sugetos forasteros: hecho año de 1817. Dado en traslado or mandato del Yntendente de Valencia, por Miguel Blesa, Secretario interino del Ayuntamiento de Soneja, a 21 de Abril de 1826.

111. Padrón de las Casas, Tierras, Viñas y fincas de toda clase que oseia cada uno de los 173 vecinos de la Baronia de Azuebar, sugetas a la paga anual de censo, particion de frutos, y demas acordado en la Escritura de Encartacion, o nueba poblacion del año de 1609, a fabor del Exmo Señor Duque de Montellano, dueño de dicha Baronia, y tambien de las que en su termino poseian sugetos forasteros: hecho año de 1818. Dado en traslado por mandato del Yntendente de Valencia, por Bautista Garbi, Secretario del Ayuntamiento de Azuebar, a 18 de Abril de 1826.

112. Cinco arrendamientos de la heredad llamada de Joyar, situada en el Monte y termino de la Baronia de Soneja, hechos or diferentes sugetos a fabor de los Exmos. Señores Duques de Montellano, el $1^{\circ}$ ante Ygnacio Torres y Selma, Excribano en Castelnovo a 9 de Nobiembre de 1788, el $2^{\circ}$ ante el mismo a $1^{\circ}$ de Nobiembre de 1793; el $3^{\circ}$ ante el propio a 8 de Octubre de 1797: el $4^{\circ}$ antge el citado a 21 de Agosto de 1803: y el $5^{\circ}$ en 140 libras anuales: ante Blas Jose Madalenes, Cescribano en Valencia, a 22 de Diciembre de 1819.

113. Arrendamiento otorgado por Vicente Martinez, y Juan Campos, Vecinos de Mazamagrell, a fabor del Exmo Señor Duque de Fernan Nuñez, de Montellano, y del Arco, de todos 1sos Derechos Dominicales de sus Baronias de Soneja, Azuebar, por tiempo de dos años, y precio en cada uno de 4.300 libras moneda Valenciana, ante Blas Jose Madalenes, Excriano en Valencia, a 22 de diciembre de 1819, siguen otras copias de arrendamiento.

114. Decreto dato por el Capitan general de Valencia, Almodobar, mandando a los Alcaldes Constitucionales de las Baronias de Soneja, Azuebar, y Serra, y tambien a el de Castelnovo, no impidiesen a el Exmo Señor Duque de Fernan Nuñez, de Montellano, y del Arco, o a sus Representantes, o Arrendadores, la ercepcion de los Derechos que no estaban abolidos, bajo de responsabilidad y rigurosa multa: su fecha en Valencia a 19 de Abril de 1820. El que fue hecho sabar a dichos Alcaldes. 
115. Ymbentario de las Erramientas y otros utensilios para el Servicio de los Molinos de Aceyte, y Arina, Bodegas de Vino y Aceye, Horno de cocer Pan, Mason y Carniceria, de la Baronia de Serra, entregados por D. Luis de Luca, arrendador de los Derechos Dominicales de dicha Baronia, al representante del Exmo Señor Duque de Montellano, dueño de ella: ante Miguel Conejos, Cescribano en ella a 6 de Nobiembre de 1821.

116. Cedula espedida por la Regencia de España, en la cautibidad del Rey D. Fernando $7^{\circ}$, por la cual relaciona que con motibo del decreto de las llamadas Cortes estraordinarias de 6 de Agosto de 1811, habian quedado los Señorios Territoriales y Solariegos en clase de propiedad particular, y abolidos los Pribilegios llamados esclusibos de Jurisdicion, Caza, Pesca, Hornos, Aguas, Montes, **por lo cual la Diputacion de los Grandes de España habia representado que a la sombre de dicho decreto se les despojaba por los Pueblos y Colonos, de los derechos no precedentes de Jurisdicion, preserbados por el mismo decreto, solicitando su pronto reintegro, lo que asi se mando por Reales decretos del año de 1814; los que no pudieron obserbarse por los sucesos ue sobrebinieron en 7 de Marzo de 1820, a acabados bolbio a insistir la Diputacion de los Grandes se llebase a efecto su egecucion; a cuya ultima solsicitud se acordo espedir esta cedula por la cual se manda que los Señores territoriales, y Solariegos, conforme a lo prebenido en el Real decreto de 15 de setiembre de 1814 sean reitegrados en el goze de la percepcion de todas rentas, prestaciones, emolumentos, y Derecho de sus Señorias Territoriales y Solariagos, según los tenian antes de dichos sucesos: Firmada dicha Cedula por la Regencia del Reyno, siendo su Presidente el Duque del Ynfantando, en Palacio a 15 de Agosto de 1823. Circulada a la Real Audiencia de Valencia, tres dias desues, y esta en su Acuerdo de 1 de Octubre siguiente, la mando circular al Pueblo de Azuebar, para que sus Vecinos pagasen a su Dueña la Exma Señora Duquesa de Montellano, y del Arco, viuda de Fernan Nueñez, los Derechos y Prestaciones que le debian, y para ello se les notifico en 20 del mismo mes y año.

117. Apeo, amojonamiento, o mojonera general de los Abrebaderos, Azagadores, malladas, y pasos de todo el termino de la Baronia de Serra; hecho de comun consentimiento y asistencia del representante de su Dueño el Exmo Señor Duque de Montellano, y del Arco, y de la Justicia y Personero de dicha Baronia, el dia 20 de Febrero de 1826; principiando a señalar el paso de los ganados por el arco llamado del Muladar, camino de Valencia, siguiendo por el Azagador de la Bocha???, y direcciones seguidas, renobando los mal puestos, y señalando otros en los parages mas precisos: todo ane Jose Puig Secretario de dicho Ayuntamiento.

118. Renobacion del deslinde y amojonamiento que en el año de 1788, se hizo de la raya divisoria de los terminos de las Baronias de Serra, Naquera, y Albalat, y Cartuja de Portaceli; por la que atendiendo que entonces no se pusieron los Mojones para señelar la raya dibisoria de dichos terminos, acordaron hacerlo amigablemente el representante del Exmo Señor Duque de Montellano, dueño de la Baronia de Serra, y el Marques de Sardeñola, dueño de la Baronia de Naquera, y sus respectibos Alcaldes, y para ello reconocieron dicha araya divisoria de dichos tres terminos, principiando desde el Barranco del Salto del Agua, siguiendo a los Montes Moncudio, Satareña, y de la Torreta, al Puntalet de Carchant, y direccion seguida hasta la Loma de la Baceta, y Carretera de Montes blancos, en cuya estension pusieron 12 Mojones de Cal y canto, dejando suspenso el $13^{\circ}$, trifinio que en dichos Montes blancos dibide los terminos de Serra, Naquera, y Portaceli, or no haber perecido ningun representante de aquel Combento, aunque para ello fue citado; todo paso ante Antonio Vicente Moliner, 
Cescribano de Probincia de la Real Audiencia de Valencia, desde 10 hasta 14 de junio de 1826. Le sigue una copia simple.

119. Posicion del $13^{\circ}$ Mojon trifinio en la Carretara partida de la Baseta, que dibide los terminos de la Baronia de Naquera, propia del Marques de Sardeñola, y de la Real Cartuja de Portaceli, que quedó suspenso en las diligencias de 10 al 14 de Junio de 1826, cuya posicion se realizo con la altura de 10 palmos, a presencia y consentimiento de los Apoderados de los Barones de Serra , y Naquera, del Padre D. Marias Peña, Procurador de la Real Cartuja de Portaceli, y su Compañero Fray Antonio, ante Matias Lorente, Excribano de Torrestorres a 2 y 3 de Octubre de 1826. Le sigue una copia simple; y asi en esta como en el original resulta que dicho $13^{\circ}$ mojon puesto en la Carrera de la Baceta, divide los 3 terminos de Serra, propia del Exmo. Duque de Montellano, del de Naquera, y Portaceli, como claramente se espresa en el estracto de dicha posicion numero 119, que se omitio coia aquí.

120. Censo perpetuo otorgado por Pedro Soriano y Almazan, vecino del Lugar de Soneja, a fabor del Exmo Señor Duque de Montellano, y del Arco, de 22 dineros anuales, sobre cinco jornales y medio de tierra monte en termino de Soneja, Partida de la Palomera, y asi mismo a satisfacer el derecho de frutos que le pertenece con arreglo a los Capitulos de Poblacion, ante Manuel Torres, Cescribano en Castelnovo, a 7 de Diciembre de 1827: dado en traslado por el mism Cescribano a 8 de Febrero de 1828.

121. Testimonio en relacion del Censo perpetuo que ante Manuel Torres, Escriano en Castelnovo, a 7 de Diciembre de 1827, otorgo Pedro Soriano y Almazan, vecino del Lugar de Soneja, a fabor del Exmo Señor Duque de Montellano y del Arco, de 22 dineros anuales, sobre cinco jornales y medio de Monte en termino de Soneja, partida de la Palomera, y asi mismo oi satisfacer el derecho de particion de frutos que le pertenece con arreglo a los Capitulos de Poblacion de Soneja: dado en Castelnovo, a 22 de Diciembre de dicho año por el mismo Cescribano.

122. Testemonio en relacion del Censo perpetuo que ante Manuel Torres, Cescribano en Castelnovo, a 5 de Abril de 1828, otorgo Manuela Babre, viuda, vecina del Lugar de Soneja, a fabor del Exmo Señor Duque de Montellano, y del Arco, de cuatro dineros por cada jornal de tierra haciendo viña y diez dineros por anegada reduciendolo a Huerta anuales, de las tres anegadas y media de tierra secana que habia tomado a este fin en termino de dicho Lugar, partida llamada del Pozo de la Buelta, y asi mismo a satisfacer el derecho de frutos con arreglo a los Capitulos de Poblacion de Soneja; dado en Castelnovo, oi 7 del mismo mes y año, por dicho Cescribano.

123. Testimonio en relacion del Censo perpetuo que ante Manuel Torres, Cescribano en Castelnovo, a 26 de Agosto de 1828, otorgó Nicolas Molina Gil, vecino del Lugar de Soneja, a fabor del Exmo Señor Duque de Montellano, y del Arco, de un sueldo y ocho dineros anuales por cada una de siete anegadas de tierra Riera, situadas en la Baronia de dicho Lugar, partida nombrada del Terreno, y a satisfacer la particion de frutos con arreglo a los Capitulos de Población: dado en Castelnovo, a 13 de Noviembre de dicho año por el mismo Cescribano.

124. Testimonio en relacion del Censo perpetuo que ante Manuel Torres, Cescribano en Castelnovo, a 2 de Setiembre de 1828 otorgó Luis Lopez vecino de dicha Villa, a fabor del Exmo Señor Duque de Montellano, y del Arco, de pagar a S.E y sus sucesores la particion de frutos de eis jornales de tierra monte inculta, en termino de la Villa de 
Azuebar, y Lugar de Soneja, partida del Sar, y demas derechos con arreglo a los Capitulos de Poblacion de Soneja; dado en Castelobo a 13 de Noviembre del dicho año por el mismo Cescribano.

125. Testimonio en relacion del Censo perpetuo que ante Manuel Torres, Cescribano en Castelnovo, a 22 de Diciembre de 1828 otorgó Matias Molina y Gil, vecino del Lugar de Soneja, a fabor del Exmo Señor Duque de Montellano, y del Arco, de cuatro dineros anuales, por cada uno de dos jornales de tierra inculta, situados en el Monte y termino de dicho Lugar, partida llamada Deesa, y asi mismo a satisfacer el derecho de frutos que le pertenece con arreglo a los Capitulos de Poblacion de Soneja: dado en Castelnovo, a 30 de dicho mes y año; por el mismo Cescribano.

126. Testimonio en relacion del Censo perpetuo que ante Manuel Torres, Cescribano en Castelnovo, a 18 de Marzo de 1829 otorgó Miguel Miquer de Jose, vecino del Lugar de Soneja, a fabor del Exmo Señor Duque de Montellano, y del Arco, de 4 dineros por cada uno de siete jornales de tierra inculta, en termno de dicho Lugar, partida de la Deesa, y asi mismo se obligo a satisfacer el derecho de frutos con arrglo a los Capitulos de Población de Soneja; dado en Castelnovo, a 21 de Marzo de dicho año por el mismo Cescribano.

127. Testimonio en relacion del Censo perpetuo que ante D. Blas Jose Madalenes, Cescribano en Valencia, a 19 de Mayo de 1829, otorgó Jose Soriano Blay, vecino del Lugar de Soneja, a fabor de la Exma Señora Duquesa de Montellano, y del Arco, de 4 dineros por cada uno de seis jornales de tierra situados en el monte termino de dicho Lugar en partida llamada Almaroz, y asi mismo obligó a satisfacer el derecho de frutos que le pertenece con arreglo a los Capitulos de Poblacion de Soneja, dado en Valencia, a 22 de Mayo de 1829, por el mismo Cescribano.

128. Testimonio en relacion del Censo perpetuo que ante Manuel Torres, Cescribano en Castelnovo, a 3 de Junio de 1829, otorgo Jose Martinez y Piquer, vecino del Lugar de Soneja, a fabor del Exmo. Señor Duque de Montellano, y del Arco, de dos sueldos y seis dineros anuales, por anegada y media de tierra.Riera inculta en termino de dicho Lugar, partida del Pozo de la Buelta, y asi mismo a satisfacer el derecho de frutos que le pertenece, con arreglo a los Capitulos de Poblacion de Soneja; dado en Castelnovo, a 6 de Junio de dicho año, por el mismo Cescribano.

129. Testemonio en relacion del Censo eretuo que ante Matias Lorente, Excribano en la Villa de Torres.Torres, a 10 de diciembre de 1827, otorgó Jose Navarro de Manuela, vecino de la Baronia de Serra, a fabor del Exmo Señor Duque de Montellano y del Arco, sobre un jornal de tierra inculta, en termino de dicha Baronia, partida del Retamar, con la obligacion de satisfacer todos los derechos que le pertenecen a S.S. Con arreglo a los Capitulos de Poblacion de Serra; dado en torres-torres, por el mismo Cescribano a 26 de Enero de 1828. Contiene otros cinco que siguen.

130. Nota suplente que se verterá en el Yndice para la debida inteligencia.

Por el testeminio $\mathrm{n}^{\mathrm{o}}$. 129 consta que ante Matias Lorente, Cescribano en la Villa de Torres-Torres, a 10 de diciembre de 1827, otorgó Jose Navarro de Manuela, vecino del la misma Baronia de Serra, un Censo perpetuo, a fabor del Exmo Señor Duque de Montellano, y del Arco, sobre una Era, y una porcion de tierra inculta, en termino de Serra, partida a la linde de la misma Baraonia, con la obligacion de satisfacer los derechos que le correspondan con arreglo a los Capitulos de Poblacion de Serra; dado en 
Torres-torres, por el mismo Cescribano a 26 de Enero de 1828. Debe colocarse aquí copia autorizada de dicho Censo y de todas sus consecuencias.

131. Nota suplente que dice lo que sigue.

Por el testimonio $\mathrm{n}^{\mathrm{o}} 129$ consta que ante Matias Lorente, Cescribano en la Villa de Torres-torres, a 10 de diciembre de 1827, otorgó Jaime Navarro, menor, vecino de la Baronia de Serra, un Censo perpetuo a fabor del Exmo Señor Duque de Montellano y del Arco, sobre un jornal de tierra secano en termino de dicha Baronia, partida del Puntal de Muño, con la obligacion de satisfacer el derecho de particion de frutos y demas que le correspondan con arreglo a las Capitulos de poblacion: dado en Torres-torres, por el mismo Cescribano a 26 de Enero de 1828. Debe colocarse aquí copia autorizada de dicho Censo, y de todas sus consecuencias.

132. Nota suplente que dice lo que sigue.

Por el testimonio $\mathrm{n}^{\mathrm{o}} 129$ consta que ante Matias Lorente, Cescribano en la Villa de Torres-torres, oi 10 de diciembre de 1827, otorgó Roque Navarro, vecino de la Baronia de Serra, un Censo perpetuo a fabor del Exmo Señor Duque de Montellano, y de Arco, sobre un jornal de tierra secano en termino de dicha Baronia, partida titulada el alto del Pino, con la oblacion de sotisfacer el derecho de paticion de frutos, y de mas que le corresponda con arreglo a los Capitulos de Poblacion: dado en Torres-torres, por el mismo Cescribano a 26 de enero de 1828. Debe colocarse aquí copia autorizada de dicho censo, y de todas sus consecuencias.

133. Nota suplente que dice lo que sigue.

Por el testimonio $\mathrm{n}^{\mathrm{o}} 129$ consta que ante Matias Lorente, Cescribano en la Villa de Torres-torres, a 10 de diciembre de 1827, otorgó Jose Arnal de Pascual, vecino de la Baronia de Serra, un Censo peretuo a fabor del Exmo Señor Duque de Montellano, y del Arco, sobre un sitio de cincuenta baras para construir una Casa, sito en el ambito de dicha Baronia, con la condicion de edificar en el termino de seis meses y obligacion de satisfacer el Censo y demas derechos con arreglo a los capitulos de Poblacion: dado en Torres-torres, por el mismo Cescribano a 26 de Enero de 1828. Debe colocarse aquí copia autorizada de dicho Censo y de todas sus consecuencias.

134. Nota suplente que dice los que sigue.

Por el testimonio $\mathrm{n}^{\mathrm{o}} 129$ consta que ante Matias Lorente, Cescribano en la Villa de Torres-torres, a 11 de Diciembre de 1827, otorgó Cristobal Perez y Fuertes, vecino de la Baronia de Serra, un Censo peretuo a fabor del Exmo Señor Duque de Montellano, y del Arco, sobre un jornal de tierra senao en termino de dicha Baronia, partida del Barranco Lobero, con la obligacion de satisfacer el derecho de particion de frutos, y demas que le correspondan con arreglo a los Capitulos de Poblacion: dado en Torres torres, el mismo Cescribano, a 2 de Enero de 1828. Debe colocarse aquí coia autorizada de este Censo y todas sus consecuencias.

135. Censo perpetuo otorgado por Ramon Melia, vecino de Serra, a fabor del Exmo Señor Duque de Montellano, y del Arco, de un Sueldo anual, sobre tres jornales de tierra secano inculta, en termino de dicho Lugar, partida del Alqesar, a asimismo a satisfacer el derecho de particion de frutos con arreglo a los Capitulos de Poblacion: ante Matias Lorente, Cescribano en Torres-torres, a 4 de Marzo de 1829. Es simple, e incluye otros tres, que siguen.

136. Nota suplente que dice lo que sigue. 
Del numero anterior aparece tambien que Vicente Catala, vecino de Serra, otorgó Censo a fabor del Exmo Señor Duque de Montellano, y del Arco, de un sueldo y 4 dineros anuales, sobre cuatro jornales de tierra inculta en termino de dicho Lugar, partida de la Baseta, y asi mismo a satisfacer el derecho de particion de frutos con arreglo a los Capitulos de poblacion ante Matias Lorente, Excribano en Torres.torres, a 26 de Marzo de 1829. Está simple y debe colocarse copia autorizada de él.

137. Nota suplente que dice lo que sigue.

Tambien aparece del Numero 135 que Vicente Catala, vecino de Serra, otorgó Censo a fabor del Exmo Señor Duque de Montellano, y del Arco, de un sueldo anual, sobre tres jornales de tierra inculta, en termino de dicho Lugar, partida de la Baseta, y asi mismo a satisfacer el derecho de particion de frutos con arreglo a los Capitulos de Población: ante Matias Lorente, Cescribano en Torres-torres, a 27 de Marzo de 1829. Está simle y debe colocarse copia autorizada de él.

138. Nota suplente que dice lo que sigue.

Tambien aparece del numero 135 que Salbador Ros, vecino de Serra, otorgó censo a fabor del Exmo Señor Duque de Montellano, y del Arco, de ocho dineros anuales, sobre dos jornales de tierra secano incultas, en termino de dicha Baronia partida del Cuco, y asimismo a satisfacer el derecho de particion de frutos con arreglo a los capitulos de Poblacion; ante Matias Lorente, Cescribano en Torres-torres, a 26 de Marzo de 1829. Esta simple, y debe colocarse copia autorizada de él.

139. Testimonio en relacion del Censo perpetuo que ante Manuel Torres, Cescribano en Castelnovo, a seis de Abril de 1828, otorgó Jose Murria de Tomas, vecino de la Villa de Azuebar, a fabor del Exmo Señor Duque de Montellano, y del Arco, de una libra y 10 sueltos anuales, sobre el sitio de 60 palmos para una casa en el monte del Castillo, termino de dicha Villa, y asi mismo a satisfacer el derecho de particion de frutos con arreglo a los Capitulos de Poblacion; dado en 7 de dicho mes y año por el mismo Cescribano.

140. Testimonio en relacion del Censo perpetuo que ante Manuel Torres, Cescribano en Castelnovo, a 7 de Abril de 1828, otorgó Diego Molina, vecino de la Villa de Castelnovo, a fabor del Exmo Señor Duque de Montellano, y del Arco, de 4 dineros anuales, por cada uno de cuatro jornales y medio de tierra inculta en termino de Azuebar, partida del Sas, y asi mismo a satisfacedr el derecho de particion de frutos con arreglo a los capítulos de poblacion: dado en 8 de dicho mes y año, por el mismo Cescribano.

141. Testimonio en relacion del Censo perpetuo que ante Manuel Torres, CCescribano en Castelnovo, a 22 de Febrero de 1830, otorgó Mateo Churria y Zorrilla, vecino de la Villa de Azuebar, a fabor del Exmo Señor Duque de Montellano, y del Arco, de dos dineros anuales, sobre medio jornal de tierra monte, en termino de dicha Villa, partida del Pino de Escales, y asi mismo a satisfacer el derecho de particion de frutos con arreglo a los Capitulos de Poblacion: dado en 25 de dicho mes y año por el mismo CCescribano.

142. Testimonio del Establecimiento hecho por Miguel y Jose Piquer y Gorriz, reconociendo al Exmo Señor Duque de Montellano, y del Arco, por Señor Directo de dos jornales y medio de tierra inculta, en termino de su Baronia de Soneja, de donde eran Vecinos, para reducirla a cultibo, pagandole anualmente cuatro dineros por cada jornal, y los demas Derechos de los Capitulos de Poblacion; y lo mismo por dos anegadas en el 
propio termino con un sueldo y ocho dineros por cada una; ante Manuel Torres, CCescribano en Castelnovo, a 29 de Noviembre de 1830.

143. Testimonio de otro Establecimiento hecho por Vicente Murria y Sanchez, vecino de Azuebar, de un sitio o Solar de 30 pasos de larga y 18 de ancho, en la calle que sale en dicho Azuebar para Segorbe, pagando por el a su Dueño y Señor Duque de Montellano, y del Arco, una liba y diez sueldos anuales, a hacer Casa en el; ante Manuel Torres, CCescribano en Castelnovo, a 26 de Noviembre de 1830.

144. Licencia concedida por el Administrador del Exmo Señor Duque de Montellano, y del Arco, en Valencia al Alcalde y Ayuntamiento de la Baronia de Serra, para que pudiese cortar y rozar toda la leña baja y broza de la Deesa llamada de la Jara, propia de S.E. En aquel pueblo, para quemar con ella el yeso necesario para reparos de la Torre, y campanario de la Yglesia de dicho pueblo: su fecha 25 de Junio de 1831.

145. Testimonio del Censo impuesto por Lorenzo Garat, a fabor del Exmo Señor Duque de Montellano, por un jornal de tierra secana en termino de Serra, que S:E: le concedio para reducirlo a cultibo, y pagarle por el lo que señalen los articulos de Poblacion. Al mismo tiemo se obligo Bautista Melchol a pagar igual Censo a S:E: por otro jornal de tierra en dos trozos en el propio termino de Serra. También se obligo Manuela Calbo, viuda, a pagar a S.E. El Censo correspondiente a Dos jornales de tierra monte en Serra, que tomó para reducirlo a cultibo. Y tambien Ramon Tomas, se obligó pagar a S.E: cada año los Derechos correspondientes a otros dos jornales de tierra en Serra, que tomo para reducirlos a cultibo, y todos pasaron ante Matias Lorente, CCescribano en Torres-torres, a 27 de Diciembre de 1831.

146. Testimonio de un reconocimiento hecho por Jayme Zorrilla y Molina, vecino de Azuebar, de pagar al Exmo Señor Duque de Montellano, un sueldo y cuatro dineros por 4 jornales de tierra inculta en dicha Baronia de Azuebar, que le dio S.E para reducirla a cultibo; ante Manuel Torres, escribano en Castelnovo, a 3 de Abril de 1832.

147. Testemonio del Establecimiento hecho por Manuel Gomez y Vila, vecino de Azuebar de un Solar de 60 palmos en cuadro que le concedió el Exmo Señor Duque de Montellano, para fabricar Casa en el, en dicho Azuebar, pagando anualmente a S.E. Una libra y diez sueldos; ante Manuel Torres, Cescribano en Castelnovo, a 23 de Mayo de 1833.

148. Testimonio en relacion del Censo enfitéutico impuesto por Antonio Zorrilla, vecino de Azuebar, de cuatro sueldos anuales por el terreno de 160 palmos de largos y 30 de ancho, para hacer un corral, inmediato al castillo de dicha Baronia; ante Manuel Torres, Cescribano en Castelobo, a 9 de Julio de 1835.

149. Tres notas simples de otros tantos arriendos hechos el $1^{\circ}$ por Matias Gorriz, de 3 anegadas 3 cuartas y 9 brazas de Tierra Huerta partida de los arenales de Soneja, en 622 rs. $32 \mathrm{mrs}$. cada año; el $2^{\circ}$ por Francisco Arnau de 4 anegadas 22 brazas de Tierra Huerta en la misma partida por precio anual 606 reales $6 \mathrm{rms}$; y el $3^{\circ}$ Gabriel Andres, de 4 anegadas y 5 brazas de tierra Huerta en la misma partida de los arenales de Soneja, en precio anual 348 reales y 12 mrs: ante Manuel Torres, Cescribano de Castelnovo, en 8 de diciembre de 1827.

150. Otras tres notas simples de otros tantos arriendos hechos el 1 por Jose Conde de 3 cuartas y 47 brazas tierra Huerta partida de los arenales de Soneja por cuatro años y 
precio en cada uno de 601 reales de bellón; $2^{\circ}$ por Bautista Montaña, de una parte de la Posada de Soneja, otra casa contigua y una tierra al Tablar, por tiempo de 3 años y precio en cada uno de 124 libras, y el $3^{\circ}$ por Vicente Gómez y Llopis, de la Venta de Soneja, en la Calzada de Valencia a Zaragoza, por tiempo de tres años y precio en cada uno de 140 libras: ante Manuel Torres, Cescribano de Castelnovo, a 8 de diciembre de 1827.

151. Dos copias simples de otros tantos arriendos hechos el uno por Francisco Martinez y Martinez de las 4 anegadas y 22 brazas de tierra partida de los arenales, por 4 años y precio en cada uno de 482 reales y 14 mrs; y el otro por Gabriel Andres de 8 anegadas y 5 brazas de tierra Huerta en otra partida por tiempo de cuatro años y precio en cada uno de 238 reales 28 mrs.; ante Manuel Torres, Cescribano en Castelnovo a 2 de enero de 1832 .

152. Otra copia simple del arriendo hecho por Matias Gorriz, y Blas Martinez, de las 3 anegadas 3 cuartas y 9 brazas de Tierra Huerta citadas en las notas anteriores situadas en la partida ade los arenales de Soneja, por tiempo de cuatro años y renta cada uno de 505 reales 32 mrs: ante Manuel Torres, Cescribano en Castelnovo, a 31 de Diciembre de 1833.

153. Tres copias simples de otros tantos arriendos del Huerto llamado del Señor, en Soneja, de 4 anegadas 1 cuarta y 10 brazas de tierra; el $1^{\circ}$ por Miguel Martínez y consorte, por tiempo de 4 años y precio en cada uno de 583 reales; 16 naravedís; el $2^{\circ}$ a D. Joaquín Sebastián, por otros 4 años y precio en cada uno de 752 reales $32 \mathrm{~m}^{\text {rs }}$; y el $3^{\circ}$ por otro Miguel Martinez, por otros 4 años y precio en cada uno de 455 reales $10 \mathrm{~m}^{\mathrm{rs}}$, ante Manuel Torres, Cescribano de Castelnovo, a 18 de Diciembre de 1827, y 2 de Enero de 1831 y 1832 .

154. Dos copias simples de arriendos de la Venta junto al Camino Real de Valencia, el uno por Vicente Gomez y Llopis, y consorte, vecinos del Lugar de Sot, por tiempo de tres años y precio en cada uno de 72 libras; y el otro por Diego y Manuel Marzo, por tiempo de tres años y precio en cada uno de 1365 reales de vellón, ante Manuel Torres, Cescribano en Castelnovo, a 31 de Diciembre de 1837.

155. Dos copias simples de arriendos hechos a Jose Montaña, vecino de Soneja, del Meson, y casa del Alcalde mayor situadas en la Plaza de otro Lugar, y dos anegadas de tierra en termino del mismo, ambos por tiempo de tres años y precio en cada uno el $1^{\circ}$ de 108 libras, y el $2^{\circ}$ de 1.400 reales $16 \mathrm{~m}^{\text {rs }}$ anuales: ante Manuel Torres, Escribino en Castelnovo, a $1^{\circ}$ de Enero de 1831, y 31 de Diciciembre de 1833. Otra en 1837.

156. Tres copias simples de arrendamientos hechos del Horno de Pan cocer situado en la calle del Meson de Soneja, el $1^{\circ}$ a José Almazán, vecino de dicho Lugar, por tiempo de tres años y precio en cada uno de 75 libras; el $2^{\circ}$ a Francisco Martinez y su muger por otros tres años y renta en cada uno de 60 libras; y el $3^{\circ}$ a Silvestre Morata, y consorte, por tiempo de tres años y precio en cada uno de 1030 reales 20 mrs.: ante Manuel Torres, Cescribano en Castelnovo, sus fechas 14 de Junio de 1828, 30 de Diciembre de 1830, y 31 de Diciembre de 1833. Siguen otras posteriores.

157. Tres copias simples de arrendamientos hechos del Molino arinero llamado del Señor en Soneja, a Manuel Bella, cada uno por tiemo de 3 años y precio en cada uno de ellos el $1^{\mathrm{o}}$ de 9 reales diarios y los otros en renta de 8 reales tambien diarios, ante Manuel Torres, Cescribano en Castelnovo, sus fechas 8 de Diciembre de 1827, 31 de Diciembre de 1830, y 30 de Diciembre de 1833. Siguen otras copias de arrendamientos posteriores. 
158. Dos copias simples de arriendos hechos del Molino arinero en termino de Serra, a Juan Cabo, vecino de dicha Baronia el $1^{\circ}$ por tiempo de cuatro años y precio cada uno de 60 libras; y el $2^{\circ}$ por otros cuatro años, e igual precio: ante Matias Lorente, Cescribano en Torres torres, a 5 de Enero de 1829, y ante Vicente Antonio Barrachina, Cescribano en Valencia, a 24 de Febrero de 1832.

159. Dos testimonios de arriendos hechos del Horno de Pan cocer en Serra, por Jose Piña, vecino de dicho lugar, el $1^{\circ}$ por tiempo de cuatro años y precio en cada uno de 42 libras; y el $2^{\circ}$ por otros cuatro años 7 precio de 37 librasen cada uno: ante Matias Lorente, Cescribano en Torres Torres, sus fechas 10 de Diciembre de 1827, y 4 de Enero de 1832.

160. Nota del arrendamiento hecho a Jose Saesa, vecino de Serra, de la Casa Meson de dicha Baronia, por tiempo de tres años y renta en cada uno de 28 libras; ante Matias Llorente, Cescribano en Torres Torres, a 5 de enero de 1829.

161. Dos copias de arrendamientos hechos de la casa y tierras nombradas de Jayar, en termino de Azuebar, el uno a Miguel Rivas, por tiempo de 3 años y precio en cada uno de 110 libras; y el otro a Salbador y Tomas Soriano, vecino de Soneja, por igual tiempo, y precio en cada año de 90 libras: ante Manuel Torres, Cescribano de Castelnovo, sus fechas 6 de Abril de 1828 y 30 de Diciembre de 1830. Siguen otras copias de arrendamientos.

162. Dos copias de arrendamientos hechos del Meson de Azuebar, a Tomas Mirabite, y consorte, vecinos de dicho Lugar, el uno por tiempo de 3 años y precio en cada uno de 38 libras, y el otro por igual tiempo y precio de 37 libras: ante Manuel Torres. Cescribano en Castelnovo, a 31 de Diciembre de 1828, y 31 de Diciembre de 1831, y otras posteriores.

163. Dos copias simples de arrendamientos hechos a Miguel Gomez, vecino de la Villa de Azuebar, del Horno de dicha Villa, el uno por tiempo de 3 años precio en cada uno de 36 libras: y el otro por igual tiempo y precio de 30 libras ans. Ante Manuel Torres, Cescribano en Castelnovo, a 31 de Diciembre de 1828, y 2 de Enero de 1832. Siguen unidas otras copias de arrendamientos hechos 1838 y 1841.

164. Copia de la escritura de venta otorgada por el Exmo. Señor Duque de Fernan

Nuñez, Montellano y del Arco, del solar de la Casa Meson en el pueblo de Serra, en Valencia, de la Baronia del mismo nombre, a favor del Ayuntamiento de dicho pueblo de Serra, en precio de 2000 reales vellón: ante D. Juan Genoves y Cause, Cescribano del Colegio de dicha Ciudad de Valencia, en 30 de Junio de 1854.

165. Testimonio de Escritura de Venta otorgada por el Exmo. Señor Duque de FernánNúñez, de una Casa sita en el Pueblo de Soneja Calle del Calvario, en precio de 2.374 reales y 20 maravedís; en favor de Joaquín Soriano y Blas vecino de dicho Pueblo; ante Juan Genovés y Cause, fecha en Valencia, 19 de Agosto de 1854. El testimonio se dio en 27 de enero de 1855 ante el mismo Cescribano.

166. Escritura en copia de venta otorgada por los Exmos. Señores Duques de FernánNúñez de diferentes bienes en el Pueblo de Serra a favor de D. Francisco Dolz y Catalá, a saber: un horno de cocer pan calle del horno, carniceria en la plaza del cementerio viejo, un molino harinero término de dicho pueblo. Y un pequeño solar destinado en lo antiguo 
a horno de cocer teja que se utilizó en Iglesia, espresando en todos los linderos, y en precio 38.000 reales: ante D. Timoteo Liern Cescribano, en Valencia 18 de Julio de 1859.

167. Dos copias de Escrituras de Venta otorgadas por el Exmo. Señor Duque de Fernan Nuñez de dos Casas la una llamada Carniceria del Lugar de Soneja y la otra nombrada de Carrucio: ante Timoteo Lieru, Cescribano en Valencia 20 de Diciembre de 1859.

168. Copia simple de Venta por S E a favor de Francisco Peyró y Gómez, de una Casa en Soneja llamada de la Enseñanza (antes del Mesón) en su Plaza mayor, en 600 escudos; ante D. Francisco Pastor Cescribano en Valencia, 24 Marzo de 1868.

(ací acaba el f. $75 r^{\circ}$ ).

(fulls 76 a 355 totalment en blanc)

\section{f. $356 \mathrm{r}^{\mathrm{0}}$}

\section{LEGAJO 7. ÁRBOLES GENEALÓGICOS Y PAPELES SIMPLES}

Este legajo contiene algunos árboles genealógicos sueltos, y papeles simples, y no se les cita ni numera progresivamente por no ser auténticos ni merecer fee en juicio como los que van numerados y seguiran en el quinto Legajo precedente; y sólo se les da este destino por algunas noticias que contienen del gobierno económico antiguo de estas Baronías, a los cuales se podrá recurrir en algunas dudas.

\section{f. $357 \mathrm{r}^{\mathrm{o}}$}

\section{LEGAJO 7. CUENTAS DE SUS RENTAS}

Este legajo contiene las Cuentas de la Administracion de las rentas de estas Baronias desde el año de 1742 a 1800, y las que faltan de años intermedios se hallan en la de Mazalabez, y Marquesado de Castelnovo, por administrarse juntos, para que en cada uno haya el debido conocimiento de lo que produce anualmente, lo que no se tendria presente si se aplicasen a uno solo, o en globo, como se pasaron de la Contaduria al Archivo, en 9 de Marzo de 1829. Y á continuación se colocarán del mismo modo las que sucesibamente se bayan remitiendo, en lo que se lograrà la claridad que se desea. 


\section{f. $358 \mathrm{r}^{\mathrm{o}}$}

APENDICE

folios

Legajo $1^{\circ}$

Ynstrumentos de pertenencia de estas Baronías desde el año de 1609 al de 1712 3

Legajo $2^{\circ}$

Ynstrumentos de su pertenencia desde el año 1713 al de 1756.

Legajo $3^{\circ}$

Ynstrumentos de su pertenencia desde el año de 1757 al de 1764.

Legajo $4^{\circ}$

Ynstrumentos de su pertenencia desde el año 1765 al de 1800 $.35 v^{0}$

Legajo $5^{\circ}$

Ynstrumentos de su pertenencia desde el año 1801 adelante. $44 v^{\circ}$

Legajo $6^{\circ}$

Arboles genealogicos, y papeles simples 356

Legajo $7^{\circ}$

Cuentas de sus Rentas en Valencia desde el año de

1742 a 1800 y sucesivas .357 


\section{APÈNDIX DOCUMENTAL}

1609 novembre 26

\section{DOCUMENT I}

Capítols de població de les baronies de Serra i Ria (antiga ref.: Pap. 22, $\lg 1, \mathrm{n}^{\mathrm{o}} 1$ ).

AHN (FN), c. $1165, \lg .1, \mathrm{n}^{\circ} 2$

Nota: indiquem en negreta les notes marginals en castellà:

\section{Die xxvi mensis Novembris anno a nativitate Domini MDCviiii}

In Dey nomine amen, Nosaltres $\mathrm{D}^{\mathrm{n}}$ Joseph Folch, i de Cardona, Cavaller del Orde i milicia de Alcantera, Gentil hom de la boca de Sa Magestad del Rei Nostre Senyor, i Senyor de les baronies i llocs de Serra, Ria, Soneja i Adzuevar de una, i Berthomeu Salvaterra, Miquel Sanchiz, Juan Sanchiz, Joan Munios, Antoni Salvador, March Palacio, Jaume Noguera, Juan Teruel, Francisco Moreill, Miquel Domingo de Bartholom, Miquel Domingo de Marti, Sevastià Ribes, Domingo Diago, Antoni Esteve, PereYvanies, Domingo Manies de Miquel, Juan Palacios, Menau Lanes, Jayme Fonfria y Miquel Saez, nous pobladors per al dit loch de Serra. Miquel Rives, Visent Sarigó Rivera, Joan Guillem, Miquel Graneill, Joan Salvador, Luch Salvador, Doiningo Vilanova, Antoni Sanchiz, Miquel Garcia i Joan Ruvio, nous pobladors per al dit Loch de Ría. De part altra.

Attenent i considerant que per executio del Real Bando, i mandato de Sa Magestat del Rei $\mathrm{N}^{\text {re }} \mathrm{S}^{\mathrm{r}} \mathrm{D}^{\mathrm{n}}$ Phelip de Austria tercer de gloriossa e inmortal memoria publicat, i ab beu de publica Crida preconizat per los Llocs acostumats de la Ciutat de Valencia en vint, i dos dies del propasat mes de setembre del ani corrent de mil siscens, i nou, son estats trets, Llançats i expelits de tot lo present Regne, i portats á terra de Barberia tots los moros que en aquell (any) hi havia, per justissimes causes i rahons en dit Real bando contengudes, i expresades, i com ditta baronia i llocs de Serra, i Ria estaven tots poblats de moros, i aquells, obtemperant al dit real mandato se hagen embarcat tots, i passats en terra de Africa, i axy han restat dits Llocs despoblats deserts, i sens veins ni havitadors alguns, i nosaltres dits particulars desigem poblar la ditta baronia, i llocs de Serra i Ria, i havassallarnos, estar, habitar, i recidir en aquella, i hagam pregat i suplicat al dit Senyor $\mathrm{D}^{\mathrm{n}}$ Joseph sia servit admetrens á nosaltres, $\mathrm{i}$ als nostres succesors per vasalls seus, i dels Señors, qui per temps seran de dita baronia, i per nous pobladors Veins, i havitadors de áquella, i lo dit $\mathrm{D}^{\mathrm{n}}$ Joseph de Cardona sia estat content de admetre'ls al dit vasallatge, i a la dita nova població Veinatge i havitació de la dita baronia i llocs, i per al dit efecte sien estat fets, tractats, convenguts i concordats, per i entre nosaltres, dites parts, los pactes dejús escrits en lo modo, forma, i manera que dejús se conte Per ço de nostre bon grat, i certa sciencia ab lo tenor de aquesta present publica carta ara, i per tots temps perpetuament valedora, $i$ en ningun temps revocadora com millor podem, i devem, yns es licit, i per mes conforme á furs del present Regne et alis de Justicia confesam la una part a laltra, i laltra al altra ad invicem et visessim presents, $\mathrm{i}$ aceptans, i als nostres sucessors que en e sobre la dita nova població de la dita baronia, i llocs de Serra, i Ría, se han tractat, consertat, concluit, havengut i concordat per i entre nosaltres les dites parts los pactes, condicions i coses inmediate seguents:

\section{i) Sumision}

Primo que lo dit $\mathrm{D}^{\mathrm{n}}$ Joseph de Cardona per mi, i per tots los meus sucesors imperpetuum en la ditta baronia, i llocs de Serra, i Ria haja de admetre segons que admet á Vosaltres tots los dits particulars de super nomenats, i a tots los vostres succesors ab los pactes 
empero, i condicions, que davall se diran e no sens aquells aliter nec alias a la dita nova població de la dita baronia, i llocs de Serra, i Ría i que vosaltres, per vosaltres, i per tots los vostres succesors vos hajau de avassallar en dita baronia i llocs en continent fer lo present acte, i prestarme los homenatges i jurament de fidelitat acostumats renunciant a qualsevol vostre propi fur, Sotsmetent-vos al fur, i jurisdicció mia, i dels meus succesors en dita baronia i llocs.

\section{ii) Obligación de residencia personal.}

Item: que nosaltres dits nous pobladors nos hajam de obligar segons nos obliguam per nosaltres $\mathrm{i}$ per tots los nostres sucessors a residir personalment $\mathrm{i}$ continua ab nostre domicili i cap major en dita baronia, i llocs de Serra, i Ría i los qui faltaran per temps de sis messos en dita residència personal encorreguen en pena de comis lescases i heretats que tindran en dita baronia $i$ terme de aquella.

\section{iii) En qué forma se pueden vender o traspasar las haciendas.}

Item: que nosaltres dits nous pobladors i los qui per temps seran no pugam ,ni puguen vendre, donar ni en quansevol manera alienar les cases i heretats que tindran en la dita baronia i son terme a foraster algú, sens preceir lisència del Senyor i que primerament aquell no se obligue dins dos messos comptadors desde el dia de la tal alienació á avassallar-se en la dita baronia i llocs, i a portar sa casa i família a aquells i efectuar açò dins dit termini, sots pena de comís de la tal casa i heretats.

\section{iiii) Emphiteusis. Luismo y fadiga.}

Item: que totes les cases $\mathrm{i}$ heretats de la dita baronia $\mathrm{i}$ de tot lo terme de aquella estiguen censides als censors respectivament que davall se dirà ab dret de fadiga i loïsme $\mathrm{i} a b$ tot altre plen dret emphiteotich segons furs de València al dit Don Joseph Senyor de dita baronia $\mathrm{i}$ als seus sucessors en aquella, ab totes les prerrogatives que los senyors directes tenen en lo present regne en los bens censits i emphiteoticals i se hajen de fer de dites cases i terres los stabliments que necessaris seran, segons lo tractat i concertat entre nolsaltres les dites parts.

\section{v) Censos de casas.}

Item: que cascú de nosaltres dits pobladors i los nostres succesors qui per temts seran sien tenguts i obligats a donar impagar cascun any en lo dia i festa de Tots Sants al dit Senyor Don Juseph i als seus sucessors en la dita baronia i llocs per cascuna casa que posehixen i posehiran, trenta sous de cens per fadiga i loïsme, posats i aportats en casa i habitació del Senyor dins lo present regne a tot risch, perill i despesses nostres, lo qual dit dret de cens de trenta sous siam aysí mateys tenguts i obligats nosaltres i los nostres sucessors a pagar i regoneixer al dit Senyor i al demes qui ho seran de la dita baronia de cascuna casa ques edificarà de nou o quant alguna de les belles se partirà donant porta al carrer per a distins domicili i habitació.

\section{vi) Censos de tierras.}

Item: que nosaltres dits nous pobladors i los qui per temps seran, hajam i hajen de pagar al Senyor cascun any per les heretats que ens seran senyalades i establides en la horta de dits llocs i en lo regadiu, çò és, per cascuna cafisada de terra deu sous de cens ab los drets de fadiga i loïsme i altres emphiteoticals desús dits, en lo dia de la festa de Tots Sants en la una paga i ayxí mateis i de la mateysa manera en lo dit termini hajam i hajen de pagar cascun any per les heretats del secà a rahó de quatre diners per cascuna cafisada.

\section{vii) Paga de frutos $y$ frutas.}

Item: que nosaltres dits nous pobladors i los nostres succesors, ademés del dit cens i del delme i primícia siam i sien tinguts i obligats a pagar al dit Senyor qui ara és i per temps serà, cascun ani al temps de la collita, la sisena part de tots los grans i fruits de qualsevol 
gènero i espècie que sien, qu'es colliran en les terres de regadiu. I la huytena part en les terres del secà, sens pagar terç delme, del qual dit Senyor nos fa francs, i al mateix respecte i de la mateysa manera se haja de pagar així de les fruites com dels demés fruits, qualsevols que sien de tots los arbres de la horta i del secà, çò és de la horta a la sisena part i del secà a la huytena, alfarraçant dites fruytes $i$ fruits dels dits arbres una persona nomenadora per lo Senyor i altra per nostra part; i conforme dit alfarràs se haja de pagar lo qu'es deurà al dit Senyor en diners comptants en continent que seran acabats de collir dits fruits cascun any excepto les garrofes, que de les de la horta se haja de pagar la sisena part i de les del secà la huytena, i també exceptat que de les sireres, albercocs, prèsechs e peres no se haja de pagar cosa alguna sinó que lo Senyor pera son menchar i de sa casa puixa pendre la fruita que li pareyserà; i també de la palla qu'es collirà en la horta i en lo secà se haja de donar al Senyor una sarria gran per cada casa.

\section{viii) Vino y pasas.}

Item: que de la que procehirà de les vinies del terme de la dita baronia i llocs, ara sia vi, ara pansa, o altra qualsevol cosa, se haja de pagar al Senyor la huytena part en allò mateix qu'es collirà o procehirà de les dites vinyes, sense pagar terç delme; i que en la horta no hi puga haver vinyes sens lisència del Senyor.

\section{viiii) Derecho de ganado.}

Item: que dits vasalls hajen de pagar al Senyor per raó del ganado que tindran, ayxí llanar com cabriu, ço és, de la cria a rahó de huit/hú per tot delme i primícia.

\section{x) Derecho del carbón.}

Item: que dits vasalls puguen fer carbó en lo terme de dita baronia, de llentiscle, de rabaça $i$ altres mates, i no de arbres alguns, pagant al dit Senyor un sou per cada càrrega gran i sis diners per cada càrrega chica de jument e/o asnet.

\section{xi) Reserva de la Xara, partida del Castillo.}

Item: que ningun particular de la dita baronia puga entrar enla partida dita la Xara que està junt lo casteill a tallar arbres ni fer llenya ni arrancar rabaces sots pena de sexanta sous, com la dita partida haja de restar i reste reservada per al dit Senyor. Açò declarat, que los ganados ayxí del carnicer com dels particulars de dita baronia hi puguen entrar sense encórrer en pena alguna.

\section{xii) De venta de casas y heredades.}

Item: que nosaltres dits pobladors o los nostres sucessors no pugam ni puguen vendre, alienar ni transportar casa, terra ni heretat

alguna de les que seran establides per lo dit Senyor Don Juseph a persona alguna a rahó de franch, així dels dits censors en diners com de les dites parts de fruits de super expresades sots pena de comís.

\section{xiii) Taberna, Horno, Carniceria, Molino, Almácera.}

Item: que nosaltres dits pobladors $\mathrm{i}$ los que per temps seran no pugam hi puguen fer hostal, parar taberna, ni piló de tallar carn, fer forn algú, encara que fós per a usos propis de nosaltres i de nostres succesors; ni molí, ni almacera, en la dita baronia i llocs ni en son terme, perquè totes aquestes regalies han de restar i resten reservades per al dit Senyor i los sucessors i que siam i que los nostres succesors sien tenguts i obligats á coure en lo forn, comprar en la tenda, fleca, taberna i carniceria del dit loch, sots pena de sexanta sous per cascuna vegada que es contrafarà, i sots la mateixa pena hajam i hagen de moldre en lo molí de la Senyoria donant a dit molí bon recapte a hon no puixen anar a moldre hon bé els pareixerà i també s'haja de fer lo oli en la almacera del Senyor si hi haurà ara o per algun temps, i que aixi mateix lo netejar i escurar la sèquia del dit molí vinga á càrrech 
dels veïns i habitadors dels dits llocs i baronia. I per a refer i adobar lo açut de dita cequia sempre que convinga, haja de posar lo Senyor mestre i cals, i los vasalls tot lo demés.

\section{xiiii) Cargas de Moros.}

Item: que si serà cas que sobre alguna de les cases o terres que s'establiran per dit Senyor se trobaren carregats alguns censals per la universitat dels moros qui son estats expellits de la dita baronia, o per alguns particulars, especialment ab licència del Senyor, que en tal cas tinga obligació dit Senyor de eximir la dita casa i terres dels dits censals.

\section{xv) Jurisdicción para cobrar los derechos.}

Item: que dit Senyor per a cobrar los drets qu'es deuran a la Senyoria puga compelir als dits vasalls o haver-los de pagar al prompte i real eixecusió, segons en deutes reals i fiscals és acostumat.

\section{xvi) Exenciones del Señor.}

Item: que quansevol dret de sequiatge, escura, dret de la sal, peites i altres qualsevol, com semblants càrrecs reals, personals i vehinals, los hajam de pagar nosaltres dits pobladors $i$ los nostres succesors veïns i havitadors de la dita baronia i llocs, conforme se acostuma pagar en lo present regne, sens que lo Senyor, per dita rahó, no sia obligat a pagar cosa alguna.

\section{xvii) Forma de nombrar Gobierno.}

Item: que dos dies ans del dia i festa dels Reis se hajen d'ajuntar los Justícia, Jurats, Mustasaf i consellers dels dits llocs i enviar o donar al Senyor de la dita baronia o Batle que asestirà en aquella, per lo dit Senyor, nomina de a huit vehins dels dits llocs, i d'aquells lo Senyor o Batle ne puixa borrar i llevar los que li pareyxerà fins en número de quatre inclusive, posar-ne altres, los que voldrà, en loch dels que llevarà, i de les huit persones que hi haurà en dita memòria lo dit Senyor o lo dit Batle haja de nomenar i nomene Justícia per als dits dos llocs i un Jurat per a cascú i un Mustaçaf i un Clavari per als dos llocs, per a l'any apres inmediate següent. I los que seran elects i nomenats per als dits oficis hagen de prestar lo jurament acostumat i necesari, en poder del dit Senyor o Batle de que se hauran bé i lealment en dits oficis respectivament. I que dit Justícia haja de nomenar, en continent, son lloctinent en dit ofici, en lo dit loch de Ria per a el seu any, prestant etiam aquell dit jurament. I que de tots los dits juraments, e si menester serà, de les dites eleccions i nominacions dels dits ofiçials se reben actes públics per lo escribà de la Cort de la dita baronia o per altre notari públic qui voldrà dit Senyor o son Batle.

\section{xviii) Reserva de Escribanía.}

Item; per quant la escrivania de la Cort de la dita baronia així la del Justícia com la del Batle és regalia pròpia del Senyor. Per açò, se declara que al dit Senyor toca i se's guarda lo nomenar tantes quantes vegades li pareixerà Scrivà per a la dita Scrivania i mudar-lo sempre i quant voldrà i li serà ben vist a sa mera voluntat, sens que en açò se puixen entrometre en manera alguna los vehins i habitadors de la dita baronia.

\section{xviiii) Dazas i forrajes alfalses.}

Item: que les ferratges i dacses i altres herbes que es faran per a les cavalcadures, exepto los alfalsos, se hajen de alfarracar cascun any per una persona nomenadora per lo Senyor i altra per los vasalls. I conforme dit alfarràs se haja de pagar al Senyor la sisena part en dinés contants. I si en respecte dels alfalsos se haja de pagar al Senyor dotze sous per fanecada cascun any mentres duraran dits alfalsos.

\section{xx) No pueden cortar árbol alguno sin expresa licencia.}

Item: que ningun vehí de dita baronia puxa tallar pins, garroferes, oliveres, ni altres arbres alguns de qualsevol gènero i espècie que sien, així en la horta com en lo secà, ara sien 
verts ara secs, sens llicència del Senyor o de son alcayt, sots pena de sexanta sous per cascun arbre i los arbres hajen de ser del Senyor.

Per açò prometem la una part al altra ad invicem et vicissim ac viceversa per nosaltres i nostres succesors, respectivament, tenir per ferm i agradable, observar, efectuar i complir lo contengut en lo present acte e segons a cascuna de nosaltres dites parts toca $\mathrm{i}$ besguarda, i del modo, forma i manera que desús se conté, i per a attendre i complir dites coses obligam la una part al altra o l'altra a l'altra ad invice et vicissim, tots nostres bens i drets mobles e inmobles, sehens i semovents, privilegiats i no privilegiats, haguts i per haver a on se vulla, que sien i seran, que foren fetes dites coses en lo dit loch de Serra, en vint i sis dies del mes de Nohembre de l'any de la Nativitat de Senyor Deu JesuChrist mil sis-cents i nou. R. Jual de midet, Don Joseph Folch i de Cardona. Senyals de nosaltres Bertomeu Salvaterra, Miquel Sanchis, Joan Sanchis, Joan Munyoç, Antoni Salvador, March Palacio, Jaume Noguera, Joan Teruel, Francisco Morell, Miquel Domingo de Bertomeu, Miquel Domingo de Martí, Sebastià Ribes, Domingo Diago, Antoni Esteve, Pere lbanyeç, Domingo Manyes de Miquel, Joan Palacios, Menau Llanes, Joan Fonfria i Miquel Saeç, nous pobladors per al dit loch de Serra. Senyals de nosaltres Miquel Rives, Vicent Sarigó Ribera, Joan Guillem, Miquel Granell, Joan Salvador, Domingo Vilanova, Antoni Sanchis, Miquel Garrués i Joan Rubio, nous pobladors per al dit loch de Ria, sobredites coses i sengles de aquelles singula singulis referendo loham concedimus firman.

Presents foren per testimonis, çò és, a les fermes de tots los sobredits, exeptuats Joan Palacios i Menau Llanes, qui estaven absens, Arnau Moles i Jaume Silvestre, llauradors de la baronia i Lloch de Soneja habitadors, de present atrobats en lo dit lloch de Serra. I quant a la ferma del dit Menau Llanes qui après fermà en lo dit loch de Serra, en vint i nou dies dels dits mes i any, foren testimonis Nicolau Simó, escrivent habitador de València i Francisco Palma Barrasa, criat del dit Don Joseph, i quant a la ferma.

\section{(Acte d'homenatge):}

Dictis die et anno, Nosaltres, Bertomeu Salvaterra, Miquel Sanchis, Joan Sanchis, Joan Munyoç, Antoni Salvador, March Palacio, Jaume Noguera, Joan Teruel, Francisco Morell, Miquel Domingo de Martí, Miquel Domingo de Bertomeu, Sebastià Ribes, Domingo Diago, Antoni Esteve, Pere lbanyeç, Domingo Manyes de Miquel, Joan Palacios, Menau Llanes, Jaume Fonfria i Miquel Saeç, nous pobladors per al dit loch de Serra. Miquel Ribes, Vicent Sarigó Ribera, Joan Guillem, Miquel Granell, Joan Salvador, Domingo Vilanova, Antoni Lluch Salvador, Antoni Sanchis, Miquel Garves i Joan Rubio, nous pobladors per a el dit loch de Ria, tots ajustats en la casa del Senyor en lo dit loch de Serra per nosaltres i per tots los nostres sucesors de nostre bon grat $\mathrm{i}$ nostra llicència ab lo tenor del present acte ara $\mathrm{i}$ tots temps $\mathrm{i}$ perpetuament valedor omni meliori modo quo possumus nos fern i constituim vasalls conforme a Furs devalencia et alias de justícia del Senyor Don Juseph Folch i Cardona, Cavaller de la orde i milicia de Alcàntara i Senyor de les baronies i lllocs de Serra i Ria i Soneja i Adsuevar situades en lo junt regne de València present $i$ aceptant, $i$ dels seus sucesors en les dites baronies, i jurament del dit Don Juseph a nostre Senyor Deu i als Sants quatre Evangelis de aquells de les mans nostres dretes corporalment tocans $\mathrm{i}$ en virtud del dit jurament prometen estar habitadors i residir en la dita baronia i llocs de Serra i Ría i tenir allí lo nostre domicili i com major ab nostres mullers, fills i famílies onservant i millorant les cases i conreant i percurant les terres a us de bons llaurados $i$ bons vasalls i pagant anualment en sos deguts terminis tots los drets i censals a les dites cases $i$ terres en lo acte de Població de dita baronia i llocs, rebut perl lo notari dejús escrit en lo dia de hui poc ans de ara al qual nos referim contenguts i expresats i aiximateix en virtud del dit jurament prestam homenatges per besament de mà i muscle al dit Senyor Don Joseph i a tots los seus sucesors Senyors que seran de dita baronia en virtud dels quals juraments i homenatges prometem al dit Senyor present i aceptant i tots los seus sucesors encara que absens empero lo notari dejus escrit com millor pot de justícia estipulant, aceptant i rebent que tindrem aquells per Senyors i os seran bons, verdaders i fiels vasalls i farem tot çò i quant com a tals didrem obligació conforme a Furs del present regne et alias de justícia i conforme lo dit acte de Població i renunciant al nostre propi fur i es sotmetem al fur i jurisdicció del dit Senyor i dels dits sous sucesors prometent no 
contravenir a les dites coses ni a alguna de aquelle\& ans be tenintles per fermes $\mathrm{i}$ agradables ara $\mathrm{i}$ tots temps per nosaltres i per tot $\&$ los nostres sucesors, sots obligació de nostres persones i de tots los bens i drets nostres i de aquells mobles e inmobles reens i semovens, priviligiats i no priviligiats, habuts i per haver on se vuliga que sien i seran quo foren fetes les dites coses ysengles de aquells en lodit loch de Serra en vint i sis dies del mes de Novembre del any de la Nativitat de nostre Senyor Deu Jesucrist mil siscents nou. - ni als de nosaltres Bertomeu Salvaterra, Miquel Sanchis, Joan Munyoç, Antoni Salvador, March Palacio, Jaume Noguera, JoanTeruel, Francesc Morell, Miquel Domingo, Bertomeu Miquel, Domingo Martí, Sebastià Ribes, Domingo Diago, Antoni Teruel, Pere Joanes, Domingo Manyeç de Miquel, Joan Palacios, Manuel Ibanyeç, Joan Fonfria, Miquel Saeç, pobladores per al dit loch de Serra, Miquel Ribes, Vicent Sarigó Ribera, Joan Guillem, Miquel Granell, Joan Salvador, Lluch Salvador, Domingo Vilanova, Antoni Sanchis, Miquel Garves, Joan Rubio, nous pobladors per al dit loch de Ria, sobreditti qui totes les dites coses i sengles de aquelles singula singulis referendo loham concedim i ferman prenent per testimonis a totes les dites coses qui supra ac pro ut superviss continentur.

Precedincert populaciones sive poblacionis et avasallamenti instamenta in his decern et septem papiri cartulis presenti comprensa abstractu fuit a protocolo Gregori Tarrasa q. ${ }^{\circ}$ rol Valentini I illorum receptoris per me Juseph Insa civis et regni valenos libros et protocola dicti Gregori Tarrasa vegentem et in fiden. Ego dictus Jusephus Insa a nobis uti regens supra dictur. Signat.

Ordin serbum poblationis instrumentum publicum et abstractum fuit prothocolo Gregori Tarrasa notarii valentium illius receptoris perora Ildephonsum Serrano civitatis et Regni Valentie notarium libros et prothocola superdicti Terrasa Regentem et in fidem dictus Serrano notarius. 'Signat.

1646 novembre 15

\section{DOCUMENT II}

Relació de cases i caps de casa de Serrayria (sic.). Cens nominal de 1646.

ARV-Generalitat, sg. 4826, f. 227.

Die XV mensis novembris anno a nativitate domini MDCXXXXVI

Certifico Yo Vicente Murria, notario y escribano publico de la Ciudad y Reyno de Valencia, como en quince dias del mes de noviembre del año del nacimiento de N.S. Jesucristo de MDC cuarenta y seis, ante mi, dicho notario, personalmente comparecieron en la ciudad de Valencia Jossephe Català, lugarteniente del Justicia del lugar de Sierra y Ria, Francisco Ruvio y Martín Domingo, Jurados de dicho año de dicho lugar, los cuales, mediante juramento, dijeron e hicieron fe como en dicho lugar de Serra y Ria havia las casas y vecinos cabezas de casa siguientes:

Primo: Jussephe Giberto, rector

Francisco Ruvio

Agustín Salvador

Bautista Catala menor

Jossephe Catala

Martin Domingo

Antonio Esteve

Domingo Moreno

Miguel Domingo

Matheu Esteve

Domingo Diago mayor

Domingo Diago menor, los dos en una casa

Jossephe Domenech

Jussephe Suastre, tierrateniente

Matias Cabo 
la viuda Epila y Antonio Arnal, en una casa

Vicente Arnal

Joan Yvanyes

Jayme Perez

Bautista Domenech

Vicente Ruvio

la viuda Navarro

Domingo Navarro

Bautista Catalan mayor

Todos en cómulo son veinte y cinco cabezas de casas, y casas veintitrés de dicho lugar, e recibida la dicha información y relación de los dichos lugarteniente y jurados me requirieron a mi dicho notario.

Les recibí este auto público para que de ello conste en Juicio y fuera de él, al cual por mí dicho notario, les fue apercibido en Valencia, día, mes e año sobredichos, a las cuales cosas fueron puestos por testigos Honorat Amigó, ciudadano, y Gaspar Fullat, torcedor de seda, vecinos de la ciudad de Valencia.

En fe y testimonio de lo cual yo, Vicente Murria, notario y escribano publico de la ciudad y reino de Valencia, aquí pongo mi acostumbrado signo.

1700 juny 16

\section{DOCUMENT III}

Establiment fet i signat pel Marqués de Castellnou a favor dels Justícia, Jurats i demés particulars del lloc de Serra y Ria, del forn de coure pa i altres coses...

ARV, Escribanías de Cámara, any 1714, exp. 21, f. $13 v^{\circ}$ a $14 v^{\circ}$.

Anno a nativitate Domini millesimo septingentesimo. Die vero numerao sexdecimo mensis junii: Compareix davant de mi Josep Vinet, Notari Públic de la present ciutat y Regne de València, i dels testimonis davall escrits...

Il-lustre Don Vicent Folch de Cardona Milà i Alagón, Marqués de Castellnou i de Pons, del Consell de Sa Majestat en lo Sacre Suprem d'Aragó, majordom de la Reina Nostra Senyora, Cavaller del hàbit de Nostra Senyora de Montesa y Sant Jordi d'Alfama, baró de la Baronia de Massalavés, de la del lloc de Soneixa, Assuévar, Serra i Ria, habitador de la Vila de Madrid, lo qual dix:

Que atenent i considerant que Josep Vidal, ciutadà major de dies, son procurador general al temps quant prengué la possessió del dit lloc de Serra y Ria, oferí de paraula als Justícia, Jurats y demés particulars de aquell fer-los algunes gràcies y establiments, considerant lo bé que es havien portat $\mathrm{y}$, entre altres coses que oferí fonc el fer-los les mateixes Gràcies que se haurien fet o es farien dels Justícia, Jurats y demés particulars del lloc de Soneixa: Atenent... (açò mateix) ...que per part de dits Justícia, Jurats y demés particulars de dit lloc de Serra i Ria, se li hauria suplicat el que tingués efecte la promesa feta per lo dit Josep Vidal. Per açò, atenent a lo desús dit y posant en execució lo que prometé lo dit Josep Vidal; en lo millor mode que podia y ab tenor de la present publica carta, Dix establia, concedia, redimia y transportava dels Justícia, Jurats y demés particulars del dit lloc de Serra y Ria, y successors en aquell absenti, jo lo notari estipulant, rebent y acceptant per aquells lo immediat següent:

Primer: establia, cedia i transportava si per acord de establiment ad bene meliorandum et non deteriorandum la Casa e/o Forn de coure pa, situat posat en dit lloc de Serra per a detenir i possehir arrendat, vendre's y transportar aquell y cobrar la renta de dit forn desde el dia de hui en avant, amb càrrec de pagar tots temps perpetuament, així al it Il-lustre Sr. Marqués com als successors en dit lloc, com a Senyor directe de dit forn, dotze diners moneda reals de València de (¿cert?) lluïsme i fadiga pagadors tots los anys en lo dia i terminis que es paguen los demés censos de les cases de drets, lo qual feia amb pacte que es returava lo dit Il-lustre Marqués la Senyoria 
directa de dita casa e/o Forn, amb tots los drets de lluïsme, fadiga i demés drets emfiteuticals segons furs de la present Ciutat y Regne de València, y de que no puguen dits veïns ni son successors elegir reconèixer i proclamar a altre Senyor directe sinó al dit Il·lustre Marqués Senyor de dit lloc i son successors en aquell, sots pena de decomís.

Ítem: així mateix Redimia a tots los veïns de dit lloc de Serra absents ut supra lo cens que cascú respectivament paga, açò és, així com pagaven cascuna casa quinze rals de cens, lluïsme i fadiga, hagen del dia de hui en avant pagar deu rals per cascuna casa anualment, a dit Il-lustre Marqués.

Ítem: que si per donacions o particions, alguna de les cases del dit lloc de Serra es dividiren o partiren, no hagen de pagar més ni tinguen fer pagar sinó lo cens que els tocarà a cascú de la part de casa que es dividiran per raó dels deu reals que aquella, del dia de hui en avant ha de fer ¿prepòsit? de cens.

Ítem que qualsevol siti que se establirà a qualsevol veí per a fabricar casa o cases no el puga carregar del cens, n'estiga obligat a pagar més que quatre sous moneda rals de València cascun any per cascun siti de Casa, pagador en lo mateix termini que los demés censos.

Ítem: per quant fins lo dia de hui han pagat de tots los grans que es cullen en la horta del dit lloc de sis/una al Sr. d'aquell, que del dia de hui en avant no paguen ni tinguen obligació de pagar los veïns de dit lloc al Sr d'aquell sinó de vuit/una i no de més, per redimir-los, com los redimeix, les dos que van de sis a vuit.

Ítem que del dia de hui en avant los veïns del dit lloc puguen tenir una fanecada de terra franca en l'horta per a efecte de fer herba o hortalissa sens que per aquella hagen de pagar cosa alguna a dit Il·lustre Marqués, Senyor de dit lloc, de cens.

Ítem: que sempre quant lo dit Il-lustre Marqués del lloc, fer capbrevar no puga fer-lo pagar quantitat alguna més que lo que importarà lo acte de cascú.

Ítem et últim: que del dia de hui en avant los veïns del referit lloc de Serra hagen de pagar a dit Il-lustre Marqués, per raó dels fruits i grans del secà, lo mateix que paguen los veïns de dit lloch de Soneixa a dit Il-lustre Marqués Senyor d'aquell, lo qual establiment de dit Forn, amb los referits ¿palefs?, reducció de censos e les cases i gràcia de fruits dix feia dit Il·lustre Marqués en lo millor mode que podia i de ¿atret? li era permès i lícit salvant sempre la Senyoria directa, dret de lluïsme i fadiga i qualsevol altre que li toque en dit lloc; prometent no contravenir a tots lo supraexpressat. Instituïnt quatenus fosuit dits justícia, jurats y demés veïns d'aquell vertaders Senyors de dit forn amb tots los drets (---) ut insimilibus volent e entenguen compreses en lo present totes i qualsevol clàusules que serien necessàries per a major fermesa de lo supraexpressat encara que no es trobaren ací inserides. De tot lo qual, lo dit Il·lustre Marqués requerí a mi, dit Notari, rebés Carta Pública per a memòria en lo esdevenidor, la qual li fonc rebuda en València los dia, mes e any desús dits. Essent presents testimonis Mosén Patricio Barberà i Mosén Berthomeu Martínez, preveres habitadors de València. Hs Recepi Joseph Vinet V. N. insidem sig. (rúbrica)

1714 abril 14

\section{DOCUMENT IV}

Els veïns de Soneixa, Serra i Assuévar reclamen a Josepa Folch de Cardona i a son marit, el duc de Montellano, que respecte les gràcies i concessions que els hi va fer el pare de la Senyora.

ARV, Escribanías de Cámara, any 1714, exp. 21, f. $18 v^{\circ}$ a $19 v^{\circ}$.

Francisco Alfonso en nombre de la Baronía y lugares de Soneja, Serra y Azuévar, según de mi poder parece por las tres escrituras que en forma presento y son señaladas bajo los números 
1.2.3; ante Vos comparezco y como más haya lugar de derecho, sigue: Que Don Joseph Severio Cardona, Conde de Villafranqueza, como Procurador de Don Vicente Folch de Cardona, Marqués de Castelnovo y Señor de dicha Baronía, al presente ya difunto, y con escritura por ante Francisco Mestre, escribano, a los 20 de febrero del año 1697, que también presento y juro sub $\mathrm{n}^{\circ} 4$, en atención a que los vecinos de dicha baronía de Soneja le dieron posesión de aquella, Les concedió diferentes gracias e beneficio del común y particulares de dicha baronía, Las cuales se expresan en la dicha escritura que llevo presentada. Y después, el mismo Marqués de Castelnovo y con dos escrituras que autorizó Francisco Járrega, escribano, a los 30 de Marzo del mismo año 1697, que también presento, y .../... juro sub $\mathrm{n}^{\circ} 5$ y 6; estableció y concedió en emfiteusi al dicho lugar de Soneja un ámbito o exacción alta contigua a la Casa del Consejo del dicho lugar, para su ampliación a censo anuo de un sueldo y el derecho y regalía del dicho mesón de dicho lugar a censo anuo de 1 libra, con tales demás reservaciones expresadas en los dos próximamente citadas escrituras; y al dicho lugar de Sierra, mediante escritura por ante Joseph Vinet, escribano, a los 16 de junio de 1700, que también presento y juro, sub $\mathrm{n}^{\mathrm{0}} 7$, estableció y concedió el horno de cocer pan y demás cosas expresadas en dicha escritura, a que también me refiero), cuyas gracias y concesiones han tenido su debido efecto, observancia y cumplimiento hasta el día, de la muerte del dicho Marqués de Castelnovo que las concedió en la forma dicha.

Y porque dicho Marqués pretendió que los dichos vecinos diesen posesión de la dicha Baronía a Doña Josepha Folch de Cardona y Bellvís, su hija primogénita, por causa del fallecimiento del dicho Marqués, su padre, para que así no se le embarazase el aprehenderla ( ) algún contradictor que le disputase las ( ) de dichas baronías, otorgó poder, la dicha Doña Josepha Folch de Cardona al dicho Conde de Villafranqueza y Pons, ( - ) de Calatayud, Conde de Cirat, para que cualquiera de entrambos pudiesen tomar dicha posesión (---) el tiempo de aprehenderla hacer cuales (---) las absoluciones y remisiones a favor de los vasallos y vecinos de dicha Baronía según parece de la escritura de poder que pasó ante Miguel Bas, escribano ya difunto, a los 15 de marzo del año 1704, que también presento y juro sub $\mathrm{n}^{\circ} 8$, cuyas gracias con todo efecto hizo el dicho Conde de Villafranqueza en virtud del dicho poder y en el mismo tiempo $\mathrm{y}$ acto de aprehender dicha posesión, y se reducen a ratificar y conceder de nuevo todas las gracias y establecimientos hechos por el dicho Marqués de Castellnovo y su poder habiente, que todas las casas que pagaban de anuo censo a razón de diez reales se reduzcan a solos cinco reales, y que se les hubiese de establecer y conceder en enfiteusis un pedazo de tierra huerta que serán siete anegadas poco más o menos, francas de todos frutos y arresponsión de anuo censo de 20 sueldos, y que dichas gracias hubiesen de tener su efecto y cumplimiento después de los días del dicho Marqués de Castelnovo, según más por extenso se expresan en la escritura de posesión que autorizó Francisco Mestre, escribano, a los 19 de marzo del año 1704, que también presento y juro sub $n^{\circ} 9$.

Y porque seguida la muerte de dicho Marqués se le movió pleito a la dicha Doña Josepha sobre la sucesión de dicha Baronía, y con sentencia dada por el Consejo Real de Castilla (h)á obtenido a su favor la declaración de sucesión, procede por medio del Licenciado Ignacio Labarios, Presbítero, Procurador General de dicha $\mathrm{D}^{\mathrm{a}}$ Josepha Folch de Cardona y de Don Joseph Solís y Gante, consortes, residentes en la villa de Madrid, conste de su majestad Dios se guarde apremiar a los vecinos de dicha Baronía á hacer la partición de frutos no conforme a lo expresado en dichas gracias y no quiren observar aquellas y, sin embargo, de que los vecinos de dicha Baronía extrajudicialmente se han opuesto protestando la salvedad de sus derechos adquiridos en furza de dichas concesiones y contrato innominado que para ellas precedió como parece por la protesta que pasó ante Francisco Járrega, escribano, a los 6 de julio del año 1713, que también presento y juro, sub $\mathrm{n}^{\circ} 10$. Sin embargo, dicho Procurador General procede con apremio ante dicho vecinos contraviniendo a dichas gracias, (siendo) así que aquéllos están prontos por su parte y (----)las y se han ofrecido y ofrecen a pagar y con (---) y puntualmente todo lo pactado y convenido (----) aunque esta misma representación han (---) dichos Doña Josepha Folch de Cardona y Don (Vicente) Solís, consortes (No quieren dar cumplimiento a las gracias, sin tener motivo que justo para ello (----) providencias necesarias para su observancia (---) (----) hacérsele a mi parte notorio agravio y fuerza. 
A vos pido y suplico que mandando tener es(----) por Corte, mande darme su carta y provisión (---) y mandando a los dichos Don Joseph Solís y Gante y Doña Josepha Folch de Cardona, consortes, residentes en la villa de Madrid, se abstengan en adelante de proceder penas y por las interpuestas personas de sus procuradores contra dicha Baronía y vecinos de aquella en contravención de dichas gracias y concesiones se decretó de nulidad y pena, si que, antes bien las cumplan, guarden y observen a la letra y según su tenor en todo y por todo, declarando en consecuencia por ¿ningunos? y asentados todos los procedimientos hechos contra mi parte, por la parte de dichos consortes en contravención de dichas concesiones desde el día de la muerte del dicho Don Vicente Folch de Cardona hasta el día de oy y condenándoles en haber de restituir a mi parte dentro de diez días, es del término a V. A. bien visto todo y cualquier exceso de frutos y demás responsiones de que sus Procuradores Generales se hubieren incautado excediendo lo taxado en dichas concesiones, bajo los apercibimientos ordinarios pido justicia, etc.

Otrosí, por cuanto recelo que durante este pleito se intentará molestar a mi parte, en contravención de dichas concesiones, lo que no es justo, fundándome en las públicas escrituras que llevo presentadas, también pido y suplico Mande V. A. que durante este pleito y hasta su definitivo pronunciamiento no se innove cosa alguna contra lo pactado en dichas escrituras, so decreto de nulidad y pena, pido también justicia, etc.

Otrosí también pido y suplico Mande V. a los dichos Don Joseph Solís y Gante y Doña Josepha Folch de Cardona, consortes, constituyan y nombren Procuradores en esta Real Chancillería dentro de quince días...

Valencia, Abril 14 de 1714.

Notifíquese a los Ilustres Don Joseph Solís y Gante y Doña Josepha Folch de Cardona, consortes, sobre la cobranza de las gracias y concesiones, y esta petición refiere; y si algo tuvieren que decir acudan a esta Corte, y para ello dense los derechos necesarios; lo mandaron los Sres. Torres, Alzedo y Miravete.

\section{Francisco Conejo (rúbrica)}

Notifícación. En la ciudad de Valencia, en diez y siete días del mes de Abril de mil setecientos y catorce años, el presente escribano de cámara, notifiqué el auto que antecede a Juan Boria En nombre de los tres, Don Joseph Solís y Gante y Doña Josepha Folch de Cardona, Marqueses de Castelnovo y Pons, en su persona, de que doy fe.

\section{Francisco Comez (rúbrica)}

En la ciudad de Valencia, en veinte días de Abril de mil setecientos catorce años se notifica al Licenciado Ignacio Lavarios, rector de la Iglesia Parroquial del lugar de Massalavés, en nombre de los Ilustres Don Joseph de Solís y Gante y D Josepha Folch de Cardona, Marqueses de Castelnovo y de Pons...

1715 gener 1

\section{DOCUMENT V}

Francesc Morell ven a Pere Martínez una mula per 16 lliures (notari Joan Font). APCC, 21044

Die primo mensis jannuarii ann a nativitate domini MDCXV.

Ego Petrus Martines dictus minor agricultor loci de Ria habitatori scienter et gratis cum hoc presenti publico instrumento etc. confitentii et in veritate recognosco me debere vobis Francisco Morell pannorum primi civitattis Valentie habitatore presenti, acceptanti, et vestris sexdecim libras moneter regalium valentie ex de pretio cuius dam muli de cuius sanitate et bonitate sum contendus et plenarie satisfactus et quia etc renunctio et quas quidem sexdecim libras solvere et 
paccare promitto scilicet in die sive festo sancti Joannis mensis junii primo venturii currentis que anni promito dare atque solvere vobis sex barcellas tritici boni et receptibilis ad pretium cuiu bile dicto in terminare et in die sive festo nativitatis sacratissima Virginis marier triginta arrovas sive arroves lignetum sive de garrofes ad pretium curribile dicto in tempore et residuam quantitate in die sive festo omnium sanctorum primo venturo currentis que anni omnibus dilationibus etc. sub pena viginti solidorum dicta moneter dandorum etc qua pena et ratto pacto manente etc. ad qu(.)rum omnium et singulorum etc. fiantque linde etc. ad hec autem etc. Ulterius juro ad dominum deum etc. no litigare nec appellare etc. Renuncians quibusuis apellationibus etc. dandorum etc Ratto pacto etc. Proquibus etc. obligo etc. mobilia etc. Actum in loco de Serra.

Testes huius rei funt Dominicus Diago agricultor et Anthonii Salvador, llauradors, loci de Serra habitatores.

\author{
DOCUMENTS VI, VII, VIII, IX i X \\ (mostra d'impresos sobre plets: portades)
}

1624. Barcelona.

Substancial del plet d'Enric d'Aragó, duc de Sogorb i Cardona, contra Josep Folch de Cardona, sobre la possessió d'Assuévar, Soneixa, Serrra, Ria, Armell...

ADM (consultat en fundació Caja Segorbe), roll 115/2798.

1645 febrer 1.

Argumentació de Josep Folch de Cardona contra demanda interposada pel seu cosí Vicent Milan sobre la possessió de les baronies de Soneixa i Serra.

ABV, fons Gregori Mayans, segle XVII/722(10).

1704 novembre 12

Addició a memorial ajustat del plet entre Vicent Folch de Cardona (marquès de Castellnou, senyor de Serra...) i altres litigants (marquès d'Ariza, marquès de la casta $\mathrm{i}$ nou "comte de Cardona") per la possessió del marquesat de Guadalest i agregats...

Digitalitzat en Google books: https://books.google.es/books?id=hYhGqWvRLvQC.

1711 juny 13.

Consultación en derecho sobre la successió del ducat de Cardona (inclou totes les propietats vinculades), per Josep Folch de Cardona i Erill.

Digitalitzat en Google books:https://books.google.es/books?id=85nAGvyeKhcC.

1764 maig 21

Addició memorial presentada pel duc de Medinaceli (i Cardona i Sogorb) contra Alons Vicent Folch de Cardona (marquès de Castellnou, senyor de Serra...)sobre la successió de les baronies de d'Assuévar, Soneixa, Serra, Ria, Armell... 
$A D M, 115 / 2798 \quad(p .612 \times 5 s)$

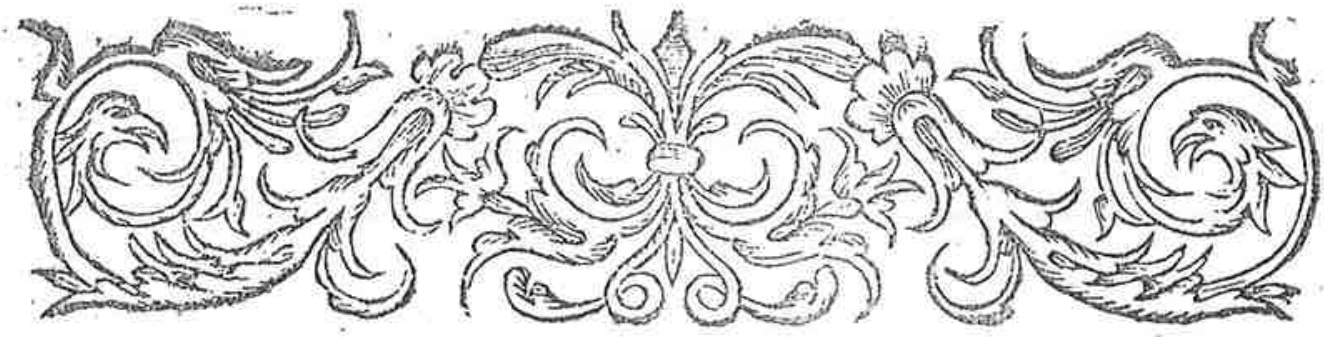

\section{SVSTANCIAL (eny1624):}

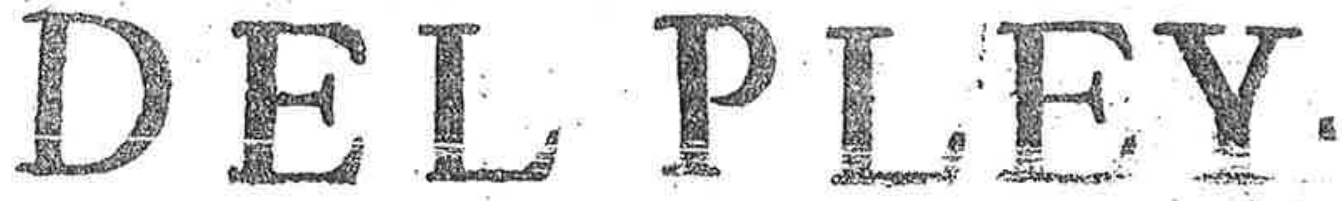

TO DE DEMANDA QVE SETRATA EN LA RBAL AVdiencia de Valencia, entre el Duque dé Segorue, y de Cardona, don Hénrique de Aragon, con don Iufepe de Cardona, fobre las Baronias de Afueua, Soneja, Pellunes, Morguera, Sierra Armell, Ria, fircadas en el Reyno de Valencia, que fe intento por parte y áinftan. cia de la Duquefa doñalluana de Aragón, A guela del

Duque que oy la profigue, contra don Galceran de Gardona, padre de don lufepe poffetiedor refpectiuamente de dichas Baronias, y Lugares.

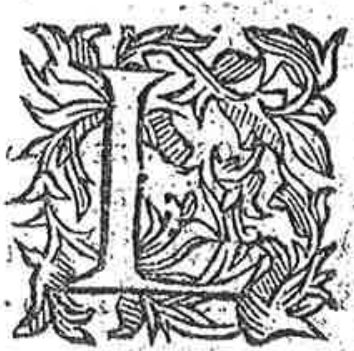

A parte de la dicha Ducqué, y en fur nombre $\mathrm{Pe}$ dro Lorente fu Procurador prefentò peticion ante el Virrcy y Real Audiencia de Valencia en z 7 diás del mes deHebrexo del ano 1576 . pidiendo dichas. Barotilas y que fueffe cos dera do dicho don Gal ceran de Cardona, gentonces las pofle hilas en baúce las de refticuys a la dicha Duquefa va cu frudibus y à efta inftancia fue ciocada la Real Audic cia y cometrda a $1 \mathrm{Dotor}$ Gafpar Roca, porel qual fue hecha proúfión que re tecibiefen teltigos, fobre los Capiculos, y articulos en que la dichä demanda fe fundò por parte de la Duquera, y fobre ellos, y en virtud de prouifiones hechas defpues en la caufa fe recibieron no folo los tefigos que feproduzieton 


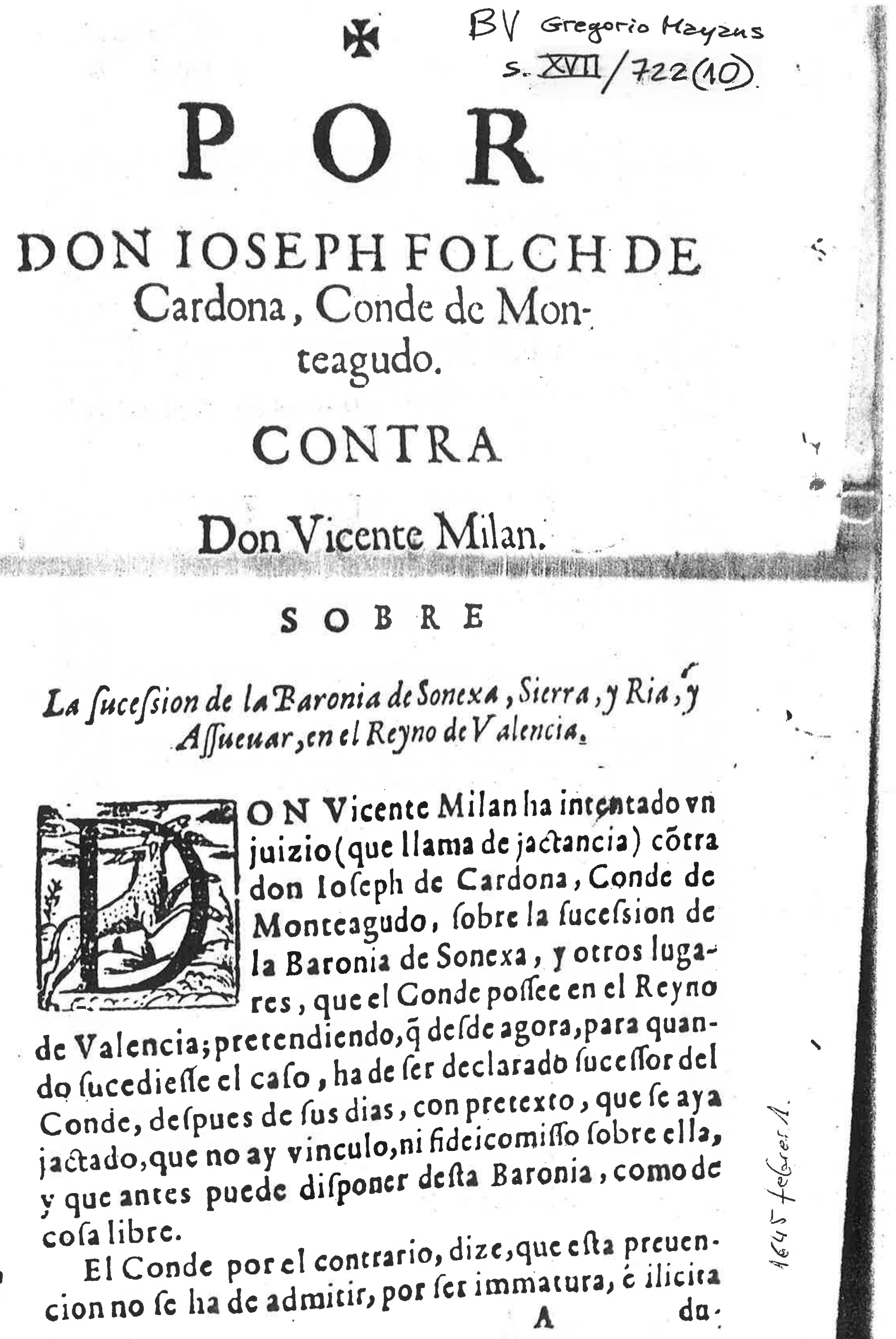




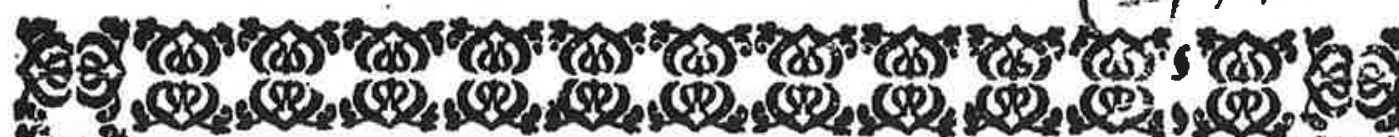
3. ล $A$
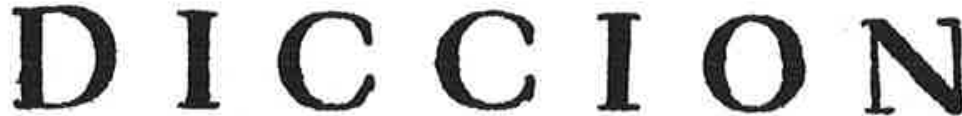

AL MEMORIALAJUSTADO 38 del pleyto, que le tigue en efte Confejo Supremode Aragon por reales letras cauja videndi:

ENTRE PARTES;

DE LA VNA,

EL ILUSTRE DON VICENTE FOL. CH DE CARDONA, Marqués de Caftelnovo:

Y DE LA OTRA,

EL ILUSTRE DON JUAN ANTONIO PALAFOX FOLCH

\section{de Candona,Marquès de Ariza:}

Y EL IIUSTRE DON JUAN PARDO DE LA CASTA FOL CH de Cardona,Marquès de la Caftra

QUE OY SE CONTINUA CON EL ILUSTRE DON JOSEPH Folch de Cardona y Eril, Conde de Cardona, por muerte de dicho Iluftre Marquès de Caftelnovo:

\section{$S O C \quad B \quad R \quad E$}

EL MARQUESADO DE GUADALEST. $y$ /us anexos.

Pines oemiona inde immiffio a polfefrion do do conoto an.

ida, 3 ,
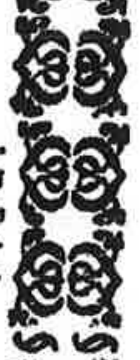

ริ8

ESTA ADICCIONSE HAZE EN VIRTUD de provifsion del Confejo, de 12. de Noviembre de efte prefente año de 1704 .
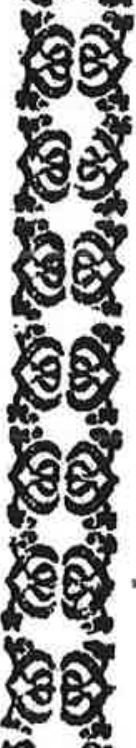

$\infty$ \%
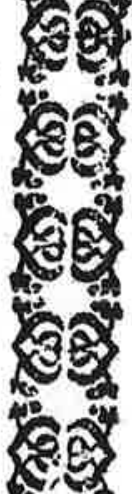

.

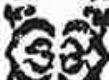

D

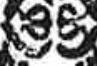

(2)

8.

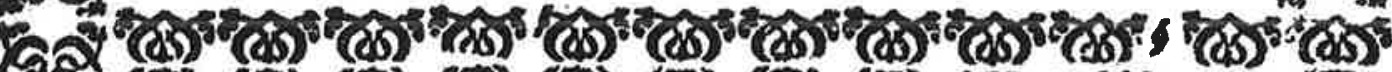

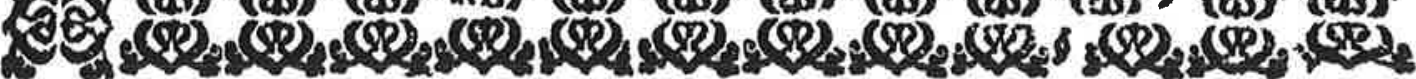




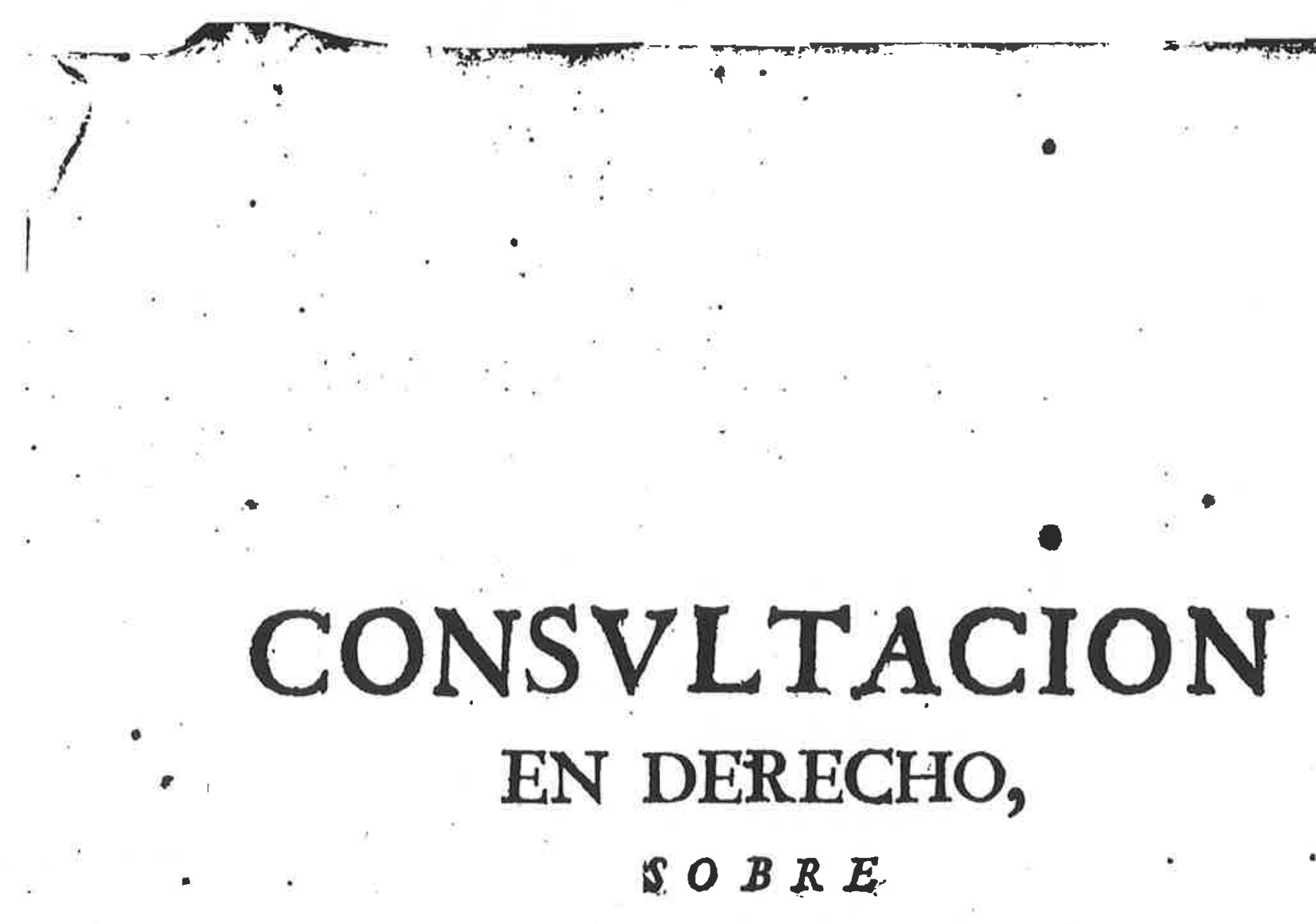

\section{LA SUCESSION DEL DUCADO

\author{
D B
} \\ C A R D ONA.

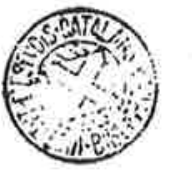

\section{MARQUESADO DE VILLAMUR,}

Y DEMÁS ESTADOOS UNIDOS, Y ADJACENTES.

$$
\text { Juny } 13 \text { de } 1711
$$

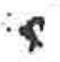

Barcelona. Con licencia delkey N.S.
Impressa par Ratoel Figueró, su impressor. Año1,711: 
) AHN $(F N), 0.263 / 2 x_{3} 30^{1764 \text { mago } 21}$

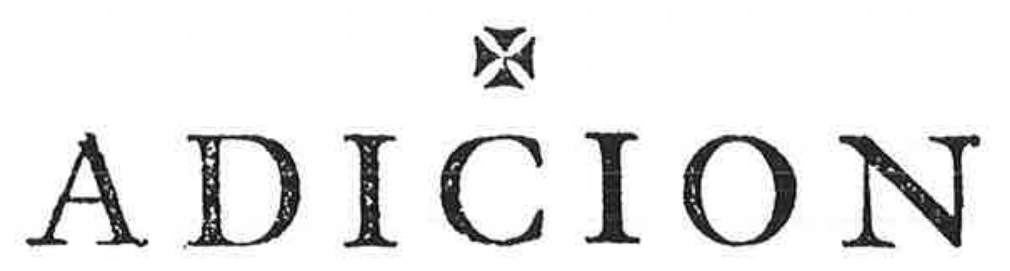

\section{AL MEMORIAL AJUSTADO, DEL PLEYTO,}

QUE SIGUE EL MUY ILUSTRE DUQUE de Medinaceli Don Luis Antonio Fernandez de Cordova, Conde de Prades ( cafa 36. del Arbol).

EN GRADO DE VISTA'

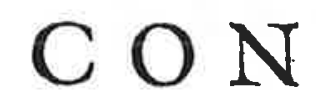

DON ALONSO VICENTE FOLCH DE CARDONA? Solis, y Gante, Marquès de Caftelnovo (cafa 3 5.)

$$
S O B R E
$$

LA SUCCESSION EN PROPRIEDAD DE LAS BARONIÄS de Adfueva, Soneja, Peluñes, Mofquera, Serra, Armell, y Ria.

EN EL QUE EN VIRTUD DE AUTTO DE 17. DE MAYO DE 1764. fe notan las equivocaciones, y omirsiones padecidas en dicho Memorial ajuftado.

I

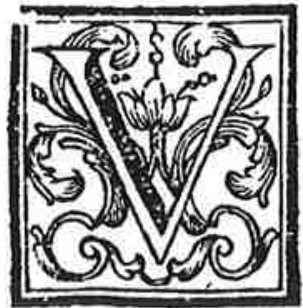

Ifto el Pleyto en I 2. de Febrero de 1761. que figue el Muy Iluftre Duque de Medinaceli contra el Marquès de Cạtelnoyo, fobre la fuccefsion en: propriedad de las Bar ronias de Adfueva, y demàs, y concedidofe licencia à las Partes para efcrivir en derecho ; por la del Muy Iluttre Duque en 17 .de Setiembre de dicho año de 6.1. fe prefentò Pedimento, acompańado de los poderes queifen 
1720 juny 10. Vila de Morvedre.

\section{DOCUMENT XI}

Escriptura d'arrendament dels bens dominicals de les baronies de Serra i Soneixa.

AHN (FN), c. 35, d.19 (n $\left.n^{\circ}\right)$

Matheo Condomina, escribano público del Rey Nuestro Señor, domiciliado en esta villa de Murviedro, del Reino de Valencia, Doy Fe y verdadero testimonio para todos los señores, los que el presente vieren, como con escritura de Arrendamiento de Derechos Dominicales, que pasó ante mí, dicho escribano, a los diez y ocho días del mes de Marzo de mil setecientos diez y nueve años, el Señor Pedro Esles, residente en la villa de Madrid, Corte de su Majestad que Dios guarde, en nombre y como a Poderhabiente del Exmo. Señor Don Josep de Solís y Gante, caballero de la Orden de Calatrava, Conde de Saldaña, Padres y legítimo administrador y así mismo como a tal tutores y Curador de la persona, heredad y bienes del Ilustre Señor Don Alonso Vicente de Cardona y Borja, Señor de las Baronías y lugares de Soneja, Azuévar, Sierra y Ría, sitos en este presente Reino de Valencia, como parte del poder que autorizó Tomás Pastrana, escribano del Rey Nuestro Señor, residente en dicha Corte, a los días cinco de Noviembre de mil setecientos diez y seis años, de que yo, el desusso (sic.) e presente escribano, de ser así doy fe. El cual poder habiente dio y concedió en arrendamiento d Josep Ribas el mayor, Josep Mañez y Félix Ribas, labradores habitantes en dicho lugar de Soneja, a Jerónimo Fabregat, Josep Cabo el mayor, Josep Cabo de Luis y Juan Garay, también labradores y habitantes de dicho lugar de Sierra, respectivamente; presentes y aceptantes a todos de mancomún y a cada uno de por sí e in solidum, los derechos dominicales de censos, frutos, luismos, regalías, réditos, productos, emolumentos y demás, pertenecientes al Señorío de dichos lugares de Soneja, Azuévar, Sierra y Ría (excepto los que desusso se declararán) tales cuales y en la forma que se han acostumbrado percibir hasta ahora por el Señor de dichos lugares, sus Administradores o arrendadores que fueron y han sido, por tiempo de cuatro años firmes, y estos contados des del primero de enero de dicho año mil setecientos diez y nueve y fenecerán el último día fin del mes de diciembre de año mil setecientos veinte y dos; por precio en cada año de mil quinientas cincuenta libras $(1.550 \mathrm{~L})$ moneda de este presente Reino de Valencia, pagadoras por igual mitad todos pagos, a saber, en dicho primer año el primero en el día último del mes de julio de entonces de dicho año mil setecientos diez y nueve, y el segundo medio pago en el día de Navidad siguiente de dicho mes de julio de dicho año asimismo de mil setecientos diez y nueve; y en los últimos tres años asimismo se ha de pagar en los días de San Juan de Juno y Navidad por mediano, a razón de setecientas setenta y cinco libras en cada una paga de los años que después del primero se siguieren mientras y durante dicho arrendamiento. El cual otorgó con los pactos, capítulos, condiciones y obligaciones que siguen, a saber:

Primeramente, con pacto y condición que el siguiente arrendamiento se hace para cuatro años firmes y precisos, que deben empezar a contarse y correr desde el primero día del mes de enero de presente año 1719 y fenecerán en fin de diciembre del año 1722.

Otrosí, con pacto y condición de que dichos arrendadores sean obligados a pagar el precio de este arrendamiento a dicho Exm $^{\circ}$ Señor de dichos lugares o baronías, su legítimo procurador o quien su derecho representare, puesta en la ciudad de Valencia a sus riesgos y costas, con moneda valenciana usual y corriente.

Otrosí, con pacto y condición que este arrendamiento se hace de todas las regalías de dichas baronías y lugares, como son: hornos, molinos de harina en donde al presente lo son, tiendas carnicerías, otros molinos de aceite y demás regalías, con todas sus ahynas (sic.) y adherentes, de que se ha de hacer inventario y aprecio, las cuales hayan de conservar dichos arrendadores y restituirlas fenecido el arrendamiento, volviéndolas a estimar entonces; y si hubiese peoras las hayan de pagar dichos arrendadores., y si hubiesen mejoras no las puedan pedir. 
Otrosí, con pacto y condición de que en este arrendamiento no se comprenden ni entienden arrendar el Palacio y huerto de dicho lugar de Soneja ni los censos de las dos casas de Francisco Gil, bayle de dicho lugar de Soneja, porque esto se lo reserva dicho Exmo. Señor.

Otrosí, con pacto y condición que en este arrendamiento no se comprenden ni entienden arrendar las jurisdicciones civil y criminal, ni penas, reservándose su $\operatorname{Exm}^{\circ}$ con todos sus emolumentos lo referido, concediéndoles sólo la jurisdicción civil que necesitarán así para la custodia de los frutos como para la cobranza de ellos y de los censos, rentas y emolumentos dominicales durante el arrendamiento.

Otrosí, con pacto y condición que todos los reparos (reparacions) que durante el arrendamiento se ofrecieren hacer en hornos, molinos y casas de las regalías de dichos lugares hayan de ir a cargo de dichos arrendadores como no excedan de diez reales de moneda valenciana, y los que excedieran sean descuenta y cargo de su Exc ${ }^{\mathrm{a}}$ o quien lo represente y que no les puedan hacer dichos arrendadores sin dar antes curso a su Exc ${ }^{\mathrm{a}} \mathrm{o}$ su legítimo procurador.

Otrosí, con pacto y condición que las pagas de los molinos y hornos hayan de venir y vengan a cargo de dichos arrendadores, sin que por dichas pagas o la menor razón de ellas puedan pretender rebajas del precio ni refacción alguna.

Otrosí, con pacto y condición que el arrendamiento se hace a todo riesgo y peligro de dichos arrendadores; de manera que por hambre peste, guerra, esterilidad, avenidas de aguas, piedra, niebla, nieves, langosta, despoblación, ni otros iguales quiera accidentes de inclemencia dl tiempo, ni malicia humana, no pongan ni puedan pretender dichos arrendadores disminución alguna, rebaja ni refacción alguna, entendiéndose comprendidas en este capítulo las condiciones con que se arriendan los frutos y derechos decimales de este Arzobispado, por el Arzobispo e ilustre Cabildo en cuanto a lo referido.

Otrosí, con pacto y condición que dichos arrendadores tengan obligación de conservar el Garroferal de su Exc ${ }^{\mathrm{a}}$ en el término de dicho lugar de Soneja, dándole una reja (llaurada) en cada un año de los cuatro de dicho arrendamiento, y haciendo en él los demás trabajos necesarios para su conservación, de manera que si faltare lo referido sean obligados dichos arrendadores a pagar a su Exc ${ }^{\mathrm{a}} \operatorname{los}$ daños y menoscabo que por razón de no haberlo hecho se siguieran.

Otrosí, con pacto y condición que en este arrendamiento, su Exc ${ }^{\mathrm{a}}$ se reserva la facultad de dar licencias a los enfiteutas y vasallos para vender, cargar censos, dividirse, empeñar y para los demás contratos que necesiten de aquella, y de hacer las loaciones, hechas las cuales puedan dichos arrendadores cobrar los luismos.../... y también se reserva su Exc ${ }^{\mathrm{a}}$ la facultad de conceder las fadigas.

Otrosí, et último, con pacto y condición que dichos arrendadores sean obligados a pagar por entero el derecho subastación de este arrendamiento y el salario de la escritura, y a entregar una copia franca de ella a su $\operatorname{Exc}^{\mathrm{a}} \mathrm{o}$ a su legítimo procurador, desde luego.

Con los cuales capítulos, pacto, condiciones y obligaciones, y no sin ellos ni de otra manera, Otorgó dicho Procurador este arrendamiento y, a su firmeza. Obligó todos los bienes y derechos de dicho Exm $^{\circ}$ Señor, su principal, en el referido nombre; y hallándose presentes los desusso dichos Josep Ribas el mayor, Josep Mañez, Félix Ribas, Jerónimo Fabregat, Josep Cabo el mayor, Josep Cabo de Lluís y Joan Garay, aceptaron dicho arrendamiento por el tiempo, precio y pactos referidos; y todo juntos de mancomún y cada uno de por sí e in solidum, prometieron pagar a dicho Exm ${ }^{\circ}$ Señor Conde, en el referido nombre a su legítimo Procurador o quien le representare, las referidas mil quinientas cincuenta libras $(1.550 \mathrm{~L})$, precio de dicho arrendamiento, en los plazos desusso expresados, puestas en la dicha Ciudad de Valencia; y cumplir ls Capítulos, pactos, condiciones y obligaciones arriba referidos a la Letra. 
Y para el cumplimiento de todo lo cual obligaron asimismo, todos de mancomún y cada uno de por sí e in solidum, las personas todos sus bienes y derechos habidos y por haber, y dieron poder a las Justicias de Su Majestad a cuya jurisdicción se sometieron y demás cláusulas de Poderío de estilo de mí, dicho Escribano.

Y renunciación de la ley de duobus reis debendi, la autentica presente (Fidejussoribus) y demás de la mancomunidad y fianza y con sus testigos y fecha a que me refiero. Registro y original de dicha escritura queda en mi poder protocolizada y alargada. Y en fe de ello, a pedimento de dicho señor don Pedro Esles y Campero, en el referido nombre doy la presente, que signo y firmo en la misma villa de Murviedro de dicho Reino de Valencia, a los diez dias del mes de junio de mil setecientos y veinte años.

(signe de Matheo Coromina).

Para ejecutar las diligencias judiciales y extrajudiciales que para la cobranza de lo que contiene esta escritura se necesiten, Habilito a Francisco Gil, vecino y batlle de Soneja. A 12 de marzo de 1721.

Don Pedro de Esles (signat).

1740 desembre 18. València.

\section{DOCUMENT XII}

Arrendament (1741-1744) dels bens dominicals de la baronia de Serra.

AHN (FN), c. 35, d. $19\left(n^{\circ} 3\right)$

Joaquín Medina, escribano del Rey Nuestro Señor, público en esta Ciudad de Valencia y de ella vecino, doy fe y verdadero testimonio a los señores que el presente vieren, como con escritura que ha pasado ante mi en el día siete de los corrientes, Onofre Candao, vecino de la misma, en nombre del Exm ${ }^{\circ}$ Señor Don Alonso Vicente de Solís Folch de Cardona, Borja y Milán, Conde de Saldueña, Frigiliana y de la Roches, Marqués de Castelnovo y de Pons, Vizconde de Dave y Barón de Massalavés, Soneja, Azuévar, Serra, etc.

Arrendó todos los derechos dominicales y frutos de dicha baronía de Sierra a Vicente Sales, labrador de la vega de esta ciudad, por tiempo de cuatro años precisos que se empezarán en primero de enero del año primero viniente, por precio en cada uno de quinientas y cincuenta libras $(550 \mathrm{~L})$ moneda corriente de a ocho reales de plata, que ha de efectuar sus pagas en San Juan y Navidad de cada año medieramente, en la cual escritura se le capitularon diferentes pactos y, entre otros: Que las pagas de dicho arriendo las debía depositar en la persona que para ello se le señalaría, en esta ciudad; Que había de tomar al precio corriente los frutos pendientes de este año que paraban en poder de Pedro Sivera, recaudador, y pagarles de contado; Que no efectuando los pagos dentro de un mes caída, se rescindiera la escritura y que el mismo efecto obrara siempre que se faltara por el arrendador al cumplimiento de éstos y demás capítulos; Que hubiere de afianzar dicho arrendamiento a satisfacción del apoderado de $s u \operatorname{Exc}^{\mathrm{a}}$ y mejorar las fianzas siempre que se pidiera. Y en la misma se halla por fiador y principal obligado final e in solidum, Josep Llorens, mercader, vecino de la misma y aceptado el arriendo por ambos, como todo es de ver en ella (escriptura) que alargada queda con todas las cláusulas de obligación, poderío y demás de su naturaleza y demás de estilo a la que me refiero.

Para que conste doy el presente a pedimento de dicho Onofre Candao, que signo y firmo en Valencia, a los diez y ocho días del mes de Diciembre del año mil setecientos cuarenta.

En testimonio de la verdad:

Joaquín Medina (signat). 
1744 setembre 19 . València.

\section{DOCUMENT XIII}

Arrendament (1745-1748) dels bens dominicals de la baronia de Serra.

AHN (FN), c. 35, d. 19 (no 2)

Joaquín Medina, escribano del Rey Nuestro Señor, público en esta Ciudad de Valencia y de ella vecino, doy fe a los señores que el presente vieren, como hoy, día de la fecha, Onofre Candao, Procurador General del Exmo. Señor Don Alonso Vicente de Solís Folch de Cardona, Borja y Milán, Conde de Saldueña, Marqués de Castelnovo y de Pons, Señor de las Baronías de Massalavés, Soneja, Azuévar y Serra, según los poderes que autoriza Juan Navarro, escribano de Madrid en 26 de mayo del año pasado de 1741, [arrendó todos los dere]chos dominicales de la baronía de Serra, en ocho de septiembre arrendó a Vicente Sales, labrador de la huerta de la ciudad, los derechos dominicales de la baronía de Serra por tiempo de cuatro años que empezarán a correr en el día primero de marzo del año viniente de 1745, por precio, en cada uno, de seiscientas veinte y cinco libras $(625 \mathrm{~L})$, moneda valenciana, que ha de pagar en dos iguales pagas, la primera día de San Juan de dicho año 1745, la segunda día de Navidad del mismo; y así a los demás años sucesivos, cuyo arrendamiento se ha otorgado con diferentes pactos, capítulos y condiciones; los mismos se han acostumbrado hasta ahora arrendar los derechos dominicales de dicha baronía y son regulares y del estilo, el cual se halla aceptado por dicho Vicente Sales en la forma regular y pactada, según capítulo, por Josep Sales que ha otorgado la pauta correspondiente, otorgándose a pagar dichas $625 \mathrm{~L}$ a los plazos referidos simul e in solidum como todo es de ver en dicha escritura que original queda alargado en el registro protocolario de escrituras públicas que queda en mi poder, al que remito todas las cláusulas, obligaciones, poderíos, estimaciones especiales que en estilo y de práctica. Para que conste doy el presente a requerimiento de dicho Onofre Candao, que signo y firmo en Valencia, a diez y nueve días del mes de setiembre de mil setecientos cuarenta y cuatro años.

En verdad:

Joaquín Medina (signat).

\section{DOCUMENT VXIV}

1788 gener 4

Portaceli paga pel terç-delme d'Alfara del Patriarca.

Nota inserida en ACV, 4276, sense paginar)

Muy Señores míos: Con el debido respeto, recibí la de VV.SS. en la que se dignan darme noticia como el Exmo. Sr. Arzobispo de esa Santa Iglesia y su Muy Ilustre Cabildo han concordado con su Majestad (que Dios guarde) por otro cuarto Cuatrienio sobre la Colectación, cobranza y pago de la Casa Mayor Diezmera de este Arzobispado, con la obligación de haberle de satisfacer en cada un año 181.562 Reales y 9 maravedíes vellón, que deben repartirse a proporción, con más los gastos, etc.

Quedo enterado de ello y esperando el repartimiento que haga ese muy Ilustre Cabildo (que no dudo será equitativo) y la parte que le corresponda a este Monasterio por el $3^{\circ} \mathrm{X}$ de Alfara del Sr. Patriar ca, para en su inteligencia acudir a pagar la parte que nos toque.

Dios Nuestro Señor guarde a VV SS. $\mathrm{m}^{\mathrm{s}} \mathrm{a}^{\mathrm{s}}$ Cartuja de N. Sra. De Portaceli y Enero, a 4 de 1788.

$\mathrm{L}^{\mathrm{s}} \mathrm{M}^{\mathrm{s}}$ de VV.SS.

Su más humilde y atento Servidor y Cap ${ }^{\mathrm{n}}$ Fr. Josef Alcover, Prior

Muy SS. míos Sr. D. Juan Antonio Mayans y Sr. D. Félix Rico. Canónigos. 
1836 agost 20

\section{DOCUMENT XV}

Jurament de la Constitució de 1812 per la pedania de Portaceli (Serra)

ADPV, Govern Civil, C1, caixa 33, Exp. n 93.

Como Alcalde pedáneo del término de Portaceli he recibido la circular de V.I. de 13 del actual, con el oficio del Sr. Comandante General Presidente de la Junta de Gobierno de esta Provincia de la propia fecha, por lo que al par que se comunica la instalación de dicha Junta, previene se promulgue y jure por los Ayuntamientos de los pueblos la Constitución política de 1812, de cuyo solemne acto se remita a V.I. el oportuno testimonio.

En tres diferentes instancias y también por medio de oficio dirigido al tiempo de liquidar las Cuentas del ramo de policía de Portaceli, pertenecientes al pasado año 1835, he puesto en la consideración de V.I. que en dicho territorio, después de suprimida la Comunidad de la Cartuja de N. Sra. De Portaceli, no existen más vecinos que los mayorales, criados o jornaleros, todos pobres, de las tres casas de Campo o Masías que radican en él, cuya mayor parte tienen su domicilio en diferentes pueblos, razón por la que habiendo dependido mi subsistencia de la suprimida Comunidad como criado que era de la misma, me veía en el día precisado a buscarlo fuera de dicho territorio y reclamaba de la bondad de V.I. y ahora lo reproducen se sirviese relevarme del cargo de Alcalde de Portaceli que cerca de 3 años ejerzo.

Lo dicho parece bastante para dar a V.I. una idea de que en el territorio de Portaceli es absolutamente imposible la promulgación y jura de la referida Constitución política, pues que no existiendo Pueblo, Ayuntamiento, fondo de ninguna especie, persona que reúna las circunstancias que se requieren para en su caso ejercer el empleo de Alcalde, ni más vecinos que los de las tres casas de campo referidas, no pueden ser acomodables al mismo las órdenes y disposiciones para los pueblos que por razón de tales deben cumplir con la Ley de Ayuntamientos; y por esta causas que tengo manifestada a V.I., por el ramo de Policía se vio la imposibilidad de que me hiciera cargo de Pasaportes y papeletas para el presente año, no existiendo, como no existe, la Comunidad de la Cartuja ni sus criados que los consumían.

Así que espero que sirviéndose V.I. tomar lo dicho en consideración con los demás antecedentes de que llevo hecho mérito, se servirá tenerme por cumplido en la circular de 13 de este mes que previene se promulgue y jure la Constitución política de la Monarquía Española del año 1812.

Dios guarde a V.I. muchos años. Portaceli, 20 de Agosto de 1836.

Por el Alcalde, José Cortina, que no sabe firmar, y de su orden, Gabriel Martí (signatura).

1836 setembre 4

\section{DOCUMENT XVI}

Jurament de la Constitució de 1812 pel poble i autoritats d Serra.

ADPV, Govern Civil, C1, caixa 33, Exp. n 260.

Francisco Ros, secretario del Ayuntamiento de Serra,

Certifico: que en cumplimiento a lo mandado en circular de S.I. en fecha 13 de agosto último, y reunida en esta el dieciocho del mismo, en la que manda se promulgue y jure la Constitución del año 1812, los Señores del Ayuntamiento acordaron su obedecimiento y cumplimiento, para lo cual, en acta celebrada el diecinueve del mismo, acordaron asimismo se les haga saber al Cura Párroco, Oficiales de la Guardia Nacional y demás vecinos acudiesen a la misa mayor celebrada en el dia de hoy con el indicado objeto, la que concluida sea puesto una mesa competentemente adornad al pie del Altar Mayor y sobre ella el libro de los Sagrados Evangelios 
y después de una larga explicación por el Señor Cura, se procedió a dicha jura primero por el mismo, segundamente por los señores del Ayuntamiento y oficiales de la Guardia Nacional, con una porción de vecinos que acudieron a la función. Seguidamente se cantó el solemne tedeum, concluyéndose con vuelo de campanas y muchos vivas, observándose entre los vecinos un singular regocijo. Y para que conste lo firmo como también el señor Alcalde, tercer regidor y Síndico Procurador y por los que no saben yo, el Secretario. En Serra, a 4 de septiembre de 1836.

Signem: Francisco Dolz (regidor tercero), Manuel Cabo (síndico), Francisco Navarro (el alcalde) y Francisco Ros (secretario).

1837 maig 2. París

\section{DOCUMENT XVII}

Testament de $\mathrm{M}^{\mathrm{a}}$ Vicenta Solís, duquessa de Montellano. AHN (FN), lg. 438/1

Consulado de España en París. Don José López Bustamante de Belanude Almanzano y Mondragón, caballero de la Real y distinguida Orden Española de Carlos Tercero, de la Americana de Isabel la Católica, condecorado con tres cruces de distinción por acciones de guerra en la de la independencia, Cónsul de España en París.

Certifico: que en el archivo de este Consulado de S.M. de mi cargo y en el protocolo de testamentos se halla uno cuyo tenor en pie de la letra es como sigue:

"En el nombre de Dios todopoderoso. Yo, Da María Vicenta de la Soledad Solís Laso de la Vega, etc. Duquesa de Montellano y del Arco etc. Digo: que hallándome buena y sana, con cabal juicio, y deseando tomar mis disposiciones con entero conocimiento y reflexión, para después de mis días, he determinado hacer mi testamento en la forma y con las cláusulas siguientes.

$1^{\text {a }}$ Declaro que creo firmemente en todos los Misterios de nuestra Santa religión Católica, Apostólica, Romana, en la que he sido criada y protesta vivir y morir, y encomiendo mi alma a Dios nuestro Señor Jesucristo que la creó y que la redimió con su preciosísima sangre padeciendo muerte y pasión.

$2^{\text {a }}$ Encargo a mis albaceas testamentarios que eviten toda pompa en mis gastos funerales, pues al contrario, quiero y deseo la mayor sencillez y humildad en ellos.

$3^{\mathrm{a}}$ Mando que se digan por sufragio y bien de mi alma quinientas misas repartidas entre los puntos principales en que se hallan situados mis bienes, y el pasaje de mi fallecimiento.

$4^{\mathrm{a}}$ Mando por una sola vez a las llamadas vulgarmente forzosas, como son la conservación de los Santos lugares de Jerusalen, redención de cautivos cristianos, hospitales general y pasión de Madrid, y pobres viudas y huérfanos, que quedaron de la guerra de la independencia, la limosna prevenida por Reales Decretos, con lo cual, las separo, quito y aparto de cualquier derecho y acción que puedan tener a mis bienes.

$5^{\mathrm{a}}$ Mando que se distribuyan por una sola vez entre los pobres hasta la cantidad de veinte mil reales vellón, destinando una décima parte para los del sitio donde yo falleciere, otra para los de donde tengo los bienes de Bélgica y las otras ocho distribuidas proporcionalmente en los pueblos de España donde tengo mis bienes, según lo tengan por conveniente mis testamentarios.

$6^{\mathrm{a}}$ Declaro haber sido casada en primeras nupcias con el Exmo. Señor Don Carlos Gutiérrez de los Ríos y Sarmiento, Duque de Fernán-Núñez, de cuyo matrimonio tuvimos dos hijas que han fallecido, doña Carlota María de la Esclavitud, de menor edad, y doña Francisca María del Rosario que ha estado casada con el Exmo. Señor Don Felipe Osorio y de la 
Cueva, Conde de Cervellón, dejando una hija, mi nieta, la Exma Señora Doña María del Pilar Loreto, Osorio, Gutiérrez de los Ríos, Duquesa de Fernán-Núñez

$7^{\text {a }}$ Declaro que me hallo actualmente casada con el Exmo. Señor Don Filiberto Mahy y Brauly, de cuyo matrimonio no tenemos hijo alguno.

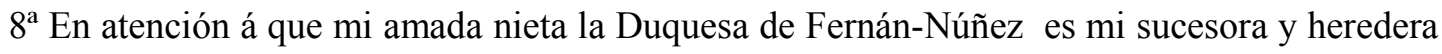
de los bienes (á excepción de los que me reservo disponer con arreglo a las leyes vigentes) dejo á su cargo y durante su menor edad á su padre y curador el Conde de Cervellón, para que se cumplan las mandas siguientes:

A mi Secretario y Contador Don Julián Álvarez, a mi archivero Don Tomás de Almeyda, y á los oficiales que componen hoy dichas oficinas y lo sigan siendo al tiempo de mi fallecimiento, se les darán las dos terceras partes de su sueldo durante su vida si no continuaran empleados al servicio de mi sucesora, en el caso de que más adelante se los relevase ó jubilase de dichos destinos. Y al fallecimiento de dichos mi Secretario y Contador y archivero, gozarán sus mujeres actuales las viudedad de diez reales vellón diarios, mientras permanecieran en el estado de viudez, sin pasar á otro, aunque sea el de Religiosas. Del mismo modo es mi voluntad que á los criados españoles que se hallan a mi servicio en el extranjero y que continúen sirviéndome al tiempo de mi fallecimiento, sea dentro o fuera de España, se les de igualmente las dos terceras partes de su sueldo durante su vida, si no siguiesen al servicio de mi sucesora o se les adjudicase en cualquiera tiempo, y lo mismo debe entenderse con el portero Vicente Carbonell. Pero á los criados Manuel Hernández y Antonio Santomé se les dará su sueldo por entero. Igualmente se continuarán pagando los legados, jubilaciones y pensiones que existen en el día, durante la vida de los que gozan dichos señalamientos.

$9^{a}$ Mis ropas se repartirán entre las criadas que se hallen a mi servicio al tiempo de mi fallecimiento, y si fuera una sola serán para ella todas dichas ropas.

$10^{\mathrm{a}}$ Es mi voluntad que a Don Mariano de Agustín, inspector de los bienes de Bélgica se le continúe el sueldo anual que actualmente disfruta de doce mil reales de vellón por los días de su vida y por vía de pensión.

$11^{\text {a }}$ Es así mismo mi voluntad dejar las pensiones siguientes: a mis tias Sor Josefa de Santa Getrudis Solís, religiosa en Sevilla, la cantidad de doce reales diarios; a Don Ramón Carlos Roca veinte y cuatro mil reales de vellón al año, y á Don Ramón Frías y Mercader seis mil reales vellón anuales, á todas tres personas durante los días de su vida.

$12^{\mathrm{a}}$ Dejo a mi amada nieta un alfiler de brillantes unidos que fue regalo de la Reina MAria Luisa, una de las cinco flores de brillantes, la que tiene la simiente de oro en forma de girasol, y un medalloncito redondo guarnecido de brillantes pequeños que contiene pelo de sus padres.

$13^{\text {a }}$ Dejo a mi hijo el Conde de Cervellón, todos los retratos de mi hija.

$14^{\mathrm{a}}$ Dejo a mi amado esposo Don Filiberto Mahy y Brauly la carretela o carruaje que él escoja.

$15^{\mathrm{a}}$ Declaro que habiéndose establecido en toda su fuerza y vigor los Decretos de las Cortes de veinte y siete de setiembre del año de mil ochocientos veinte y diez y nueve de junio de mil ochocientos veinte y uno, sobre supresión de toda especie de vinculaciones, es mi voluntad usar de la facultad que los mismos me conceden de disponer como dispongo de la mitad de todos mis bienes vinculados como propios y libres, y por consiguiente quedan libres desde ahora, y por tanto serán comprendidos en el cuerpo de bienes libres al tiempo de mi fallecimiento. 
$16^{\mathrm{a}}$ Declaro que tengo hecha donación a mi esposo Don Filiberto Mahy de la cuarta parte de los bienes de Dave Nanines y Bonchines, en la provincia de Namur, Reino de Bélgica, cuya donación se la hice el día quince del mes de octubre de mil ochocientos treinta y cinco con arreglo a las leyes de dicho país.

$17^{\mathrm{a}}$ Declaro que habiendo yo hecho dicha donación sin contar para ella con los bienes libres que poseo en España, es mi voluntad dejar como dejo además a dicho mi amado esposo Don Filiberto Mahy y Brauly la quinta parte de todos mis bienes libres de España que yo posea al tiempo de mi fallecimiento, incluso los mencionados en la cláusula quince de este mi testamento y para que dicho mi esposo disponga de todo lo que le he donado y dejo á su libre voluntad como de cosa propia y sin limitación.

$18^{\mathrm{a}}$ Dejo a mi referido esposo Don Filiberto Mahy y Brauly (separando la memoria que dejo en la cláusula doce a mi nieta) todas mis alhajas, brillantes, perlas y demás, cuyo valor será a cuenta del quinto de los bienes de España que le dejo, y es mi voluntad además que se los siga completando el haber y pago de dicho quinto con los bienes que me han quedado en Bélgica después de la donación.

$19^{\text {a }}$ En el triste caso, lo que Dios no permita, de que mi amada nieta y sucesora actual faltase antes que yo, Declaro que es mi voluntad legar a mi esposo Don Filiberto Mahy y Brauly todos mis bienes libres, habidos y por haber, y que como tales me pertenezcan al tiempo de mi fallecimiento, en cualquier país que se hallen situados. $\mathrm{Y}$ en este caso será de su cargo satisfacer las pensiones señaladas en la cláusula once de este mi testamento á mi tía la religiosa de Sevilla, a Don Ramón Carlos Roca, y a Don Ramón Frías y Mercader, en los mismos términos y durante la vida de estas personas: entendiéndose estas pensiones sobre los bienes de España. El deseo de no dejar a la ventura asuntos de tanta trascendencia me hacen tener tan dolorosa previsión, pues que los decretos y disposiciones de la divina providencia son inescrutables.

$20^{\mathrm{a}} \mathrm{Y}$ en el remanente de todos mis bienes, acciones y derechos que en el día de mi fallecimiento me pertenezcan por cualquier título y manera, y puedan pertenecerme en lo sucesivo (después de deducidas, separadas y cumplidas las partes de que llevo dispuesto en las cláusulas anteriores de este mi testamento, sustituyo por mi única, legítima y universal heredera a mi amada nieta, la Exma. Señora Doña María del Pilar Loreto, Osorio, Gutiérrez de los Ríos, duquesa actual de Fernán-Núñez.

$21^{\text {a }}$ Nombro por mis albaceas testamentarios, si yo falleciese en España, a mi esposo el Exmo. Señor Don Filiberto Mahy y Brauly, a mi hijo, el Exmo. Señor Conde de Cervellón, a mi primo el Exmo. Señor Conde de Santa Coloma, y a mi amigo el Exmo. Señor Marqués de San Martín, y si yo falleciese en cualquier punto del extranjero, lo serán mis referidos esposo e hijo, mi hermano Don Camilo Gutiérrez de los Ríos, y otra persona que nombre el primero, pudiendo sustituir los ausentes su encargo por poderes.

$22^{\mathrm{a}} \mathrm{Si}$ al tiempo de mi fallecimiento encontrase entre mis papeles algún codicilo de fecha posterior á este mi testamento, hecho y firmado por mi propio cuño, debe tenerse como fehaciente y formar parte integrante de este mi testamento.

$23^{\mathrm{a}}$ Revoco y anulo todos y cualesquiera otro testamento o testamentos, codicilos, y cualesquiera otra disposición testamentaria en cualquier forma que fuese anteriores á esta fecha, salvo el presente testamento que ahora hago, el cual es mi ánimo, deliberada y decidida voluntad se cumpla y lleve á entero efecto en todas sus partes escrito todo de mi propio puño y cerrado y sellado con un sello de plata de mis armas, en París, Reino de Francia, el día dos del mes de Mayo del año de mil ochocientos treinta y siete. Fdo. María Vicenta de la Soledad Solís, Laso de la Vega, Duquesa de Montellano y del Arco, con rúbrica."

P.D.: 
En la ciudad de París hoy trece de junio de mil ochocientos cuarenta, me fue entregado por el Exmo. Señor Marqués de Miraflores, Embajador de S.M. en este Reino, un pliego cerrado y sellado con cinco sellos, y en la carpeta escrito lo siguiente:

"Este es mi testamento, hecho escrito y cerrado por mi misma Da María Vicenta de la Soledad Solís Laso de la Vega, Duquesa de Montellano y del Arco, en París, Reino de Francia, el día dos de Mayo del año de mil ochocientos treinta y siete", firmado "Yo María Vicenta de la Soledad Solís Laso de la Vega, Duquesa de Montellano y del Arco" con rúbrica, cuyo pliego fue abierto á presencia de los testigos siguientes del Señor Don Elías Javier de Lanza, Canónigo de la Santa Iglesia Catedral de Zaragoza, Don Manuel Rubio de Pradas, Vice-Cónsul de S.M. en la Capital, Don Mariano de Agustín, archivero cesante de la Embajada de S.M. en esta dicha Capital, Don Andrés Muriel, Canónigo de la Santa Iglesia de Osma, Don Manuel Hernández, Mayordomo de la Casa de la Excma Señora difunta Duquesa de Montellano, Don Constante Delatre, antiguo mayordomo de la casa del Exmo Señor Conde de Fernán-Núñez, y del Presbítero Don Gregorio Alonso de Prado, los cuales á quienes conozco, de que doy fe, dijeron bajo juramento que la letra y firma de la difunta Doña María Vicenta de la Soledad Solís Laso de la Vega, Duquesa de Montellano y de Arcos, puestas en el testamento que tenían á la vista y que acaba de leerse, fallecida en Tours, el cuatro de junio corriente, eran verdaderas, y las mismas de que había usado durante su vida. En su consecuencia publiqué este testamento para que fuese como será protocolado en los archivos de este Consulado de S.M. y para que se den de él los testimonios que se pidieren por los interesados. Y en testimonio de verdad, firmaron conmigo esta diligencia los siete Señores testigos ya enumerados de que doy fé yo el infrascrito Cónsul de S.M. Elías Javier de Lanza. Mariano de Agustín. Andrés Muriel. Manuel Rubio de Pradas. Gregorio Alonso de Prado. Manuel Hernández. Constante Delatre. Ante mi, José López Bustamante. Confrontado concuerda con su original, al que me remito.

Y para los efectos consiguientes doy la presente copia testimoniada refrendada con el sello de este Consulado, en París á quince de junio de mil ochocientos cuarenta. José López Bustamante. Hay un sello del Consulado de España en París, Número mil doscientos cuarenta y cinco. Visto en este Ministerio de Estado para legalizar la firma de Don José López Bustamante, Cónsul que ha sido de España en París. Madrid once de octubre de mil ochocientos ochenta. El Secretario, Rafael Ferran. Hay un sello del Ministerio de Estado. Examinado este testamento de la Exma Señora Duquesa de Montellano, de Fernán-Núñez y del Arco, por el Negociado de Contribuciones extinguidas, se devuelve el mismo al interesado por acuerdo del Señor Jefe Económico en fecha de hoy, y porque la traslación de dominio que tuvo lugar en mil ochocientos cuarenta de herencia directa de ascendiente a descendiente legítimo no devengaba derechos ni impuesto alguno á la Hacienda pública en la citada fecha.

Málaga ocho de noviembre de mil ochocientos ochenta. El Jefe del Negociado, José L. Ayllón. Conf ${ }^{\mathrm{e}}$ Garrido

Hay un sello de la Administración Económica de la Provincia de Málaga.

Sin pago de impuesto sobre transmisión d bienes por no devengarlo las sucesiones directas cuando tuvo lugar la de que se trata, queda inscrito el título de heredero que contiene este documento á favor de la Señora Doña María del Pilar Loreto Osorio Gutiérrez de los Ríos, Duquesa de Montellano y de Fernán-Núñez en el folio ochenta y tres del tomo trescientos ochenta del Registro de la Propiedad, libro ochenta de Distrito de la Alameda de esta Ciudad, finca número dos mil trescientos seis, en el folio doscientos cuarenta y siete del tomo trescientos setenta y uno, libro setenta y siete del Distrito de la Merced número dos mil doscientos sesenta, en los folios ciento cuarenta y seis, ciento cincuenta y uno, ciento cincuenta y cinco, ciento cincuenta y ocho, ciento sesenta y uno, ciento sesenta y cuatro, ciento sesenta y siete, ciento setenta, ciento setenta y tres, ciento setenta y seis, y ciento setenta y siete, del tomo trescientos setenta y seis, libro sesenta y seis del Distrito de Santo Domingo, número mil novecientos noventa y siete á dos mil siete, inclusive en los folios doscientos veinte y cinco, doscientos veinte y siete, doscientos treinta y dos, doscientos treinta y cinco, doscientos treinta y ocho, doscientos cuarenta y uno, 
doscientos cuarenta y cuatro, y doscientos cuarenta y siete, del tomo trescientos sesenta, libro catorce del Distrito de Alharin de la Torre, números quinientos sesenta y ocho a quinientos setenta y cinco, inclusive, y en los folios dos, seis, diez, catorce, dieciocho y veinte y dos, del tomo trescientos ochenta y uno, libro quince del Distrito deAlhaurin de la Torre, números quinientos setenta y seis a quinientos ochenta y uno inclusive, inscripción primera en todos los números.

Málaga, seis de octubre de mil ochocientos ochenta y uno. Antonio Senpau. Hay un sello tinta azul del Registro de la Propiedad de Málaga.

Concuerda con su original para este efecto exhibido por Don Antonio María Segovia, de esta vecindad y apoderado general de la Casa y estados de los Excmos. Señores Duque de FernánNúñez y otros títulos, a quien se 1 devuelvo y firma su recibo de que doy fe, y á que me remito. Y para que conste a instancia del mismo, yo el infrascrito Notario del Ilustre Colegio y de esta Villa de Madrid, libro el presente que signo y firmo en ella, y seis pliegos clase décima, números seiscientos quince mil veinte y tres al veinte y ocho inclusive, hoy veinte y uno de Julio de mil ochocientos ochenta y siete.

Recibí el original: Miguel Díaz Arévalo

(segell de tinta i rúbrica). 